\title{
BRIDGING AUSTRALIA AND JAPAN VOLUME 1
}

THE WRITINGS OF DAVID SISSONS, HISTORIAN AND POLITICAL SCIENTIST 



\section{BRIDGING AUSTRALIA AND JAPAN VOLUME 1}

THE WRITINGS OF DAVID SISSONS, HISTORIAN AND POLITICAL SCIENTIST

EDITED BY ARTHUR STOCKWIN

AND KEIKO TAMURA

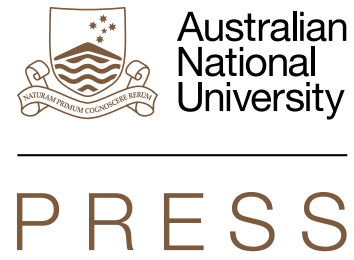

ASIAN STUDIES SERIES MONOGRAPH 8 


\section{ANU \\ PRES S}

Published by ANU Press

The Australian National University

Acton ACT 2601, Australia

Email: anupress@anu.edu.au

This title is also available online at press.anu.edu.au

National Library of Australia Cataloguing-in-Publication entry

Creator: Sissons, D. C. S. (David Carlisle Stanley), 1925-2006, author.

Title: Bridging Australia and Japan : the writings of David Sissons, historian and political scientist Volume 1 / J. A. A. Stockwin, Keiko Tamura, editors.

ISBN: 9781760460860 (paperback) 9781760460877 (ebook)

Series: $\quad$ Asian studies series; 8.

Subjects: Sissons, D. C. S. (David Carlisle Stanley), 1925-2006.

Emigration and immigration.

International trade.

Australia--Relations--Japan--History.

Japan--Relations--Australia--History.

Other Creators/Contributors:

Stockwin, J. A. A. (James Arthur Ainscow), 1935- editor.

Tamura, Keiko, 1955- editor.

All rights reserved. No part of this publication may be reproduced, stored in a retrieval system or transmitted in any form or by any means, electronic, mechanical, photocopying or otherwise, without the prior permission of the publisher.

Cover design and layout by ANU Press

This edition (C) 2016 ANU Press 


\section{Contents}

Acknowledgements . . . . . . . . . . . . . . . . . . . vii

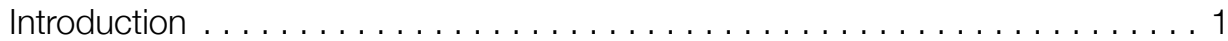

Arthur Stockwin

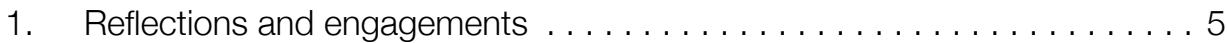

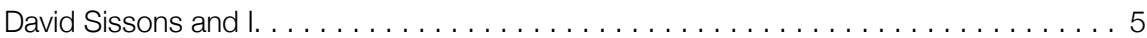

Fukui Haruhiro

My reminiscences of David Sissons. . . . . . . . . . . . . . . . . . . 9

Okudaira Yasuhiro

David Sissons, my doctoral supervisor and mentor . . . . . . . . . . . 16

Arthur Stockwin

David Sissons and Shiba Ryōtarō . . . . . . . . . . . . . . . . . . . . . . . . . . . 25

Watanabe Akio

David Sissons, his methods of supervision and the adventures of one

of his students: A memoir of the days when the world was wide $\ldots \ldots \ldots \ldots \ldots 28$

John Welfield

2. Australian-Japanese relations: The first phase $1859-1891 \ldots \ldots \ldots \ldots$. . . 41

3. The Lady Rowena and the Eamont: The 19th century . . . . . . . . . . . . 87

4. The Japanese in the Australian pearling industry. . . . . . . . . . . . . . 97

5. Japanese in the Northern Territory, 1884-1902. . . . . . . . . . . . . . . 119

6. Karayuki-san: Japanese prostitutes in Australia, 1887-1916 (I \& II) . . . . 171

7. Immigration in Australian-Japanese relations, 1871-1971 . . . . . . . . 209

8. An immigrant family . . . . . . . . . . . . . . . . . . . . . . 231

9. Private diplomacy in the 1936 trade dispute with Japan . . . . . . . . . 247

10. Manchester v. Japan: The imperial background of the Australian trade diversion dispute with Japan, 1936 . . . . . . . . . . . . . . . . 267

11. Correspondence on the trade diversion episode . . . . . . . . . . . . . . 293

12. Japan and the Australian wool industry, 1868-1936 . . . . . . . . . . 311

13. James Murdoch (1856-1921): Historian, teacher and much else besides. 



\section{Acknowledgements}

This is the first of two volumes of the work of David Sissons, historian of relations between Australia and Japan. The second volume is in preparation and will cover his writings on the War in the Pacific and Australian war crimes trials on south Pacific islands, for some of which he interpreted. In preparing these two volumes devoted to the work of David Sissons, we are above all indebted to David's widow Bronwen, who has supported this project from the outset and has been an invaluable source of information about David, and insights into his career, his passions and concerns, as well as his personality and temperament. We are also grateful to their son, Hilary, who helped with access to relevant computer files; and their daughters, Meredith and Miranda, for their understanding and support for this project.

We thank Dr Pam Oliver, who gave us valuable advice at an early stage of this project and Drs Yuriko Nagata and Lorna Kaino for their comments and encouragement. We are grateful to Dr Craig Reynolds for his enthusiasm about making David's work on Australia-Japan relations more widely known, and to the staff at ANU Press for their hard work in the production process.

David's important work on cryptography was published by ANU Press in 2013 as Breaking Japanese Diplomatic Codes: David Sissons and D Special Section during the Second World War (Desmond Ball and Keiko Tamura, eds). That volume may be considered in a sense an integral part of our attempt to make David's historical and political research more generally available. We have profited from the insights given in conversations with Professor Desmond Ball concerning the broader aspects of David's concern with relations between Japan and Australia, especially relating to the tragic period of the relationship that ended in 1945. Sadly Professor Ball died after a long illness on 12 October 2016 at the age of 69 .

We also wish to acknowledge the kindness of David's former doctoral students, Professors Haruhiko Fukui, Akio Watanabe and John Welfield, and his great friend the late Professor Yasuhiro Okudaira, in writing of their memories of him.

We are grateful to Dr Miyume Tanji for providing research assistance in the shape of photographing a portion of the documents in the 60 boxes of materials that David placed in the National Library of Australia. These are items that we selected for inclusion in this book. Support and help provided by the National Library staff 
who knew David, including Ms Mary Gosling, Ms Amelia McKenzie, Ms Karen Johnson and Ms Mayumi Shinozaki, are greatly appreciated. We should like also to thank Peter and Margaret Janssens for their friendship and hospitality to Arthur Stockwin during his several stays in Canberra working on this project.

We are grateful for reprint permissions that were generously granted to us, and we thank the State Library of Queensland, the State Library of South Australia, Transactions of the Asiatic Society of Japan editorial board, and the publishers Taylor \& Francis and Wiley. We also acknowledge the work of digitising the mostly pre-digital (and, in some cases, hard to read) typescripts provided by Sanarosu and high-quality scanning work of the National Library's Copy Direct section and the ANU University Printing Service. We would like to acknowledge and thank the ANU Publication Subsidy Committee for a grant to assist towards the copyediting, so ably done by Ms Justine Molony.

Above all, we give our profound thanks to our sadly departed friend and mentor, David Sissons, for the monumental work of meticulous scholarship that he accomplished in the course of his career, which brings us close to a definitive understanding of the structures, personalities and sometimes conflicted trajectories of the relationship between two peoples that share that part of the globe bounded by the western Pacific.

Arthur Stockwin and Keiko Tamura 


\title{
Introduction
}

\author{
Arthur Stockwin
}

David Sissons was born on 21 December 1925 and attended Scotch College in Melbourne, from which he matriculated in 1942 . He spent one year at University of Melbourne, reading classics, before being called up for active service on 27 June 1944, aged 18. He was at a training camp at Cowra, New South Wales, at the time of the mass breakout of Japanese prisoners from the nearby prisoner-of-war camp on 5 August, and was involved in rounding up those who had escaped. After eight weeks at the training camp, he was sent for seven months of Japanese-language training and, between April and September 1945, he worked as a linguist/ translator in the D Special (Diplomatic Special) Section, a highly secret unit of the Australian Military Force HQ in Melbourne, involved in cryptographic decoding. Little or nothing was known about the D Special Section until, in the 1980s, David and Professor Desmond Ball, with others, began to unearth and publish information relating to it. ${ }^{1}$

In November 1945 David was posted to Morotai, on which was located the headquarters of the Australian element of the Allied Translator and Interpreter Section. Morotai and neighbouring islands were the scene of Australian field trials of Japanese officers and men accused of war crimes and, in February 1946, David served as a defence interpreter for three trials. ${ }^{2}$ In Morotai, he also had opportunities to mix with surrendered Japanese troops and to improve his proficiency in their language and culture. A trial in which he was involved resulted in a Japanese officer, Captain Kato, being found guilty of the murder of an Australian prisoner of war and executed. David believed the trial process to have been fair, however, he judged

1 For a comprehensive account of their findings, see Desmond Ball \& Keiko Tamura (eds), Breaking Japanese Diplomati Codes: David Sissons and D Special Section during the Second World War (Canberra: ANU E Press, 2013). 2 Georgina Fitzpatrick, 'War crimes trials: "Victor's Justice" and Australian military justice in the aftermath of the Second World War', in Kevin Jon Heller \& Gerry Simpson (eds), Histories of War Crimes Trials (Oxford University Press, 2013), p. 329. 
the death penalty as excessive in light of subsequent judgements in later trials. ${ }^{3}$ No doubt it was this experience that stimulated his later determination to research issues of atrocities and war crimes trials, and he regarded his work in this area as being among the most important of his research career. The extent of his concern with issues of justice in these trials is shown by his anguish at the condemnation of an officer (Katayama) who had, under orders, executed a Canadian officer but who was, in David's opinion, essentially a man of moral rectitude.

David did not confine his investigations to atrocities that were allegedly committed by Japanese military personnel, but also applied his sharp analytical approach to possible ill-treatment by Australian armed forces of Japanese prisoners in the islands. The depth of David's commitment to understanding such situations is graphically indicated by a long letter (see volume 2 , in preparation) to his brother, Hubert, a distinguished physician, concerning the effects on prisoners of heat stroke and related illnesses. Hubert wrote back telling David, in effect, that David now understood more about the subject than he did.

In March 1946, David was posted to the British Commonwealth Force in the Allied Occupation of Japan, based in Ube, western Japan, where he once again acted as interpreter. He was also asked to teach English in a school and was part of the Occupation effort to propagate the values of democracy. He regarded his first time of arriving in Japan as one of the most exciting events of his life. Ube was near to Hiroshima, and so he visited that city and saw the devastation caused by atomic bombing. He noted, however, that the main railway station was functioning and the trams appeared to be running normally. When asked towards the end of his life how he regarded the destruction of Hiroshima, he replied that at the time he was perhaps not so sensitive to the suffering caused, but that he now regarded it as a war crime. He remained in Japan until the early months of 1947 , when he was demobilised and returned to the University of Melbourne to complete his undergraduate degree. In 1950 he graduated with a BA Honours and, between 1951 and 1955, was a tutor in international relations at Melbourne, as well as a research officer for the Australian Institute of International Affairs. In 1956 he was working as a research assistant for Professor W Macmahon Ball, then head of Political Science at the University of Melbourne, who exerted a strong influence on him and convinced him to move into the field of political science. In 1956 he graduated with a Masters in political science from Melbourne, having written

3 David Sissons, interview, 15 August 2003, in Australians at War Film Archive, Archive number 653, Part 3/9 27' 30" to 34' 00"; australiansatwarfilmarchive.unsw.edu.au/archive/653-david-siss ons?destination =aXR1bXNfcGVyX3BhZ2Uma2V5d29yZHM9c21zc29ucyZvcD1TZWFyY2g mZm9ybV9idW1sZF9pZD1 mb3JtLXhHUEpwWjFBT2FodEF2OHM5MFh6dFZmbEgxbz FPRWFZVUZIRWo1bXZfeGcmZm9ybV9pZD1zZWFyY2hfYmxvY2tfZm9ybQ (accessed 14 March 2016). 
a thesis entitled 'Attitudes to Japan and defence, 1890-1923'. This is said to be the most consulted unpublished thesis on Australian history in existence. It is, however, available online. ${ }^{4}$

Between 1956 and 1960, David was supported by a Saionji Memorial Scholarship to conduct research in Tokyo on issues of contemporary Japanese politics in what was then a highly contested political scene. His article 'The pacifist clause of the Japanese constitution', published in International Affairs in 1961, was a pioneering piece of original research on this enduring and still controversial issue.

In 1961 he was appointed to a research fellowship in the Department of International Relations at The Australian National University (ANU) in Canberra, and was promoted to a full fellowship in 1965 . He remained at ANU until his retirement in 1990 and, from the late 1960s, redirected his attention from contemporary Japanese political matters towards issues in the history of relations between Australia and Japan. David maintained this historical interest following his research for his Masters, and it became the principal focus of his study.

Following his retirement from ANU in 1990, David took up a three-year post to establish an Australian Studies Centre at Hiroshima Shūdō University in western Japan. Returning to Canberra for what was technically his retirement, he pursued his archival researches with vigour and persistence across a wide range of aspects of the Japan-Australia relationship.

David Sissons was, in many ways, a shy man, whose shyness concealed a mind of great subtlety and historical understanding. He was also meticulous in everything he did, to the point where his innate perfectionism inhibited him from publishing much of his research because he was not satisfied that he had fully covered every aspect of the subject under review. After his retirement, he gathered together his research materials, including both published and many unpublished articles, as well as voluminous correspondence with archivists and participants in the events he was analysing, carefully organised them and placed them in 60 capacious boxes at the National Library of Australia Manuscripts Collection in Canberra. When he was diagnosed with what was to be his final illness, he added more research material to the boxes at the National Library, and made sure that his work was carefully ordered according to categories of research. Librarians there remember him visiting the library for this purpose in a wheelchair. He died on 17 October 2006.

4 The thesis is available online from the University of Melbourne Library: minerva-access.unimelb.edu.au/ handle/11343/38791. 
Using David's archive, it has been our task as editors of these two volumes to bring into the public domain the outstanding research output of this most important historian of Australia, Japan, and the complex interactions between them since the 19 th century.

This volume begins with five essays, one written by a Japanese colleague of David Sissons and the remaining four by doctoral students that he supervised at ANU, reflecting on their engagements with him. We have selected seminal papers that he wrote, both published and unpublished, on Australia-Japan relations, and these constitute the remaining chapters. The topics he covered are diverse, but his meticulous and detailed research is evident in every chapter, and readers will appreciate his approach of examining historical incidents from both Australian and Japanese perspectives.

The second volume of David Sissons' work is in preparation and will cover his research on the Pacific War and Australian war crimes trials in the south Pacific. These two volumes will be a companion to Desmond Ball and Keiko Tamura (eds), Breaking Japanese Diplomatic Codes: David Sissons and D Special Section during the Second World War (2013). 


\title{
1 \\ Reflections and engagements
}

\author{
Fukui Haruhiko, Okudaira Yasuhiro, Arthur Stockwin, \\ Watanabe Akio, John Welfield
}

\section{David Sissons and I}

\section{Fukui Haruhiro}

The late David Sissons was my $\mathrm{PhD}$ adviser and supervised the preparation of my doctoral dissertation at The Australian National University (ANU) from mid1964 to mid-1967. Yet, my memories of him are fragmentary and blurry. I wish I had kept a diary during that period, but I didn't. My following remarks are, therefore, based on my faded and unreliable memory. And, to be honest, David was and remains to this day largely a mystery and enigma to me.

To begin with, prior to my arrival in Canberra in the early summer of 1964 as his newest ward, I had known somebody I assumed was him only as one of a dozen translators of the selected works of the University of Tokyo political theorist, the late Maruyama Masao, which were published by Oxford University Press in the early 1960s. In the widely publicised collection of Maruyama's works Thought and Behaviour in Modern Japanese Politics the translator of an article entitled 'Some problems of political power' was named David Sisson. I am not aware of any other instance of my Sissons signing his family name without the last 's'. It is unlikely that he deliberately signed himself as 'David Sisson' in an important publication. On the other hand, I know of no other potential translator of Maruyama's works with a similar name and must assume that my Sissons either mispelled his own name or somebody else did. This scenario, however, is itself an enigma to me, because he was normally extremely careful, even fussy, about minute details, including grammar and spellings, in his own writings and reviews of others'. 
As a graduate student at the University of Tokyo in the autumn of 1960, I worked as a research assistant for the eminent political scientist Robert E Ward. I continued in this role as a Fulbright exchange graduate student at the University of Michigan from the fall of 1961 to the summer of 1963.I then returned to Tokyo with Ward to assist in his research on the postwar Allied occupation of Japan. It may well have been he who first heard about and brought to my attention the ANU scholarship program. In any case, I successfully applied for a scholarship with Ward's strong personal support and letter of recommendation. Conscious of my work as Ward's research assistant and record as a graduate student at an eminent American university, I arrived in Canberra in late June 1964 as an older-thanusual and very cocky 29-year-old on a three-year doctoral student scholarship. I spent the next few years with my wife and our infant son, who was soon joined by another, living in the married student housing at ANU and commuting every weekday to my study in the Department of International Relations of the ANU Research School of Pacific Studies (RSPS). I shared this modest room with another Japanese graduate student, Watanabe Akio, who enrolled in the same scholarship program a year or so earlier. My routine continued throughout the three-year period, except for about three months in early 1966, when I conducted fieldwork in Japan.

One incident that broke the monotony of my routine, which I remember vividly and with a sting of remorse, was a short but sharp verbal exchange between David and myself during lunch in the dining hall of University House at ANU. Both Watanabe and I usually had a brown-bag lunch in our study and went to the dining hall only on special occasions. I don't remember what the special occasion was on the day the incident occurred, but it arose from David's intervention in our conversation in Japanese, which was a stern rebuke against our use of Japanese instead of English. He had probably told us that we should make it a rule to speak English all the time on the university campus, if not at home, but we habitually broke the rule. In any event, we were caught red-handed and, rather than apologising, I retorted that I saw nothing wrong about two Japanese nationals speaking Japanese to each other and, worse still, added a totally gratuitous remark to the effect that I had not come to ANU to learn English. David was only trying to help us improve our obviously and grievously inadequate command of English. Watanabe was mature enough to understand that and quietly listened to his admonition, but I was too immature and brash to follow his example. The enigmatic aspect of this incident, however, was that David quickly quit the fight and didn't mention the English-only rule again during the rest of my time at ANU. This incident, among other things, gave me a lasting impression that, despite his occasionally disciplinarian demeanor, he was a fundamentally gentle and shy person - perhaps even a born pacifist. 
I found a somewhat similar paradox in his attitude toward money. He was an extremely thrifty person. I remember buying and sending him a copy of the Asabi Nenkan (yearbook) from Tokyo during my fieldwork trip to Japan. At his request, I sent it by airmail, the postage for which cost more than the yearbook itself. Upon my return to Canberra, I found him visibly distressed by the price of the postage that I charged him against the receipt. I did think it somewhat absurd to pay more for sending something than for the thing sent, but I had assumed he had known the cost all along and was surprised by his reaction. I was also extremely thrifty at that time, living literally week by week on a meagre scholarship-based stipend paid on a biweekly basis. My thrift, however, was a product of sheer necessity and may be described as situational or even opportunistic. If I could afford to splurge, I would. David's thrift, on the other hand, seemed fundamental and principled, less to do with what he could afford to spend on something than what he should spend on it. I came to believe that it was based on faith and commitment, whether religious or philosophical, deserving of my respect.

David was remarkably effective in supervising my doctoral work in general and preparation of my dissertation in particular. Throughout my stay in Canberra, I was somehow made to feel constantly under his watch without, however, much actual physical contact. In fact, I saw and consulted with him no more frequently than once a week at most throughout the three-year period. Nonetheless, he included a preliminary draft of a section of my dissertation, entitled 'The associational basis of decision-making in the Liberal Democratic Party', in the RSPS's in-house publication, Papers on Modern Japan, edited by him and published in 1965, less than a year after I arrived in Canberra. This was my first scholarly publication, and it was followed three years later by a draft of another section of my dissertation, entitled 'The Liberal-Democratic party and constitutional revision', in the next (1968) issue of the same in-house publication. A slightly revised version of the latter article was published in the same year in the Washington Law Review, under the title 'Twenty years of revisionism', which was in turn reprinted in the book The Constitution of Japan: Its First Twenty Years, 1947-67 (Dan F Henderson, ed.).

I cannot pinpoint the exact date when I began drafting the text of my dissertation, but it must have been only a few months after I returned to Canberra from my fieldwork in Japan in the spring of 1966, considering that my scholarship support was to expire at the end of June 1967. I do, however, remember how I proceeded with the preparation of the drafts: David ordered that I prepare and deliver to him the draft of each chapter each fortnight; I did so, and he would quickly go over it, probably jotting down a few comments in the margins; he would then send it over to Dr Arthur Stockwin, who had completed his doctoral work under David's supervision a few years before and was teaching in the undergraduate division at ANU at the time, for a detailed and thorough editorial job; and, finally, he would return it to me, more for my information than for my approval. My original draft was obviously full of grammatical errors and syntactic irregularities. It was therefore David's misfortune to have served as my dissertation adviser-cum-editor. 
Even more unfortunate was Arthur Stockwin's luck to have been where he was at the time. My dissertation would neither have been written the way it was written, nor finished when it was finished, but for the presence and help of these two individuals.

Thanks to their help, I completed and submitted my dissertation before my scholarship period ended in June 1967. I had yet to sit for an oral examination to defend my dissertation, however, and David set up an exceptionally distinguished examination panel, composed of Professors Nobutaka Ike (Stanford), Ronald Dore (London School of Economics) and Colin Hughes (University of Queensland). It took a few more months to send by mail a copy of the dissertation to each member of the panel and have Ike and Dore send their opinions to Hughes, also by mail, a period I had to endure without scholarship support. To my pleasant surprise, David negotiated for me a one-semester temporary lecturer appointment with the history department of the University of Adelaide.

Following the end of my appointment at Adelaide, I sat for and passed the oral defence of my dissertation in November 1967. No sooner had I done so than David sent an edited copy of my dissertation to ANU Press and had it accepted for publication. Meanwhile, I had a job offer - a tenure-track assistant professor position - from the Department of Political Science at the University of California, Santa Barbara (UCSB), which I accepted. David suggested at the time that I should consider staying at ANU as a research fellow and write another book or two before moving to another university in the United States or elsewhere. As usual, however, he brought it up only once and never returned to the subject, and I moved to and began teaching at UCSB in the winter of 1968.

As soon as he realised that I was headed to UCSB against his advice, he arranged, again without my knowledge, simultaneous co-publication of my dissertation by ANU and UC presses. As a result, the dissertation was published in 1970 under the imprints of the two university presses as Party in Power: The Japanese Liberal Democrats and Policy-making. About the same time, I was urged by a Japanese political scientist, the late Seki Hiroharu, then of the University of Tokyo Institute of Oriental Culture, to translate the manuscript into Japanese for publication in Japan as well. I promptly undertook and finished the translation and had the result published by a well-established, though relatively unknown, publishing house in Tokyo, Fukumura Shuppan. To my great and pleasant surprise, this edition was reviewed favourably in all major Japanese newspapers and sold exceptionally well for an academic work. While Professor Seki, rather than David, was directly responsible for this development in my academic career, it was obviously built on the foundation already laid by David and Arthur.

A decade after I left ANU upon the completion of my doctoral work, I returned there as a visiting fellow in the RSPS Department of International Relations to work with Arthur on a joint research project on Australian-Japanese relations 
in the early to mid-1970s, with special attention to the twists and turns in the negotiations for the Basic Treaty of Friendship and Cooperation under the governments of Gough Whitlam (later Malcolm Fraser) and Tanaka Kakuei (later Miki Takeo). I spent the last half of 1976 in the department and am sure to have met David at least several times during the period. Yet, I don't remember any specific detail of personal contact with him then, perhaps because we were both very busy with our own work but, more likely, due to my poor memory.

To my shame, the same applies to my last meeting with him a decade and a half later. This happened sometime in the early 1990s in Tokyo. I was on a short research trip and he was a visiting professor at Hiroshima Shūdō University. We ran into each other at the International House of Japan in Tokyo and shared lunch. We talked for some time, mainly about his research on the origins of early Japanese migration to Australia and mine on the structure of political patronage and corruption in contemporary Japan. To my great embarrassment and regret, however, my memory of this last meeting with him is just as foggy and insubstantial as those of our earlier contacts back in Canberra in the 1960s.

Despite this impenetrable fog that envelopes and clouds my image of him, I know with absolute certainty two things about him and our relationship. One is that he launched me on my lifelong professional career. He, and he alone, was responsible for the timely completion of my doctoral dissertation at ANU and its virtually instant publication by two university presses, which in turn promptly earned me the tenure-track teaching position at UCSB and ensured my job security for the rest of my professional working life. The other is that he did this with total selflessness, neither asking for nor receiving anything in return, at least from me. At a more general and collective level, the government and people of Australia at the time treated foreign scholarship students with what strikes me as an extraordinary manifestation of transnational altruism and generosity. In such a context, he may have been the embodiment of the policy of his government and the sentiment of his people. That, however, detracts nothing from the huge personal debt of gratitude I owe to him. I only wish I had thanked him more appropriately when it was still possible to do so.

\section{My reminiscences of David Sissons}

\section{Okudaira Yasuhiro}

David and I met for the first time in 1956. He was conscripted towards the end of the Pacific War and was serving in uniform. After Japan's defeat, he was stationed at Iwakuni (Yamaguchi prefecture) as a member of the British Commonwealth Occupation Force and remained in Japan for about two years. We met, however, during his second period of residence in Japan. 
In everything that he did, David was temperamentally modest and circumspect. While in military service, he underwent training in Japanese, and apparently had experience as an interpreter, but I think that in his relationship with me there were more occasions when we spoke English than when we spoke Japanese. As for me, I had absolutely no skill in English conversation, and so David was probably too shy to use Japanese.

In 1956 David came to Japan as recipient of the Saionji Kinmochi Scholarship, and enrolled as a researcher at the Institute of Social Science of Tokyo University. At that time (1953-58) I was a research assistant at the same institute. We worked together in the same university office, and were in the habit of taking lunch and tea together, and we talked about everything under the sun.

Among our discussions, he told me how as a youth he had walked in the mountains near where he lived, taking several days at a time, on his own and without meeting a soul. This struck me as remarkable and impressive. When he became tired on these walks, he would always look out for a shepherd's hut, these huts were usually left unlocked, and appropriate eating utensils were provided for anyone to use. The fact that private shepherds' huts were also provided for public use struck me as representing the 'Waltzing Matilda' spirit of Australia.

Talk of mountain walks brings to mind a time we went skiing together in winter to Nozawa onsen (hot springs) in Nagano prefecture. Neither of us were particularly good skiers but, as soon as we reached the onsen, he found a ski instructor and entered into a regime of studying the art of skiing. I am not skilful, but am content if I can somehow slide down the slopes by my own efforts, but David was the deliberate type who had to cope with skiing by learning the skill steadily, step by step.

The inn where we were staying at Nozawa onsen was pure Japanese style, and included a splendid bath. Since I yielded to nobody in my enthusiasm for onsen, over the days that we were staying at that inn I used to go into the baths any number of times day and night. I don't know how it is nowadays, but at that time my kind of onsen mania was nothing out of the ordinary. But, since David had no connection with this onsen 'culture', he seems to have regarded my frequent bathing as a trifle surprising. I remember that he said: 'The Roman Emperor Nero liked bathing in hot springs so much that he ruined himself as well as the country.'

Once, at Tokyo University, David and I had finished our lunch and were returning to the university when, near to Akamon (the Red Gate), we encountered the wellknown Professor Maruyama Masao walking with somebody else on the other 
side of the road. Something that David said on that occasion struck me as most interesting and has remained in my memory: 'Maruyama has a fine face, doesn't he? He ought to be a Kabuki actor.'

One day, David came along with a young official of the British Embassy and myself to have lunch at a famous eel restaurant at the top of Masago Hill (today that whole area has changed and the restaurant no longer exists). I was surprised when the official arrived in a splendid car, with a Japanese chauffeur. During the meal we talked about all sorts of things and, in the course of the conversation, David suddenly said to me 'His English and my English differ a good deal, don't they?' David's impression was that the embassy official's English was the English of Oxford and Cambridge, whereas his English was that of Australia. I replied that I didn't think there was a great deal of difference.

Some years later, I spent a couple of years at the University of Pennsylvania Law School and, as a result, inevitably my usage became Americanised, but I feel sure that my English is basically the English that David taught me.

I was studying the US constitution and administrative law at the University of Pennsylvania between the autumn of 1959 and the end of spring 1961. In the meantime, about halfway through 1960, David came to the University of Washington, Seattle, and took the opportunity to survey Japanese studies (Japanology) in the United States. One day a letter came from David, saying that he was soon going to return to Australia but that, before going home, he would like to meet up with us on the East Coast. When he arrived at Philadelphia airport, I met him with a car, but I was new to America and had only just got a driving licence. My car was a venerable Chevrolet from the early 1950s that I had just received from a friend returning home to Finland, and even now I have feelings of nostalgia about it.

My wife and I were living a life of poverty with everything in a single room. Since there was only one bed, we took the mattress off the bed and we slept on that, while David slept on the bed without its mattress. It was better than camping outside and, anyhow, it was only for three days, so nobody felt put out by these arrangements.

The problem was the next morning. Early in the morning a cold front came through and created a blizzard. Our first plan was that morning to drive the car to New York City. We brushed off the snow and tried to start the car, but the battery was flat and the car would not start. After charging the battery at a nearby gasoline station, we managed to get the car started. Luckily it was fitted with snow tyres, and there was no problem in driving on the snow. 
To tell the truth, it has completely slipped my memory whether or not the three of us actually got to Manhattan. For me, only just licensed to drive, the battery problem first of all and then the sudden blizzard scared me out of my wits. David, however, reacted entirely differently, staying calm and collected, and methodically helping to sort things out.

In 1961 David was appointed to a position in the Department of International Relations, Research School of Pacific Studies, at The Australian National University. In early summer of the same year, we returned to Japan, but my appointment was in the Faculty of Law of Nagoya University. Soon after I moved to Nagoya, around 1962, David returned to Tokyo, and for a year stayed and collected research materials. I was delighted that once during his stay he came to see us in Nagoya. It was summer, and thus the season to enjoy the regional specialty of cormorant fishing on the Nagara River in Gifu City. For both of us this was our first experience of going to see the spectacle of cormorant fishing. In ancient times, cormorant fishing meant using these birds to catch fish. Today it means reviving what used to be a method of fishing as a performance for sightseers. To create an atmosphere in which men clad in ancient costume actually use cormorants time and again as a fishing spectacle, and call it 'cormorant fishing', is a great performance at which tourists enjoy dinner parties on the river bank, washed down with saké. For me this is a kind of ceremony or pattern, whereby what has been done since ancient times is revived, and I take it as example of cultural continuity.

This was my first and last experience of cormorant fishing, and I think it was the same for David.

While I was working at Nagoya University, David, still in Tokyo, wrote me a letter: 'At present a retired judge of the Tasmanian High Court is in Tokyo. Do you think you could manage to get an invitation for him to lecture from the Nagoya Lawyers Association?' (I now cannot for the life of me remember the name of the judge, so I will just refer to him as 'the judge').

Based on this written request from David, through the good offices of a senior professor in the Law Faculty of Nagoya University, I entered into negotiations with the Nagoya Lawyers Association to make arrangements for a lecture (and to provide expenses associated with the invitation). Without difficulty, I received the go-ahead from the association, and the judge's lecture meeting duly took place. My memory of the lecture has faded, but I think it was a presentation about law in general, focusing on the rule of law. I undertook the interpretation and, being in my early 30s, even though my interpreting was inexpert, I did it off the cuff and without too much fuss, but when I think of it now it sends a shiver down my spine. 
The accommodation that the association prepared for the judge was a fully Japanesestyle inn called the Inuyama at the famous Inuyama Castle on the outskirts of Nagoya. It was not a small inn, but nobody on the staff spoke English. For my part, thinking that this would be an interesting experience for the judge, I asked one of the managers to treat him as he would a Japanese person, but I showed the manager the judge's schedule for returning to Tokyo the next day, and asked him to stick to it. Then without taking dinner with the judge, I parted from him.

Later, David told me that the 'judge' had been his senior officer during his military service. In any case, he gave the impression of being a military type of person. (It is strange that David hardly opened up at all about his period in the military. He spoke a very little about his experiences on duty near the Cowra prisoner-ofwar camp, as well as of his service after the war at the Iwakuni military base of the British Commonwealth Occupation Force, and very occasionally added other stories to these, but that is all.)

When it was I am unable to remember, but while both of us were in Tokyo, David suddenly came out with the statement: 'Tomorrow, I am going to cast an absentee vote.' I did not understand what this was all about. Since in Japan at that time, at the level of national elections, no system of absentee voting by Japanese citizens resident abroad existed, I could not work out what this might actually mean.

In Japan, the right for Japanese living abroad to vote in elections for the House of Representatives and the House of Councillors was first granted by a revision of the election law in 2005. By contrast, in the case of Australia, perhaps taking the United Kingdom as a model, I think an absentee voting system was established at almost the same time as the federal government was established in 1901. This made me realise that there were many differences among the ways in which democracy was accepted in Japan and Australia,

After living for around five years in Nagoya, in 1966 we (the Okudairas) returned to Tokyo. I returned to work in my old nest, the Institute of Social Science at Tokyo University. One day in 1969 a letter came from David, sounding me out about whether I would like to spend a year in Canberra together with my family. This invitation was really wonderful, and I was delighted to accept. Thus for my wife and me, together with our son and daughter, this was a great undertaking.

ANU provided for our family one of the single-storey houses scattered between the campus and Lake Burley Griffin. I still remember that our daughter, who was in a lower grade of primary school, said delightedly: 'Wow! This is the first time since I was born that I have lived in a detached house!' It remains in my memory that David and Bronwen had filled our refrigerator with all sorts of food items 
ready to use, and I do not forget this. From then on for a year our family received the warmest treatment from them in all sorts of ways, so that we could enjoy life in Canberra to the full.

As for me, rather than making Australia itself the object of my research, I thought I should seek to understand the country in a broad and general way. As the least courtesy from a visitor to a country that had treated us so generously, I thought I should attain a broad understanding of the founding history of this country, and so I read general histories. One thing that I learned in studying this way was that Japan looked at the world with a focus on Britain, the United States and Europe, but had Australia in its sights hardly at all. By contrast, Australian people were concerned with what was going on behind the scenes in Japan, and had tended to view Japan as a potential enemy. There seems to have been a feeling of danger that Japan, which was exercising control over China and Korea, might turn its sights onto Australia; Australians were deeply suspicious of what lay behind the Greater Japanese Empire, and were watching it very closely. To learn about this historical environment was for me a big surprise. For me this was in truth a precious education in history.

While I was at ANU, David was working hard to write a piece on the Japanese constitution. But for me, while I was staying on purpose in Australia, I had no desire to write about things in Japan, since I thought that would be a waste of time. Whereas I was negative towards this, David's advice was very positive. At that time (the early 1970s), the number of articles in English about the Japanese constitution was extremely small, and I think he wanted to get me to fill this gap. In the end, following David's advice, I wrote a short article about it. This was 'The Japanese Supreme Court: its organisation and function. ${ }^{1}$ Since my ability to express myself in English was limited, the article emerged only after immense assistance from David.

David gave great consideration to make sure that my stay in Australia should be fruitful. One of the things he did was to organise dinner parties and so on, so that I could meet some of the most distinguished legal scholars in the land. The first of these that I should mention was Sir Kenneth Bailey, who should probably be regarded as the most active Australian lawyer on the world stage. Despite his fame, his temperament was genial and amiable, and of course he was master of a wide range of issues. I remember that I met him in 1971 and, since he died the following year, I had the immense good fortune to meet him when he had not long to live.

1 LAWASLA, vol. 3, no. 1 (April 1972), p. 67. 
More than 20 years after that time,I had occasion to take an interest in the abdication of the British King Edward VIII. One of the many issues of constitutional procedure involved was that King Edward was not only king of the United Kingdom, but was also king of the British dominions beyond the sea, as well as Emperor of India, giving rise to a complexity of titles. Recognition of his abdication was not just a question of having everyone accept the UK example. Many students of public law wrote all sorts of articles on this problem. I have not collected these articles, but there was a truly exceptional one by Bailey (then a professor in the University of Melbourne Law School, I am afraid I lack the citation at present). Sir Kenneth in his younger days stood out from the crowd.

Another person that I was able to meet through David was Professor Geoffrey Sawer of the ANU. Not only was he at the summit of Australian constitutional and administrative law studies, but he was also famous as a theorist and commentator in the broad sphere of politics and administration, including international politics. In 1950, when ANU was being established, he moved from the Melbourne University Law School to become one of the founding members of ANU.

Sawer, while he was at Melbourne University, had been one of the disciples of Bailey, who told me: 'Sawer was a splendid and incomparable law school teacher, and was loved by the students at the Melbourne Law School. When he moved to ANU, he was constrained to act more as a researcher than as a teacher, and I am inclined to think that that was Australia's loss.'

After a year and a half in Australia, I returned to Japan. After returning home I have never, even till now, deliberately continued studying the Australian constitution and administrative law. I don't know a great deal about contemporary Australian constitutional development. Even so, reform of the Australian public law system in the second half of the 20th century is impressive. In particular, administrative law reform and the development of the freedom of information system contain outstanding features. Even though the constitution of the Commonwealth of Australia lacks a bill of rights, it is most enviable that constitutional democracy based on an administrative investigation system along US lines has put down roots and continues to develop. In my opinion, behind this establishment of constitutional democracy, lay the theoretical work conducted by Bailey and Sawer. The fact that I have been able to arrive at this understanding undoubtedly owes everything to David.

Finally, I would like to mention a particular personality that I was able to meet with David's help. This was Professor William Macmahon Ball, who had been David's academic supervisor while he was studying at the University of Melbourne. One day in 1971, when I was able to investigate materials relating to the 
administration of broadcasting at the Melbourne headquarters of the Australian Broadcasting Commission (ABC) (an arrangement that David had set up for me) he also fixed up a meeting with Ball.

Ball was, for the Japanese, an outstanding personality during the Occupation (1945-52) as the British Commonwealth representative on the Allied Council for Japan, which had been set up in relation to the postwar management of Japan. He was somebody who might even be described as a transcendent being. When I visited his house, he had left official duties behind and was leading a life of comfortable retirement, in a chalet deep in the mountains. In order to take me from central Melbourne to this remote mountain chalet, the office of the $\mathrm{ABC}$ provided a car and driver (this was undoubtedly something that David had arranged on my behalf).

To the image that I had of Ball was attached to some extent the description of an imperious individual, but in reality he was affable and friendly. Since this was a meeting for which I had not prepared a set of questions beforehand, the interview ended up as a discursive evaluation of Japan in general terms. Indeed, I now realise to my regret that I should have asked him to speak about the position he took as British Commonwealth representative about whether or not to retain the Emperor.

I think that at this point I should end this tribute to David. His last stay in Japan was after he retired from ANU at the beginning of the 1990s and came as a professor of Hiroshima Shūdō University. Just before he left for Hiroshima we had dinner together in Tokyo and, for the two of us, this was our final meeting. In fact, one of David's first articles was on the so-called 'pacifist clause' (article 9) of the Japanese constitution. I knew this article, but had lost the citation, and I intended to ask him for it, but then I found I had lost the chance of doing so. ${ }^{2}$

\section{David Sissons, my doctoral supervisor and mentor}

\section{Arthur Stockwin}

David Sissons was the supervisor of my doctoral thesis at The Australian National University between 1961 and 1965. I owe him an enormous debt of gratitude for putting me on the right path in researching and thinking about Japan and its politics. I will go so far as to say that my subsequent career depended crucially on the supervision he gave me over those early years. He was not an easy

2 Professor Okudaira died in January 2015. 
supervisor and, at times, I thought he was being unreasonably demanding, but that was in the end a boon since, at the time, I lacked not only research experience but also the discipline needed to successfully complete a doctoral course.

David only took over my supervision about a year after my wife Audrey and I arrived in Canberra from the United Kingdom for me to take up a $\mathrm{PhD}$ scholarship. Having spent 18 months in the mid-1950s on an intensive Russian course at the Joint Services School of Languages, successively at Bodmin, Cambridge and Crail, and having graduated in Philosophy, Politics and Economics at the University of Oxford, I proposed in my application to ANU that I would write a thesis on Soviet foreign policy in Asia. No doubt there was an element of grantsmanship in this proposal, but in any case when I arrived I found that there was nobody at ANU with the right sort of expertise to supervise a thesis in that area. At the time, reliable information from the Soviet Union was hard to come by but, in pre-researching Soviet foreign policy in East Asia, I became interested in Japan, so that I began to look at the foreign policy of Japan and, more generally, find out what I could about that country. I remember spending hours immersed in successive volumes of Keesings Contemporary Archives following developments in Japanese politics and foreign policy since the war. I also enrolled in first-, and then second-, year Japanese at the Canberra University College, and also did conversation classes with various Japanese graduate students at ANU. But when I started I doubt if I knew more about Japan than I did about Argentina, and the sum of my knowledge about Argentina was Eva Peron and Fray Bentos beef.

When David arrived in the Department of International Relations in 1961, my situation rapidly improved. I had been working, more or less, under my own steam, trying to prepare an outline of a workable thesis topic on Japanese foreign policy since the war, but my ideas lacked focus and I was unsure how to proceed. David had recently spent some three-and-a-half years in Tokyo, researching the latest developments in Japanese politics, and he understood what was important and what was not. In 1960 he had published an important article in two parts on the Japan Socialist Party, ${ }^{3}$ and he suggested to me that I research the concept of 'neutralism' or 'non-alignment' that underpinned the foreign policy prescriptions of what was still the principal opposition party in Japan.

'The neutralist policy of the Japanese Socialist Party' thus became the title of my thesis and, much later, the thesis was the basis for my first book. Once David arrived, I found myself under purposeful direction for the first time since my arrival in Canberra. He insisted that I redouble my efforts to improve my still very basic Japanese, and I accordingly arranged still more language lessons with Japanese students at ANU. These normally took the form of two-hour sessions, one hour in

3 David CS Sissons, 'Recent developments in the Japanese socialist movement', Far Eastern Survey, March \&June, 1960. 
which I engaged the student in English conversation, and the other hour where he would engage me in Japanese conversation. I also recorded short-wave broadcasts in Japanese from Nihon Hōsō Kyōkai (the state broadcaster), barely audible through the static, and these formed material for lessons. I remember replaying time and again a tape that included the phrase bigashiyama no fumoto $e$ (towards the foot of East Mountain [in Kyoto]).

During the fieldwork research for my thesis, David arranged for a fee waiver for me at the Institute of Social Science (Shaken) of Tokyo University, found me a supervisor (the historian Professor Hayashi Shigeru) and gave me a number of useful introductions and briefings about what to expect in Tokyo.

And then, very early in 1962, Audrey and I, with our six-week-old red-haired daughter, embarked in Sydney on the Suez Maru, of the venerable OSK line (Ösaka Shōsen Kaisha) for a two-week voyage, with one stop in Brisbane, to Japan. This was a cargo ship, taking 12 passengers, including a young Japanese man importing racehorses from Australia to Japan (the horses were in a stable on the deck). There was an elderly Japanese doctor with little English who explained to us the workings of a baby's digestive system by drawing the mechanism on a blackboard. The ship's purser bore a striking resemblance to the Emperor, which was a source of hilarity among other officers, thus challenging our assumptions about continued reverence for the Emperor. During the course of the trip, the French conducted their first nuclear test, and the population of Tokyo passed 10 million. We disembarked, not at Yokohama, but at the small port of Yokkaichi, to the west of Nagoya and later notorious for pollution-induced asthma, and travelled thence to Tokyo on the leisurely rail service that preceded the development of the Shinkansen. We were inexperienced parents, my Japanese was still far from adequate for research purposes, and this was our first sight of Japan. But we had one unexpected social asset in the form of our baby daughter who, with her flaming red hair, introduced us to many new friends.

Once we had settled in to a prewar wooden house in the suburb of Nishigahara, several kilometres north of the Hongō campus of Tokyo University, I was able to concentrate on my research. David set me on a regime of writing a substantive paper to be despatched to him at the end of every month. He would send these back to me promptly, emblazoned with comments in red ink, some relating to content and some to style. This was years before Lynne Truss wrote her book on punctuation, but David was probably even more punctilious about how to punctuate than she. He also swooped on verbosity with sharp talons, and gradually guided my writing towards a spare style unencumbered with surplus adjectives, though I probably never quite measured up to his ideal. Over the 15 months we were in Japan, he not only taught me much about research, but also about how to write. At first, I think I was shocked by his stern approach, but later I came to appreciate its merits. 
Every month, alongside my report to David, I had to send him accounts of what we had spent, which then formed the basis of our living allowance from ANU. From David's point of view, this was not a formality and, on one occasion, he disallowed reimbursement for strawberries. While we were still in Canberra, he told me that I should register for the 'rice ration', but when I enquired about this at Shaken, I was told that it no longer existed. I also found that at Shaken he was famous for his skill in minimising his living expenses over the years he had been attached there, eking out, I believe, a two-year scholarship to last three-and-a-half years. Unlike my acceptance of his supervisory rigour, our appreciation of David's financial discipline might be described as 'muted'. Even so, when towards the end of 1962 he came to Tokyo for a period of research leave from ANU, we had a brief conversation about finances, in which he sent himself up as 'bastard Sissons'.

After he arrived in Tokyo he probably judged that I was on the right track, and so his supervision became less critical, and we were able to discuss my research in a more relaxed manner. For a week or so in the winter of 1962-63 he and I went skiing at Akakura in Nagano prefecture. We travelled in the evening (perhaps overnight) on a train packed with skiers and, for most of the journey, had to stand in the corridor. We were part of a group from Shaken that had hired a lodge belonging to the university's Department of Forestry (or perhaps a government forestry institution). The external temperature was far below freezing and, except for the kitchens, there was no heating other than a kotatsu, a heated depression in the floor beneath a low quilted table, on which we rested our feet in the evening. At night we would bury ourselves under futon. In the mornings we would spend about 20 minutes travelling on a ski lift up through the fog, dressed in every stitch of clothing we had with us, until the sound of Austrian yodelling music signalled that we were approaching the summit.

My period of research in Japan was supposed to last a year, but David realised that I needed more time, and negotiated for me an extra three months so that I could do more interviewing. My Japanese only became sufficient to conduct interviews two or three months into our stay, so I had some interviewing backlog to catch up with. We therefore did not leave Japan until May 1963. I secured a berth on another cargo ship taking a few passengers, the Tenos of the Australia West Pacific Line, travelling with a bunch of people who had walked straight out of a story by Somerset Maugham. One of the passengers was the wife of the head of a British oil company in Japan, travelling to Australia to clear up an estate. There was another woman, rather down at heel in appearance, whose son, according to the oil company lady, had been involved in black market operations in Japan. This piece of intelligence she had no intention of keeping to herself. Another passenger attempted unsuccessfully to recruit me to help the Australian security services. 
The ship began its journey from Kōbe, so that we had to travel down the country by train with accumulated luggage, including research materials I had collected. David had arranged to come to our house at a given hour and help us to bring our luggage to the railway station (probably Tokyo central station). The hour came and went without a sign of David until, eventually, he turned up having travelled on a slow clanking tram (the old toden) rather than by taxi, thus no doubt saving a few hundred yen. As it turned out, it hardly mattered, but for an anxious period we wondered what had happened to him.

Some time in the late 1960s, David once again spent a period of research in Japan, having expected to be able to use the National Diet Library, the central repository of material about Japanese politics. But unfortunately, the library was closed for rebuilding more or less throughout the period he was there. Thus fortuitous circumstance led to a fundamental shift in his research direction. For several years, he had been researching the history of relations between Australia and Japan, devoting, as he told me, every Thursday to this task. Now, he shifted his focus almost entirely onto research into the history of Australia-Japan relations, and that field was enormously enriched by his efforts during the rest of his life.

In June 1971, the Australian Institute of International Affairs held a conference in Sydney on 'Japan and Australia in the seventies' and, after the conference, I was asked to edit the proceedings for publication. David contributed a paper for the conference, dealing with the history of immigration, trade and defence relations between the two countries. When it came to the task of editing the proceedings, I told David that his paper was longer than I could accommodate, and asked him to make it shorter. After a while, he sent me his revised paper, with additional material, so that it was appreciably longer than the original. We easily came to a compromise: his paper would include only material on immigration, and he could expand that if he wanted to, but up to a specific word limit. ${ }^{4}$

Between November 1971 and September 1972 the Standing Committee on Foreign Affairs and Defence of the Senate of the Commonwealth of Australia held regular hearings on the broad and comprehensive topic 'Japan'. David acted as specialist adviser to the committee. He also submitted and presented papers on the history of immigration and defence issues between the two countries. I myself made submissions to the committee and was 'examined'. I remember well the important part that David played in the proceedings. There is one memory I still retain from that exercise, namely an informal conversation during a tea break between Senator Sim, the committee chairman (Liberal), David and me about the rights and wrongs of the atom bombing of Hiroshima. Senator Sim was arguing that the decision to bomb was inevitable in the circumstances, and probably

4 DCS Sissons, 'Immigration in Australian-Japanese relations', in JAA Stockwin (ed.), Japan and Australia in the Seventies (Sydney and London: Angus and Robertson, 1972). 
justified. David was minded to see both sides of the argument, though inclined rather towards Senator Sim's position. I had very recently visited Hiroshima, including the atomic bomb museum and, rather than advancing any intellectual argument, simply interjected two or three times into the conversation the phrase 'that city is full of ghosts'. My impression is that neither David nor Senator Sim were quite sure how to react to such an 'emotive' and 'irrational' argument.

Both David and I in the 1970s occasionally gave commentaries over ABC (Australian Broadcasting Commission) radio relating to events in Japan. On one occasion (possibly in the 1960s), David was in a link-up on the ABC with the Australian ambassador in Tokyo. The commentator asked David the question 'is the Japanese government pacifist?' (or possibly 'is Japan a pacifist nation?', or just 'is Japan pacifist?'). According to his own account, David replied that this was a question he could not possibly answer, as it was a political question and therefore fell within the ambassador's sphere of responsibility, not his own. I remember that when he told me this, I found it difficult to imagine that an academic specialist, who had published in leading journals of Asian affairs on Japan's 'pacifist constitution', should have found it necessary to defer to an ambassador, whose knowledge of the subject was probably much more superficial than his own.

But this anecdote reveals an important facet of David's personality, namely his extreme modesty. I am certain that there was no false modesty here, and that his response to the $\mathrm{ABC}$ commentator was motivated entirely by his belief that it was up to the ambassador in such circumstances to answer a political question. This was not the only occasion when David by diligence and hard work became more expert than the 'experts'. In his research on the treatment of Japanese prisoners by Australian forces in the Pacific islands at the end of the Pacific War, he accumulated specialist medical knowledge on relevant tropical diseases. Modest as usual, however, deferential to authority and far from content with his independent investigations into the subject, he wrote an immensely detailed letter stating his findings to his elder brother Hubert, a distinguished physician working in London. Hubert wrote back simply: 'You clearly know much more about this subject than I do.'

A mutual acquaintance and fellow academic in the international relations field, the late Arthur Burns, once commented to me that 'David Sissons is an absolute non-generaliser'. ${ }^{5}$ It is easy to understand the apparent cogency of this observation given the fact (or perhaps more accurately, the belief) that David felt he could not possibly write about the history of Japanese pearl diving off Broome, Western Australia, without first examining every grave in the Japanese section of the Broome cemetery, and then researching in detail the personal history of every individual so identified. Nevertheless, after going through the 60 boxes of material

5 Private conversation, probably late 1960s. 
that David placed in the National Library of Australia in Canberra, I am convinced that the 'non-generaliser' label is wide of the mark. The boxes contain, among other things, bunches of material with the note 'research completed'. This was a sure sign that David had not only completed a thorough examination of the subject matter concerned, but had also arrived at clear and cogent conclusions about where the balance of truth lay in that particular area. To take one important example, he was firmly of the opinion that the trade diversion episode in 1936, which penalised Japanese textile imports in the interests of the Lancashire cotton industry, was a case of ill-conceived policymaking that did no good to any of the participants. Again, with good reason, he identified Anthony Clunies-Ross as the most enlightened and far-sighted policymaker in relation to Japan of any Australian official during the 1930s. And, most strikingly, his exhaustive treatment of the Katayama case was underpinned by David's deep commitment - his passionate commitment - to humanity and justice, and his sense that by executing Katayama the relevant Australian authorities had disgracefully betrayed those principles.

It is perfectly true that David was sceptical of most theoretical approaches, whether in political science or other disciplines. I remember having a conversation with him, while I was still his student, about organisation theory, which was still a fashionable body of literature in the early 1960s. He told me that he had indeed attempted to come to grips with it but, in the end, abandoned the attempt because he found it boring. For David, the idea that a research project should have as its primary purpose the generation of theory, or still more that it should be confined within the framework of some body of theory - while making minor refinements to that theory - was putting the cart before the horse. Rather, his approach was to investigate a research 'territory' (my word, not his), cover it exhaustively and, by so doing, reveal the underlying logics (the plural is deliberate) inherent in the phenomena under investigation. But curiously enough, that tended to lead him back, with due allowance for scepticism, into concerns that we might well call 'theoretical'. For instance, my doctoral thesis had as one of its main concerns the phenomenon of factionalism in Japanese political parties, and whether factions were ideological groups or simply groups seeking power maximisation. David well appreciated the theoretical implications of this distinction and gave me excellent advice on how to research and pin down the ways in which the system worked. I very much doubt, however, whether he would have been much impressed by the recent obsession of many political scientists, especially in the United States, with rational choice theory, often seen as the ideological underpinning for the political economy of neo-liberalism.

This leads on neatly to the question of David's political orientation. When I first met David, and talked with him over a certain period, I formed the impression that he was a kind of romantic conservative, taking comfort from tradition and settled authority. There was, of course, a specifically Australian set of elements involved in this. He was reflecting on an Australia that still maintained strong sentimental links 
(as well as many material links) with 'the old country', as symbolised by the Royal Family, the Westminster parliament, and British institutions of all kinds. Much of this, no doubt, went back to his experiences of the Second World War, and its sense of joint purpose against common enemies. He once mentioned his memories of broadcast speeches by King George VI, in which the king was struggling to overcome his stammer (an impediment that was the subject of a recent film). This reminded me of my own childhood in Britain where, during and after the war, such feelings would have been common currency among my parents and their friends. But, by the 1960s, in both countries, things were changing fast. When we went to the cinema in Canberra in the early 1960s, everyone respectfully stood up for the playing of the (British) national anthem was played. By the end of the 60s, it was no longer played in cinemas. And I believe that happened in Britain, too, over the same period.

I remember a conversation with David, probably in Japan in the early 60s, about the Indian Raj. At the time I had formed a fairly clear view about imperialism, that it was closely linked with exploitation and attitudes of racial superiority on the part of European powers, and that the decolonisation that had occurred so widely since 1945 was entirely or largely justified. David, however, disagreed. He mentioned to me a book (I forget which) that lauded the contribution made to India by the Raj and those many people of British origin involved in it. I think that in the end we agreed to differ.

One long weekend in 1961, David was away. When he came back, he told me that he had spent the weekend at a camp with the army reserve, and asked me whether I would like to be involved as well. Having had my fill of square bashing and bullying NCOs in national service in Britain, I declined. But I realised that military service was something that David valued highly. At the time, I almost certainly did not realise how extensive his military service had been in the Australian forces towards the end of the war, as an interpreter at Australian war crimes trials in the South Pacific islands, and in the Occupation of Japan. He spoke very little of these things. But I remember being puzzled by one thing he insisted on, which seemed to me essentially irrelevant to the task at hand. Not long into his supervision of my thesis, he mentioned that two books in English on Japanese affairs had recently appeared, and I might like to try my hand at reviewing them for publication in an international affairs journal. One of these was a general book on Japan by a former British ambassador to Japan, Sir Esler Dening. I agreed, read the books and wrote a review, which I gave to David. 'Ah', said David, 'but you haven't mentioned that Dening was in the AIF (Australian Imperial Force)' during the Great War. I was puzzled by his reaction and suggested to him that this fact was hardly relevant to a review of a book that was about modern and contemporary Japan. Nevertheless, David continued to insist that I say something about Dening's background. And so, my first-ever book review contained the following passage: 'Sir Esler Dening was born in Tokyo in 1897, and after receiving his secondary education in 
Brisbane, was in 1915 commissioned from the ranks in the 31st Battalion A.I.F. After a distinguished career in the Japan Consular Service, he served as British Ambassador to Japan from 1952-57. Thus with a fluent command of Japanese and most of his life spent in the Far East, he is one of the last of the "specialist ambassadors".' I now understand - as I didn't then - that it was tremendously important to David that someone with such a close life involvement in both Australia and Japan should have served as the first British ambassador to Japan after the Occupation. Nevertheless, I found the book surprisingly boring, and implied that in my review. I don't think David disagreed.

This picture of David as an old-fashioned conservative does, however, require modification. I know - because he told me - that at the watershed elections of December 1975, when after the dramatic dismissal of the Whitlam Labor Government by the Governor-General, Sir John Kerr, the Australian Labor Party was soundly defeated by the Liberal-National coalition, leading to the election of the first government of Malcolm Fraser, David actually voted Labor. Or, more precisely, he voted for the local Labor MHR, Kep Enderby, who had been minister for the Capital Territory under Whitlam. The reason he gave was that Enderby had overruled objections from his department to David's request for access to certain closed materials in the National Archives, enabling David to progress with his research. But I think there is more to it than that, because he once said to me, probably in the late 1960s, that he would like to see a Labor government 'in order to shake up the Liberals'. Moreover, I remember thinking by the mid-1970s that David had become more relaxed, more at ease with himself, and thus less fixed and more moderate in his political opinions than he was when he was supervising my doctoral thesis. Perhaps this was because from 1965 (after I had graduated) he was married to Bronwen, and they later had three wonderful children.

Although David was normally decorous and polite in conversation, and also kept most of his army experiences to himself, he did once tell me a story that I hesitate to repeat, but will nevertheless do so because, having seen service in the armed forces, he understood the world at its more basic levels. While David was serving with the British Commonwealth Forces at Kure in Western Japan, one of his duties was to give talks in local schools about democratic values and what the Occupation was trying to achieve, and no doubt also about life in Australia. At the end of one of these talks he called for questions and a boy he described as 'a swot sitting at the back of the class' put up his hand and asked a question in passable English, as follows: 'Please Sah, what is meaning of " $\mathrm{f} *$ *** off Tojo"?' David concocted the best reply he could think of, such as 'that's not a very common expression, so you really don't need to bother about it'. 'But Sah', replied his determined questioner, 'New Zealand soldiers in my village say it to me every day.' And the Nisei (Japanese-American) class teacher gave no sign whatever that anything unusual had been asked. 
To conclude, David Sissons was a careful scholar, meticulous in his research to an extraordinary degree, deeply empirical and suspicious of abstract theory, who in the course of his academic career uncovered much of the underlying structures of the relationship between two countries of crucial importance to each other, namely Australia and Japan. He was also a singular and engaging human being, tough and somewhat puritanical but also generous. In my case, he was more than just a thesis supervisor, he was the person who put my career on track. For that, and for his friendship, I am eternally grateful to him.

\section{David Sissons and Shiba Ryōtarō}

\section{Watanabe Akio}

Shiba Ryōtarō was one of the most popular Japanese writers, but he wrote a short story, on a topic most unusual for him, entitled 'Night meeting on Thursday Island' (first published in 1977 by Bungei Shunjū, reissued 1980). In this story, which I came across by accident, I was amazed and not a little nostalgic to find that, unexpectedly, Shiba had met David Sissons. Before I go on to describe my relations with the latter (my mentor), I want to introduce the reader to the portrait of him that emerges from Shiba's story.

It is a story about divers in the seas around Thursday Island, situated among the many islands of the Torres Strait, gathering black-and-white mother of pearl, which is greatly valued for the creation of sophisticated buttons. For some reason, Europeans, Malays, Chinese and others did not persist in this work, but Japanese, and in particular those originating from a small area of Wakayama prefecture, displayed a special capacity for it. The novel begins with a citation from the book by David CS Sissons of The Australian National University, Japanese in Australia, 1871-1946, to the effect that 'The first Australian businessman to employ Japanese for this work was Captain Miller of Thursday Island'. Later, on the question of why Japanese should have had this particular set of abilities, Shiba cited Sissons' view that 'what characterised the Japanese was their energy and strong motivation to succeed, as well as their desire to earn high wages. Since there were many candidates, those chosen as divers were, by dint of selection, outstanding. Moreover, the level of the divers' remuneration increased with the amount of work accomplished, so that the Japanese divers, determined to earn as much as possible, worked all hours provided only that the sun was up', and Shiba judged that this perception was absolutely correct. If we guess from Shiba's words that David had discovered the essence of the situation by putting together stories that he had heard from locals in Wakayama, including the old man who was the model for the hero of Shiba's novel, then the image of my mentor David gathering information at first-hand from this old man floats before my eyes and, although it is impossible to prove, I imagine that perhaps, before Shiba wrote his novel, he and 
David travelled together to Kushimoto in Wakayama, and met those old people there. In this way, David's methods of research, consisting of building up the detail of the situation and steadily conducting practical investigations, makes this a plausible episode. Meanwhile, since Shiba, having been a journalist, was the type of writer who would gather information by actively visiting relevant locations, the two of them should have got on well. Starting with the night meeting on Thursday Island, described in the latter part of the story (where the author is treated as an honoured guest), and going on to discuss an aspect of relations between Japan and Australia, Shiba's account is full of interest but, as it is not so relevant to the topic of this article, I shall therefore leave it aside and move on to describe my encounters with my mentor, David Sissons.

I do not know when Shiba first knew of the existence of David Sissons, but it was probably not so long before the first appearance of the story in 1977. On the other hand, in my case, I left Japan in the (northern) spring of 1963, went to Canberra and began studying for a $\mathrm{PhD}$ at $\mathrm{ANU}$. At that time David was conducting research into his specialty of Japanese politics at the Institute of Social Science at Tokyo University. He had been invited by Professor Hayashi Shigeru, whose interests lay in Meiji period political history. At the time, I had finished a Masters thesis at the Graduate School of Tokyo University, and had also completed another Masters thesis, in political science, at Meiji University. I had no other position lined up, however, and being often in Hayashi's office, I got to know David and also Arthur Stockwin, who had come from ANU to Tokyo on fieldwork to study the Japan Socialist Party. From both of them I received the suggestion that I might like to go to ANU. In those days I had probably never written a letter to anybody in English, and my life was far removed from writing horizontally, so that I was very hesitant, but at any rate it was recommended to me that I should apply for an Australian Commonwealth Scholarship. Just as I was sending off an application, papers arrived from ANU and, because they did not know my level of English, I was told that I should meet a certain official of the Australian embassy in Tokyo in a certain month on a certain day. The day before, I telephoned David from a public phone and reported this to him, and he advised me to drink some alcohol and, in a relaxed mood, anticipate the next day's meeting. Of course, considering his stern character, it is possible that I am misremembering and that it is a memory that I constructed later. What is more certain though is that in the phone conversation, as the English equivalent of Nani nani shiyo to omoimasu, I said 'I think I will', and was cautioned that 'I think' was unnecessary and that all I needed to say was 'I will'. I shall skip details of the exam but, in any case, while my conversation was halting, I was improving with practice and I was told by that certain official who was acting as examiner that he would report to ANU to that effect. Soon after, I received official confirmation from Canberra that I had passed. That was the point where my relationship with David as my supervisor began. I had proposed three possible research topics, and of these I was told to tackle the Okinawa issue. In pursuance of this, I should visit Okinawa on fieldwork, so that I could spend about one 
month in Naha gathering materials, meeting people and hearing what they had to say. Okinawa at the time was under American occupation so that, armed with a travel warrant signed by Prime Minister Ikeda Hayato, I went by ship to Naha from Kagoshima, and my return was also by ship. I still retain the travel warrant signed by the American official in charge.

So, eventually, I reached Canberra. I don't know whether this was planned personally by David, or whether it was ANU policy, but I embarked on the P\&O liner Iberia at Yokohama, which stopped at Kōbe, Hong Kong and Manila, finally reaching Sydney, the whole passage taking eight days. At Sydney, somebody from ANU came to meet me and put me on the train to Canberra, where I unpacked my belongings at University House. David was still conducting research in Tokyo. Until he returned from fieldwork, I was supervised by George Modelski, whose ways of working were quite different from David's. At first I was rather bewildered but, with hindsight, to have interacted with two supervisors so different from each other, was fortunate for me. Incidentally, I am still in friendly contact with Professor and Mrs Modelski.

Another aspect of David's 'supervisory methods' is shown in the following anecdote. He said that my wife, to whom I was newly married, should not accompany me, on the grounds that if we lived together this would harm my study of English. In the end, she joined me six months after my arrival in Canberra. It is impossible to demonstrate how far this contributed to my English language competence but, while I was living on my own, I repeatedly asked Modelski when my wife would be able to come to Canberra, and I still remember with a wry smile him teasing me about how much I was in love with her.

Returning to a more dignified discourse, before long a regular relationship with David began and, on a specified day every week, I would go to his office and show him the written results of the studies I had conducted during the week. On these occasions I was often counselled to write more briefly. I had a certain sense of making explanations to my bureaucratic superior but, later on, the fact that I developed the habit of leaving out certain points that I had wanted to discuss in a chapter probably owes a lot to David. Sometimes, following his own interests, David asked me about things here and there in Japan, and quite often I was embarrassed that I did not know the answer. Among these things may perhaps be counted many aspects of the Wakayama area that emerged in 'The night meeting at Thursday Island'. However, this may be, much like his shy and somewhat withdrawn character, David's research may be modest and unshowy, but I am delighted that it has been introduced to many Japanese people, together with the work of Shiba Ryōtarō, and it is in this spirit that I have written this appreciation. 


\section{David Sissons, his methods of supervision and the adventures of one of his students: A memoir of the days when the world was wide}

\section{John Welfield}

Those who in ancient days were the best commanders

Were those who were delicate, subtle, mysterious, profound,

Their minds too deep to be fathomed -Lao Tzu, Tao Teh Ching

I remember the scene as it if were yesterday, although almost half a century has passed since then and the world has changed, in so many respects, beyond recognition.

It was a stifling Australian summer afternoon in late January 1967. I had recently been accepted as a Commonwealth Scholar into the doctoral program in the Department of International Relations in the Research School of Pacific Studies at The Australian National University, and was about to leave for three years language study and fieldwork in Japan. David Sissons, who had been appointed as my supervisor, Professor JDB Miller, the head of department, and I were sitting at a small table in the shadowy recesses of the Cellar Bar at University House, eating ploughman's lunches and addressing ourselves to cold beers.

It was Miller who spoke.

'Well, John,' he said in his mellifluous tones, 'you are going to Japan. We want you to stay there a long time, to learn the language thoroughly, to study the country's history, its culture, its politics and its foreign policy deeply, and most important of all, perhaps, to come to understand the spirit of the land and the way of thinking of its people. You should devote yourself single-mindedly to these tasks. From time to time you will receive frenzied letters both from me and from your supervisor, David here, enquiring about the progress of your thesis. You should ignore these letters, for a good thesis, like a good book, is something that cannot be hurried. It cannot be forced. It should grow, naturally and spontaneously, on the basis of real and substantial knowledge about issues of great public importance.'

David smiled shyly and nodded in agreement. Our discussion then turned to other matters, after which we walked back through the shimmering heat haze to our offices in the Coombs Building.

I had first met David Sissons in 1966, when I visited ANU to discuss the possibility of combining a doctoral program in contemporary East Asian international relations with intensive study of a major regional language. I had recently completed my honours degree and was highly motivated. The Cold War, then entering its 
second decade, the bankruptcy of Washington's containment of China policy, the continuing escalation of the Indochina War and Canberra's role as a faithful and apparently unquestioning American ally had made me decide, some years before, to abandon what was generally thought to be a promising career in European studies, begin serious full-time research on the Asia-Pacific area and devote my life to making some contribution at the intellectual level, however insignificant, to the task of reconciling Australia's Western historical and cultural heritage with the demands imposed by its geopolitical location. This was something that had interested me since my childhood, as a boy growing up in the Australian bush, whose vast, empty spaces, immense skies and profound silence seemed to stimulate serious reflection, but the horrific slaughter and senseless destruction of the Vietnam War had instilled in me a heightened sense of urgency. My principal interest at that time was China, a country about which I had read a great deal. I was also deeply interested in South-East and Central Asia.

Miller supported my proposed course of studies warmly. It would be possible, he said, to send me to Beijing to learn Chinese and conduct preliminary research, after which I would return to the ANU to complete my thesis. Professor CP Fitzgerald, the eminent China specialist, would be my supervisor. Shortly after our initial discussions, however, the Cultural Revolution had erupted in China and it became impossible for ANU to despatch students to Beijing.

'What about going to Japan instead,' Miller proposed. 'We still don't have many specialists on Japanese politics and foreign policy in this country. David can supervise your work. He has a good track record.'

I thought for a second or two and accepted the offer. I have never had cause to regret it. Within a few months I embarked on a grand adventure, which took me not only to Japan but far beyond, to explore worlds that had long fired my youthful imagination and to forge close personal ties with people from many different cultural backgrounds and different walks of life, an adventure that is yet to come to an end, although I am rapidly approaching the three score years and 10 allotted to mankind and have still to complete the academic tasks I set myself at the beginning of the journey.

With the passage of the years, I have come to realise how exceptionally fortunate I was to have had David appointed as my supervisor. As a human being he was tolerant, kind-hearted, modest and old-fashioned in his ways. In summer, when he strolled around the corridors of the Coombs Building in his voluminous Bombay bloomers and knee-length socks he looked for all the world as it he had drifted out of the pages of The Empire Boys Annual. I never discussed politics with him but I always supposed that his views resembled those of the solid, socially responsible, imperially minded Tories who appear in John Buchan's novels. A sly, boyish sense of humour occasionally broke through the crust of his outer seriousness. His approach to supervision was unique. Strictly speaking, in fact, 
apart from requiring me to write four or five detailed thesis proposals, to conduct a thorough literature search and, as my work progressed, advising me to ensure that the conclusion of my thesis was consistent with the introduction, that I should begin every chapter with a paragraph explaining what I hoped to demonstrate in it and end with a paragraph summarising the arguments and linking it with the following chapter (excellent advice, which I have always given to my own students), David did not supervise my work at all. He seemed determined not to influence the development of my ideas, directly, in any way. He gave me absolute freedom to proceed exactly as I pleased, to select a topic of my own choice, forcing me to search for materials on my own, to make my own discoveries, commit my own blunders and take full responsibility for it all. In this way he made an invaluable contribution both to my development as a scholar and as a person.

What David did was to lay foundations, to make arrangements and to provide opportunities, without always fully explaining what the true purpose of these foundations, arrangements and opportunities was. He would point to doors and occasionally even open them, without really letting one know what one was supposed to find behind them, what vistas might be obtained from the rooms to which they gave access and to what other chambers they might be connected. He would provide introductions, without necessarily explaining the role and significance of the individual to whom one was being introduced, except in the most general terms. All these things one was obliged to find out for oneself. If one did not come to understand the significance of the arrangements he had made, or avail oneself of the opportunities he offered, or explore the many mysterious rooms and corridors behind the doors to which he had provided the key, or towards which he had pointed, or which he had hinted might possibly exist somewhere, it was entirely one's fault. From time to time, too, he would administer little tests, such as withholding some vital piece of information or laying a trail of small red herrings across one's path, in order to encourage constant alertness, self-reliance and initiative.

All in all, his approach resembled that of a traditional zen master. I suspect that some of his other students may not have been altogether comfortable with this, and there were times when I felt both puzzled and profoundly frustrated, but generally speaking his method of supervision worked well for me. In retrospect, indeed, I realise how carefully, and with how much forethought, he laid the foundations for my first three years of study in Japan, how he endeavoured, without saying a word, to open my mind to certain geopolitical, cultural and historical realities that were, at that time, ignored by many Western specialists on East Asian international relations, and how he guided me, like some distant Sherpa, to the stage of thesis submission and beyond. 
Not long after our lunch at the Cellar Bar, David made three decisions that were to exert an extraordinary and continuing influence not merely on my perceptions of Japan and its relations both with the Asian continent and with the maritime world of the West, but on the whole course of my subsequent development.

His first decision was about the seemingly elementary question of how I should travel to Japan.

'It would be a good idea if you saw something of the rest of Asia before you begin your work on Japan,' he said to me one day.

I told him that I was very happy with his suggestion.

'But you should not travel by air,' he continued. 'You will see nothing that way. We would like you to travel by ship. We will purchase the tickets. You can make the necessary local arrangements as you like. Keep all the receipts and we will reimburse you when you return' (he was always careful about these matters).

Thus it was that on 22 February 1967, after a farewell dinner with my family and a small number of Australian, Burmese, Indonesian and Malaysian friends in a cliff-top restaurant overlooking the Pacific Ocean, I clambered up the gangway of the Italian liner Achille Lauro, which was bound for Europe with calls at Melbourne, Adelaide, Fremantle, Singapore and ports beyond. David had arranged for me to disembark at Singapore and told me I should make my own way, in any fashion I saw fit, from there to Bangkok, where I would board the French liner Le Laos, sister ship of Le Vietnam and Le Cambodge, on 17 March. Le Laos would take me across the China seas to Japan, via the Philippines and Hong Kong. The vessel was scheduled to dock at Yokohama on 29 March 1967 and I was then to travel by train to the Japanese language school where David had arranged for me to study. His parting gift was the address of this institution and the telephone number of my Japanese guarantor scribbled on a small piece of paper torn from a used envelope on his desk. I thanked him, put the tiny scrap of paper in my pocket, and said goodbye.

'Don't forget to contact your guarantor as soon as you settle in,' David called after me as I walked out of the door.

I was 21 years old. This long journey to Japan by sea and land was the first time I had travelled outside Australia and it left a deep impression on me. I remember it vividly. Unfortunately, there is not enough space here to describe my impressions and the adventures I went through on my way to Japan. But allow me to make just one reflection on my journey: David's proposal that I should make my own way from Singapore to Bangkok, which I had welcomed eagerly but which was, nonetheless, rather daunting in those days before the development of SouthEast Asian tourism, and when several guerrilla groups, as well as bandits, were active in the Malaysia-Thai border region, proved to be another stroke of genius. 
Looking back over the detailed diaries I kept and the letters I wrote during this journey, I realise the incalculable value of the gift he gave me, forcing me to stand on my own feet and fend for myself in a totally unfamiliar environment. While I had undoubtedly only begun to scratch the surface of things, I believe I learned more about the real world of South-East Asia in 10 days than I would have learned in many years of purely academic study.

Le Laos docked in Yokohama at midday. A bitterly cold wind swept across the city, ruffling the waters of its grey harbour, and sheets of fine, icy rain fell intermittently. Following David's instructions, I walked along the bleak pier, shivering in my light clothes, made my way to Sakuragichō station and boarded a train bound for Tokyo. It all seemed very simple. People even understood the elementary Japanese I had learned in Canberra under Dr Anthony Alfonso prior to departure.

I ought to have been more alert. David had set two final little tests for me. First, he had not told me it was necessary to change trains between Sakuragichō and Tokyo. I was only saved from disaster (as David had no doubt anticipated) by constantly practising my limited Japanese on the other passengers. As soon as she learned my destination, a helpful and amused Japanese lady hauled me physically from the train at some station before we had reached the point of no return, pushed me into a waiting train on the opposite side of the platform, bowed, then ran back to jump aboard the train we had just left.

The second of David's little tests proved to be more difficult. The address of the language school, which I had preserved faithfully in my wallet throughout the journey, was incomplete. On his tiny scrap of paper David had written in Chinese characters: 'Kokusai Gakuyū Kaikan, Shinjuku-ku, Tokyo'. Arriving at Tokyo Central Station from Sakuragichō, I successfully boarded the Chūō line, as advised. When I alighted at Shinjuku Station the Kokusai Gakuyū Kai was nowhere to be found. Not only that but no one, including the officers on duty at the police box where I made enquiries, had ever heard of it. A telephone call to the local police headquarters, however, established that the school was in Ôkubo, administratively part of Shinjuku but actually the next stop west on the Chūō line.

I am not sure I passed David's last little test. I suppose he meant me to catch the Chūo line to Ōkubo, and then walk to the school, asking directions all the way. Intimidated by the rush-hour crowds, however, the likes of which I had never seen before, and feverish with an oncoming cold, I caught a taxi, an extravagance of which David rarely approved. Half an hour later (and $¥ 500$ poorer), after crawling through an horrendous traffic jam, the vehicle swung through the gates in the high, barbed wire-topped walls of the Kokusai Gakuyū Kai into a lifeless winter garden, where a number of squat, gloomy buildings could be seen in the fading light, and where a bee, overcome by the heavy, malodorous smog, was in its death throes on the edge of a black courtyard pond. I walked into the administration office, introduced myself to the staff, took my luggage to the dormitory, then asked to see a doctor. 
To enrol me in a one-year intensive Japanese-language program at the Kokusai Gakuyū Kai was David's second inspired decision and I am extremely grateful to him for it.

'I want you to go to a place where you will actually learn Japanese,' he had said, making some disparaging remarks about the language courses for foreign students offered at various famous universities. 'If you go to such a place you are likely to spend all your time speaking English with young Americans on their year abroad program,' he declared, citing examples.

He discussed the matter with Mr Chiba Koh, the then Japanese ambassador in Australia, who recommended the Kokusai Gakuyū Kai. There would be no Western students there, David was assured, and the program was rigorous. The Kokusai Gakuyū Kai had been established in 1935 by the later prime minister Prince Konoye Fumimaro to provide Japanese-language training for students from Asia, facilitating their entry into Japanese universities and preparing them to take their place in the future Geater East Asia Co-prosperity Sphere. The co-prosperity sphere had vanished but the Kokusai Gakuyū Kai had remained, as a subsidiary organ of the Japanese Foreign Ministry, continuing to offer high-quality Japaneselanguage courses to Asian students and arranging for them to take the entrance examinations for appropriate Japanese universities. I was apparently the first nonAsian to study there, although I did hear rumours of the presence of a couple of German students during the Second World War.

The Kokusai Gakuyū Kai proved to be an extraordinarily effective language school. Classes, which began at $9.00 \mathrm{am}$ and ended at $4.00 \mathrm{pm}$, were small and were conducted from the beginning entirely in Japanese. The use of any foreign language was entirely forbidden. A relentless regime of homework kept all students busy until far into the night. By the end of six months, most students had achieved a high degree of proficiency. We could not only speak, read and write Japanese, we constantly thought and even dreamed in the language. The school's approach to teaching, propelling us from kindergarten to university-level in the space of 12 months, also played strange tricks with our concept of time. By March 1968, it seemed to me that I had spent another childhood, another boyhood and another youth in Japan, in addition to those I had experienced in Australia.

Of the 160 students from all parts of Asia who entered the Kokusai Gakuyū Kai at the same time as I did, 47 succeeded in passing the entrance examinations to Japanese national universities, 51 to private universities and four to junior colleges. Twenty decided to repeat the language course and challenge the entrance examinations again the following year. Another entered the final year of a normal Japanese high school. The Kokusai Gakuyū Kai proved to be far more than a language school. The background and character of its teaching staff, the composition of its student body, the accumulated legacy of its entire history, in fact, combined to provide a unique introduction to Meiji, Taishō and Shōwa Japan to its 
political, economic and social history and to its relations with its East and SouthEast Asian neighbours. I have always supposed that Chiba Koh, whose wife Utako was the daughter of the liberal Pan-Asianist intellectual, implacable opponent of Japanese military expansion on the continent and former prime minister, Ishibashi Tanzan, knew this when he recommended the school to David, and that David guessed what kind of a place it was when he decided to enrol me there.

The older generation of our teachers were remarkable people. Intelligent, well informed and articulate, they had personally experienced, in their various stations in life, the whole history of 20th-century Japan, the last years of the Meiji era, the First World War and the intensification of Japanese expansion in China and the Pacific, the failure of the Siberian Intervention, the brief flowering of Taishō Democracy, the Great Kantō Earthquake, the rise of Shōwa militarism, the Depression, the Manchurian Incident, the second Sino-Japanese War, the Greater East Asia War, the co-prosperity sphere, the defeat, the end of empire, the Allied Occupation and the postwar reconstruction, which was then in full swing.

One of our teachers, Mrs Shiba Junko, was a Manchurian Japanese. Her family had gone over to China sometime after the First World War, when her father had taken up a position with the South Manchurian Railway Company. She spoke with absolute contempt of Japan's ambitious drive to carve out a continental empire and castigated the country's prewar and wartime governments, as well as the Imperial Japanese Army and Navy, for the horrendous destruction they had wrought on their rampage of conquest throughout East and South-East Asia. Nevertheless, as she saw it, the Japanese themselves, as well as the peoples of China, Korea, South-East Asia and the Pacific, were all victims of Japanese imperialism. She had lost her husband when Soviet forces delivered their shattering blow against the Japanese Manchurian empire in August 1945. She had then fled to Beijing with her two small children. They were living in Beijing as refugees when the Chinese Communist forces under Mao Tse-Tung entered the old imperial capital in February 1949, at the end of the last siege of a walled city in modern times. She had spent some time in a re-education camp and was eventually repatriated to Japan in the early 1950s. Her recollections were so vivid, her narrative so powerful and so moving, that we could almost believe that we ourselves were living through the cataclysmic upheavals she described. After retiring from the Kokusai Gakuyu Kai, she devoted herself to promoting Sino-Japanese friendship and to teaching the Japanese language to the children of Manchurian Japanese who had been abandoned by their parents on the mainland in the chaos following the collapse of the empire but who had begun to trickle back to the home archipelago after the restoration of diplomatic ties between Tokyo and Beijing in 1972.

Another member of our senior teaching staff, the multilingual Iwasaki Gen, was suspected by some of the students of having worked for Japanese intelligence during the war, though he never said anything about this. Whatever his background, 
Iwasaki-sensei was also scathing in his criticism of the wartime Japanese invasion of China and South-East Asia. While he had scant regard for the co-prosperity sphere, viewing it as no more than an instrument of Japanese imperialism, he spoke with pride of the contribution made by individual Japanese Pan-Asianists such as Miyazaki Tōten and Colonel Suzuki Keiji to the liberation of Asia from the West. The creation of a community of strong, politically stable and prosperous Asian states, organised on the basis of equality, was an essential task for future generations, he believed.

Many of my fellow students and senpai had elite family connections with former leaders in South-East Asia. Just being at the Kokusai Gakuyū Kai gave me important insights into one of the most salient characteristics of Japanese diplomacy, the tendency to cultivate, generation after generation, close personal ties to key families regarded as basically sympathetic to Japan, an approach that has guaranteed a high degree of stability and continuity, generally unaffected by political upheavals.

In those days, all foreign students in Japan were required to have a guarantor. David's selection of Mr Suzuki Tadakatsu to fulfil this role was another decision for which I will always be grateful. Suzuki Tadakatsu had served as the Emperor's interpreter. As head of the Yokohama Liaison Office he had played an important role at various critical stages during the Occupation. He had subsequently served as ambassador to Australia, as ambassador to Italy and president of the JapanAustralia Society. Characteristically, David did not really tell me who Suzuki was when he announced that he had agreed to serve as my guarantor. This was something that I was supposed to find out for myself. Since Mr Suzuki, while always happy to talk about the contemporary political situation, was both modest and discreet when it came to discussing his own career, and since I myself have always been reluctant to ask personal questions, it took me some time to place this charming old gentleman in my emerging mandala of the Japanese Establishment.

Despite the gulf that separated us in age, background and experience, Suzuki Tadakatsu proved to be a valued mentor, an indispensable guide to the world of Japanese diplomacy and politics, and a good friend. We kept up our relationship until his death.

After I had completed my language studies at the Kokusai Gakuyū Kai, David arranged for me to be admitted as a research student in the Tōyō Bunka Kenkyūjo at Tokyo University under the supervision of Professor Seki Hiroharu (Kanji). This was no doubt a good idea and, during the spring of 1968, I diligently journeyed to the university's Hongo campus every day, discussed my research plans with Professor Seki, who was then entering a highly theoretical phase in his intellectual trajectory, painstakingly began compiling a bibliography in the library, then addressed myself to the task of reading books and articles, taking copious notes. (David's advice on note-taking was that I should not purchase expensive 
filing cards but should cut up scrap paper with a guillotine, write on both sides, then store the notes in old cardboard shoe boxes; I ignored his advice, bought cards at the university stationery shop and also employed Kokuyō Exercise Books, all of which I still have in my possession.)

Had not the massive groundswell of popular protest against the Japan-US Security Treaty and the Vietnam War, in which the student movement played a central role, overwhelmed most major Japanese universities in 1968, I would certainly have continued this disciplined, rather cloistered pattern of scholarly life until I returned to Australia at the end of 1969 to begin writing up my thesis. As it was, the daily confrontations between student demonstrators and riot police forced the closure of the campus and, although I continued to travel to Hongō 3-chōme from time to time, I was increasingly thrown on my own resources. Once I had settled on a thesis topic (postwar Japanese defence policy), I bought all the books relating to the subject that I could find and worked from home. (I now inhabited an eightmat room in the house of a hospitable Japanese family in Yoyogi and wrote at the usual type of low table, sitting cross-legged on the tatami.) I explained the situation to David, who could not see any alternative and was completely understanding. I also went to work in the drowsy, air-conditioned comfort of the National Diet Library, mostly in the Newspaper Clipping Section, where the private secretaries of politicians could be seen, surrounded by voluminous files and heavy yearbooks, slumped over their desks in various attitudes of repose, snoring rhythmically. From time to time I visited the National Defence Research Intitute (Bōei Kenshūjo).

More importantly, perhaps, I made the acquaintance of an unusually wide range of people from almost every section of Japanese society. I also kept up and expanded my network of friendships among East and South-East Asian students in Japan. On a number of occasions, my connections aroused the interest of the Japanese police. I mentioned this to David. He was rather concerned and gave me sound advice, drawing my attention to articles 33 and 34 of the Japanese constitution, which I committed to memory and subsequently used with much effect. He did not ask me to curtail my social activities. I think he could sense that, together with my voracious reading habits, they were helping to cultivate an informed peripheral vision that contributed substantially to my understanding of Japanese society and political culture, and ultimately to the writing of a more balanced, perceptive and useful thesis.

In retrospect, I can see how fortunate I was to have lived in Japan during those years of tremendous intellectual ferment and political turbulence, as the nation's leaders, conscious of the changes taking place in the global power balance, divided among themselves and subjected to a variety of foreign pressures, above all from Washington, attempted to steer a steady course between the shifting realities of regional politics, the requirements imposed by the US alliance and the increasingly insistent demands of domestic popular opinion. Direct experience of 
the anti-security treaty and antiwar movements gave me insights into aspects of Japanese society that have been largely dormant since the Vietnam War came to an end in 1975; popular opposition to the security treaty began to wane, and was then transformed into widespread support; the student movement petered out in directionless, often savage factional infighting; and the nationalist right wing began its long, powerful resurgence.

At its height, however, the anti-security treaty and antiwar movement, in which several of my Japanese friends participated, exerted a significant influence at the highest levels of decision-making, strengthening the position of those moderate conservative leaders, especially from the old Yoshida School, who wished to avoid constitutional revision, large-scale rearmament and excessively close involvement in the military aspects of American-Asian Pacific strategy. Some years after he retired from political life, I asked former prime minister Satō Eisaku, who had discouraged Washington's interest in 'boots on the ground' in Indochina, how he evaluated the antiwar movement. 'Ah,' he said, his eyes twinkling and his fleshy face breaking into a grin, 'the students put up a great struggle! I was always worried about the spiritual deficiencies of modern Japanese youth, but now I realise there was no need to have been concerned at all.' I had no idea that the then prime minister was thinking such thoughts when I stood near the Akamon (the Red Gate of Tokyo University), as I did many times in 1968 and 1969, observing the frenetic but bloodless clashes between veritable armies of students wielding bamboo staves and the serried ranks of the Special Mechanised Police, with their visored helmets, tall shields and batons; or watching the long struggle for possession of the Yasuda Kōdō; or the massive confrontations in Shinjuku or Shibuya at night, as I walked back to my Yoyogi home, under the polluted sky, moonless and starless, which reflected the myriad lights of the restless city like an immense bowl of incandescent lacquer.

In the summer of 1968, surprised by David's approval of my plan, I travelled on the Trans-Siberian Railway to Moscow and then by plane to Soviet Central Asia. I was able to meet Soviet academics and many other kinds of people. I lack the space to discuss in detail this fascinating journey, but I drew certain conclusions from my experiences.

First, I came to understand more clearly Russian perspectives on Japan and its place in contemporary Cold War global geopolitics. During my talks in Moscow with Soviet scholars, we took up the question of the then rapidly developing AustraliaJapan economic relationship and its role in Soviet strategies of containment. They had noted Sir John Crawford's proposal for an Australia-Japan-India economic and strategic partnership to counter Chinese influence in Asia and were devoting some thought to its possible implications. We also talked at length about the likely future evolution of Sino-Japanese relations. 
Second, the journey from Nakhodka to Moscow on the Trans-Siberian Railway made me appreciate more fully how profoundly the 'tyranny of distance' (to use Geoffrey Blainey's phrase in a different context) had influenced the outcome of the Russo-Japanese War of 1904-05 and continued to have an enormous impact on Soviet strategies to counter the US-Japan Security Treaty system and the activities of a then hostile China in East Asia. Travelling the distance and viewing the terrain brought the problem into sharper focus.

Third, I could see how many Japanese policymakers in the 19th and 20th centuries believed (erroneously) that they could detach Sakhalin, Kamchatka, the Maritime Province and, eventually, the vast territory east of Lake Baikal from Russia, transforming the Sea of Japan and the Sea of Okhotsk into virtual inland seas, fully incorporated into an ever-expanding Japanese empire that was both maritime and continental in character.

Fourth, the long flights from Moscow to various cities in Soviet Asia made me begin to question whether late 19th-century British fears of a Russian invasion of India through the Hindu Kush, the Karakoram or over the Pamirs - a strategic concern that led directly to the Anglo-Japanese alliance of 1902, which in turn precipitated the Russo-Japanese War, Japanese annexation of Korea, the Japanese penetration and absorption of Manchuria, then the Japanese advance into Eastern Mongolia and North China - had any basis in reality. After studying the matter carefully for many years, I came to the conclusion that these British apprehensions were groundless and that the Anglo-Japanese alliance, which, more than any other factor, helped launch Japan on its career of imperial expansion, was based on a strategic fantasy.

I shared my thoughts with David when we next met. He listened attentively, although it was my impression that his views on the Anglo-Japanese alliance differed from my own.

In 1969, concerned about the progress of my thesis, I (perhaps foolishly) turned down invitations to visit the USSR again, and to visit Cambodia. So that I could begin writing my thesis as expeditiously as possible, I did not return to Australia by sea but took an Air New Zealand all-night flight from Haneda to Sydney.

Back at ANU, I experienced several crises of confidence during the writing of my thesis. David gave me much-needed moral support during these long, arduous months. He and Dr Tom Millar also encouraged me to write a monograph on Japanese reactions to Chinese nuclear weapons and missile development, which was subsequently published as one of the Canberra Papers on Strategy and Defence. At the time I regarded this project as something of a distraction, but the favourable comments both from senior specialists in the United States and Canada proved most reassuring. 
Sometime during the Australian winter of 1971, David asked me if I had any thoughts about prospective examiners. I replied that I would leave the matter entirely to him, but asked that he choose a panel of people who understood Japan well and who were empirical rather than theoretical in their approach to the social sciences. The examining committee he put together - Professor Edwin O Reischauer of Harvard University, US ambassador to Japan during the Kennedy and Johnson years; Professor Herbert Passin of Columbia University; and Professor Ronald Dore of the London School of Economics - was one that inspired me with terror, although it certainly fell within the parameters I had suggested. In reality this was David's last gift to me, at least as far as my doctoral thesis was concerned.

I submitted my thesis on Christmas Day 1971. Early in the New Year David and his wife Bronwen took me to dinner at the Top Paddock, a restaurant located somewhere in the bush on the outskirts of Canberra. I remember that he ordered, among other things, a bottle of Great Western Champagne to celebrate the occasion. There is, however, no such thing as a free meal. Shortly afterwards, again to my horror, since I have always been, and remain, a poor public speaker, David arranged for me to present a testimony on Japanese security policy to the Senate Standing Committee on Foreign Affairs and Defence, which he served as academic adviser during its extended hearings on Japan.

In February I left again for Japan, once more by ship, this time as a SaionjiHammersly Memorial Scholar, to take up a position as a visiting research fellow in the Department of International Relations in the Faculty of Law at Tokyo University. The university had more or less returned to normal, although the nationwide struggle against the US-Japan Security Treaty and the movement against the Vietnam War, both of which had reached a peak in 1970, continued.

In July 1972 Reischauer, also representing the other members of the panel, took my thesis oral examination in his suite on the 12th floor of the Miyako Hotel in Kyōto. The examination began around $5.00 \mathrm{pm}$ and ended after midnight. Reischauer, that forthright and incorruptible pillar of the American Republic, was nothing if not thorough. Shortly afterwards he informed ANU that the examination committee had found no problems with my thesis and recommended that I be admitted to the degree of Doctor of Philosophy forthwith.

I reflected then, and I have never forgotten, that I would not have arrived at this point without David's constant quiet support and encouragement, his policy of fostering my spirit of independence, giving me near absolute freedom and leaving me to my own devices, the caveat being that I was to take responsibility for the outcome. Actually, I have always regarded degrees and diplomas as no substitute for the 'real and substantial knowledge about issues of great public importance' of which JDB Miller had spoken during our lunch at the Cellar Bar in January 1967, on the eve of my odyssey. Other people, however, do attach importance to these 
things, so that I was tremendously relieved when David and Miller sent me the news of Reischauer's recommendation, together with his detailed report, and those of the other examiners, all of which were highly encouraging.

I saw David, Bronwen and their children from time to time in later years, both in Australia and in Japan. I will never forget the pleasant evenings I spent at their family home on Red Hill, the very embodiment of gracious, ordered domesticity, where the $\log$ fire crackled and blazed on the hearth, illuminating rich oriental rugs and tasteful arrangements of flowers, and where a splendid dinner and good wine waited on the dining-room table. I remember too how, after I took up my position at the International University of Japan in 1982, and it eventually became necessary to consider the future education of children, David and Bronwen gave excellent advice. Although my commitments in Japan meant that our meetings became fewer and fewer with the passage of time, I will always regard them as wise mentors and trusted friends.

Urasa, in the Echigo Mountains, Niigata-ken, Japan

1 January 2013

In heavy snow 


\section{2 \\ Australian-Japanese relations: The first phase 1859-18911}

\section{DCS Sissons}

It was grog time when the visit was made, and the aldermanic party seized the opportunity for tasting 'saki', a spirit altogether foreign to their palates. The opinions regarding the beverage varied. One thought it too strong, while another of greater experience in liquor proclaimed it altogether too mild. A third would shake his head and declare that it was not fit for English throats.

Account of the visit of the Mayor and Aldermen of Sydney to HIJMS Tsukuba, Sydney Morning Herald, 10 April 1886

\section{Australia in Japan}

Not surprisingly, over the period of more than a century in which they have had dealings with each other, the response of Australians to the Japanese has been as varied as that of the aldermen to Japan's national beverage.

So far, the earliest reference that I have found to contact between Australians and Japanese is in the Sydney Gazette of 25 February 1832. There a correspondent claims that the crew of a Sydney whaler, the Lady Rowena, had recently made a landing at latitude $43^{\circ}$ on the Japanese east coast. ${ }^{2}$

\footnotetext{
1 Unpublished paper.

2 R Hildreth, Japan As It Was and Is (London: Sampson Low, 1856) cited this report (p. 494) but wrongly dated it as February 1842. Unsuccessful attempts to find it in the Sydney Gazette were made by HE Wildes (Aliens in the East: A New History of Foreign Intercourse, Philadelphia: University of Pennsylvania Press, 1937, p. 215) and HS Williams (Foreigners in Mikadoland, Tokyo: Tuttle \& Co., 1963, p. 114). Our thanks are due to Honore Forster ('A Sydney whaler 1829-32: the reminiscences of James Heberley', Journal of Pacific History, vol. 10 [1975], p. 103) for providing the correct date for the Sydney Gazette item.
} 
If this was in fact the first contact between our two peoples, then the relationship got off to a bad start for, according to the correspondent, the sailors destroyed a village and fired on its inhabitants.

There is no doubt that the Lady Rowena was in Japanese waters in the course of her 1830-32 whaling voyage. ${ }^{3}$ The following passage in the Sydney Herald of 16 July 1832 tends to confirm the report of a predatory landing:

The Lady Rowena has also brought up several curious Japanese instruments and utensils rarely met with, on account of the extreme jealously the natives of Japan evince towards strangers.

This was during the period of Japan's seclusion when any landing by foreigners would have been likely to be resisted. Hence there would have been little chance of acquiring 'instruments and utensils' other than by force.

It was in 1859 that Japan was finally forced to abandon her policy of seclusion and open designated 'treaty ports' to trade and to foreign residents. In that year a youth aged 21, Alexander Marks, a new Australian - born in the United States but raised for the most part in Australia - set up in business in Yokohama. In 1872, following the loss of two of his brothers on the Julia in a trading venture between Yokohama and the Marianas, he returned to Melbourne where he continued to be engaged in trade with Japan until his death in 1919. GE ('Chinese') Morrison, writing in 1900, described him as worth $£ 80,000$ in Melbourne and having much property in Yokohama. From 1879 to 1896, Marks was honorary consul for Japan for the Australian colonies generally. From the latter year (when a career consul was appointed in Townsville) until his retirement in 1902, he was honorary consul for Victoria. ${ }^{4}$ That his consular responsibilities were no sinecure - particularly in the earlier period - is attested by the large volume of despatches to and from him that survives in the archives of the Japanese Ministry of Foreign Affairs ${ }^{5}$ and by the fact that he had a Japanese clerk working under his direction on consular matters.

3 IW Nicholson, Shipping Arrivals \& Departures, Sydney, vol. 2, 1826-40 (Canberra: Roebuck, 1977), establishes that the Lady Rowena entered Sydney on 27 July 1832 from the South Sea fishery including Japanese waters carrying 600 barrels of sperm oil. The voyage had commenced from Sydney on 2 November 1830.

4 The Cyclopedia of Victoria (Melbourne: Cyclopedia Co., 1903), vol. 1, pp. 289-90; Far East (Yokohama), vol. 2, no. 11, 1 November 1871, p. 129; Jewish Herald (Melbourne), Obituaries, 30 May 1919; Argus (Melbourne), 22 May 1919; GE Morrison, diary, 7 February 1900; ECFG Kunz, Blood and Gold: Hungarians in Australia (Melbourne: Cheshire, 1969), pp. 25-28.

5 Japanese Ministry of Foreign Affairs, Nihon Gaīkō Bunsho (Select Documents on Japan's Diplomatic Relations) (hereafter referred to as NGB). 
He travelled extensively in connection with his consular duties, including at least one tour of inspection to Thursday Island. He was fluent in the language, ${ }^{6}$ and on occasion acted as interpreter in court proceedings. ${ }^{7}$

It is doubtful whether more than a portion of Marks's trading activities in Yokohama were with Australia: Australian imports to Japan were virtually nonexistent until wool shipments commenced in the 1890s. ${ }^{8}$ Earlier efforts by one or two wool brokers to develop a Japanese market were unsuccessful. In a letter to the Sydney Morning Herald in 1895 PL Trebeck writes:

In 1874 I collected all the best lots of wool, bales and cases from our Agricultural Society's Exhibition of that year, and consigned them to Sir Harry Parkes, K.C.B., at Her Britannic Majesty's Legation at Yeddo, and to H.E., Okubo Toshimichi, Minister of the Interior Department, Yeddo. A beautiful lot of snow white sheep and lambs' wool of Mr Kermode's was to be presented to the Mikado, and the other was for distribution among the manufacturers. In return, the Mikado sent us some good silk handkerchiefs and neckties, and also some of the cotton rugs and mats generally used in their dwellings. ${ }^{9}$

For two reasons, nothing came of this. First, as Trebeck notes, the price of wool rose by 20-30 per cent and the graziers lost interest in marketing. Second, there were not yet any woollen mills in Japan. The need, however, was there - chiefly for uniforms for government employees. As early as the 1860s, some units of the Shögun's army and navy had adopted Western uniforms and, in 1871, the police force and the post office did likewise. But all the cloth was imported. ${ }^{10}$ Trebeck appears to have become aware of the absence of a local industry for, in the same letter, he writes that, a few years later when prices had fallen, he tried to induce

6 In 1940 at Kushimoto, a village at the tip of the Kii Peninsula, an old man, Tanaka Fujitarō, remembered Marks as 'a giant of a man whose Japanese was so accomplished and polite that we felt like country bumpkins'. He had met Marks in 1899 when, in the course of his attempt to emigrate to Thursday Island on the Futami Maru, the Queensland authorities had refused him and his three colleagues permission to land and they were carried on to Melbourne (these must have been the four men masquerading as 'merchants' referred to by the Queensland Chief Secretary in his telegram to the Japanese Consul of 13 July 1899, which is published in Queensland, Parliamentary Paper A56 of 1901). Marks met the ship at Melbourne and managed to secure them admission to Thursday Island. Tanaka recounted this at a meeting convened on 16 September 1940 by the headmaster at Kushimoto for the purpose of making a record of the recollections of older citizens of matters of importance in the history of the village (Kushimoto Köyūkai-shi, 1940, p. 33).

7 Argus, 23 and 25 July 1878.

8 An exception may have been racehorses. HS Williams in his Tales of the Foreign Settlements in Japan (Rutland: Tuttle, 1958) at Chapter 18 speaks of the contribution to Japanese horse racing made by the 'fast racehorses and crooked jockeys ... that were imported from Australia', but describes this as a fairly late phenomenon. Note, however, that JH Brooke, writing in 1867, reports having witnessed the victory of an Australian horse, 'Sydney', in a Japanese race (Argus, 29 August 1867).

9 As reported in Japan Daily Mail, 26 April 1895 (Mitchell Library - 'Contributions by John Plummer', p. 4).

10 For a most informative and readable account of the progressive adoption of Western clothing and the development of the woollen industry in Japan, see K Nakagawa \& H Rosovsky, 'The case of the dying kimono', Business History Review, Spring/Summer 1963, pp. 59-80. 
some squatters to subscribe sufficient funds to provide the Japanese with a few simple modern looms and to supply some wool or yarn. Once again, however, the price of wool rose and the squatters were not interested.

Trebeck was a few years premature. In 1873 , the year before Trebeck had despatched the samples, Okubo had proposed the establishment of a woollen industry in Japan, largely to save the foreign exchange being spent on imported cloth. As the result of his representations, it was decided to establish a government woollen mill at Minami Senjū in Tokyo. In 1876 a mission was sent to Germany to purchase machinery and to engage technicians. ${ }^{11}$ In 1878 some government officials, led by a Mr Yokoyama, visited Australia to study the use of wool for military uniforms. They took back samples of wool and also some sheep. Exporting the latter did not worry the Australians, who had already made their own enquiries and found out that the merino could not thrive in the Japanese climate. ${ }^{12}$ The Minami Senjū mill began operations in September 1879. Some wool was imported from Australia soon afterwards through the Melbourne wool firm Arnold \& Co. ${ }^{13}$ It seems, however, that, until Kanematsu \& Co. set up operations in Sydney in 1890, what Australian wool the Japanese used must for the most part have been bought in the United Kingdom.

The first recognisable category of migrant from Australia to Japan appears to be settlers from the United Kingdom for whom the Australia of the 1860s belied the glittering prospects of the 1850s.

HS Williams, the doyen of today's Australian community in Japan, in his Tales of the Foreign Settlements of Japan quotes the following passage from the Japan Times Overland Mail of 27 January 1869:

We must not omit to mention the advent of a fine steamer, the 'Albion', from Australia. She arrived in June and brought a number of passengers who had been induced to move hither by the publication in the Melbourne Argus of some excessively factual letters from a countryman here describing Japan as a new E1 Dorado. We did immediately what we should have done before, published a couple of articles advising intending immigrants what class of men we wanted and to what they were coming. These and the private letters of the unfortunate victims who have been seduced hither to suffer poverty seem to have checked the movement. ${ }^{14}$

Unfortunately, however, this story cannot be accepted in its entirety. Undoubtedly the Albion did make a voyage to Japan with passengers at that time: the Sydney Morning Herald of 12 May 1868 announces her impending departure from

11 T Ichikawa, Nichigō Kankeishi (Nichigō Nyūjirando Kyōkai, 1953), part 2, pp. 181-88.

12 Monckton Synnot, letter, Argus, 3 August 1878.

13 Dalgety's Annual Wool Review for Australia, Season 1925-26, p. 88.

14 Williams, Tales of the Foreign Settlements in Japan, 1958, p. 158. 
Sydney that afternoon for Yokohama via Fiji. It gives the names of 37 passengers and the number of children accompanying them. It lists the cargo - 56 cases of champagne, ${ }^{15}$ one boat and 40 other packages for Yokohama. How many of these passengers were emigrating to Japan we do not know for not even their destinations - let alone the purpose of their journeys - are stated. A series of letters from Japan by a former Victorian had indeed appeared in the Argus. ${ }^{16}$ These, however, confined themselves to descriptions of the sights and the people through the eyes of a tourist, and contained no suggestion of employment opportunities for Europeans. Why did the Mail say otherwise? Possibly because the writer of the Argus letters, JH Brooke, may have been associated with the Mails rival, the Japan Herald. To blame one's rival for as many of the ills of humanity as possible was a common device of 19th-century journalism. Brooke arrived in Japan on Easter Sunday (21 April) $1867^{17}$ (with an amount of luggage that set Yokohama society talking for years).$^{18}$ In Victoria, fortune had initially smiled on him. In 1860, within eight years of his arrival from England, he had achieved Cabinet rank, at the early age of 34 . In 1863, however, he was omitted from the Ministry and, in the following year, he was defeated at the polls. ${ }^{19} \mathrm{He}$ became proprietor of the Herald in 1871 and was proprietor and editor until his death in Yokohama in 1902. ${ }^{20}$

Strangely enough, Brooke's predecessor as editor of the Herald was another disappointed colonist, JR Black. In the words of the rather patronising obituary written by Brooke in 1880:

Mr Black was a native of Scotland; he emigrated to South Australia, and resided in that colony for some years. Business with him taking an unprosperous turn, he was induced to turn his fine vocal powers to account, and, after travelling through the Australian colonies, India, and China, he at length reached Japan, where, with the exception of a short stay in China, he has ever since resided. The deceased's career was a checkered one. Of a hopeful and cheerful disposition, his views were always sanguine. His industry was great, but his business enterprises were seldom crowned by success; year after year he struggled manfully with his difficulties, but the Fates were unpropitious. At one time he held the editorship and sustained the management of this journal. Next he projected and started with a few battered types and an old wooden press, the Japan Gazette, which, not proving a lucrative undertaking, he retired from. His next literary enterprise was a periodical called the Far East, illustrated with photographs, after which he started the first newspaper conducted by a European in the native language; this he disposed of, and he

15 From Brooke's account of life in the foreign settlement at Yokohama at this time, champagne was a muchused beverage. It was served as a stirrup-cup to the 14 natives who made up the armed party that escorted Brooke and his colleagues to Edo (Argus, 29 August 1867).

16 'Impressions of Japan - by an Australian colonist', Argus, 22, 24 and 29 August; 10 and 28 September;

28 October 1867.

17 Argus, 22 August 1867.

18 Williams, Tales of the Foreign Settlements in Japan, 1958, p. 162.

19 Australian Dictionary of Biography, 1851-1890, vol. 3, p. 244.

20 Far East, vol. 2, no. 10, 16 October 1871, p. 117. Brooke's obituary, Japan Times, 11 January 1902. 
started another in lieu, but it was supressed by the Japanese Government; nor did its projector and proprietor succeed in obtaining compensation for the loss the stoppage of the paper was to him. For a brief period he was in the Government service, after quitting which he continued the publication of his magazine in Shanghai, and whilst there was concerned in the starting and publication of the Shanghai Mercury. Whilst so engaged his health gave way, and he came back to Japan, looking the shadow of his former self - to recuperate. His final effort was the compilation of a work, - 'Young Japan'; an epitome of the history of the foreign settlement since the conclusion of the existing treaties. ${ }^{21}$

Today Brooke is a forgotten figure. Black, however, is remembered both in the West, and in Japanese history. The first six volumes of his The Far East: An Illustrated Fortnightly were reprinted in a facsimilie edition in $1965 .{ }^{22}$ His Young Japan: Yokohama and Yedo, a perceptive and readable, though somewhat rambling, account of the last years of the Shogunate and the early years of the Meiji Government, was reprinted in $1968 .{ }^{23}$ But it was in his Japanese vernacular newspaper, the Nisshin Shinjishi, that he made history. In 1926 when the Osaka Mainichi published Jü Daisenkaku Kishaden (Ten Great Pioneers in Japanese Journalism), it numbered Black among the 10. Black set up the Nisshin Shinjishi newspaper in March 1871. In November it was granted the exclusive privilege of publishing announcements of the Sain, the deliberative organ of the Japanese Government. How was it, asks the Mainichi writer, that Black's paper achieved such eminence? His explanation is as follows:

It was solely due to the fact that he as editor was a realist and understood the useful function that a newspaper can discharge. It had a flavour quite different from the newspapers of the day. While the Chingai Shimbun, the Moshihogusa and the Köko Shimbun dealt principally in very unsophisticated political discussion and strange jottings remeniscent of the preceding era, Black told his readers of the vicissitudes of farming, of prices, of new inventions, of exports and imports, of transactions as far apart as the sale of upland pastures and the purchase of battleships. No doubt the readers could tell from this that it was a real newspaper and could see the scrupulous care with which he treated everything. His was the first newspaper to list exports and imports at Yokohama and the time-table and fares of the railway ... It is apparent that its strength was that it caused people to realise that newspapers are useful. ${ }^{24}$

21 Japan Herald, Obituary, 11 June 1880

22 The Far East: An Illustrated Fortnightly, vols 1-6, facsimile edition (Tokyo: Yūshōdō for Tokugawa Rinseishi Kenkyūjo, 1965).

23 JR Black, Young Japan: Yokohama and Yedo (London: Trubner 1881), vol. 2.

24 A Ōdawara, 'Burakku', in T Kubota, Nijüichi Senkaku Kisha Den (Osaka: Mainichi Shimbunsha, 1930), at p. 222. 
He confirms Black's boast that it was he who introduced the 'Editorial' into Japanese vernacular journalism. ${ }^{25} \mathrm{He}$ also notes that Black encouraged the writing of letters to the editor and that rising young politicians expounded their views in his columns.

In 1874 Black achieved a scoop by publishing the manifesto in favour of the establishment of an elected legislature, which had been drawn up by disgruntled elements within the government. According to the Mainichi writer, Black's paper, while in its editorials it ridiculed the childish prattle of the other papers, alone published the good points of the protagonists of both sides. More recently, in 1967, Professor Okudaira has argued that it was this particular debate, sparked off by Black's publication of the manifesto, that transformed the Japanese press from 'quasi Government gazettes' into 'newspapers engaging in political discussion'. ${ }^{26}$

A Japanese scholar selected Black as the topic for his paper at the International Conference of Orientalists at Canberra in January 1971 and was surprised to find that he was quite unknown in Australia. Presumably he was the JR Black who, according to the Adelaide Times of 1 November 1854, disembarked from the Irene with his wife four days previously. Perhaps, as more work is done on business history and the history of the performing arts in this country, we may one day learn more about both his unsuccessful business activities and the 'fine vocal powers' that proved so useful when other employment failed.

If Marks, Brooke and Black were Australian only by adoption, Australia can claim Wilton Hack as truly her own. He was born in South Australia in 1843, the son of Stephen Hack, a venerated pioneer of Quaker stock. In 1873, the year of the removal of the public notices in which the Japanese Government prohibited its subjects from adhering to the Christian religion, he went to Nagasaki and established a mission there. ${ }^{27}$ At that time there were only about 10 Japanese Protestant converts in the entire country. ${ }^{28} \mathrm{He}$ purchased a printing press, engaged a translator and distributed thousands of religious tracts among the inhabitants. He is said to have built up small followings in Nagasaki and Hiroshima among poor middle-class people. For 12 months in 1874-75 he was able to help finance his missionary activities by teaching English at a government school, the Eigo Gakko, at Hiroshima. ${ }^{29}$ This employment, however, was terminated and, in 1876, he returned to Adelaide to raise funds. During this visit he sought and received authorisation from the South Australian Government to 'lay before the

25 Black, Young Japan, 1881, vol. 2, p. 364.

26 Y Okudaira, 'Nihon Shuppan Keisatsu Hōsei no Rekishi-teki Kenkyū', Hōritsu Jì̄ō, June 1967.

27 For details about Hack and his scheme see my article 'Japanese in the Northern Territory 1884-1902', in South Australiana, vol. 16, no. 1 (March 1977). Much of my information about Hack is derived from J Cross, 'Wilton Hack and Japanese immigration into north Australia', Proceedings of the Royal Geographical Society of Australasia (S. Aust. Branch), vol. 61 (1960), pp. 55-59.

28 H Ritter, A History of Protestant Missions in Japan (Tokyo: Methodist Publishing House, 1898), p. 39.

29 T Shigemasa, Oyatoi Gaikokujin, vol. 5 ('Kyōiku, Shūkyō') (Tokyo: Kajima, 1968), p. 73. 
[Japanese] authorities and the public there full particulars respecting the terms on which settlement may take place in the [Northern] Territory and the character of the country'. ${ }^{30}$ In his subsequent correspondence with the Japanese Foreign Ministry, Hack exceeded his instructions and suggested that the South Australian Government might be willing to pay the fares of the migrants. ${ }^{31}$ The Foreign Ministry, however, adhered to its standing policy and replied that it would resist such emigration. ${ }^{32}$ It had had too much experience of having to repatriate Japanese subjects who, despite the disapproval of their government, had been beguiled overseas by unscrupulous foreigners under 'contracts' that they did not carry out. It was not until 1883 that the Japanese Government consented to the emigration of groups of its subjects under contracts of service. Hack closed down his mission and, early in 1877 , returned to Australia where he 'turned to the more dubious, worldly life of a mining speculator. ${ }^{33}$

J Hingston, the Melbourne journalist who visited Japan early in 1877 wrote: 'Scarcely an Australian but can remember some one from some part of Australia who has made Japan a home. ${ }^{34} \mathrm{He}$ reports, however, only one encounter with an Australian during his visit:'A Melbourne man, who had been a "super" at the Theatre Royal, was, I found, tutor at an up-country school at $£ 200$ a year. He intended to stay in the country.' Nothing more is known about this man. But some 11 years later, in 1888, a teacher arrived from Australia who in later years was to become famous as a Western scholar of Japanese history. He was James Murdoch. ${ }^{35}$

Born in Stonehaven, Scotland, in 1856, Murdoch became assistant to the professor of Greek at Aberdeen in 1880. In 1881 he migrated to Queensland to take up the position of headmaster of Maryborough Boys Grammar School. He was summarily dismissed from this position in 1885 in the course of a dispute with the trustees over their authority to require members of his staff to give lessons at the girls' grammar school as well as the boys. ${ }^{36}$ Letters in the 'Correspondence' column of a local newspaper suggest that additional reasons for Murdoch's departure may have been anxiety about his agnosticism and some kind of scandal

\footnotetext{
30 E W(ard), (Minister for Agriculture and Education), Minute, 5 September 1876, approved by cabinet the same day, 'Project for Introducing Japanese Settlers into the Northern Territory 1876-77', no. 358, State Archives, South Australia.

31 Hack to Minister of Foreign Affairs, 26 February 1877, 'Project for introducing Japanese settlers into the Northern Territory 1876-77’, no. 358, State Archives, South Australia.

32 Ishibashi to Hack, 27 February 1877, 'Project for introducing Japanese settlers into the Northern Territory 1876-77', no. 358, State Archives, South Australia.

33 Cross, 'Wilton Hack and Japanese immigration into north Australia', 1961, p. 59.

34 J Hingston, The Australian Abroad: Branches from the Main Routes Round the World (London: Sampson Low, 1879), vol. 1, p. 1 .

35 My information about Murdoch is derived principally from C Nomi \& M Matsumoto, 'J Mādokku', Kindai Bungaku Kenkyū Sōsho (Tokyo: Shōwa Joshi Daigaku), vol. 30 (1963), pp. 83-108 and the obituaries in the Aberdeen University Review, vol. 9, pp. 109-14, 226-33 and the Japan Weekly Chronicle, 17 November 1921. The latter obituary was reprinted as the Foreword in Murdoch's A History of Japan, vol. 3, The Tokugawa Epoch 1652-1868 (London: Kegan Paul, 1926).

36 Maryborough Chronicle, 3, 7 February, 7 March 1885.
} 
involving his wife ${ }^{37}$ It may have been at Maryborough that his first marriage broke down. From 1885 to 1888 he was second master of Brisbane Grammar School. ${ }^{38}$ There he was well regarded, the headmaster noting at the time of his departure that he had 'served the school most ably and faithfully'. ${ }^{39}$

In 1888 he turned to journalism and was commissioned to journey to Hong Kong on a ship engaged in transporting Chinese coolies to Australia and to study the conditions under which they lived and travelled. He continued on to Japan. Soon after his arrival he contributed a series of articles to the Japan Gazette on the bad conditions at the Takashima coalmine in Kyushu. ${ }^{40}$ The following year (1889), William Lane's Brisbane weekly magazine, the Boomerang, published a series of articles by Murdoch describing Japan and his experiences teaching at a school of English operated by the former daimyō at Nakatsu in Kyūshū. On 13 April of that year, the Boomerang mentions a brief visit by Murdoch to Brisbane from Japan to open up trade with Queensland. On 5 May it advertises an auction of Japanese curios and silks brought by Murdoch from Japan. Apparently Murdoch was also pushing the sale of the Boomerang in that country for, on 25 May, it claims weekly sales of 50 copies in a single Japanese town. Later in the year he returned to Japan to take up a contract with the Japanese Ministry of Education as a professor at the celebrated Tokyo First High School (Japanese Government 'high schools' were modelled on the German Gymnasium. They were the link between secondary school and university. Students entered them at about the age of 18.) Two of his students there achieved international reputations - Natsume Sōseki, the novelist, and Shidehara Kijūro, the diplomat and prime minister. Both kept in touch with Murdoch in later life. ${ }^{41}$ Concurrently with his teaching, Murdoch continued to be active as a writer. Among other things, he edited a weekly magazine, the Japan Echo. This, however, lasted for only six issues - apparently Murdoch's short stories set in the provincial towns of Queensland were not to the taste of Tokyo's international community. In 1893 he left to join his Brisbane friend, Lane, in his unsuccessful attempt to found a socialist colony in Paraguay. After a few weeks, however, Murdoch returned to Japan where he remained until 1917 writing his famous History of Japan.$^{42}$ In that year he was appointed lecturer (later professor) in Japanese at the University of Sydney.

37 Wide Bay and Burnett News, 12 and 17 March 1885.

38 S Stephenson, Annals of the Brisbane Grammar School (Government Printer, 1923), p. 15.

39 Headmaster to G Souter, 9 June 1966, 'Souter Papers', Fisher Library, University of Sydney.

40 Quotations from these articles survive in the attack on them in the Japan Weekly Mail, 13 October 1888.

41 For references to Murdoch in Natsume Sōseki's works see S Matsui, 'East and West in Natsume Sōseki: the formation of a modern Japanese novelist', Meanjin Quarterly, no. 110 (1967), pp. 282-94. I am indebted to Dr Matsui for bringing this and other Japanese material about Murdoch to my attention.

42 Vol. 2 was first published in 1903, vol. 1 in 1910 and vol. 3 (posthumously) in 1926. Few books can have remained standard works for so long. Each volume was reprinted several times, the latest edition of each being 1952. 


\section{Japan in Australia}

Until 1866 it was a capital offence for any Japanese to leave the country. In that year, after two centuries and a half of seclusion, an edict was issued permitting citizens to apply for passports to go overseas for the purposes of study or trade. ${ }^{43}$ Probably the first Japanese to be seen in Australia were on the stage. In December 1867, 12 Japanese acrobats and jugglers performed in Melbourne at the Princess Theatre where they were billed as 'Lenton and Smith's Great Novelty for the Colonies The Great Dragon Troupe of Japanese - 12 Wonders from Yeddo'. ${ }^{44}$ Their season there lasted five weeks. The Argus was sufficiently impressed to devote two full columns to a review. It did not content itself with describing the performance and the theatre in Tokyo where it originated; but also noted its significance.

That a theatrical company of one of the most stay-at-home, exclusive nations in the world - a country which until recently natives could not leave and strangers could not enter - should so far throw aside the suspicions and prejudices of education and habit as to consent to trust themselves to the chances of an excursion so wide and to them unknown a range, is a circumstance which could only have occurred within the last year or two, and affords proof of the widespread influence of the spirit of change in these latter days. ${ }^{45}$

It is interesting to note that, even at this early date, the Argus writer referred to the Japanese as 'Japs'. The term is commonly used throughout the period. Though possibly a little familiar or condescending, like the Australian's use of 'Brit' today, unlike the use of 'Pom' it had no inherently hostile connotation but was used frequently by Japanophiles like Hingston and Murdoch.

Japanese historians have noted that among the earliest Japanese to visit the United States was a group who, from their addresses, must have been acrobats but who in their applications for passports gave 'commerce' as the purpose of their journey. Passports, the historians argue, were to be issued for purposes of study or trade; but the acrobat's was a despised calling and it would have been considered harmful to the image that Japan was trying to create to let such people go overseas. ${ }^{46}$ The Argus review gives some support to this theory.

Mr Lenton selected his present company, with whom he effected an engagement for two years. There was no reluctance on their part to undertake the voyage, satisfactory terms having been agreed upon. Some difficulty, however, was experienced in getting them away from the port, the Governor for some time objecting to any females leaving the country. Every facility, it appears, is afforded to Japanese going abroad, who are likely to bring back any useful art or industrial

43 A translation of the edict is given in JR Black, Young Japan (London: Trubner, 1880), vol. 1, pp. 416-17.

44 Argus, 20 January 1868.

45 Argus, 17 January 1868.

46 Wakayama-ken, Wakayama-ken Imin-shi (Wakayama-shi: Wakayama-kenchō, 1957), p. 266. 
process to their own country, but somehow in this case, the authorities did not like the idea of these people going away as performers. Strict enquiries also were made as to whether they were wanted for any military purpose. At length permission was obtained for their departure, on the representation that they were wanted as servants to the company with which Mr Lenton was then travelling.

And so, after performing in Hong Kong, the Philippines, Batavia, Singapore, Penang and Calcutta, they eventually reached Melbourne where their audience included Queen Victoria's son, the Duke of Edinburgh. Three years later they were still on tour. In a Scottish newspaper there is an account of their performance at Abroath on 20 August 1870.47

It was a similar team of Japanese acrobats, the Royal Tycoon Troupe, 13 in number, which appeared in the same theatre in February 1874, that gave Australia its first Japanese settler, Dicinoski Sakuragawa. ${ }^{48} \mathrm{He}$ (and presumably the rest of the troupe) had arrived in Australia in 1871. By the end of the century, some hundreds of his countrymen had become permanent settlers but, only the merest handful had, like him, taken an Australian wife, become naturalised and purchased land. We can briefly trace his career by means of his contacts with officialdom. In the Victorian Registrar-General's office there is the certificate of his marriage at the Registry Office, Fitzroy, on 20 February 1875 at the age of 29 to 'Jane Kerr, Barmaid' of Bourke Street, Melbourne. His signature is in Japanese. His personal name is in ideographs and quite intelligible. For his family name he makes an unsuccessful attempt to use the phonetic alphabet used by Japanese primary school children before they learnt ideographs for he was illiterate and had left Japan before 1874 when commoners were first allowed to take family names. In the Queensland State Archives we have the evidence of his life as a travelling showman in the form of his annual applications for a theatrical performer's licence - from Dingo (1877), from St George (1880), and from Nebo (1881). Then, in 1882, comes his application for naturalisation, which was successful. From this we learn that the petitioner now had three children and had recently acquired 'a house and garden situated about 11 miles from Herberton on the Port Douglas road with the intention of abandoning his former occupation and becoming a farmer'. ${ }^{49}$ For some reason, however, his life as a farmer was shortlived. In 1883 the applications for theatrical licences begin again — this time at Mackay, C/o 'Japanese Circus'. The next, in 1888 and 1889 (from Curramulla and Ingham), are for acrobatic performances. Then nothing until 1893 when it is 'Dicinoski's Circus'. We hear of the circus again in 1917 when his son, Ewar, applied for registration under the War Precautions

\footnotetext{
47 Abroath Guide, '100 Years Ago', 20 August 1970. I am indebted to Mr HS Williams for this reference.

48 Throughout his life in Australia he used his personal name (of which the standard Hepburn transliteration would be Rikinosuke) as if it were his surname. His spelling of it in English varies from time to time: Deconoski, Decenoski, Dicinoski. As he was illiterate, it is hard to establish what his family name was. Possibilities are Sakuragawa, Sakagawa, Sakanagawa or even Takaragawa. Note that throughout this paper names are given in the Japanese order; i.e. surname preceding personal name.
}

49 Queensland, Inwards Correspondence, 1882/5058. 
(Alien Registration) Regulations. In his application, Ewar described himself as proprietor of a travelling circus, domiciled in Quilpie (Queensland). The parents must have left Queensland, for their names are not in that state's register of deaths.

Apart from these troupes of theatrical performers, the Japanese who arrived in Australia before 1883 appear to have been individual adventurers - principally seamen who had adopted the roving life by signing articles on foreign ships at one of the 'open ports' in Japan (as permitted by the treaties of 1859) and who, having come to Australia in the course of their employment, found the country to their liking and settled here. Scraps of information survive that tell us a little about some such early arrivals.

According to Japanese sources, Nonami Kojiro of Hirose in Shimane prefecture signed on a British merchantman at Yokohama in about 1874 at the age of 22 and, after some years on various European and American routes, signed off at Sydney. There he joined a pearling lugger as a pumper and arrived on Thursday Island in about 1878, the first Japanese to set foot there. He was eager to become a diver but his British employer resisted this on the ground that he was of the same race as the Chinese who had proved useless at that task. With the help of a Malay, however, Nonami got his way. Soon 'Japanese Nona' became the most famous diver on the island, with a monthly take almost double that of his closest competitor ${ }^{50}$ News of his success reached Japan and two or three Japanese arrived in 1881-82. They too did well. It was the success of Nona and his colleagues that caused the Australian pearler, Captain Miller, to go to Japan in 1883 to recruit Japanese labour for the industry. ${ }^{51}$ The only reference to Nona in the Queensland State Archives is a letter from him to the shipping master at Thursday Island dated 9 April 1892. Apparently Nona's Australian employer was rather like Dearsley Sahib in Kipling's 'The Incarnation of Krishna Mulvaney'. In the letter, Nona complained that he had been forced to contribute $£ 2$ for a Sydney sweepstake for which he had received no receipt and $£ 5$ for a raffle of a billiard table that had not taken place. ${ }^{52}$

An even greater success story is Nakagawa Tamiji,'Tommy Japan'. He first achieved fame as steward of the Sydney trading vessel the Ripple when she was attacked by natives near Cape de Gross on Bougainville in August 1880. According to a Japanese account (written 14 years after the event):

Seeing the Captain and the captain's wife murdered by the Natives, Nakagawa's anger knew no bounds. He himself was in great danger. Seizing the Captain's pistol he forced his way into the mob of brutal savages and, with the help of the

50 T Hattori, Nankyū no Shinshokumin (Tokyo: Hakubunsha, 1894), p. 10.

51 K Watanabe, 'Sasudē-tō oyobi Toresu-Kaikyō Tanken Hōkoku', Shokumin Kyōkai Hokoku, no. 29 (c. 1894), p.

39.

52 Queensland State Archives TRE/30. 
Engineer, a Britisher, drove off a dozen or more. Though he received a spearwound in the neck he more than settled the score with them and then brought the ship back to Brisbane safe and sound. ${ }^{53}$

Although it appears that, in fact, it was the mate who brought the vessel back to port, contemporary accounts confirm that Nakagawa performed most creditably. According to the report of Rev. George Brown on Duke of York Island where the survivors and the bodies were landed:

The steward was down the after hold engaged in handing up some stores by the captain's orders. He heard the captain call out 'I'm killed' and immediately received himself a dreadful wound in the neck from a tomohawk. He fell back, but recovered, and, with his revolver shot the two men who were standing over the hatchway; one of whom, it is pretty certain, was the man who struck down the captain ... The steward (a Japanese) is praised by all for his bravery; though wounded in the most dreadful manner in several places, he fought until the ship was clear and the natives driven away, when he fainted from loss of blood; and now the poor fellow wins the respect and love of us all by his care of the poor men who are fellow-sufferers with him. ${ }^{54}$

The Japanese source continues that the Brisbane press was united in singing Nakagawa's praises and that ladies and gentlemen vied with each other in contributing to his medical expenses. This does the Courier more than credit: in its account of the incident, it makes no mention of Nakagawa's efforts and urges the owners adequately to reward the mate $!^{55}$ Nakagawa moved to Thursday Island the following year. There were then only four or five Japanese on the island. But, with the widespread employment of Japanese on the luggers after 1893, he prospered first as a boarding house keeper, then as the proprietor of a billiard saloon and store. Marks, on his visit to the island in 1895, speaks of him as a 'very good character' and notes that he speaks English 'very fairly' and is of 'some assistance to the other Japanese and acts as interpreter when required to do so. ${ }^{56}$ This is confirmed by the surviving portion of the Petty Sessions Deposition and Minute Book, in which his name from time to time appears as court interpreter. ${ }^{57}$ From the same book it also appears that the fighting spirit of the hero of the Ripple sometimes reasserted itself. He must have celebrated Christmas 1888 too well for he spent Christmas night in the watchouse and was fined 5 shillings the next morning for being drunk and disorderly. ${ }^{58}$ Two years later he had ample cause for celebration: he was leader of a syndicate of 10 Japanese on the island that drew

53 Hattori, Nankyū no Shinshokumin, 1894, p. 11.

54 Sydney Morning Herald, 30 September 1880.

55 Brisbane Courier, 20 September 1880.

56 Marks to Vice-Minister, Foreign Affairs (VFM), 24 February 1885, NGB - 1885, p. 525.

57 Clerk of Petty Sessions Thursday Island, Deposition and Minute Book 11/9/77 - 2/10/85, p. 398

(19 May 1885), p. 461, Queensland State Archives CPS 13D/P1.

58 Clerk of Petty Sessions Thursday Island, Deposition and Minute Book, 13/3/88 - 7/11/89, p. 193 (26 December 1888). 
Carbine in the Tattersall's 1890 Melbourne Cup sweep. ${ }^{59}$ He returned to Japan on the Tsinan with his colleagues a month later to spend their $£ 22,000$ - after they had made a donation to the Anglican cathedral building fund that exceeded those of the governor, the bishop and the government resident combined. ${ }^{60} \mathrm{He}$ died of consumption at his home at Okudairano-mura on the outskirts of Kobe on 12 December $1893 .{ }^{61}$ His widow was murdered by a Japanese diver named Yosuke at Thursday Island on 26 October $1895 .^{62}$

Nakagawa arrived on Thursday Island in 1881. Several more Japanese came there the following year. A book on the Japanese community on Thursday Island published in Tokyo in 1894 gives 1882 as the year of arrival for three of its leading residents: Tanaka Yasugorō (Tokyo), Nakamura Kiryū (Wakayama City) and Watanabe Toranosuke (Hiroshima prefecture). By 1894 Tanaka was the proprietor of a billiard saloon. Nakamura had become a diver and his success had influenced a number of men from Wakayama prefecture to come to the island. Watanabe had progressed from diver to master pearler. ${ }^{63} \mathrm{He}$ was the owner of three luggers and had been granted naturalisation ${ }^{64}$ - one of the very few Asians ever to achieve this. Like Nonami, these three men probably left Japan as seamen on the articles of foreign vessels.

In 1883, the Japanese Government permitted 37 of its subjects to go to Thursday Island to work for an Australian pearler, Captain John Miller. This is the first contract approved by the Japanese Government for Japanese labour to work in a foreign country. ${ }^{65}$ In negotiations that occupied some months, the Japanese provincial and central authorities looked very carefully at the contract.

The initial approach was made through the British consul to the prefectural authorities at Yokohama. The latter were somewhat concerned and wrote to the Foreign Ministry for guidance. They enquired of the latter whether 'the evil custom of slavery obtains in those parts or whether other unexpected evils might befall Japanese who went there'. ${ }^{66}$ The Foreign Ministry after due consideration of the terms proposed gave its permission:

59 Brisbane Courier, 6 November 1890; Bulletin, 22 November and 6 December 1890.

60 Queenslander, 6 and 13 December 1890.

61 Hattori, Nankyū no Shinshokumin, 1894, p. 10. This is confirmed by a copy of his family register (Nakagawa

Tamiji domiciled at Hyogo-ken, Yatabe-gun, Minato-mura-no-uchi, Okudairano-mura Ban-gai 87-ban-yashiki) provided by the Kobe Municipal Office.

62 Queensland, Inquest No. 360 of 1895, Depositions, Queensland State Archives.

63 Hattori, Nankyü no Shinshokumin, 1894, pp. 11-12.

64 Queensland State Archives SCT/CF38.

65 Wakayama-ken, Wakayama-ken Imin-shi, 1957, pp. 269, 276.

66 Governor, Kanagawa Prefecture to Asada, 2 May 1883, NGB - 1883, p. 440. 
This contract with foreigners to work overseas in pearling is essentially different from a contract in which labourers go abroad to do ordinary menial tasks for foreigners. Only a small number will be employed and they all are skilled divers. Furthermore, if specific agreements are made as indicated in the documents tendered, there need be no fear that the employees may become like slaves. ${ }^{67}$

The Foreign Ministry, however, insisted that since Torres Strait was far from the consulate (Melbourne), some resident in Japan must go surety in case the employer should fail to fulfil his obligations under the contract. This role of local guarantor was in fact undertaken by Lane, Crawford and Co., a firm that continues to serve the needs of Australians travelling in the Far East. The Foreign Ministry also required that signatures be witnessed by the British consul. The contract was duly signed on 10 October 1883. In it John Miller engaged for a term of two years: six divers at $\$ 50$ per month plus $\$ 50$ per ton of shell raised; six tenders at $\$ 20$ per month; one interpreter at $\$ 15$ per month; and 10 pumpers at $\$ 10$ per month. Rations, the nature and scale of which were carefully specified in the contract, were to be provided by the employer together with return transport. Wages were to commence with the signing of the contract. In the case of sickness the employer was to provide treatment and repatriation. ${ }^{68}$

Eight days later, the 37 Japanese duly embarked from Yokohama as deck passengers on the $\mathrm{P} \& \mathrm{O}$ steamer Khiva for Hong Kong where they transshipped to the Eastern and Australian Line's Catterthun. They had complained of inadequate food on the Khiva, but found the food on the Catterthun excellent. ${ }^{69}$ They touched at Darwin on 10 November where they were amazed at the heat: 'It was unbearable even though we were wearing only a single layer of clothing, and that unlined.' Some of them may have had some grounds for being surprised at the heat: the interpreter who drew up the contracts in Japanese had used the ideographs for Austria instead of Australia! ${ }^{70}$ They disembarked at Thursday Island on 14 November. Captain Miller lost no time in putting them to work and, on the 18th, despatched them, six to a lugger, with a fortnight's rations, to the pearling grounds about 50 miles to the west of Moa Island. The Japanese were not used to deep-sea fishing. One of them wrote soon after his arrival:

We carry only two weeks' food and stay at sea for that period. If these run out we send a boat to our employer at Thursday Island to replenish them ... The situation is therefore very different from the fishing we do in Japan. Being at sea day and night is something that surprised us all. If we run out of food and there is no wind,

67 Asada to Governor, Kanagawa Prefecture, 6 August 1883, NGB - 1883, p. 444.

68 Asada to Governor, Kanagawa Prefecture, 6 August 1883, pp. 448-49.

69 S Masuda to Governor, Kanagawa Prefecture, 9 March 1886, NGB - 1886, p. 508.

70 The Japanese often confuse the two countries. One day in the late 1950s the occupant of the house opposite the Australian embassy in Tokyo was somewhat surprised when an excited stranger appeared at the front door and asked her to assist him to kill 'the Austrian ambassador who lives opposite'. The conversation that ensued confirmed that the supposed grievance was not against Sir Alan Watt but against the people of Austria! 
we cannot go to our employer. If there is no wind and we run out of water we have to wait for rain and drink the rain-water. We have often had to do this. The boats anchor at sea night after night ... We remain at work until the waves are actually breaking into the boat. ${ }^{71}$

The Foreign Ministry was mistaken in its belief that all 37 were experienced seamen. For the writer continues that, although the divers found the going easy, the depth (5-10 fathoms) apparently being less than that to which they were accustomed, it was a very different story with the pumpers. The same writer continues:

In the early stages they were in dire straits. Among them were people who had never been in a boat in their lives. Seventy per cent were seasick. When aboard, their limbs ceased to answer. If there were any waves at all they collapsed in the morning and remained in this condition all day. It was exactly as if we were taking the sick to sea ...

They often complained. Some said that the work was different from that described in the contracts with our employer that they had signed at Yokohama and that this was not what they had come for. Others begged to be repatriated because they were unable to do this kind of seafaring work.

He notes, however, that within a few months, even these had, for the most part, settled down satisfactorily. They must have made a good impression for, in the following year, Burns, Philp \& Co. recruited about 70 Japanese for various pearlers on the island. Apparently the Foreign Ministry was unwilling to approve further contracts until they had seen how Captain Miller's men fared. Burns, Philp worked through a British firm in Kobe, where the prefectural authorities issued passports endorsed 'For Hong Kong, to be employed by Fearon, Low \& Co.'72 without referring the matter to the Foreign Ministry in Tokyo. Marks lost no time in bringing this to the latter's attention:

I enclose two papers of two men engaged by Fearon, Low \& Co. in Kobe to the order of Burns, Philp \& Co. who speculate in men and make their profit by letting the men out to the pearl shell fisheries. It matters not how unsuitable the men are, as long as they are men and they can make their profit. The two men, Tokugiro and Takichi, are carpenters by trade and did not know the nature of the employment they were to be engaged in. There are about fifty engaged in the same way. ${ }^{73}$

These 50 were apparently not enough, for about another 20 appear to have been procured by Burns, Philp's agents in Hong Kong.

71 S Masuda to M Masuda, 19 March 1884, NGB - 1884, p. 486.

72 Wakayama ken, Wakayama-ken Imin-shi, 1957, p. 190.

73 Marks to VFM, 24 February 1885, NGB - 1885, p. 527. 
[T]hey scrape up all the boarding houses in that place for Japanese discharged seamen. The men are robbed in Hong Kong by the boarding house keepers and shipped off to Torres Straits by Gibb, Livingstone \& Co. The men have not the remotest idea where they are going or what they are expected to do.

Under some of these contracts, the employee was not entitled to receive any of his wages until the completion of the contract. Marks noted that even under Miller's contracts the payment of allotments to next-of-kin had sometimes been improperly delayed and that wages paid to the employees themselves had been paid not in cash but by an order on Brisbane or Sydney: 'The men, not understanding it, sell the order at from 5 to 50 percent discount.' A grievance that Marks appears to have ignored was that payment was made in truck. As Masuda, the leader of Miller's group, reported to the governor of Kanagawa prefecture on their return to Japan at the expiry of their two-year contracts: 'When we were supplied with goods that should have cost a dollar, $\$ 1-1 / 2$ was required. $\$ 1-1 / 2$ 's worth cost $\$ 2-$ $\$ 2-1 / 2$. When you convert wages in this fashion $\$ 50$ becomes only $\$ 30$, and $\$ 30$ becomes $\$ 20$. As a result, what we got came to nothing. ${ }^{74}$ This often caused despair. This lack of feeling on the part of employers cannot be done justice to on paper. ${ }^{.75}$ What worried Marks most was the absence of a single medical practitioner in a population of 1,500 . To quote Masuda once again:

When a man became ill at sea and appeared unlikely to recover immediately, he would go ashore, explain the situation to the employer and ask for treatment. There are cases where the employer did not readily consent and provide treatment. If the case was the least difficult to diagnose, he would accuse him of malingering and force him back to work. Where this was not possible he would push him into a jerry-built shed used for storing shell, give him some medicine unrelated to the illness and take no further notice of him, almost as if he were an animal. All the sick man could do was just wait for death. ${ }^{76}$

Eventually, on 2 October 1885, Marks, impressed by the discontent among the Japanese and the high death rate among them, recommended to the Japanese Government that 'all the Japanese on the fishing grounds should be sent back to Japan'. ${ }^{77}$ As a result, on 19 February 1886, he was instructed to return to Japan as soon as possible all except those whose contracts prevented this. ${ }^{78}$ The following month the Foreign Ministry also instructed prefectural authorities to discourage

\footnotetext{
74 Some nevertheless succeeded in making money. The Japanese consul at Hong Kong in 1897 reported three Japanese divers returning to Japan after two to three years on Thursday Island with $\$ 6,000$ between them (Consul, Hong Kong to VFM 16/9/97, NGB - 1886, p. 512).

75 S Masuda to Governor, Kanagawa Prefecture, 9 March 1886, NGB - 1886, p. 510.

76 S Masuda, to Governor, Kanagawa Prefecture, 9 March 1886, NGB - 1886, p. 510. See also the evidence at the trial of Nishi (TI Deposition and Minute Book, p. 461, 29 August 1885) and at his inquest (no. 510 of 1885). 77 Marks to VFM, 2 October 1885, NGB - 1885, p. 543. Of Miller's 37 Japanese employees engaged in October 1883, five died and 10 were repatriated on grounds of sickness during the two-year period of the contract (S Masuda to Governor, Kanagawa Prefecture, 9 March 1886, NGB - 1886, p. 510).

78 VFM to Marks, 19 February 1886, NGB - 1886, p. 507.
} 
all who wished to emigrate to Australia to engage in pearling and, where this proved ineffective, in each case to forward the proposed contract to the ministry to await its decision. ${ }^{79}$ There is no evidence that widespread repatriation actually took place. In any event, this would in most cases have been impossible because of the terms of their contracts. Be that as it may, the number of Japanese in Torres Strait fell from about 200 in $1886^{80}$ to about 170 or 180 at the end of 1890 and did not pick up again until $1892 .{ }^{81}$

Subsequent events did nothing to weaken the view of the Foreign Ministry that contracts for employment in Australia had to be looked at very carefully, and that, for Japanese workers, life there could be hazardous. Late in 1884 it had reminded the prefectural governments that the emigration of people from the lower walks of life for display in public performances could not be permitted. Despite this, early in 1886 an Englishman named Pemberton Willard managed to secure passports from the prefectural governments for some 40 Japanese whom he displayed throughout Australia as 'The Japanese Village'. The show consisted of craftsmen pursuing such traditional avocations as screen painting, wood carving and the manufacture of cloisonné ware; acrobats and jugglers; and waitresses who served Japanese tea to the audience. Willard appears to have hoodwinked the Japanese authorities by dividing the company into small occupational groups, drawing up separate contracts for each and distributing the applications for passports between two ports, Yokohama and Kobe, and over a period of two weeks. ${ }^{82}$

As a theatrical performance, 'The Japanese Village' appears to have been a considerable success. It remained in Australia for 15 months and performed in each capital except Perth. Its season in Melbourne extended for more than five months, during which time it was visited by the governor and (if one may believe the advertisements) by upwards of 317,000 people. Its arrival in Australia, however, had been followed by a series of despatches from Marks. He considered the wages far too low:

When Japanese are engaged at 15 or 20 yen per month ... [this] amount seems a fair rate of pay for the particular class of persons so engaged in Japan. But the moment they arrive in any European country they dress, eat and smoke European fashion and contract other expensive habits [and] therefore find the amount of pay they are receiving totally inadequate to meet their acquired European necessities. Not alone they cannot save a cent, but [they] are constantly in debt, which causes considerable trouble and discontent - more especially as they soon find out that their European fellow workmen are getting more in one week than they do in a month.

79 FM to Governors of Kanagawa and certain other prefectures, 20 March 1886, NGB - 1886, p. 511.

80 Marks to VFM, 7 February 1889, NGB - 1888, p. 569.

81 K Watanabe, 'Sasudē-tō oyobi Toresu-Kaikyō Tanken Hōkoku', c. 1894, p. 6.

82 Archives of the Japanese Ministry of Foreign Affairs (JFMA), 3.8.4.7 (Australian National Library microfilm G16163). 
He recommended that in future the Foreign Ministry should ensure that the wages offered to Japanese in contracts should be based on the rates ruling in the country concerned. He urged that this also be the case with hours 'as longer working hours would certainly engender an ill-feeling between the working classes and Japanese people in the country they are temporarily residing in' ${ }^{83}$ Marks also considered inadequate the standard of food and accommodation (both at sea and ashore) provided by Willard. In the Melbourne winter the Japanese threatened to desert unless they were provided with more blankets. ${ }^{84}$ (Two of their number had died of consumption soon after their arrival in Sydney. Their graves are in Waverley Cemetery. $)^{85}$

In Japan, Willard's venture appears to have had two consequences. It increased the reserve with which the Foreign Ministry regarded Australia as a suitable place for employment and it gave rise to the legend of a monolith in Tasmania bearing the hiragana inscription: 'kashiu zeniya gohei riyouchi' (This is Zeniya Gohei's domain). This first appeared in 1891 in Umehara Chuzōs Teikoku Jitsugyōsha Risshi-hen, which attributes the information to a Japanese acrobat who had visited Tasmania six years previously. In about 1908 in Kobe one of the women members of the troupe confirmed the story. She claimed that when they went to Tasmania the men saw the inscription but the women did not, as they did not go out. ${ }^{86}$ That the women members of the company were kept confined to their quarters during the tour of Australia is confirmed in one of Marks's despatches:

Foreigners engaging a number of Japanese people who are mostly of the poorer classes should on their arrival at their place of destination in the first instance be bound to supply them with a suit of European clothing, whether male or females. The present lot of Japanese women who are engaged by Willard are not allowed out in the streets as their appearance in Japanese costume would cause excitement and curiosity and probably rudeness on the part of the lower classes of people. ${ }^{87}$

The 'Japanese Village' performed in Hobart from 15 January to 8 February 1887. According to the 'Shipping Intelligence' column in the Argus, some members of the company embarked from Melbourne for Launceston on 11 January (SS Flinders) and 14 January (SS Pateena). The most likely explanation is that some other members made the crossing via Devonport (e.g. SS Mangana departing Melbourne on 12 January) and were shown the petroglyphs on Mersey Bluff.There are of course problems in this explanation. The inscriptions there are on horizontal

83 JFMA, Marks to VFM, 27 August 1886.

84 JFMA, Marks to VFM, 13 August 1886.

85 JFMA, Marks to VFM, 14 May 1886. Murakami Toyokichi died on 16 April; Uesaka Fukumatsu, the following day.

86 S Kaburagi, Zeniya Gohei no Kenkyū (Zenigo Kenshōkai, 1954), pp. 169-70.

87 JFMA, 3.8.4.7, Marks to VFM, 27 August 1886. 
faces of rock, not on monoliths. ${ }^{88}$ Furthermore, Tasmanian Aboriginal rock carving is based on circles and has little resemblance to biragana. There is, however, a way out of the last difficulty. In 1887 many Japanese acrobats would have been illiterate. Let us assume the locals showed the Japanese the petroglyphs and referred to the mystery surrounding them (for until about the 1930s the popular belief was that the Tasmanians were so 'primitive' that they had no art). Then let us suppose that some time between his return to Japan and 1891 one of them recounted this mystery in the hearing of a Zeniya enthusiast. It should not have required too much effort of the latter to convince both of them that what the acrobat had seen was a message from Zeniya.

During the remainder of the period under review no indentured labourers left Japan for Australia with the consent of the central Japanese Government. In 1888 the Mourilyan Sugar Co. proposed a contract for the employment of 100 Japanese on the canefields. After long negotiations, the Japanese Government was prepared to approve it provided that the company, at the time of embarkation, were prepared to pay a specified amount of the prospective wages into a trust fund to provide lump sum payments to each employee on his repatriation. This, however, proved to be beyond the company's resources and the scheme fell through. ${ }^{89}$ No Japanese contract immigrants arrived on the canefields until 1892.

Towards the end of our period, the pearlers of Western Australia appear to have succeeded in engaging Japanese labour, despite the policy of the central Japanese Government. The 1891 census shows that on 5 April of that year there were 198 Japanese males in the colony of whom all but one were north of Shark Bay. ${ }^{90}$ Of these perhaps a handful were on the Kimberley and Pilbara goldfields. It can, however, be safely assumed that the large majority were engaged in pearling. Presumably the method of recruiting was similar to those of the Queensland pearlers that Marks described in 1885.

Another class of Japanese emigrant that succeeded in leaving the country in defiance of Foreign Ministry instructions was the prostitute. Japanese brothel keepers had established themselves in Australia by 1888. Murdoch on his visit to Darwin early in that year reported that there were in that town five Japanese brothels housing 25 Japanese prostitutes and that there were "branch establishments down the Western Australian coast well nigh as far as Fremantle'. ${ }^{91}$ This occupation, no doubt, accounted for the relatively high number of Japanese women in the 1891 WA census: 62 .

88 AL Meston, 'Aboriginal rock-carvings on the NW coast of Tasmania', Papers and Proceedings of the Royal Society of Tasmania, 1931, pp. 12-17.

89 NGB - 1888, pp. 547-74; Queenslander, 30 March 1889, p. 589.

90 Western Australia, Census of 1891,pp. 116-19. Although the figures given are persons born in Japan, it appears from the information on p. 119 that none of these were Britishers born in Japan.

91 Boomerang (Brisbane), 12 May 1888. 
This evil appears to have reached Thursday Island on 29 September 1891. On that date John Douglas, the government resident, cabled Brisbane for instructions regarding the arrival of two young women, Otashi and Otoyo, whom he described as 'undoubtedly prostitutes but of a respectable and orderly type'. He kept them in quarantine pending instructions. Brisbane cabled Marks, the consul, who asked that they be deported. Instructions to this effect were cabled to Thursday Island on 2 October. There was, however, no north-bound ship until 23 November. In the meantime, the pillars of respectability among the local Japanese community apparently feared that Douglas's resolution was weakening. Douglas writes that 'Their arrival here caused some trouble among the Japanese inhabitants of this island, and I was waited upon by the whole of them with a request that I would remove the women'. ${ }^{92}$ Perhaps Douglas should have said 'nearly all', for the Mainichi Shimbun of 9 March 1892 carried a graphic account of a meeting of the Japanese residents at which an address to Douglas praying that the two women be deported was adopted. According to this report, 'when the resolution was put there was the sound of a shot, and Hirano Sennosuke was shot where he sat'. According to this report the shot was fired by a pistol-packing madam named Okiyo under whose auspices the girls were to have worked. ${ }^{93}$ Fortunately Okiyo's aim was not good and Hirano-san made a good recovery. ${ }^{94}$ As an earnest of their sincerity, the Japanese residents presented Douglas with $£ 8$ towards the cost of the girls' repatriation.

With the rapid increase in the size of the Japanese population on Thursday Island in 1892-93, the attitudes of both the residents and the Queensland authorities appear to have undergone a radical change. According to Hattori, writing in 1894, there were then 21 Japanese prostitutes on the island. ${ }^{95}$ Japan's prostitution frontier appears to have operated quite independently of her immigrant frontier. Almost all the prostitutes were from Nagasaki, a prefecture that provided very few immigrants in other occupations. Nor did it depend on a Japanese clientele. The traffic in prostitutes overseas from Nagasaki is considerably older than the reopening of Japan to the outside world in the 1850s. There is a special word in Japanese, kara-yuki-san, for a prostitute emigrating overseas from Nagasaki. Since the literal meaning of the word is 'one who went to China', the trade must have begun in that direction. Singapore is thought to have received its first Japanese prostitute in about 1870 . Soon the Japanese brothels there had become the key to a vast system, despatching their inmates east or west in accordance with the needs of the market. ${ }^{96}$

92 Queensland, Col. Sec., Inwards Correspondence, 1891/14105, Queensland State Archives COL/A680.

93 As quoted in Wakayama-ken, Wakayama-ken Imin-shi, 1957, p. 590.

94 Queensland, Col. Sec., Inwards Correspondence 1891/12674, Queensland State Archives COL/A677.

95 Hattori, Nankyū no Shinshokumin, 1894, p. 20.

96 T Irie, Höjin Kaigai Hattenshi, 1942, vol. 1, p. 231-34. According to T Fujita, Kaigai Zaikin Yon-Han-Seiki no Kaiko (Tokyo, 1931), there were about 900 Japanese prostitutes in Singapore when he served at the consulate there in 1896-97. 
Outside pearling and prostitution we can only speculate about the occupations of the few Japanese who were in Australia at this time. The 1891 census gives the following figures for the Japanese population: in Western Australia, as we have seen, there was only one Japanese south of Shark Bay; in Tasmania the only person born in Japan was a woman and she may well have been born of British parents; in continental Queensland, there were 14 males and three females; in Victoria, 26 males and four females; the figures for New South Wales were higher, 66 males and six females. Unfortunately, the SA census lumps Japanese with 'other Asians'. ${ }^{97}$

Some of these Japanese would have been household servants. Domestic service played an important role in the history of Japanese emigration. Typical among the early applicants for passports to the United States and Europe were students wishing to study overseas and servants engaged by foreign residents who wished to continue in the latters' service when they returned to their home countries. Many of the more enterprising among the young Japanese who went to the United States to gain overseas experience began as houseboys and worked in this occupation until they had acquired sufficient command of the language to enable them to move higher. A table published by the Ministry of Foreign Affairs in 1882 showing the destinations and the purposes for which passports had been issued during the years 1868-81 (inclusive) indicates that out of a total of 24 passports issued for travel to Australia, 10 were for servants (the remainder were distributed as follows: government officials, nine; commerce, four; study, one).${ }^{98}$

So far, the earliest specific reference that I have come upon to the engagement of domestic servants in Japan to work in Australia relates to the late 1880s. According to a recently published history of the Broken Bay district north of Sydney, HR Cox, a wealthy landowner in the district, returned from a world tour in about 1886 with 'ten Japanese servants and workers' under three-year contracts. Japanese reappear in the history as butler and cook when the Coxes build a large residence, 'Ettalong Hall' (completed c. 1898). ${ }^{99}$

Marks took up the question of the appropriate wages for such servants in a despatch to the Minister for Foreign Affairs dated 12 November $1891 .{ }^{100}$ He reported that two Victorians had recently brought in Japanese servants under contracts that provided wages that were too low by local standards. AT Tuckett, senior partner of the Melbourne real estate firm, Gemmell and Tuckett, and a member of the City Council, had recently gone to Japan and, using as an intermediary the interpreter at the Hyōgō hotel, had engaged a cook, a houseboy and a laundryman on three-year contracts. Marks compared the $£ 10$-per-year wage provided for the houseboy in

97 In the 1891 censuses, Tasmania is the only colony where it is not possible to separate those born in Japan of British parents from the total of those born in Japan.

98 Nibon Teikoku Tökei Nenkan, no. 2, 1883, pp. 723-25.

99 C Swancott, Good Old Woy Woy (Sydney: privately published, 1970), pp. 18-19.

100 Marks to VFM, 12 November 1891, NGB - 1891, pp. 442-43. 
this contract with the current wage of $£ 1$ per week that prevailed for such work in Melbourne. From the brief histories of their employment in Australia given to the police by Japanese in Melbourne in 1911, Tuckett's home must have been operated by a succession of Japanese brought in on similar contracts, the last of whom came in 1901. Evidently it was not unusual for them to abscond; for we are told that to prevent this Mrs Tuckett used to impound each Japanese's passport as soon as he arrived. ${ }^{101}$ Asians without passports were, of course, likely to be suspected by the police as being illegal immigrants. Some of Mrs Tuckett's employees, however, preferred to take this risk. As late as 1942 one such suspect told the authorities that he had left his passport with Mrs Tuckett in 1901!

The other case that Marks mentioned concerned 'a Mr Wilson who lives about 50 miles from Melbourne'. He had engaged four houseboys on terms similar to the Tucketts; but some two or three months after arrival they had discovered how low their wages were and had sought to terminate the contracts.

This Mr Wilson must have been WR Wilson, the owner of St Alban's, the famous stud property on the Barwon, and the chairman of BHP. Three times the winner of the Derby, he was, according to his obituary in the South Australian Register, 'a bold speculator who thought no price too high for a really first-class horse'. ${ }^{102}$ Until the Second World War broke out in 1941 there was an old Japanese fisherman called Kawajiri at Yanderup in Western Australia who was brought out in 1895 under engagement to work for Mr Wilson as cook at St Alban's. He was at the time cook at the Grand Hotel at Yokohama. As this was four years after Marks's letter we can assume that Wilson, like Tuckett, brought in a succession of servants from Japan. We know that he visited the East in 1888 to develop markets there for silver. ${ }^{103}$ Possibly it was on that occasion that he brought in his first Japanese servants. His enthusiasm for the Orient was of an eclectic nature: he named his Melbourne residence 'Shanghai Villa'.

Marks viewed such employment with some concern: 'In my opinion, more important than the question of a houseboy's wages is that, if the Trades Hall Council discovers that people of this city are bringing in cheap labour under contract, a heavy poll-tax will be imposed completely excluding such immigrants.'

Naturally it was the aggrieved who contacted Marks. When HIJMS Hiei visited Brisbane in November 1891, it was welcomed by Uemura Sadakichi, a lad of 16. A Brisbane couple had engaged him in Yokohama and brought him home with them about six months previously. He told the crew that his master and mistress held him in great affection, treating him as they would their own son. ${ }^{104}$ 
A few of the Japanese in the 1891 census would have been engaged in trade. So far as is known, the first Japanese to set up an importing business in Australia were Akiyama Teiji and Tokuta Toshihiko. Both men had been sent with Japanese exhibits to the International Exhibition of 1880-81: Akiyama by his firm, Tokuta by the Japanese Government. They remained after the exhibition and set up in business next door to Young \& Jackson's as importers of Japanese goods under the trade name Akita (formed by combining one ideograph from each of the partners' names). Akiyama died of tuberculosis on 20 November 1884 at the age of 36, having just completed his fourth journey to Australia. His grave, with its fading bilingual inscription, may still be seen in Melbourne General Cemetary. ${ }^{105}$ With his death the name of the firm ceased to appear in Sands and McDougall's directory. Another Japanese importer, J Numashima, was in business in Melbourne in Elizabeth Street from 1887 to $1889 .{ }^{106}$ The first to establish a lasting enterprise, however, was Kanematsu Fusajirō of Kobe. He first went to Australia in November 1887. At that time rice was virtually Japan's only export to Australia. It is thought that it was in connection with this commodity that he made the visit. He returned to Japan the following year and, after raising $¥ 30,000$ capital, established operations in Sydney in April 1890. The firm initially imported traditional Japanese manufactures, rice and coal. Later it developed the manufacture in Japan of Western goods specifically for the Australian market. It was this firm that in May 1890 shipped the first regular consignment of Australian wool to Japan, 187 bales of fine merino bearing the 'T over Diamond' brand of James Rutherford's 'Murrumbidgerie' station. ${ }^{107}$ To this day Kanematsu remains annually the largest consignor of Australian wool to Japan.

There were also a few artisans among the Japanese in Australia at this time; some are mentioned in the diary kept by Tomiyama Komakichi aboard Hiei. ${ }^{108}$

Ships of the Japanese Training Squadron, manned by new Navy cadet officers, at that time usually carried as passengers a few civilians whose task was to report on opportunities for Japanese enterprises in the places visited. Tomiyama was such a passenger: he reported on the possibilities of Japanese immigration to New Caledonia. ${ }^{109}$ His record of her stay at Sydney (December 1891) gives us a useful, if incomplete, picture of the small Japanese community there.

The ship is visited by Kawagoe Yoshirō and Kuwahata Hideo. Kawagoe had left the Japanese warship Kongō at Samoa the previous year and made his own way to Sydney from there. Like Tomiyama he was a civilian and a member of the

105 Ichikawa, Nichigo Kankeishi, 1953, p. 67. The location of the grave is C of E, 'X', 642.

106 Sands \& McDougall, Melbourne Directory, 1888-1890. See also his advertisement in the Argus, 17 June 1889.

107 Ichikawa, Nichigō Kankeishi, 1953, pp. 68-69, 184-85, 269-70.

108 K Tomiyama, 'Kōnan Nikki', Shokumin Kyōkai Hokoku [1892?].

109 Irie, Höjin Kaigai Hattenshi, 1942, vol. 1, pp. 104-6. 
Shokumin Kyōkai (Colonisation Society). Later in this paper we shall refer to a portion of a report by him on opportunities for Japanese enterprise in Australia that survives in the journal of that society. ${ }^{110}$

Tomiyama tells us little about Kuwahata beyond that he had been in New South Wales for six years. Fortunately a much better source of information is available. For Kuwahata Hideo was one of the few Japanese who settled in Australia, married an English migrant, raised a family and prospered. His eldest son, the late Mr TEH Kuwahata of Epping, Sydney, kindly furnished me with the following details:

Hideo Kuwahata, son of a Samurai family, was born at Kaseda, Kagoshima, Japan, on 17th September, 1863. He was well educated and a great lover of nature and art.

He brought with him a small but valuable collection of old woodcuts and prints, by famous Japanese artists.

He arrived from Japan about 1888 and began business as a landscape gardener and importer of Japanese plants. Only a few Japanese ships were coming to Sydney at that time, so he helped to supply them with some of their stores.

In 1891 he married an English lady, Mary Elizabeth Wyre. In 1892 I was born, and in the same year Messrs. Burns Philp \& Co. obtained the agency for the first regular shipping service between Australia and Japan, the Nippon Yusen Kaisha line.

My father saw the possibility, at this stage, of entering the providoring business, and his tenders for the supply of provisions, and in later years, blankets and other merchandise, were accepted by Messrs. Burns Philp \& Co. During this period, and in later years, on their visits to Australia, the Japanese Navy and training ships were supplied with large quantities of stores.

In the early years of providoring, most of the vegetables required were grown at Blackwall by a number of gardeners employed by my father. These were shipped by the small steamers 's.s. Erina' and 's.s. Woy Woy' to Sydney and unloaded at the ships' side in the harbour.

In 1898 my brother Frederick was born.

In 1908 my father purchased a large home and twenty-two acres of land at Guildford. He laid out part of the property with fish ponds, flower beds and imported plants, which were to form what eventually became the well known 'Mikado' nursery. 
Later my father rented premises at 173 George Street North, and conducted business from there as H. Kuwahata \& Sons. My brother and I joined him later. In 1929 my brother commenced a department for the bottling and sale of various medicinal and edible oils and I later set aside a section for the sale of Japanese plants, glazed pots etc. and the designing and landscaping of indoor and outdoor gardens.

The outbreak of war with Japan curtailed some of these activities and the oil business became a flourishing concern.

In 1954 I retired and my brother's son, John Kuwahata (grandson of the founder of the business) carried on in my place. He now is managing the providoring section of the business, with his father as Managing Director of what is now known as H. Kuwahata \& Sons, Pty. Ltd., Shipping Providors, Importers and Exporters.

The late Hideo Kuwahata entertained very extensively his many friends and members of the Japanese Consular and Diplomatic Service. Whilst retaining his own nationality he was most loyal to the country in which he lived and made his livelihood and was highly respected by all who knew him. He died in 1930 whilst on a health trip to Japan and was buried at his birthplace.

But to return to 1891. Tomiyama was probably witnessing Kuwahata's first venture in the providoring business, for he records that Kuwahata arranged accommodation ashore for him and a fellow passenger, and that the Nihon Yusen Kaisha's (NYK) ship Miike Maru was also in port. This was the NYK's first trial voyage to test the potentialities of an Australian service.

So much for Kuwahata. What about the other Japanese that Tomiyama found in Sydney?

The rooms Kuwahata hired for Tomiyama and his colleagues are at 'Bengal House' in 'Jackson St' where a Matsuzaki is living. This Matsuzaki is a graduate of a commercial college and has been there for two years.

Tomiyama also meets Kitamura Toranosuke, the local manager of Kanematsu.

We learn that there is another outlet for Japanese goods in Sydney, for Tomiyama visits Okumura's 'Nihon Shōten' ('The Japan Store').

Tomiyama also receives and returns a call by Yokouchi who, with Kudō Yoshisuke, had arrived only a few days previously on the Miike Maru. These two men had taken up residence in 'Beach Road' with two other Japanese, Yamaguchi Kenroku and Suematsu Zenshichi, who had arrived earlier on a British ship. Yokouchi was a copper-plate engraver; the other three were tattooers. Sands's Sydney Directory lists 'R. Yokouchi, Artist' in its 1893 edition, and gives his address as Quong Tart Chambers in King St. (It also lists a 'T.O. Sata \& Co Japanese Art Painters' in the same building.) 
Soon after the Hiei left Sydney, the tattooers added a fourth to their number. One of Tomiyama's civilian colleagues, Matsuoka Yoshikazu, jumped ship. The following day a pickpocket relieved him of all but a half-crown of his $£ 12$ capital. 'A Japanese shopkeeper' (presumably Okumura) lent him $£ 1$, and one of the tattooers took him on as an apprentice. Matsuoka, however, did not last more than a few days in that occupation. The indifferent picture he emblazoned on a burly British seaman so infuriated the latter that Matsuoka was forced to down tools and run, in fear of his life. He left his master, who kept his scant belongings in lieu of a premium. After sleeping two or three nights in the Botanical Gardens he signed on with two other Japanese at 30 shillings a month on Captain Kelly's pearling lugger, Josephine, bound for Thursday Island. ${ }^{111}$

\section{The mutual image}

\section{Australia as seen by Japanese}

Then, as now, few Japanese knew or cared about Australia. Little record has survived of their thoughts. As we have noted earlier in this paper, in the early $1880 \mathrm{~s}$ the Kanagawa prefectural authorities thought that it was probably a savage place where Japanese emigrants were likely to be exploited and deceived. We have also noted that by 1886 the experience of the early contract immigrants had inclined the Foreign Ministry also towards this view. Not only did it circulate its misgivings to the local authorities, it also communicated them directly to the public. When in 1887 four Japanese members of the crew of the pearling lugger Gamecock were chased overboard by a Malayan shipmate wielding an axe and were drowned, the Foreign Ministry issued a press statement to all the Tokyo newspapers. This drew attention to the fact that the contracts of these men were negotiated at No. 118 at the Foreign Settlement at Kobe (Fearon, Low's address), and concluded:

Among the four men some had wives and children. Besides the bitterness of untimely death at the hands of a savage and becoming a ghost in a foreign land, the grief of the parents, children and brothers that they leave behind in their birthplace is beyond imagination.

As a result of our entering into diplomatic relations with foreign countries and the improvement in transport facilities, the number of our nationals who go overseas to work is daily increasing. This is not something to be regretted. Among them, however, are people who know nothing about the country to which they are going and cannot speak its language. What is worse still, there are those who go without any contract. Needless to say such people are in a very disadvantageous position if 
an untoward event like that described above should befall them. Accordingly it is our wish that, in future, prospective emigrants should be very careful to acquaint themselves with conditions in the country concerned and that they should consult the authorities and secure detailed contracts. ${ }^{112}$

It seems a little hard to suggest that Fearon, Low's contract was defective in failing to deflect blows from an axe.

The very fact that the Foreign Ministry felt obliged to issue such a press statement indicates that there was current an enticing image of working overseas. The number of Japanese immigrants is itself sufficient proof of this. There is other evidence to confirm that Australia was regarded as a place in which fortunes were to be made. When after the Second World War the Wakayama prefectural government was collecting material for a history of emigration from the prefecture, old people in the village of Tanami told them that the first person from the village to go to Australia was Ebina Torakichi who went in 1884 and that when he returned more than four years later he contributed half the cost of rebuilding the belfry in the local temple. 'As a result,' they said, 'there was for a time much enthusiasm in the village for emigration. ${ }^{113}$ In 1954, in Melbourne, I interviewed an old Japanese, Suzuki Sakuhei, who remembered, when a small boy, the return of two of the Carbine syndicate, Hiramatsu Jimbei and Shiosaki Gorobei, to his village, Shionomisaki, in 1891. Another of the syndicate came from a neighbouring village where he was said to have squandered his winnings in such extravagances as bathing in saké. It was rumoured that Australia was so rich in gold that after rain nuggets lay uncovered in the streams. Suzuki himself emigrated to Australia eight years later at the age of $16 .{ }^{114}$ There is also other evidence that some of the early emigrants knew very little about the task awaiting them on Thursday Island. Seven of the men recruited by Fearon, Low in 1884 were from Shionomisaki. When material for the prefectural history was being collected after the war, villagers recalled the story that these men had not known what a pearl oyster was. They were used to diving for abalone (which of course was skin diving, not suit diving) and took with them tools used for abalone fishing. ${ }^{115}$

Two Japanese who visited Australia at this time have left us their impressions.

Mishima Kazuo, an employee of the Mainichi newspaper, aged 23, travelled as a civilian on the Pacific cruise of Hiei in 1889. That year Australia was not included on the itinerary. He accordingly transhipped at Samoa and arrived at Sydney on the SS Lubeck on 18 December 1889, accompanied by Kawagoe (who as we have noted earlier in this paper was still there two years later). After a short stay in

$112 N G B-1887$, p. 482-83.

113 Wakayama-ken, Wakayama-ken Imin-shi, 1957, p. 189.

114 Notes taken at interview with Suzuki Sakuhei, caretaker at Jackett's Flour Mill, Burnley, 27 June and 7 November 1954.

115 Wakayama-ken, Wakayama-ken Imin-shi, 1957, p. 181. 
Sydney he took the train to Melbourne on 27 January and remained there until he left for home via India on 22 September. He published a book on his travels the following year, which was republished in 1943 under the auspices of the Japanese navy, no doubt to stimulate popular enthusiasm for the South Pacific. ${ }^{116}$

For the first few months he lived near Caulfield Racecourse. It was, he said, impossible to express in words the passion that Australians had for horse racing. They had become the biggest gamblers in the world. There were newspapers specially devoted to horse racing. In 1889, 48 persons had died from falling off horses, and one in every three suicides was attributable to horse racing. He was amazed to see that Australia had bred a race of pygmies to serve as jockeys. From this he reached the encouraging conclusion that the Japanese could increase their stature by changing their style of life. ${ }^{117} \mathrm{He}$ had somewhat of a chip on his shoulder regarding the European assumption of racial supremacy; but he gives no example where he received discourtesy or discrimatory treatment. He was delighted to see among his landlord's prized possessions Japanese articles that to a Japanese were of no great quality.

Although these Britishers are able to look down on us Japanese, when it comes to the silks that they want, they must bow their heads to us. The Americans do not fear Japan; but for the teacups that they use, they must surrender to us. Although I cannot make Englishmen, Americans and Australians read these sentences, we can cause all men in all lands to use Japanese handkerchiefs. It is a true fact that in trade there is no discrimination among states. In the world of market demand there is no racial discrimination. ${ }^{118}$

He saw the prosperity of the white races as founded on the exploitation of the subject races that they had dispossessed. ${ }^{119}$ This is probably one of the reasons why his book was reprinted during the Second World War.

During his stay in Australia, his chief interest seems to have been to discover possibilities for increased trade between the two countries. Japan's overseas trade was then in its infancy: her trade with all countries was only one quarter of Australia's.

At the time, Japan's principal export to Australia was rice (4,938 tons in 1887). Although he noted with some apprehension the beginning of rice cultivation in South Australia, he saw a good future for the Japanese product. His argument is somewhat surprising: 'For geographic reasons, labourers constitute a high proportion of the Australian population. They would like to eat Japanese rice

116 I Suehiro, Gōshū Oyobi Indo Tankenshi (Tokyo: Nihon Kōen Kyōkai, 1943).

117 Gōshü Oyobi Indo Tankenshi, 1943, pp. 99-103.

118 Gōshù Oyobi Indo Tankenshi, 1943, p. 107.

119 Gōshù Oyobi Indo Tankenshi, 1943, pp. 155-60. 
instead of bread. '120 He provides today's reader with two other surprising pieces of information. First, the Japanese mandarin orange had become so popular among Australian housewives that they had to come to call it by its Japanese name, mikan. Second, Japanese matches were doing very badly on the Victorian market, because in this field Japanese industrial legislation was the more advanced. Victorians were still prepared to expose operatives to the dangers of necrosis of the jaw in order to have the convenience of 'strike-anywhere' matches. Japan, however, 16 years before the Berne Convention, had prohibited the manufacture of the yellow-phosphorus match. It therefore exported only the safety match, which, according to Mishima, Victorians despised. He took this rather badly and urged that the offending legislation be repealed. ${ }^{121}$

He considered that the market for Japanese objets d'art was limited and that, although the reputation of Japanese sundries was high, more care should be paid to the special requirements of the Australian market. For in Elizabeth Street he found not a few articles in which the ingenious locals had used Japanese motifs to produce products more in accord with local taste and requirements than those Japan exported.

On a locally made fruit stand there was a snow and bamboo design. Traditionally, Occidentals have no appreciation of the aesthetic refinement of bamboo amid snow. In their art and literature snow always means a couple of sledges and some dogs. If this is present, they are satisfied. They appreciated its exquisite beauty for the first time when they had become accustomed to the spirit of Japanese art. They then immediately applied it to the fruit stand ... From this the clear fact emerges that the people here, once they appreciate the elegance of Japanese objects of art, assimilate it and apply it as their own. We must pay great attention to this in the future..$^{122}$

He found that our shopkeepers, too, were enterprising.

I must reiterate that Australians are very quick off the mark when it comes to advertising.

Shops like florists, butchers and ice-cream sellers make use of the water-supply to attract customers. They all have water flowing from the ceiling down the shop windows and write their advertisements in front of the tumbling water.

There is a photographer's shop that, when it becomes night, projects pictures from the tower on the top of a building more than twelve storeys high so that they can be seen from every direction. The pictures change every two minutes and are very interesting. 
Bookshops and tobacconists use clock-work dolls for their advertisements.

In front of the office of a tannery stands a seven-foot kangaroo and emu. When you go inside there are stuffed animals everywhere. It is just as if you are in a zoo. There is a seemingly endless variety of such things as monkeys carrying satchels and possums with purses in their mouths.

When you come to the companies that trade with New Guinea you would think that you were at a New Guinea exhibition. In the windows are stuffed birds-ofparadise and emus with feathers even more beautiful than those of the American ostriches. Women's hats made of these feathers are also on display. In addition there is white coral and the actual jewels that the natives wear stuck through their noses. $^{123}$

If he found Melbourne shops exciting in the way that many Australians find those of Tokyo today, his description of Australians and the Australian way of life has much in common with the 'eager beaver' stereotype of the Japanese that is current in Australia at present.

They venerate speed even in eating and at the lavatory. If the latter takes time they feel aggrieved. Milkmen, bakers, and butchers do their rounds at a dizzy speed. People don't get a minute's rest in the day, but work with the sweat pouring down their faces. Even so they are upbraided by their overseers. Compared with them our way of doing things in Tokyo seems on a par with the Samoan or Hawaiian natives who take all day to move four or five bananas and take turn-about in carrying them.

According to him the Australian civilisation was built on long hours, the day commonly worked being 16 hours for men and 14 for women. Admittedly this was the year of the Maritime Strike and Henry George's visit (both of which he records in some detail). ${ }^{124}$ Nevertheless he must, surely, be exaggerating.

As the price of speed, the community, he considered, put up with very shoddy workmanship. He also found us basically untidy behind a pretentious veneer.

If you look at the houses, the front door is ornately decorated in such a manner as to cause wonder. Inside however, are broken bottles and scattered slices of meat left over from a meal. ${ }^{125}$

The other Japanese visitor whose detailed impressions of Australia at this time have survived is Hirose Takeo.

123 Gōshù Oyobi Indo Tankenshi, 1943, p. 135-36.

124 The American political economist Henry George was known for his advocacy of a single tax on land value (eds).

125 Gōshù Oyobi Indo Tankenshi, 1943, pp. 138-39. 
In my youth there were two pictures that every Australian schoolboy knew. One was Simpson and His Donkey. The other was Frank Salisbury's representation of Jack Cornwall VC, aged 16, on HMS Chester at the Battle of Jutland, tending his gun while the rest of its crew lay dead around him. In Japan it was Cdr Hirose that every schoolboy was exhorted to emulate. During the Russo-Japanese war, after sealing off Port Arthur with block-ships, he had died in an attempt to extricate the demolition parties. As a national hero his collected works, including the diary that he kept as a 23-year-old sub-lieutenant on Hiei during her 1891 cruise, ${ }^{126}$ were avidly read until they were banned by Gen. MacArthur in 1945 .

When Hirose checked in at Lennon's Hotel, Brisbane, on 23 November 1891 it was his first encounter with a European environment. He was surprised to find that, unlike Japanese inns, here there were separate rooms for each officer and that, in addition, one also bathed alone. His particular room was on the third storey. With some displeasure he records in his diary that there was no lift. Instead of the food being brought to one's room he notes that 'at 1 p.m., a bell rang and everyone rushed to a dining-room and took possession of the tables'. Luncheon and dinner were sumptuous meals with a great variety of courses. He looked forward to an equally hearty breakfast. To his dismay he found only eggs, toast and tea.

On board, good will was poured on them by thousands of enthusiastic sightseers. Hirose, however, found their compliments somewhat irritating.

They are endless in their civilities, and using such expressions as 'How splendid!', 'How clean!', and 'How ship-shape!',go through the whole gamut of commendatory phrases. They cannot believe that the entire ship's company is Japanese. Every one of them you meet says 'The Captain is a European?', 'Haven't you Europeans among the officers?' or 'Isn't the Chief-Engineer a European?'. They are almost dumbfounded when we reply 'No. We are all Japanese'. This can only mean that they are unaware how civilised our country is and how our navy has progressed. That we are still not credited with such achievements is something greatly to be deprecated. It is humiliating that they regard civilization as the preserve of Europeans and Americans ...

They appear surprised that the officers and midshipmen understand English (The newspapers expressed amazement at this. They made the comment that, although when asked if we spoke English we replied 'Only just' or 'Only a little', nevertheless in conversation we proved very good). How sad the lot of us Japanese: we are thought to know no English; and we acquire merit through speaking it. Will there not come a day when we shall make these Europeans feel ashamed if they can not speak Japanese. 
(Unfortunately events were soon to demonstrate that their navigation was not yet up to European standards. On their journey from Brisbane to Sydney it was not until they identified the entrance to Jervis Bay that they realised that they had overshot Port Jackson by 70 miles!)

At Sydney, he was greatly impressed by the harbour. From the standpoint of defence he considered that its natural advantages were such that if its existing fortifications (which he enumerated in detail) were improved, it could easily be made impregnable to a hostile fleet. The city itself also impressed him: 'Most of the buildings are at least three or four storeys high; some are seven or eight.' Like Mishima, it was the bustling activity that he noticed. In his diary he wrote that a walk down Pitt, King and George streets immediately brought to his mind the description given of the capital of the Chinese province of Sei by Soshin more than 2,000 years before: 'Sleeve touched sleeve in an endless curtain and perspiration poured like rain.'

The evidence tendered to the second Voyager inquiry indicates that of recent years one of Tokyo's attractions for Australian bluejackets is its Turkish baths. In 1891 such aspects of civilisation had not yet reached there. Hirose's first introduction to one was at Sydney - close by the Hotel Metropole. He was so impressed that he described the architecture and procedure in minute detail. From this it appears that in those pre-White Australia days the attendants in the steam room were coloured - probably Lascars or West Indians.

But, if Hirose was not averse to many of the amenities and efficiencies of modernisation, there were aspects of Western society that displeased him. At Brisbane the level of class antagonisms apparent in the newspapers and in the novels at the bookstalls caused him concern. Then, at Sydney, the ship was decorated with lights and flowers and the city fathers and their ladies were invited to a dance on the poop deck (the officers had enjoyed honorary membership of the Australian Club during their visit). Hirose did not participate in the dancing. The thought of men and women keeping time to music in each others' arms was distasteful to him. It was an activity unbecoming warriors of the land of the gods, and officers whose minds even in time of peace should be devoted to war. He was delighted when it rained solidly from $9.30 \mathrm{pm}$.

While in Sydney a chance meeting with one of its citizens made Hirose more tolerant of foreigners and their ways. On 15 December he wrote in his diary that he had never met one and that he had a reputation for disliking them. Five days later he visited the home of $\mathrm{Mr} \mathrm{R}$ Brown, a builder, at Strathfield. After getting into conversation with two midshipmen, Brown had called at the ship and offered hospitality for the following Sunday. 
Hirose and three midshipmen duly made their way to Strathfield station where Brown and two friends were waiting for them. From the moment they shook hands things appear to have gone well. First Brown (whom Hirose describes as 'a man of cheerful countenance') took them to a local vineyard to sample its product. Hirose notes that the service was excellent. After a while Brown picked some flowers and put them in everyone's lapels. Then he summoned cabs and took them to his house - where they had another drink. Hirose found him 'by nature frank and open, large minded and fond of drinking - a man who did not raise barriers against us'. Brown pressed gifts on them - for Hirose a framed picture; for the midshipmen some cushions that he had bought in Yokohama. Embarrassed, they demurred. Hirose then presented Brown with the fan that he was carrying and a photograph of himself. Brown was delighted and poured more drinks. He then summoned cabs and showed them the river while one of his colleagues made arrangements for lunch at a nearby hotel. En route Brown took them to the house of a German friend, where more drinks were served. At the hotel, the food was excellent. Brown, however, had by now become somewhat rowdy. When some of the hotel guests tried to start a conversation Brown brushed them aside telling them that they were socially the inferiors of these Japanese gentlemen. In due course they returned to Brown's house and made their farewells.

Back at the ship Hirose and the midshipmen pondered over the events of the day. There had been embarrassment; but there had been enjoyment also. They were staggered by the extent of Brown's good will and hospitality. They all agreed that he was 'quite unlike a European' - indeed that he was like 'an eccentric Oriental of old'.

But more was to come. At noon the following day a delivery boy arrived at the ship with a parcel for Hirose. It was a picture from Brown.

Japanese are punctilious about repaying gifts with something of equal value. Hirose enquired how much the picture had cost. When the boy answered ' 21 guineas', his heart sank. He had only one possession of similar value - the Japanese sword forged by an Hakata craftsman, given to him by his father. He duly despatched it to Brown with an appropriate covering note.

The entry in his diary for that day ends with the following words:

Because my reputation was that of a dyed-in-the-wool conservative hostile to foreigners, the fact that I had received this gift was the talk of the ship. They said that if they told my friends in Japan about it they would think that I had joined the enlightenment and had cast my lot with the extroverts.

More than one Japanese who has travelled in Europe has remarked to me that in contrast with the formality there, in Australia their personal relationships have a warmth that reminds them of friendships at home. Like all compliments, this must of course be taken with a grain of salt; but the fact that they chose this 
particular compliment is interesting. One of the reasons why I have dealt in some detail with Hirose's encounter with Brown, and with his reflections upon it, is that I suspect that, during the 80-odd years that have elapsed since then, a number of Japanese have felt a similar feeling of affinity on becoming acquainted for the first time with an Australian in an Australian environment - perhaps on a pearling lugger at the turn of the century, learning animal husbandry at Gatton in the 1930s, working in a British Commonwealth Occupation Force cook-house in 1946, or living in an Australian undergraduate hall of residence in the 1970s.

\section{Japan as seen by Australians}

The writer has come upon four detailed accounts of impressions of Japan written by Australians during the period under review — by JH Brooke (1867), J Hingston (1876) and JS James ('The Vagabond', 1881) in the Melbourne Argus; and by James Murdoch in the Boomerang (1888). Of the four, Brooke is the most balanced and perceptive.

The Japan of 1867 that he described in his six letters to the Argus $^{127}$ is very different from that seen by the other writers. He wrote a few months before the Meiji Restoration. The shögun still ruled Japan and the daimyō still ruled their fiefs. The samurai still carried their arms. Brooke reported how 'feeble old men will stagger about with a couple of cumbersome gold-bedizened weapons (which literally burden their existence) rather than have their quality momentarily mistaken'. Similarly 'Japanese boys of noble birth, some carrying a baby brother or sister, blunder about in their daily walks embarrassed with two little swords, which sadly interfere with spinning a top or jumping over a street post' ${ }^{128}$ There were, however, many samurai who were by no means feeble and who loathed foreigners. Their swords were a real threat to the foreigners. Within the confines of the Foreign Settlement in Yokohama, the 250 foreign residents were safe under the protection of a British battalion. But outside the settlement they carried personal firearms, moved under the protection of escorts, and exercised constant vigilance. It was less than three years since Major Baldwin and Lieutenant Bird of the British Regiment had been hacked to pieces by two anti-foreign rōnin at Kamakura. Their fate was much in the mind of Brooke and his fellows. ${ }^{129}$ Tokyo was still called Edo and could be visited by a foreigner only at the invitation of one of the legations. At the French legation where Brooke stayed he was given the password before retiring, in

127 'Impressions of Japan - by an Australian colonist', Argus, 22, 24 and 29 August; 10 and 28 September; 28 October 1867.

128 'Impressions of Japan', 10 September 1867.

129 'Impressions of Japan', 24 August 1867. 
case they had to stand to arms during the night. ${ }^{130}$ When his party visited Asakusa a truculent samurai put his hand to his sword, whereupon the escort interposed itself between him and the party. ${ }^{131}$

Despite this aspect of the environment, Brooke was on the whole favourable. $\mathrm{He}$ noted the dirty clothes of the lower classes and the night soil buckets, but also remarked on the frequency with which everyone bathed, the cleanliness of the houses and streets and the absence of offensive smells (apparently it is only since Melbourne was sewered that its citizens have found Tokyo malodorous). He was surprised to see women bathing naked in public but on reflection felt that the 'too conscious prudery of civilised mankind' might not stand up to careful examination. Though he found the food insipid, the samisen tedious, the women plain and the wrestlers, by British standards, clumsy, he was most impressed by the courtesy and good spirits of the people: 'a gayer, light-hearted, people than the Japanese I cannot imagine under the sun; and they have also an amount of natural and easy politeness that I believe nowhere to be excelled'. ${ }^{132} \mathrm{He}$ was also impressed by the high degree of religious toleration enjoyed: 'The utmost freedom of conscience is permitted here. ${ }^{133} \mathrm{He}$ noted important barriers to progress. There was the pride of the high officials and their remoteness. The latter led to the presence of concentric rings of courtiers who had to be bribed before business could be expedited. There was the disproportion of unproductive classes.

$[N]$ othing more impresses a stranger than the vast number of that baneful class, the retainers of the Diamios. They may be counted in the empire by hundreds of thousands ... It is this locust tribe of hungry troublesome soldiery that keeps the peasantry in poverty. There is no respectable middle class in Japan, beyond a comparatively few artizans and shopkeepers. No professional men worthy of the name can be found. No manufacturers - except those who provide in a small way for simple local requirements. ${ }^{134}$

But he also noted Japan's latent assets. Very soon after his arrival he noticed that 'a knowledge of reading, writing, and arithmetic seems universally diffused'. ${ }^{135}$ Furthermore, 'there is a curiously extensive knowledge of fine mechanism and scientific appliances existing here and there throughout Japan'. ${ }^{136}$ He was surprised to see a Japanese arsenal producing modern ordnance and ammunition without the assistance of a single European. ${ }^{137}$ His prognosis was favourable, if somewhat patronising: 'it will not be many years before this naturally quick and intelligent people will come to understand the advantages of constitutional government

130 'Impressions of Japan', 29 August 1867.

131 'Impressions of Japan', 10 September 1867.

132 'Impressions of Japan', 28 September 1867.

133 'Impressions of Japan', 28 October 1867.

134 'Impressions of Japan', 10 September 1867.

135 'Impressions of Japan', 22 August 1867.

136 'Impressions of Japan', 28 October 1867.

137 'Impressions of Japan', 10 September 1867. 
and the rights of citizenship together with the blessings of civilization, social refinement and four pronged forks'. ${ }^{138}$ He hoped, however, that they would soon come to realise that commercial prosperity is the real foundation of national power and cease to squander incredible sums on a weak fancy for acquiring a knowledge of scientific warfare. ${ }^{139}$

Hingston, a regular contributor to the Argus, visited Japan at the end of 1876. Much had happened to Japan since the time of Brooke's letters. The fiefs had been abolished and their samurai disarmed and pensioned. A strong central government had been established. Compulsory education and conscription had been introduced. The railways were being built.

Hingston's picture of the Japanese $\mathrm{e}^{140}$ is uncritical and idealised, but coincides with Brooke's in most respects. To him the Japanese were 'the cleanest of mankind'. ${ }^{141}$ He found the rivers and canals unpolluted by sewage: 'not a stench from sewage matter can be found in Japan save at sewage depots'. ${ }^{142} \mathrm{He}$ too stresses the good spirits and geniality of the Japanese: 'they are the most polite, cheerful and pleasant of people'. The Japanese 'always smiles and looks pleasant. Nothing can make him grumble, and he has not learnt to swear. He is satisfied to be paid his due, and never asks for more. ${ }^{143} \mathrm{He}$ makes a great point of their contentment and tranquility.

Generally ... all the many wondrous revolutions made and making in Japan are quietly effected. Folks are all pleasant and complaisant there - born philosophers, who seem to think that all institutions must change, or end, some time or other, and that there is nothing in this world much worth fretting or fighting about. ${ }^{144}$

The picture of Japanese as people who considered that there was nothing worth fighting about is one quite different to that painted by each of the other three Australians whose writings we are considering. It would have surprised anyone after the Japanese victories in the Russo-Japanese War (1904-05). The image, however, was shared by at least one other besides Hingston even after the SinoJapanese War of 1894-95. In the latter year shortly after Japan's final victory, Kenneth Mackay, a keen militia officer and backbencher in the NSW parliament, published a novel, The Yellow Wave - A Romance of the Asiatic Invasion of Australia, in which Australia is captured by the Russians and Chinese. In it he depicts Japanese immigrants as loyal to Australia because of their implacable hatred of the Chinese, but militarily useless because of their peaceful disposition. ${ }^{145}$

138 'Impressions of Japan', 28 October 1867.

139 'Impressions of Japan', 10 September 1867.

140 J Hingston ('HH' of the Argus), The Australian Abroad: Branches from the Main Routes Round the World (London: Sampson Low 1879), vol. 1, pp. 1-88. This is a collection of articles that originally appeared in the Argus. 141 The Australian Abroad, 1879, p. 7.

142 The Australian Abroad, 1879, p. 67.

143 The Australian Abroad, 1879, p. 4.

144 The Australian Abroad, 1879, p. 10.

145 K Mackay, The Yellow Wave - A Romance of the Asiatic Invasion of Australia (London: Bentley 1895), p. 289. 
The famous 'Vagabond' (JS James) of the Argus visited Japan late in $1881 .{ }^{146}$ Like his predecessors he found the Japanese well washed - in the attention they devote to personal ablutions they are surpassed by no people in the world' - and merry:

I have seen beautiful nights in lovely localities all over the world ... but nights spent in the country districts in Japan, with the harvest moon's mellowing lights contrasting with broad shadows of hill and pine forest, are as beautiful as anything I remember ... generally, the people appear to rejoice in the fullness of their own life, and the beauties of nature, and their light hearts take advantage of the occasion to be en fete and merry and glad whilst they may.

This is about the only good thing he has to say about Japan and the Japanese. Hingston's picture of the Japanese as a people who 'think ... that there is nothing in the world much worth ... fighting about' is a very different from his. The passage from the Vagabond that we have just quoted continues:

In the joyous, happy, peaceful life all around one, you find it hard to believe that these apparently innocent people could have beneath the lacquer of good nature the fierce cruel passions which the records of the Samurai and Ronins, their popular literature, show were commonly possessed by their immediate ancestors, and which cannot yet be extinct within themselves ... In Japan the people are, as they always were, semi-savages lacquered. ${ }^{147}$

In his famous articles about the underprivileged and oppressed in Melbourne, James wrote as if there was a distinction between externals and moral worth. In Japan, however, he made less attempt to differentiate between the two. The piece just quoted was written near the end of his visit. His concept of the Japanese as 'semi-savages lacquered', however, seems to have taken firm root with his first sight of Japanese in their homeland - the boatmen who rowed him ashore at Nagasaki. These were dressed rather sensibly for the task. They wore only fundoshi, the diminutive Japanese loincloth. This appears to have upset him greatly:

What a distance between these naked savages and the smart young gentlemen who, in lacqured boots and store clothes, every detail of their apparel European, made such a display of themselves and their amiability at late international exhibitions [presumably the exhibitions in Sydney 1879-80 and Melbourne $1880-81$, DCSS]. The suspicion crosses one that there is a good deal of lacqueer (sic) about this people. Two such extremes as $\mathrm{Mr}--$, my Sydney acquaintance, who made such good speeches on public occasions, and these tatooed boatmen, both belonging to the same city, Nagasaki, imply a good deal of show for the outer world and little decency in home life. ${ }^{148}$ 
Brooke had noticed that not all shopkeepers would bargain with him. He attributed this to apathy or language difficulties. ${ }^{149}$ The Vagabond, however, has a less favourable explanation:

A Chinaman will never refuse an offer if he can make a cent by the transaction. Here I wish to buy a gourd from an itinerant vendor who is lying down gambling. He asks a yen, an extortionate price. I offer 10 sen [i.e. 1/10 of a yen, DCSS], he refuses, and five minutes afterwards sells one to a countryman for five sen. I am told this is often the case. The natives won't deal with foreigners unless they can cheat them. ${ }^{150}$

He dislikes the Japanese; but he does not admit to fearing them:

Far different to what I find it in China, the Jap in no case has worked out the European. The Caucasian is not played out here, as in so many instances in Shanghai ... [T] he white man's brain is still supreme here, and ... when he has a chance he is still the 'boss'. Indeed, except in their official positions, I find that the Jap hasn't much of the boss in his nature. In uniform he can stalk about and endeavour to look majestic, but in work or trade he seems nowhere. He is too lazy ever to come to the front as a worker, and in trade he proves such a liar that he can get neither credit nor trust - the foundation of commerce - from foreigners. ${ }^{151}$

This 'laziness' (which Mishima might have admitted but which none of the other Australians observed) worried the Vagabond a great deal: 'A Jap will live on very little sooner than work. ${ }^{152} \mathrm{He}$ notes that even the horses are slackers: 'The man who leads them might almost carry the light loads; but this loafing along, making a pretence of doing something, suits the Japanese wonderfully.'153 All calculations are done on the abacus, because 'mental calculation is too much for the Japs'. ${ }^{154}$ English engine-drivers were employed on the night trains 'it being considered that natives would very possibly go to sleep at such a time. ${ }^{155}$

So far as the period under review is concerned, it appears that it was the Brooke rather than the 'Vagabond' attitude that prevailed. Sometime in 1889 Murdoch, probably at the request of the Japanese Government, wrote them a short report on conditions in Australia. In this he said that 'Australian popular opinion is wonderfully favourably inclined towards Japan and the Japanese'. ${ }^{156}$ Murdoch himself was a Japanophile; but there are no indications that the enthusiastic articles on Japan that he had just written for William Lane's Brisbane weekly,

149 'Notes from Japan', 22 August 1867.

150 'Notes from Japan', 21 January 1882.

151 'Notes from Japan', 14 January 1882.

152 'Notes from Japan', 28 January 1882.

153 'Notes from Japan', 21 January 1882.

154 'Notes from Japan', 28 January 1882.

155 'Notes from Japan', 18 February 1882.

156 The report, which is undated, is published, in English, in NGB - 1889 at pp. 551-53. 
the Boomerang, ${ }^{157}$ were unacceptable even to the many radicals among that very nationalistic journal's wide readership. As time goes by, more students will no doubt work on the newspapers and magazines and private diaries and letters of the period and may turn up more evidence on what Australians at this time thought of the Japanese. In the meantime, we must make what use we can of the snippets of information that come our way. All we can say is that there was a steady trickle of Australian tourists who had heard enough that was favourable about the country to decide to visit it. These included among their number not only journalists and teachers, but cabinet ministers and wild colonial boys. The Vagabond, in 1881, noted:

The names of many Australians are registered on the hotel books here. The 'Duke of Melbourne' was here recently. That's the title he chose to assume when demanding an audience with the Mikado. But the bon farceur did not obtain his wish. ${ }^{158}$

The Olympic swimmer Dawn Fraser was not the first Australian to jump into the moat near the Emperor's palace: Douglas Sladen recalls how on his visit to Tokyo in 1889 his secretary fell into the moat with a 'drunken Australian squatter' whom she was trying to help across the bridge into their hotel. ${ }^{159}$

Some years ago, my old friend, Leslie Oates, a mine of information both on the Japanese language and on comparative religion, drew my attention to a passage in the diary of the American theosophist, HS Olcott, that revealed that in 1887 one of Brisbane's leading citizens was so impressed by things Japanese that, on his return from a vacation there, he built himself a Japanese house. ${ }^{160} \mathrm{I}$ wrote to the Oxley Library to see whether they could provide confirmation of this. Their answer was so unexpected that I must embark on a digression and outline the remarkable history of this remarkable house.

They referred me to an item in the Brisbane Courier of 21 December 1887, of which the following is an extract:

Some months ago his Honour Judge Paul took advantage of a well-earned vacation to pay a visit to 'beautiful Japan'. His sojourn there was from beginning to end a pleasing surprise to him. The people, their habits and customs, and their mode of daily life were an interesting study which he would willingly have prolonged and he was especially struck with the construction of their dwelling-houses, which, as all who have seen them aver, appear to be in every way suited for the comfort of their inhabitants, whether they are situated in temperate or sub-tropical latitudes.

157 'Where McIlwraith is going', Boomerang, 1, 8, 15 and 22 December 1888; 5, 12 and 19 January; 2 February 1889; 'In a Japanese jail', Boomerang, 8 May 1889.

158 Argus, 25 February 1882.

159 D Sladen, My Long Life: Anecdotes and Adventures (London: Hutchinson, 1939), p. 118.

160 HS Olcott, Old Diary Leaves: The Only Authentic History of the Theosophical Society, 4th series, 1887-92

(London: Theosophical Society Publishing House, 1910), p. 282. 
Judge Paul before leaving Japan determined to prove to himself whether a house constructed on Japanese principles was or was not suitable in a South Queensland climate. Accordingly, he appointed as his agent an English merchant, who agreed with a Japanese contractor to construct, ship, and erect in Brisbane a house in every respect but one [i.e. the height of the ceilings and doorways, DCSS] the double of the building in which Judge Paul resided at Kobe ... The contractor ... guaranteed that it should last 100 years ... In due course the house arrived in Brisbane, and with it came three Japanese carpenters and two plasterers, who were a part of the contract, for the only obligation resting upon the Judge in regard to them was to provide them with food. The site was chosen for the house was at New Farm, at the corner of Langshaw-street and Bowen-terrace. ${ }^{161}$

The library provided the additional information that there was every prospect that the contractor's 100-year guarantee would be made good. When the site was sold for redevelopment in 1962, a couple from Ingham, 1,600 kilometres to the north, bought the house itself (about 30 squares in area) at the demolition sale. ${ }^{162}$ They engaged a member of the Faculty of Architecture at the University of Queensland and four of his students to supervise the demolition and mark each piece for re-erection. The pieces were then transported by rail to Ingham where, with great care, a local builder rebuilt the house virtually in its original form. During the demolition, some patches of dry rot were detected under some exterior paintwork. Elsewhere, where the timber, following Japanese custom, was unpainted, it was sound. ${ }^{163}$ When I visited the house in 1973 the only sign of deterioration was where some planks of new local timber used for repairs during the re-erection in 1963 had begun to decay.

Although the move to Brisbane was entirely fortuitous, it was from the historical standpoint very appropriate. What could be more fitting than that this living representation of the continuity and durability of Australian-Japanese relations should be at Ingham where, in November 1892, the first of some 2,300 Japanese contract labourers who worked in the Queensland sugar industry ${ }^{164}$ were landed 50 men to work at Macknade and Ripple Creek plantations. ${ }^{165}$ Three of them died there during the following year - Nishimura Tomokichi of nephritis, Fujiwara Tomejin of dysentery and Oshima Kankichi of sunstroke. ${ }^{166}$ Their graves have long been lost beneath the tropical vegetation; a much happier reminder of their contribution and those of the many who followed them is Judge Paul's house.

161 See also Boomerang, 24 December 1887.

162 Courier Mail, 21 July 1962; Sunday Mail, 20 October 1963.

163 WH Carr, 'The Japanese House, New Farm, Brisbane', Architecture in Australia, December 1964, pp. 98-100. 164 'Return of Japanese agricultural labourers engaged for service in Queensland ... as at December 1898', compiled by Bowden Bros \& Co., Queensland State Archives PRE/102.

165 Irie, Höjin Kaigai Hattenshi, 1942, vol. 1, p. 394. Brisbane Courier, 1 December 1892.

166 I am indebted to the Queensland Registrar-General, Mr HW Tesch, for his kindness in making this information available. 
But let us return to the subject in hand. Murdoch's articles in the Boomerang were written during 1888 . The country and the people had not changed greatly in the six years since the Vagabond's visit. In one respect, however, the latter might have felt that progress had been made. One of Murdoch's articles could have been subtitled 'Lament on a G String'. On a summer tour of rural Kyūshū, he was surprised when, on approaching a village large enough to sport a police station, his rickshawmen put down the shafts:

Here we make a discovery. It is that the Mikado's Government have determined to fine its subjects into decency. The poor rickshaw men, who by this time are steaming like so many cauldrons, have to stop and don each a pair of scanty breeches. Failing their putting on the unmentionables they are liable to a fine of 50 sen.

This is too much for Murdoch the republican, free-thinking, classical scholar:

This regulation appears to be the outcome of a yielding to Western ideas, in a case where the ideas are only prejudices ... The men that made Thermopylae a name in world history didn't run about in Lacedaemon with abbreviated unbuttonable unmentionables. Let Japan adopt the salutary parts of our civilization, but in the name of goodness let her not pander to our prejudices or pay court to Mrs Grundy. ${ }^{167}$

The picture Murdoch painted of the Japanese was decidedly favourable:

A Japanese who has not been spoiled by a residence in an open port is just about as pleasant and nice and jolly a fellow as you could wish for as a chum or a companion ... I'd rather tramp and trudge and eat my food with chopsticks and scribble with him for a mate and a bed-fellow than with the great majority of my 'even Christians'. And as for fidelity and standing by you in a scrape, you can't find his equal out of the Scotch Highlands or Switzerland. He is polite, thoughtful for you in every way, always laughing and good for a joke and thoroughly imbued with that sturdy independent honest pride that has its basis in self-respect ... if 'gentleman' means a man whose leading characteristics are the outcome of 'gentleness' and manliness the Japanese are just right in it up to the armpits and a good deal further. In the point of pluck they are about as dare-devil a lot as are to be found in any corner of the globe whatsoever; in regard for the feelings of others they are simply unique ...

The sum and substance of the whole matter is that by instinct and training the Nippon-jin is a real good radical. He is not at all self-contained or selfish in his joys and his enjoyment of life. He insists on sending his good things round. ${ }^{168}$

167 Boomerang, 19 Janaury 1898.

168 Boomerang, 15 December 1888. 
It may be that Murdoch's decision in 1888 to extend to Japan his voyage to China was the result of a suggestion by another writer for the Boomerang, his friend and fellow radical, Francis Adams, who had visited Japan the previous year. To Adams, as to Murdoch, 'gentleness' was an essential Japanese quality. There was another observation common to both men. Murdoch saw individual Japanese whose native virtues were spoiled by contact with Westerners in the treaty ports; Adams saw the whole nation and an ideal way of life doomed to contamination by British influence:

\section{TO JAPAN}

Simple You were, and good. No kindlier heart

Beat than the heart within your gentle breast.

Labour You had, and happiness, and rest.

And were the maid of nations. Now You start

To feverish life, feeling the poisonous smart

Upon your lips of harlot lips close-pressed,

The lips of Her who stands among the rest

With greasy righteous soul and rotten heart.

$O$ sunrise land, $O$ land of gentleness,

What madness drives you to lust's hateful bed?

O thrice-accursed England, wretchedness

For ever be on you, of whom 'tis said,

Prostitute plague-struck, that you catch and kiss

Innocent lives to make them foully dead! ${ }^{169}$

Such enthusiasm for Orientals is at first sight surprising in men among the inner circle of writers for a journal that, under Lane's leadership, was at the forefront of the White Australia movement. 'What', asked Lane, 'could we dream of getting from the hordes of Easterners but the East without its virtue, the East in all its loathsome nakedness and shame?' As his biographer justly observes: 'In his discussion of the coloured question, Lane lost all sense of equality, internationalism, decency, and respect for science. ${ }^{170}$ That the Japanese at this time were exempt from the opprobrium that the Boomerang attached to colour suggests that among Lane and his supporters this sprang directly from the presence of coloured labour in their midst. That labour was Chinese and Kanaka. As we have seen, there had never been more than a handful of Japanese on the Australian continent. The popularity of the Japanese may have been linked not only with their remoteness from the Australian scene but also with the fact that they too were hostile to the Chinese. This is not far below the surface in the article by Murdoch that we have already quoted:

169 FWL Adams, Songs of the Army of the Night (Sydney, 1888), p. 83.

170 L Ross, William Lane and the Australian Labor Movement (Sydney: Lloyd Ross, undated), p. 69. 
You may live a year with a Chinaman, you may eat the proverbial peck of salt with him and yet know no more about the construction of his mental clockworks than when you first lifted chopsticks in his company; in short you can never get him out of his winding. With the Japanese it is entirely otherwise ...

They [the Japanese] will calmly tell you that one Japanese is good for five Chinamen. Now a Chinaman physically speaking is about twice as heavy as the ordinary Nippon-jin. But, as old Napier has it, the moral is to the physical as three to one in warfare, and that is where the Japanese does the boom over the Flowerylander. I really and honestly believe that the peppery daredevil Jap would actually make his vaunting boast good if it came to actual blows.

This aspect comes out much more clearly in another article eulogising the Japanese published by the Boomerang at this time. In it Thomas Finney, a large city storekeeper who contributed to many of Lane's causes, wrote as follows:

He [the Japanese] doesn't impress you as yellow but as having more of a brown tinge to his skin. The Chinese, just across the Yellow Sea, are a sulky, churlish, cruel-looking lot of people, whose every way and mode of life repel 'barbarians', as they call us; but here, in Japan, the people seem what I can only explain as a 'loveable race'. They are as kind as it's possible for people to be. They go out of their way to oblige strangers and appear to oblige one another in just the same way. And they have as well, such a jolly cheerful, laughing look, that it does your heart good to sit and watch them ... I never in all my life saw people who seemed to take such pleasure in living as the Japs.

[T] here can be not doubt that he [the Japanese] is destined to attain the highest civilization known and that already he has won the right to be considered not as Asiatic but as Western. His sympathies and proclivities are all with us against not only his old feudal civilization but as against the Mongols, and his value as a bulwark against the latter can hardly be overestimated. ${ }^{171}$

We have already observed how to Kenneth Mackay the Japanese were proAustralian because they were anti-Chinese.

Besides Chinese labour the Boomerang's other bête noire was monarchy. The purpose of Australian defence was to ensure that 'none of the crowned robbers of the Old World will care to poke his fingers into this hornet's nest of the Far South Seas'. ${ }^{172}$ In this context Japan posed no threat. Indeed, the Boomerang hoped, if need arose, to see 'Australia, Japan and America stand shoulder to shoulder against European aggression in the Pacific'. ${ }^{173}$ In his report to the Japanese Government, Murdoch urged:

171 'The Japs and the future', Boomerang, 3 November 1888.

172 Boomerang, 20 April 1889.

173 Boomerang, 30 March 1889. 
It would be highly impolitic to allow anything to happen likely to cause any check to the current of Australian good-will that has set in so strongly towards Japan. The introduction of 'cheap' Japanese labour would certainly have a cooling effect upon the enthusiastic admiration Australians at the present moment entertain for Dai Nippon. ${ }^{174}$

When in November 1889 a rumour circulated that Japanese contract labourers had been landed at Mourilyan Harbour for work on the canefields, the Boomerang was in the vanguard of the attack:

We shall be told that the Japs are neither Chinese nor Kanakas nor Cingalese, but a patient, kindly and harmonious race. That may well be, but they are not being brought here for what to us are virtues, but for what by every white worker must be and is regarded as the vilest vice. They can underwork us. They have not the white ambitions nor the white discontents ...

$[\mathrm{I}] \mathrm{t}$ is nothing to us if the Japs are nice people or not; their very nicety makes them more dangerous; the more industrious they are at 30s. a month the more we have to fear from them and the more determinedly we should resist their introduction. ${ }^{175}$

The 1889 landing was a canard put into circulation by a provincial newspaper. Soon afterwards Marks (who advocated limited Japanese immigration at Australian rates of pay) warned Kawagoe in terms similar to the Boomerang that any arrival of Japanese labourers in large numbers would undoubtedly lead to the imposition of some such indignity as the poll tax that was applied to Chinese immigrants.

Kawagoe's response was truculent, but not unperceptive:

If any country disparages our rights, then we Japanese are resolved to put an end to such insults. There is no reason why we should abandon our interests and place ourselves at their discretion in a cowardly fashion. If we at the outset are to retire in the face of such pressure, how shall we, when putting our best efforts into trade and agriculture overseas, compete successfully and implacably. If what Marks says should unfortunately come to pass, then we resolute Japanese would have to get such illegalities corrected. If, however, we got involved in disputes before our enterprises were established and before we acquired property rights, then there would be no alternative to our overthrowing such laws. Accordingly we should, at the outset while our enterprises are being set up, work under cover and use only a few men. ${ }^{176}$

The advice of Murdoch, the Boomerang, Marks and Kawagoe was disregarded. When the 50 Japanese contract labourers were landed at Ingham in November 1892, they caused little comment. But when 520 were landed the following June

$174 N G B-1889$, p. 553.

175 Boomerang, 30 November 1889.

176 Kawagoe, ‘Gōshū-Dan', [1892?], p. 92. 
the response was very much as Murdoch predicted. The result was the resolution at a conference of premiers in March 1896 to extend the Chinese exclusion legislation to coloured races generally. The resolution was effectively accomplished by the federal Immigration Restriction Act in 1902. This was regarded as an insult by many Japanese less chauvinist than Mishima and Kawagoe. Furthermore, as the latter predicted, it prevented not only Japanese immigration but also the establishment of Japanese businesses in Australia.

\section{DCS Sissons}

Department of International Relations

Research School of Pacific Studies

The Australian National University

3 October 1978 


\section{3 \\ The Lady Rowena and the Eamont: The 19th century ${ }^{1}$}

\section{DCS Sissons}

Australian contacts with Japan in the 19th century can be seen to fall into three, fairly distinct, periods. The first was the final years of the sakoku period when Japan was still a closed country - Japan before the appearance of Commodore Perry and his black ships and the ensuing negotiation of the Ansei treaties with the foreign powers, opening Japan to foreign residents and permitting Japanese subjects to go abroad. The second period - from about 1867 to about 1891 can be seen as one of unfettered but infrequent and small-scale contact. It was, however, in the latter part of this period that Japan became an important source of labour for the pearling industry on Thursday Island, and at Darwin, Cossack and Broome. And it was in the late 1880s that the Japanese prostitute made her appearance in a string of Japanese brothels extending in the east from Thursday Island to Melbourne, and in the west from Darwin to Bunbury and Coolgardie. The third period from, say, about 1892 to 1901, we may call the period of more numerous emigration sponsored by the large commercial emigration companies. This ended with the enactment of the Immigration Restriction Act, which prevented the entry of non-Europeans to Australia.

1 Unpublished paper. 


\section{The sakoku period (c. 1633-1866)}

During this period there were two occasions when the crews of Australian vessels came ashore in Japan. Both were whaling ships - the Lady Rowena of Sydney and the Eamont of Hobart. In 1819 whales had been discovered in large numbers off the Japanese coast and those waters soon became part of the Pacific whalers' itinerary.

\section{The Lady Rowena}

The Lady Rowena cleared out of Sydney on 2 November 1830 on a whaling voyage that was to last until 25 June 1832. We have a detailed account of the voyage for her captain, Bourn Russell, devoted much time and energy to entering the log, which has survived. Poor catches in the Solomons caused Russell to abandon the south Pacific grounds earlier than he had planned and some months before the seasonal movement of whales to the Japanese grounds. He decided to spend the interim in pursuit of the right whale in Aniva Bay at the southern tip of Sakhalin. He was thither bound when it became necessary for him to beach the vessel in order to repair a leak. Accordingly, on 31 March 1831 they entered Hamanaka Bay on the coast of Hokkaido about 50 kilometres south of Nemuro.

At the village of Kiritappu they found the Ainu inhabitants friendly and happy to exchange curios. The three Japanese whom they encountered, however, regarded them with 'cold indifference'. When they next put ashore two days later, the inhabitants had fled, taking all their food with them. Regarding this as a breach of the duty to assist ships in distress, they began helping themselves to firewood, salt, utensils and 'many little things of little value'. The following day, when collecting more firewood, they neglected to extinguish their cooking fire, which then spread and burnt a house to the ground. The next day when Russell espied a 'hostile party' of four horse-soldiers riding in the direction of Akatoma, the town at the top of the bay, he despatched a boat in that direction. From this he tried, unsuccessfully, to shoot a horse from under the rearmost rider in order 'to take one person on board and prove to them that we were friends and not enemies as they suppose or rather feign to believe'. As they approached Akatoma they observed a dozen men armed with swords and muskets manning a dummy battery consisting of a canvas screen on which was painted the representation of five cannons' mouths. He wrote that they 'could not refrain from trying the effect of a shot on this ludicrous scene and accordingly fired'. After an interval the sound of three musket shots rang out on the hill. Two days later, having replenished their ammunition, Russell put 23 men armed with muskets and bayonets into four boats and, in his own words, 'proceeded to chastise those contemplable [sic] Japanese for presuming to fire on a Stranger seeking shelter from a leaky Ship'. According to his account, they advanced in file until the fort was in musket range and then 'kept up a continuous 
fire for 10 minutes which made the hill smoke as tho' it was on fire - behind which they had got'. Victory was complete. The defenders were driven off, one prisoner was taken and there appears to have been no casualties on either side.

Six days later, as the Lady Rowena weighed anchor, the prisoner was released with some gifts for himself and a letter addressed to the Emperor warning him of the consequences of treating British subjects inhospitably. Finding the Nemuro Strait still frozen over, Russell then made for Hachijojima (in the Izu Archipelago off Shizuoka prefecture) where he landed and, without incident, peacefully secured water and provisions. From there he proceeded to the whaling grounds off Miyagi prefecture. On 29 May he boarded four Japanese junks off Kinka-san and bought from them fish and a compass. On 8 June he was successful in catching three whales. By 22 June four of his crew had scurvy and he was considering making another landing. On 30 June, however, he encountered another Japanese junk and decided to secure the necessary fresh vegetables from it. In mid-August scurvy finally made him abandon the Japanese whaling grounds and make for Guam.

\section{The Eamont}

Nineteen years later, at about 3.15 am on 23 May 1850, the Hobart whaling vessel the Eamont (WH Lovitt, Captain), with her crew of 32, was wrecked off Mabiro, near Akkeshi, about 40 kilometres south of the Lady Rowena's Hamanaka Bay. Heading for the whaling grounds in the Sea of Okhotsk, the Eamont strayed two degrees off course and struck a bed of rocks about 400 yards from the shore, close to the small island of Kojima, whence the crew made in boats. They then moved to the mainland and established themselves in some deserted huts to which they rafted moveables from the ship. On the third day, they came upon some inhabited huts, whose inhabitants treated them very kindly. Towards evening they were visited by a party of about 20 Japanese, armed with swords, who led them to the local village. Two days later, on 27 May, three small junks arrived and transported them, their livestock and their possessions to Akkeshi about six miles distant. They were marched to their place of confinement at the District Office by a large guard armed with firearms and swords along a route screened from foreign eyes by rolls of cloth and banners bearing the daimyo (feudal lord) crest. They were served fish and rice three times a day, varied occasionally with cockles, oysters and cakes. There they were to remain in close custody for nearly four months.

On 12 September they were escorted together with their belongings to two junks, the Chobo Maru and the Antai Maru, which were to take them to Hakodate and thence to Nagasaki. Once again 'curtains were placed on each side of the road to prevent them seeing anything'. The Choho Maru with 12 of the Eamont's crew arrived at Nagasaki on 4 October. The Antai Maru with the other 20 did not reach Hakodate. On the second day out it was caught in a gale and driven ashore off 
Oshamambe. One of the Japanese managed to swim to the shore with a rope and all were saved except the Eamont's cooper, James Higgins, who was swept from the rope and drowned. They travelled the 70 miles to Hakodate on horseback.

At Hakodate they (together with the corpse of Higgins, pickled in brine) were put aboard another junk and arrived at Nagasaki on 6 October. There Higgins was buried among the Dutch graves in the grounds of the Goshinji temple. The convict records at Hobart show that he had been sentenced at Londonderry to seven years transportation in 1840 and that he served his sentence at Port Arthur in the boys' prison at Point Puer (where coopering was one of the trades taught). In so far as he chose to remain in Van Dieman's Land at the expiry of his sentence rather than return to Ulster, I think that we may claim him as a migrant and his grave as the earliest Australian grave in Japan. Unfortunately we cannot mark the spot - it is one of four unidentified graves dating from that period.

It was the practice before handing over foreign seamen to the Dutch for deportation to summon them before the magistrate who would determine whether they had breached the law by wilfully entering the country or by adhering to the prohibited religion, Christianity. They were, accordingly, taken from their place of confinement (the Seikoji temple in Dekidaiku-machi) and transported, each in a closed palanquin, to the court house, where, through interpreters, they were asked: (i) their names, ages, nationalities, and personal particulars; (ii) the date of their departure from Hobart Town; and, (iii) the circumstances surrounding their landing at Akkeshi and Higgins's subsequent death. The religious examination was interrogation and observation of the subject's demeanour when required to undergo the traditional test of fumie - trampling on a small religious image about six inches in diameter. The records of such examinations of foreign seamen at Nagasaki show that, from the time of the deportation of the Lawrence survivors in 1847, the religious examination was devised in an ingenious manner so that, while the prescribed procedures were carried out to the letter, the subject was carefully shielded from apostasy. It appears that the question asked was something like 'You have no gods do you; but reverence heaven to achieve integrity and enlightenment?'; for this is the substance of the answers recorded against not only the entire crew of the Eamont but against the Lawrence survivors in August 1847, against the Canadian, Ranald MacDonald, in October 1848 and against the Trident deserters in 1850. As for the fumie test - they were told, as Lovitt reported, to tread on 'the image of the devil'. MacDonald in his memoirs records that his instructions were in similar terms. By nature curious and observant, however, MacDonald examined the object closely and found it to be an image of the Virgin and Child. For him this presented no problems: 'Told to put my foot on it, being a Protestant, I unhesitatingly did so.' 
Satisfied by their answers, the governor commanded them never again to enter Japan and handed them over with their personal possessions to the Dutch for transportation to Batavia aboard the Delft, to whose captain who had made over 85 sacks of rice and 300 thaler, requesting that the passengers be treated with the greatest care and kindness.

\section{The second period (1867-91)}

\section{Jugglers and acrobats}

The first Japanese to set foot in Australia were members of touring troupes of Japanese jugglers and acrobats that arrived in Australia in late 1867.

It was not until 1866 that the Japanese Government, under pressure from the Treaty Powers (United States, Great Britain, France, Russia and The Netherlands), revoked the edict under which for two centuries Japanese subjects were prohibited, on pain of death, from venturing beyond the realm. Contrary to expectation, the first to avail themselves of the new dispensation were not merchants or students, but jugglers and acrobats recruited by foreign impresarios through the good offices of foreign trading firms in the Treaty Ports. Japan's first passports were issued on 23 November $1866-14$ to the Matsui troupe engaged by a Britisher, W Grant, and 18 to the Hamaikari troupe engaged by the American acrobat, Richard Risley. They embarked for London and San Fransisco on 2 December and 5 December. Another 12, the Kanawari troupe, had already embarked for San Fransisco on 29 October without passports.

In May 1866, at the end of Thomas Lenton's troupe's two-year tour of the Australian colonies, Lenton had entered into a partnership with the Melbourne circus manager, John W Smith, for the Lenton troupe to tour South-East Asia and China, with Smith accompanying them as manager. After performing in Hong Kong, the Philippines, Java, Singapore, Penang and Calcutta, the troupe arrived in Melbourne aboard the P\&O mail steamer Avoca from Ceylon on 16 December 1867. They toured Australia and New Zealand until February 1869, performing under the name of Lenton \& Smith's Great Dragon Company in each capital except Perth and Brisbane, and in Ballarat, Geelong, Bendigo, Castlemaine and Launceston. When the length of their season called for a change of program, the troupe added drama to their repertoire and performed an adaptation of one of the famous sword-fighting scenes from a kabuki drama, the 'Death of Kokingo' scene from Yoshitsune Senbonzakura.

At the end of 1867, Japanese troupes of this nature were a common sight on the world scene. Four were performing in the United States and another two had already moved on from there to Europe, where the Matsui troupe had been performing since February. Such competition extended to the antipodes. 
The Lenton \& Smith troupe had disembarked in Melbourne in December 1867 only to find a rival group, the Tycoon Japanese Troupe, performing in Geelong. Recruited and led by a Deshima Eurasian, Tanaka Bushichiro (born of a Japanese mother and Dutch father), it had arrived on the previous month's steamer from Ceylon. It was a smaller group, consisting of three men, whose repertoire included top-spinning, juggling, tumbling and slack-rope walking, and three women, who sang and danced and provided accompaniment on the shamisen. It toured Australia and New Zealand until the following October (1868), performing in Melbourne, Sydney and Adelaide and their suburbs, the Hunter Valley, the cities and towns of western Victoria as far as Avoca, and at Gawler and Kapunda in South Australia.

These were followed two years after by a group of eight led by Matsunosuke, which, under various names, performed in Victoria, New South Wales, Adelaide, Brisbane and New Zealand from February 1871 to January 1873.

A group of 13 members led by the juggler Awata Katsunoshin arrived in July 1873 and toured Australia and New Zealand for two years. When their contracts expired at Hobart in September 1875 the group split and its members secured engagements with various Australian circuses. Five were to settle here and become our first Japanese immigrants. The shoulder-balancer, Rikinosuke, who had married an Australian in 1875, performed with her and their daughter in Queensland towns until his death in 1884. The partner in his act in the Awata troupe, the boy Iwakichi married an Australian acrobat in 1892 and with her, their children and some performing animals, operated an itinerant family show out of Quilpie (Queensland) until 1917, when he took up farming. He died in Brisbane in 1938. Cooma Kitchie (Kumakichi) the tumbler and rope-walker was a working partner in Wirth's Circus at its inception in 1882 and was joined there by Bungaro (Bunjiro) the tub-balancer and his juvenile partner Itchi (Ichitaro) the following year. Bungaro and Itchi continued to perform together in vaudeville programs and country shows until shortly before Bungaro's death at Grantham (Queensland) in 1903. Itchi died in Brisbane in 1917, survived by his widow and their five children. While Cooma Kitchie was with Perry's Circus, an Australian Aboriginal woman at St George (Queensland) bore him a son, Henry Coome Kitchie, whom the Perrys later adopted. Henry grew up to be a clown with Eronis' and later Soles' circus. In the 1940s he was employed by Perry's on the road as their advance agent. He died at Wentworth Falls (New South Wales) in 1969 and was survived by his two daughters.

Among later groups to perform in Australia were the Tetsuwari/Tachibana troupe, which formed part of 'The Japanese Village' (an exhibition of Japanese traditional craftsmen at work, engaged by the Australian actor and impresario Pemberton Willard) that toured Australia from April 1886 to July 1887. The Goday family troupe came in 1891 and performed in vaudeville and with Wirth's Circus and Fitzgeralds' Circus until Goday's death in Melbourne in 1900. Two of his daughters settled in Melbourne and spent their lives there. 


\section{The pearling industry}

In 1866 the Treaty Powers secured the right for their merchant vessels to sign on Japanese crew at any of the Japanese Treaty Ports. British captains made extensive use of this right. Sometimes they did so unscrupulously and took advantage of Japanese recruits' ignorance of the English language to bind them to very unfavourable conditions. It was after several cases had come before the Melbourne police courts in which Japanese seamen, engaged as a result of such subterfuges, instituted criminal proceedings against their captains for various acts of ill treatment that the Japanese Government on 4 November 1879 appointed Alexander Marks honorary consul in that city. This was one of the earliest Japanese consulates in the British Empire, preceded only by Hong Kong (1873), London (1876), and Singapore (April 1879).

Nonami Kojiro of Hirose in Shimane prefecture joined a British merchantman at Yokohama in this fashion and, after a couple of years on the world's sea lanes, took his discharge at Sydney. There in 1876, aged about 25, he signed on as a pumper on a Torres Strait pearling lugger. He was hardworking and ambitious. He learnt to dive from a Malay diver and soon achieved a high reputation as a diver. During the next few years, several other Japanese sailors arrived in similar circumstances and some of these became divers. The men performed so well - either as crew or divers - that the pearlers began to recruit Japanese overseas. In 1883 there were about 15 or 16 Japanese recruited in Hong Kong to work as pumpers on the Thursday Island luggers on 18-month contracts. Later in that year the Torres Strait pearlers began to recruit in Japan itself; at Yokohama on 10 October Captain JA Miller engaged 37 Japanese (six divers, six tenders, 24 pumpers and an interpreter - all on two-year contracts). The performance of these men was such that the Australian pearlers continued to seek labour in Japan. The following year another 69 were recruited for them by Fearon, Low and Co., a British firm in Kobe. Of these, about 45 went to Thursday Island and 15 to Darwin. In June 1885 Streeter and Co., the largest of the Western Australian pearlers, recruited at Yokohama six divers and an interpreter on terms similar to those of the Miller contracts.

\section{Commerce}

In February 1890 Kanematsu Fusajirō, a businessman from Kobe, arrived in Sydney to set up the Sydney office of his trading firm. With him was his manager designate, Kitamura Toranosuke, aged 24. In 1918, when the patent firm in Japan became a public company, Kitamura was the principal shareholder, holding 18 per cent of its capital. In 1922 when the Sydney office became a separate company, F Kanematsu (Aust) Ltd, he was its managing director. He died in harness in 1930 and was survived by one son and three daughters in Australia. In the previous year the firm had endowed the Kanematsu Memorial Institute of Pathology and Biochemistry at Sydney Hospital. During his 40-year reign in 
Sydney, the number of bales of wool shipped by the firm from Australia had risen from 200 in 1890-91 to 100,000 in 1930 (in which year Japan supplanted France as the number two market for Australian wool).

\section{The third period (1892-1902)}

In 1891 the number of Japanese on Thursday Island was about 100. In that year 12 arrived; in 1892, 100; in 1893, 264; and, in the first quarter of 1894, 152. The government resident reported that this influx had caused wages to fall to half their previous level and had produced widespread unemployment - half the 222 Japanese ashore were unemployed. He expressed fear that the pearling industry might pass into Japanese hands: 'Two years ago there were not 20 boats owned and manned by Japanese. Now there are upwards of 70, and of these 38 are owned by Japanese. This is a matter that merits the serious attention of Parliament.' The following appear to have been among the factors contributing to this flow of immigrants.

There was the impact of the wealth of the immigrants returning to their villages on the expiry of their contracts. On Thursday Island it was rare for a man to send home less than $¥ 100$ a year (even in his first year). At home he would have earned about $¥ 40$ a year and out of this have had to buy food. Some brought home very much more. In November 1890, it was a syndicate of 10 Japanese on Thursday Island that drew Carbine in Tattersall's Melbourne Cup sweepstake. They returned to Japan the following month with their winnings - $£ 22,500$. Three of them are still remembered in their villages in Wakayama prefecture: Hiramatsu Gorobei and Urita Jinemon from Shionomisaki, and Ebina Torakichi from Tanami. Hiramatsu invested his winnings in mountain land and became known as 'the forest king of the Kinan district'. Urita put his money into a boat for deep-sea tuna fishing. He also rebuilt his home and put around it a fine stone wall (which is still standing). Ebina bought from his employer the beautiful Fukuhara geisha, whom he married. He also donated half the cost of rebuilding the belfry at the local temple. In his lengthy report on Australia and its potential as a field for Japanese emigration, Watanabe Kanjuro in 1894 wrote that because of the savings that people (including the Carbine syndicate) were bringing home, villagers from Wakayama prefecture were swarming to Australia.

Another factor may have been the adoption by the Japanese Government of a more positive attitude to emigration on the appointment of Enomoto Takeaki as foreign minister in May 1891 and the establishment soon after by private enterprise of large companies to finance and broker emigration. The first of these, the Yoshisa Emigration Co. was founded in December 1891 by Yoshikawa, vice-president of the Nihon Yusen Kaisha (NYK) - Japan's largest shipping company. Hitherto 
the Foreign Ministry had been fairly circumspect in issuing passports to contract labourers, but now the vice-minister took the view that if labourers were able to make proper arrangements, the government would assist them as best they could.

It was under the auspices of the emigration companies that in the years 1892-1902 a total of about 2,600 Japanese contract labourers were brought to the Queensland canefields; the first group, 50 strong, landing in November 1892. By December 1896, 1,126 had arrived; but by then the attitude of the Queensland Government, initially favourable to Japanese immigration had, under the pressure of public opinion, begun to change. At a conference of premiers in Sydney in March 1896 it was with Queensland's support that resolutions were unanimously passed that each colony 'should extend without delay the provisions of the Chinese Restriction Acts to all coloured labourers'. In the months that followed, however, the Queensland Government adopted an alternative course of action and in March 1897, by means of a special protocol in which the right of either party to regulate the immigration of labourers and artisans was expressly recognised, entered the 1894 AngloJapanese Treaty of Commerce and Navigation.

In April 1897, probably as a result of the establishment of a monthly Australian service by the NYK line with steerage accommodation at half the prevailing price, the tempo of Japanese arrivals at Thursday Island again began to increase, once more in a situation of unemployment. In prompt response to cables from the consul, the Japanese Government in June prohibited the emigration to all parts of Queensland of all labourers or artisans except where a contract with an employer in Australia could be negotiated before embarkation. There were notorious cases in which these restrictions were circumvented by the emigration companies for example, on 16 June, 59 uncontracted immigrants landed at Thursday Island bearing passports made out for the Northern Territory.

A proposal by the Queensland Government for complete cessation of Japanese immigration was rejected, but after prolonged negotiations a settlement was reached in October 1900 in which the Japanese population of Queensland at 31 October 1898 of 3,247 was accepted as a ceiling not to be exceeded. In the months that followed, however, the Japanese made no special exertions to restore their numbers to 3,247. Their total in Queensland at the 1901 census was only 2,269 .

In February 1902, the federal Immigration Restriction Act completely closed Australia to further settlement by Japanese. At that date the Japanese population was 3,593, of whom 90 per cent were in Queensland, the Northern Territory and Western Australia. Thereafter, the only Japanese to enter Australia were a handful of merchants, tourists and students on temporary visas, and contract labourers for the pearling industry. 



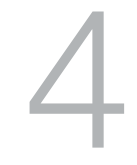

\section{The Japanese in the Australian pearling industry}

Published in Queensland Heritage,

Vol. 3, Issue 10, pp. 9-27, 1979.

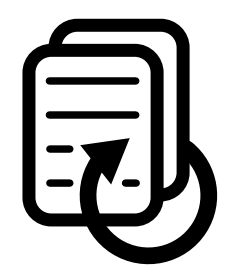




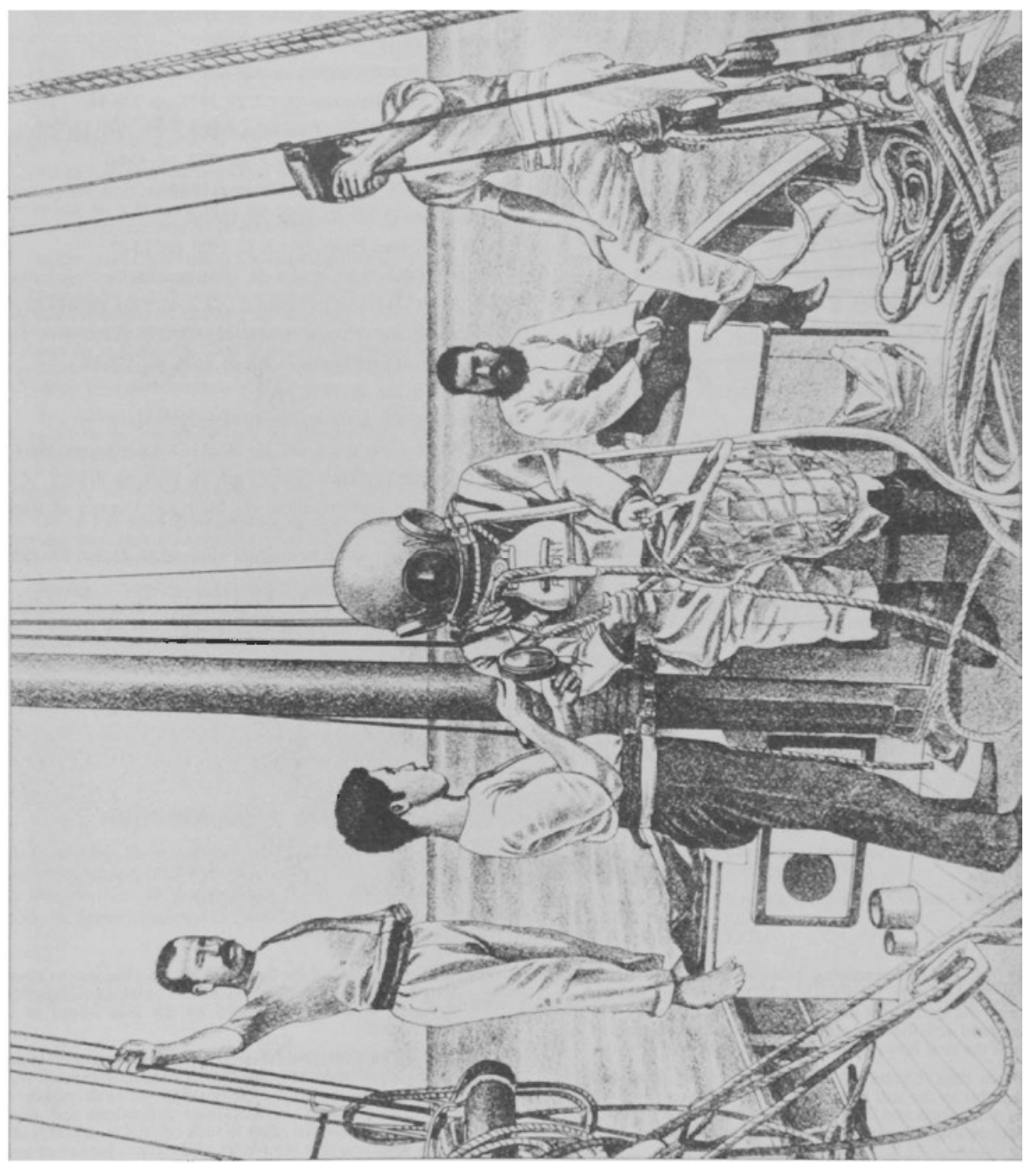

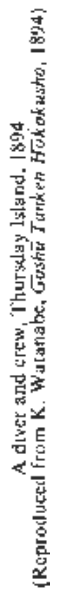




\section{THE JAPANESE IN THE AUSTRALIAN PEARLING INDUSTRY}

by

D. C. S. SISSON'st

The diver and the industry that grew up around him were importanl elcments in the econony of tropical Australia from the late 1860 s iwhen the commercial exploitution of pearl-shell in Australian waters commencedl until the early 1960s when the plasige futton finally ousted it from the enarket. Taking moher of prearl, trochus, and trepang as a singic industry, the value of its production in Australia in any year fron the 18905 onwards was rarely lower than E250 000 and sometimes exceeded $5500000{ }^{1}$ The industry was an exception to the White Auslralia policy. Ithourghout its eqlire life it depended on coloured immigrants for both its skilled and unskilled

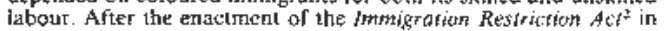
1901 thesc could be introduced in limited numbers by peatlers who were preparsd to enler into a substanlial hond with the Cansmonwealih Government, which was forlcited ir the indentued man absondest.

Japanese began to appear among the luggers' erews in the late 1870s. From early in 1893 they were the largesil national group employed in the indestry at Thursday Island ${ }^{3}$ [n 1908 they achieced the same predominarice at Broomic. In 1913 when the indusiry reactod its peak, there were 1166 Japunese 'indents' at Broome and 574 at Thursday Ialand when the war broke out in 1941 athe Australian pearling industry had aboul 500 indentured Japanese in its employmerst.

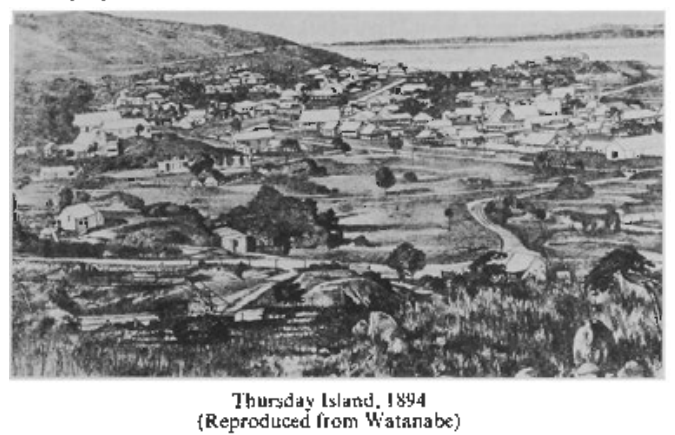

So lis as is known, the forst Japantse to be employed in the Australian pearling indusery was Nonami Kojiro of Hirose in Shimane peefecture.

In 1866 the Japanese Government had lifted the edict that, on pain of death, Corbade Japanese subjects io depart from lfheir nalive land. A proclanation of $23 \mathrm{May}$ of that year authorised the issute of passports to citizens uishing to go overseas for the purpose of study or commerce. The scope of this exemotion was broadened a month bater when the Treaty Powers secured the right for thejr merchant wessels to sigth oth Japatiese as crew at any or the Japantese Trealy
Ports." British edplains made Extunsive use of this privilege Soretimes they did so unistupulously atd took advantage of the Iapa nese rocuits' ignoratce of the English language to hind them to

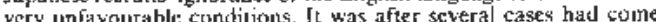
boliore the Mistbourni police cours in which Japanest seamuth,

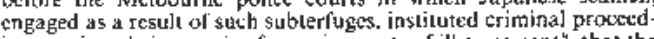
ingk against thcir ceptains for tariols acts of ill-irediment" that the Japabe Government on 4 Novets bes 1879 appointed al Honorar Consul, Alexander wajks in that cily. This was one of the earlies. Japaese consulates in the British Etupire, preceded only by Hong Kong (1873), London (1876), and Singapore (April 1879 ), is

Nonami joined a British mefclentman at Yokohama in this

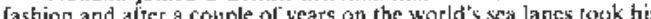
discharge al Sydney. There in 1876, aged about 25 , he signed on as a crewman on a Torres Strait pearling lugger " " It thas just at this time that the first buildings were being erected at Thursday lsland in preparalion for the Iransiter of the port facililies altd administrative controtrom Somersel at the tip of Cape York Penissu] the following jwar.

Initially, pearling in Austualjan waters had been carried out withot the aid of the diving suil using small bopals manned predominanily by South sea islanders. Depths of up to seven or eipht predominanily by south seat islandas. Depths of up to seven or tight were introduced to Torres Strait:" This greally enlarged the pearliat area and called for larger boats that could fertitith at seat independently, for longer periods. For the crevs of these off-shore vessels wallys and Filipinos catne to be pefered. As regards the divers initially ondy Caucasians donned the stibs but they soon trained Pacific lylanders from such plates as Rotumah and the Loyaly Fslands. By the tine of Nomami's ajrival storeral Malays and Filipinos were al kb hoing employed in this role.

Nonami was ambitious and hard-working. Ho leamt to diwe from a Mutay and sown achieved a high feputation as a diver. Durin the ntat lew years scteral other Japanese sailors arrived in sinilar circumbiances and sonk of these tecalne divers. Thes men perlonted so wixll-both as crew and as diwers that the rearler began to recruit Japanese o verseas. First, they appeur to have tapped the shepply of dischatged Japatrese searitn in Hong Kong. The agen of Burns Philp and Company there. Gibb. I ivitugsiont and Company, appeitr to have used boanding-house kepers as "crimps to

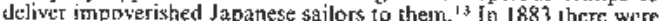
ubout fifteen or sixteen japantsc recruited in Hong Kong to work as pumpers on the Thursday fsland Juggers on eighteet-month

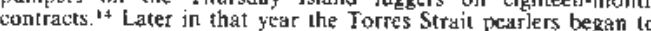
recruit in Japan itgell when at Yokohama on 10 Oelober Capidin J A. Miller is engaged thirty-seven Japanese dsix divers six tenders twenty-four punpers and an interpteter all on two-year eantracts).

The Milles conltacts asc inpottane in the history of Japanest

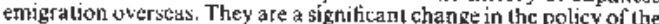
dapanese Gowernmenl, which hitherto had consistenily fefused to approte the emigertion of coniruct labourets to any destination These refusts were pat lly is reflochin of then experience in 1868 and 
1869 when a number ol labourts wete beguiled to Fawaii, Guam. and Culifornia and left standed the ce by unscopulaus foreignes,

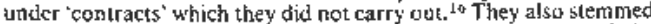
fron Janan's conscious polticy of atopting the standards of the advanced countejes. In accordance with this policy the Japanese Government had in 1872 enacted Iegislation prohibiling tonthacts of serwice tor periods exceding one ycar, on the gound thal such werc Vantamouni to slavery.

The negutiation of the Miller contracts took six manubs, during which period the Japanese provincial and central autboritio subjected them la close sicruliny

Miller"s at pents made their initial approsch. thrount the Britiah consul, to the orefoctaral authoritics it Yokohama. The latter wrole lo the Foretgr Ministry tor guidande, inguiring whet thet the evil custem of siaber obtains in those regions and whether whe unexpected misfortunas may berall Japancest who might go there', ?

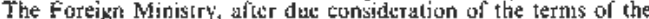
drali contract dran up by the apto selectud by the prefectura govetnment to recruit the labeur, gave its permision. Il justified its decision in the following temis:

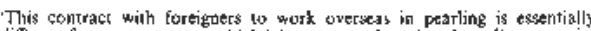
differed from a contrant in. which labourers go abroad to do ordinary mani tasks for Fortigars. Only a small number will be employed and they arc a the

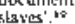

The Foreign Ministry insistod the since Tortes Sugit mas Ea from the wonsulate ( case the employer fated to fultil his obligations. It atso required that the signatures be withessed by the Bitish consul.

In theit contracts, the Australian pear/ers werc accustomed to the provistons required by the Singapore Gibuth ment to saleguatd the wicll-being of its pcople. For example, the employer was to provide medied treatment. The Miller contracts in addition specified the falion scale in wonsiderable detail and made cleas that the mprloyer's liability to provide transport to and foom Australia was not confined to cases whete the contract ex rended for ils full teth; bu extended to cases where the employe was repatriated earlier on thedice] grounds. ${ }^{20}$

The thirty-sewen fapanese arrived al Thurglay ] sland on 14 Nonenber 1883 . The Foreign Minestry was mistaken in its belief tha all of them were experienced seamen. One of the tenders, Masuda Sanjiro, seml home very disparaging remarks aboul some of the pumpers:

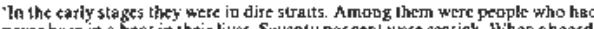

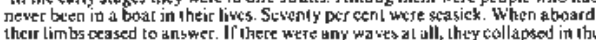

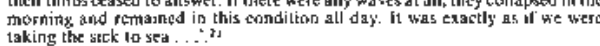

He notes, however, that within a few months, ewen these bad for the gost part setted down satisfactorily. Indeed, the perforimance of these men was sach that Australian pearlers continued to soek labour in Jepan. On I June L8E5 Stroter and Company, the tareses of the Western $A$ ustralian pearlers, recrujted tit Yokohama si $x$ djwers and an inte pre ter on conlracls approved by the Foreion Winistry and the prefectural govermment 21 The tems of these contracts wic similar to the Millar contracts. And unbeknawn to the Forcign Ministry andhet sixty-mine men had been recruiled in Japan for Australien pearlers duting 1884 by fiearom, Low and Company, a Brilish firm i Kobe ${ }^{3}$ Of these, thirty came from Wakayana prefecture. These were the first group of labourers from this prefecture to seck employmas averseas. They began an exodus that contintwed utitil afler World War II. In 1940, according to a survey by the Foreign Ministry, sume 22000 people from this prefecture imore than 2 per cent of its population w were livithg abjoad. 24 They also eslablishod what was to be a perma nent chacacteristic of Japanese enigration to
Australia-the preminems position of Wakayana prefectufe. The tombstomes at Thursday lsland and Brome provide stark evidence of this. Or the 930 cases were the inscription gives, as well as the nanie, the place of birth, 529 ( 5 ; pur oeni) are from Wakaydma. ${ }^{2}$

Ogawa Taira, a lacal historian, has recently established that of those thirly men from Wakayama under contract lo Fearon, Low and Company in 1864 , at least twenty-five came from three villages at the soluthern lip of the prefeclure-Shiononisikj (sewenteen), Kushimoto (seven) Tanami (one) is There is a local oral tradition that link: the departure of these men for Angtralia with Joscph Dick, one of a group ot Scotstien sent out do Japan to traie Japanese lighthouse kepers. The ligh thouse at Kashimosaki, about ejght kilmmelres frart Kushimoto, was built under the superyision of the British chinger, $R$. Brunton, in $1870 .{ }^{27}$ Dick serwed in a number of Japanese lishthonses during the period $1869-79$. It is nol known how long be was at Kahinosikj but he cetrainly was resident thete in $1875,0 n$ was at Kathinosak; but ite cetla 1879 Dick remaincd in Japan. lo the

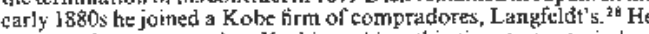
secms to have returned to Kashindsaki at this time to $17 y$ lo induce sane of his cormer servants to sel ug hose for hith in Kobe Following this a number of local youth s wcril to wotk fat foreigners in that city. Some of these were among the thirty who signed the peatling contracts with Fearon, Low and Company. It is reasonabte to suppose that either Dick ot these youths suggested to the lat ter fir that they could obtain addicional rectuits in this district. IL is said that when they werc lold that they would be diving for shcll, the thought that this must be abalone atad took with them the chiscls they
used when diving lor abalous at home. overwhelming proportion of the emigrauts from Wakayana prefec ture un Austra lia continucd to conc from this part of the prelecture the eighty kilaneire sureteh from Shingu to Susami of the firy tarrow sitip of plain between the sea and the mountains. Unless stated to the contrary, all of the cown and village names appearing in this article arc situated there. The prefeture is billy even by Japanese shandards-only 10 per cent of it is arable (compared with the

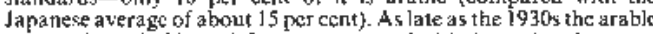
area we household was 1.5 acses, comparad with the national avera of 2.65 acres. About Lwo-thirds of the [aming households had to cngage in not -farmits activities to make a living. Most of thase that emigrated came from villages that engaged joinlly in fishing and farming. Today, thanks to tefrigeration and good access by land to the and osaka matket, fishing thrives throughoul the area- This is a recenl development. Weljl the railway berwen Shing and Wakayamat Cily uas comploted in 1940 , there was no-one io eat the fish but this ecnnomic pressuet there would not have beet emigration. But though it was a necessary condition, it wes not a suflicient condilion There were wholly agricultural villages l'tom which, although their s.andard of lixing was cqualiy low, there was wery litte cmigration. Accordireg to local setholars. the additional fretor was the lraditiona outward-looking attitude of these fisher-folk. Untikc the landsmen who sa w the seat as a barrier, they suw il as a highway. .

Of the sixty-nine men rocruited by tearon, Low and Company in 1884, abou forty-five " were senl lo Thursday lsland and fiecen ${ }^{3}$ to Darwin. [e appears that the prefectural gouernment at Kobe issut the passports wilhowl examiping the contracts. J' certainly did not refer them to the Foreign Mithistry, Aceordingly jo was with some surprise and concern that the latter, lak in Isg4, received a report to the effect that there uere ubout a humdred Japanese at Thurghay Istand. that matny of them had been Iocruited as a resull of crisrepresentations about local conditions and the nature of their duties, and that partly as a result of language dificulties one Jetpancis

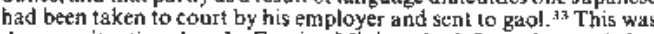
the wery situation that the Foreign Mitistry had, for solong. ITied to prevent-the presence of a large group of Japantese of the lowcr chsses, enfoloyed to perform physical labour for foreigners whose languge and cusioms they could not undesstand. ${ }^{34}$

Poge Tes Quensiand Herrage 
The jurisdetion of the Honorary Consul, Alexander Marks, did not extend beyond the confines of Victoria. The Foretgn Muristry, tegarding the matter as one of some urgency, instrueted him to visit Thursday lsland in bis private capacily. jnyestigate the sil astion there and do what he could to astist any Japancse subjects in necd of protection. At the same time it initianes the fomal procedure to sxiend his jurisdiction fo cower all the Eastern siates. It atse requested the prefectural aythorities al Yokohama to provide it with all arailable information about how the men under contract is Captain Mfiller werc faring.

The situation as is whered from these and subsequent reports was that, with oecasiontal execptions, the men wiese not subjected to cruel treat ment." Captain Miller in particular appears to have gone 10 some troutble to provide egst and other spacially nutritious foud for those ol his men who were sick. 3e But he soon departed lronu the scene. In September I8:s, when hecleased Sydney it command of the barque, Siar of Peace, bound for Torres Strail, he slarted drinking. On 2 Oclober iter boltles of whisky and the best pan of a cuse of gin lateri) he was hoisled askine in a chair at Prince of Wales lsland. Though quite lucid, he was depressed by the erroneous betief that he had mat been to the toilet for len days and by the fear that he had accidentally taken poison. He retired to bed with a pistol under his pillow and, during the night, shot himself. Unforlunately his successer wias often dilatory in paying wages s. $^{3-}$ and seems to haye been by disposition critical and impatient with employees. ${ }^{3 \theta}$

The men on Fearon-Low contracts wiere discributcd among a number or employers "'s Some of these mey an oxdasion, hate driten bard, men whom they considered were malingering."

One grievance that was widespread was the high price of liquor, tobacco, and other items provided at sea from the enployer's 'slopchest. These seem to have been charged at about 50 per cent abowc the prices previlitig ashore." Some entployers also paid wages. not in eash, but by order's on Brisbatte and $\mathbf{S}$ ydney that could be cashed only ut tales of discount that raned from 5 . per cent to 50 per cent.43 It was treatment such as this that cansed Masuda to describe the It Wus lreatment such as this that callsed Misudial to describc the ing to him the Malays were more sucoussful than the Japantese in resisting sulch impositions hecause they had some knowledge of English.

A conkiderable amount of erincism way direcled against Fearon, Low and Company, and somb of the employers to whor they provided labont Acoording to Miths, they resorted to misrepresentation and provided a number of men quite unsuited to the rigours of sea-faring life:

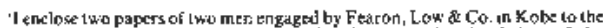
onder of Burres, Filp \& co. whe speculair in men and mate their profil by ledtry the men out lo the pearl shell bisheries. Tt maters not how unsuitable the

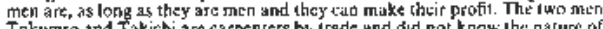

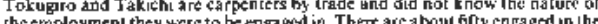

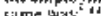

The Fearon-Low contracts appear to have ben wery sketchy and Ltsalisfactory docunaents. They were capable of the interpretation that the wages were die only at the completion of the period specilied in the Articles that is at the end of thrite years (this. int fact, was the

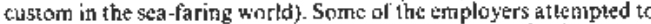
Tuthere 10 this interpretation t5 The contracts contained no pro yisions dealing with sicktess or medical trealment. Solne eftuployers seem to have taken advanage of this to charge tor medieines and, where a Japarcse wes ritpatriated for medical reasons, to deduct fom

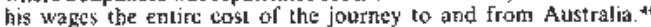
Captain willer as we bayc sten, did wilat he eou]d if any or his men became sick but in the absernere of any hospital or medical practitioner on the island there was not a great deal that he could do. Nishij Isokichi, one of the Feeron-Low men, died in gaol three wecks after he had been convicted of having peasls in his possession (unde the contracts all pearls remained tat property of the cmpluter it il was his retroting sick that originally altracted suspicions; this was regarded as part of a ruse to smuggle the pearls out of the pearling station. ${ }^{27}$ The coroner's findirig wits that his death was due to plearis and could have been prevented if there had been a doclor on the island ${ }^{4 *}$ It was probably this incident that prompted Masuda to write:

"When a man becange ill in wen und appeared unlikedy ro recomer inumediately, he

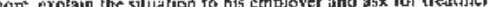

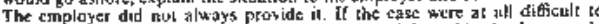

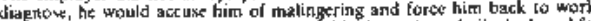

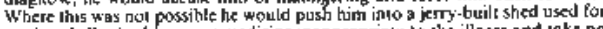

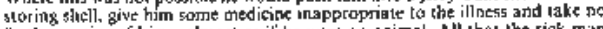

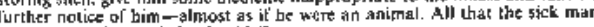

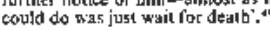

Or the thirty-sewen men under contrat to Captain Mi]ler. about ten ware sent back to Japan sick, befoes the uxpiry of their corltacts

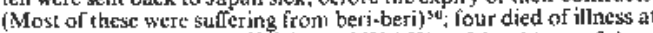
shore-stations at Priace of Wules and Wej-Wer [sland itwo of them from dysentery) and ote died on Thursday Island from alcoholic poisnging.

Of the sixumenine merk seat lo Australia by Fearon, Low and Company in 1884, wis have no information on the number Iopatriater for medica] todsons. The I hursday Island and Wesi A ustralian death registris, howewer, indicale that up to February 1896, in addition to Nishi, thres had died in Torres Strait itwo of heart disease on Fringe of Wales lslartd and one of 'feyer' on. Thargday lyland and IwD on Darwin Jugger pearling of Derby cone ftom measles and one from Darwin Juger perarling

Laty in $15 \% 6$ the Foreign Ministry came to the decision that the sicuatiun on Thursday lst and must not be allowed to continue. On I Febroary it instructed Marks to advise al] Japanese employed in the industry to returin at ouce to Japan except where their contract prevented this " ${ }^{5}$ On 20 March il instructed prefectutal governmers to giwe the full pict ure to any citizens proposing to to thete and if this failed 10 dissuade them, to refer their contracts to the Ministry. This, however, was closing the silabledoor alter the horse had bolied unbcknown to the Foneign Minjsty, Fearon, Low and Compaty ha chespatched anothcr group of about sixty or more during 1885.5

The events of the nexl lwo yeats did nothing lo weaken the wiew of the Foreign Minjsiry that conlfacts for employment in Ausiralia had to be lowked al wery carcfilly and that, for Japanese whrkers life there could be hazardous. Late in 1894 it hat notifed the prefectural authorities at Kobe of reports that ath EDglishman ves recrujting people from the lower walks of infe tu be pul on public display as a Japanese exhibition in Loadon. Enugration lor such a plapose was not southing that the Governmen! would oermil. If anyone accepted such employment the Ministry was io be prompily intermed. Similasly. whereves there werc a large number of applications Ior passports in which the statod purpose of the travel was cduction, commerce or the arts, there was to be carelul scruting lo ensure that this was not a subteriuge.

Despitu these prectations, early in 1856 an Englishoman named Fembirton Willard managed to secure pasporis loj some ror Japunese with whom he touted Auscralia as "The Japanese Village" This comsisted of craltstuen putsuing such iraditional aworations as screctrpainting, wood-carving and the manufacture of doisontewate; acrobats and jugglers; and watrcses who served Japantestca to the andience. Willard appears to have hood winked the Japaneso authorities by dividing the company into small oceupational groups, drawing up sepatate contracts for each, and distributim the applications for passports between two porls, Yokohama and Kobe, and over a period of some weks.

As a theatrieal peffornathe 'The Japanese village' appears to have been a tonsiderable sucoss. It remained in Austialia for fifteen moths and performed in each capinal except Perth. "I su season in 


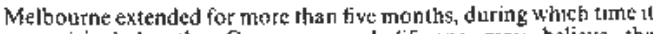
was visiled by the Governor, and (if one may believe the advertisement by upuards of 317000 people. Willand was no purist and by the tirme it reached Brjstane for its fortnight's season in the Exhibition Building it had also acquired hali-in-dozen performing dogn and a small elephant. The Bribome Cosider was much intpressed by lie "wery chaming Japanese lady, who plays a musical instrumen in the form of a banjo and oceasionally with considerable amiabilit sings in the soft, monotonuts minor key common to the singers of the

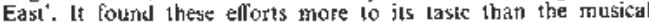
interiudes proyded by a local band among whose perlotthers there

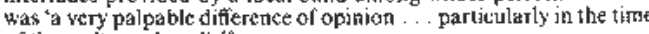
of the waltere played'.

Benteth the surlace, howeret, all was not well. Its arrival in Australia had called forth a series of despatches from Warks in which he was wery crilical of the conilracts. He considered the wages ifn example $\$ 15$ month for the makers of clotsonne-4rare lar tor low in terms of losal prices (jincluding the price of foreign luxuries to which nembers of the company were exposed so This hid mitle the Japanese very disconiented. if could also bring down on Iapan the bosijlity of argariscd laboltr throughout Australia. Murks ulso considered that Willard was indifleren towards the healih and wetfare of his moldeyes. In the Welpoume wister they had threalemed desertion unless they were provided with more blankels. (Two of theis mitmbers had died of consumption soon ater their atrival in Auscratia) 60

In Japan: Willard's wencure appears to bave had two kun-

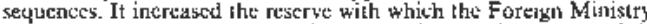
regarded Australia as a suitable place for employnent and it provided the basis of the leyend of a motholith in Tasmania bearist the hiragare inseription 'Kashiu 2eniya goned riyouchi' (this is the

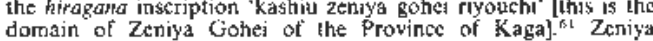
(1773.1852) appeats to have been the Reg Ansett of Japan in the werly ninereenth century. He went into the matine Iransport indusiry in I8I! and is sidid Is have establislted thist -four buaches throughout Japas. He 4 as also an early wiction of the anti

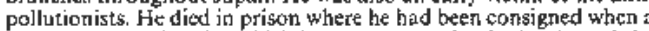
reclamelion project for sitheh he was contracling hidd poisoned the fishes. It sems wery likely that Zeniya's acliwities extended as ta south as the Philippines The story of his annexation of Tasmatia howrwer, appears to have originated with Willand's accobats. ${ }^{2}$ M theory is that on theif journey from Melbourne to Hobart some of them werc routed thiougl Dewomporl and were shoun the petrogly'ph on Mersey Blufi. A3 At that time many Japanese acrobats wer illiterate. To such the Aboriginal rock carijngs maj well bave secrembled hirctuma.

On 7 April 1887 a Tokyo daily, the Chơ Shmbum, published a

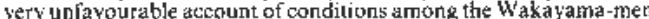

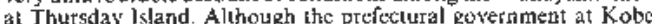
folut that it was a garbled version of exagutated complaints found that it was a garbled wersion of exaggtated complants
circulated by one of the Fearan-Low men who had relurthed to Japas more than eighteen months prcwiously, the Minisiter fot Foreign Afrairs himbeli of 1 july used it as an opportunity lo isste a privalo instruction to the Governor or hisarama prelocuere that whentier snmernte applied for a passport to go to Thursday Island eqery effor should be made to discourage him."

The Foreign Ministry's apprebengions about Australia had rucently been stengthened by the arrival in Tokyo ar seports of the morder of fout Japanese on 22 February 1887 aboard the luger Gomerook off banks Istand whitn the cook a Malay, ran anok with a hatchel Two of the deceased Kasuy Chósuke and Maruyana lwakichi both from Shionamisaki) we from the sixty-thine rectuited by Foaron, Low and Company in 1884 . The oltes [ro Akimo10 Churabura (Ehime prefecture) and Kawasaki Kösuke (Osaka prefect lart), were from the group ol similar siat provided by the some company is February 10s5. The Foreign Ministry,

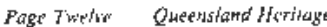

accordingly in the press retense that it issued on the incident 11 y Sepuember $188 \mathrm{~g})$, drew altention to the fact that all four of the dead meth had becn recruiled by Fearon. Los' and Company, and in the

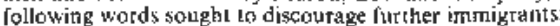

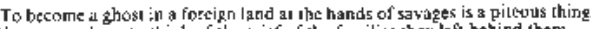

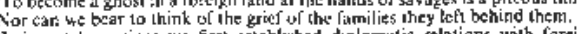

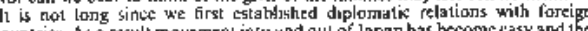

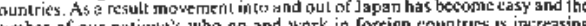

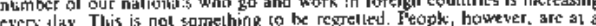

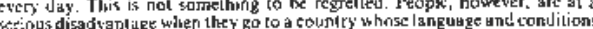

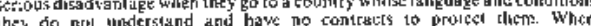

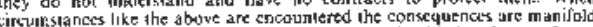

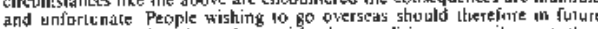

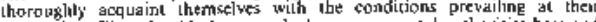

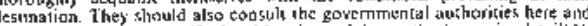

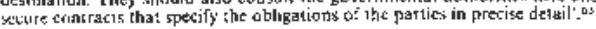

It was probably becuse of the Foreign Ministry's atritude that the numbers of Japanewe in Torres Sttail felt rtom about 200 in $186^{\circ}$ [o about 170 or 180 at the end of 1890 , "No peating conls acts appear to have been signed in Japar durine this period for inded [or

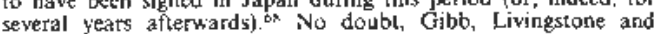
several yeats afteriards. No doubl, Gibb, Livingstone ano Hong Kong. There is also cidence that pearlers operating off the Weslero Australian coant recruited some Japanese al Singaphra this ime whether they uere seamen bocally dischatged or witether ther were brough! from Japan wie do nol know. The later, however, strms the more lithely. Certainly, in later years, most of the Japanese amployed in the industy in Westert Auslealis wiers siged on in Simgapore and wene from Japan to Singapore for that purpose.

With few exceptons, the men who relunted wite obwous proof of the considerable saving that could be amassed out of wages. Masuda in 1 \$ 86 reported from Thursday Island inat when Nonam returned to Japan Eor a visil the previous year he had several thousand yen to his name. Late in 1 ds two Fearon-Low men. Miyanoshitil Kyuemon and Ogawa Ryizō, reternad to Wathayama prefecture at the comptelion of cheir contracts with about $f 40$ prefecture at the comptetion of heir contrats with atoul 4400

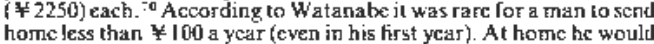
have on med aboul $¥ 40$ a yoar and out or this have had co buy food 3 Ewen the reports of the men who were Iepatriated sick were favourable. There was as much rice and olther free rations as the could cal and, lor those who did not drink, it was easy to save "7 $A$ riec diet was what all Japanesc aspired to. In the vilages in Wakayama where the emigrants cajie from il was a luxury reserved for the sick-the staple diet was the cheaper barley and sweet polalus ${ }^{73}$ At Whaseki today, rormer divers remember how belore they went to Thursday lsland in the $1920 \mathrm{~s}$, they had waten unadulterated rice only al the time of the annual bon lestiwal. For the

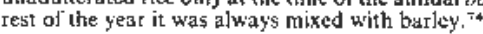

It is unlike/y that Marks was able to prewil on many of the Japarese alfeady at Thatsday lsland io recurn home. The proportion who were houfd by contract to rimain probubly exceded 50 per cent. But, both for those who had come under cont ract and those whth had conce independenuly, there wis litile reason to be much infiuetned by the Foreign Winistry's wishes-paticularly as il was nol offering lo repatriale then at Government expense. They wece on the spol and kncw better than anyone else whither it was to their findacial advantage to stay or to return. We know that some of the Fearon-Low men remained al Thurstay ls] and at the end of thei engagentent5. ${ }^{7 \$}$

In l\&chl only tweliwe Japanese arrived at Thursday Island. In I892 and 1893 the figures were 100 and 264 respoctivery almosh all of then from Wakayama prefocture. is The following appeas to have been among the factors that contributed to festoring and expanding this fow: 
The firs was the debising of local machinery to fimance the passage now that the Foreign Ministry had clused the door on contracis in which this was providet by the Austra liaticmployet. The cosit of a single passage to Thursday I sland for a Japanese labourer a

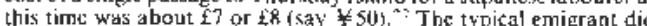
not have sufficient sccuricy to rase a personal ban of such propertions.

It was found, howcver that in recturn ligr a lien on their wapes, the more substantial eitizens were prepated to advande the neceisary funds to a group of ten or more going jointly from their willatg prowided that the eroup accepted joint respunsibility for the debt." Writing at the end of 1893 , Wetatabe claims that most of the 30 o Wrakayama men at Thursdoy Istand had gone there as menterk nf

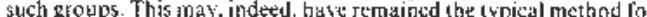
Wakayana men to join the ptarling industry until the Japanese emugration companes enered this lield in about $1897^{-n}$ The amoun adranced was usually abour equal to $¥ \mathrm{i}$ to $¥ 130$ a metriber. Witl this they were fiest required to take our lile insutance for the perirod ol

\section{TO DIVERS}

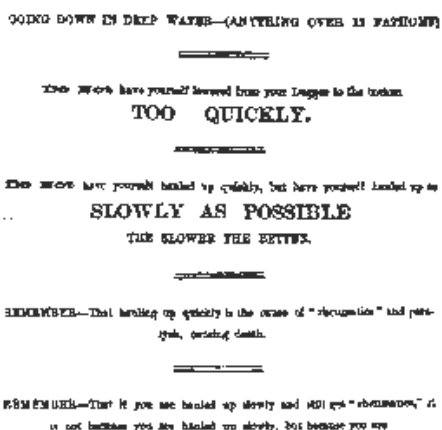

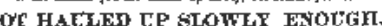

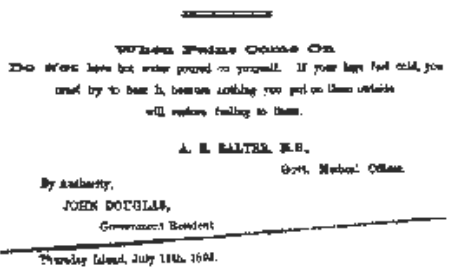

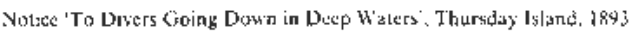

the loan. This was a prudent precaution on the pare of the louder, for pearl diving had troently hecome a dangerous task. Al the time of Captain willer's coneracts it was nor. Pearlune in llorres Strait was

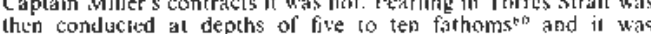

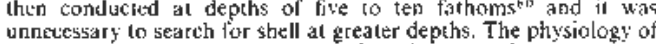

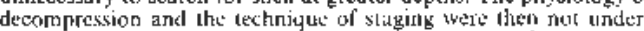
stonet; but from later regezreh wre know that al depth of lest than six

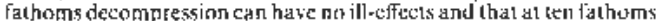
no stigine is required if the duration of the dive does not crocel twenly minules. "Similasly in western Anstralid, so long as the

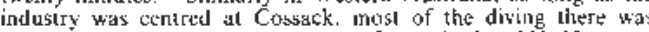
conducied in relatively shallow wulw, it wits in the 1888 so seasun

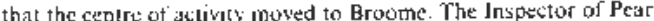

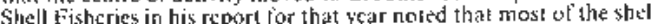
was obtained at depth ol I westy lo lwerty-fist fachoms and that the derp diving had produced a number of dealth. ${ }^{\text {s. }}$ The first recorded derth from diver's paralysis of a Japanese employed in the A ustrahat

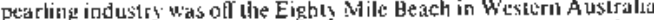
on 26 . Ausust 1890.5 By September of the following year there

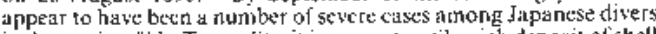

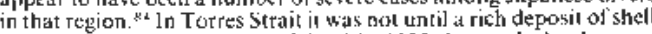
was discovered ncar Darney inland in 1893 that such dephs were worked. The resule was that hienty dibers died these within a jear anong them five Japanese. "s

To return to the collective loans in wakasama willages Mfler the Puren of the insurathe premiums the remaindat of the lotin usa

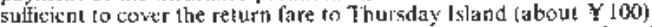
the purchase of whathing and kit for the joutncy. and hoard and

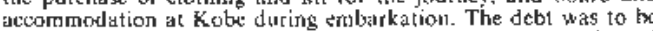

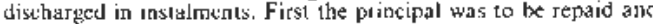

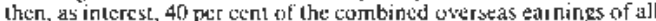
members of the group (ineluding the insurytece moncy of any who hat died after deducting the principal. Althotath the collective responsibility of the whole greup made the posinon of the lender relatibely secure, the rate ol inferest, ths Walanabe obserwed at the

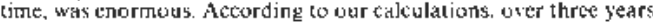
(the nurmal periad for such agrumentsh it wotd provided

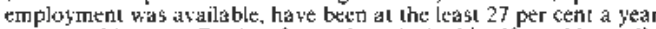
compuond inceres. Bus insoles as the principal itself would usually

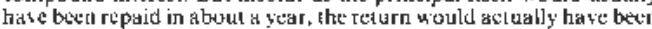

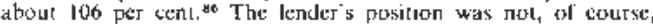

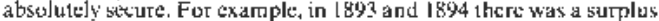
ol labour at Thursaly Jistind as a Jesuli of which the waes of crew'men licl] by 50 per cent (liom 13 lo 30 s a montli) and thete were mote than lon Japathese (maty ol them reced arrizals) onem. p]oytod.

A second faclor concributing to the increase in the number of Japanese goitng to Thureday island may have been the adoplion by

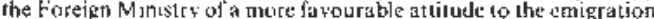

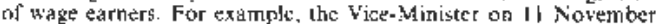
1891 isformed Harks that

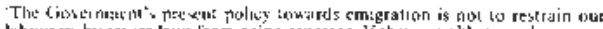

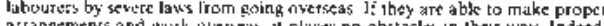

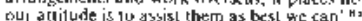

This mer hate been in bart the result of the appoirlment as Forripr Minisier of Enomoto Takedk, who later fnunded the Shokwh

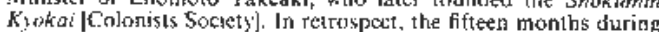
whis he held that portiolio appersts to be the obly puriud when a Japanese cabines showed any positive enthusiasin lor emirralion.

A third ractor wis the relum to Japan eagly in 189] of the ten

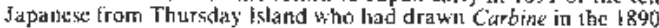

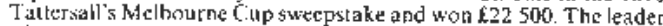
of [he group, Nakagawa Tamiji. of "Tomoly Japut", served the locil Japantse community ili a number of roles-ds boardieg-housc keeper, proprietion of a billieds salnon athd shontine gallery, cour interpreter and. whin uxestion demanded it, as undertaker. Born in

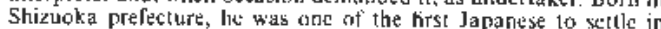
Ausiralia. He probably came to Sydnty as one of the etew of an

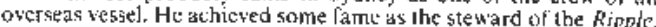
an wand uxding wessel based iu Sydney, whell she was attacked by natives ncar Cape de Gos on Bubgamijle in Augus I 800 . Accosding to the report of the incidenl given to the Stade't Horring

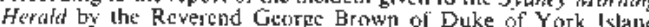
where the surviwors and the bodies of those kilted were anded Nitragawa performed most credilably

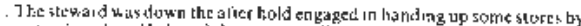

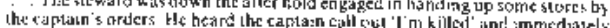




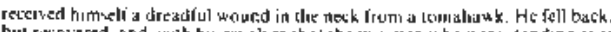

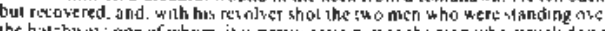

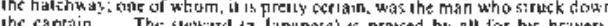

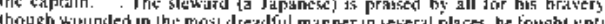

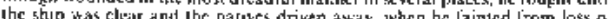

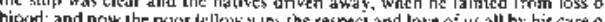

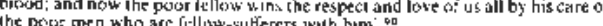

He mowed 10 Thursday Island the follow mo year." There, il thems, the lighling spich of the he ro of the Rrote 50 metimes reasserted itsect. He must hist celebrited Christmas 18 st wo will tor he spent Christmas Sight in the watch-house and was fired 5 s the next

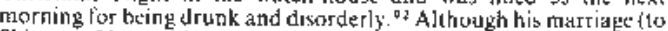
Shime, a sagasakj worman, in 1885 ) wis the first in the Japanese connmunity to bs: solemnized in the Roman Catholic Chutch this did nol prebeol him and his pariners in the Corbin' synd toale from marking their departure with a donatuon to the Anglican cathedral building fund that exeeded thuse al the Gowetnor, the Bishop, and the Goversment Residequt combined ou

It was, homprer, thesexpedilute of these men back in japan that influenced Japiddese jombratuon to Australia. At least rour of them are still remenhered in Wakryama prelecturét: Hiramalsu Ciomobei and Lisia Iin'emos lrom Shionomisuki, Ebina Torakichi feor

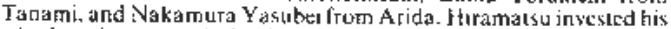
winnimgs in mosntaig ]and. Heconcinted lo prosper and bectume kthown ab the forest kink ol the Kinat distriet. His eldest soth an idler who liked expensive plepsures, squandercd the low, Ćrila put his money unu at bodt for deep-sco luna fishreg. He also rebuil his home

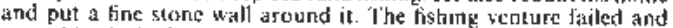
ewery ihing he had was sold. The house is gone and only the stone atall

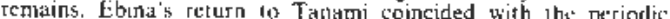
rebulding of the belfry of the lacal te mples. He donatud half the cost.

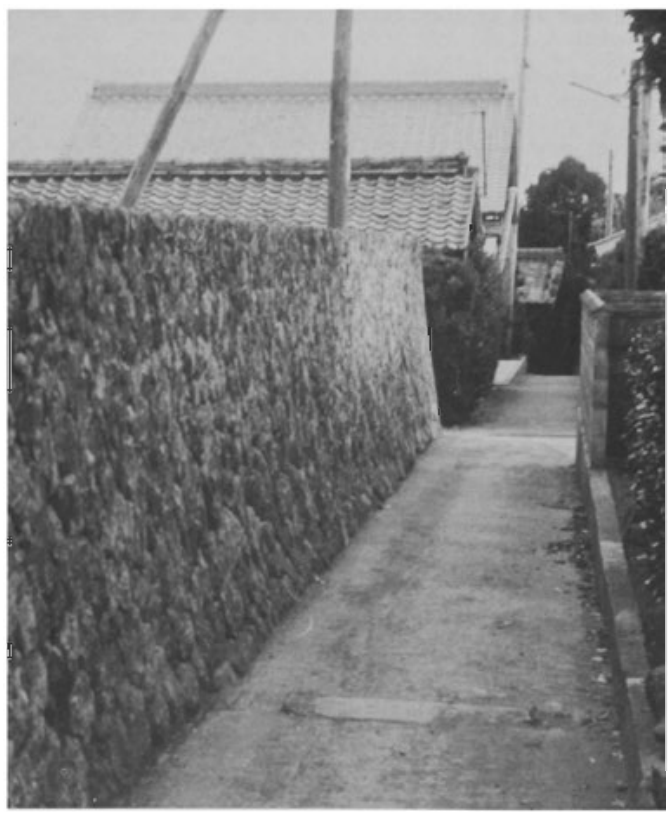

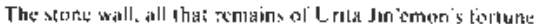

Prese fordierm

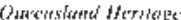

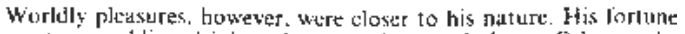

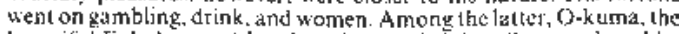
beauliful Fukuhara acister whom he marrited is stull remembered by

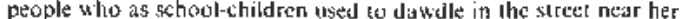
house boping lo calch a glimpse of her when sht came oul.

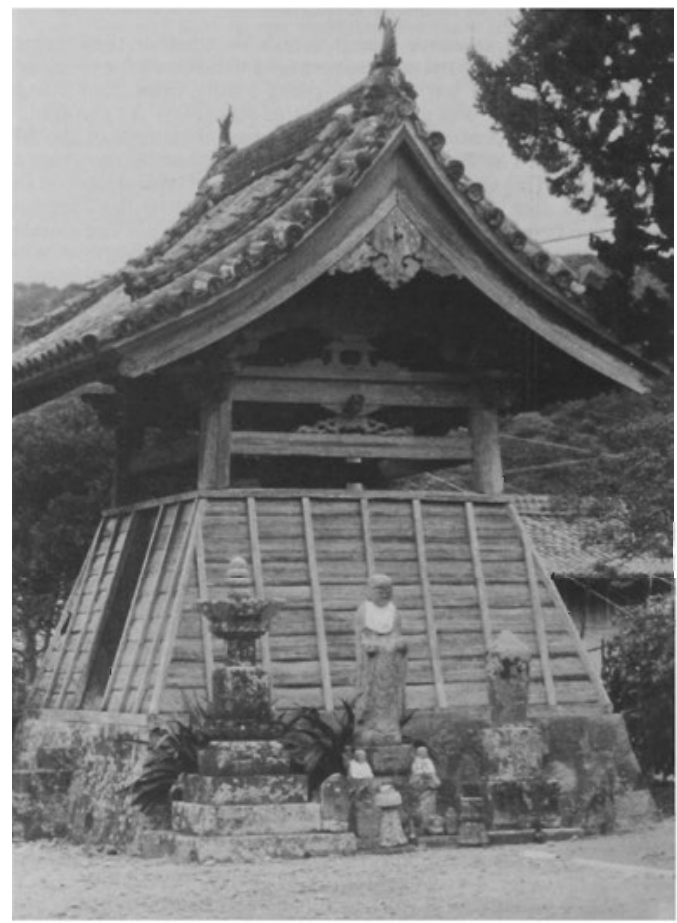

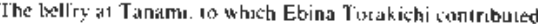

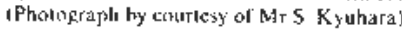

In 1954 I came atros; a Japanese. Suruki Sakuhej, who was workinges as the cistaker of a flour-mill at Burnley in Melbourge. $\mathrm{He}$

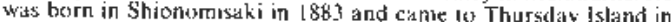

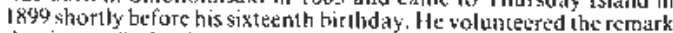

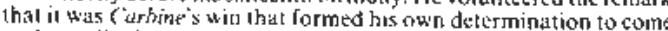
fo Austratia it ures he who litst gave de Hiramatsu s name. He hat

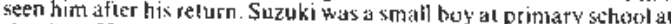

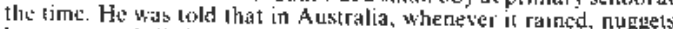
lay uncotered al along the river-banks. One of the Corbine sujticato in a mighthouritng village was sid to be sowealthy that he used to fill

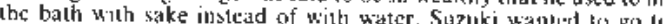
Aush talia there and then, hut bis mother mede hitri with unlil he had Pisistad sclioul w

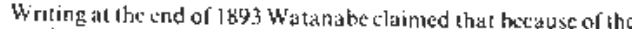

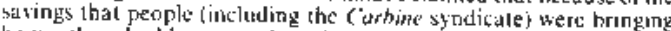
home. iheete liad been a rush In Australia from the prelesture:

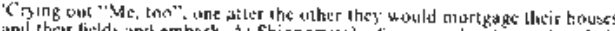

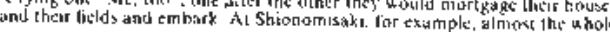




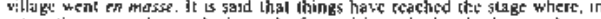

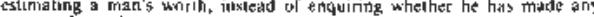

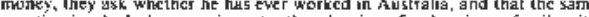

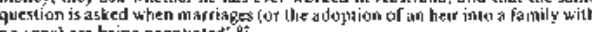
no soms) are be ing meprotheledi of

It these circumstances the Japanes population at Thursday

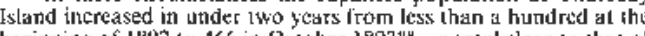
begining of 1892 to 466 in Otober $1899^{4+4}$ a total close io that of the Catcasian population (475). Orer the same periad the number of lupers owned by apanese had increased from two to aboul thirly When Walanabe wisited Thursday lsand in Septenber and Oelober 1897 this had produced the Tollowing atmosphere

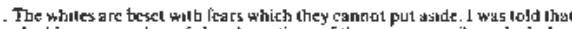

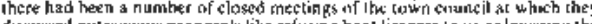

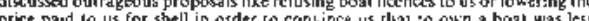

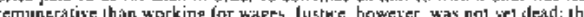
remune lo ve the

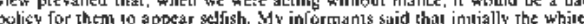

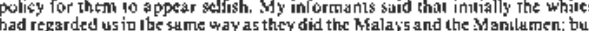

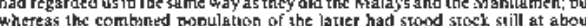

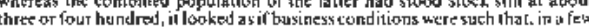
years time, the Japariesc, under che same circurnstances, would $d$ fHe ahead of

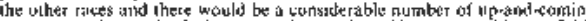

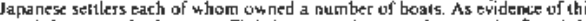

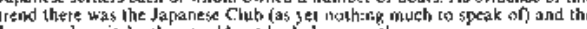
Japanese haspicit- lhey could not lool down on these.

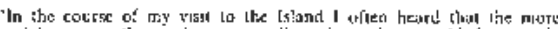

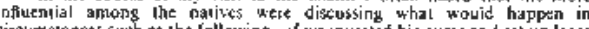

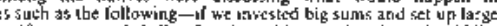

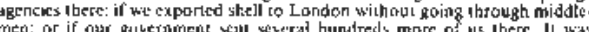

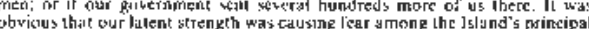
merchants and ahopkerpers.

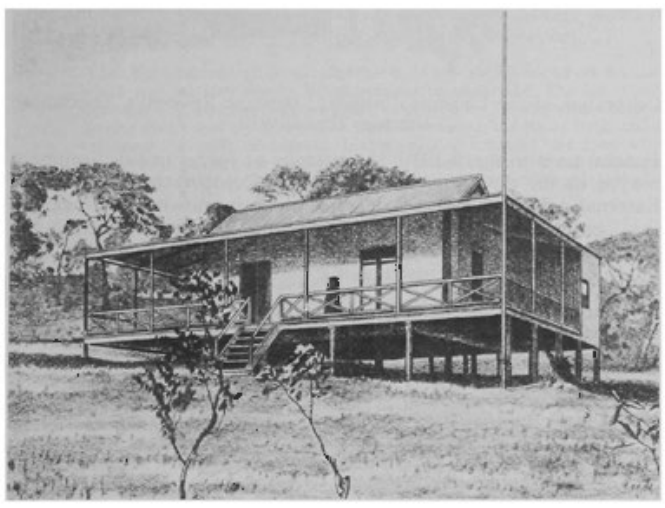

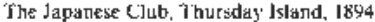

iRcproduced from Wialanabs]

That offiatalorm was at this time becoming concerned at the Japdnese presence on the istand is curfirtmed in at lelles despatched by lac local magiserate, John Douglas to the Colonial Secrelary on 2 October 1893. Douglas reporied that there was more than a possibility of the Japanese coming down in such numbers as ro render il probable that the Pearl Shelling indusiry will to a greal cxtent pass into cheir hands'. 10. On I! November he wote again:

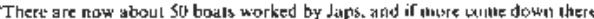

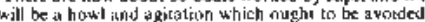

I am mosl decidedly of Ihe opurion that all boals in this Fishery should to owhed by Gritish swejects and thas no boste excrpt thase belonging to Estish subjoc ts should be lecensed'. '.
Aculin on Douglas's advice, ate Premier, Sir Hugh Nelson, on 21 Nowmber through the Honorary Consul rectuested the Japanes Gouemment lo imil the number of emigrants. ${ }^{102}$ The flow, hawe wer. continued Is Wach 1894 the number of Japanese on Thursay lisland had risen io 720 and, as we have al ruady observed, this incrcase had been atlended by exretsiwe unemployracil and a sharp lall in wage rates. 102 This fgure dacs nut appear to have butn exceded until 1897. Mote than 100 of the unemployed Japanese mowed to the mainland in search of work during 1894 and there wiere fow ncw

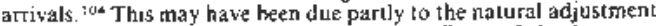
of supply to demand 105 and party to itwe efforls of the Japa nese Foreign Minislry which in July isg4 issued fustuctions to the Governors of Hyogo and Wakayama prefoctites to resirain emigralion to Thursiay Islatid. or

Conflicting cridence makes il parlicularly dificult to form an ucuratc utimate of the extert of boal ownership by the Japanest Thow: who feand ils consequestos terdtod to overest imale its exlent. Similarly, the largest of the Australiafy pearlers. Janes Clask, appears to hawe produced inflated figures jil order to support his counter ateucks against the shors-based pearlets uho cifculated petitions

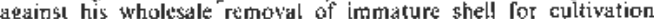
purposes. His areument was that the opposition to him sias organised purposes. His argument was that the opposition to him trias organised

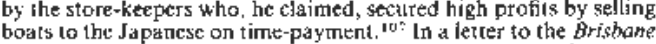
Cours on 17 Nowember 1893 Clurk usertud that the Japanese owned 'sixly-scren boats, which number they are constantly atditig

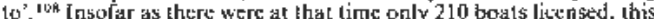

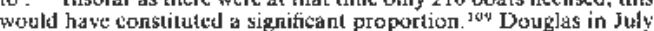
1855 condueted an investigation and, as a risult, atas inelined to acetept a consideratyly lowe figure: cight owned and lwenly-mine hired by Japanescin (ouk of a tolal of 183 boats licensed). The twenty-ninc tubld have intluded some in prosess of beirg bought uthder hire-purchose asrcemenls. Naturally the lapanese ekercised their options to purshase, only when the boat perrormed well. Clark claimed that the Japanese purchased about one in eight of the boals that they hired. 12 In March 1897 the Quens]and Government appointed the Hamilan Commission lo inquire inlo the operation of the pearling lecislation. The cridence presented to it ind tesend that the Japarese population had rutahed rough.] loon and that of the 231 pearling boats licensed, twenty-iwo were owned by and fotty-six

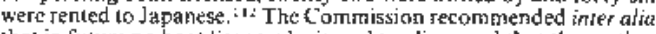
that in future no boat licertoes be jssued to aliens and that the stonting

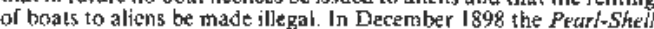

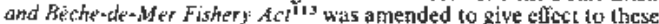
I wo recommendations. No attempt as ande to disulise the race that the legiclation was aimed a the Japancse. It wis cotimon knowledge that Ministerial discretion would be exercised both to grant na iuralisation to Europun aliuns seukin: to pace themsel wes outside the ambit of the restrittions and, as in the pest, to withlols naturalisation from Asigns." It In the course of his Second Readim spech the Fremier quoted with approwal a sentence from Clark's widence to the Commission: "this is is British Colony, and ] think the protits made should belone to while men iostuad ol the Japanese', 113 4. Opposition speakcr, William Kidston, alcscribed the spirit of the legislation in less fattering terms:

14 15 the recotratian ... that there are and there grught $10 \mathrm{~b}$ be lwo tares in

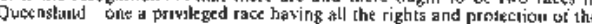

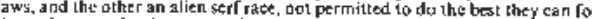

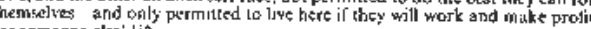
or someone else' 1 :

The Japanese lad opened a tegular consulate in Townswille in March Is96. In tesponge to the advior of the consul that, anless the for of emigrants diminushed, the Queenslatid Government in the atmosphere gererated by the procedings of the Hareilion Commission was hikely to introduce an intriferation testriction bili, the lapante Government issued ithst rucinoms to prefectural gowernment

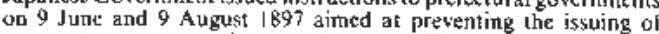

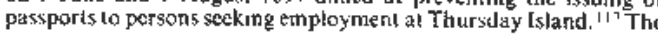


intenion was that these rescrictions should be temporary; but in fact this troucd to be the end of unrestricted strigraljon to Thursday Island. In August 1898 the Quensland Government adopted the policy of perinting the cintry of Japanese labourers and artisans. only when their employmint had in each case rectived the pritot approval of the Qucensland Goternment 1 i initially the Quechilath Government ased this power to rejoct al applications to irmport Iapanese babour liom all pearless botb Caucssian athd Japanesc alike ewen for keeping the crews of already licensed boats up in strength. "W The Caucasiass the the siluation by making greeter use of other coloured races. I" The Japanese, hourever, appear always to have been reluctant is enploy any but their ond countrymen. This Firtual prohibiuon on the necruilruent of Japanesc labour a prears to have contitined unti] 30 Qutober 1900 when, wndcr ststained pressure frotn the Jipanese Government, Queensland agred lo aceept the Japates poptalion in 1898 (324T) as a coling ug 10 which teplacements solld be mads-provided that no more that twentyfive arrived on the onc ship 121 Even under the nuw aproment howewer. the Quechland Governmenl appeses to hate approwed requests to introduce Japanese crewnen only when they were made by Caucisian pearters.

This polich on the part of the Queenstend Goyernment appeat It have beter steocesful in reducing Japinese inflence in the local industry. Belween 18.98 and I901, while the number of lioensed boats

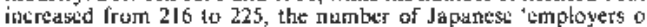

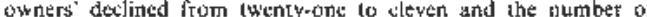
Japanese crew on shipping a tricles declined from 472 10 $3 / 3$. Lit lt was during this period that the only man ol capital among the Japancse communily, Sato Torajio, became insolvent and returned to Japat permantenuly. In March $] 900$ when his petilion was filed he was the whner of twency-nine luggers, and the lessee of a genetal store, a boatbuilding yard and slipway, and tive boarding-houses for pearling crebs. It the affidarils acrompanying his pelilion, be gave as the calses of his insolvency 'inability' to collect book debls, fal]ing oft in she]l returns consequent on bad seasons, pressute of credilors'. The book debts, which amounted to 113 659 were estima ted to produce only f3517.2s.6d 124 in may weth be thal an significant proportion of the bad debis due to him were the result of the effect of the Ouenslend Goverthment's policy on the level of business antivity among the Japances communily, Sato keturaed to Japan in 1901. Furm 1903 lo 1909 he was a member of the Japanese House of Reprosentatives. In 1910, following the Japanzes annexistion of Kored, he tanslerfed his eqnergies 10 agriculture in that county and acquired latge estates there fie died in 1928 as a resuli of injurics sustained fiom a bomb attack by a Kortan mationalist who mistook. him for the Goremor-Greneral

Followint Federation, the control of immipretiots Was ish 1902

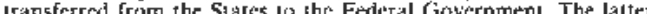
Inok the number of coloured persons then employed in the inddistry and allowed replatements up to that lewel. Within these hinits no restrica ions were placed on particular nationalities initially, its policy was to grant addilional permils lor crews for any new boats added to the pearline flests. In Noweraber 1905, however, when the Senate

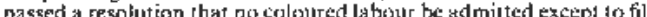
existing vacagcies, this dispensation was disconlunted, 125 This fixed the maximum number of eloured persons for tumporary udmision 40 serwe on furgers at about 4000 lior the Cormon utealth as a whole of whom about 2500 were al Broone. 120 There. oher the period 1909 to 1910 , the proportion of Japanese rose from $32.6 \mathrm{pcr}$ cent to $\$ 1.3$ per cent. $1^{n}$ A t Thursday lstand, in the later year the proportion of Japanese was 55.3 per cent and, or the Ifil licensed divers there, 150 were Japantese se Since the time of the Hamilton Commiscion, the belier that the peasling industry should not be an exception to the While Australia Palicy had exlended considerably beyond the membership of the Labor Parly and the trade ubions. This betiel

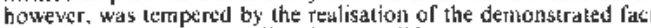
that life aboded the perarling lugerers did not attract Australian workers, When Labor waured its first long term of ulfice at the

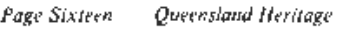

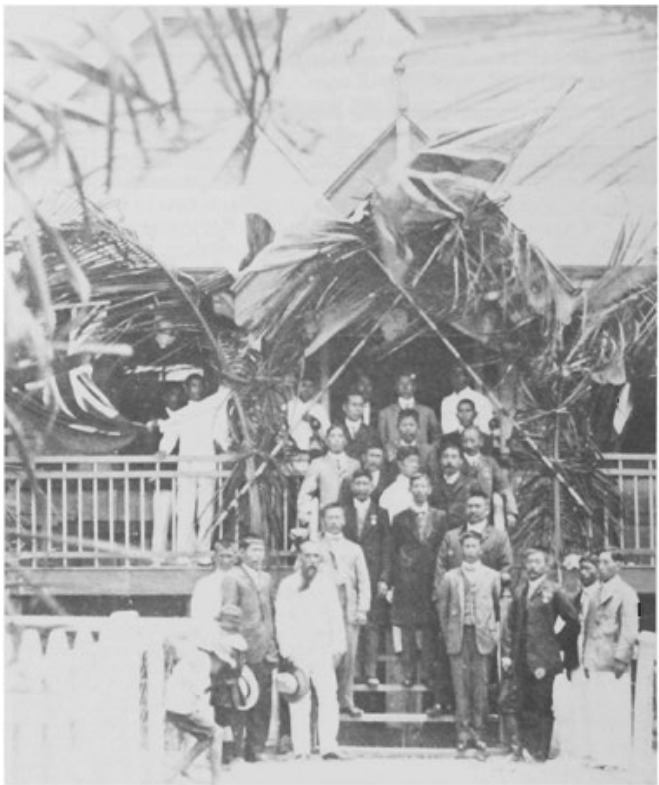

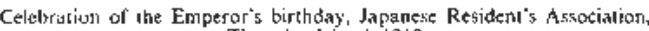
Thurtay Island, 1910

Fiederal lewel in April 1910, the balanos of forces in this argoment moved in the direction of iteology. In Ostober the Minister for Exlereq Affairs, Egerton Batchelor, made it knorwn to the pearlers that unless they took stcps to integdues white labour into the industry, the Government would take action. ${ }^{19}$ On 2 Janbary ly] be issued the following instrutiogs:

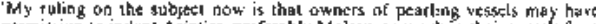

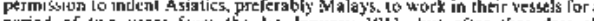

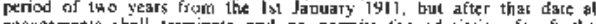

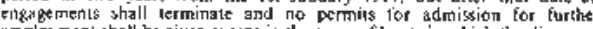
emplay menl shall be given except in the cases of baals it which the diwer and

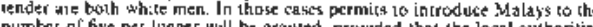
number a the per lugger will be grintedd. provided that the local aulhoritic

The two references to Malays in this passage indicate that the Minister. like many peopte in the community. was concectied with the rise in the proporacn of Jaganese to olher colouted indtents and that te wished to do somthing aboul it. Indoed, he appears to have been quite frank about this in his remarks to the perrlers in Ortober. ${ }^{3} 1$ I April Cabinet, as a result or representations by the industry and by the Wicstern A Ustralian Govermment, deferced the int roduction of the new systetn tuntil 3] December 1913.192 In Jume 1912, it was further deferred unti] I January 1915.13

In July 1913 the federal Royal Commission on the Pearl-Shelline Industry (the Bamford Commission, aptoitited by the Government In 19121 strengthened the Governiten 's hand bu pascing a resolution "that the special altention of the Depariment of Extertha] Alfarc be diawin to the question of the prepondetance of Japantese in the Pearling landusus'. . , with a wisw of laking into consideration the possibjlity of pretenting ang race preponderaling in the Industry", 13 a 
Although al the elections ith May a conserkalive government had achieved office, the re was no reversal of policy on this issue. The Department of External Affuirs used the Royal Conmission's reschlution as an apportunity to inquire of the Wiest Australian Pearlers Assuciacion their allitude on the question of arranging for a

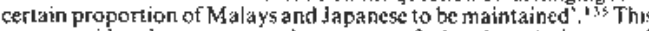
was considered at a geteral meenng of the Associanion on September and a motion was catried in fiavur of "meting the wishes of the Federal Govermment in connection with the sibstituation of more Malays for Japanese . " $\$ 36$ From the detailed report of the meting given in the daijy press at is appatent that the morion was supported even by pearlers who used wholly lapanest orews. Thej mote itrithednate worty was that thejr livelihoud depended on their continuous recruitmen of crews ancrses. The methanics of the industry requited this to be done on three-yesr contracts. with the enbatgo on the employment of colouted divers and tenders beyond 1 Jamuary 1915 . they had been uniabe to rocuil for sume monihs pas! Thej primary need was therefore to bcure a furber deferment of thi deadlime. They urgued that there has no hope of the Government

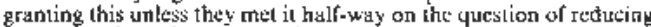

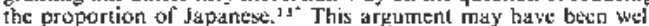
based the following June (1914) the alcalline was mowed to 30 Jume 1918, therebs enabling the purlets to continue unil 30 June 1915 to enter into their customary threc-ycas agrecments. In February ISIS pone of the lactors that jufuenced the Foderal Government it allowing James Clark (who since 1905 hed conducted all his pearling

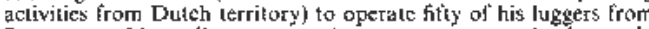
Broome was his readiness to enter into an engage ment that he would "nol emptoy more than fifty per tent erest of any' one nationality

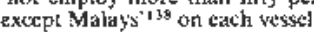

The entire policy of while labour for the pearling industery was abundond duriog the lask weeks of the Labor Cabinel when the

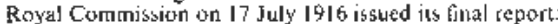

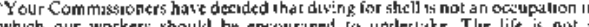

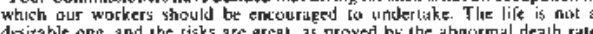
desirabite ont, and the riiks are grtal, as groved by the abnormal death rale

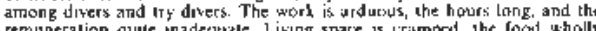

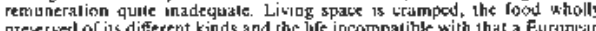

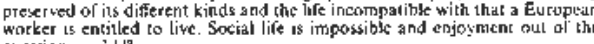
gutsition

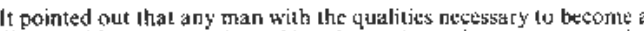

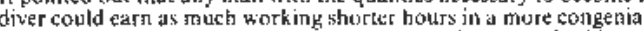
atmosphere ainore. Aocording] $\mathrm{y}$, there was no incentue lor hith $t$ enter an ocendation in which he would in at lew years become

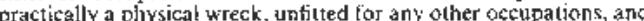
unlass more than ordinajly fortunate, likely to bocome a hurden undws more than ordinasly fortunate, likely to bocome a hurden rajeced the aralogy of the sugar indusliy. These Aastralia had boen able to replace colouted Jabour with Caucesian labour by passing on to the A ustrabat consumer ia the form of higher prices thí additional costs entuiled th the higher water that had to be puid. Suyar, lyourever

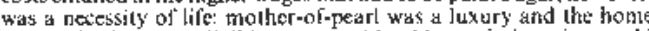
market for it was negligible; any considerable sise in is price would restlt in its being replaced by substilutes:

Alihough the Commission did not elaborale ot this point, the additionil cost was oteater than the mere dithence in the low the mares that would hove wo paid. The evidence presented to the Commiscion indicatul that the anoul death-ratle amone the Japathese divers at that tirat was more llaa ten per cent. ${ }^{42}$ Had these men beet

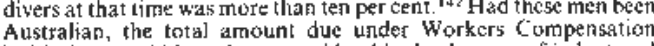
lecistation would have been considerabte. In the tust of indentlered loreign labute, however, such compensation was nol payable. ${ }^{\text {t- }}$

Ont reson for the Commission's uthequirocal abandonment a the while diver objective was evidence presented 10 it durjng its 1916

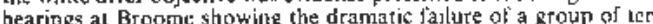
divers recruited in the United Kingdan by some of the Brome

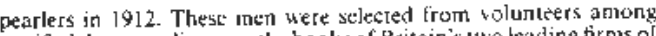

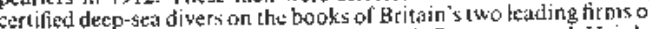
submatine coginars. Sicbe, Guman and Company and Heink

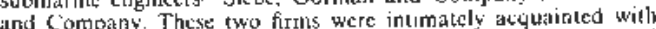
conditions it the Australjun industry and, throughout ils history. hat between them suppliod all the diting suits and equipment. The selection commiltee included the physiologisl, Poressor L. H. Hill la wordd cxperl an diwers paralysisl. and Linutenane Daniant R.X. who

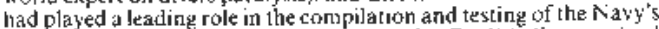

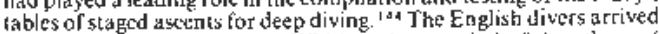

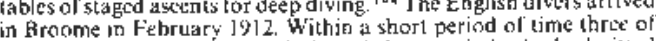
them had died of dinters puraly's is ad the remainder had adtuilted

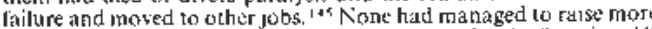

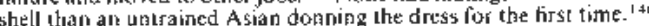

Although je was gon abcepted that the industry must cont tone to be worked with o oured abour the tolic objective of teducine the proportiot of Japa nese labour contirued It trits not for some ilme

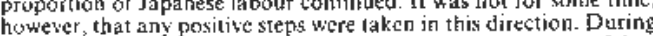

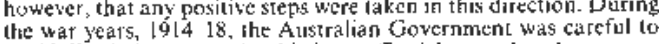

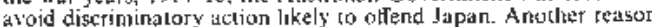
thas that labour [om other aress (for enamin]e Malaya and Papua)

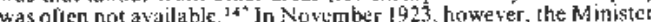
lor Home Allairs and Territeres lonaly issued instructions that in fubure the cusloumary allolmenls of pertilits for coloured ]abour (i.e

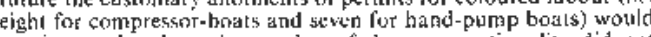
continue only where the number of the sionte nationality did not exceed five in the former and four th the latter. ${ }^{\text {an }}$ The principlt underlying this was that the diwter must be liee lo walect from his on compatriots the men an whom his lite depended ir.p. the tender and the men providisg the aic supply and that one member of the same nationality could double as "1ry-diver to leario how to dive and to rellite the diver.

It is possibte that armong lhe factors which intluencod the

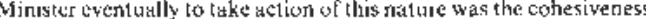

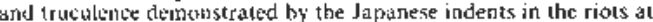
Broune in December 1920 in which they fought atebed butle with the Tinotest", and in their militant demogstration agajnst the eduployers a 7 hursday island at the time of the an nual negotiation of wiages in February 142 ;. 15 :

The ruling meant that je effect the disus and the mijorily of the crew in most of the lugers continusd tn be Japanese. At thurgday Is]land, for exaraple, the proportion of divers licences held by

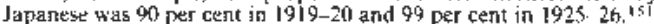

In his tesimngy belore a Outrostand Royal Commission the Aacky Commision in 190 , the demen of the A ustralian pearlers. James Clark, referred to the 'wel'-underst nod fact I hat the besl diver in the world lor geteing shell was the lapanese lis it is, perbaps. appropriate at this slape to examige why, throughout the hiscory of the indusiry. The majority ar the Australiun putders prefered Japantese io other races as diwers.

An employer's reccipls were ditectly propertional to the guanluly at shell raised by his tivers. The gualitits look ad for in a dwer were therelore the ability to deted shell where il existed and the willingrtess and capacily to work loth hours under water lagking for it.

Thi wight of the evidence prosentod to the Bamford Commission sugesses thath the ability to retognice shetl on the bollom and

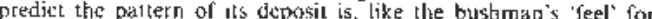
terrain, something that can be acquired only by those who have special innate guaticy of perception. ${ }^{153}$ Actording to one wilness,

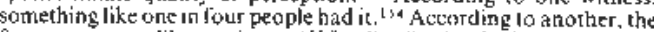
figure uas morc like onc in telh, is? Jis distributin hat nothing to do wilh race. Any diver uhlo did nol have it was a dead loss. When the

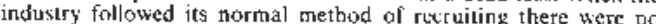
problems, II engaged people initially as trewmen people lo tura a 
pump hardle ar hanl up an agchor. There were five of six of these to

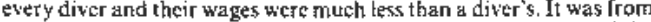
among these that divers were recunter. If the walunicer showed the necessary potential he was encoutuged and giwen opportunities to

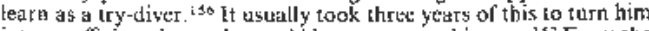
into an wficitenc diver who would be sent onit on his own. ${ }^{15 ?}$ From the law of aberazes onc might in ler that nne, ot perhaps 1 wo, or the ten English alecp-sea divers brought out in 1912 would have had this Innte quality of perception. But in less than aightecn months three of them had died al paraly'sis. None of the resh remaiged long conough io enable such lleories to be verified.

It appears that many of the Wakayana-men who wich ic Thursday lsland and Broone whe youluet nons. Aceording to Japanese cuslom all property was inlierited by the etdest son. Today in Miwasaki ore is told how before world War If the only way for a jounger son to earn enough money to set up a house of bis own wisto visited Susani in 1974. When Vamamoto Kenkichi lithed seventere in 1919 he had two choices. He could stay al school and prepure tor the entrance examination for the Teqchers Training Collcge. I successful the would five years later, become a teacher int the Susam Primary School will a monthly wage or $¥ 17$. A tie rnatiqely, he could beave schnol inmediately and go to Thursday Island. There his starting wage an a crewrian would to 25 . As soon as be beame

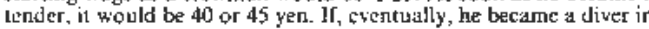
charge of a lugger, he would gel several times thal amoune. He chose Thursday Island. Wrages at home eontinued a be low throughout the period. If 1936 the monthly satary of the Hextmaster (ated filty) at

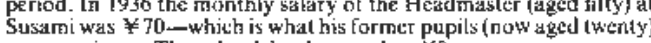
were getting et Thursday Islind as tenders. 1:5

Somb when to Austalia to froe the family property of debt Humatuchi Unojire und his brother went 10 Thutsday Island from

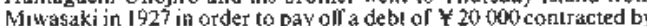
their father in 1913. I took them twepty yeass, each of them contributing 1 roul ach year

These men did not cone as seuters. Their objock thids to carn the nocessaty sum as quickly as they coutd in order 60 Tet urm humbitio and pursue their traditional occupations of fisherman or fatmer. To thes and they were pepard to cake tisks. In their cocupations al home death was no stranger to them. Furthormore the spuril of "nothing rentwre, bothing gain was part of the culute of the Kumano diste from whence ther came ${ }^{3}$ Thus, to the locals at Thuriday laland Lley appersed 'wery keen co make money' In/The A ustraliag concept of the Japancse diver is summed ap in John Douglas's relerence to the death from paralysis of a Japanese divet in his teport for $1994-95$ :

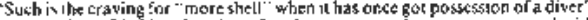

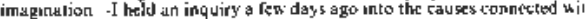

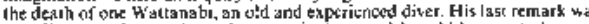

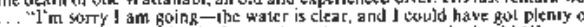

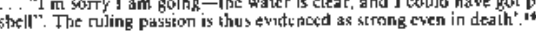

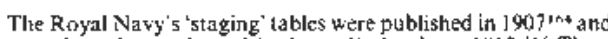

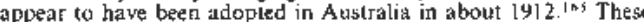
entabled the diver to work in deep utter for relatively long stretches for example for twichly minules al Iwen[y-live lathomb. Under the

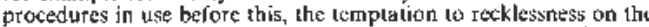
part of the diver was bansiderable. The old theory was to mike euth "dip." very shor for example al wenly-fice falboms, fite

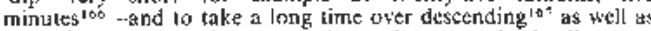
asecending. This was time-consuming and, as a result, the diver thas sonelienes unable lo spend more than hall an bour on the botom

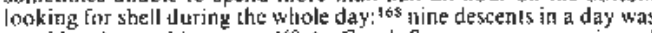
considcred at athicwement, ${ }^{16}$ As Frank Sumners, an experienced diver. ruefully told the Mackaly' Comthission: "A man will see a few

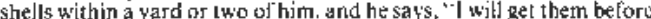
1 go up" ". Th This js easy enough to uaderstand. Not only was a diver's pay proporional to the amount of shell he ratised; but in addirion lbere would glways have beath the liceling that the shell one Ief bchund contained the peatl of a lifetime. An additional elemen

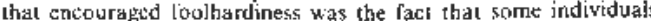
were morc tolerathe to dectmpression than others. This no doubt prompled the carclessress that goes with the tieling that 'I won' il be mit. When there shere white divers in the ind ustry, they appesar to have been just as feady to lake risks, no doubt fot motives similar to these of the Japancse. Summers was lucky enough to excape with wimor symoms of the bends . $1^{-1}$ A numbir of olthers were net 30 fortugate The death-rate among the Cancisian divess in Torres Serail in 1893 was dever aceded by the Jajtancse ${ }^{42}$ Similarly. nothing could have betn more teckless than the behaviour of Mebber, the most senior of the English divers, on the day of his dealh in Western Auscralia in 1912. Ho was repeatedly coning straight lo

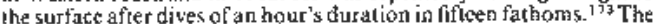
death of his compalriol, Besley, the following year appears to have occurred under similar citcünkstances. $1^{\text {4A }}$ Unfortutately very few diwers in the indusiry. Japanese or Caucasian, appeat cwer to hat taken the slaging lables serjousily. Jn 1978 at Miwasaki i had the good forlune to mext severs mern who thad been divers or tenders al Thurgday 1sland in the $1920 \mathrm{~s}$ and $1930 \mathrm{~s}$. None of them bad exier used stagigg lables, bul worked enlirely accordje to his ow personal judgerement and experience, is

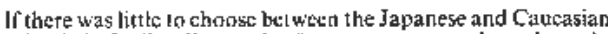
divers in their foolhardiness the lorines appear to have brough much ereater energy and enduranee 20 the lask. They would conmente al dawn and continue until dusk. They might make fifty diwes a day. Sonsetimes they would be at sea for lour months on end. In the words of one of the English divess, this was 'skull cracking work". It would hawe ben quite unlike anything he and his colleagues were used to. At Dower he would have bera makiag four or five dives a day and would have slept at home. I th

Shiba Ryotaro, the lamous conteriporary Jepanese nove list has didresed himust to the task of explaining the suppriorily of the

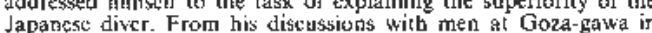
Wakayama prelecture who were divers at Thurklay lsiand ard Broome before the was, be considers that the compelitive spirit thet existed amogg the Japanese divers was an imporiant factor. In his rccent book Mok w wo to no Yokai [A Party at Thursday ishand] he puls the following words jnto the moutb of 'Miyaza', a sometime champion diver

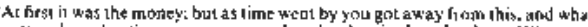
millered was bealing your but reoord or ibe chap in the other boal. When yol

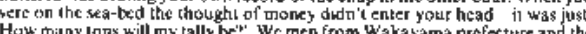

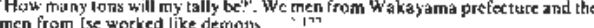

I mould agrec with Shiba on this point. Intereslingly crough alhough is is a point that has been owerlooked by later observers, it was noted by Douglas in 1894 in the context of the sucocsion of Talalilies that followed the discowery of shell in the 'Dantey Decos' the provio bs year: "such ... is the eaget degise to make a good sore. and stach is the rivalry between conpeting diwcIs... thal risks aIe Tasily encountered and precautions disreparded'.

Shibu alio makes the observation that the prowess of the Japunese in the water was oothing new, It had surprised the Chinese fiom kery early times. The Gish Wajm Der compiled in China in the this dentury records how the Japd nase gathered fist and clams under water and how, while engaged in this activity, they lattoot then faces and bodiss to wete away large predators, ity

Iwasaki in his ficld renearch in Wakayama prefocture in 1936 stressed the talue of impowements to local property that had ber finathed form overseas earmings. ln particular he noted how the chluster of poor bark-roofed dwellings builu low for prolection ugainst the wind, which had consituted Shionomisaki had becn replaced by imposing tiled houses surrounded by high stonc walls. He also noted that foregre clothing. Forcign habits (tor trample, punctuality) and 
foreign words (like the Australian 'tucker') had fome into daity use, "\$o Simulatly when Father Cairns, an Austualiat priest, was posted to that districl as a missionary in the eatly $1960 \mathrm{~s}$ he was surprised to find that the people were gteat bread catcrs and that sonte of them put thilk in their lea. At that time the first was unusua outside the big cilies. The second remains unusual loday anywhere Alse in Japan. Much ol this must have been the result of the Australian connection. In that district (Nishimuro-gun) emigration to Australit began belote emigration to North. America and even an late as 1940 the number of mestolk absent in Australia and the Afa[ura Sea (535) was a dose second to the number abent in the Linited Sta tes (666).

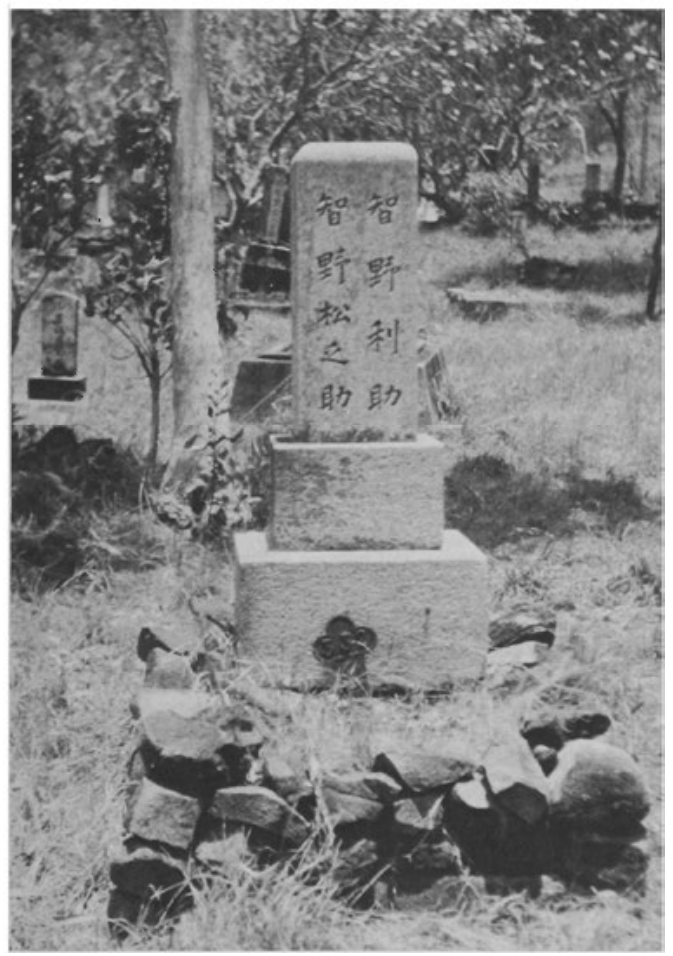

An early Japanese grave al Thursday Island Chino Risuke and Chino

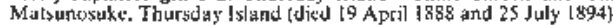

A prico was paid for this prosperily. In the Japanese cemckry at Broome there are 786 tombstones still stanjing. On these, 100 natmes arc still lc ilble. In the cutse of 410 , the person's ane is given. The disrriburion of thc ages is significant: aged $20-29,47$, I per cent: aged discriburion of the ages is significant: aged $20-29,47$. per cent: aged per cent: under 20 yeats, 5.3 per cent: aged $5059,2.9$ per ent. The pat lem is the same with the 562 Japanese lombstones slill standing al Thursday Island, On ISo of these the ages are given. The distribution is: aecd 20-29 520 per cent' aged 31-39,28.5 per cent ated 40-49 7.3 per cent; uinder 20 years, 5,3 per cent; aged $50-59,4.0$ per cent; aged 60 and over 2.6 per ceni tw. We know from the evidence [codered to the Bamliond Commisgion that, at Thatsday Is]and

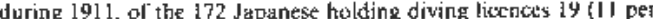
conl died either from paralyis or in the diving suit ats Two years later there wite Enurtern suth deaths among the Japadse at Broome - Tha The distribution of the tombstones that we have given sugests that a latge proportion of the deaths at both places continued to be of this nature. The ireligibility of thu dead men's dependanis to receire compengation under the State ${ }^{\text {us }}$ workers compentisation acls continued throughout the history of the industry In Quesisland a Japanest who was injured was entitled the same tompensilion as olher workers but, in the case of death. com:

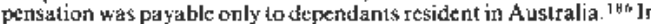
Wiestern Australia the Workcri Compensation Ack wis deljberatel dratted lo exclude compensalion either for death or injuty suffe red by indentured labour in this indusiry. The Western Australian Gowernment sought to justify this policy as follows

The mburtence at indentured labour wald mian a heavy burden on th

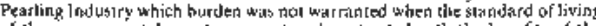

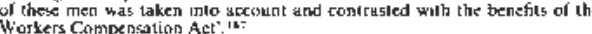

Both in the neceriations wich Sir John Lathames good-rill mission in Iokyo in $1934^{139}$ and in the trade tredty negotiations with Sir Henty Gulletl in Canberra in $1935^{\text {Hv }}$ the Japanese Governmont soughi, unsuccesstully, a sourt compensation for injury no death equal to that given to A this lre lian wiorkets.

The names on the gravgs do not, of cours, give the complete

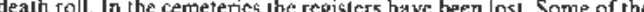
combsiones hawe becn broken or have otherwise become illegible. Otien there was never mare than a wooden post witl the bitme painled on it and these did not survire the ravages of time. Although there is a monument bearing the names of the Japaness who perishito in the three greal yye] ones in Western Austialia-26. April 190.

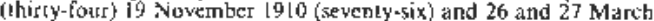

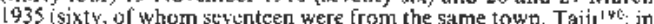
Wakayama prefecturs) thert is none for the sc wenty-hix Japanese who Ferished riear Cape Melvile in the Queensland syclothe of 4 and 5 warch bis9. There were other ecmeteries. For example Kyühara Shuji has fecently astablished that, over the years 1896 to 1913 .

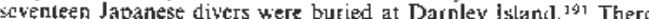
must 3 so be many like 'Sataro' of Yokohanta iwho acsurding th the Register of Dearhs for the Biroume distrjel died of paralysis on 16 Rovember 1897 and was buried at whist|er's Creek. Admiral Bay') rasting close to where they died, far from human babitation.

Although a Yedical Otfice was appointed at Thursd ay Island it

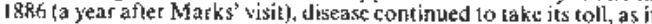
hat antothe Caplain Miller's original indencs*. For examole five Japanese died the of malaria in 1894 ${ }^{1 \%}$ and. of the lorty-me it the

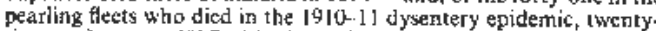
six were Japanese ${ }^{2 * 3}$ Beri-beri temainted serious problem until miel

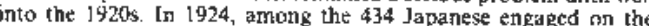
luggers in Torres Strait, rorty-four were sufering from it. 1\% Ore or the difficulties in combaling it wits the Japanese altachment to uapolishod rice. In 1925, a former hisd of the Quensland Healuh Commission took adrantage ol a tisic to Tokyo to setk the advice of Japanese nutritionat experts on amending the ration seale to replace. propurtion of the rise with other readily avaliable japanese Inodstufts. ${ }^{\text {is }}$ This carly example of A ustralian-Japanese scientifie co-operation appears to have been wery suocesslul-by 1933 the total among all races sulfe ring l'rom beri-beti had fallen to six. ${ }^{1 \text { wo }}$

Same of the deaths were bomicide. The comecock was nol the las ugger whose decks rall with blood. On 30 Crtober 1959 a diwer. Andō Taiji, or Oiliz prelocture, was murdered by Potrodelo Crin aboard the briganline, Ethel, in Western Australia 197 [n May 189 Yumbaki Kamematsu and Hagimolo $\$$ anco both from Shionomisaki) werc murdered on the Mirdmato when four Aboriginals armed with tomahawk boarded her in search of phutder as she lay al anchor 
near Cape Melwille They did mot die unacesed. A patti of police was seul to inrestigate and, in the words of the Sub-lnspuetor who commanded il, we discouted the tribe of blacks that oommitted the murder and punished them accordingly. "lig Marks. in bis despatch to Takyo on the subject, asked the Yice-Minister not to embarass the Questis/and Government by asking for further details and gave his uhit inlerpretalioth of the S bb-Inspector's report:

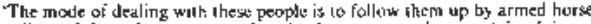

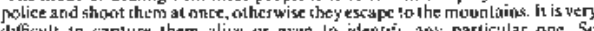

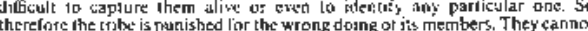

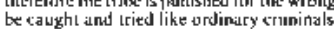

Better knowin are the ditlacks on the jatanese creus of Australiun lugers in the Northem Terrinory. Eatly in 1923 Caplatin H. C. Edwarls sent I wo ot his 1 repane luepers lo Caledon Bay with the Japances and two Aboriginals aboard cach. Some days alter landing they warc altacked by local natives. Two Japands and oste or thejr Aboriginal crewriner, wicre killed. The others mataged to escape in the

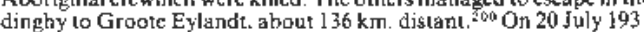
Napata and two olher Japanese from Victor Clark's lugger, Oxida weTe murdered at Porl Kears (TTeachery Bay) tus la 1932 it was Caledon Bay man again. The crews of $\mathrm{V}$. R. Keppert's lugers. Myrle Orger and haf were attacked by the batamumu trjbe whil curing trepang achote. They were very unwise to have landed there. The tribe aldeady had iwenty-one known murders to its credi

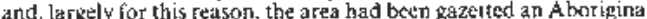
rescre inso which enty was prohibied without a licence. Five of the

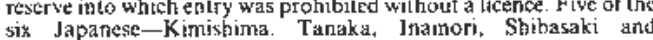
Higashi-were killed. There we sume ewidence that they may have provoked the attack by beuting somu ot the to bes, who were providing labour in retur for titions. One of the Japanese. Kinjo, escaped athd with six Aborizinal membuts of the crews walked 185 miles to the mission at Milingimbi. ${ }^{201}$

Kawano Yoruichi of fukuoka prefecture and Kusalio Sonosuke ol Nagasaki pretecture died of hẹt wounds in the batele between the Japanose and the Timorese at Binome in Deceribe

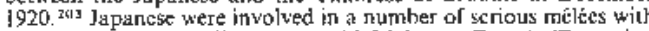
oher races in the pearlinj cowns: will Malays at Darwin (Decenbet

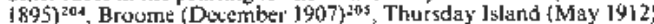
and Por Hedlitnd (September 1919) ${ }^{206}$, with Timorese at Brome (Deember b14) 1918)

That it was only in the 1920 dash that lives were lost (two Japanesc and one Timorces' speaks well both for the skill and courate of the very simall police detachments in these outlying districts and for the authority and rostrainl of the leaders of teach racial woup. The causes of these outbreaks lave yet to be studied The Brome pearler, A. C. Gregory, in his repott lo the riayy Ofice after the 1520 riot gawe the following explatiation of its or igen:

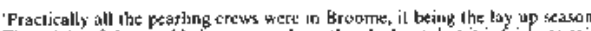

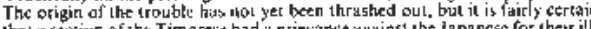
that a section or the Time

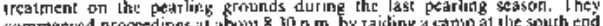

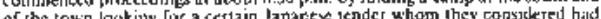

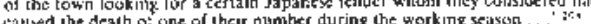

Elaboration on the ill-kreathunt received by the Timorese while at ar he remed tha they "campl do the anoun of mork that the avcrage Jap can, and an boats that do not carry a white man they frequently ket knocked aboult. Gregory had a Japancse parther and among the Bruome pearlers. was the last man one sould call antiJapaneus. His explantion may eventually he found to bu

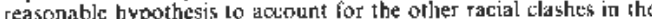
pertling towith that we hawe listcd. In it lukger with a mixed crew. the minority races could. while at sea, do lithle but gria and bear it. Their opporiunities- with the help of thejr compatriots-to altack an

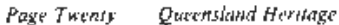

enemy when he was temporarily separaled from his fellows. This cxplanation appers to fit the 1512 clash between Malays and japarose al Thursday Island, which imfadjacly followed the killing or a Malay, Lowe Eongoe, by a Japanese ahoard the logger, Freya. ${ }^{200}$ Little has becn discowered about the c] ash bet ween the Japanese and the Papuans in September 1910.2 Lo Alehough uncoritected wilh that particular incident, there are scattered pieces of evidence or illreatmen of Papuag mealbers of lugers crews. in 1907 when thre Japanesc were tharged with the murder of Guari on Butns. Philp and Company's lugger, Teuzer, near Booby Istand, a Quensiand jury accepted the arpument of the defence coutsel that Guari had been tak $\mathrm{en}$ by a shark. There are, however, People still liwing in Wakayama precture who believe that he was beaten to death lor steqling the saltad figh for the thexl day's meal.2.2 In November 1908 a jury at Tuwnswille found fHamianchi Muramatst guilty or the na ralaughter

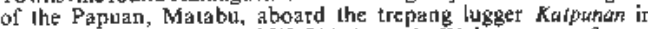
waters ofl the Barrier Reef. ${ }^{1}$ old-rinacs in Wakayama prefecture also say that when Bartes Philp and Company's trepang inger Bordior, was wrecked on the Batrie Reer on 4 April 192I, the nine Japanese members of the cres mede off in the only dinghy leaving two Paptatis to drowis. ${ }^{2}$.

50 tar, as cwidence of the price paid by the fapantese for whatewer gains they won [rom their emp]oyment in the industry, we have considered only dealh. There were, however, hardships which, though they did not result in death, were newertheles grichous enouget

The Bamford Commussion saw the diwer who surwiwed as likely to become practically a physical weck-a burden upon his rriends ar upon the community. This was the fate that ewentually overionk Furula Olomatsu. In 1914, at the age of twenty, he performed a memorable feat of coltrage and endurance. When the luger, Vido

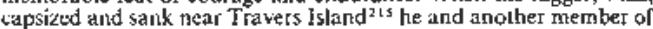
the cren' tuanaed to tread water wnil the current deposiled them atter erghreen hours on an utrinhatited jsland. Thoy survived by taling natue planls and were rescued by islanders a week laler. Furuta continued it the industry and became a diwer. He sulfered paralysiluice ${ }^{2}$ to $\mathrm{He}$ ditd in his home village, Oshing, in 1976, an ald mas sulch respected for liw kindiness and cheerfulness. Although boll legs wire pertmanetaly aftected, he endeatoured to make himsel useful bo to the and by helping his son's widow witl the copking. ${ }^{2}$

Among the kardships sulfered by the Japanese 'indents', cxploilalion and ill-trcatment by their Australlan employers ubas, al we have scen, often alleged in the days of the Fearon-Low contracts. There are some indications that, al least in the years immedately Eollowine, this did nent entifaly die opl.

For exabple. fom a led ter from Nonami to the Shipping Master

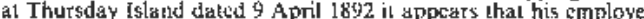

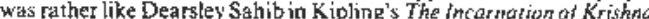
Wtyortey. In the letter Nondmicomplatned that he had forced him to contribute f2 (lot which he had received no teceipl) for a Sydney sweepsake and $E S$ lor a rafe of a billiard-table that had nol laken place 2

In 1891 the Crown Law authorilies in Western Austealia Look a serious nitu of the conplajots of Nagano Cholaro and Kato Sadakichi, who hat been recrujed at Singapore by the Auslralian pearing torm. James Clark and Company, in July 1890 . At Broome Ithe foilowing month these metn wure taken to court by Clark's manager, Caplain Coventry, and scntenced to twe]we tocks im prisoliment under the Merchas Shipping $A$ 's for relusing duly. AL the end or theit serntence : hey rerused to return to the luger and were gyain chaged with reFusing duty and sentcraed to imprisonment. This was duly tepeated at the end of wach subseguent sentence At the firth of thesc Irjals (at Derby on I jume I89 l' they somplainod of ill45age by their employer and. on the advice of the Resident Magistratc put their grievance in writing. They claimed that they originally tefused duty bevause the rations were in auficient and that 
they were then strunt up by the thumbs, wilh their tors birely touching the gotond, tar four days. In his willen report the Resider Magisirate comonested that lie lace that che two men preterred contimuat imstisonement to returfing to wark and werc guict and hard-working in prison tended to coulirm their story. The Crown Solitive urEed that the ther should be releated

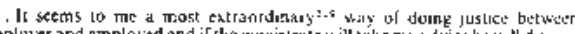

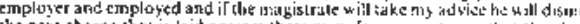

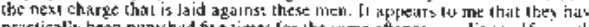

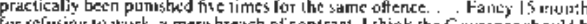

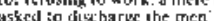

The Giowernor was so adrised and the men were releawed on $A$ September. Katō by ilhis cime hand hand wough and prompty teft the district. Ragano comaided abd was duly charged again on 2 ? October. Although this tine the Residert Magistrate mercly impost

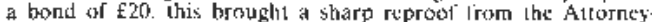
Gicneral who drew his allention to the tace that 5 -ction 159 of the

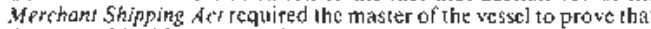
the accused bat been properly signed on in the presence of the locit shopping-master and agked for an explanation why the Residen Magislrate had lailed eithes to chares the master of the sessel writh assault or [0 vase the Sub Collector ol customs to conduct ar inquiry with a view tor revoking his tickel on the bound of iycannous bebaviour. ${ }^{2 k 0}$

On 17 February lons the Japathese Conul in Townswille addressed the following complatit to the Westurn Austalian Cutonial Secratary

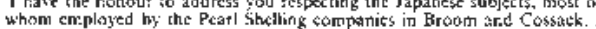

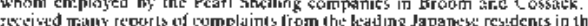

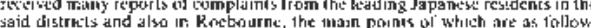

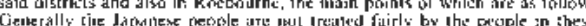

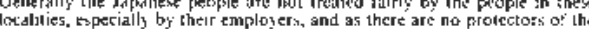

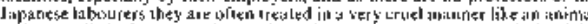

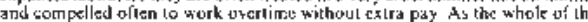

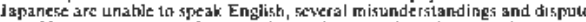

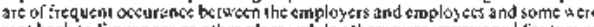

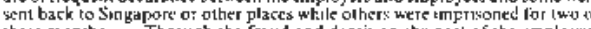

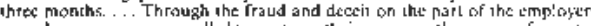

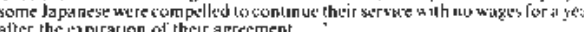

Insofar as the Consul gawe only onte example in support of these allegations, one suspects that wuch of the untormation that he had roceived was mere runour und gossip and that it was thetetore as exagarated and une-sided as such material tents in be. Be this as it

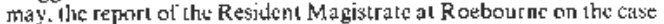

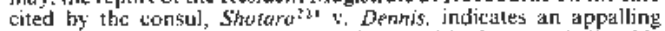

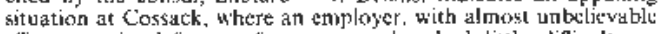
elliontery in defiance of a coury order, had lituli difticulty it] manipulation the Sub-Collector of Customs and a Justice ol the

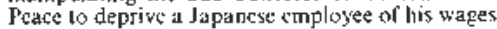

On 28 Nowember i 904 Frank De nits the owner of the lueger.

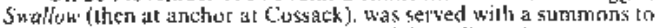
atuend Robourne Courthousc (some le kilu, distanth to askwet a

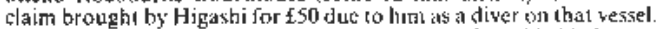

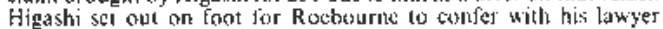
regerdithe the cane uluereupon Dennis infunted the police that he

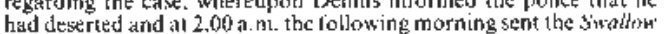
lu sea. In the opinion of the Resident Mingistrate. Detnnis's intention in sending the lugger to sur was to remowe Higeshi to prevete his

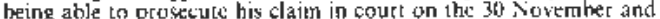
Hiajshi deserted because he thad rot wind of this. Such action by: Dentis constituled an oflence under section 21 b al Ihe iterchors Shipping Adr wich requiged that when a seaman wished to make a complain to a Juslice ol the Pcace the Master of the vessel should permit him to po ashore.

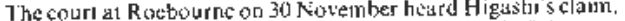

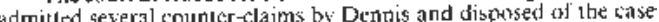

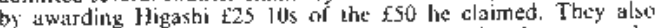

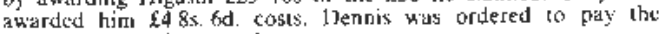

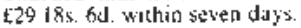

On 7 Tecember Denus took Hitashi in the Custopus House at

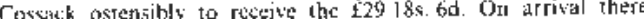
a] though the terins al the order of 20 November were that the multey be paid inu soutl at Rocbourne. Dennis handed the cheque to the

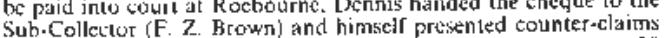
additional to hose that he hat prosented to the court on 30 Gowember. Bitumilo, hereupon. heard the councer-clains and admitted Ilen to the exkent of $\mathrm{f} 37 \mathrm{lg}$ s. Thus, insegd of coming out the

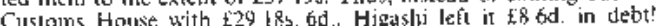

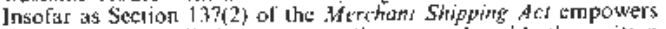
such offers 10 adjudicale wages disputes only with the writleth conscrt of both putlies, Brirn's action thas patently jllegal.

That night Higashi once more walked $25 \mathrm{~km}$. 10 L $\mathrm{ry}$ and filtct out from his solitilur whal has going on. The foltowing day no soone

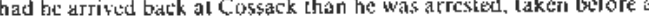
Cosseck Jutice of the Prace and senuenced to nat munth's imprisoument lor his 'degertion' of 29 Ocrober!

A prulasl drated by Higashi's solthilot was immediatel wegraphed to the authorities in Perth. A futnight loter. on 22

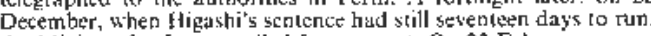
the Minister fir Jusise called fes it report. On 23 February. sey weks after Higaghi had comploted his stutcroes. the report wits pregenced. On 23 warth, the Consul was ioluthed that if Sholaro

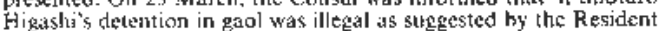
Magistrate, !n had his proper remedy at law which he did not lake." " Higashi did, how'cher, get some sal uslaction. It seems thal he

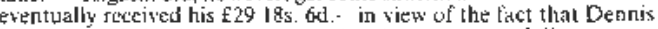
had not paid this inlo court dis ardered, a widrant of distress wits

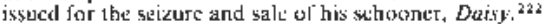

Som of the hatdships une selt-milicted. By no means all the mancy earned was remilted home. Oku Yuhito, who tirs wemk to

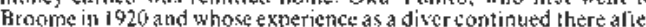
World Wak II, is defiaite hat only: the divers and lenders pere able

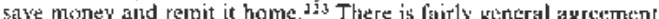
that cambling was al greal pubblets 224 for example, Ishikawa

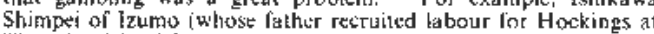
l'bersday laland from aboul 1942) considers that mosh of the met

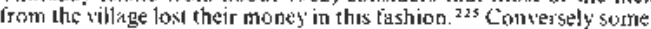

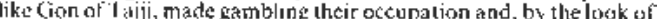
the houses they huilu on their Juturn to Iapan, did woll wut ul it.

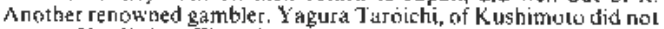
relurn. He died at Thus daty Island in the dystentery epidernic in 1911. The sualit's of his way-ons ot the besl preserved in the

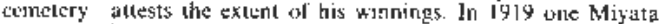

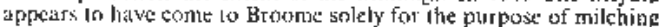

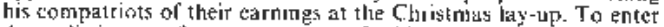
Australia in was. of courst, necessary for hizh to sisn wn as a member

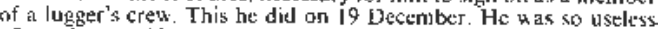
afloat that of 22 Decembor his mister dischased him ind madr actangerberils for his repaltiation on the next ship. By the lime the

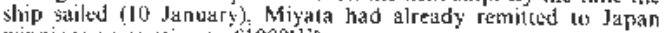

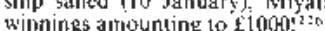

Another cause of hardship was drank. Some of the Japanese would have spent a lais amound ol their pay on this. Reterring tes the

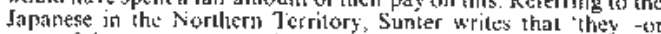

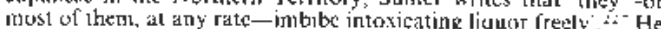

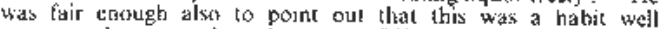
represtented among the other caces. Lite on the lugers would

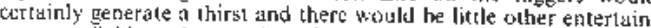
menl available at lay-up time, Scatrited evidedec does survive of 


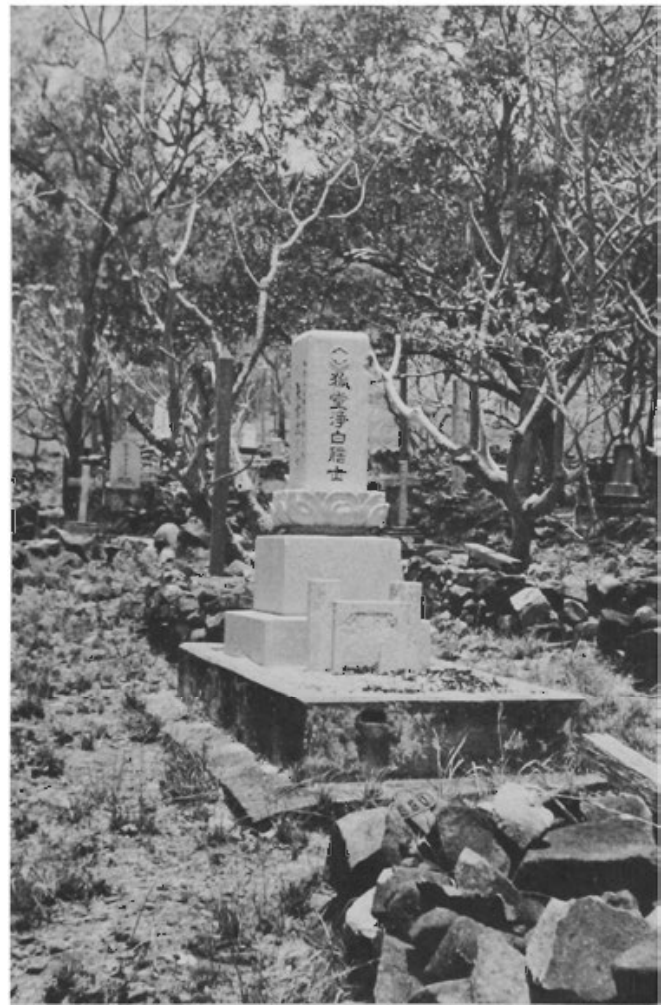

Grate or Yagura Teroichi. Thursday Island

heary drokung. For example. as we have already noted. one of the ortglinal group rectuited by Captain Milles, died of alcoholic posoning aftet lwo years at Thursdy lsiand 228 in Broothe in 1896 the bebeating of Takishita and subsequent suicide of Nakashima look place in the course of actidd s birthday parly when al the adults were tader the influence of liquor. Sh Similarly. at Broome in Fubrusty Igl 3 il was al a party on the foreshore afier several hours hard drinkitg that Nishimura mas stabbed to death in the course of a cispute over how to sing a song. 2 ,

Historical research, of its very nature, has to relly chiefly on

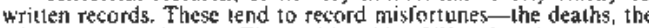
crimes atid the dispules. The postive side of life is less documented. Many Japanese found that employment by Australian nearlers suited their nocds beller that life in Japan. This is demonstraled by the latge number of men thito re-engaged when their contracts expired and who, after neturning to Japan fot a break, signed up abain. Il is also demonstrated by the high proportion amoris illegal inmigrants of people who had served in the industy befors."1 ar who were close re]cines of pepple who had tonc so. ${ }^{21}$ Men from Thursday island that one meels in Wakayama prereciure loday look back with considerable pleasure on the jears spent there. There appcars to be

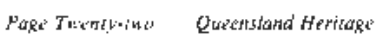

much mose to this than the houses and parcels of la nd purch ased with the procosds. Despite the numerous strikes for hight wages (the Japanese assimilated this element of Auslatian culture wery rapidy

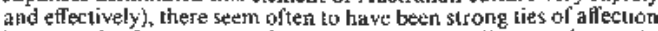
beluter the Japanese enployee and the Australjan employer. At Susami in 1973 Kosaka Sejkichi spokt to me in wam lerms of the kindness he recelyed froth the Jardine lamily for whom he had worked in Torres Srail before World War I ${ }^{3.3}$ Similarly Ogawa records how Hiramarsu Shimpachi, who was employed by Bums, Philp and Company at Thursday Island in 1501, told bim that the locol manager and his wile treated him like one ol their own children. ${ }^{2}$ there was of ter mutual respec. When one speaks to Cormer pearlers and formet diwers it is inleresling to obser we that when each sedrches for a word to describe the other race they often conle up with 'hortest'.

\section{ENDNOTES}

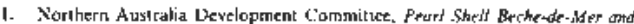

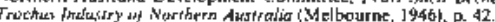

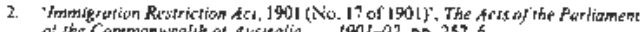

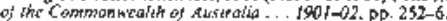

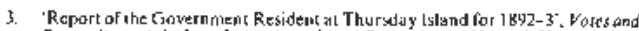

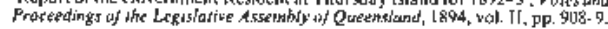

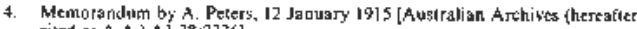
citad as A. A.j A 1 is:2336].

5. A A. $M P 74255 ; 2: 253$

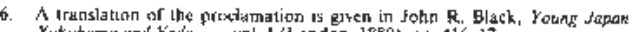

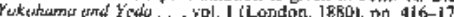

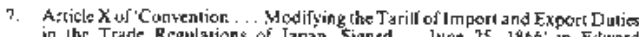

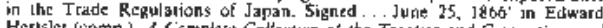

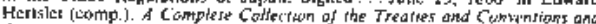

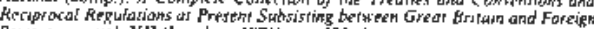

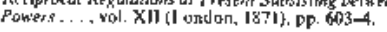

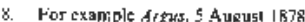

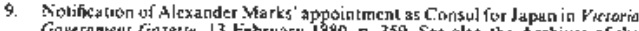

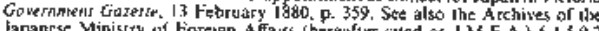

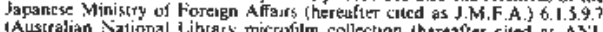

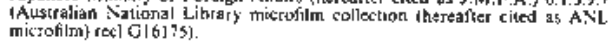

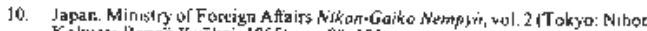
Kokkusan kengö $\mathrm{K}$ yōkai, 1955h. pp. 94. 101.

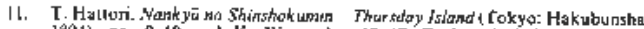

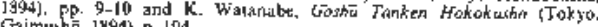
Gamulno, 1840), F. 194.

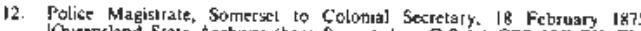

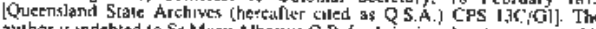

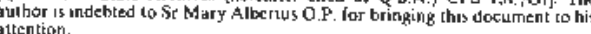

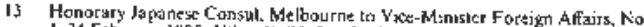

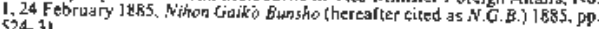
524 - 11 .

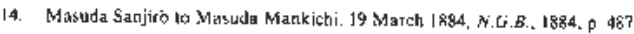

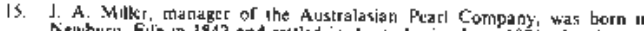

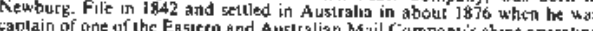

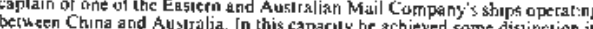

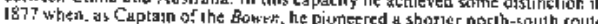

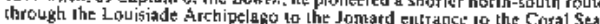

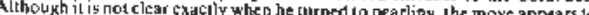

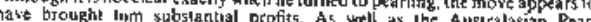

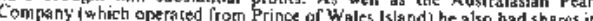




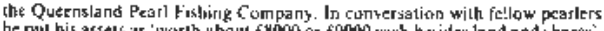

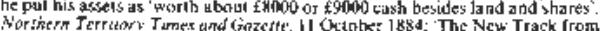

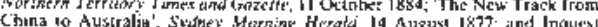

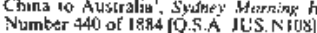

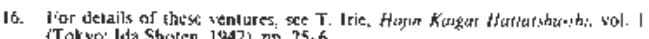
(Tokyo: lda Shoten, 1447), nj. 25.6.

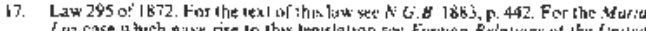

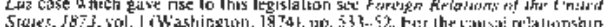

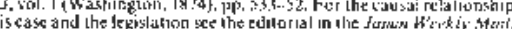

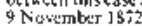

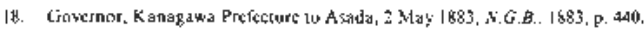

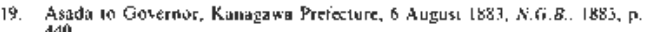

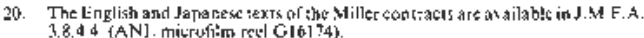

A

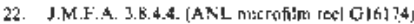

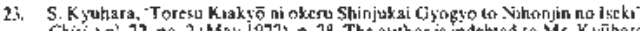

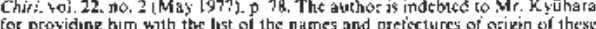

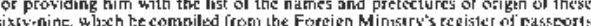
issued al $\mathrm{k}$.

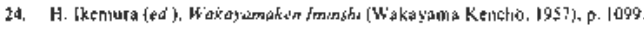

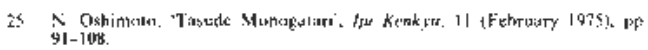

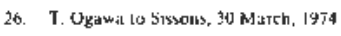

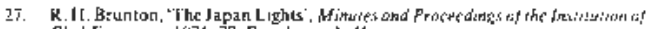

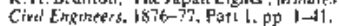

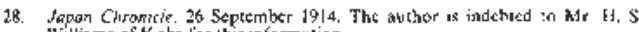
Williams of Kobe lior this infomial ion.

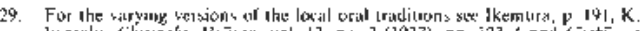

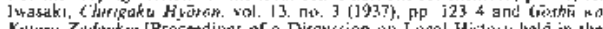

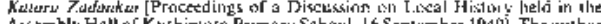

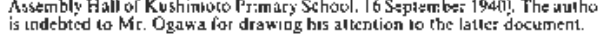

30. Jkerwuri, pp. 7907,124 6.

i1. As cor endnote ld.

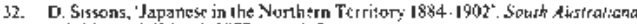
vol. 16, no. I thanch 14731. pp. 45

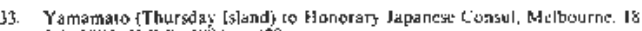
July: 1884, M.G.H., I854, p. 49 .

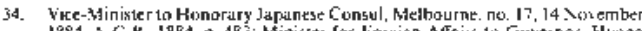

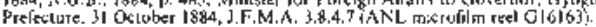

35. Honorary japanese Consul, Melbourne ta h'

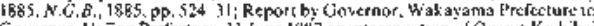

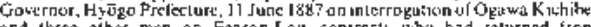

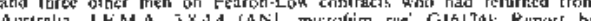

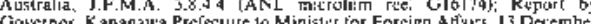
IBue on

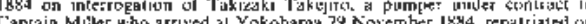

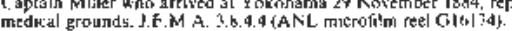

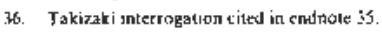

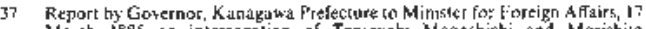

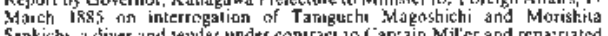

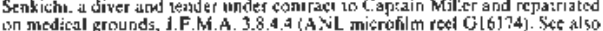
sal medical grounds. F.M.A.

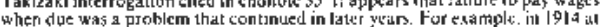

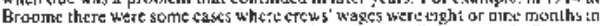

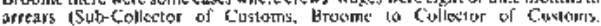

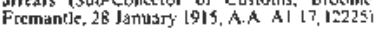

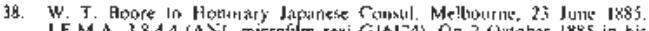

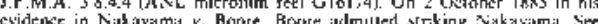

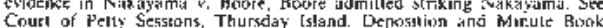

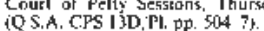

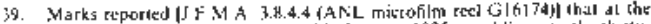

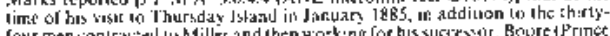

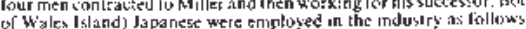

Pres Islandy la panese we

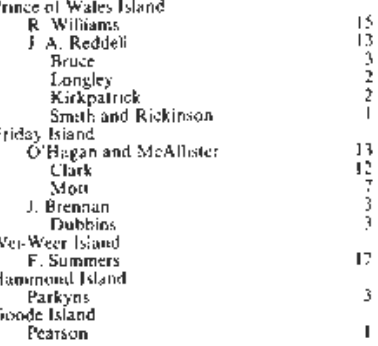

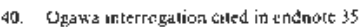

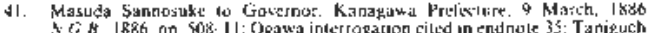

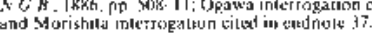

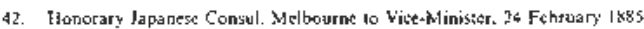

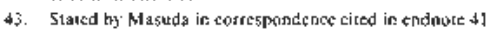

44. As ior entinote at

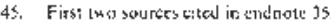

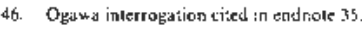

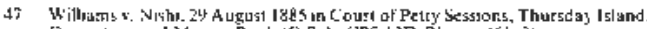

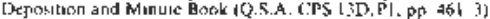

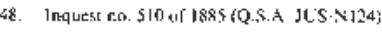

19. An for end hina al

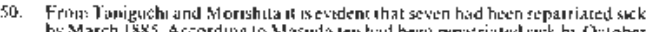

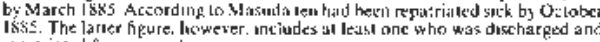
ropatriated for miscondual.

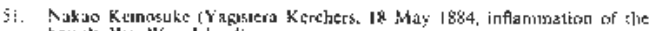

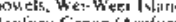

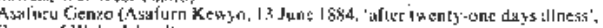

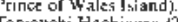

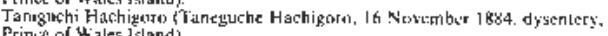

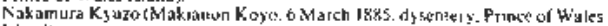
Iiland?

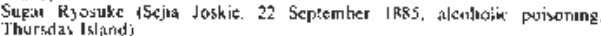

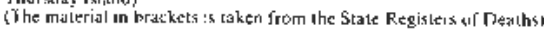

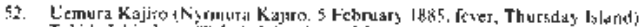

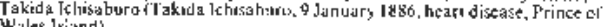

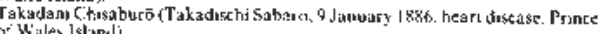

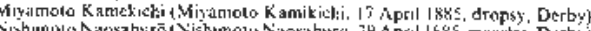

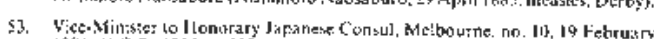

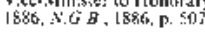

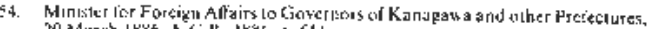

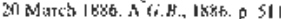

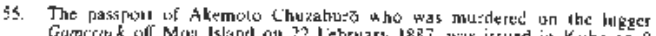

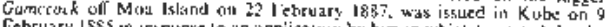

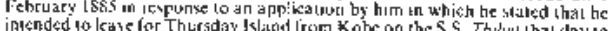

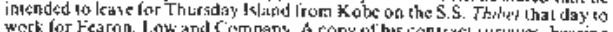

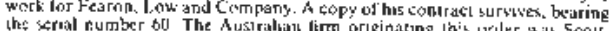

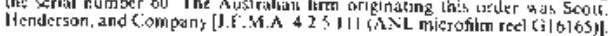

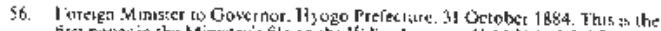

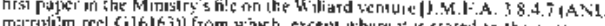

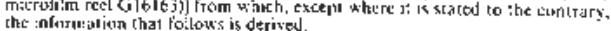

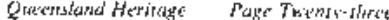




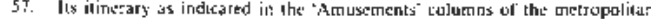
preses his

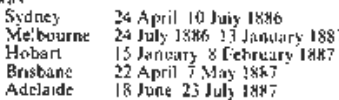

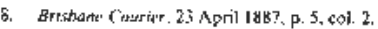

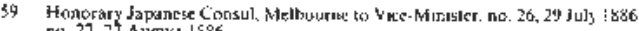
nu. 27. 24 August | 886

60 Marks lin Wi!lind. 1? Augusil I8sio.

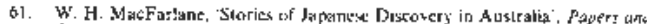

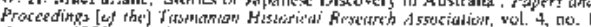

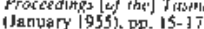

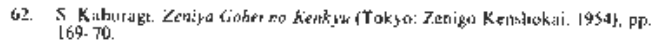

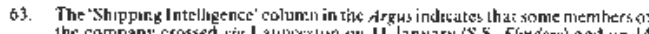

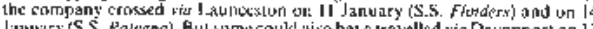

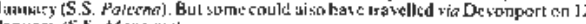

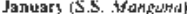

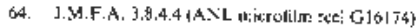

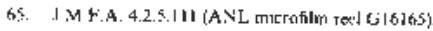

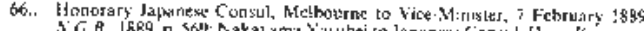

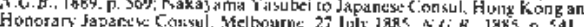

b). Wiglanghe, P. I.96.

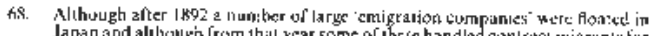

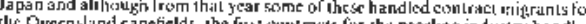

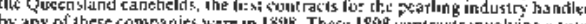

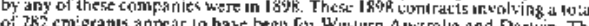

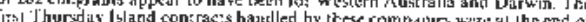

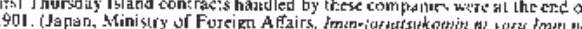

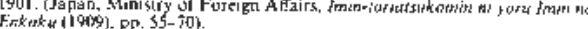

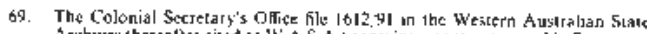

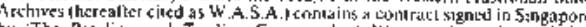
b) 'The Paral libe ind Trading Comprany' of Mestern Australla and tie

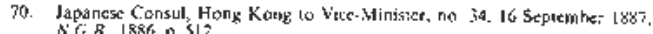

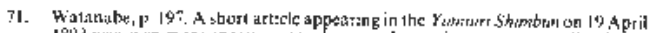

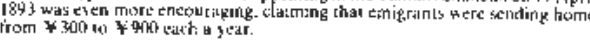

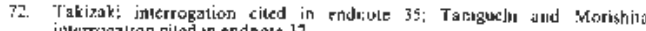

73. Iwaskki. p. 121

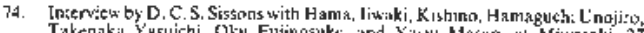

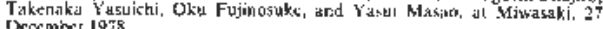

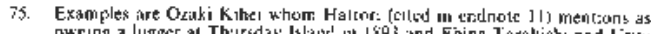

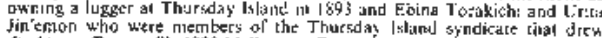

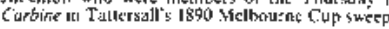

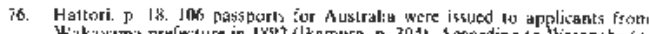

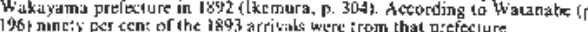

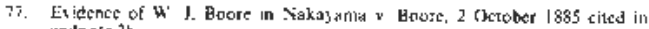
undmare is

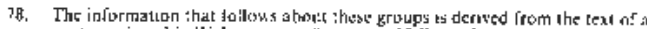

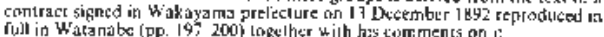

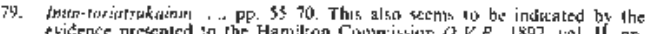

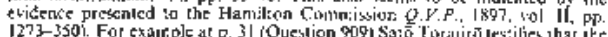

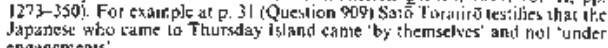
engagemenus'

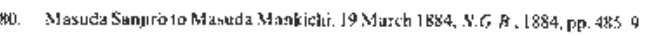

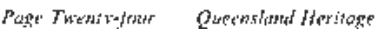

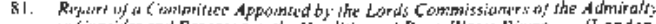

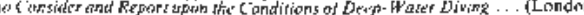

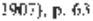

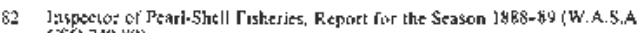
$\cos 74$.

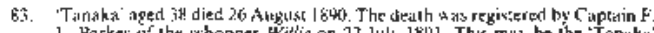

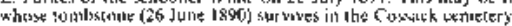

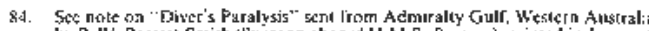

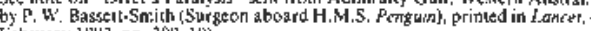
Fetruajy 1442. pp. 3019-10]

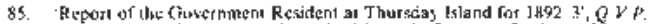

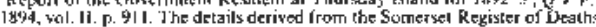

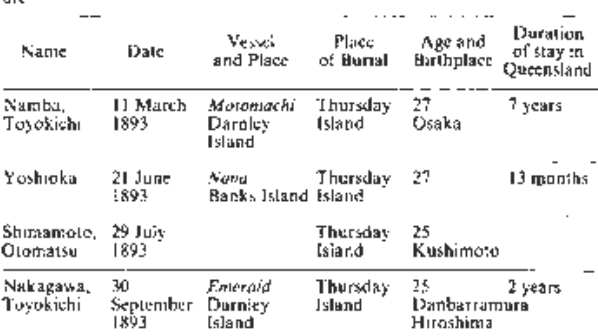

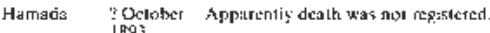

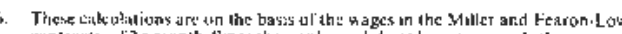

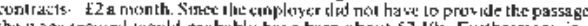

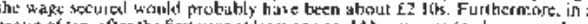

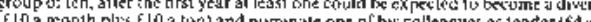
110 a

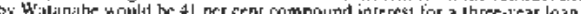

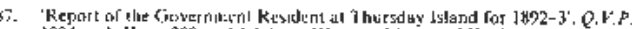

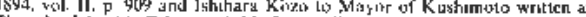

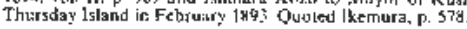

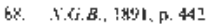

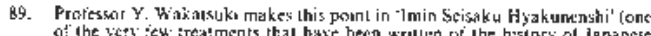

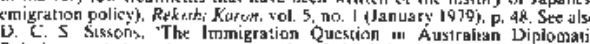

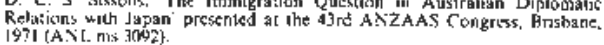

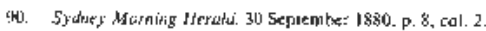

91. [1 anluri. pF. 1011

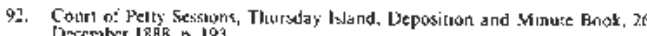

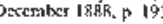

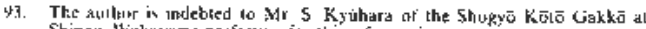

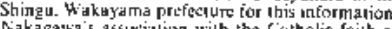

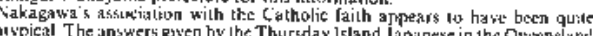

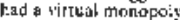

Ecligivus Denom natuiun!

Hagariand Malhometiari

Chutch of Eagland

4hasent

Othet Protesturits

Uthet ritlgghns

$\begin{array}{cc}\text { Mals } & \text { Femiales } \\ 254 & \\ 31 & 4 \\ 1 & 4 \\ 510 & 07\end{array}$

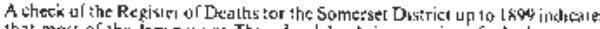

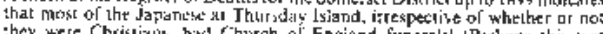

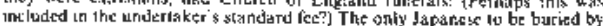




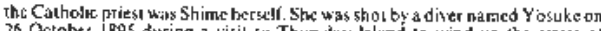

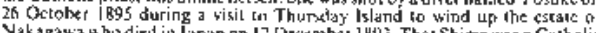

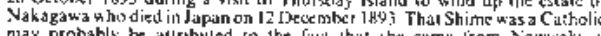

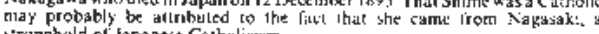
s:Jonghold of Japa neste Conthalicusm.

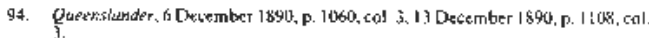

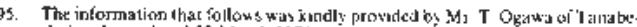

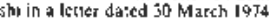

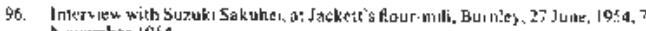
navimber 19.54 .

9: Walatiate pp. 195 o.

98. Wialamabe, p. 16.1

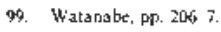

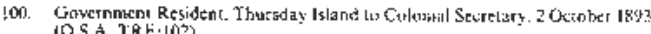

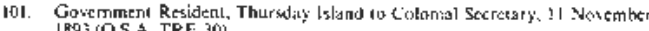
1893 (OQS.A. TRE. 301

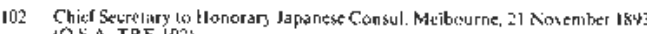
Q.S.A. TRE.ID2!

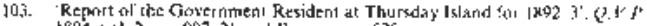
togia. vol. 2. pp. 907 21 and lkenum id p. 57

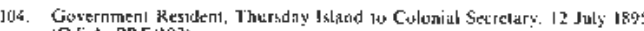
[Q.S.A. PRF.:IOY].

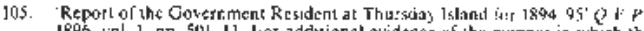

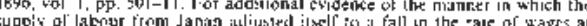

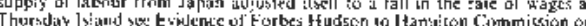

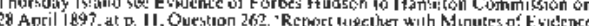

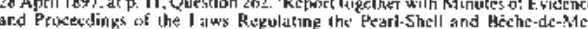

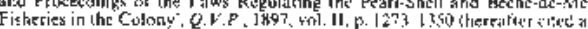

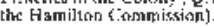

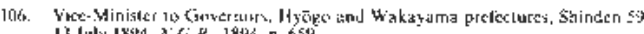

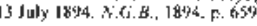

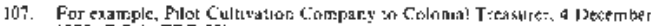
1 IST

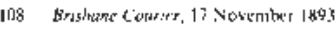

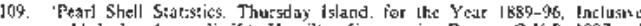

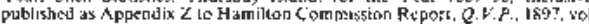
II. ;. 1 ;.5].

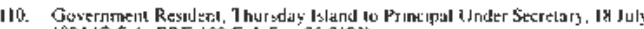

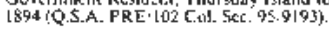

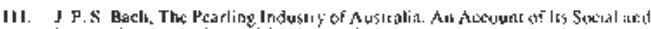

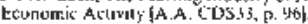

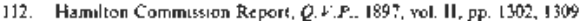

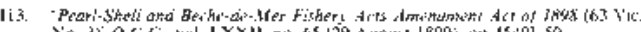

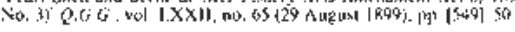

1/4. See for exampte the gemarks of the Gimernenent Resident at Thussdan [s:and ils

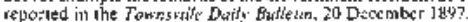

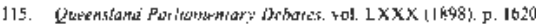

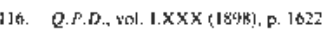

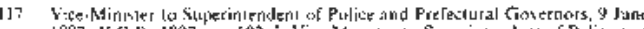

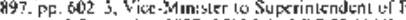

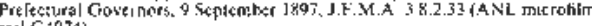

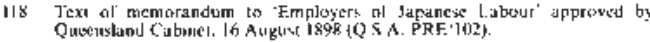

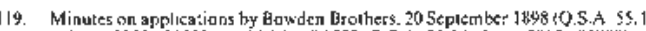

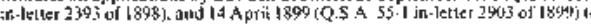

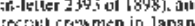

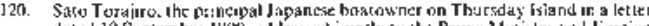

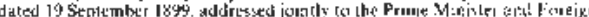

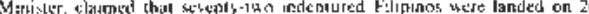

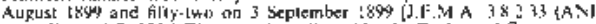

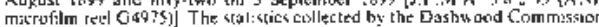

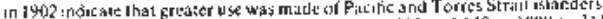

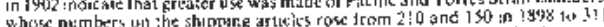

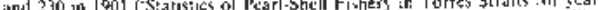

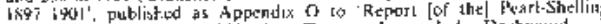

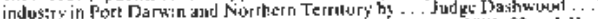

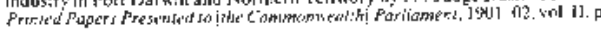
[I010|]].

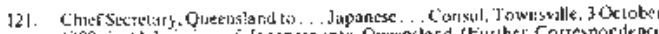

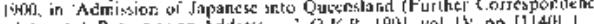

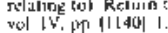

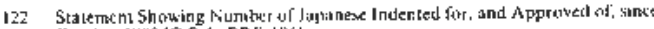

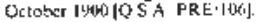

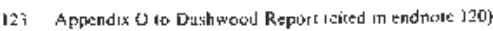

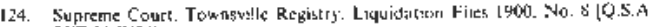
Sc:T 11,1424 .

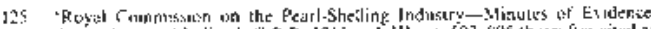

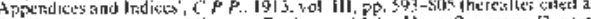

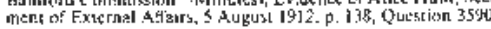

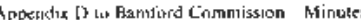

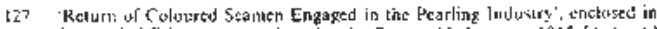

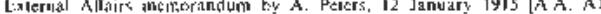
38.2534

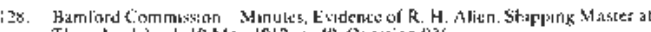

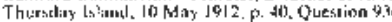

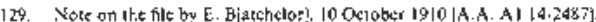

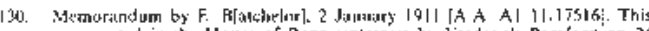

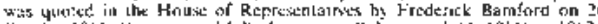

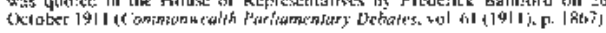

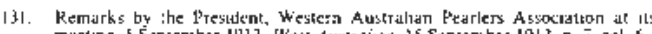

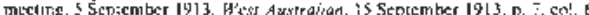

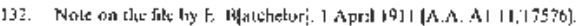

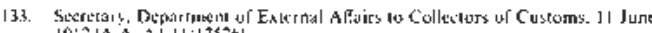

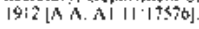

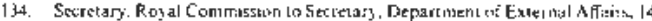

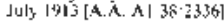

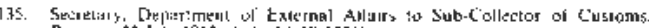

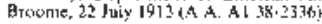

it A. Hor endrotelit.

13.. As lin endrole! 31 .

136. A.A. AI 23, 2606

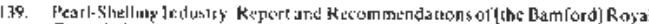

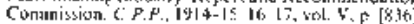

144. As for tondnete I59

14l. As fint endrute $\mathrm{i}$ io

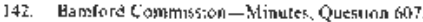

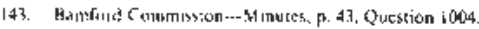

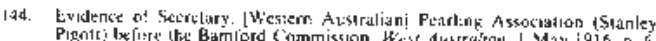

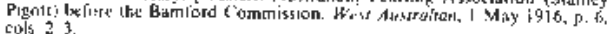

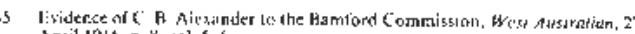

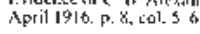

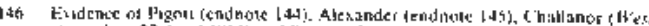

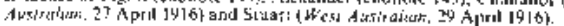

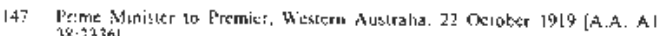
Bsistis!

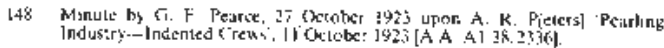

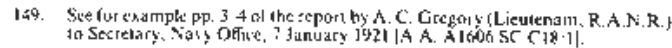




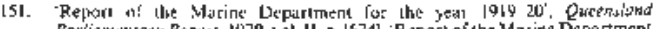

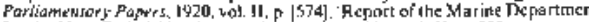

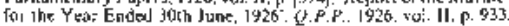

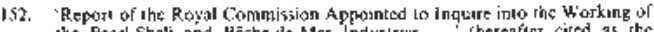

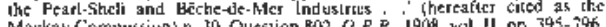

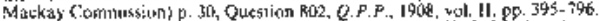

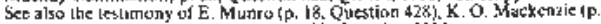

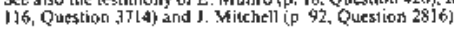

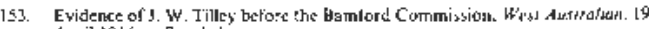
April 1916. p. T. col. I.

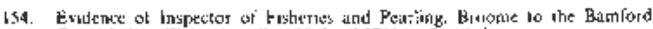

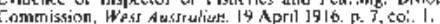

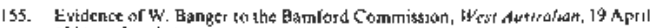
$19 \mid 6 . \mathrm{F}$ i, 601.1 .

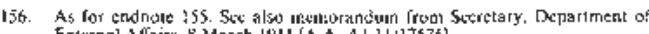

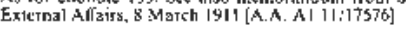

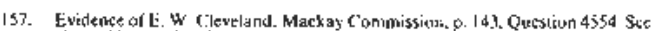

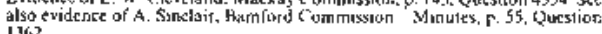

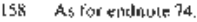

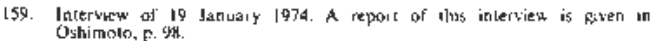

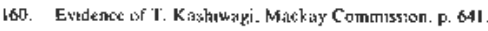

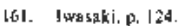

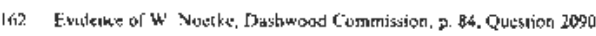

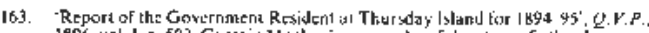

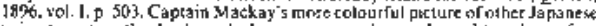

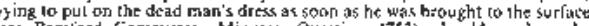

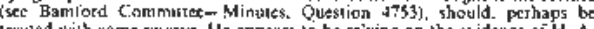
Ireated with some rustre tle appeire to be reiving on the chidelos at H. A.

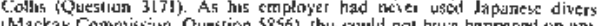

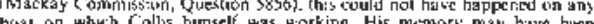

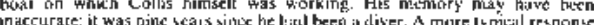

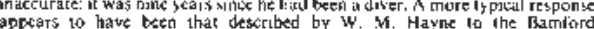

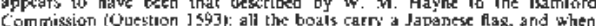

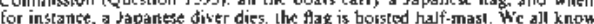
whan thas sighal means'

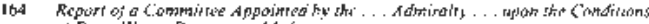

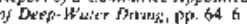

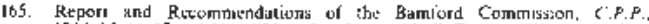

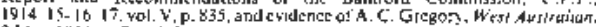
3 औty

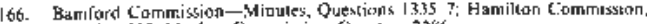
Questian 819: hiackay Commission. Queston 226

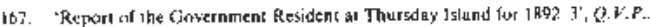
1394, 4ol. II, p. 911 .

168. Hamulcon Commisgion, p. xanu and Queston 320

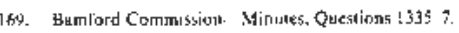

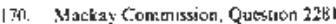

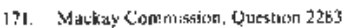

172. To ute hhre: whice men mentioned by Douglas in hys 'Report of the Gurem-

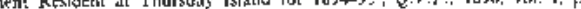

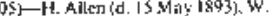

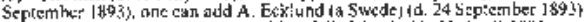

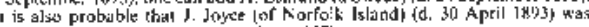
puepronderanly cavessian (see end nole 167 ).

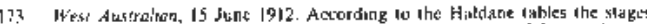

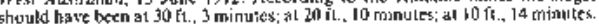

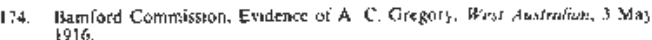

Poge In'empl-six Obonflund Furidge
175. As lo: endnote id Particulars ars

\begin{tabular}{|c|c|c|c|}
\hline Mami & $\begin{array}{c}\text { Dalc oi } \\
\text { Birth }\end{array}$ & Employcr & 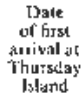 \\
\hline $\operatorname{Hami} \quad-$ & $9 \pm 0$ & 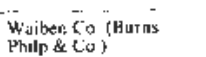 & {$[91]$} \\
\hline 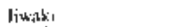 & 1009 & Fiaruli:e \& $\mathrm{Cot}$. & 1922 \\
\hline Kushina & $1 \% 7$ & Henitssy do co. & 1922 \\
\hline Hamaguch IJnojiro & $141 !$ & Burms. Fliplp \& $\mathrm{Co}$ & 1527 \\
\hline Jakenalka Yaspuchu & 140 & Burne, Philp \& Cot. & 1927 \\
\hline Oku Fujimosuki & 1919 & Wianetia Co. (Hockingil) & 1929 \\
\hline Yasui Masso & 1914 & $\begin{array}{l}\text { Wraiten Co (Butns. } \\
\text { Philp \& Co) }\end{array}$ & (4) \\
\hline
\end{tabular}

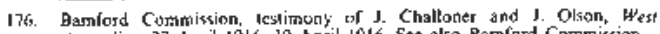

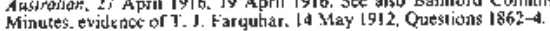

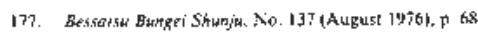

178. As ror condrate $16 i$

1:3. Shibil. 728

160. lrassai. pp 119-24.

IkI. Ikemura, p. I hoo.

172. Qspomatón. Pr. 1023

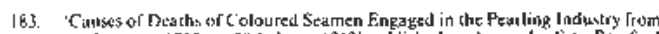

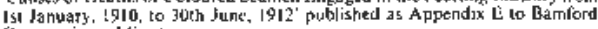
Combusson-Miriules.

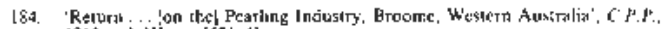
19] ) yol. ili, pp. [57l 6.]

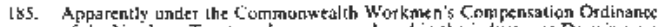

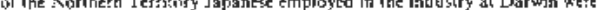

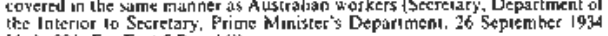
[A. A. 931 I. Fár East 5 T'arr [oj].

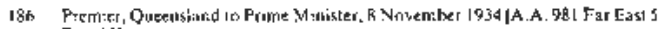
Pan 16 i].

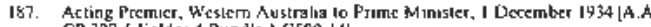

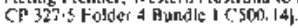

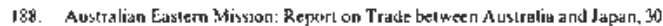

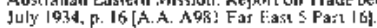

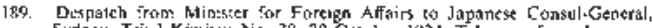

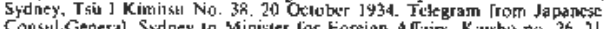

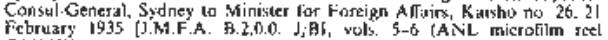
Q161690|

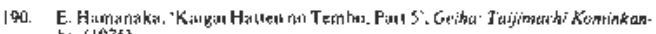

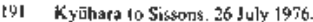

197. Snoturac: Reggenter of Thaths.

193. As ror tondmore 163

144. A.A. A IS: 70;2

99. A.A. B 1928 820.4.

196. A.A. 1927 .70.1

197. Register of Thaths. Eruore. Yo. 30 ol 19010.

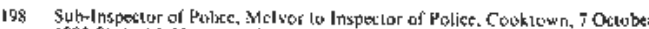

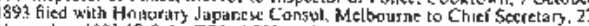

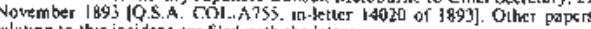
retaling to this incident are filed pish ihe icticer.

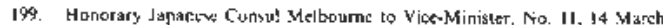

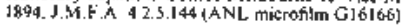

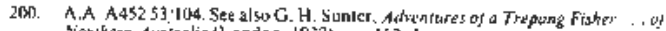

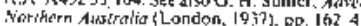

201. A,A. A.46। L. 3001. 


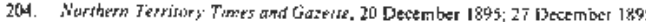

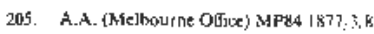

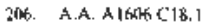

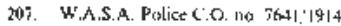

206. A.A. Al606 sc 6181 .

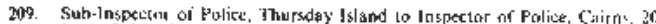

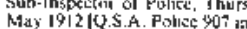

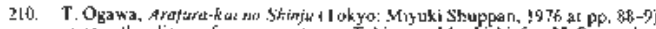

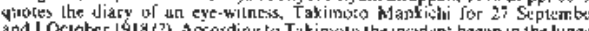

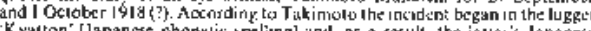

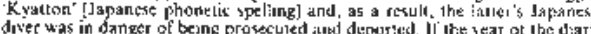

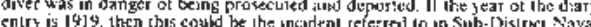

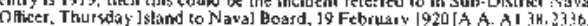

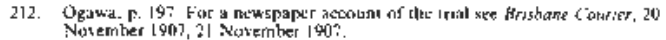

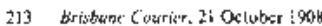

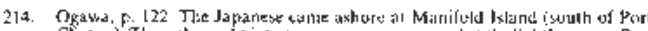

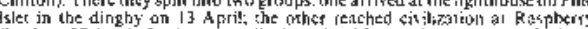

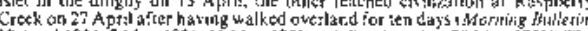

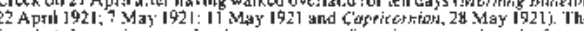

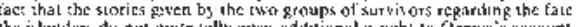

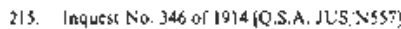

zib. Ogawi, PF. 124 B

317. Ogaria to S15000, 19 Septembe: 1974

2IB. OS.A. TRE 3 .

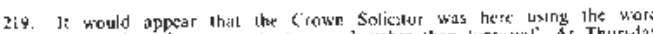

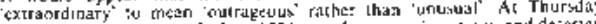

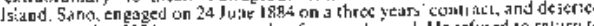

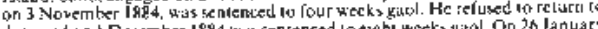

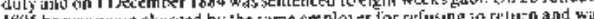

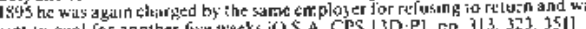

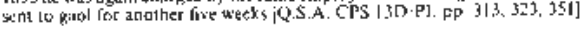

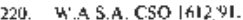

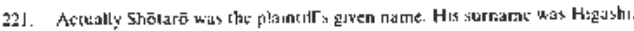

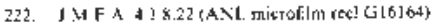

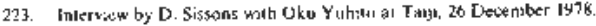

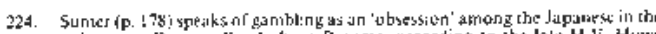

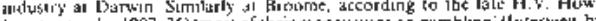

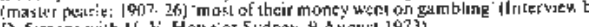

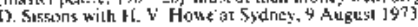

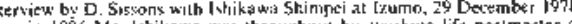

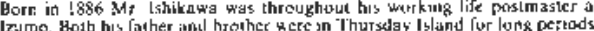

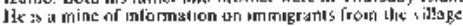

22b. A.A. Al 20․ 31,5,

207 Sunicr, p. $17 \mathrm{H}$

the sien Findnoue 5 i

2he. Brushare Couritr, 17 June 189

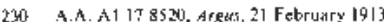

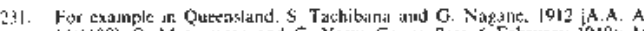

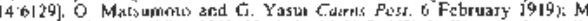

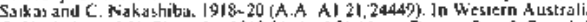
A

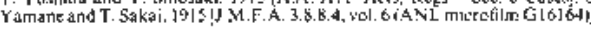

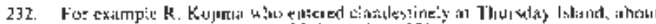

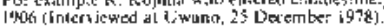

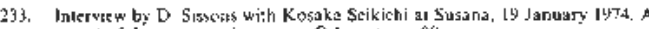

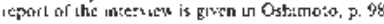

23.4 ggand. T. Ts 
The Japanese in the Australian pearling industry 


\section{Japanese in the Northern Territory, 1884-1902}

In South Australiana,

Vol. 16, No. 1, pp. 2-50, 1977.

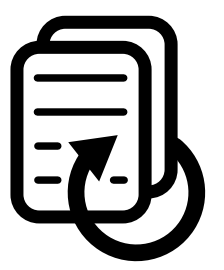



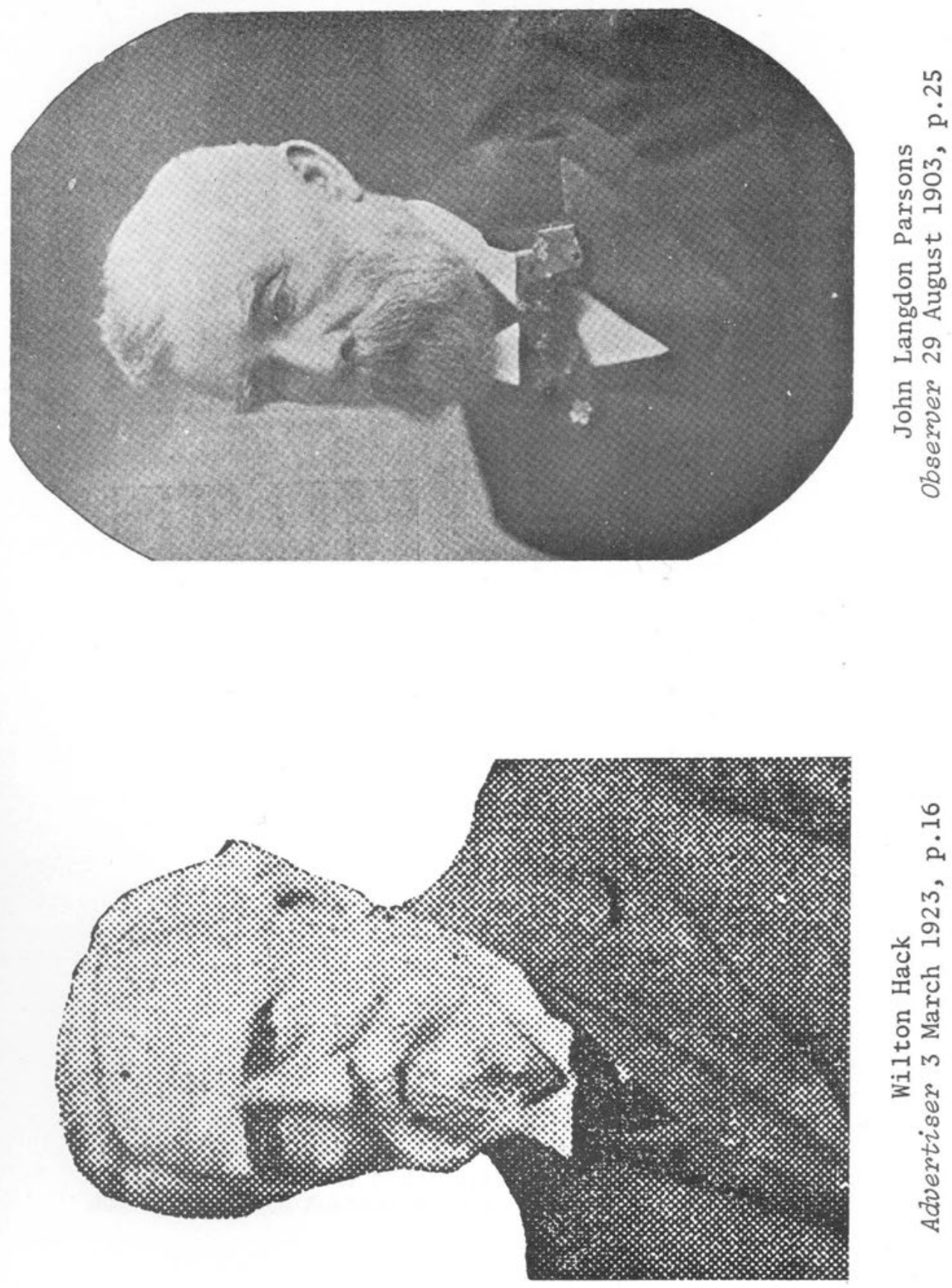

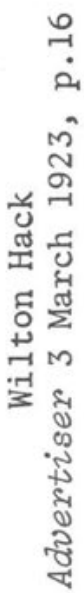


JAPANESE IN THE NORTHERN TERRITORY 1884-1902

by D.C.S. Sissons

\section{PEARLING $1884-1887$}

After several abortive at tempts commencing in 1824, the first permanent settlement in the Northern Territory by Caucasians was established in 1869. This was known as palmerston until 1911 when, on the transfer of the Territory from the South Australian to the Federal govermment, what had hitherto been the name of the port only, Darwin, was officially adopted as the name of the town.

Although men from the Celebes were not deterred by the white settlers from continuing their annual visits to the coasts of the Territory to fish for trepang and pearl-shell, the few attempts by Caucasians to raise she11 in this area in the 70 s were not a financial success and were soon abandoned. I

It appears that in 1882 several small proprietors independently began pearling operations based on Darwin; but they do not appear to have fished for she11 within the harbour. At the end of 1883 some of them attempted to float a company, the North Australian Pearlshe11 Co. There was an inadequate response from the public until, coincidentaliy, E. Streeter's schooner, Sree Pas Sair, called at Darwin on February 10th (1884) at the end of a cruise in which she had prospected for shell westwards from Admiralty Gulf (W.A.). Within a few days she had raised about l $^{\frac{1}{2}}$ tons of shell from the bed of Darwin harbour. The 
Sree Pas Sair carried no diving dresses, and after working over the shallower areas accessible to its 60 swimning divers, moved on. The public, rightly concluding from his discoveries that there would be more shell in the deeper waters of the harbour, now showed more interest in the North Australian Pearlshell Co. (which from the outset had proposed using diving suits) and by February 16th all its shares were taken up. At the first meeting of the Company (which was held on that date) it was announced that it was considering importing Japanese divers from hong Kong. ${ }^{2}$ It must have gone ahead with this; for the South Australian Register reports the arrival at Darwin of 12 Japanese divers on S.S. Kee Zung from Hong Kong on June 30 th and the arrival of 3 more on S.S. Catterthum on July 20th. ${ }^{3}$ These men were described by the Register as 'steady and industrious'.4 This apparently marked them off from the majority of divers who, according to the Government Resident, had been 'indulging in a prolonged debauch' and were 'quite unfitted for their work'. 5

It is possible that these Japanese were recruited by Gibb, Livingstone \& Co., a Hong Kong firm which, according to Alexander Marks (the Honorary Japanese Consul in Melbourne), was at about this time procuring Japanese on behalf of the Thursday Is. branch of Burns Philp \& Co., using two methods: it combed the Hong Kong boarding-houses patronised by discharged Japanese seamen; it also recruited in Japan using the Kobe firm, Fearon, Low \& Co. 6 According to the Passport Registers of the Japanese Ministry of Foreign Affairs, a number of passports were issued during April, May and June 1884, for Hong Kong, to men 'employed by Fearon, Low \& Co.' The names of the men are listed in the Registers and several of them became well known in the Japanese community at Thursday is. But the destination of one of them, Okada (whose passport was issued on May 24th) is known to have been Darwin. ${ }^{7}$ It is reasonable to conclude that the other fourteen who 
arrived at Darwin at this time were recruited in the same manner. Several Darwin pearlers bought their diving dresses, pumps, etc. from Burns Philps's Thursday Is, branch and it would have been only natural for such pearlers to have sought the assistance of this Company for their labour requirements aiso.9

Undoubtedly it was from Thursday Is that the N.A. Pearlshell Co. got the idea of using Japanese. Individual Japanese had begun to arrive in Thursday Is. by their own efforts in about 1878 and by the beginning of 1883 these numbered about 15. In November of the latter year the first group of Japanese recruited under contract for the industry were brought to Thursday Is. by the master pearler, Capt. John Miller. There were 37 in this group. 10 Communications between Thursday Is, and Darwin were, as we have seen, well developed and the businessmen of Darwin would have been aware of Miller's venture. Furthermore, they may well have seen the members of Miller's party taking exercise ashore when their steamer called at Darwin en route for Thursday Is. in November 1883.

The men who arrived at Darwin on 30 June 1884 may not have been the first Japanese divers at Darwin. As soon as the news of the Sree Pas Sair's success reached Thursday Is. the pearlers there joined in the rush. By early May there were 23 boats from Thursday Is. working at Darwin, Among them were some belonging to Capt. Miller. il These could well have had Japanese anong their crews.

The first report in the Dawwin press of any Japanese casualties among the crews of Darwin-based pearling boats appeared on 30 May 1885, when the Northerm Termitory Times \& Gazette reported that Capt. Denis's Lameroo (one of the N.A. Pearling Co.'s vessels) had returned to port at the insistence of the Japanese crew who had been disheartened by the deaths of three of their fellows. 12 Additional information 
on this point is provided in the official Register of Deaths for the Colony of Western Australia, which shows that on April 30th, at Derby, Capt. Philip Denis notified the death from measles the previous day of Nishimoto, a diver aged 26. Possibly Miyamoto, a seaman aged 20, whose death ('supposed to be dropsy') was registered at Derby one week earlier by 'Francis Ward, publican', was another of Denis's crew. These are the only Japanese deaths recorded in Westem Australia between 1883 and 1888.13 In June 1885 the occurrence book!14 of the police station of the Western Australian pearling town of Cossack (further to the south) records the presence of the Company's pearling schooner, the Flowerdale, 15 with one Japanese, Kinosuke, among its crew. This is the first Japanese name to appear in the cossack occurrence book. These entries suggest that the Japanese may have been first introduced into the Western Australian pearling industry by the Darwin pearlers rather than by the Thursday Is. fleets that moved to there in early $1886^{16}$ or by western Australian pearlers.

\section{PROSTITUTION}

Like former attempts, this attempt to establish at Darwin a pearling industry based on locally raised shell also ended in failure. By 1887, as the beds in Darwin harbour became depleted, most of the pearlers (who were also discouraged by the heavy Iicence fees demanded by the South Australian Government) moved off to more attractive bases elsewhere. 17 pearling in Darwin appears to have remained fairly inactive until 1892.18 Another industry, however, soon attracted some Japanese to Darwin. The Queensland weekly magazine, the Boomerang, on 12 May 1888 carried a report on a recent visit to Darwin. The literary style of the writer suggests that he was James Murdoch who, a generation later, achieved fame as the author of the famous three-volume History of Japcon. He reports that there were then in Darwin five Japanese brotheis con- 


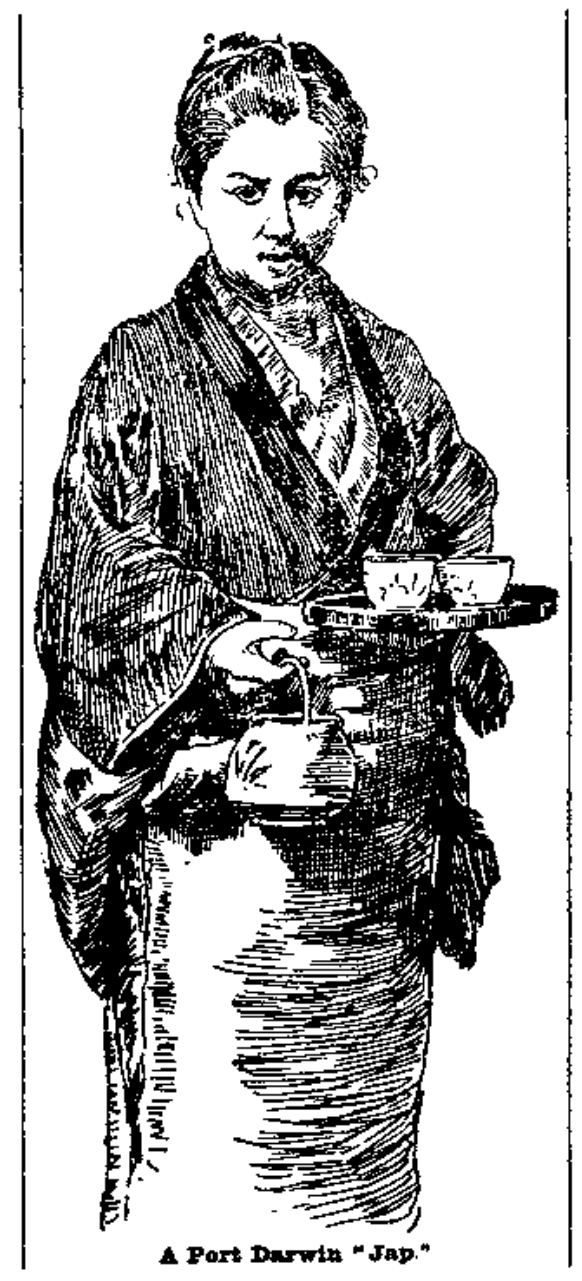

From the Queensland weekly magazine, the Boomerang, 12 May 1888. 
taining 25 Japanese prostitutes and that there were 'branch establishments down the Western Australian coast well nigh as far as Fremantle'.

A letter to Alexander Marks from H. Sato, a local government official from Hokkaido who visited Darwin the following April (1889), 19 puts the number of Japanese prostitutes in Darwin at that time at 19 . Sato's report also indicates that despite the downturn in pearling there were several Japanese men in Darwin engaged in other activities; for he mentions that a Iocal Japanese, Fujii, had become impoverished as a result of a fraud perpetrated on him by Takada (one of the principals engaged in the traffic in women) and that two local Japanese carpenters had come to Fujii's assistance and provided him with the money with which to return to Japan. Sato describes the two carpenters as 'ships carpenters'. Possibly, like the first Japanese arrivals at Thursday Is., they had left Japan by joining the crew of a foreign vessel and had eventually taken their discharges in Australia.

There is one other piece of evidence which confirms that there were some Japanese men, presumably unconnected with prostitution, in Darwin during the period between 1887 and the revival of pearling in 1892. When in 1895 a Royal Commission on the Northern Territory was appointed, one of the witnesses who gave evidence was C. Mann, a railway engineer. He was questioned about natters in the Territory during the period that he was there, i.e. from February 1888 to the beginning of 1890. He spoke of Japanese there as 'very natty little chaps' who 'beat the Chinese into a cocked hat'; they were very ambitious; they were refined in comparison with the Chinese; some were gentlemen. 20

In 1893 the Japanese Diet voted $¥ 10,000$ to defray the cost of surveys of overseas territories likely to be suitable for Japanese emigration. 21 of this sum 
$¥ 2,000$ was allocated to $K$. Watanabe to visit and report on Australia and some Pacific islands. In his 300-page printed report on Australia, Watanabe gives more detail about the Japanese prostitutes in Darwin and the means by which they were procured. According to Watanabe, there were at that time twelve Japanese women in Darwin all of whom had come there as prostitutes after plying their trade at places like Hong Kong and Singapore. All were from Kyushu - most of them from Nagasaki prefecture. Most were between 24 and 30 years of age; but some were only 17 or 18 . Two had married in Darwin. The women were distributed among three brotheis, 3 or 4 at each. Watanabe gives a very circumstantial account of the manner in which the traffic was conducted. The procurer would seek out poor fanilies and make an advance of $¥ 20$ - $¥ 30$ to the victims. (The par value of the yen was close to $2 /-$ sterling). He would then make arrangements with the captain of a foreign ship to smuggie them to Hong Kong or Canton at $¥ 50$ - $¥ 60$ per head. They would be put aboard from a fishing boat as soon as they were beyond the radius of surveillance by the water police. At Hong Kong the procurer would seli them for about $¥ 200$ $¥ 300$ and then return to Japan and repeat the process. 22 The letter from Sato to the Honorary Consul to which we have already referred 23 shows that the traffic was conducted in a similar fashion four years earlier. Writing in 1889 Sato states that Takada had come to Darwin with five young Nagasaki women who had been residing in Hong Kong. Of these he sold one to a Malayan barber for $£ S O$ and two to a Chinese at $£ 40$ each. One he put to work as a prostitute on his own account. The remaining girl he kept as a concubine. The c.i.f. price of Takada's women at Darwin is sufficiently close to Watanabe's price for Hong Kong to make both fairly credible. Other things being equal, one would expect the price at Darwin to be the higher. There would be a greater outlay on transport. Furthermore, according to the Japan Weekly Mait, the average monthly income of a Japanese prostitute was higher in Australia than any- 
Where else in the world - four times that available at Hong Kong. 24 On the other hand, a girl freshly landed from Japan might be expected to fetch a higher price than one who had been engaged in the trade for some time at Hong Kong. Doubtless, the market also fluctuated in accordance with the supply and demand locally.

At the present stage of our research, not much has been discovered about Japanese prostitution in Darwin after this date. It is possible (but by no means certain) that the Premier (Kingston), when in the course of a debate in Parliament in July 1896 he described Japanese arrivais in Darwin as 'of the worst sort', was using this phrase as a more refined altemative to the word 'prostitutes'.25 There is also a passing reference to Japanese prostitution in the course of the debate in the South Australia Imorgration Bill in December 1898. On that occasion one of the Members for the Northern Territory, V.L. Solomon (who incidenta11y was one of the original promoters of the N.A. Pearlshe11 Co. in 1883-4), referred to the provision which sought to make prostitutes a specific category of prohibited immigrants. He remarked that many Japanese prostitutes had lately landed in Northern Australia. 26 The texm 'Northern Australia', however, is a wide one and he may possibly have had in mind northern Queensland and the north of Westem Australia where there were many references to Japanese prostitutes in the newspapers of the day. 27 An article written at this time by the Sydney journalist, John Plummer, however, explicitly places the Northern Territory in the same category as the other two regions in this respect: The imnigration of Japanese women for immoral purposes is beginning to attract attention in Northern Queensland, the Northern Territory and Western Australia. They are said to filter through Hong Kong and Port Darwin ... 28 More concrete evidence of their presence emerged from time to time in the local press. On the night of 5 April 1898 Nagatomi, a Japanese diver 
employed by a pearler named Trehearne, was found dead in Cavanagh St. At the trial it was established that he had died from knife wounds inflicted by another Japanese, Okanoto, in a Japanese brothel. 29 My guess is that, as elsewhere in northern Australia, Japanese prostitution continued to thrive in Darwin until the federal Immigration Restriction Act in 1902 prevented further recruitment, and that it continued thereafter on a limited scale until, in the 1920s, the girls introduced before 1902 became too old for the business.

That there was at least one Japanese brothel operating in Darwin in March 1901 emerges from the evidence in the trial of a Japanese diver convicted for the attempted murder of a young Japanese woman at the rear of a house in Cavanagh St. 30 The proprietor, a Japanese woman testified that this was a house of ili-fame and that the victim was one of the inmates. The victim had received some $£ 8$ or $f 9$ from the diver, who wished to marry her. She had prevaricated and he had eventually become jealous. Armed with a sword and a pistol he had called her outside, upbraided her for 'deceiving him so many times', and shot her in the breast at point-blank range. The diver made off and wrote his suicide's letter in large Japanese characters on the surface of the town's tennis court. His resolution, however, failed him and, a week later, he gave himself up quietly at the police station. Apparently he had lived in Darwin for some time and was given a good character. Before sentence was passed the victim indicated that she did not wish a severe sentence to be imposed. According to the report in the press, the judge (Dashwood) 'after some hesitation agreed to take this into account', whereupon he sentenced him to 7 years hard labour 'and commented in severe terms upon coloured people going about armed'. This case has much in common with several others involving Japanese men and Japanese prostitutes at Thursday Is., Cossack, Boulder and Kanowna. The only unusual features, indeed, are the diver's choice of 
writing materials and his failure to make a serious attempt on his own life.

The South Australian census of 31 March 190131 shows that there were 39 female 'coloured natives of Japan' in the Colony on that date. It shows 38 of these as Iocated in the Northern Territory and the one remaining as in the category 'shipping'. This probably means afloat on census night. We can therefore say fairly confidently that this Japanese woman was aboard a pearling schooner or lugger based on Darwin. 32

According to the Census all of these 39 Japanese women were between the ages of 15 and 34 ; twelve of them were between 15 and 19 , seventeen of them were between 20 and 24 . Twelve were illiterate in their own language. Twenty-eight were unmarried. Of the 39, nine gave housewife as their occupation. The breakdown of the occupations given by the remainder is as follows: household servants 14 , lodgers 7 , visitors 3, tailoress/seamstress 3, boarding-house keepers 2, hospital inmate 1. Much more information is available about the Japanese women in Queensland and Western Australia at this time and from that information $I$ have been able to establish that more than half were prostitutes. ${ }^{33}$ In the light of this and of the ages, literacy, conjugal condition and stated occupations of the Northern Territory women I should be very surprised if the proportion of prostitutes among them was not very similar. The Missionary Review of 12 December 1898 in a report on the 'Moral Atmosphere of Darwin' put the proportion much higher: 'The Japanese women are almost all professional prostitutes, the Malay women are nurse-girls, the Chinese women are mostly patient grudging wives', 34 
Pearling at Darwin revived in 1892.35 According to the evidence given by the master pearler, Capt. Edwards, before the Dashwood Commission at Darwin in 1902, this was thanks to the arrival from Western Australia of a diver naned 'Charley Japan'. 36 This was only a year before the report by Watanabe to which we have already referred. Fortunately the Iatter deals with him in some detail. 37

Watanabe does not appear to have met him; for he does not give his Japanese name, Hamaura, 38 but refers to him only as 'Charley'. According to Watanabe, he was from Nagasaki prefecture and left Japan as one of the crew of a foreign ship in 1880. After three years on the world's sea lanes he took his discharge somewhere in the northern part of Australia and was employed for a long time in the pearling industry at Cossack (W.A.). The seafaring life had, however, made him restless and he moved from place to place in Australia, finally ending up in Darwin in February 1892. Just at that time a Caucasian happened to be setting up in business as a pearler. He employed him as a diver. Hamaura found such a quantity of shell that before the end of 1892 he was able to equip his own boat and summon some of his countrymen from Western Australia to serve as his crew. Other Japanese heard of his success and came to Darwin, bringing the Japanese population of Darwin up to about 30 in 1892 . The Government Resident in his annual reports to the South Australian parliament for the years 1892 and 1893 confirms this overall picture. He notes that with the abolition of the annual licence fee pearling was resumed in 1892 , that at the end of the year three boats were shelling in the harbour and that these were 'owned and worked chiefly by Japanese'.39 Watanabe writes that in 1893 Caucasian owners, attracted by the success of the Japanese, entered the industry using Japanese labour. Watanabe was exultant and used such phrases as 'In the 
field of pearling here the Japanese already have the mastery' and 'Here if you say "Japanese" you mean "diver" just as if you say "Chinese" you mean "miner"". In more restrained Ianguage the Harbour-Master in his report for 1893 reached a similar conclusion: 'The divers and crew are principally Japanese - a fine, sturdy and steady lot of men'.40

Watanabe noted that at that time (1893) there were 21 Japanese men and 12 Japanese women in Darwin. of the men 16 came from Wakayama, 3 from Nagasaki, 1 from Fukuoka and 1 from Miyazaki prefectures. Al1 but one of them (a photographer) was engaged in the pearling industry. Three out of the 21 were masters, not employees. This gave him considerable satisfaction. He contrasted California and the State of Washington, where thousands of Japanese were other men's servants, with Darwin and Thursday Is. where Japanese were engaged in independent occupations and could look whites in the face. The Japanese wage-earners, too, he said, were doing well. The ordinary Japanese were getting $£ 3-£ 5$ per month and the better divers $£ 7-£ 8$. In al1, he concluded that the local Japanese had only one thing to be ashamed of - the prostitutes. 4 I

At the end of 1893 only two of the six luggers operating from Darwin were owned by Japanese. The remainder were owned by Caucasians. 42 Nevertheless, on December 28th of that year a deputation of the latter waited on the Government Resident (Dashwood) and urged that no more pearling licences be issued to Asiatics. They claimed to be apprehensive of 'an influx of boats owned by Asiatics from Thursday Is. 143 Dashwood feit that to restrict licences in this manner would have the effect of confining to its existing size and its present owners an infant industry capable of considerable expansion. Alternatively, the policy would be frustrated as a result of some Caucasians taking out Iicences and leasing the boats to Asiatics. Instead, he proposed that those of the petitioners who 
had recently discovered new areas of shell be given for a period the exclusive right to fish them. The Government adopted this course. In his advice to the Minister, Dashwood spoke highly of the Japanese and their contribution to the industry:

Those principally engaged in the active part of the work are Japanese. There are six or seven employed in each boat. They spend their money in the place and from all $I$ learn are anything but undesirable Colonists.

Even if it be considered advisable to discontinue issuing licences to Japanese $I$ have no doubt that they will be enployed in the fishing operations as they carnot very well be done without; they are undoubtedly the best divers.

In April 1895 the Caucasian boat-owners reiterated their request in a petition to the South Austraitian Parliament, arguing that there was a danger that Asians would monopolise the industry. 44 But the threat, if any, seems to have come not from the Japanese, but from Europe. The Report of the Government Resident for 1894 indicates that at the end of that year the total number of luggers engaged in the industry was 18. The $J$ apanese had increased their number from 2 to 3 ; the Iocal Caucasians still had 6; but 9 luggers belonging to a lnited Kingdom company had arrived from the Kai Is. 45 In this situation it is hard to give credence to $w$. Griffiths, the junior Member for the Northern Territory, when, on July 3ist in leading the debate on the petition in the House of Assembly, he asserted that 'very great harm [was] being done to the pearling industry in the Territory owing to the increase of Japanese engaged'. Nor, in the light of the prominent part played by Hamaura in the revival of the industry in 1893, can we accept Griffiths' complaint that the Japanese were profiting from discoveries made possible 
by the investment of vast sums by white enterprises. 46 Replying for the Govermment, the Treasurer (who was concurrently the Minister responsible for the Northern Territory) took the contrary view. He argued that it was the Japanese who were the prospectors and that the present extent of the pearling industry was largely due to their entexprise; it was desirable that the industry should be developed and the Japanese were the most likely people to develop it. 47 One Member, P.M. Glynn, took the argunent a step further and suggested that the real purpose of the petitioners was to ensure that the Asiatics had no alternative to working for then at starvation wages. 48

On September 20th (1895) the Northem Temitomy Times drew attention to the arrival of a Japaneseowned lugger from Thursday Is, to prospect for shell on the Northern Territory coast and to the 'current runour that a rush of Japanese boats from Thursday Is. to Port Darwin will shortly take place'. It reported a similar rumour on October $4 \mathrm{th}$. On October 5 th the South Australian Government abandoned the position that it had maintained during the debate in Parliament in July and, in announcing that the other Australian Colonies had agreed to its proposal for an intercolonial conference to consider both Asian imnigration and the Anglo-Japanese commercial treaty, added that in the meantime it would issue no further pearling Iicences to Asiatics. 49

This was a diplomatic way of imposing a ban that was intended to be permanent; for the purpose of Kingston, the South Australian Premier, in calling this conference was to ensure that no Australian colony entered the Treaty and to ensure that aIl the colonies extended their existing anti-Chinese legislation to prevent the entry of other coloured peoples such as Indians and Japanese. Kingston had for years been committed to Asian exclusion. He was a member of the South Australian Government that provided the initi- 
ative for calling the conference in Sydney in 1888 that drafted the uniform legislation to exclude the Chinese. At that conference he was a member of the sub-comittee that drafted the uniform legislation. This subcomnittee had proposed that the legislation apply to all Asian 1abourers generally; but the Conference had overridden it on this point and confined the operation of the legislation to Chinese. 50 Kingston had since 1892 been trying to hold an inter-colonial conference to remedy this deficiency, but had been blocked by the resistance of the New South Wales Government. It would appear that he was now taking advantage of the ratification of the Anglo-Japanese treaty on 25 August 1894 (and the provision in it that gave each Australian colony the option, limited to two years, to join it) to secure his basic objective of overall Asian exclusion. Aiso, faced with the possibility of a greater influx of Japanese boat-owners (and their Japanese crews) from Thursday Is. than in July he had believed likely, he was now provided with a convenient opportunity discreetly to abandon the position that his Government had adopted on that occasion. Accordingly, in a telegram to the Queensland Premier on October 8th he requested the latter to ensure that the Japanese at Thursday Is. were informed that they could not rely on the South Australian Government's issuing them with licences for pearling in the Northern Territory. 51

At the inter-colonial confexence, (which duly met in March 1896) the colonies agreed to introduce legislation excluding all Asian immigrants. The legislation passed by the South Australian Pariiament, however, failed to secure Royal Assent. It appears that the number of Japanese employed in the pearling industry continued to rise.

From the following account in the local newspaper of the affray that took place in Darwin's chinatown on the night of 18 December 1895 it is evident that the Japanese community was at that time large enough to 
possess a two-storey club house and to field a side of 30 to 40 against a similar array of Malays and

Manilamen.

The trouble was between a crowd of Japanese on one side and an array of Malays and Manilamen on the other, and the fight was very furious until Sgt. Waters and $M / C$ Campbell got in amongst them and scattered the rioters. Sticks and stones were the implements of warfare, and with these heads were cut, bodies bruised, and houses turned into ruins. Rackiman's barber's shop was smothered in broken glass, whilst the two-storied Japanese club house over the way had not a solid pane of glass left above or below. It was truly a willing battle, the upshot of which, if it had not been stopped by the police, would certainly have been murder. It is estimated that the combatants mustered thirty to forty a side .... The only humorous incident of the battle was the landlord of the Japanese ciub consistently blowing a trumpet while the doors and windows were being smashed all about him...52

The South Australian Govermment do not appear to have collected statistics which would enable them to know with any accuracy the size of the Japanese population in the Northern Territory in these years. 53 Fortunately, for the years 1896-1900 'the Darwin area' appears as an entry in the census conducted by Japanese consulates annually on December 3lst. From these it is possible to compile the following table. 
Annual Consular Returns of Japanese Population

in the Darwin Area

$1896-190054$

\begin{tabular}{|c|c|c|c|c|c|c|c|c|c|c|c|}
\hline & \multicolumn{2}{|c|}{$\begin{array}{c}\text { Public } \\
\text { officials }\end{array}$} & \multicolumn{2}{|c|}{ Students } & \multicolumn{2}{|c|}{ Trade } & \multicolumn{2}{|c|}{ Others } & \multirow{2}{*}{\multicolumn{2}{|c|}{$\begin{array}{l}\text { Total } \\
\text { M F }\end{array}$}} & \multirow[t]{2}{*}{ Total } \\
\hline & $M$ & $\mathrm{~F}$ & M & $\mathrm{F}$ & $M$ & $\mathrm{~F}$ & M & $\mathrm{F}$ & & & \\
\hline $\begin{array}{l}31 / 12 / 96 \\
31 / 12 / 97 \\
31 / 12 / 98 \\
31 / 12 / 99 \\
31 / 12 / 1900\end{array}$ & & & & & $\begin{array}{l}2 \\
6 \\
1 \\
2\end{array}$ & $\begin{array}{l}2 \\
3 \\
- \\
-\end{array}$ & $\begin{array}{r}130 \\
92 \\
270 \\
237 \\
183\end{array}$ & $\begin{array}{r}35 \\
9 \\
18 \\
35 \\
28\end{array}$ & $\begin{array}{r}130 \\
94 \\
276 \\
238 \\
185\end{array}$ & $\begin{array}{l}35 \\
11 \\
21 \\
35 \\
28\end{array}$ & $\begin{array}{l}165 \\
105 \\
297 \\
273 \\
213\end{array}$ \\
\hline
\end{tabular}

How many of the 'Others' shown in the above Table were in each year engaged in the pearling industry we cannot say with certainty. An undated report by the Consul made some time during 1897 does, however, give a breakdown into occupations at that time. He notes that, since the preceding December the total Japanese population had fallen from 165 to 91 because a number had been attracted by better conditions at Thursday is. and, to a lesser degree, at cossack. He notes that, with the exception of 1 doctor and 5 boarding-house keepers, aI 1 are engaged in pearling and that about $70 \%$ are from Wakayana prefecture. 55 In the absence of any evidence to the contrary, we may assume that, at least during the season, a very high proportion of the Japanese were each year engaged in pearling. In March 1896 the employment of $40 \mathrm{~J}$ apanese on construction work on the jetty prompted an editorial in the Northern Territory Times which conjured up visions of Japanese competition against white labour more serious than the existing competition from Chinese 1 abour. 56 This was, however, during the lay-up period, when storms and dirty water made pearling impossible and the crews were paid off. This period normally extended from December 
to March, 57 but in the year in question continued into April.58 Such employment would have been permitted only when white labour was not available. 59 The South Australian Census of 31 March 1901 demonstrates that a very high proportion of the Japarese men in the Northern Territory at that date were engaged in the pearling industry. Of the 166 male coloured natives of Japan in the Colony it shows 64 as located in the Northerm Territory, another 99 in the category 'shipping', and the remaining 3 as located in Adelaide. We can say fairly confidently that the 99 described as 'shipping' were aboard pearling schooners or luggers based on Darwin. 60 The 3 Japanese in Adelaide are not a sufficiently large number to make the census breakdown by occupations for the whole Colony misleading if applied to the Northern Territory only.

$$
\begin{aligned}
& \text { S.A. CENSUS OF } 31 / 3 / 1901 \text { - } \\
& \text { COLOURED NATIVES OF JAPAN (MALES) }
\end{aligned}
$$

OCCUPATIONS AND AGES

\begin{tabular}{lcc}
\hline Occupation & $\begin{array}{c}\text { Number so } \\
\text { Occupied }\end{array}$ & $\begin{array}{c}\text { Employment Status } \\
\text { (All are wage- } \\
\text { eamers unless } \\
\text { otherwise indicated) }\end{array}$ \\
\hline Ordinary Seaman & 36 & 3 unemployed \\
Pearl Diver & 28 & 3 unemployed \\
Pearl Diver's Tender & 1 & \\
Pearl Diver's Yardman & 3 & \\
Ship's steward & 9 & \\
Miner - gold, quartz & 7 & \\
Miner - gold, undefined & &
\end{tabular}




\begin{tabular}{lcl} 
Occupation & $\begin{array}{c}\text { Number so } \\
\text { Occupied }\end{array}$ & $\begin{array}{c}\text { Employment Status } \\
\text { (All are wage- } \\
\text { eamers unless } \\
\text { otherwise indicated) }\end{array}$ \\
\hline Miner - undefined & 1 & \\
Mine Night Watchman & 1 & self-employed \\
Boarding-House Proprietor & 1 & \\
Boarding-House Cook & 1 & \\
Domestic Cook & 3 & both self-employed \\
Domestic Servant & 2 & self-employed \\
Laundryman & 2 & 1 employed; \\
Merchant & 1 & \\
Shopkeeper & 2 & \\
Storeman & 2 & 1
\end{tabular}

It will be observed that of the total of 166,151 were wage-eamers, 6 were unemployed, 6 were selfemployed, and 2 were employers. The young predominated. Dividing the total according to age groups we have: $20-24$ y.o. $59,25-29$ y.o. 50, 30-39 y.o. 35, 4049 y.o. $8,50-54$ y.o. 4 . The Census also reveals that 160 were unmarried and 81 were illiterate in their own language. 
Assuning, as is not unreasonable, that the large majority of the 62 ordinary seamen were crewmen on pearling vessels, we may conclude that close on 130 of the 166 Japanese males in South Australia on 31 March 1901 were engaged in pearling in the Northern Territory. outside the pearling industry the next largest occupational group anong the Japanese were those employed in the mining industry - $18 \mathrm{in}$ a11. As in the other two Colonies where mining was carried on extensively (Queensiand and Western Australia), Asiatics were ineligible to receive a miner's right on new goldfields. It is therefore not surprising that these 18 were all wage-earners. 61

The information about employment status suggests that by 1901 none of the Japanese operated pearling luggers; for only two of the Japanese - the carter and one of the shopkeepers - are described as employers. As we have noted, the policy of issuing no new pearling licences to Asiatic aliens was adopted in 1895. At that time Japanese held licences for four luggers: Hamaura - Cleopatra and Black Jack; Oto Okanura Jack; Haru - Bulldog. 62 By February 1898 the figure had declined to one - Hanaura's cleopatra63 - and this seems to have lapsed during 1899.64 In 1899 Okamura bought Garnet from A.E. Jolly \& Co. and was issued with a Iicence. This, however, was revoked almost immediately on the ground that, although with Hamaura he had been one of the pioneers of the local industry, he nevertheless was not in possession of a current licence at the time he bought Gamet. Complaints were made by Caucasian pearlers (sometimes on the basis of information received from their own Japanese crews) that Japanese continued to operate boats by getting European 'dumies', for a consideration, to take out licences for then. (This, as we have already observed, is what Dashwood had predicted). In January 1899 it was alleged that Electra and Daisy, licensed to A.E. Jolly $\xi$ Co., were in fact operated by a Japanese syndicate. In March the Sub-Collector of Customs, as a result of 
similar suspicions, refused applications for four additional licences for this firm. In April it appears that licences may have been witheid in the case of a lugger or luggers in which two Japanese, Asari and Fujimoto, had an interest. 65 In November regulations were gazetted which made mandatory the denial of licences to Asiatic aliens. (The basis of this policy in the past had been administrative discretion). The new regulations also made the licencee liable to a maximum penalty of $\$ 100$ and the forfeiture of the vessel if any Asiatic alien leased, chartered or had any direct or indirect interest in it. 66 How effective these regulations were, at the time or in later years, we cannot tell. In Western Australia where similar legislation was enacted, very few charges were ever laid because it was found next to impossible to secure evidence sufficient to sustain a conviction. 67 Possibly it was the same in the Northern Territory.

The size of the Japanese population as given in the Consular return for 31 December 1900 (v. supra p.18) is sufficiently close to the Census figure for 31 March 1901 for us to regard the Consular returns as reasonably accurate. We may therefore accept that, as shown in the Consular returns, there was a decline in the Japanese population after 1898. Whether there was any reason for this other than fluctuations in the requirements of the pearling industry is not known. On 20 July 1898 a Proclantion was issued by the South Australian Executive Council directing all Customs officers 'subject to the approval of the Honourable the Treasurer ... to refuse and prevent admission into South Australia of any alien not entitled by treaty to enter South Australia ...' Some two months later, in the course of the debate in Parliament on the abortive Immigration Restriction Bill, Kingston explained the function of this Proclamation. 68 He said that while, in the absence of a statute such as that under discussion, there was no power to prevent the entry of British subjects (e.g. Indians or Hong Kong Chinese), 
the decision given by the Privy Council in Chung Toy $v$. Musgrove 69 in 1891 established that aliens had 'no legal right, enforceable by action, to enter British territory' and that, accordingly, they could be excluded by executive act. In answer to a question by another Member, he elaborated on this and stated that, in the case of the Japanese, the Govermment had two strings to its bow; the first was the dictation test in English provided in the Bill; but in the case of a Japanese who was proficient in English they could rely on the Proclamation. The latter continued to be published regularly in the Northern Territory official Gazette until the federal imnigration Restriction Act came into effect in 2902. Shortly after the Proclamation was issued in 1898 the South Australian Government also warned the shipping companies trading between Darwin and the Far East that steps were being taken to prevent the introduction of Asiatics into the Northern Territory. 70 Whether, like this warning to shipping companies, the Proclamation was used merely as a deterrent, or whether it was ever invoked to prevent the entry of Japanese into the Territory, is not known. In my opinion it would have been surprising if at this time the South Australian Government prevented the entry of Japanese employees under contract to Caucasian pearlers. It appears that some may have been adnitted in the months following the March 1901 census - either by the South Australian Government or, after December 1901, by the Federal Govermment; for the Dashwood Report published in 1902 shows a slight increase over the census figures in the number of Japanese engaged in pearling at Darwin ( 37 divers and 99 crewmen as against 36 divers and 94 crewmen). 71 It is, however, possibie that the difference could have been the result of movement from Thursday Is. or Western Australia.

SIZE OF JAPANESE POPULATION AT DARWIN COMPARED WITH THURSDAY IS. AND BROOME

It should be bome in mind that, as the following table indicates, just as the total take of shell at. 
Darwin was small in comparison with that at Thursday Is, and Western Australia, the number of Japanese at Darwin was sma11 in comparison with those places.

\begin{tabular}{|c|c|c|c|c|c|c|}
\hline & \multicolumn{3}{|c|}{$\begin{array}{c}\text { Take of Mother-of-Pearl Shell } \\
\text { (tons) }\end{array}$} & \multicolumn{3}{|c|}{ Japanese Population 73} \\
\hline & $\begin{array}{l}\text { Northem } \\
\text { Territory }\end{array}$ & Queensland & $\begin{array}{l}\text { Western } \\
\text { Australia }\end{array}$ & $\begin{array}{l}\text { Darwin } \\
\text { Area }\end{array}$ & $\begin{array}{c}\text { Thursday Is. } \\
\text { Area }\end{array}$ & $\begin{array}{l}\text { Broome } \\
\text { Area }\end{array}$ \\
\hline 1896 & 189 & 1089 & 362 & 165 & 618 & \\
\hline 1897 & 137 & 1223 & 366 & 105 & 1044 & \\
\hline 1898 & 193 & 1061 & 538 & 297 & 1416 & \\
\hline 1899 & 211 & 1200 & 610 & 273 & 1138 & \\
\hline 1900 & 174 & 1060 & 607 & 213 & 994 & 362 \\
\hline
\end{tabular}

This remained the case throughout the history of the industry. The maximun take in the Northern Territory was 804 tons in 1937 (cf. 1131 tons in Queensland and 919 tons in W.A. for that year). The maximum take in Queensland was 1,429 tons in 1929 (cf. 750 tons in the Northern Territory for that year). The maximum take in Western Australia was 2007 tons in 1917 ( $\mathrm{cf}$. 30 tons in Northern Territory for that year).

Pearl shelling off the Northern Territory coast by Japanese-owned vessels on the Japanese registry is a phenomenon belonging to a later era - 1931-1941. Some unconfirmed figures for the numbers of Japanese luggers operating there in that period are 193416,193674 , $1937120-145.75$ 


\section{JAPANESE GRAVES AT DARWIN}

In contrast to the large number of Japanese graves at Broome and Thursday Is., there are few surviving Japanese graves in Darwin cemeteries. In October 1973 at the old ("Palmerston") cemetery76 I counted 7 Japanese headstones commemorating 16 deaths. Of these one was undated, the others ranged from 1913 to 1931 . In the newer ('Gardens Rd.') cemetery77 I counted 21 Japanese headstones commemorating 27 deaths. All of these were dated. They ranged from 1924 to 1938 .

ABORTIVE PLANS TO DEVELOP AGRICULTURE IN N.T. USING JAPANESE IMMI GRANTS

It is apparent from the 1901 Census that none of the Japanese in the Northern Texritory at that time were engaged in the agricultural or pastoral industries. This shows a situation quite different from that in Queensland, where the Census taken on the same date indicates that out of the total of 2,072 Japanese males no less than 947 were engaged in these industries, distributed as follows: sugar plantations 817 , sugar-mills/refineries 63 , farm servant/agricultural labourer 32 , firewood cutter/chopper 18, market gardener 9, fruit grower/orchardist 8 .

It appears that at least three attempts were made to introduce Japanese immigrants into these industries in the Northern Territory. Each was abortive.

\section{Wilton Hack's Venture 1876-77}

In $1924 \mathrm{~S} . \mathrm{H}$. Roberts published his account of a plan in 1876-77, supported by the South Australian Government, to attract Japanese immigrants to the Northern Territory. 78 His discovery that such a $\mathrm{p}$ tan existed has added an interesting and unexpected fact to the history of Australian-Japanese relations and 
his most important conclusion - that the South Australian Government of the day was not opposed to imnigration from Japan - is correct. There is, however, much that is incorrect in Roberts's account and, since its inaccuracies are still finding their way into print fifty years later despite the publication of a more accurate interpretation by another scholar, $\mathrm{J}$. Cross, in 1960,79 it is appropriate that they be corrected.

Roberts's account is as follows:

The apex of this activity came in 1876 with a scheme, which, had it come to fruition, would have changed the whole nature of the Northern Territory's history and the social and economic development of all of Australia. This, the most important single scheme ever propounded for Australian development, was no less than a plan to transplant portion of Japan in toto to northerm Australia. There cannot be the slightest doubt as to the implications of the plan, for the documents still exist in manuscript in the Home and Territories Department, Melbourne; nor can there be any doubt as to its aims, for Blyth made it a special point to secure the signature of each individual Minister in his Cabinet - probably in case anything went wrong.

Japanese Jabourers, Japanese farmers, Japanese aristocrats - all were included in the scheme - and it was declared again and again that their position was not to be that of the Chinese coolies. They were not to be mere mine-workers or servants on the stations, but were to have their own land in fee-simple, and were to enjoy the rights which they had in their native-1and, plus the privileges ordinarily assigned in law to Australian citizens. For example, the Minister for Foreign Affairs at Yokohama was informed 
"that this proposition is not intended to bring about the emigration of a labouring class only, to be hired out to foreigners, but that those who emigrate should settle upon land of their own selecting, and be in this way their own masters free to depart from Australia the moment they are disposed to do so".

A special land clause was drafted for the settlers; copies of the regulations were translated and broadcast among the peasantry of Japan; a free passage was promised to all emigrants; a bonus was to be given to sugar producers; and arrangements were made for a reproduction of Japanese social conditions. To expedite all of these, the Government appointed a special paid Agent - Wilton Hack - an ex-missionary of a leading South Australian family. Incidentally, this man was the first diplomat appointed by a colony to negotiate directly, and without the consent of Britain, with a foreign power.

After special Cabinet meetings, Hack was directed to proceed to Tokio "and to lay before the authorities and the public there full particulars respecting the terms on which settlement may take place in the Territory, and the nature of the country". He was given letters as the paid and accredited Agent of the Government, with authority to deal officially with the matter. At first, he was successful, for, early in February, 1877, the Japanese Foreign Office agreed to the general principle. "I was assured," reported Hack, "that no obstacle would be placed in the way of Japanese emigrating". The arrangements for shipping "some three or four hundred" Japanese had practically been completed; the Government had considered such details as the actual site of the proposed settlement; and satisfaction had been expressed with the idea that a bonus of 
24,000 dollars made it possible for Japanese middlemen to join the venture; when the whole plan was ruined.

At this point, Australian history links on to Japanese feudalism, for, just a fortnight before Hack's appearance in Japan, there had commenced a revolt against the abolition of the last relics of feudalism. This was the first organized at tempt to overthrow the "Heiji" or enlightened rule. Therefore, when the popular hero, Saigo Takamori, called out the Satsuma swordsmen of the West, the very existence of the Kyoto Government was threatened. Europeanization in Japan was on its trial; and news of the western upheaval had just reached the Imperial Court in the very week of Hack's negotiations. Surely the chronological coincidence could not be clearer. As tidings of the formidable nature of the rebellion filtered through to Kyoto, and when it was seen that this was no mere local disorder, the Government inevitably turned away from foreign ventures, such as that proposed by Hack.

Novel and hazardous schemes of emigration could not be considered when a return to feudal ism was imminent. Accordingly, after more negotiations, Tshibashi [sic] of the Foreign Office informed Hack that, "as to the question of Japanese emigration to South Australia, it is a matter which the Japanese Government is not disposed to encourage or aid under present circumstances". This was quite unexpected by South Australia's envoy, for, on the morning of Februaxy 16th, 1877, he had considered matters so far clinched that his attitude was quite dogmatic on small points, while, by that evening, the plan had been decisively rejected, and his attitude was that of a suppliant. The Japanese Govemment's attitude can easily be explained, for they realized that the feudal 
revolt was a watershed in the history of Japan, and they knew how serious it was. The revolt actually meant seven months of hard fighting before Saigo's head fell, and by that time, of course, there were problems of reconstruction. Reporting in September, Hack wrote "the continuance of the insurrection in Japan continues and increases the complicated relationship which exists between Japanese and foreigners, and $I$ an afraid some time must elapse before there is much hope of facilities being put into the way of would-be enigrants from Japan".

Thus the proceedings are faicly complete. The South Australian Goverment did formulate plans for a systematic colonization of the Northern Texritory by all classes of Japanese, and, in defiance of their constitutional position, $d i d$ appoint an Agent to deal directly with a foreign power. For its part, the Japanese Government, newly awakened from medievalism, $d i d \vec{c}$ considex the scheme and $d i d$ receive and recognize an accredited Agent of one of the Australian colonies. No other Australian Government has ever promulgated a schene of such magnitude and so far-reaching implications as did Blyth's Cabinet of 1876-1877; and that they desired to push this scheme to its utmost is evident, for, even when receiving Hack's final report, the last word of the Cabinet was in "regretting that your negotiations were not more successful".

The following corrections are suggested as a result of an examination of the collection of papers now in the South Australian Axchives from which Roberts' account was solely derived. 80

In the first place, the Ministry in office throughout the whole episode was the Colton Ministry (consisting of $J$. Colton, Sir H. Ayers, J.C. Bray, R.D. Ross, 
J. Carr, E. Ward), not the BIyth Ministry. Secondly, from Roberts's account one gets the impression that the Government drew up a fairly elaborate scheme and then selected Hack to carry it out. Roberts definitely claims that there were special Cabinet meetings and that the 'plan' was accepted by Cabinet, with the Premier (in rather sinister fashion) ensuring that each individual Minister put his signature to it. This picture is not supported by the evidence in the documents.

Hack was born in South Australia in 1843. A Baptist layman, he went to Nagasaki as a missionary in 1873. ${ }^{1}$ This was very early in the history of Protestant missions in Japan; for, although under the treaties of 1859 the freedom of foreign missionaries within the Concessions in the Treaty Ports was guaranteed, up to 1873 to be a Christian remained a criminal offence for a Japanese. Up to 1872 there were only 28 Protestant missionaries in Japan and they had baptised only 10 Japanese. In 1873 the old 'Edict Boards' proscribing Christianity were removed and another 29 Protestant missionaries arrived. 82 Hack, no doubt, was one of these 29. How long he remained in Nagasaki is not clear; for in a Japanese Ministry of Education's list of foreign missionaries in its employment Hack appears as a teacher of English at a school in Hiroshima (some 200 miles from Nagasaki) from June 1874 to May 1875.83 According to Cross, Hack's teaching appointment was terminated by the Japanese Government because of his missionary zeal and, deprived of his source of income, he found it necessary to return to South Australia in 1876 to appeal for funds for his missionary work. It was during this visit that Hack raised with the South Australian Government the possibility of securing Japanese immigrants for the Northern Territory. On July 29 th he wrote to the Commissioner of Crown Lands drawing his attention to the excellent qualities of the Japanese as cultivators and offering to take up the 
question with the Japanese Government. Cabinet on August 14th approved his 'visiting the Northern Territory and obtaining what information he can with a view to his disseminating the same in Japan, particularly anong Japanese who have been accustomed to gold mining operations'. On September 5th it approved the grant of $£ 50$ to cover Hack's expenses, plus an additional $f l 00$ if he found it necessary to visit the Northern Territory. Hack in turn undertook 'to lay before the Government of Japan the particulars relative to this matter'.84 The extent of these 'particulars' is indicated by the Minister of Education and Agriculture's minute on Hack's offer. 'He would ... Iay before the authorities and the public there full particulars respecting the terms on which settlement may take place in the Terxitory and the character of the country'.85 There is nothing in the documents to suggest that these terms differed from the normal terms available to any settler in the Territory. Nor is there anything to suggest that these two Cabinet meetings were anything more than ordinary meetings at which Hack's proposal was a minor item on the agenda. Roberts's view that all ministers were required to sign the decisions can only arise from a misinterpretation of the two groups of initials, H.A. and C.S., appearing each time after 'Approved in Cabinet'. These, however, merely indicate that the writer was ' $\mathrm{H}$. Ayers (Chief Secretary)'.86 The only indication that the project was ever again before Cabinet was the minute, 'Forwarded to the Hon. Chief Secretary for information of Cabinet', which appears on Hack's later letter announcing the failure of his negotiations with the Japanese Government. 87

The elaborate plan which, one gathers from Roberts, was before Cabinet, was in fact never before them. Its details Roberts derived from letters from Hack, seen for the first time by the Minister of Agriculture and Education after the failure of Hack's negotiations in Japan. There is nothing to suggest 
that even at that date Cabinet would have seen them. Some of the details, such as assisted passages, Roberts derives from an advertisement Hack drew up in Japon for subsequent approval by the South Australian Government. 88 As Cross points out, Hack had no authority to offer assisted passages and it is most unlikely that the South Australian Government would have sanctioned this. 89 Roberts's mistaken conception of the plan arises also from his misunderstanding of passages in one of Hack's letters to the Japanese Minister for Foreign Affairs.90 In this letter Hack referred to his enclosure of 'a copy of the land act of South Australia, with the special clause annexed, that has direct reference to the proposed occupancy of Australian lands by Japanese'. It was from this presumably that Roberts concluded that 'a special 1 and clause was drafted for the settlers'. Although an Act to Amend the N.T. Land Act 1872 (No. 48 of 1876) received assent on October 27,1876 , it is obvious from its contents and from the debate on it in Parliament ${ }^{91}$ that it had no relevance to the proposed Japanese immigration. The act which Hack forwarded was without doubt the principal act dealing with selection in the Northern Territory, the Northern Territory Land Act 1872 (No. 28 of 1872), and the clause which he marked was Sect. 81, the particular provisions of which are exactly paraphrased in the advertisement Hack intended to publish - 'every settler has the right to select for himself a tract of fertile land varying from a few acres to more than a thousand. For this ground he pays to Government 12 cents per annum for each acre as rent. At the end of 5 years if one half of the ground selected is under cultivation, and the whole surrounded by a fence, the whole lot or selection will be handed over to the selector without further charge'.92 Similarly Roberts is mistaken when he implies that a bonus on sugar production was arranged for the Japanese. The bonus Hack refers to dated from 1870.93 
Roberts's final conclusion is also disputable 'that they [the Cabinet] desired to push this scheme to its utmost is evident, for, even when receiving Hack's final report, the Iast word of the Cabinet was "regretting that your negotiations were not more successful"'. In the first place this view, attributed to Cabinet, is merely that of the Minister of Agriculture and Education. 94 This sentence is in fact that Minister's cold and effective reply to Hack's plaintive suggestion 'Should you be pleased or satisfied with the way in which I conducted the negotiations in Japan is it too much to ask that you so express yourself in writing ${ }^{1} .95$ (Previous to this, in the letter in which he announced the failure of his negotiations, Hack had sought Govemment employment in the Northern Territory.96 The Minister's answer had been that he was 'at present ... unable to offer ... any appointment .97 )

The picture that energes from the documents is not sensational. It is that the Cabinet were certainly prepared to accept Japanese migrants and to offer them the terms generally available to all settlers. To this end they were prepared to defray the modest travelling expenses of an enthusiastic missionary who, as events tumed out, was also somewhat lacking in judgment. As Cross points out, Hack's position was no different from that of other temporary publicity agents with whom the South Australian Government was in contact in Mauritius, Hong Kong and Malaya: there was no suggestion of granting him diplonatic or consular powers. Roberts also lays too much stress on the 'South-Western Revolt' as a factor underlying the Japanese Govemment's rejection of Hack's scheme. some years past the Japanese Governnent had been opposed to emigration. This was largely the result of their experience of having to repatriate Japanese subjects who, in the face of the disapproval of.their Government, had been beguiled overseas by unscrupulous foreigners who then failed to carry out theix undertakings.98 Capt. Miller's engagement of the 37 Japan- 
ese for pearling at Thursday Is. in October 1873 was in fact the first occasion for more than a decade on which this standing policy was relaxed. 99

One can of course agree with Roberts that had Japanese intigration to the Northem Territory then taken place (and it was through no fault of the South Australian Government that it did not), and had that immigration been successful, then it might have 'changed the whole nature of the social and economic development of Australia'.

The failure of his negotiations with the Japanese Government apparently left Hack in straitened circumstances; for his return with his family to Australia became possible only when the British Consul at Nagasaki in April 1877 opened a subscription list for this purpose among local British residents. 100

Enquiry through Harrold Bros., Adelaide in 1891

In July 1891 a local firm of general merchants and shipping agents, Harrold Bros. wrote to the South Australian Treasurer that 'with a view to a direct Mail Line Service being established between Japan and the Colonies' it had been asked to enquire whether the Government had any objection to the introduction of Japanese immigrants into South Australia and the Northern Territory and whether the restrictive legislation enacted against the Chinese would apply to them. In the course of this letter they wrote: We need hardly point out that the Japanese have an excel lent reputation for being a steady and industrious people'.

Some months later Harrolds were appointed Adelaide agents for Japan's largest shipping Company, the Nippon Yusen Kaisha (N.Y.K.).101 This Company transported most of the Japanese contract labourers to the Queensland canefields and in December of that year its President founded the Yoshisa Emigration Co., the firm that 
recruited most of the Japanese immigrants who came to Austraiia. My guess is that the enquiries made by Harrold Bros. were on the N.Y.K.'s behalf. The emigration trade was an important source of revenue to it in the early years when it sought to break in on the routes in which powerful foreign lines like $P$. \& 0 . were well entrenched. 102

Cabinet considered the matter on September 7 th and authorised the Treasurer to reply to the effect that the legislation restricting the immigration of Chinese did not apply to Japanese, but that in the event of any large number of the latter being likely to come the Government might feel it their duty to bring the matter before Parliament. 103 Apparentiy, for Harrold's' principals this was a sufficient answer; for nothing more was ever heard of the matter.

The Japanese Government had abandoned the negative attitude to emigration that guided its policy at the time of Hack's proposals. When Marks, the Honorary Consul, informed the Japanese Ministxy of Foreign Affairs of Harrolds' enquiry he was instructed that:

The Government's policy towards emigrants at present is not to restrain Iabour by severe legislation from going overseas. If our labourers are able to make proper contracts for working overseas it places no obstacles in their way. The spirit is to facilitate this as best we can. You should, therefore, when there are any requests like the present one, examine the contract in detaj1, find out what kind of work is involved and how many labourers are required and report to us accordingly. 104

The importance which the Japanese Government now attached to emigration as a national interest should not, however, be overemphasized. For example, when 
in 1893 a private Member in the South Australian House of Assembiy introduced a Bill to extend the Chinese Immigration Restriction Act to cover ald Asiatic races, Marks was instructed not to make a formal protest against it.

If the Act referred to positively points out and exciudes the subjects of this Empire, there are strong reasons for protesting against such an action, but when it relates to 'persons of Asiatic origin' in a general way and by this designation Japanese subjects are included therein only as a natural consequence, it will. be very inexpedient to place ourselves in a situation to make a positive protest against the Act, for, I fear, it will be difficult to obtain any practical result ...

He was told, instead, to content himself with explaining to the authorities at a favourable opportunity that the Japanese Government's policy was to dissuade from emigrating all but those who were respectable and had definite objects in view. He was also to get influential persons in the Northern Territory to lobby so that the Japanese would be left outside the ambit of the Bill. 105

The Bill was, in fact, withdrawn after the Second Reading, at the request of Kingston who, while applauding its objective, argued that this could be achieved only by coordinated action by each colony.

Attempted Sale of N.T. Land by J.L. Parsons, 1898

A test of the Japanese Govermment's attitude came in 1898 in connection with an attempt by J.L. Parsons, an Adelaide merchant, to arrange the sale of freehold land in the Northern Territory to Japanese capitalists. 
Parsons had had a long and intimate Association with the Territory - as the cabinet minister responsible for its affairs from 1881 to 1884 , as Government Resident at Darwin from 1884 to 1890 , and as one of its elected representatives in the Lower House of the South Australian Parliament from 1890 to 1893.

The facts of this incident were in dispute at the time and the intervening years have failed to provide any fresh material on it.

Parsons arrived at Yokohama on 14 April 1898 and remained in Japan until about June $26 \mathrm{th} .107$ It was not his first visit to Japan. In 1895 he had been sent by the South Austraijan Government to China and Japan to promote a market for South Australian products. Following that visit the Japanese Govermment had in 1896 appointed him Honorary Consul at Adelaide, a position that he heId until his death in 1903. His 1898 visit to Japan, however, appears to have been unconnected with his consular duties.

On 4 May 1898 the British Minister in Tokyo, Sir Emest Satow, wrote officially to the Governor of South Australia as follows:

I have the honour to report that the Hon. $J$. Parsons, Japanese ConsuI at Adelaide, is at present in Tokio endeavouring to negotiate with Japanese capitalists the sale of lands situated on the banks of the Victoria River, in the Northem Territory ... and to induce them to send thither a large body of Japanese settlers. I have not yet heard that his efforts have met with success ... 108

When this dispatch was later published in the Register, Parsons promptly wrote to Satow claiming that it contained two serious errors: (1) He had shown Satow two plans which showed certain areas of 
freehold land in the Northern Territory which he was authorized by the purchasers from the Crown to offer for sale; but neither plan contained the Victoria River; nor had he mentioned Victoria River during the interview. (2) The total area of 1 and that he was empowered to offer 'was not large enough to carry what can properly be designated a large body of Japanese settiers' 109

The first of these questions, the location of the land, is one of fact. There appears to be no particular reason why an attempt to sell land on the Victoria River should be more discreditable to Parsons' reputation than an attempt to sell land elsewhere in the Territory. Furthermore it would be quite easy for Satow, who no doubt had never been to the Territory, to have become confused over the name in question. As the largest river there, he is more 1ikely in the course of his life to have heard of the Victoria River than of any other rivex there. We therefore may conclude that the land in question was not on the Victoria River. We may, however, be fairly sure that the land was on some watercourse; for Parsons did show him the maps and even a most inexperienced map-reader could hardly confuse a watercourse with another type of natural feature or with a boundary.

I think it quite likely that the land in question was on the Adelaide River. Satow was more likely to confuse the names of two queens, Adelaide and Victoria, than, say, Daly, Roper or Alligator and Victoria. There were 1 arge areas of freehold along its banks. 110 For land in this area Parsons would have been a most suitable salesman. It had been opened in 1880 for selection by persons desiring to establish sugar plantations. Following failures among the original selectors, Parsons had himself as Government Resident done a reconnaissance of the area with some technical experts in 1884. They described it as fine agriculturai land. 111 Although all attempts at agriculture 
were soon abandoned, Parsons remained confident of its suitability for sugar. In 1895 , as a witness before the Royal Commission on the Northem Territory, he had reiterated his view that 'the land on the banks of the Adelaide River corresponds almost identically with the best sugar land of British Guiana'. 12

The second point in dispute between Parsons and Satow, the amount of labour likely to be used by the prospective purchaser in making use of the land, is one of degree - or rather, of words. In an interview with a reporter from the Sydney Moming Herald on 25 July (two days after his arrival from Japan in S.S. Tsinan) Parsons indicated that the land was purchased from the Crown after the enactment of the Act to Encourage the Introduction of Indian Native Imnigrants (1882) and that the calculations of the purchasers about its viability, on the basis of which they acquired it from the Crown, were premised on coloured labour being available to work it under that Act. parsons pointed out that, since successive Governments had failed to appoint the Immigration Agent provided in that Act, the owners had been unable to make use of the 1 and and were accordingly eager to dispose of it. 113 This was indeed one of Parsons' favourite themes. He had made the same point to the Royal Comission in 1895.

Indeed on that occasion Parsons revealed that he too had bought land in the Territory on these premises. 114 Whether Parsons still owned such land in 1898, and if so whether it was among the parcels that he was trying to sell in Japan, is unknown. Parsons refused to divulge the names of the owners. In my opinion, the logic of Parsons' remarks to the Sydney Morning Herald is that the land would be an economic proposition to a Japanese purchaser only if he contemplated using Japanese labour. Accordingly there seems little merit in Parsons' contention that 'a large body of Japanese settlers' was not involved. 
Parsons had, for many years, been an enthusiast for development of the Northern Territory using coloured labour. His views on this subject were expressed in some detail in his Reports as Government Resident from 1884 onwards and in his evidence to the Royal Commission (1895). Underlying his concept of Northern Territory development were three basic premises:

Caucasians were incapable of physical labour in the tropics for a prolonged period. Healthy acclimatiz-

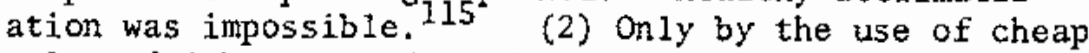
coloured labour could the Territory produce tropical and semi-tropical agricultural comodities that could compete on domestic and overseas markets. 116 (3) The employment of coloured labour for field work was the only way in which tropical agriculture could provide employment for a considerable number of Caucasians. These would be the overseers.117

Parsons' fixst preference was at a11 times Indians indentured under the auspices of the Indian Government. lis But he would not confine himself solely to these. In one of his Reports in 1885 he wrote that:

If suitable soil were set aside in the Territory some Chinese cultivators would come and settle down, those with money paying their passages, and in some cases, bringing their wives and children .... It is not thought that any large number of women would come to Australia. Those Chinese who brought their wives would return to China as soon as they had made a competency. 119

The presence of a certain number of these Asian cultivators was an exception to his general principle that the Asian Labourer, either in agriculture or mining, must at the end of his period of indenture be either repatriated or reengaged. This exception remained part of his concept throughout. In 1895 he told the Royal Commission that, although he would prevent Asians acquiring freehold tenure, he 'would permit then to 
take up agricultural leases ... It would not be a disadvantage if we did anchox a certain population [sc. of Asiatics] in the Territory ${ }^{\prime} .120$

As he gained more experience of them, Parsons became less convinced of the suitability of the Chinese in his scheme of agriculture. To quote his evidence to the Royal Commission: 'I do not like Chinese labour. They are a dangerous population. They are not content to continue as 1aborers'. 121 Since even at this early date Australians, like the rest of the world, saw the typical Japanese as a person intent on bettering himself, parsons in 1898 must have realised that in seling the land to Japanese he was taking some liberties with his basic concept. He may, however, have been confident that the South Australian Government would insist on repatriation on the completion of the period of indenture. In 1895 he saw the Javanese as, next to the Indians, the most suitable. 122 Although he did not like the Chinese, Parsons saw now alternative to them for mining; for the Indian Government would not permit the indenture of its subjects except on plantations or in Govermment enployment. 123

Parsons saw the land boundaries of the Terxitory as a kind of Mason-Dixon line. When one of the minority on the Commission who were opposed to coloured labour suggested that it was not in South Australia's interest to convulse the whole of Australia with the coloured laboux question, Parsons replied:

How does it touch South Australia when it is 2000 miles away? What does it matter to working men of South Australia, who are working in fields 2000 miles away on the north coast of Australia? It does not interfere with their labour .... you can confine it to the Northern Territory, you would have nothing but plantations there, You can get Indian coolies oniy for the 
planters there, and they would not be allowed off the plantations. If any escaped the planter would be responsible. 124

Parsons' views were endorsed by the 1895 Royal Commission in its majority report. 125 The report, however, was not followed by the Government, which since the conversion of playford in $1892^{126}$ had been committed to a White Australia.

Satow's despatch of 4 May 1898 was passed by the Governor of South Australia to his Ministers on June 15th. It was considered by Cabinet on June $17 \mathrm{th}$ and, as a result, a cable was despatched to London the same day requesting that the Foreign Office convey to the Japanese Government the hint that any action along the lines of Parsons' Tokyo proposals might result in the 'Natal' type of imnigration restriction legislation (due to be introduced in the South Australian Parliament the following week) being withdrawn in favour of similar legislation couched in terms that gave less consideration to Japan's comour propre. 127

This information was conveyed to the press and by the time it had passed through the hands of the Northerm Territory rimes and Gazette to a protest meeting of Darwin citizens on June 25th, Parsons' scheme had become an agreement entered into between the British and the Japanese Governments without consulting the South Australian Government to lease 4000 square miles of country on the Victoria River to the Japanese on condition that 5 Japanese to the square mile were settIed on the land within a specified period!128 After 'a crisp and in places, unnecessarily personal debate' the meeting of Darwin citizens by a show of hands of some 40 to 50 'emphatically declared itself opposed to the scheme, and declined to hearken to the voice of the proAsiatic tempter'. But long before the Northern Terpitory Times and Gazette, a weekly newspaper, was able, in its next edition, to inform the world of this vital decision, the Japanese Foreign Minister had acted. 
The British Foreign office on June $23 \mathrm{rd}$ had passed to the Japanese Legation the message from the South Australian Govemment. The Legation had cabled this to the Foreign Ministry in Tokyo describing the matter as negotiations by Parsons 'with Japanese capitalists to introduce a large number of Japanese emigxants to South Australia'. This cable was received at the Foreign Ministry on June $28 \mathrm{th}, 129$ by which date Parsons appears to have already left Tokyo on his journey back to Australia. On June 30th the Foreign Minister replied to the Legation in London by cable as follows:

It is true that the scheme was proposed by the Honorary Consul while he was in Tokyo but he has abandoned it through my advice and further every restriction is being enforced against Japanese emigration to Australia generally. You may inform Marquis of Salisbury accordingly. 130

Frorn the text of this cable two things emerge. First, the Foreign Minister did not challenge the Legation's description of the scheme. Therefore when Parsons discussed the matter with him the Foreign Minister, like Satow, must have been given the impression that a large number of Japanese immigrants would be involved. We may therefore reject Parsons' subsequent denials on this point. The other thing that emerges from this cable is that the Foreign Minister had squashed the scheme, from considerations of Japan's own interests and policies, before any indications of Australian attitudes had been received. 


\section{ENDNOTES}

1 Sister Mary Albertus O.P. (Santa Sabina, Scarborough, Western Australia), 'The Story of Port Darwin' (typescript, $17 \mathrm{pp}$. , 1974, unpubl.).

2 ibia. citing Northerm Territory Times and Gazet te (hereafter referred to as $N T T$ ) $26 / 8 / 82,9 / 2 / 84,23 / 2 / 84$.

J.P.S. Bach, The Pecoling Industry of Austratia: An Accomt of its Social and Economic Development (Canberra, Department of Commerce and Agriculture, 1956) (Australian Archives, Canberra office, CDS33], pp. 20-23.

See also South Austration Register (hereafter referred to as Register) 8/5/84 (supplement).

3 Register, 1/7/84, 21/7/84.

4 Letter from $\mathrm{Sr}$. Mary Albertus $3 / 2 / 74$ citing $N T T$ 5/7/84.

5 Register 14/8/84 (supplenent).

6 Honorary Consul, Melboume to Vice-Minister for Foreign Affairs, No. I, 24/2/1885, Wihon Gaiko Btonsho - 1885 (Tokyo: Minjstry of Foreign Affairs), p.527.

7 Hakayamaken, Hakayconaken Iminahi (Wakayama: Prefectural Government, 1957), pp.190-91, 297-98.

8 Regieter, $19 / 6 / 84$ (supplement).

$9 \mathrm{Sr}$. Mary Albertus has also drawn ny attention to an item in NTT $1 / 3 / 84$ in which Burns, Philp's Thursday Island branch congratulates a member of the NA Pearlshell Co. for discovering shell and offers its services to supply 'divere, pumping gear, etc.' (D.C.S.S. italics).

10 See D.C.S. Sissons, 'Inmigration in Australian-Japanese Relations 1871-1971' in J.A.A. Stockwin (ed.) Japxen and Austratia in the Seventies (Sydney: Angus and Robertson, 1972), p.195.

11 Register, 5/6/84 (supplenent).

12 Letter from $\mathrm{Sr}$. Mary Albertus $3 / 2 / 74$ elaborating on reference to $N T T 30 / 5 / 8 \mathrm{~S}$ in Bach, op.cit., p.23.

I3 I am indebted to the Registrar-General, Mr C.A. Ockerby, for access to the Registers of Deaths for this period.

I4 Cossack Police Occurrence Book (Manuscript A/366, Battye Library, Perth, W.A.).

15 The ownership of the Ftowerdate has been identified by Sr. Mary Albertus in 'The story of Port Darwin' from a reference to it in the NTT $7 / 10 / 82$.

16 The date of the exodus of the Thursday Island pearlers to westem Australia can be established from North Australian 12/3/86 cited by Sr. Mary Albertus in her letter of $3 / 2 / 74$ and from $W T T$ 24/4/86 cited in Bach, op.cit., p. 23 .

17 Govermment Resident's Report on the Northerm Territory for the Year 1892 (South Australia, Proceedinge of Parliament, 1893, vol. 3, no.158).

18 Pearling from Darwin does not, however, appear to have been completely abandoned during this period. Northem Territory Times Alnonac and Directory for 1890 at pp.115-16 lists pearling among the activities of a schooner and 4 luggers, each owned by Cautcasians. 
19 Archives of Japanese Ministry of Foreign Affairs: file Mr 3.4.48.

20 Report of the Nonthern Temitory Comission together with Minutes of Evidenee (SA, Procegdings of Paritionent, 1895, vol.2, no. 19),$p .98$.

21 Shimpo 12/1/94 reproduced in Shimbun Shusei: Neiji Hennenshi, 9.12 .

22 K. Watanabe, Goshu Tanken Hokokusho (Gaimusho Tsushokyoku, 1894), p.281. (Australian National University, Merzies Library os 3950 / 3354).

23 vide supra, footnote 19.

24 Japan Week $t_{y}$ Hait, 30/5/96.

25 South Australia, Pantiamentamy Debates, House of Assembly, 1896 , p. 136 .

26 ibid. 1898-99, p.1003.

27 See pp. 27-36 of my paper on 'The Japanese in Australia, 18711946' presented to Section 26 of the $45 \mathrm{th}$ Congress of the Australia and New Zealand Association for the Advancement of Science at Perth on 14 August 1973 (Australian National Library, Ms 3092).

28 Contribution dated Sydnoy 6/8/98 published in Japon Weekly Mail $10 / 9 / 98$.

29 NTT, 8/4/98, 3/10/98. Further details of this case are not. available. The press reports were very sketchy. Nor does the judge's notebook appear to have survived in the registries of the courts in Adelaide or Darwin.

$30 N T T, 29 / 3 / 01,5 / 4 / 01,18 / 10 / 01$.

3) SA Census of 1901 - Pcot 7: Birthplace of the People (SA, Proceedings of Partioment, vol.3, no.74).

32 The WTT 5/4/O1 and the Register 30/3/01 and 5/4/01 show that there were no Japanese ships in South Australian ports on census night and that the only ship in port bound to or from Asian ports, the Offembach, had no Japanese among its passengers.

33 vide supra, footnote 27.

34 Cited in $N T T 20 / 1 / 99$.

35 vide supra, footnote 17.

36 Peari-Shelling Industry in Port Damin and Northem Temitom Report by His Honour, Judge Dashood (Austra1ia, Partianentary Papers, 1901-02, vol.2), p.32.

37 Watanabe, op.cit., p.280.

38 South Australian State Archives (hercafter referred to as SAA), Group 1374 (N.T. Govt. Resident's Incoming Correspondence 18701911), 1899/8737 (H. Clark to Sub-Collector of Customs, 31 Januaxy 1899). Hanaura is the most 1ikely of the various ways in which from time to time, it is spelt in the local press and official correspondence.

39 vide supra, footnote 17.

40 South Australia, Proceedings of Porlioment, 1894, vol.2, no.53.

41 Watanabe, op.cit. pp.266-67,281. In the light of the figures that he cites for the prevailing wages of Caucasian and Chinese labour in the Territory it is a little surprising that he found so satisfactory the wages received by the Japanese in such a dangerous occupation as diving. 
Caucasion Labou Operating mine machinery Mine foreman Groom or cowherd Agricultural overseer Manager of a shop Shop assistant

Chinese Labow Domestic service Carpenter or mechanic Agricultural overseer Mine worker, underground Other

$$
\begin{aligned}
& \qquad 6 \text { per week } \\
& £ 3 \text { " } " \\
& £ 2-£ 4 \text { " " } \\
& f 10-£ 15 \text { per month } \\
& £ 30-£ 50 \text { " } " \text { " } \\
& \text { up to } 210 \text { " } \\
& \qquad 5 \text { per month (all found) } \\
& 10 /- \text { per day } \\
& \mathcal{L} 4-£ 6 \text { per month (a1l found) } \\
& 12 /- \text { per day } \\
& 6 /- \text { per day } \\
& 5 /-10 /- \text { " }
\end{aligned}
$$

$42 S A A$, Group 790 (Minister Controlling the N.T. - In-coming Correspondence) $1893 / 468$ (Telegram from Dashwood to Minister, 4 January 1894).

43 On 6 March 1894 John Douglas, the senior Queensland official at Thursday Is, was to write:

... Two years ago there were not twenty boats owned [sic] and manned by Japanese. Now there are upwards of seventy, and of these 38 are owned by Japanese. This is a matter which merits the serious attention of Parliament.

Partly from this cause and partly from a belief that the industry is overdone, there has been a good deal of talk among the pearl-shellers about clearing out for [elsewhere].... As there were 253 boats operating from Thursday Is, at that time, 38 does not, in absolute terms, appear an excessive number. The rate of increase, however, as Douglas points out, was rapid. Furthermore, it is possible that some of the other 32 boats manned by Japanese were in process of being bought by them on time payment. (Report of the covemment Resident at Thursday Is. for 1892-3), p.3.

44 Petition Against Licensing Astaties for Pearl sheling (South Australia, Proceedings of Portiament, 1895, vo1.3, no.43).

45 Govermment Resident's Report on the Northerm Territory for the Year 1894 (South Australia, Proceedings of Partiament, 1895, vol. 2, no. 24), pp. 9, 20.

46 South Australia, Pariziomentary Debates, 1895, p.749.

47 ibid. p. 750.

48 ibid., p.756.

$49 \mathrm{NTT}, 11 / 10 / 95$.

50 South Australia, Partiamentary Debates, 1893, vol, 2, pp.2807, 2814,4 October 1893, Mx. Kingston.

51 South Australia, Proceedings of Portioment, 1895, vol.3, no. 103A.

52 NTT 20/2/95, See also ibid., 27/12/95.

53 From passenger returns it was able to deduce a nett increase of 61 in the three years $1 / 7 / 93$ to $30 / 6 / 96$. This information, however, was of limited use since it had no figure for the Japanese population at the earlier date. (SAA, Group 790, 1896) 280). 
54 These figures are taken from the table 'Kaigai Zairyu Hompojin' appearing annually in the Wihon Teikoku Tokei Nenkan [tr. 'Japan Statistical Yearbook"] published by the Bureau of Statistics in the Japanese Cabinet office.

55 Report of the Japanese Consul, Townsyilte, published in Shokumin Kyokai Hokoktusho, no.63 (1897).

$56 N T T, 6 / 3 / 96$.

57 Dashwood Cormission (vide supra footnote 36) pP. 30, 31, 34, 35, 37.

$58 N T T, 3 / 4 / 96$.

59 For evidence that the Government was forced to apply a policy of preference to white labour in Government employment in the Northern Territory see SA, Parliomentary Debates, 1894, p.2580 $(28 / 11 / 94) ; 1895$, p.1136 $(28 / 8 / 95), p .1754(10 / 10 / 95)$ and $S A$ Paritianentary Debates: House of Assembly, 1898, p.300 (17/8/98). 60 vide supra footnote 32 .

61 S.A. - Gold Mining Act Amendment Act, No. 353 of 1885, Sect.3. For an example of the kind of jobs performed by Japanese on the goldfields see $S A A$, Group 1374, 1901/10521, a report on injuries sustained by a Japanese operating a stone-crusher at Yam $C k$. battery.

62 Northem Territory Atmanas 1896 (Palnerston: NT Times \& Gazette, 1896), 'List of Vessels Employed in Harbour and Coasting Trade ...'

$63 S A A$, Group 1374, 1898/8071.

64 Northem Temitory Times Year Book 1899, pp.29-30. This shows Cleopatra as engaged in pearling during 1899 but indicates that its 'Official Number' was 'cancelled' - presumably during the year. The Govemment Resident's Report for the Horthern Territory 2899 at p.18 also states that all the pearl fishing boats are owned by local people'. At all events, Hamaura's licence had lapsed by 1902; for in that year the report of the Dashwood Commission (vide aupra footnote 36) states at p.4 that all 9 employers or owners were Europeans.

$65 S A A$, Group 1374, 1899/8737, 8951, 8972, NTT, 27/1/99. See also Bach, op.cit,, p.90.

66 SA, Govermment Gazette, No.48 (9 November 1899), p.1070.

67 West Australian State Archives: Prenier's 381/21; Fisheries $11 / 24$.

Australian Archives, Canberta Office: Al 25/16390.

68 SA, Parilamentary Debates, Houee of Assembly, 1898-99, p.632-33, 6 October 1898.

69 Chumg Toy v. Mhisgrove, [1891] A.C. 272.

70 SA, Porizinentory Debates, House of Assembly, 1898-99, p.216, 27 July 1898, Mr Kingston.

71 vide supra footnote 36 .

72 Northern Australian Development Connittee, Pearl-Shell, Bechede-Ner and Trochus Industry of Northern Australia. (Melbourne 1946), pp.44-6.

73 vide eupra footnote 54.

74 vide supra footnote 72 .

75 Bach, op.oit., pp.224-37.

76 Situated between the Stuart Highway, Goyder Road and Stokes Street in the suburb of Parap, lis miles from Darwin P.O. 
77 Situated westward of Gardens Road and eastward of Gilruth Street.

78 S.H. Roberts, 'Northern Territory Colonization Schemes', Report of the 17th Meeting of the Australasian Assooiation for the Advoncement of Soience (Adetaide Meeting, August 1924), pp.422-4. This material was also incorporated into S.H. Roberts, History of Australian Land Settzement (Melbourne, 1924) at pp.358-63.

$79 \mathrm{~J}$. Cross, 'Wilton llack and Japanese Imulgration into North Australia', Proceedings of the Royal Geographicat Society of Australasia (South Austration Bronch), vol.61 (1960), pp.55-9.

80 SAA, Minister for Northem Territory (Gps. 790 and 793): out lettex-books 1876-77; Incoming dockets $286,357,368,376$ and 392 of 1876; Incoming dockets 260, 369, 489 and 508 of 1877 .

81 Cross, op.cit., pp.55-6.

82 H. Ritter, A Ristory of Protestant Missions in Japan (Tokyo, Methodist Publishing House, 1898), pp.39, 45.

83 Reproduced in T. Shigehisa, Oyatoi Gaikokujin (5): Kyoiku Shukyo (Kajima Kenkyujo, 1968), p.73. The school at which Hack taught was the Hiroshima Eigo Gakko [tr. 'Hiroshima English Language School $\left.{ }^{\dagger}\right]$ and his salary was 200 yen per month.

84 Minutes on Hack to Commissioner of Crown Lands, 29/7/76.

85 Minute on Hack to Minister for Agriculture and Education, $4 / 9 / 76$.

86 This and Roberts' error about the Ministry in office was brought to my attention by Mr J.McLellan, late State Archivist of South Australia.

87 Minute on Hack to Minister for Agriculture and Education, $15 / 3 / 77$.

88 Hack to Minister for Agriculture and Education 26/10/77. Roberts evidently misinterpreted the phrase, 'with the sanction of your Government" appearing in the sentence, ' 1 have also the Japanese translation of regulations proposed by myself, and which, with the sconction of your Government [D.C.S.S. emphasis], I had intended to have submitted to the intending settlers'. (Hack to Minister for Agriculture and Education 25/9/77). Roberts takes this to mean that Hack had already received such sanction. That this, however, was not the meaning is evident from his next letter $(26 / 10 / 77)$, in which he wrote 'I have found a copy of the "statement" I had translated into Japanese, and which, had the emigration of Japanese been possible, I should hove submit ted [D.C.S.S. emphasis] to you for approval'.

89 Cross, op.cit., p.57.

90 Hack to Japanese Minister for Foreign Affairs, 16/2/77.

91 SA, Parliconentcory Debates, 1876, p.1549.

92 Hack to Minister for Agxiculture and Education, 26/10/77.

93 SA, Parliamentamy Debates, 1870, p.831.

94 Secretary to the Minister for Agriculture and Education to Hack $25 / 10 / 77$.

95 Hack to Minister for Agriculture and Education, 25/9/77.

96 Hack to Minister for Agriculture and Education, 15/3/77.

97 Secretary to the Minister for Agriculture and Education to Hack $25 / 7 / 77$. 
98 For the details of notable ventures of this nature that ended in failure (in llawaii and Guam in 1869 and in California in 1870) see T. Irie, Hojin Kaigai Hattenshi (Ida Shobo, 1942), vol.1, pp. 25-6.

99 Until this occasion the Foreign Ministry had argued that projects of this nature contravened Law No.295 of 1872 (which prohibited contracts of service exceeding one year's duration, on the ground that such were tantamount to slavery).

100 H.S. Williams, Foreigners in Mikadoland (Tokyo: Tuttle, 1963), p.182 on the authority of Japan Daily Herald 26/6/77 and the records of the British Consulate at Nagasaki.

101 Advertiser (Adelaide) 16/12/91.

102 For further details of the activities of the NYK and the Yoshisa Enigration Co. at this time see pp.23-5 of my paper, 'The Immigration Question in Australian biplonatic Relations with Japan', presented at the 43rd Congress of the Australian and New Zealand Association for the Advancement of Science held at Brisbane in May 1971. (A copy is deposited in the Australian National Library).

103 SAA, Premier's Department 1891/925.

104 Vice-Minister for Foreign Affairs to Hon. Consul Melbourne, 11 November 1891, Withon Gaiko Bronsho - 1891, p.442.

105 Vice-Minister for Foreign Affairs to Hon. Consul Melbourne, 7 Decenber 1893, Nihon Gaiko Eunsho-1893, pp.748-50.

$106 \mathrm{SA}$, Parliomentary Debates, 1893, vo1.2, pp.2813-14, is November 1893, Mr Kingston.

107 The Japon Times $15 / 4 / 98$ shows him on the passenger list of the Empress of China which arxived from 'Hong Kong and ports' the previous day. He appears on the daily lists of guests at the Imperial Hotel, Tokyo published in the same newspaper on the following dates: 19-23 April, 1-27 May, 9-26 June. According to the Argus 26/7/98 he arrived back in Sydney on the Trinan on July 23. As the Tsinon left Yokohama on June 19th Parsons presumably joined it at Kobe.

108 Reproduced in Comespondence $r^{2}$ Introduction of Japanese Settlers into the Northerm Territory (Australia, Parlianentary Papers, 1901-02, vol.2, no.A15\}.

109 Reproduced in Introduation of Japonese into Nonthom Territory Further Correspondence Respecting (Australia, Partiamentany Papers, 1901-02, vol.2, no.33).

110 Report of the Nowthem Territory Connission together with Minutes of Evidence (SA, Proceedings of Porlitoment, 1895, vol.2, no.19, p.70). Hereafter referred to as NT Comission.

111 Goverment Resident's Qwater iy Report on the Northern Territory, 12 August 1884 (SA, Proceedings of Paritionent, 1884, vol.3, no. 53A).

$112 N T$ Comission, p.68.

113 Sydney Morning Herald 26/7/98.

114 NT Conmission, p.42.

$115 N$ Conmission, p.38,

116 ibid., p.42. Govermsent Resident's Quarterly Report on the Northern Territory, $3 I$ March 1885 (SA, Proceedings of Paritioment, 1885 , vol. 3, no.54), p.5. 
117 HT Comission, p.41. Parsons calculated that probably one third of the amount spent in wages would go to the Caucasian overseers.

118 For the role of the Indians in Parsons' concept of colonization see the debate on the private members bill that he introduced (but failed to carry) in the S.A. House of Assembly in 1891. Its object was to guarantee to N.T. landowners for $2 I$ years the right to use Indian indentured labour (S.A., Parliomentary Debates, 1891, pp. 2539-46).

119 Goverwent Resident's Quarterly Report on the Northem Territory, 31 March 1885, p.6.

120 WT Commission, p. 46.

121 ibid., p.49.

122 ibid., p.49.

123 ibid., p.67.

124 ibid., p.69.

125 ibid., p.211.

126 Notes of a Visit to India and the Northern Territory - for Information of Ministers - by the forn. T. Playford (SA, Proceedings of Parlicment, 1892, vol.3, no.97).

127 vide supra footnote 108. This is my own very free paraphrase of the South Australian Govermment's message.

$128 N T$, $1 / 7 / 98$.

129 Cable no.73 from Minister, London to Ministex for Foreign Affairs, despatched 25 June 1898 (The text and transmission details are available in the U.S. Library of Congress microfilm series of the Japanese Ministry of Foreign Affairs Archives 1868-1945, Telegrams, Reel 20).

130 Cable no.561 from Minister for Foreign Affairs to Minister, London, despatched 30 June 1898 (Telegrams, ReeI 21). 
END OF REPRINT

Japanese in the Northern Territory, 1884-1902 


\section{Karayuki-san: Japanese prostitutes in Australia, 1887-1916 (I \& II)}

In Historical Studies, Vol. 17, Issue 68, pp. 323-341 and Vol. 17 Issue 69, pp. 474-488, 1977.

Taylor \& Francis Ltd, www.tandfonline.com reprinted by permission of the publisher.

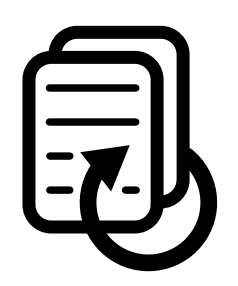





\title{
KARAYUKI-SAN: JAPANESE PROSTITUTES IN AUSTRALIA, 1887-1916-I*
}

\begin{abstract}
them, sung to the samisen, used to be popular:
Carried on the drifting current,

Her destination will be

In the west, Siberia;

Or in the east, Java.

Which country will be her grave?

Lovers' chatter

Is like the dust

Of any country.
\end{abstract}

TARYUKI was the word which the Japanese used in the earlier years of $h$ this century for those of their countrywomen who sought the means of subsistence in South-east Asia or the Pacific. At that time a plaintive song about

'Ihc ideographs comprising the word, karayuki, literally mean 'going to China'; for most of the karayuki, as we shall demonstrate, were from Kyüshū, the part of Japan closest to China. There was a substantial fiow of these women to China before emigration to South-east Asia bcgan.

According to an article appearing in the Japan Mail early in $1896{ }^{3}$ there were at that time some 200 Japanese prostitutes in Australia-about the same number as in British India, about twice as many as in Hong Kong, and about two-thirds as many as in Singapore. Furthermore, according to figures it cites, in Australia their per capita income was much higher than anywhere else, averaging 400 yen $^{3}$ per month ( $c f .200 \mathrm{yen}$ in India, 120 yen in Singapore, and 100 yen in Hong Kong). The article continued that the women who went overseas were smuggled out of Japan by various ingenious devices on board foreign steamers. Usually they went first to Hong Kong, where they found agents engaged in this special line of business. After a short stay they drifted southward to such places as Singapore, Penang, Australia, India etc. Generally they paved the way for Japanese traders: when a batch of five or six women settled in a port,

* This is the first instalment of a two-part article. The second part will appear in October. The following files (or portions of them relating to Australia) from the archives of the Japanese Foreign Ministry referred to in this article are available on microfilm in the Australian National Library:

3.8 .4 .8

3.8 .8 .4

4.2.2.27

4.2.2.34

6.1.5.9.7

6.1 .6 .29

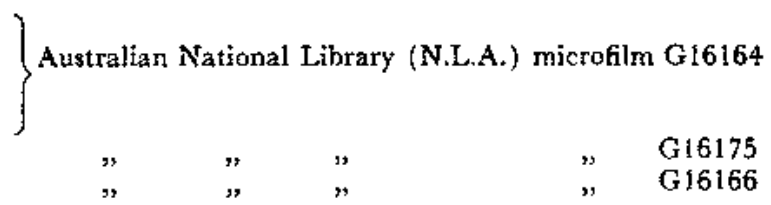

1 Japan Weekly Mail, Yokohama, 30 May 1896, p. 609. It cited the Tokyo daily Kokumin as its source, but the original has not yet been located. The English-language Mail appeared as both a daily and a weekly.

2 The rate of exchange at that time was about $£ 1$ Stg. $=10$ yen. 
the Japanese merchant soon followed with the goods to satisfy their various needs. After the merchants came the Japanese labourers.

Unfortunately there are no figures for 1896 from Australian sources against which the total given by the Japan Mail for Australia-200-can be checked. The scattered information available for particular regions a little later, however, suggests that it may not have been an overstatement.

When a return showing the number of Japanese women in each Queensiand police district was requested by the Home Secretary in September 1897 he was informed that there were 116 Japanese women in the colony and that all hut one of these, the Consul's wife, were prostitutes: Thursday Island 34, Cairns 16, Chitders 15, Croydon 14, Innisfail 13, Machay 9, Cooktown 4, Townsvilie 3, Halifax 3, and Rockhampton, Ingham, Port Douglas and Normanton one each. $^{3}$

We have more detailed information about the Japanese women in Thursday Island not very long luefore this-at the end of 1893. Hattori in his book on Thursday Island, published carly in 1894, gives a complete breakdown of the Japanese population into their prefectures of origin. He gives the total number of women as 32. It is very close to the number given by the police in their 1896 count. Fortumately he goes further and divides them into: prostitutes, 21; and respectable women, 11." Wc can accept this as accurate. Hattori would have been no more eager than the Qucensland Police to over-estimate the proportion of respectable women. He was favourably inclined towards the anti-prostitution movement there, and his principal informant, Matsuoka, was one of the leaders of that movement. Nlthough it would probably be safe to accept Hattori's figure rather than that of the Police for Thursday Island, it might be unwise to apply Hattori's ratio of I respectable: 2 prostitutes, across the board to the Police totals for the other towns. The Japanese population at Thursday Island was probably more than twice the size of that at Townsville, Cairns or Mackay, and there would have been mere handfuls in the other towns. On Thursday Island to a greater extent than elsewhere the Japanese population would have been large enough to sustain some respectable services. It is doubtful whether

s PRE/103, Col, Sec. 97/11771, Queensland State Archives (Q.S.A.). Police Headquarters do not appear to have given the lady in Rockhampton the benefit of the doubt. The telegram from the local Inspector merely stated that she was 'not doing anything at present for a living' (Q.S.A., POL/J 1, I3M). The Police Commissioner (W. E. Parry-Okeden) thought that in some districts there were more Japanese prostitutes than this count indicated. The results of a more carcful survey of coloured aliens by the Police on 31 October of the following year suggest that his doubts may not have been without substance. This later count put the total number of Japanese women at 220. Queensiand Legislative Assembly, Votes and Proceedings, 1898 , vol. 3, p. 821 . During the interval $1 / 9 / 97-31 / 10 / 98$ the net infux of Japanese women from overseas was only 40, Q.S.A., PRE/103, Arrivals and Departures at Queensiand Ports 189\%-1901. Other figures showing annual arrivals and departures by both sea and rail indicate net increases of only 66 for the calendar year 1897 and 6 for the calendar year 1898. Queensland Legislatine Assembly, Votes and Proceedings, 1898, vol. 3, p. 332; 1899, vol. 3 , p. 522 .

4 T. Hattori, Nankyü no Shinshokumin, Tokyo 1894, p. 21 . 
there would have been the same degree of 'respectability' among the Japancsc elsewhere in Quecnsland.

The official decennial Censuses conducted by the Governments of each colony indicate that in that era the only other parts of Australia where there were significant numbers of Japanese women were Western Australia (209 in 1901) and Northern Territory (38 in 1901).5

The first Japanese consulate in Western Australia was not established until 1910. Fortunately, however, among the scattered remnants of the Australian consular correspondence that survive in the archives of the Japanese Foreign Ministry, there is the report made by Aiba Tsuneji, a clerk from the Sydney Consulate-General, of the official visit that he paid to the southern portion of Western Australia in August-September $1901 .^{b}$ For this report Aiba compiled a table giving the breakdown by sexes, occupation and prefectures of origin of Japanese residing within an area whose extremities are roughly Geraldton, Cue, Kalgoorlie and Albany." This table is reproduced below, omitting only the 48 prefectures of origin. He shows all the 58 or 59 women in the area as prostitues and 49 out of the 207 Japanese men as living off their earnings.

What of the Japanese women in the other parts of Western Australia? The Census of March 1901 shows 209 Japanese females in the State, but does not give their occupations. Its regional breakdown tends to confirm Aiba's: in the municipalities covered by him its total is 70 compared with his 59 . The remaining 139 are scattered among pearling and mining settlements. ${ }^{8}$ Of these, probably Broome alone had a large enough Japanese community (303 males, 63 females) to sustain a few respectable married families. There seems no good reason to believe that, for Western Australia as a whole, the proportion of Japanese who were prostitutes was vastly different from that in Queensland.

The date closest to the Japan Mail article for which we have detailed information about Japancse prostitutes at Darwin is 1893. In that year the Japanese Diet voted 10,000 yen to survey territories likely to be suitable for Japanese

5 The 1901 Census figures for Japanese women in the other parts of Australia were: the renainder of South Australia 1; N.S.W. 9; Victoria 1; Tasmania 0 or possibly 1 (i.e. 1 nonChinese Asian).

a Japan, Foreign Ministry Archives (J.F.M.A.), 6.1.6.29.

i Aiba regarded these figures as substantially complete for the area covered by the table, exccpt for insignificant exceptions such as Mt. Magnet, Day Dawn, Nannine, and Norseman. At the W.A. Census of 31 March 1901 the Japanese population of these places was $\$, 2,1$ and 1 respectively, and all were males. In the narrative part of his report he gives unconfirmed figures for the settlements on the branch lines extending out beyond Kalgoorlie. The pattern seems to be the same. At Kanowna 'There are two men and two women. There is a laundry but it seerns to double as a brothel'. At Menzies 'There are 15 or 16, of whom 8 are women. There are, I an told, 4 laundries and 4 brothels'. At Kookynie (at that time the railhead)' $i$ can't find out how many are there, but there arc 8 women among them. There are 5 brothels and I laundry'.

8 For details of the regional distribution of the Japanese population in the W.A. Census 1901 see the Appendix to my unpublished paper 'The Japanese in Austratia 1871-1946' read to Section 26, 45th ANZAAS Congress in Perth in 1973, Ms. 3092, N.L.A. 


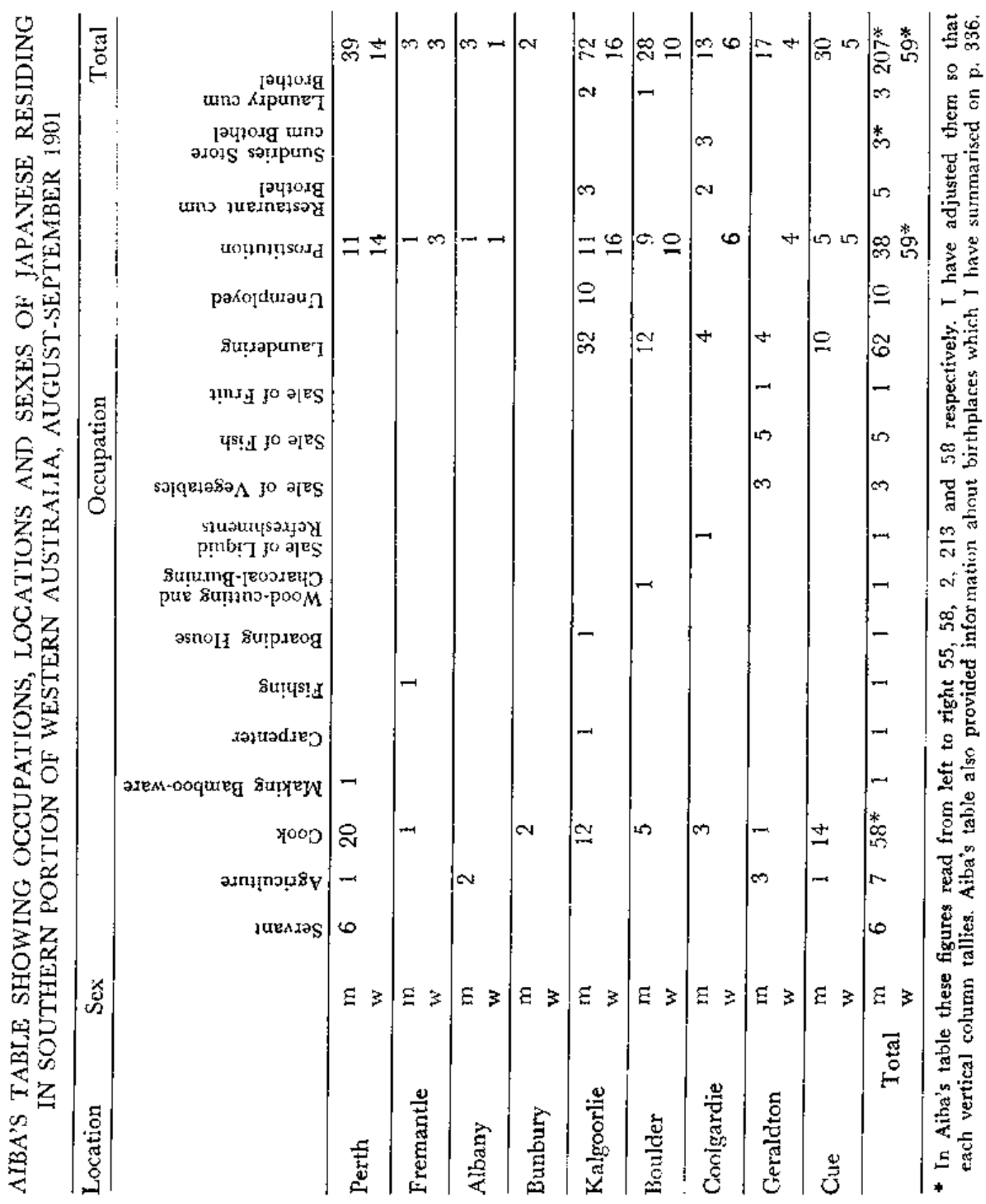


emigration. ${ }^{9}$ Of this sum 2,000 yen was allocated to Watanabe Kanjūrō to visit and report on Australia and some Pacific islands. His 300-page report was completed on 3 May 1894 and was printed. ${ }^{10}$ According to Watanabe, there were at that time 12 Japanese women in Darwin, all of whom had come there as prostitutes. Two had married in Darwin. The women were distributed among three brothels, thrce or four at each.

That prostitution continued to be the principal activity of the Japanese women in Darwin is suggested by the following comment on Darwin's division of labour in the Methodist Missionary Review of 12 December 1898: 'The Japanese women are almost all professional prostitutes, the Malay women are nurse-girls, the Chinese women are mostly paticnt drudging wives'. ${ }^{12}$ It seems unlikely that their numbers in Darwin would decline until the Immigration Restriction Act came into cffect in 1902. ${ }^{12}$

Adding together these figures for Queensland, Western Nustralia and Darwin, it would appear that the total given by the Japan Mail for Japanese prostitutes in Australia, 200, may have been a little too low.

\section{Were the prostitutes the first Japanese arrivals?}

As we have already observed, the Japan Mail claimed that, in the spread of Japanese immigration to South-cast Asia and beyond, the prostitutes were the pioneers paving the way for the shop-keepers and the labourers in turn.

The most detailed and best documented work on Japanese prostitutes overseas is Shōfu: Kaigai Ryūrōki ly Miyaoka Kenji. ${ }^{13}$ He cites numerous sources that support the Japan Mail's thesis. For example, when the first Japanese shop in Shanghai, the Tashiro-ya, opened in 1868 (one year hefore the establishment of the Japanesc consulate) part of its sales were Japanese cosmetics. From this he deduces, not unreasonably, that the Japanese prostitutes had already arrived. ${ }^{14}$ It must have been the same in Hong Kong; for when Itagaki, the leader of the Liberal Party, visited there in 1882, he noted that the Japanesc

9himpó, 12 Jan. 1894, reproduced in Shimbun Shüsei: Meiji Hennenshi, vol. 9, p. 12.

$10 \mathrm{~K}$. Watanabe, Gōshü Tanken Hökokusho, Tokyo 1894. I am indebted to Prof. Katō Shunsaku of Kanto-Gakuin University for drawing my atlention to this report.

11 Missionary Review, Sydney, 12 Dec. 1898, cited in Northern Territory Times, 20 Jan. 1899.

12 The South Australian Census of 1901 indicates that there were 39 female tcoloured natives of Japan' in the Northern Territory on that day. For details see my 'Japanese in the Northern Territory 1884-1902', South Australiana, vol. 15, no. 2 .

${ }^{13}$ K. Miyaoka, Shôfu: Kaigai Ryūrōki, Tokyo 1968. After graduating in political science at Keio Lniversity, Mr. Miyaoka in 1922 entered the Osaka Shōsen shipping company. In the course of his many overseas visits, particularly to South America, he became interested in the history of the Japanese overseas. He built up a private library of some 3,600 books devoted principally to accounts of their overseas travel or residence written by Japanese since the 1860 's. A copy of the catalogue of this collection, Miyaoka Bunko Shomoku, is held in the Australian National University Library. His book is written on the basis of eye-witness accounts from the books in this collection.

14 Ibid., p. 105. 
population consisted of about 10 men, and about 20 women of whom most were prostitutes. In Singapore the first Japanese women were operating by 1877 . Ten years later there were more than a hundred women and only 17 men. It was principally for the prostitutes that the Japancse cemctery was established at Serangoon the following year. ${ }^{15}$ Even in 1897 the overwhelming proportion of the local Japanese population were the prostitutes and their touts. It was only by conducting a door-knock appeal around the brothels that the Consul was able to finance the freworks display which was the Japancse communily's contribution to Queen Victoria's Diamond Jubilcc celebrations. ${ }^{16}$

In Australia, however, the sequence appears to have been rather different. The first reference to Japancse prostitutes in Australia that I have come upon was in 1887. In that year it was brought to the attention of the Honorary Consul, Alexander Marks, that two Japanese prostitutes were operating in Melbourne and four in Thursday Island. Marks made cforts to get these women to leave the country and, in the case of those in Melbournc, was successful ${ }^{1+}$ This, of course, was long after Japanese had appeared in both these places. In Melbourne the marriage between Rikinosuke, a Japanese acrobat, and one Jane Kerr was registered in 1875. In 1881, just after the International Fxhibition. Akiyama and Tokuta set up in business as importers of Japanese goods, next door to Young and Jackson's in Flinders Street. At Thursday Island the first Japanese to arrive appears to have been Nonami Kojiro in $1878 .^{18}$

The next reference that I have come upon is in William Lanc's magazine, the Boomerang. Its issuc of 12 May 1888 carrics an account of a recent visit to Darwin. Idiosyncracies of style indicate that the writer was undoubtedly Lane's friend, James Murdoch, who had just resigned from the position of Second Master at Brisbane Grammar School and was on his way to take up a teaching position in Japan. ${ }^{14}$ In this article Murdoch reports that there were then five Japanese brothels in Darwin containing 25 Japanese prostitutes and that there were branch establishments at Cambridge Gulf (i.e. Wyndham) and 'down the Western Australian coast well nigh as far as Fremantle'.

25 Ibid., pp. 111, 120-3.

16 T. Irie, Hompō Kaigai Haltenshi, Tokyo 1942, vol. 1, p. 237.

17 Data paper prepared on the instructions of the Minister for Foreign Affairs, 20 Feb. 1891. J.F.M.A., 4.2.2.34 (vol. 1).

18 For details of early contacts betwicen Australia and Japan see D. G. S. Sissons, Australian-Japanese Relations: The First Phase, 1859-91; Canherra 1971, mimeographed, Ms. 3092 , N.L.A. I have been unable to find anything to substantiate the unfikely assertion made by the Japanese Legation in London in 1900 that Japanese were engaged in the pearling industry at Thursday Island as far back as 1875. Enclosure in Hayashi to Chief Secretary, Queensland, 30 July 1900, reproduced at p. 19 of 'Admission of Japanese into Queensland-. Further Correspondence Relating to', Queensland Legislative Assembly, Votes and Proceedings, 1901, vol. 4, p. 1139 .

19 In later years Murdoch achieved an international reputation with his three-volume History of Japan. In 1919 he was appointed Professor of Oriental Studies at Sydney University. For biographical details about Murdoch see J. H. Longford's preface to vol. 3 uf Murdoch's History of Japan, London 1926, the obituary in Sydney Morning Herald, 31 Oct 1921, the appreciation in the same newspaper, $26 \mathrm{Nov} .1921$ by M. Miyata, and the reference at p. 15 of S. Stephenson, Annals of the Brisbane Grammar 1869-1922, Brisbane 1923. 
Murdoch was back in Australia briefly in mid-1889 and appears then to have heard that Japanese prostitution had spread to Normanton, Burketown, and some other ports in the Gulf of Carpentaria:, ${ }^{a n}$

Unfortunately for the Japan Mail's thesis, the cmployment of Japanese crewmen on pearling luggers at Darwin, and on the north-west coast of Western Australia, predates this by several ycars. ${ }^{21}$ The Register (Adelaide) reports the arrival at Darwin of 12 indentured Japanese from Hong Kong on 30 June 1884 and of three more on 20 July. ${ }^{22}$ Pearling vessels from Darwin operated from the outset on the north-west coast. Early evidence of Japanese among their crews appcars in Westem Australian official records. The death of a Japanese diver named Nishimoto was registered at Derby on 30 April 1885. The following June the 'occurcnce book' of the police station at Cossack records the presence of a Japanese, Kinosuke, aboard the pearling schooner, Flowerdale. . $^{23}$

The proceedings of an inquest into the shooting of a Japanese prostitute, Aramaki Kumie, aged 22, at Wyndham on 7 March 1889, indicate that Murdoch was right about there being a Japanesc brothel in Wyndham, and that there were certainly Japanese prostitutes at Cossack, 500 miles to the south. The story that emerges from the depositions is that at the end of 1888 Kumie and another Japancse girl, Kiku, were operating at Cossack. Kumie was kcpt by a Chinese. We are not told whom Kiku was working for. Kumie forms an attachment with Taniuchi, a Japanese who was spending two months at Cossack pearling. He sells his boat at Cossack for $£ 110$, and advances $£ 20$ to Kumie, and takes her to Wyndham where he deposits her with a Japanese couple, Masaichi and Taki, who have been engaged in prostitution there for some time. Taniuchi returns to Cossack via Darwin to finalise details of the sale of the boat. At Cossack he spends a week with Kiku, who then travels with him to Wyndham where she joints the other three. Three days later Kumie is found shot about 300 yards from the town. The police arrest Taniuchi.

The Japanese witnesses testify that Kumie was much put out when Taniuchi and Kiku arrived from Cossack and Taniuchi stayed at the hotel instead of with her, that on the night of her death she had found him in bed with Kiku, whereupon she had rushed out of the house. At the time of his second visit to Cossack Taniuchi had left his belongings in the care of Kumie. She accordingly had access to his revolver. The implication was that when she rushed out of the house she took it with her and, in a fit of jealotisy and depression, shot herself. She

20 Article by Murdoch on 'Japanese Paphians' in Japan Echo, Yokohama, 15 Nov, 1890. This fortnightly journal, of which Murdocl was Editor, lasted for only six issues, 1 Nov. 1890 to $15 \mathrm{Jan}, 1891$. A complete file, 138 pages in all, is in the National Diet Library, Tokyo.

21 Mr. Hoolan in the Queensland Parliament also claimed that the prostitutes were the first Japanese to arrive at Darwin, Queensland Parliamentary Debates, vol. 70,28 June 1893, p. 183.

22 Register, Adelaide, I and 21 July 1884.

23 Cossack Police Occurrence Book (Ms. A/366), W.A. State Archives. 
also had access to his moncy which, Taniuchi testifies, was found to be missing when Kumie rushed out. Together, the Japanese witncsses present Taniuchi with a firm alibi. The jury expresses its dissatisfaction with them but, reluctantly, returns an open verdict. Taniuchi is released. ${ }^{24}$

This case presents intriguing possibilities. Had Taniuchi amassed the capital for his boat by trafficking in women; or was he a legitimate pearler who was also a Lothario? The freedom with which the girls seemed to move from town to town is somewhat surprising. According to Taniuchi, Kiku and Kumie were not satisfied with their prospects in Wyndham and had decided to take the boat to Darwin two days later, make money there, and return to Japan. All this suggests that Murdoch may have been correct when he referred to the brothels in the North-west as branch establishments of the Darwin brothels. Could the girls, in fact, move only with Taniuchi's consent and with him as escort? What was the role of Suzuki Tokujiro who, according to the Melboumc Consulate, lived in Lahvana (Gavanagh?) St., Darwin, and reported Kumie's death to the authorities in Tokyo?

One thing that emerges is that the Wyndham case does not support the Japan Mail's thesis. Even in Wyndham, there were Japanese who do not appear to be connected with the brothel (which, incidentally, was at the most only a two-room affair) -in the course of the inquest we meet two other Japanese householders and the court interpreter.

Fven though, in the case of Australia, the Japanese prostitute may not have been the cause of subsequent Japanese immigration and commercial activity, she may have played a role in the accumulation of capital by some of the Japanese enterprises that came after her. According to Muraoka Iheiji Jiden, said to be written by the biggest trafficker in Japanese women in South-east Asia in the 1890's, 75 per cent of the heads of successful Japanese enterprises in the Pacific were ex-convicts or fugitives from justice, who first became prosperous as procurers. ${ }^{25}$ Muraoka is, as we shall sec, a suspect source and anything said in the autobiography must be treated with caution. But Professor Mori Katsumi, after fieldwork at Amakusa, the district that provided many of the prostitutes for South-cast Asia, argucs that prostitution was an important factor in the development of Japanese wealth in Malaya where, he claims, the Chinese capitalists would never lend money to Japanese for other purposes. ${ }^{26}$

Irie Torajiro, whose history of Japanese emigration, published in 1942, still remains the standard work on the subject, takes a similar view, observing that when the Consul-General in Singapore finally closed the brothels in 1920 the withdrawal of the capital which they had provided to other local Japanese enterprises caused a chill wind to be felt throughout the Japanese resident com-

24 C.S.O. $1296 / 89$ and $269 / 90$, W.A. State Archives.

25 Y. Kawai (ed.), Muraoka Theiji Jiden, (The Autobiography of Muraoka Iheiji), Tokyo 1960 , p. 57. I am indebted to G. J. Toff of Nagoya Kögyö University for bringing this useful source to my notice.

26 K. Mori, Jinshin Baibai: Kaigai Dekasegi Onna, 1959, p. 166. 
munity. ${ }^{27}$ Mori camc across the case of a doctor from Fukuoka prefecture, who in the Netherlands East Indies was able to acquire coconut and rubber plantations with money which he borrowed from the local Japanese prostitutes. ${ }^{28}$

We have already raised the possibility that Taniuchi in the Wyndham case may have bought his lugger from money made out of trafficking in women. It was asserted in the Sydney Bulletin (6 January 1894) that the Japanese prostitutes at Thursday Island 'often devote their savings towards purchasing boats for their male friends'. This was something that seriously worried the senior representative of the Queensland Government on the Island, John Douglas, the Government Resident. In October 1893, reporting to the Qucensland Colonial Secretary on an official inspection of the brothels, he wrote:

The profits are very considerable. I have not been able to ascertain cxactly how these profits are divided-Several Japanese women are known to have madc a good deal of money, and much of this has been invested in shares of shelling boats. There are now forty boats owned by Japanese....

Douglas at the time was very worried that the Japanese might gain control of the pearling industry and, partly for this reason, he recommended that steps should be taken to prevent the entry of more prostitutes. ${ }^{29}$

\section{Who were the traffickers?}

There arc two early cases where the modus operandi of the traffickers is described.

In April $1889 \mathrm{H}$. Satō, a local government official from the northern island of Hokkaido, visited Australia. He passed through Darwin on his journey south. What he heard therc disturbed him so much that he wrote (in English) to the Honorary Consul in Melbourne about it. He reported that there were 19 Japancse women in Darwin, all of them leating 'a shameful life to the disgrace of their countrymen'. Five of them, atl young women born in Nagasaki, had come from Hong Kong to Darwin with Takada Tokujirō. One he had sold to a Malay barber for $£ 50$, two to a Chinese at $£ 40$ each, one he had kept as his concubine; the fifth he was working as a prostitute. ${ }^{30}$

We have already mentioned Watanabe's reference to prostitutes in Darwin in his report on his visit to Australia in $1893 .^{31}$ This states that the 12 prostitutes (all of them born in Kyushu, most from Nagasaki prefecture) had all come to Darwin after plying their trade in places like Hong Kong and Singapore. Accor-

27 T. Irie, Höjin Kaigai Hattenshi, Tokyo 1942, vol. 2, p. 230.

28 Mori, op. cit., p. 210.

29 Douglas to Hon. H. Tozer, 2 Oct. 1893, Q.S.A. 55/1, Col. Sec. 93/12777. Also Douglas to Col, Sec., 7 Oct. 1893.

30 In Darwin Takada had aiso managed to ruin anothcy Japanese by fraudulent dealings and was planning trs abscond by the next boat to Singapore. H. Satory to A. Marks, 12 April 1889, enclosed in Marks to Vice-Minister of Foreign Affairs, no. 11 of 24 April 1889. J.F.M.A., 3.8.8.4.

s1 See page 327 above. 
ding to Watanabe the procurce in Japan would seek our poor families and make an advance of 20-30 yen for each victim. He would then make arrangements with the captain of a foreign ship to smuggle them to Hong Kong or Canton at 50-60 yen per head-they would be put aboard from a fishing boat as soon as they were beyond the radius of surveillance by the water police. ${ }^{32}$ At Hong Kong the procurer would sell them for about 200-300 yen and then return to Japan and repeat the process.

In 1960 a formcr Professor at St. Paul's University, Tokyo, Kawai Yuzuru, published the autobiography of Muraoka Iheiji $\mathrm{i}^{33}$ who (as already noted) claimed to have been a leading figure in the operation of Japancse prostitution overseas. In the autobiography he states that from about 1890 to 1894 his headquarters were at Singapore, and that during that period he superintended the smugging of 3,222 women from Japan to Singapore whence he despatched them as prostitutes as far west as Mauritius. ${ }^{34}$ He clains that at one time during this period he was sending 20-30 girls per month to Australia. ${ }^{35}$

Among Japanese scholars a controversy still rages as to the reliability that should be accorded 'Muraoka's' assertions. For example, Yamazaki Tomoko, in the preface to her book, Sandakan Hachiban Shokan, publishcd in 1972, argues that very littlc reliance can be placed on them. ${ }^{38}$ She bases her argument principally on two grounds: (1) Many books have been written by Japanese travellers and residents in South-east Asia, and several of these mention the names of the principal Japanese brothel-kecpers. Muraoka is not mentioned in any of these. Furthermore, Miss Yamazaki has interviewed a dozen or so old women now in their $80 \mathrm{~s}$ and $90 \mathrm{~s}$ who in thcir youth were prostitutes in Southeast Asia and none of them had ever heard of him; (2) Several of the claims in the book are at variance with the facts. For example, although Muraoka alleges that he met two famous Japanese statesmen, Itagaki and Itō, in Singapore in December 1890 and October 1891, Japanesc newspapers indicate that each of these was in Japan at those datcs.

There are, however, others who regard Muraoka as a valuable historical source. Naturally, among these is Professor Kawai who published the autobiography. In the 1930's Kawai was teaching at the Japanese Higher Commercial College at Taihoku in Formosa. He claimed that in 1936 on a visit

32 We do not have to rely on Watanabe for evidence that giris were at this time shipped to Singapore in this fashion. On $10 \mathrm{Feb}$. 1894 the Master of the MacDuff testified at Singapore that he had brought 34 women and 6 men in this manner. Ten women and 3 men came aboard the night before the ship left Kuchinotsu (Nagasaki prefecture). When they had cleared the harbour he picked up the remainder from a boat. He was promised $\$ 30$ per head (J.F.M.A., 3.8.8.4).

33. See frotnote 25 above.

34 An Asthi Shimbun correspondent visiting Zanzibar in 1925 met a Japanese prostitute there who had reached Mauritius from Bombay before the turn of the century, I. Shirakawa, Jitchi Tósa Higashi Afurika no Tabi (cited in Miyaoka, op. cit., p. 184).

gs Ibid., p. 87.

30 T. Yamazaki, Sandakan Jachiban Shökan (Brothel No. 8 at Sandakan), Tokyo 1972, pp. 14-19. 
to the Philippines he met Muraoka who gave him his notebooks to edit and that in 1937 Muraoka spent three wecks with him in Formosa helping him to remedy obscurities in the text. He is convinced that Muraoka's notebooks were honest attempts to set down fact. His personal assessment of Muraoka is that he was quite lacking in the imagination and literary talent that would have becn required to concoct such a story. ${ }^{3 \pi}$

Professor Mori, on the basis of research in Amakusa, the district in Kyushu that provided many of the prostitutes for South-east $\Lambda$ sia, also places considerable reliance on the autobiugraphy. He claims that names that Muraoka mentions as coming from this district do, in fact, tally with the names of people who went overseas from the district. ${ }^{38}$ Miyaoka, to whom we have already referred, considers Muraoka ' $75 \%$ reliable'.

What reliance should we place on Muraoka's references to Japanese prostitution in Australia?

They certainly cannot he accepted without qualification. I have already referred to his claim that at onc time he was sending 20-30 girls a month to Australia. The Western Australian Census figures, however, stiggest that he could not have maintained such a rate for any length of time. ${ }^{\text {in }}$

The only part of Australia that Muraoka mentions is Western Australia and the only specific place-name that he gives is rendered by his editors in Japanesc phonetic script (katakana) as 'Fu-ru-ga-tc-n'. Referring to his activitics late in 1889 (corrected by his cditors to 1890), Muraoka writes:

As soon as I got back to Singapore [from India? I provided women for the Australian region. I took 8 to Takano at Furugaten in Western Australia and, in the same way, 11 to Nishiyama. The natural products there are gold, silver, pearl-shell, wool and coat. The natives are called 'binghi'. 'There the Japanese prostitutes also go inland. An old madam, O-some, goes on tour with two girls. They carry their tents with them on their backs. O-natsu-san also goes on circuit with two girls. Each of them has put away three or four thousand yen. A man from Wakayama prefecture is working 5 girts in Furagaten; so next I provided Osaka and Sakata with 8 girls each and set them up in business. . . After that I got Matsuda and Araki each to take 5 girls to Furugatern. ${ }^{41}$

If Muraoka's handwriting was at all hard to read and his editors readily admit that it was) Fu-ra-ga-te-n could well be Ku-ru-ga-de, i.e. Coolgardie. The problem is that, while by his own account Muraoka appears to have ceased operations in Singapore in 1894, local material strongly suggests that Japanese prostitutes did not appear in Coolgardie until the first half of $1896 .^{42}$ Assuming

37 Kawai, op. cit., postscript.

38 Mori, op. cit., p. 145.

39 Interviewed by D.C.S.S., 12 Nov. 1973. See p. 327 above.

40 The number of Japanese females in Western Australia rose from 62 in 1891 to only 209 in 1901.

12 Kawai, op. cit., p. 67.

42 See detailed account of the history of prostitution in Coolgardie in Coolgardie Pioneer, 17 April 1897. See also ibid., 8 July 1896. 
that 1889 or 1890 is correct, the region that corresponds most closely with Muraoka's description is Cossack-Roeboume and the Pilbara Goldficlds (proclaimed July 1889) to which it was the gateway. Of the 62 Japanese females in Western Australia at the 1891 Census 39 were in this region (North).$^{43}$ Cossack, Rocbourne and the Pilbara would explain Muraoka's references to pearl-shell, wool, gold and binghis. Moreover, from the $W$ yndham inquest we know that Japanese prostitutes were operating in Cossack as early as 1888.

One item in his autobiography suggests to me that Muraoka was acquainted with Western Australia's immigration procedures (which for that day and age were somewhat unusual). He states that on his first arrival at Singapore in March 1889 (corrected by his cditors to 1890), he stayed at a 60-room hotel cum brothel operated by Inada Shinnosuke, where he claims there were 15 or 16 girls who were going to Australia. He claims that he and two other Japanese who had arrived on the ship with him joined the party and went to be examined in order to get permits for Australia. He passed the examination, but his two male companions failed. ${ }^{4+}$ Not wishing to be separated from his companions, he decided to remain in Singapore. As I understand the Western Australian Imported Iabourcrs Registry Act in force at that time, Muraoka and his male companions, as Asians of the labouring classes, would have been required to undergo a medical examination at Singaporc before cmbarking. ${ }^{45}$ Accordingly, I do not reject out of hand his other references to his operations in Australia.

My own position is ahout one-third the distance between Miss Yamazaki and Professor Mori. I think Muraoka was a boaster, the scale of whose operations was very much smaller than he gave out. I also think that, in writing some years after the event, his memory may have let him down. In, say, 1896 the stream of Japancse prostitutes may for at while have been directed to the Coolgardie/Kalgoorlie district. In after years Muraoka may have remembered the name, Coolgardie, but forgotten such names as Cossack or Roebourne.

$\mathrm{He}$ clains that in Singapore he recruited an organisation of dozens of Japanese ne'cr-do-wclls-mostly criminals who had cither escaped from gaols or fled the country to avoid imprisonment. One can assume that the Japanese. police and prison authorities were rather more cfficient than to let dozens escape to Singapore alone. But let us say that he was associated in some way or other with a few such people. He claims that he used these as procurers and cscorts to set up branch establishments. He gives brief hiographies of several of the men that be set up in Western Australia.

Of the men in the passage that wc have quoted ahout his consignment to Western Australia in 1889 or 1890 , Muraoka gives us additional information

43 The remaining 23 were divided between: Kimberley West which included Broome and Derby, 20; and 3 in Gascoyne which included Shark Bay. There were no Japanese on the Kimberley Goldfields at the time of the Census.

${ }^{44} \mathrm{Kawai}$, op. cit., p. 44 .

4548 Vic. No. XXV, Sects. 3, 10 and 11 . 
about Osaka, Sakata, Matsuda and Araki. In Japan Osaka Tamekichi used to enjoy throwing stones at shop windows and pinching the bottoms of the girls among the throng of spectators that this attracted. He had finally heen apprehended and sent to prison for eight months. Sakata Junzaburō had seduced his employer's daughter, planning to return after the birth of the child and be accepted as heir. Instead, his employer offered a reward for his capture. He was imprisoned but escaped to Singapore. Matsuda Hitoshi had been in and out of gaol in Japan for armed robbery and for smuggling girls out of the country.

Later in the autobiugraphy Muraokat says that, when he wound up his establishment in Singapore, he sent one of his employees, Ueda Tomosaburo, to Australia with the injunction that he was to send him every penny he made. $\mathrm{He}$ also warned him that he had more than 10 henchmen in Australia who would deal with him seriously if he was caught ill-treating the women. ${ }^{46}$

Perhaps these men were Muraoka's superiors or competitors, and not his henchmen; but like Kawai, I doubt whether Muraoka could have made them all tip.

Fortunately we do not have to rely on Muraoka for evidence that, before the cnactment of the Immigration Restrict Act, both prostitutes and souteneurs used to move from Singapore to Australia, and back again, as opportunities presented themselves. Nishimura Takejirō who lived as a medical practitioner in Singapore from 1902 to 1936 , recounts the following story told to him by a Japanese prostitute in Singapore in 1904.

It was when I was working at No. 15. It was the couple who are now operating in surh a big way in Malabar St. (the rentre of the Japanese brothel area in Singapore). Now he is the proprietor of a magnificent store. When the was young he bought some giris, and without paying for them, went to Australia where he set up a brothel. The brothel-keeper here told me to go to Australia and dun him for the money. I set off-partly to see Australia. It's a hot place. Even out at sea it's much hotter than Singapore. During the daytime you can't venture outside for a inoment. It's like being baked in an oven. The houses have only four or five rooms and are single storeycd with a galvanised iron roof. Around you there is nothing but sand-not a blade of grass or a trec to be seen. It's a tiresome place. ${ }^{57}$

\footnotetext{
46 According to Muraoka, Ueda had been orphaned when he was 14 years old. Son afterwards, when he discovered that the children next domr were stealing his lamily's grain, he set up a bomb as a booby-trap. This blew off a child's foot, and he was sent to a reformatory until he was 20. He had no sooner returned home than he beat up a child that his sister had adopted. For this he was put in the local lock-up. He escaped, however, and in revenge set about burning down some 14 or 15 of the houses of his neighbours. Fortunately, it had been raining and the fires did not take. He fled to Hong Kong. As a brothel-keeper in Australia he prospered and returned to Shimane Prefecture where he became a large landowner. Kawai, op. cit., pp. 54-5, 93-4.

47 T. Nishimura, Zainan Sanjügonen, Tokyo 1936, p. 46. Miyaoka (op. cit., pp. 155-6) quotes this passage and, without stating any reason, makes the locale Thursday Island. The description of the climate and the terrain, however, is more suggestive of the North-west.
} 
Additional evidence that the smuggling of women out of Japan was controlled by operators in Hong Kong and Singapore, whose activities extended to Australia, is provided by Sano Makoto, a trainee in the Ministry of Agriculture and Trade who was sent on a tour of South-east Asia. On the ship that took him to Macassar he met a Japanese prostitute who told him the following story. She was born in Kumamoto prefecture and was working as an operative in a local cotton mill. She and her boy-friend and five others were smuggled out of Moji with the promise that there would be work for them at high wages in a mill at Singapore. When they arrived at Singapore four or five bullies were waiting for them. The women were sold to the brothels, and the man was sent to 'the gold mines in South Australia', "When I first read this I was inclincd to reject it as fictional, because there were no gold mines in South Australia and because Asiatics were usually prohibited in mining arcas. When it is remembercd, however, that, at that time, South Nustralia included the Northem Territory, the picture changes. Furthermore, South Australia, unlike Queensland $^{49}$ and Western Australia, ${ }^{50}$ had no legislation excluding Asiatics from gold fields. At the 1901 Census, of the 166 Japanese males in the State, 16 were employed in gold-mining, making this their next largest occupational group after the pearling industry.

\section{Where did the women come from?}

Our best sources for the birthplaces of the Japanese women who came to Australia are the applications by Japanese residents for Alien Registration in $1916^{51}$ and the inscriptions on such Japanese tombstones as still survive at Thursday Island and Broome.

Among the 54 Japanese women who applied for Alien Registration in Queensland the birthplaces of 50 are stated. Of these, 54 per cent were born in Nagasaki prefecture and 12 per cent in the neighbouring prefecture of Kumamoto. At Thursctay Island, out of the 8 Japanese women whose birthplaces are stated on their graves, five were from Nagasaki prefecture and one was from Kumamoto prefccture. ${ }^{52}$ Nagasaki prefecture also provided most of the Japanese women who went to Western Australia. In 1901, of the 59 women in Aiba's tahle (abovc, page 326) 30 came from there and 5 from Kumamoto prefecture. In 1916, among the 87 Japanese women who applied for Alien Registration in Western Australia, the birthplaces of 80 are given. Of these 51 (i.e. 59 per cent) were born in Nagasaki prefecture and 6 (i.e. 7 per cent) were horn in Kumamoto prefecture. At Broome 10 of the 15 Japanese women

48 M. Sano, Nanyōshotō Junkōki, Tokyo 1913, quoted in Miyaoka, op. cit., p. 42.

18 Queensland, Mining Act 1898 , Sect. 15.

so W.A. Goldfields Act 1892, Sect. 3; Minerals Lands Act 1892, Sects. 8 and 12.

i1 Bristane Office, BP 4-3-51; Perth Office, PP 14/3, Australian Archives (A.A.)

52 I am indebted to Mr. Ochiai of Tharsday Island and to the Consul-General in Brisbane (Mr. S. Okamaru) for kindly providing me with a copy of their list of inscriptions on alt the surviving tombstones on Japanese sraves at Thursday Island, compiled by local Japanese residents in about 1972. 
whose birthplaces are stated on their graves were from Nagasaki prefecture. ${ }^{53}$ Professor Mori in his research on cmigration from this region analysed the birthplaces of 304 prostitutes named in Muraoka's autobiography and obtained a similar result: the largest number $(34$ per cent) were from Nagasaki; while Kumamoto provided 16 per cent. ${ }^{54}$

Unfortunately the Queensland Alien Registration Applications rarely show which parts of the prefectures the women camc from. Mori, however, has been able to establish that 55 per cent of the women from these two prcfectures mentioned in Muraoka's autobiography came from the Shimabara Peninsula, and from the Amakusa Islands, which face the peninsula from across the Hayasaki Strait. These together amount to only about 12 per cent of the combined area of the two prefectures.

So far as I am aware, little demographic work has been done on the Shimabara Peninsula. Mori, however, has done some interesting work on the Amakusa Islands. From the accurate population and taxation records that have been kept, he demonstrates that, between 1691 and 1856, their population more than trebled, while rice production increased by a factor of only 1.08 .

In this part of Japan accurate records were kcpt of people who were absent from the district. The region was converted to Christianity in the 16 th century and, in order to stamp out this religion and detect its adherents, the whole population was required annually to trample on a Christian image. A register was kept of those who, because of absence, had not been tested. By comparing this register for the village of 'Iakahania for the years 1828, 1849 and 1859 with the taxation returns, Mori demonstrates that it was the households with cither a small output or a large number of mouths to feed who had absent members-i.e. who were sending members away to earn money to kecp the family solvent. From similar records for the same village he also demonstrates that by 1862 it was the women who were being sent away." The region's dependence on emigration continued until World War II. In 1941 about onesixth of the total population was outside Japan-and, as in the past, among its emigrants, women were in a majority." The Osaka Mainichi Shimbun hefore World War II calculated that the annual remittances home from Amakusa women overseas exceeded 200,000 yen. According to Mori this would go a long way towards covering the import surplus of the region, ${ }^{\text {in }}$

\section{How were they procured?}

Muraoka writes that, when at the outset of his operations in Singapore he collected his band of ruffians to procure women in Japan, he instructed them

53 I am indebted to Mr. T. Kawabata, formerly Consul-General at Perth, for providing me with a copy of the list of the inscriptions on all the surviving tombstones on Japanese graves at Broome, compiled by local Japanese residents in 1956.

54 Mori, op. ait., p. 177.

sв Ibid, pp. 35-40.

s lbid., p. 190.

57 Ibid., p. 212. 
to go, not to busy places, but to the country; to choose girls with as little education as possible and avoid those who had been to secondary school. They should also avoid girls whose parents had capital. ${ }^{58}$

The few primary sources that are available to us suggest that Japanese women who came to Australia were for the most part very young. Of the 33 women from Nagasaki and Kumamoto Prcfectures applying for Alien Registration in Queensland, the ages on arrival of 32 can be deduced. ${ }^{99}$ They were as follows: under 13 years, 3 ; $15-17$ years, $8 ; 18-20$ years, $13 ; 21-23$ years, 5 ; 24-27 years 2, 28 ycars and older, 1. Similarly, of the six Japanese women whose deaths were registered at Broome between 11 February 1896 and 16 October 1901, five were born at Nagasaki. The age on arrival of all five was between 18 and 21 .

The only information available about the education of the Japanese women is the proportion of them who were illiterate. Of the 209 Japanese women in Western Australia in 1901, 206 over the age of five years answered the literacy question in the census. Of these 61 (i.e. 29 per cent) answered that they conld not read any language. 'This was almost the same proportion as amongst the men (30 per cent).

Less evidence is available regarding parental wealth; but what very limited information we have suggests that, as one would expect, the women who came to Australia from Nagasaki and Kumamoto wore daughters of farmers or labourers. In the Broome register of deaths the father's occupation is given for three out of the five Nagasaki women. They are: farmer, lighterman and labourer. Among the Japanese women in Queensiand who were interned in 1941 were eight who had arrived from these two prefectures hefore the enactment of the Immigration Restriction Act. For seven of these the occupation of their father is known: farmer, 3; shopkeepcr, 2; ship's captain, 1. Possibly the status of the ship's 'captain' had risen in the daughter's imagination over the years.

The only completely reliable picces of evidence avaitable about how the traffic to Australia operated are two references in communications from the Govermment Resident at Thursday Isiand.

In 1893 he reported that he had placed in quarantine three prostitutes who had arrived from Hong Kong en route to Normanton and Croydon, their fares paid by Chiyokichi of Thursday Island, 'with whom they are under an agreement'; $\$ 80$ had becn paid to the parents of two of the girls; the third girl was going to her sister's 'coffee-shop' in Croydon. ${ }^{60}$ We have heen able to establish the age of one of these girls from other evidence-it was 15.

The other case reported by him was in December 1897. He transmitted to the Home Secretary the deposition of a recently arrived prostitute, Hashimoto

58 Katwai, op. sit., p. 56.

59 These ages are only approximate, as the original registration particulars are recorded in rounded years.

So Q.S.A. 55/1, C.S.O. $93 / 14648$. 
Usa, aged 21, from Nagasaki. She claimed that in June of that year in Nagasaki a man named Konishi had offered to take her to see her sister who ran a lodging house in Singapore. He embarked her along with 10 other young women on a sailing ship at midnight without passports. At Shanghai they were transferred, without landing, to a steamer for Hong Kong. At Hong Kong they were all put into a Japanese lodging house. She suspects that the proprietor of this lodging house paid a considerable amount of money to Konishi for her. The proprietor told her that she could not land in Singapore without a passport, and urged her to go to Thursday Island, where a passport was not rcquired. She agreed and was duly despatched to Thursday Island with other Japanese women, escorted by a Japanese calied Matsubara. Matsubara handed her over to a brothel-keeper, Shiosaki, in Thursday Island, in return for cash. Accordingly, she entered into an agreement with Shiosaki whereby she undertook to pay him $£ 100$ out of her carnings. ${ }^{.1}$

Had the girl booked a passage from Japan to Thursday Islind in the normal way, it would probally have cost her about \&12. ${ }^{62}$ Instead, she incurred a debt of $£ 100$ which she had to pay off by prostitution. in return for the hardships of a stowaway. The ordeals of the latter sometimes ended in a horrible death. Katō Hisakachi, for many years a ship's captain on the China run, writes of an incident that took place carly in this century. On a voyage from Kyüshü to Hong Kong, engineers investigating loss of pressure in a water pipe found in the bunkers a group of girls who, in the last stages of starvation and exhaustion, had bitten a hole in the pipe to secure water. Buried under the coal beside them were the lacerated bodies of their two procurers on whom the girls had taken a terrible revenge as what they thought were their own last hours approached. ${ }^{\text {es }}$

In a book that he wrote when an official of the Seamen's Union in 1918, Honekubo Mitsusuke, the formcr ship's captain who, in 1947, became a minister in Japan's first Socialist Cabinet, also describes the terrible fates that sometimes awaited these stowaways. Women hidden in the bunkers were crushed to death when the coal shifted with the rolling of the ship, or burned to death when the coal caught firc by spontaneous combustion. The only sign of their one-time presence would be when a fireman's shovel brought up a shred of cloth or a piece of bone. The Kachidate Maru which nperated between Kyushu and Hong Kong/Singapore was said to be haunted by the ghosts of nine women and two men. The story is that, in return for money, some firemen hid them in the space betwecn the boiler-room and the ballast tanks. Just out of Nagasaki the boilers burst and they were scalded to death. The firemen waited till dark and secretly dumped the corpses into the sea, like refuse. For this reason the ghosts of the women were unable to leave the ship and remained to haunt it. ${ }^{84}$

61 Q.S.A., Col. A/822, 97/15833.

22 Hattori, op. cit., p. 47.

e3 H. Kato, Sentó no Nikki kara, quoted in Miyaoka, op. cit., pp. 3 l-2.

*4 M. Yonekubo, Madorosu no Hiat, Tokyo 1918, qquted in Miyaoka, op. cit., pp. 34-5. 
Another hazard for the women who were smuggled aboard in this fashion was suffocation. When the Fushiki Maru arrived at Hong Kong on 26 March 1890, 12 Japanese stowaways from Nagasaki were discovered in the coffer-dam separating the engine-room from the hold. Of these, 8 (7 women and 1 man) were dead and the remaining 4 women were barely alive. The coffer-dam was $3 \mathrm{ft}$. wide and extended for the width of the ship; its height varied from about 18 inches to about $3 \mathrm{ft}$. After the stowaways had entered, the hold had been filled with coal and this had rendered their hiding place virtually airtight. The surviving girls testified that the dead man, who went from house to house selling cooking oil, had lured each of them aboard by promises of good situations in Hong Kong. Some of them had got aboard dressed as coal coolies. $^{65}$

As we have noted, Hashimoto Usa arrived in Australia with a debt of $£ 100$, in return for which she had received nothing. This illustrates one of the aspects in which the overseas prostitutes' Int was worse than that of the women who cntercd prostitution in Japan. As Mori points out, under Japanese law, ${ }^{\text {bo }}$ an agreement by a woman to enter a brothel as a prostitute had to be registered at a police station. The police at the time of registration satisfied themselves that the woman was a willing party and that the advance against future carnings stipulated in the contract was actually paid. The police also established that the woman was at least 18 years old. ${ }^{67}$ This was another safeguard that the girls who went overseas did not enjoy: as we have observed, many of those who went to Australia were well under 18 .

The girl in the case just mentioned deserves much sympathy. At the same time, a closer look at the documents reveals that her sister's lodging house in Singapore was in Malabar St., the centre of the Japance brothel area. Her real intention in leaving Japan may wcll have been to join her sister in that business. Muraoka, however, describes a casc which, if true, is much mort serious. In 1895 a 19-year-old girl delivered to him at Singapore for despatch to Australia implored him instead to keep her for himself. Her story was that she was the daughter of a draper in Kyoto. She was engaged to be married to a university student in Tokyo the following year. A procurce overheard her say that she would like to spend the months before her marriage learning how to do housework. The procurer came forward and said he knew just the job in Nagasaki where, in the course of acquiring such skilts, she could earn 6.7000 yen-and the train left that night? At Shimonoseki he transferrcd her and three other girls surreptitiously into the hold of a steamer, telling them to make no sound or they would be apprehended and punished as illegal emigrants. The ship took them to Singapore.

6. Japan Weekly Mail, 12 April 1890. For further details see J.F.M.A., 3.8.8.4, vol. 1.

os Nainushôrèi: Shögi Torishimari Kisoku (Oct. 1900).

a7 Mori, op. cit., pp. 98-9. 
Although by his own account Muraoka rarely repatriated a girl unless she had become ill or deformed, he claims that on this occasion, he notified the girl's parents and gave them the chance to redcem her for 600 yen. They did so. ${ }^{88}$

Australian National Lniversity

D. C. S. Sissons

68 Kawai, op, cit., pp. 99-101. 


\section{KARAYUKI-SAN: JAPANESE PROSTITUTES IN AUS'TRALIA, I $887-1916-$ II $^{*}$}

\section{Women stowaways landed in Australia}

In the pre-federation period Japanese women do not appear to have entered Australia as stowaways. It is not until after 1900 that allegations to this effect begin to appear periodically in the Austratian press. ${ }^{1}$ Until the Immigration Restriction Act came into force in 1902, in the three colonies in which we are interested, only the Government of Western Australia had a statutory power to prevent the landing of prostitutes or persons living off them. Furthermore, this statute was not enacted until December $\$ 897$. $^{2}$ The only other statutory powers with regard to the landing of immigrants appear to be, in the case of Western Australia ${ }^{3}$ and South Australia, ${ }^{4}$ the power to levy a $\$ 200$ bond for persons likely to become a charge upon the public. Chung Toy v. Musgrove in 1891 established that an alien who had been denied admission had no Icgal remedy: ${ }^{5}$ but despite this, Colonial Governments in Australia appear to have been almost as reluctant as the British Government to use the crown prerogative in order to deny entry to immigrants by categories. For example when on 23 August 1894 a deputation waited on the Western Australian Premier, Sir John Forrest, seeking the closure of the Japanese brothels in Geraldton he replied that 'There was a difficulty in this matter and unless they prohibited the ingress of Japanese altogether they would hardly be able to keep out members of this particular class.' 6

My guess is that until at least the late 1890 s prostitutes entered Australia as they did the United Kingdom, virtually without let or hindrance. Admittedly, in I 891 two Japanese prostitutes on arrival at Thursday Island were deported by the Queensland Government 10 Hong Kong. ${ }^{7}$ This action, however, seems to have been most unusual. The fact that in this case their deportation was formally requested by the Japanese Consul may perhaps have had something to do with it. The South Australian Government, acting not under statute but under the prerogative, on 20 July 1898 issued a proclamation directing all Customs officers, subject to the approval of the Treasurer, 'to refuse and prevent admission into South Australia of any alien not entitled by treaty to enter South Australia'. Whether this Proclamation was ever invoked to prevent the entry of a Japanese into the Northern Territory is not known.

\footnotetext{
* Part I appeared in the previous issue.

1 An exception is a Thursday Island report in the Bulletin (11 Jan. 1896 ): 'Within the last two months they have introduced women in men's clothing for the purpose of prostitution. These women are attended by a keeper to every gang, and are praclically slaves, as the police hete know.'

2 Immigration Restriction Act 1897, 61 Vic., No. XIII, Sect. 3f.

s Customs Consolidation Act 1892, 55 Vic., No. XXXI, Sect, 339.

- Immigration limitation Act 1891,54 and 55 Vic., No. 519, Sect. 2.

s. Musgrove v. Chen Teeong Toy (1891) A.C. 272.

- Geraldion Advertiser, 27 Aug. 1894.

Q.S.A., COL/A680, C.S.O. 9]/14105.

* South Australian Government Gazette, 1898, No, 30 (21 July), p. 107.
} 
As late as July 1898 nine Japanese prostitutes and their three escorts were permitted to land from the Tokyo Maru at Thursday Island. Since they had come aboard at Hong Kong and not in Japan, the shipping company was, presumably, not contravening Japanese law. I he three men apparently carried some quantities of clothing as samples to lend credence to their claim that they were merchants. ${ }^{9}$

In such circumstances there would have been little need for Japanese prostitutes, on the last leg of their journey to Australia, to stow away.

Obviously Japanese brothels in Australia could not continue indefinitely to operate profitably unless they were replenished by younger women as those introduced before 1902 aged. The brothels continued and this led to suspicion that young women were being smuggled in. As late as 1928 for example the Queensland Branch of the National Council for Women forwarded to the Customs authorities allegations that batches of Japanese women were being landed at Townsville at regular intervals. ${ }^{10} \mathrm{H}$. W. Hardie, the Sub-Collector of Customs at Thursday Island, referred to this question in the course of a report to the Secretary, Home and Ierritories, at the end of a tour of North Queensland in search of Japanese male illegal immigrants in January $192 \mathrm{t}$.

I have just recently been placed in possession of some very disquicting information regarding the stowaway question and the story, which is briefly as here related, is being followed up. Each of the Japanese mail boats has a secret compartment which has been built by the boatswain or the carpenter. It is fitted with electric light and has an electric fan to keep the air sweet. On every trip women are brought down. These women are led to believe that they are being taken to Austratia to fill honourable positions and they go the length of entering into bogus contracts. When they are on the vessels they are subjected to such treatnent that their scruples are broken down and they then lead the immoral life that they were originally intended to follow. It is stated that they are landed on an island near Thursday Island in collapsible boats; that a depot is in existence somewhere in forth Queensland and that a launch proprictor takes them from the island where they land to such depot, whence they are subscquently distributed over Australia. It is said that two of these women are now at $A y r$. Of course it will be seen that there are flaws in the story, but it is possibte that there is a grain of truth in ir. I know that something similar was done in 1908 and it was in connection with the story that 1 held up Nobu Ide's Ciertificate of Elxemption from the] D[ictation] T[est] pending investigation. ${ }^{11}$

Fortunately there survives in the Commonwealth Archives the Register of prosecutions initiated under the federal Immigration Restriction Act for the period 1902-30. ${ }^{12}$ From the Register it appears that no Japanese woman was ever charged as a prohibited immigrant under Sect. $3(\mathrm{f})$ - 'any prostitute or person living on the prostitution of others'. The Register indicates, however, that several Japanese women were charged for falure to pass the dictation test. Such Department of Home and Territories files as exist suggest that some (perhaps all) of these were prostitutes.

- Acting Consul, Townsville to Vice-Minister for Foreign Affairs, No. 3, 25 July 1898, Japan, Ministry for Foreign Affairs, Nihon Gaikō Bunsho, 1898, vol. 2, p. 102.

10 Prostitution - registration details of Home \& Territories file $28 / 8880$, A.A. A31.

17 H. W. Hardie to Sec., Home \& Territories, I9 Jan. 1921, A.A. A2219.

12 A.A. A19. 
Ide Nobu, the woman referred to in Hardie's report, was one of two 'young, fresh-looking girls' discovered in a Thursday Island brothel in 1910 when the police were following up an anonymous letter that claimed that three women stowaways had entered Queensland the preceding year aboard the Yawata Maru. On failing the dictation test, they were prosecuted as illegal immigrants under Section 5(2) which empowered officers to administer the test to any immigrant withit one year (amended in September 1910 to two years) of arrival. In court both girls testified, rather unconvincingly, that they had arrived on the Omi Maru in 1897 or 1898 . The Crown, however, failed to convince the magistrate that the test had been administered within the statutory period and they were acquitted. ${ }^{13}$

The Yawata Maru remained the object of suspicion for some time. It figured in another prosecution under the same sub-section the next year (1911). Following a tip-off that this vessel had landed eight Japanese (three men and five women) in a small boat forty miles north of Townsville, the police discovered an apparent 'new chum', Urita Otomo, among the Japanese prostitutes at Charters Towers. Although the Crown managed to cast serious doubt on her testimony that she had arrived on the Futami Maru in 1900, it once again failed to convince the court that the dictation test had been administered within the prescribed period. ${ }^{\text {t }}$

In the third of the Yawata Maru cases the prosecution managed to secure a conviction. The Register indicates that at Thursday Island on 13 June 1913 Yoshida Tsumoe was convicted under Sect. 5(i) and that as a result Constable Merrit was paid $£ 5$ reward. Section $5(i)$ provides that an immigrant who evades an officer or who enters the Commonwealth at any place where no officer is stationed may be given the dictation test if at any time thereafter found within the Commonwcalth. Prosecutions under this sub-section were very rare. Presumably this was because, of its very nature, the task of proving that the accused had evaded an immigration officer was a difficult one. Where the circumstances permitted, it was customary, as we have seen, to lay charges under Sect. 5(2). Since Yoshida was not charged under Sect. 5(2) we may presume that she landed some time before June of that year, i.e. on the voyage commencing Yokohama 10 December 1910 or that commencing 4 March 1911. Since she was convicted on so difficult a charge, our guess is that Constable Merrit had been able to secure a confession. This appears to have been the only case where the landing of a Japanese woman stowaway in Australia was ever established beyond reasonable doubt.

Ihe archives of the Japanese Ministry for Foreign Affairs contain a despatch from the Consul-General at Hong Kong reporting another incident involving the

is A.A. A1, 10/5858. In 1921 in was because Hardie suspected that the two women at Ayr were working for lde (who now resided in that town) that he considered denying her the exemption certificate without which she could never re-enter Australia. 'Confidential Notes for the Guidance of' Officers: Immigration Restriction Act 1901-10' (A.A. A I, I //6266) laid down that such certificates should be refused to brothel-keepcrs. Evidently Hardie failed to establish this; for the certificate was issued and with it she in duc course re-enlered the Commonwealth. The Department's Book of Precedents indicates that being a prostitute did not per se render an applicant ineligible for an exemption certificate ("C.E.D.T. - Jap. prostitute - application appd. - 19/2263". A.A. A 3823 ).

t4 A.A. A 1, 12/12137. See also Exening Telegraph, 8 Feb. 1912, and Northern Miner, 9, 23 Feb. 1912. 
Yawata Maru - that prior to its departure for Australia from that port on 26 January 1913, 13 Japanese stowaways (including two women from Hakata, the port of Fukuoka City in northern Kyushu) had been discovered in the hold and handed over to the police. ${ }^{15}$

'These two open-and-shut cases involving the Yawata Maru suggest that there may have been some substance in the two earlier charges. The length of the journey to Australia meant that operators would use only a ship in which the co-operation of some members of the crew could be secured. Once this was known to be available the tendency would be to use the same ship.

The Register of Prosecutions lists only three other cases where Japanese women were charged under the Immigration Restriction Act. Of these only one, Sakurai Iye, convicted at Broome on about 9 November 1905 and deported on 12 November could have been a stowaway. But here, as in the Yoshida case, we lack any details; for neither the Departmental file nor the local newspaper for that period appear to have survived.

\section{Other women prosecuted under the Immigration Restriction Act}

The remaining prosecutions referred to in the Register of Prosecutions are of interest in confirming that Japanese prostitution in Australia was often conducted under the front of legitimate shop-keeping and that even its small operators may have had connections with the trade elsewhere in Southeast Asia and the Pacific.

On 31 July 1909 Oyasu, a fare-paying passenger on the S.S. Nera holding a ticket from Columbo to Noumea, tried to land at Fremantle claiming a domicile in Western Australia, which she had left in March 1906 in order to return to Japan. ${ }^{16}$ As she did not hold an exemption certificate she was given the dictation test and, when she failed, was prevented from landing. Ishï Hide, a Japanese resident of Western Australia since 1888 who claimed to be her husband, then secured her release by a writ of habeas corpus in the Supreme Court. In her trial as a prohibited immigrant that followed in the Police Court, it transpired that Hide and Oyasu had cohabited successively at Cossack, Geraldton, Coolgardic ${ }^{17}$ and Perth since about 1894, that Hide had from time to time carried on business as an importer of Japanese goods, that he had at one time bought a woodyard at Coolgardie for $£ 2,000$ and that he owned four shops at Cue which until three or four years ago had brought him $£ 20$ per week in rents. The prosecution tendered evidence that in both Geraldton and Coolgardie they had lived in houses occupied by prostitutes. The magistrate, in finding Oyasu guilty of failing the dictation test, remarked obiter that the evidence pointed very strongly to the fact that she carried on prostitution. From the evidence, it would appear that at the time of Aiba's visit

15 Con. Gen. Hong Kong to Foreign Minister, Köshin 12, $16 \mathrm{Jar} .1913,3.8 .8 .4$ vol. 5(2), Archives of Japanese Foreign Ministry [hereafter referred to as J.F.M.A.].

${ }_{16}$ For details of this case see Weat Autralian, 2, 4, 26 Aug. 1909, and registration details of papers $08 / 3283$ to $10 / 452$ in A.A. A30. (The file itself appears to have been destroyed.)

${ }^{17}$ She may have been the 'Mrs Oyas' whom the Police at Geraldton (W.A.) in 1894 charged (unsuccessfuily) with keeping a house of ill-fame (Geraldton Advertiser, $27 \mathrm{June} 1894$ ), and the 'Oyasu \& Co., Shaw Street, Coolgardie' listed under Refreshment Rooms in Wise's W.A. Post Offüe Directory 1898. 
to Western Australia in 190 I (see Part 1, p. 326) the Ishïs would have been in Coolgardie. In the light of Aiba's analysis of the occupations of the Japanese in Coolgardie at that time one may accept the magistrate's dictum and also infer that prostitution was the initial source of Hide's capital.

The remaining prosecution is that of Shigematsu Mitsu. It has some similarities with the preceding case. Mitsu apparently made her pile in Australia through a mixture of prostitution and shop-keeping, rcturned to Japan (presumably for good) without first obtaining an exemption certificate, tried her fortune in various parts of Southeast Asia and, eventually, attempted to return to Australia. At her trial she claimed to have arrived at Thursday Island in about I 883 , aged 12 . If this is true she must have been one of the first of her kind in Australia. She said that she had spent eight years on Thursday Island, seven in Cairns, three in Rockhampton, two in Sydney and then (c. 1903) returned to Japan. She produced witnesses who testified that she had kept a Japanese fancy-goods shop in Cairns at the material time. The police, however, claimed that there were Japanese prostitutes on those premises. After two years in Japan she married and with her husband spent a total of about two ycars in Hong Kong, Singapore, Manila and Penang. In March 1909 they arrived at Thursday Island claiming to be commercial travellers and carrying passports. The Customs Officer was inexperienced and admitted them despite the fact that they had no visas. In May the policc reported that they were at Atherton, engaged in prostitution. In August the dictation test was adiministered to them. They failed; but the court proceedings were delayed while they left Australia at their own expense by the next ship. Nothing daunted, on their arrival in Japan they went to a British consulate, secured a visa and returned to Australia. They landed at Thursday Island on 26 April 1910 and arrived back in Cairns on 24 May. The dictation test was again administered on 11 June. They failed; but this time refused to leave the Commonwealth at their own expense. They were tried, found guilty and were deported on 23 August. ${ }^{18}$

Our general conclusion is that, thanks to the federal Immigration Restriction Act, the Japanese brothels in Australia declined steadily after 1902. There is no reason to doubt the accuracy of the following return on the number of Japanese prostitutes within his area furnished by the Consul-General to the Foreign Ministry on 1 September 19 I6: Fremantle and Perth 12, Broome 20, Rockhampton 3, Cairns 9, New Britain 7, Total $51 .{ }^{19}$

The Japanese brothels and public order

In its issue dated 2 January 1897 the Coolgardie Pioneer contained a piece of doggerel on the Japanese prostitute, written on the theme: 'Where are you going to, my pretty maid?' One of its verses went as follows:

1* A.A. Al, 10/5151. See also Caims Post, 9 Oct, 1910. I am indebted to A. '1'. Yarwood, Asian Migration to Australia, Melbourne, 1964, p. 186, for drawing my attention to this case.

10 J.F.M.A., 4.2.2.27, vol, 5 . 
'Do you turn your mind when the sun has sunk lo something better thals earth - dear maid?'

'On no! I turn the slumbering drunk and snavel ${ }^{20}$ his shammie, "Sir", she said. ${ }^{22}$

To the Pioneer's editor, F. C. B. Vosper, any stick would do to beat the Asiatic. In fact, the culprit in the only casc of theft in a Japanese 'cool drink shop' reported in its pages at that time was a Caucasian. ${ }^{23}$

Not long afterwards the Cairns Post made similar allegations:

It will hardly be credited that there are now in Cairns 37 Japanese women. They look very nice in their light, flowing Oriental costumes, and, woman-like, know it. These creatures are openly engaged for export in Japan for a number of years - generally four - at a salary of three or four pounds per annum. As prostitution machirtes in a town like Cairns, they are worth, on an average, about $f 12$ per week to the Japanese pimps who preside at the doors of the Chinatown hovels... Rows are now the order of the night in Chinatown... The Japs are clever thieves, and it is a shilling to a gooseberry about anyone leaving an establishment with his pockets correctly balanced. They are also adept at the bully business, and the slightest altercation with a lady is regarded as sufficient pretext to start an axe-handic row at the termination of which the visitor leaves the presence of his lair Chrysanthemum looking kind of anyhow. And there arc $37 . .^{24}$

From the local police reports, however, it seems that the Cairns Post like the Coolgardie Pioneer was inaccurate in its references to such matters.

The attitude of the Queensland Police to prostitution was similar to that of law enforcement agencies throughout most of the world. It was summed up by the Commissioner (W. E. Parry-Okeden) at about this time in connection with a case in Bundaberg. Human nature and sexual impulses being what they were, he considered that a certain level of prostitution must be tolerated. In particular he felt that in the sugar districts there must be outlets for the sexual passions of the kanakas and that it was less revolting and degrading if these were satisfied by Japanese rather than by Caucasian women. Accordingly, he saw the role of the police not as exterminating prostitution but as 'controlling it so that its evils and pernicious influences may be lessened as much as possible' and ensuring that 'the doings of the persons concerned in carrying on this loathsome trade should be kept from being openly, flagrantly offensive and demoralizing'. Where prostitution was quietly conducted he considered it expedient, in the public interest, not to interfere. ${ }^{25}$

Instead of the Post's 37 Japanese prostitutes, the police at Cairns could only find 15. Insofar as the activities of these prostitutes had, however, become a subject for

20 Snavvle: Australia - to snaffle or steal, Webster's International Diationary, 1948 ed.

21 Shammy: Australia - a bag of chamois leather in which miners keep their gold dust, Oxford English Dictionary, 1933 ed.

22 'The Ubiquitous Jap', Coolgardie Pioneer, 2 Jan. 1897.

23 Ibid., 23 Sep. 1896.

2s As reproduced in the Bulletin, $29 \mathrm{May} 1897$.

25 Minute by W. F., P[arry] Ofkeden] on a report by Snr. Sgt. P. Bowen of 7 March 1899 and me mo by Parry-Okeden enclosed in his letter to the Under Secretary of 23 March 1899, Q.S.A. HOM/A24, $99 / 04177$ 
public discussion, they had been seeking evidence to support charges against the Japanese proprietors for keeping disorderly houses. But in this they had been quite unsuccessful. There were two particular difficulties. The first was that each of the six Japanese brothels maintained a good pretence of being something else - a store, a boarding-house, a laundry, etc. The other difficulty was that these women altho a nuisance by reason of their calling are so orderly in their conduct that a stranger coming to town would have to seek them before he would find them'. The Sub-Inspector was not aware of a single instance where a Japanese woman had created a disturbance. Rows occurred occasionally in and around the brothels when Japanese workers at the sugar plantations came to town. These were among the Japanese themselves and were probably the result of jealousy. The police considered that the whole matter had been much exaggerated and noted the fact that one of the signatories to a petition requesting the removal of the Japanese was the owner of the premises occupied by the town's two Caucasian prostitutes. ${ }^{26}$

Many people sought to have the Japanese brothels suppressed - a petition to this end presented to the Western Australian Premier by citizens of Geraldton in I 894 was reported to be 31 feet 6 inches long and to contain 733 signatures. But from Wyndham to Kalgoorlie and from Thursday Island to Brisbane there seems to have been a fairly general consensus that they were well conducted. The Govermment Resident at Thursday Island reported (I 893) that 'On the whole these establishments are well conducted - There are no rows, there is no drinking $\ldots{ }^{27}$ The Murchison Advocate (1898) in a leading article demanding the removal of the cight or nine Japanese brothels in Cue couched its argument in the following terms:

We do not say that they are ill-conducted ... or that they are disorderly in any sense but a technical one, we do not argue that they are not a necessary evil; we are not indeed, prepared to contend that they would be an evil outside the town boundaries. What we do say is ... There is no reason why they should disfigure the two main thoroughfares of the town ... ${ }^{28}$

Even the Bulletin (1895) published a not entirely unfavourable comment from a Roebourne contributor:

'The Jap women' (very numerous in Westralia) totally eclipse their white competitors. They are particularly clean, modest, sober, exceedingly polite, don't thieve, and look upon their calling in a purcly commercial sense. No white woman can compete against those brown dots of humanity.... ${ }^{29}$

\footnotetext{
28 Sub-Inspector, Cairns to lnspector, Cooktown, 24 Nov. 1897 enclosing report by Act. Sgt. Griffir 23 Nov. 1897. 'Japahesc Women', Q.S.A. POLJII. I am indehted to R. Evans, 'Soiled Doves: Prostitution and Society in Colonial Queensland, Hecatp, vol. 1, No. 2, July 1975, for drawing my attention to this memoraturn.

27 Q.S.A. 55/1,93/12777.

24 Murchison Advocate, 19 Nov. 1898.

${ }^{29}$ Bulletin, 16 Now. 1895 . For a similar comment on the Japanese prostitutes at Roebourne see A. F. Calvert, My Fourth Tour of Western Australia, London 1897, p. 249.
} 
Generally they appear to have been conducted unobtrusively. There were occasional exceptions. Marks in a despatch to the Foreign Ministry dated June 1888 reported that at Darwin the brothel-keepers caused the women to toiter in public places improperly clad. ${ }^{30}$ At Charters Towers at a later date the girls appear to have been put on display in much the same fashion as was done in the licensed quarters in Japan. The autobiography of the journalist, Claude McKay, contains the following description of Charters Towers' yoshiwara.

We walked along the street they occupied. The women were perched on raised plat forms, fanning themselves in the heat; behind their heads was a light with a reflector. They were dressed in their mational costume, and wore lacquered ornaments in their hair . . .

One of the Charters Towers town councillors, C. J. Frazer, used this as an argument in a deptutation to the Premier in 1900 seeking Government approval for a specias municipal bye-law to deal with the Japanese brothels. Frazer described the displaying of the Japanese women as 'resembling a wild beast show in their little cages'. At the same time, however, he admitted that the Japanese women 'did not create any disturbances, and were in no way noisy, as were white women of the same class'. It was for this reason, he argued, that special legislation was required to deal with them. ${ }^{32}$ The Crown Law officers, however, persisted in their refusal to confer on municipalities the power to enact a law of indecency unknown to Courts of Justice in the British Dominions. ${ }^{33}$ The difficulty in securing evidence with which to proceed against Japanese brothels also seems to have been at the back of representations made in 1902 by church and citizens groups in Charters Towers, Townsville, Innisfail and Ipswich urging the Government to amend the Local Government Act so that municipal inspectors could enter suspect premises. Ihe Home Secreaary, however, refused to countenance this proposal - 'Under it any person's house would be liable to be entered without warrant upon mere suspicion' ${ }^{34}$ In Geraldton (W.A.), at the time of the 1894 petition to which we have already referred, the municipality was confronted by the same problem - the difficulty of securing sufficient evidence. ${ }^{35}$ In similar fashion the Council there urged the Government, unsuccessfully, to add to the Police Act a special provision relating to houses of ill-fame occupied by aliens.

It will be remembered that the report from the Cairns police in 1897 indicated that sometimes rows occurred among the Japanese community as a result of the

30 Data-paper prepared on the instructions of the Minister for Foreign Affairs 20 Feb. I891 J.F.M.A. 4.2.2.34, vol. i.

at C. McKay, This is the Life, Sydney 1961, pp. 51-52.

32 Northem Miner, 11 June 1900.

33 Minue by A[rthur] RIutledgel on Town Clerk. Charters 'Towers to U/Sec, Dept. of Justice, 10 March 1899. Q.S.A. COL/O 19.

34 [bid, Minute by J. F. G. F[oxton] (Home Secretary) on Ipswich and West Moreton Christian Citizens Assoc. to Home Sccretary 8 Sep. 1909 .

is According to the Attorney-General, in Western Australia the municipalities had no power to deal with this subject by bi-law's and the only stattue which applied was the Police fict 1892 , Section $65(7)$ of which provided up to 6 months inprisomen for 'the occupier of any house which shall be frequented by reputed thieves. prostirutes, or persons who have no visible means of support' (Geraldton Advertiser, 27 Aug. 1894). 
presence of the prostitutes and that jealousy was usually the cause. On 19 November a case had occurted there in which one Japanese had seriously wounded another with a sword stick. Sometimes the jealous lover made a murderous attack on the prostitute. Omatsu (Thursday Island 1894), ${ }^{36}$ Orui (Thursday Island I896), ${ }^{37}$ Ode (Broome 1896), ${ }^{38}$ and Osano (Kanowna 1903) ${ }^{39}$ met their deaths in this manner while Masano (Cossack 1898) ${ }^{40}$ Fukugi (Darwin $1903)^{41}$ and Ohana (Thursday Island 1907$)^{4 z}$ were wounded. Usually the assailant killed himself immediately afterwards. There were also the joint suicides that in Japan were so much a part of this aspect of life. In 1898 at Kalgoorlie Mukai and Otana kitled themselves when they were unable to raise $£ 35$ to buy out Otana's share in the brothel that she and another prostitute ran as a partnership. ${ }^{43}$

According to Miyaoka, more often than not, Japanese brothels overseas refused to admit Japanese customers. He notes that this was particularly the case in Siberia. The adoption of such a rule would have meant an unacceptable loss of business in places like Thursday Island and Broome where Japanese predominated; but the incidents referred to above suggest that it might have been appropriate elsewhere in Australia. According to Miyaoka, the reason underlying this practice was not the safety of the prostitute but fear by the brothel-keeper that she might form attachments and waive payment. ${ }^{44}$

Of course not all the violence inflicted on the Japanese women was perpetrated by Japanese. Two were stabbed by an escaped prisoner at Nulligene in $1898 .{ }^{45}$ In the same year another appears to have been raped by two Caucasians at $\mathrm{Mt}$ Malcolm. ${ }^{46}$ Another was stabbed at Onslow in 1900 by a Manilaman. ${ }^{47}$

On at least two occasions breaches of the peace occurred involving Japanese living off the earnings of Caucasian women. In Perth in 1911 a French prostitute, Marguerite du Tour, was shot dead by Seto Tsunekichi, whom she had left after four years. He was under the influence of liquor at the time. This (and the fact that he attempted to shoot himself also) appears to have impressed the judge and the jury and he received a sentence of only twelve months. ${ }^{48}$

In about August 1922 a Japanese named Nishi Taröichi who had resided in Australia since 1899 arrived on Thursday Island from the Queensland mainland. With him was a young white woman whom he claimed was his wife. He installed her in the Japanese quarter and returned to the mainland. His 'wife' appears to

${ }^{36}$ Cooktown Courier, 24 April 1894; Evening Observer, 28 May 1894.

37 Inquest No. 22 of 1897 , Q.S.A.

38 Police 654/96, W.A. State Archives.

se Western Argus, 31 March 1903.

4t. Police $701 / 98$, W. A. State Archives.

1 For details of this case see my 'Japanese in the Northern Territory 1884-1902', South Australiana, vol. I5, no. 2.

12 Depositions, $R$ v. Nakai (Supreme Court, Cooktown, 19 Sept. 1907) Q.S.A.

${ }^{13}$ West Aistratian, 1, 9 Sep. 1898.

\$4 Miyaoka, op. cit., p. 62 .

45 Police Department, Subject Index 1898: 'Offences', W.A. State Archives,

4t West Australian, 8, 19 Oct. 1898.

47 Police Department, Subject Index 1900: 'Murder', W.A. State Archives.

4" West Australian, 21 Feb. 1911. 
have received customers and on I September this was the cause of an attack on a Japanese by two Caucasian residents. A situation of such tension developed that the Sub-Collector of Customs ordered all Japanese indentured crewmen back to their luggers and, on the ground that the presence of the woman was 'a menace to the peace between whites and Japanese on Thursday Island', requested the Department of Home and Territories to move her on. This they had no power to do. Instead they denied Nishi an exemption certificate. ${ }^{49}$ Presumably this did lit te to hamper 'Mrs Nishi's' activities. All it could do was to prevent Nishi from making his projected visit to Japan.

The most bizarre of the public disturbances associated with Japanese prostitution occurred at ' 'hursday Island in 1891. On 29 September of that year Douglas cabled Brisbane for instructions regarding the arrival of two young women, Otashi and Otoyo, whom he described as 'undoubtedly prostitutes but of a respectable and orderly type'. He kept them in quarantine pending instructions. Brisbane cabled Marks, the Consul, who asked that they be deported. There was, however, no north-bound ship until 23 November. In the meantime the pillars of respectability among the local Japanese community apparently feared that Douglas's resolution was weakening. He writes that 'Their arrival here caused some trouble among the Japanese inhabitants of this island, and I was waited upon by the whole of them with a request that I would remove the women'. ${ }^{0}$ Perhaps he should have qualified his remarks and said that nearly all of the Japanese residents had so requested him. Some months later a Nagasaki newspaper, Chinzei Nippō, carried a very graphic account of the meeting of the Japanese residents at which the address to Douglas praying that the two women be deported, was adopted. In this account 'when the motion was put, a shot rang out and Hirano Sennosuke was shot where he sat', According to the newspaper the shot was fired by a pistol-packing madam named Okiyo under whose auspices the girls were to have worked. ${ }^{51}$ Apparently Okiyo's aim was not good and Hirano made a good recovery. There are inaccuracies in this story. For example the only shooting incident among the Japanese community reported by Douglas at this time took place on 26 October, two days after the petition of the Japanese residents had reached him. The important point is that the Japanese residents did make representations to Douglas along these lines. Indeed, as an earnest of their sincerity they presented him with $f 8$ towards the cost of repatriating the two girls. I'he attitude of the Japanese residents and the Japanese Government to the prostitutes throughout the period merits examination in some detail.

The attitude of the Japanese residents to the prostitutes

In their petition to Douglas in 189 l to suppress Okiyo's brothel the signatories argued, with some perception, for securing to themselves and their countrymen the continuance of their "past goodly reputation of being a well conducted law

49 A.A. A1,26/11048.

so Q.S.A. COLA677, 91/14105.

5 As reproduced in Mainichi Shimbun, 9 March 1892. 
abiding and orderly portion of the community' and in terms of anxiety that if the evil were not put down it would 'continue to be the cause of many dissensions, quarrels and perhaps most serious ones amongst our own countrymen and between the other inhabitants'.

In later years we see evidence of similar responses elsewhere. In November 1897 a Japanese resident at Coolgardie wrote to Marks complaining at the large number of Japanese engaged in prostitution at Perth (nearly 70), Coolgardie (about 50), Kalgoorlie (nearly 60) and Menzies (nearly 20)..$^{2}$ Early in 1899 the police at Bundaberg (Qld) reported that Japanese men and women had been arriving in the town almost daily and setting up brothels disguised as fruit or soft-drink shops in the main street. The Japanese residents responded by sending a deputation to the police station requesting that proceedings be taken against all the Japanese brothel-keepers. They said that 'they as working people thought it could injure them seriously in the opinions of the white population if the brothels ... werc allowed to continue ... .53

\section{The attitude of the Japanese Government}

From the time it was established, one of the principal objectives of the Ministry of Foreign Affairs was to maintain and enhance Japan's prestige in the eyes of the rest of the world. This is, of course, one of the primary functions of all Foreign Ministries, but it was particularly the case with Japan. The revision of the unequal treaties and the abolition of extra-territoriality in Japan was an urgent political task for every Japanese cabinet. In order to bring this about it was necessary at all times to impress upon the foreign powers that Japan was a civilised, westernised community. Very early in the Meiji period the Japanese Government came to realise that the system of public prostitution practised in Japan was prejudicial to this image, and took steps to modify it to conform with Western standards.

For the same reason the Foreign Ministry also viewed with concern the presence of Japanese prostitutes overseas. From about 1882 a stream of reports began to arrive from the consulate at Shanghai drawing attention to the increasing number of prostitutes operating openly there. In September 1884 the Consul claimed that of the 488 Japanese women there, 90 per cent were prostitutes. As a result four consular police were sent from Tokyo and action was taken locally against 43 persons. By the following year the evil appears to have spread to most of the China coast and the Korean ports. Under 'Regulations for the Control of Japanese Residents in China and Korea' promulgated in March 1883 , Japanese consuls in that region had the power to move on Japanese residents who they considered were subverting public morals. It appears that they made some use of this power to

s2 J.F.M.A. 6.1.6.9.7., vol. I.

ss Q.S.A. HOM/A24, 99/04l77. In other parts of the world a similar attitude to the prostitutes appears to have developed as the Japanese residents in legitimate occupations became more numerous. For example, the action taken by the Japanese Government in 1920 to close the brothels in Singapore and Malaya appears, at least in part, to have sprung from a resolution passed at a conference of representatives of Japanese residents societies there (Consul-General Singapore to Secretary to the High Commissioner 30 Jan. 1920, J.F.M.A. 4.2.2.27., vol. 5. See also Miyaoka, op. cit., p. 136). 
deal with prostitutes. The principal consequence, however, was merely to transfer the problem elsewhere. People dealt with in this manner rarely returned to Japan. Those denied residence in Korea went to Shanghai; if they were not admitted there they went to Hong Kong; if they failed to secure public prostitutes' licences there, they went to Burma, India or Austratia. Like government departments in Inany lands, the enthusiasm of the Ministry of Foreign Affairs appears to have moderated a little when it came to expending money from its own budget. It seems only rarely to have repatriated prostitutes at public expense. In Singapore in 1894 when the immigration authorities drew the consul's attention to the plight of six girls smuggled from Nagasaki, he disclaimed any responsibility for their repatriation and left it to local Japanese residents to collect money for this purpose ${ }^{54} \mathrm{It}$ was much the same at Thursday Island in $189 \mathrm{I}$ - although it was the Honorary Consul, Marks, who asked the Queensland Government to deport Otashi and Otoyo (see p. 474 above) their passages were finally paid for by the Queensland Government and by the local Japanese community. It seems, however, that Marks did induce the two Japanese prostitutes in Melbourne in 1887 to leave the country - possibly at the expense of the Japanese Government. ${ }^{55}$ When he tried in the same manner to put an end to Japanese prostitution in Darwin in 1889 he was unsuccessful. $^{56}$ Perhaps, the Foreign Ministry refused to make the funds available.

After 1896, career diplomats were appointed to the principal Japanese consular posts in Australia. These men, like Marks, appear to have regarded the presence of the prostitutes as prejudicial to Japan's reputation. What few records survive suggest that, when requested by the Australian authorities, they provided their co-operation in dealing with them. Eitaki, who was appointed Consul in Sydney in 1898 , records in his autobiography his embarrassment when, as well as the Japanese divers, the prostitutes turned out to welcome him when the shipcarrying him and his credentials called at Thursday Island. ${ }^{57}$ When Mrs Shigematsu returned to Australia in 1910 (see above p. 478) masquerading as a merchant, the Consul-General, at the request of the Department of External Affairs, wrote to her urging that she leave the Commonwealth without delay. ${ }^{58}$

In an attempt to cope with the problem of Japanese prostitutes overseas, the Foreign Minister on 6 July 1885 issued instructions to prefectural governors tha1 the antecedents, occupations and destinations of all women proceeding overseas unaccompanied by their families should be carefully checked and that in suspicious cases passports should not be issued and the women made to abandon their journeys. This, too, failed to produce the desired effect. It merely resulted in the women leaving clandestinely, without passports. In an attempt to remedy this,

34 Saitō to Protector of Chinese 12 June 1894, J.F.M.A. 3.8.8.4., vol. 1.

ss Data-paper prepared on the instructions of the Minjster for Foreign Affairs 20 Feb. 1891 J.F.M.A. 4.2.2.34., vol. 1 . This presumably is the case referred to by the Melbourne agents of Butterfield and Co. in the Evening Standard (Melbourne), 6 July 1889.

s6 See interview with Marks reported in Evening Standard, 6 July 1889.

"H. Eitaki, Kaiko Nanajünen, Tokyo 1935, p. 95.

so Con.-Gen. to Sec., External Affairs 31 May 1910, A.A. A 1, 10/5151. 
police surveillance at the ports was stepped up. At Nagasaki in the 18 months from January 1888 to Junc 1889 escorts with their women in tow were caught in the act on 21 occasions. The police however could only remove them from the ships: leaving Japan in this manner was not a crime.

In these circumstances the Foreign Ministry drafted a bill providing penalties of up to two months' imprisonment for women attempting to go abroad for the purpose of prostitution and up to three years imprisonment for persons attempting to despatch them. ${ }^{59}$ The bill was introduced as a Government measure during the inaugural session of the Imperial Diet, but for reasons that are not clear it was withdrawn at the end of the session, before it had been passed by both Houses.

Before its acceptance in Cabinet, the Bill had come under very strong attack by the Hosseikyoku-chōkan, the Government's senior legal adviser. He considered it fantastic to make criminal the act of going overseas to indulge in what was not criminal either at home or overseas. He also pointed out that in order to secure a conviction it would be necessary to prove intent and that this would be a very difficult process. He considered that the matter would be much more satisfactorily dealt with by legislation requiring all women to secure a permit before going overseas. The Foreign Ministry, however, considered that this would be an unwarrantable interference with legitimate travel. It considered that legislation of the type that it had drafted would be the more likely both to scotch the stories, prevalent among the classes at risk, that it was a simple matter to get out of Japan and make fortunes overseas, and to protect society in Japan itself against the depredations of the traffickers. ${ }^{60}$

The Foreign Ministry also used the argument that unless effective action was taken Japan's international prestige might be damaged by foreign governments themselves taking action to deport the prostitutes. Accordingly it continued with the task of drafting legislation along the lines of its original proposal, for presentation at the next session of the Diet; but in the course of so doing it appears to have come to realise the logic of the Hosseikyoku-chökan's objections and eventually abandoned its attempt to deal with the problem by special legislation. ${ }^{61}$ For the present it had, perforce, to content itself with instructing the metropolitan and prefectural chiefs of police to hinder the procurers' operations and warn women against them. ${ }^{62}$

A year later the Ministry of Foreign Affairs returned to the task of dealing with the matter by legislation, as part of a wider plan to submit all emigration and emigration agents to greater control. The method it now adopted applied to all emigrants the kind of screening which the Hôseikyoku-chökan in 1890 had proposed

59 A translation of the text of the bill as it emerged from the committce stage in the House of Peers is available in the Japan Weekly Mail, 7 March 1891. It contains no substantial departures from the original Foreign Ministry draft.

80 Data-paper prepared on the instructions of the Minister for Foreign Affairs 20 Feb. 189I, J.F.M.A. 4.2.2.34., vol. I

a1 Foreign Ministry internal memo on reasons for not proceeding with the kaigai fujo hogo bill, ibid.

62 Gaimushō, Kunrei I of 3 Feb. 1893. 
tor women, and which the Foreign Ministry had, on that occasion, vigorously opposed. The Emigrants Protection Regulations, issued as an Imperial Ordinance, received royal assent on 12 April $1894 .^{63}$ It provided that all emigrants seeking work overseas had to have passports and, more importantly, limited recruiting to approved firms. In 1896 the Regulations were re-enacted in amended form as a statute, the Emigrants Protection Law. ${ }^{64}$ 'This legislation does not appear to have been very effective in preventing the emigration of prostitutes. It would hardly have appeared a fearsome deterrent to the stowaway. Moreover as the case of the Tokyo Maru at Thursday Island in 1898 (see above p. 475) indicates, it was possible to circumvent its provisions by carrying a few samples and masquerading as a 'merchant', a category which did not fall within its definition of an 'emigrant'. But the statistics of the number of women charged under the Emigrants Protection Legislation suggest, at least, that the Japanese Government was not completely insincere in its professions: 1894,$12 ; 1895,11 ; 1896,76 ; 1897$, $37 ; 1898,66 ; 1899,9 ; 1900,43 ; 1901,5.3 .^{\text {ps }}$

The number of Japanese prostitutes overseas appears, nevertheless, to have continued to rise. At Singapore the peak may have been reached in about $1904-05^{68}$ and there seem to have been ample replenishments until the British authorities in about 1915 began to take steps to reduce prostitution there ${ }^{67}$ As early as 1895 Nosse, the Consul at Vancouver, was commenting on the ineffectiveness of the new legislation. Although the point of his complaint was the indiscriminate issue of passports to persons of either sex, and not prostitution, his remarks may also explain the continued emigration of prostitutes in contravention of the law. Nosse pointed out that it was, in the last resort, the prefectural officials who issued the passports. He suggested that, irrespective of the instructions issued to them by the central government, officials in the poorer prefectures could hardly be expected to be too zealous in screening applications for passports. Every passport issued meant one less mouth to feed. Several prefectural Governors regarded emigration almost as a panacea for all the ills of their prefecture. As an example Nosse mentioned Matsudaira, the Governor of Kumamoto prefecture (where, as we have noted, many of the prostitutes came from) who hoped to rid himself of 30,000 citizens by emigration. ${ }^{68}$

\section{Conclusions}

From the late 1880 s the women from Nagasaki and Kumamoto prefectures played a role in prostitution in Australia quite disproportionate to the size of the Japanese community there. Moreover, throughout most of the 1890 s Australia may have been important among the terminals in the vast net of vice that extended from Kyũshü north to Siberia and east to Cape Town. Although in Australia the

63 Imin Hogo Kisoku (Chokurei 42 of 1894).

84 Imin Hogo $\mathrm{Ho}$ (Law 70 of 1896 ).

Bs Shihōshō, Keiji Töket Nempō (annual).

Miyaoka, op. cit, p. 123.

87 Gov., Straits Settlement to Sec. of State No. 89, 13 July 1917, Singapore National Archives.

a Consul, Vancouver to Foreign Minister 23 Aug. 1895, Nihon Gaikö Bunsho, 1895, vol. 2, p. 689. 
prostitutes were not the trail-blazers for the Japanese immigrant, they were posted from their bases in Hong Kong and Singapore to what for Australians was the sweftering frontier of toil. By 1887 they had reached 'Thursday Island. By 1888 they had spread from Darwin westwards down the coast past Cossack - possibly as far as Geraldton. The following year they were in Normanton, Burketown and other Gulf towns. The trio operating inland on a pack basis on the Pilbara Goldfields in 1890 is one of the less unlikely entries in Muraoka's memoirs. It was the same a decade later on the Eastern Goldfields: in 1901 Aiba could report them strung out along the branch lines that extended out from Kalgoorlie - with five brothels at the raithead at Kookynie.

Some observers, as we have noted, attributed the success of the Japanese brothels to the honesty, sobriety and other refined qualities of their inmates. There may be some truth in this. But to me, experienced management is a more obvious explanation. There are, no doubt, special skills involved in running a brothel, as in running any other enterprise, and the Japanese had been developing these for generations. They had also, since the days of the Tashiro-ya at Shanghai, had extensive experience of the particular problems involved in operating on an international basis. From the accounts given by Murdoch and Douglas, the brothels at Darwin and Thursday Island were not only orderly; they were professionally conducted along traditional Japanese lines. To what extent they provided the capital with which local Japanese acquired pearling vessels remains to be established. In the meantime we may accord to Douglas's beliefs on this aspect of the question the respect due to those of an intelligent and well-informed observer on the spot.

The Foreign Ministry and its representatives in Australia and elsewhere appear consistently to have been opposed to the traffic but lacked the political or administrative power to deal with it at its source.

With the passage of the Immigration Restriction Act in 1901 the brothels were effectively deprived of new blood. Nevertheless they took a long time a-dying. This is not surprising: a girl of sixteen who arrived in 1900 , unless cut down by the occupational hazards of disease ${ }^{69}$ or murder, would still have been capable of earning money in this occupation in 1930.

Australian National University

D. C. S. Sissons

69 This aspect has not yet been studied systematically. From scattered information it appears that, following an epidemic of syphilis at Thursday Island in 1901 , some infected Japanese prostitutes were sent back to Japan by the Government Medical Officer there. Another example was Cairns where three cases of syphilis were teported among the Japanese prostitutes in 1900 (Q.S.A. COLA934, 11/10972). 


\section{END OF REPRINT}

Karayuki-san: Japanese prostitutes in Australia, 1887-1916 (I \& II) 



\section{Immigration in Australian-Japanese relations, 1871-1971}

In Japan and Australia in the Seventies,

Edited by J.A.A. Stockwin,

Sydney: Angus and Robertson, 1972.

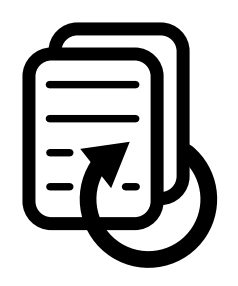





\section{Appendix 1}

Mr D. C. S. SISSONS*

\section{Immigration in Australian- Japanese Relations, 1871-1971}

Contacts between Australia and Japan are as old as the treaties that marked the end of Japan's seclusion. The young Melbourne merchant, Alexander Marks, established himself in Yokohama in 1859 , the year that port was opened to foreign trade. ${ }^{1} \mathrm{~J}$. R. Black, the Scotsman acknowledged by Japanese writers as one of the fathers of the modern Japanese vernacular newspaper, arrived in 1862-from South Australia where he had failed in business. ${ }^{2}$ In $1867, \mathrm{~J}$. H. Brooke, after his youthful and short-lived career as a political leader in Victoria, went to Japan where he spent the rest of his life as the proprietor and editor of the Japan Daily Herald. ${ }^{3}$

The first Japanese arrivals in Australia were somewhat later; for at that time the edict of the bakufu that on pain of death forbade Japanese subjects to depart from their native land was still in force. It was repealed in 1866 by a decree authorising the issue of passports for the purpose of study or trade. The earliest Japanese of whom records survive who came to Australia under this dis-

* Mr Sissons is Fellow in the Department of International Relations, Research School of Pacific Studies, The Australian National University.

1 The Cyclopaedia of Victoria (Melbourne: Cyclopaedia Co. 1903), vol. 1, pp. 289-90.

2 M. Paske-Smith, Western Barbarians in Formosa in Tokugawa Days 1603-1868, (Kobe: Thompson \& Co., 1930), p. 355; (Japan Daily Herald, 11 June 1880); T. Kubota, Nijütchi dai senkaku kishaden (Ōsaka: Ōsaka Mainichi Shimbun, 1930), pp. 211-38.

3 Japan Times, 11 January 1902. 
pensation and remained was Sakagawa Rikinosuke. ${ }^{4}$ Like severaI of the carliest Japanese to go to the United States, he was an acrobat. Like them (and like other acrobats who performed in Australia in the following decade), he probably misstated his occupation when he applied for his passport, for in the eyes of Japanese officialdom, his was an unworthy calling. Sakagawa arrived in 1871. By the end of the century some thousands of his countrymen had come to Australia. Of these some hundreds had become permanent settlers; but only the merest handful had, like Sakagawa, taken an Australian wife, become naturalised and purchased land. Forty-six years later he was still in show business, a circus proprietor, moving through Queensland, town by town.

In the century that has elapsed since the arrival of this first Japanese settler, Australian attitudes and policies towards Japan have been chiefiy influenced by three considerations, immigration, trade and defence. Trade receives detailed treatment in Appendix 2 . This paper will deal specifically with questions of immigration.

Until the 1950s, there appears to have been a fairly widespread belief in Australia that the Japanese Government wished to despatch immigrants to this country. Despite occasional extempore statements by prominent Japanese that are consistent with such a belief, ${ }^{5}$ there is, in my opinion little to suggest that this was at any time the case. This is not to say, however, that the exclusion of Japanese subjects from Australia has not been an irritant to good relations between the two countries. It can, I think, be argued that the history of Japan's negotiations with Australia (as with the United States) over the right of entry indicates that immigration per se was never regarded by the Japanese as a national interest, but that exclusion inevitably raised the question of prestige, which was a national interest. In the last resort, Japan would always accept a 'Gentlemen's Agrcement' formula as a permanent solution. By this I mean a treaty right to most favoured nation treatment as regards right of entry, coupled with a declaration in some less solemn document such as a protocol or exchange of notes in which Japan indicated that she would herself prevent the emigration of labourers and artisans. This was the nature of the agreement reached with Queenstand in 1897. The same for-

4 As this man was illiterate in both Japanese and English his name is difficult to establish with certainty. It could equally well be Takaragawa. Queensland State Archives, Col. Sec. 1882/5058.

See for example the reply of the Japanese Prime Minister, Mr Kishi, to a question in the House of Representatives on 3 February 1959 (Dai-3Ikai kokkai, Shägiin, yosan iinkai gijiroku, daj-3-gô, p. 25). 
mula was repeatedly offered to the Commonwealth. A similar formula was negotiated with the United States and Canada in 1908. Provided Japan's face was saved by a treaty recognition of equality with the Europcan countrics in the right of entry, she would concede the substance. The record suggests to me that the Japanese Government did its best to carry out these agreements, and that the apparent aberrations that caused such bitter feeling were usually the result of Japanese provincial authorities, influenced by local considerations, issuing passports in disregard of instructions from the central Government.

Until about 1890, the attitude of the Japanese Government towards the emigration of indentured labourers was gencraliy hostile. In 1872 the Japanese Government had enacted legislation prohibiting contracts of service for periods of more than one year's duration, on the grounds that such were tantamount to slavery. ${ }^{\circ}$ This policy appears to have been applied rigidly for some years. The first known case where it was relaxed was in 1883. Interestingly enough, this was a case involving Australia. Captain Miller, a pearler from Thursday Island was permitted to employ 37 Japanese to engage in pearling operations there for a period of two years. This marked a change in the attitude of the Japanese Government from blanket disapproval of all emigration under contract, to grudging approval of contracts in occupations that it considered consistent with Japanese prestige and whose terms it considered satisfactory. In negotiations that occupied six months, the Japanese provincial and central authorities looked very carefully at this contract and required several amendments. ${ }^{7}$

The only other group recruited in $\mathrm{Japan}^{8}$ who came to Australia under this dispensation were some 40 or 50 men and women brought to Sydney by P. W. Willard in 1886 , under a contract approved by the Japanese Foreign Ministry whereby he was to employ them in manufacturing. This, however, was a subterfuge. Willard was apparently a showman and had recruited them for an exhibition, 'The Japanese Village', which he presented in the Exhibition Building, Sydney, over the Easter holiday-a fact which the Honorary Consul in Melbourne (Alexander Marks) duly reported to Tokyo. ${ }^{9}$

6 Regulation No. 295 of 1872, reproduced in Gaimushö, Nihon Gaiko bunsho 1883 , p. 442 . This series will hereafter be cited as NGB.

7 lbid, p. 444.

8 There were also some Japanese recruited in Hong Kong for pearling at Thursday IsIand. $N G B-1885$, p. 527.

- Gaimushō tsūshō kyoku, Imin toriatsukainin ni yoru imin no enkaku, (Gaimuş̄ō, 1909), p. 56. 
Late in 1890 , a more positive attitude to emigration becomes apparent in the communications from the Foreign Ministry to Marks. On 11 November 1890 he was instructed that 'the Government's present policy towards emigration is not to restrain our labourers by severe laws from going overseas. If they are able to make proper agreements and work overseas it places no obstacles in their way. Indeed, our attitude is to assist them as best we can'.10 This may have been the result of the appointment as Foreign Minister of Enomoto who later founded the Shokumin Kyobai (Plantation Society). As we shall see, it was neither an extensive nor a permanent change of policy.

It was also in November 1890 that there occurred a chance event that may have lured more Japanese to better their lot in Australia. A syndicate of ten Japanese drew 'Carbine' in the Tattersall's sweepstake and returned to Japan the following month with their winnings, $£ 22,500$. They were not ungenerous. Before their departure, they made a contribution to the local cathedral building fund that exceeded those of the Governor, the Bishop and the Government Resident combined. ${ }^{11}$

Of greater significance, perhaps, was the emergence of the large Japanese companies established to act as brokers in the emigration of labourers. The first of these, the Yoshisa Emigration Co., was founded in December 1891 by Yoshikawa, Vice-President of the NYK (Nihon Yūsen Kaisha)-Japan's largest shipping company. ${ }^{12}$ The relationship between emigration and the newly emerging shipping companies was important. From now on there are occasions when, although the Foreign Ministry and its officcrs in North America and Australia insisted that the emigration of labourers should be reduced or prevented as injuring Japan's diplomatic and commercial relations and her image overseas, the flow of emigrant labourers nevertheless continned. This may well have been due in part to the political influence of the shipping industry. ${ }^{13}$ The expansion of her mercantile marine was regarded

${ }^{10}$ NGB-1890, p. 442.

- 11 Queenslander, 3 December 1890.

12 T. Irie, Hôjin Kaigai hattenshi, (Tokyo: Ida Sbobō, 1942, vol, 1, p. 10i).

13 Japanese Consul to Premier of Queensland, 16 March 1900. [Queensland, Votes and Proceedings of Legislative Assembly (hereafter QV\&P), 1901 , vol. 4, 'Further Correspondence-Admission of Japanese into Queensland ..., p. 1137].

Consul to Premier, 20 August 1900 (private), p. 3 [Queensland State Archives (Hereafter QA) PRE/102].

R. E. Minger, 'Taft's Missions to Japan . . ., Pacific Historical Review, vol. 30, no. 3, p. 288 . 
as an important Japanese national interest. Commercially, the carriage of emigrants may have been very important to the shipping companies as a steady source of revenue-particularly in the early stages of establishing new services against the competition of powerful foreign shipping companies. It was not without difficulty that NYK broke into the Australian service dominated by the Eastern \& Australian, and the China Navigation lines.

The number of Japanese in Thursday Island rose from about 100 in 1891 to 720 in March 1894 causing widespread unemployment. ${ }^{14}$ In response to representations from the Queensland Government the Japanese Government thereupon placed restrictions on emigration there. ${ }^{15}$

Under the auspices of the Yoshisa Emigration Co., whose area of operations was New Caledonia, Australia, Fiji and Guadeloupe, Japanese labourers were first recruited for the canefields in 1892.16 By December 1896 their number had risen to $880 . .^{17}$ By this time the attitude of the Queensland Government, initially favourable, had under the pressure of public opinion begun to change. In Parliament and the press a new stereotype of the Japanese was beginning to emerge: 'the Jap . . . is a very capable man and a great imitator who will not only compete with the white labourer but eventually must not only drive out the labourer but the artisan and trader as well'. ${ }^{18}$ Soon Gladstone's aphorism, "We fear them for their virtues', coined for another people, was applied to the Japanese, furst by the Brisbane Courier, (with acknowledgment) and then, successively, by the Member representing Thursday Island in the Legislative Assembly, and Alfred Deakin (without acknowledgment) ${ }^{19}$

With the possibility of imposing some restriction on Japanese immigration in mind, ${ }^{20}$ Queensland alone among the Australian colonies had in May 1896 commenced negotiations with the Japanese Government to join the 1894 Anglo-Japanese Treaty of

$14 Q V \& P, 1894$, vol. 2, 'Report of the Government Resident at Thursday Island for $1892-93$, p. 909 .

18 NGB-I894, vol, 2, p. 659.

Io Brisbane Courier, 1 December 1892, Irie, op. cit., vol. 1, p. 394.

${ }^{17}$ Bowden Bros \& Co., 'Return of Japanese Agricultural Labourers . . . as at December 1898' (undated) (QA PRE/102).

18 Queensland Parliamentary Debates, vol. 70, p. 144 (Mr Turley, Labor, 28 June 1893).

18 Brisbane Courier, 12 May 1897. Queensland Parliamentary Debates, vol. 77, 24 June 1897, p. 108, Mr Hamiton. Commonwealth Parliamentary Debates, vol. 4, 12 September 1901, Mr Deakin.

20 Telegram from Nelson to Premier W.A. 14 March 1895 (QA $\mathrm{PRE} / 105)$. 
Commerce and Navigation, She entered the Treaty in March 1897 by means of a special protocol in which the right of either party to regulate the immigration of labourers and artisans was expressly recognised. ${ }^{21}$

In April 1897, probably as a result of the establishment of a monthly Australian service by NYK with steerage accommodation at half the prevailing price, ${ }^{22}$ the tempo of Japanese arrivals at Thursday Island began to increase, once again in a situation of unemployment. ${ }^{23}$ In prompt response to cables from the Consul, the Japanese Government in June prohibited emigration to Thursday Island for pearling, and in August prohibited the emigration to all parts of Queensland of all labourers or artisans except where a contract with an employer in Australia could be negotiated before embarkation. ${ }^{24}$ There were notorious cases in which these restrictions were circumvented by the emigration companies. ${ }^{25}$ These gave rise to suspicions that the Japanese Government was insincere in its policy of restriction. That this was not the case is apparent from the reply of the Vice-Minister (22 January 1898) to a suggestion by the Acting Consul that the restrictions could be relaxed:

It is not our policy to encourage emigration heedless of the manifold probiems to which it gives rise--just so that a few people can emigrate. Accordingly, until there is a complete change in the attitude of Queenslanders to Japanese immigration we shall continue to prohibit from going there emigrants who do not have contracts of employment. ${ }^{26}$

A proposal by the Queensland Government for complete cessation of Japanese immigration was rejected, but after prolonged negotiations a settlement was reached in October 1900 in which the Japanese population of Queensland at 31 October 1898, i.e. 3,247, was accepted as a ceiling not to be exceeded. ${ }^{27}$ In the period that

${ }^{21}$ For a detailed treatment see J. B. Armstrong, "The Question of Japanese Immigration to Queensland in the 19th Century', (M.A. qualifying thesis, University of Queensland, Department of History, 1970), Ch. 4. 51.

${ }^{22}$ Sce a consular report c. 1897 in Shokumin kyōkal hōkoku, no. 23, p.

${ }^{23}$ NGB-1897, pp. 601-2.

${ }^{24}$ NGB 1897 , p. 603; Japanese Ministry of Foreign Affairs archives file MT 3.8.2.33.

25 e.g. The landing of 59 uncontracted immigrants at Thursday Island on 16 July 1898 with passports for Northern Territory.

26 NGB-1898, vol. 2, pp. 62-3.

${ }^{27} Q V \& P 1901$, vol, 4, "Further Correspondence-Admission of Japanese into Queensland ...', pp. 1140-41. 
elapsed before the coming into effect of the Federal Immigration Restriction Act in 1902 the Japanese made no special exertions to restore their numbers to 3,247 . Their total in Queensland at the 1901 census was only 2,269 . Furthermore, in 1902, although as a question of law the Japanese Government denied the Federal Government's contention that the Immigration Restriction Act superseded both the Agreement and the application of the AngloJapanese Treaty to Queensland, they nevertheless accepted it in fact. At the same time they continued to grant Queensland products the benefits of most favoured nation trcatment until the Treaty was formally denounced in 1908 .

The attitude of the Japanese Government to the Commonwealth's Immigration Restriction Act and the similar legislation that had been introduced into the Colonial legislatures after 1895 was as follows. Although they considered unreasonable the proposition that Australia's wide area and bounteous gifts should be enjoyed by the white races exclusively, ${ }^{28}$ they did not join battle with this or with the determination of Australians 'to preserve unmistakably the European character of Austratian colonisation', ${ }^{29}$ They were, however, preparcd to accept the cxclusion of their labourers and artisans provided this were done in a manner acceptabje to their national pride: 'The point which had caused a painful feeling in Japan was not that the operation of the prohibition would be such as to exclude a certain number of Japanese from immigrating to Australia, but that Japan should be spoken of in formal documents, such as Colonial Acts, as if the Japanese were on the same level of morality and civilisation as Chinese and other less advanced populations of Asia'. ${ }^{30}$ They would accept a degree of exclusion by such means as a test in the English language: This would exclude her labourers and artisans but not her merchants, tourists and professional men and would place Japan on the same footing as European nations. ${ }^{31}$ The Immigration Restriction Act, however, provided a test not in English but in 'an European language', and it was administered in a manner to exclude all Japanese. As such, it was the object of protest by Japanese Government.

In February 1902, the Immigration Restriction Act completely 28 NGB-1897, p. 607 .

29 Salisbury to Katō, 24 August 1897 (Public Records Office F.O. 46/548).

\$0 Katō to Salisbury, 7 October 1897, (F.O. 46/548).

31 Memorandum by Hayashi to Foreign Ofìce, 8 August 1901, (F.O. $46 / 548$ ). 
closed Australia to further settlement by Japanese. At that date the Japanese population was 3,593, of whom 90 per cent were in Queensland, Northern Territory and Western Australia. That total has never since been exceeded. Thereafter, until 1952, the only Japanese to enter Australia were a handful of merchants, students and tourists on temporary visas, and contract labourers for the pearling industry. None of these was permitted to remain for more than a few years.

The discriminatory treatment of Japanese subjects on account of race remained an important issue in Australian-Japanese relations. This was a wider question than immigration; for laws had been passed and continued to be passed circumscribing the rights of Japanese already in Australia. Among these laws the most important were, at the Federal level, the Franchise Act, the Nationality Act and the Bounties Act (whereby bounties were payable only for the products of white labour), and in Queensiand the Elections Act (which disfranchised naturalised Asians), the Pearl-shell and Bêche-de-Mer Fishery Act, the Leases to Aliens Restriction Act and the Sugar Cultivation Act (which applied the dictation test to the acquisition of boat licenses, the renting of land, and employment in the sugar industry). A similar grievance was a Queensland industrial award that excluded coloured labour from cane cutting. ${ }^{32}$ To remove these disabilities and marks of racial inferiority, as well as to secure her newly-won export markets against postwar competition, Japan in 1915-17 attempted to barter additional naval assistance to the Allied cause for Australia's entry to the Anglo-Japanese Treaty of Commerce and Navigation of 1911.33 She offered safeguards regarding the immigration of labourers and artisans similar to those given to Queensland in 1897.34 Australia, however, was adamant in her refusal to end such discrimination.

Similarly at the Paris Peace Conference of 1919 it was Australia that played a prominent role in bringing about the defeat of Japan's attempt in 1919 to insert in the Covenant of the League of Nations a clause whereby Members would undertake to accord

82 Award of Court of Industrial Arbitration, 27 June 1919.

${ }^{33}$ Hughes to Pearce 21 April 1916 (Australian War Memorial, Pearce Papers, 'Letters and Cables-Mr Hughes').

Col. Sec. to G/G Aust. 3 January 1916 (F.O. $371 / 2688$ p. 267).

Ambassador, Tokyo to Sec. of State, Tel. No. 93, 16 February 1916, ditto Desp. No. 64, 24 February 1916, (F.O. 371/2690 pp. 26 and 53).

34 F. M. (Kat̄̄) to Arrbassador, G.B., No. 2, 15 January 1915 (NGB1916, vol. 1, p. 184 ff.). 
equal treatment to aliens in their territories, irrespective of race. ${ }^{35}$ This Japanese demarche prompted E. L. Piesse, the Director of the newly established Pacific Branch of the Prime Minister's Department, to include in the brief for the Australian delegation to the First Session of the League of Nations a memorandum in which he argued: 'In regard to the greater part of the Japanese nation, there is probably little reason now for applying discriminations based merely on race which are not thought necessary in regard to the less advanced European nations'. The Prime Minister, Hughes, minuted this passage with the single word, 'Rot'. In this document Piesse recommended inter alia that discriminations imposed on Asiatics on economic grounds should be reexamined in order to see whether they were still necessary on economic grounds and that those Japanese merchants, students and tourists who in fact were allowed to remain in Australia indefinitely should not be required to make yearly applications for extensions of stay. The memorandum elicited an indignant cable from the leader of the Delegation, Senator Mitlen, that it amounted to 'such whittling away of existing restrictions as would result complete abandonment White Australia Policy'. ${ }^{3 e}$

In 1930 some very limited progress was made in the direction that Piesse had proposed and merchants, students and tourists were thereafter required to apply for extensions only biennially. ${ }^{37}$ Nothing however was done to amend discriminatory legislation. Accordingly, in the negotiations for a commercial treaty that commenced at the end of 1934 , the Japanese pressed hard for most favoured nation treatment not only in tariffs but also over a wide field of activities. On this occasion their initial proposal was less accommodating than any made by them on this subject to an Australian government since 1897 . They would recognise the right to regulate the immigration of manual labourers but not artisans and such regulations must apply equally to similar immigrants from all other countries. ${ }^{38}$ The Australian side from the outset

${ }^{35}$ See E. Scott, Official History of Australia with War of 1914-18, vol. xi, (Sydney: Angus \& Robertson, 1937), pp. 789-97.

96 Prime Minister's Department: S.C. 42/2 'Papers Prepared in the Pacific Branch in Connection with the General Assembly of the League of Nations; S.C. $42 / 12$ Cable-Mitlen to Hughes 17 October 1920 ; S.C. 42/12 Piesse to Secretary Prime Minister's Department 20 October 1920. (Piesse Papers, MS 882. Australian National Library)

${ }^{37}$ Exchange of Notes, 20 June 1930 (Commonwealth Archives Office (hereafter CAO) A981 Trade 68 Part 2).

3s Cable No. 115 from Prime Minister to High Commissioner London, 10 December 1934 (CAO A981 Trade 68 Part 1). This is the formula that the Japanese tried unsticcessfuly to secure in their treaty with the United States in 1894. 
consistently refused to consider this. ${ }^{38}$ From the very incomplete official files that are available in the Commonwealth Archives Office it appears that, after some fairly persistent battling, ${ }^{40}$ they offered to withdraw this proposal if in return Australia agreed to make the extensions of stay for exempted classes of immigrants indefinite (instead of triennial) and abolish visas. This the Australian side appears to have been prepared to examine. The Japanese however continued to insist on the recognition of most favoured nation treatment in all that relates to or is necessary for the pursuit of their callings and in the acquisition and possession of "every description of property . . . For these and other reasons the negotiations broke down. ${ }^{41}$ To this day Australian governments are unwilling to negotiate with any country treaties that extend most favoured nation treatment to persons. The idea of a treaty of this nature was received by the Japanese firms at the annual joint meetings of the Australia-Japan Business Cooperation Committee in 1969 and 1970 but received no support from the Australian firms. ${ }^{42}$

The Japanese population in Australia declined from 3,593 in 1901 to 2,080 in 1933 . At the outbreak of war in 1941 all Japanese residents and with a very few exceptions their Australianborn children-a total of 958-were interned. At the end of the War the Australian-born were permitted to remain but all but 75 of the Japanese-born were compulsorily returned to Japan. ${ }^{43}$ Their embarkation evoked an indicative response from the Melbourne Age. Under the headline Sons of Heaven Sent Home-Packed in Holds of Japanese Ship the reporter wrote: 'The main impression gained was that there was sufficient evidence on the ship to turn the whole of Australia against the Japanese and their code of morality for years. The holds .. . looked like resurrccted Black Holes of Calcutta. . . How the total of nearly 3,000 [i.e. POWs

38 Comptroller-General. Trade \& Customs to Cons-Gen., 19 December 1934; 18 January, 5 April, 8 November;

Min. $\mathrm{i} / \mathrm{c}$ Trade Treaties to Cons-Gen, 4 February 1936

Min. $i / c$ Trade Treaties to Min. External Affairs 13 February 1936 (CAO A981 Trade 68 Part 2).

40 Cons-Gen, to Comptroller-General: 8 January, 7 March 1935 (CAO A981 Trade 68 Part 2).

a1 Cons-Gen, to Min. i/c Trade Treaties 18 January 1936 and enclosures. Min. E.A. to Min. w/o Portfolio [i.e. Min. i/c Trade Treaties D.C.S.S.] 11 February 1936.

42 West Australian 10 May 1969; Age 20 May 1970.

43 The birth and place of reiease of each internee is given on their Australian forms A111 and A112 which are filed as MP1103 at the Commonwealth Archives Repository at Melbourne. 
and civilian internees D.C.S.S.] on the ship will fare in the tropics was left to imagination. ${ }^{44}$ Today, the wartime achievements of the Allied navies and airforces suggest themselves more readily as the cause of the cramped accommodation than does the Japanese code of morality.

Little remains to record the presence of the Japanese immigrants, except perhaps the 378 headstones in the Japanese cemetery at Broome and the scores of inquest files in the Queensiand State Archives, most of which record how yet another Japanese pearl diver, bent on earning more, tried to cut down the time lost in staged ascents. ${ }^{45}$ In the United States, many Americans of Japanese descent today cultivate farms established by their immigrant forbears. But only a handful of Japanese immigrants in Australia married. Under the Immigration Restriction Act there could be no 'picture brides'. Today, one or two Japanese names survive here. Although most of those who settled on the Australian mainland probably came to work on the cane-fields, very few ever became farmers. ${ }^{46}$ The typical occupations of the Japanese who remained after 1902 were field labourer, mill-hand, boatman, launderer and itinerant station cook. Apart from these there were a very few storekeepers and artisans (boat-builders and carpenters). ${ }^{47}$ The Queensland legislation prohibiting Asians from selecting land or leasing more than five acres is a partial but not a complete explanation, for even before the enactment of the Leases to Aliens Restriction Act very few Japanese leased land. ${ }^{48}$

44 Age 22 February 1946.

48 S. Saitu, Ösutoraria tsrishin, (Tokyo: Kokusai Kaihatsı Jânaru sha, 1971), p. 112.

From evidence presented to the Royal Commission on the Pearl-Sbelling Industry it appears that the death-rate among Japanese divers in Australia from this cause in the year 1911 was 11 per cent. Commonwealth of Australia, Parliamentary Popers (hereafter C of A, PP) 1919 vol. 3, p. 593 , q. 607 ff.

46 From the applications for exemption from the Queensiand Sugar CuItivation Act of 1913 it appears that there were at that date only 19 Japanese cane-farmers (Queensland Archives AGS/N359 $159 \mathrm{G}$ 'List of Cane-Farmers'). The applications for Alten Registration in 1917 reveal an additional seven who were corn-farmers in that State (Commonwealth Archives, Brisbane Repository, Japanese Applications for Alien Registration 1916). On internment in 194114 of the Japanese residents in Queensland gave their occupations as farmer or vegetable gardener. Only 7 appear to have possessed any assets, of whom only 3 appear to have leased more than 5 acres. (Commonwealth Archives, Melbourne Repository, MP1103).

${ }^{47}$ Application for Alien Registration 1916. Internees' Australian Army Forms A112, 1941.

${ }^{49}$ NGB-1905, p. 240. 
Some people had big plans for Japanese agriculture in Australia, but none of these saw the light of day. The South Australian Government in 1876 supported the scheme of Hack, a local missionary, to establish Japanese selectors in the Northern Territory. The Japanese Government, however, vetoed this. ${ }^{49}$ Alexander Marks in May 1896 wrote to the Foreign Minister:

For the last two years I have been using my private influence to obtain a position in the Torres Straits for a Japanese colony and trying to obtain a large concession of territory from the Queensland Government. 50

Like much that Marks did, this appears to have been quite on his own initiative. Whether the Foreign Minister replied is unknown; in 1898 J. L. Parsons, a former Cabinet Minister and Administrator of the Northern Territory, attempted to arrange the sale of a large area of private land there to Japanese for cultivation. He was prevented from doing so by the South Australian and the Japanese Governments. ${ }^{51}$ In the same year, Komine, a successful Japanese pearler at Thursday Island, applied for naturalisation so that he could hold land as trustee for 'a number of wealthy Japanese' desirous of investing 'many thousands of pounds' in cultivating sugar and other tropical products in the Cairns district. ${ }^{52}$ By that time the Queensland Government had decided that no more Asians were to be naturalised. Komine transferred his activities to German New Guinea where in 1914 he was officially conmended for assisting the Australian Expeditionary Force in capturing the German naval yacht 'Komet'.

There were others who, like Komine, left Australia prosperous men. Nakagawa Matsugoro, the 'Tommy Japan' in the winning Tattersall's syndicate had in the ten years preceding his win risen from steward on the island trader Ripple (which, though badly wounded, he heroically defended against an attack by natives at Bougainville), ${ }^{53}$ to the proprietor of two billiard saloons and a boarding house on Thursday Island. ${ }^{54}$ Another unsuccessful applicant for naturalisation was Sato Torajirob. He arrived in Thursday Island in 1893 aged 25 . He had already acquired a law degree at

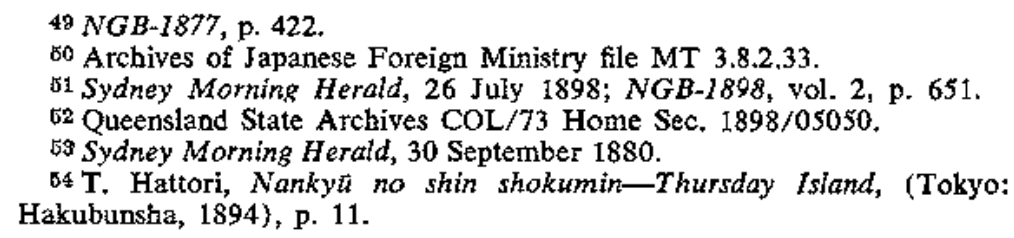


the University of Michigan. By the time he returned to Japan in 1901 he was a prosperous businessman with interests in pearling, ship-building and trade. On his return to Japan he founded a newspaper, the Yokohama Shimbun, was twice elected to the House of Representatives, and became a large landowner in Korea. ${ }^{55}$

There is little in the above story that is surprising. It was natural that a British colony of settlement with a large and exfranchised working class should wish to build the community in its own image and exclude races that it patentiy could not anglicise. This ideal meant as much to Australian Ministers in the $1930 \mathrm{~s}^{56}$ as it did to Reid and the other Premiers when they championed Asian exclusion at the Colonial Conference in the year of the Diamond Jubilee. It was not until the 1960 s that people found that the dream had vanished unobtrusively some years before. It is not surprising that men of Hughes' generation, with this ideal and with the recollection of Chinese immigration and the towns in Australia with Chinese majorities that resulted, should have insisted on the conplete exclusion of Japanese settlers. With the knowledge that we now have it seems obvious that the admission of Japanese merchants to settlement would not have prejudiced the attainment of their ideal. However with the recollection fresh in their memory of labourers arriving with merchants' passports in 1898, it is hardly surprising that in 1901 the Federal Government was prepared to take no chances-particularly as no one wanted Japanese merchants anyway.

Since 1952 a small number of Japanese have been admitted for permanent residence. Until the end of the Occupation, Australia refused to allow those of her servicemen who had married Japanese to bring them to Australia. This policy was abandoncd only a few weeks before the Peace Treaty came into effect. Although figures are not available, it is thought that about 600 Japanese war brides were admitted. 57 The contrast between the long and disheartening struggle fought by the husbands and their well-wishers ${ }^{58}$ before this was permitted and the ready acceptance of the brides by the Australian community may perbaps cause future historians, with some justification, to see this as a watershed in the development of

55 Wakayama-ken, Wakayama-ken imin shi (Wakayama-shi: Wakayama kenchō, 1957) p. 580-82.

56 E.g. Pearce to Bruce, Cable No. 11510 December 1934 (CAO A981, Trade 68, Part 1).

${ }^{57}$ Mainichi Shimbun, 4 October 1959.

${ }^{58}$ For some details see I. Carter, Alien Blossom, (Melbourne: Lansdowne 1965), passim. 
Australian attitudes to the Japanese. The success that the very large majority of these women earned in their roles as wives, mothers and citizens in a new country ${ }^{59}$ was no doubt one of the factors that made it relatively easy for the Australian Government in 1956 to lift the ban on the naturalisation of Asians, which had been in operation since Federation: Asians became eligible for naturalisation upon marriage to an Australian; other Asians became eligible after 15 years residence. ${ }^{60}$ This enabled the war brides and the handful of Japanese who had remained since before the passing of the Immigration Restriction Act to become citizens. It ended the disqualification of the Iatter from old-age pensions. In 1956, the way was also opened for the occasional 'highly qualified and distinguished person' to enter for an indefinite stay and, if allowed by the Innmigration Department to remain for as Iong as 15 years, to become naturalised.

In 1966 this latter category was enlarged to inciude "persons with specialised technical skills for appointments for which local residents are not available', and naturatisation became possible after 5 years. ${ }^{B 1}$ According to a statement by the responsible Minister in 1968, a non-European, in order to qualify for admission under this category would need to possess a special skill which is in demand in the Australian community; 'as a rule of thumb' he would need to be a university graduate; there would have to be the probability that he would be accepted by the people with whom he mixed, who would recognise his work "by the way he dresses, the things he likes', ${ }^{62}$ In the light of this it is not surprising that out of 2,244 non-Europeans approved for settlement during the first three years of the new system (March 1966-February 1969) 1,960 were residing in Commonwealth or former Commonwealth countries, Europe, or the U.S.A., and that in comparison with 39 Japanese (19 principals and 20 dependents) there were 878 Indians and more than 550 Hong Kong or Straits' Chinese. Occupationally the Japanese were also at a disadvantage. The 2,244 non-Europeans approved were made up of 812 principals and their 1,432 dependents. Of the 812 principals the largest single occupational category was medical doctors, 183 . None of these were Japanese; for a Japanese medical degree is not recognised in Australia. Of these 19 Japanese principals, 11 were academics,

\footnotetext{
59 Mainichi Shimbun, 4 October 1959.

Bo Commonwealth Parliamentary Debates (Hereafter CPD) Representatives, vol. 13, p. 1595, 18 October 1956, Mr Holt.

61 Ibid., 9 March 1966, Mr Opperman.

${ }^{62}$ As reported in the Age 16 July 1968.
} 
research workers, teachers or librarians. The 19 were selected from some 3,250 inquirers. ${ }^{\text {B3 }}$

Before the War the only Japanese admitted to Australia were, generally speaking, merchants (and their clerks and domestic servants), divers, students and tourists. Since the early 1960s, with the emergence of Japan as the principal market for our mineral exports and the need for Japanese capital and 'know-how' in 'joint ventures' in this and other industries, Japanese have been admitted for limited periods in managerial and specialist roles and, on rare occasions, as skilled tradesmen. This has involved considerable changes in traditional attitudes-particularly on the part of the Australian Labor Party and the trade union movement. In 1963, for example, the Leader of the Labor Opposition in the Western Australian Parliament agreed that there were occasions when it was reasonable that the Japanese should be able to send geologists, technicians and 'certain forms of management' to mines in which Japanese interests were concerned." To this end his Party accepted legislation that empowered the Minister to issue certificates of excruption from Section 291 of the old Western Australian Mines Act which prohibited the employment of Asiatic and African aliens. ${ }^{65}$ In 1965 the Western Australian Trades and Labour Council announced that there would be no objection to importing skilled tradesmen from Japan or elsewhere provided that there was a genuine shortage of Australian labour in the categories involved. ${ }^{\text {B }}$ On this basis it permitted some Japanese specialists to be employed on a dredge to enlarge the harbour at Port Hedland to accommodate ore carriers. The Japanese were enrolled as members of the AWU. A great deal of water had passed under the bridge since the turn of the century when the AWU adopted its famous rule excluding coloured aliens from union membership. ${ }^{\text {ez }}$ In 1967 strikes did occur at Port Hedland in the course of implementing a similar agreement with the AWU regarding the employment of Japanese on a second dredge. The strikes were, however, settled satisfactorily on the basis of the principles enunciated in $1965^{\text {es }}$ According to a statement made by the Minister for Immigration

83 These figures are calculated from information kindly provided by the Department of Immigration.

64 Western Australia Parliamentary Debates, vol. 164, (1963), pp. 754-57. 6s Ybid., vol. 166 (1963) pp. 3915-17.

88 [Perth] Daily News, 14 January 1965.

47 Australian Workers' Union Constitution and General Rules-as adopted at a Conference of Delegates of the Queensland and Southern Workers Unions at Brisbane, February 1904, 5 .

Gs West Australian, 16 and 28 August, 28 and 30 September 1967. 
to the Federal Parliament in 1967, Government policy in such cases is, after close consultation with the unions, to issue permits for periods no longer than the time likely to be required to train Australians for the job (e.g. an initial permit for 6 months, renewable thereafter at 4-monthly intervals for a maximum of 2 years).$^{69}$

As of 31 December 1969 there were in Australia 225 Japanese specialists with 40 dependants. These were in addition to the 487 managerial and executive staff with their 625 dependants attached to the 146 branches of Japanese companies in Australia. ${ }^{70}$

Naturally a policy that regards them as less desirable than the nationals of other non-English-speaking countries with lower levels of education, public health and per-capita income is distasteful to the Japanese. Nevertheless, as emigration is not a Japanese national interest, discrimination against Japanese as settlers has not been the subject of official protest by the Japanese Government, although there is clear evidence that it disturbs well-disposed Japanese officials who regard warmer relations between the two communities as highly desirable politically for both countries. ${ }^{7 x}$ Recently, however, Australian procedures for the admission of businessmen for temporary stays have been under attack from Japanese firms ${ }^{22}$ and these have been given open support by the Japanese Government. ${ }^{73}$ On this subject the Tokyo correspondent of the Australian Financial Review (5 June 1970) made this interesting comment

An analysis of the situation indicates that these days at least this type of discrimination is a good deal less common than most people think. But it is difficult to convince Japanese businessmen of this, partly because of actual discrimination in the past, but mainly because many Japanese tend to transfer their anger at Australian discrimination against Japanese immigrants into this area.

Early in the same report he says that

... many businessmen who do considerable business with Australia, while professing an enthusiasm for Australia, also

69 CPD (Representatives), vol. 57, pp. 1566-67 (3 October 1967).

70 Sydney Morning Herald, 22 May 1970.

71 See reviews of the Japanese Ambassador's book Ôsutorariya tsashin in the Australian, 11 June 1971 and The Australian Financial Review, 9 July 1971 .

72 See The Australian Financial Review, 5 June 1970.

${ }^{2}$ See the remarks of the Consul-General in Sydney Morning Herald, 22 May 1970. 
make clear that they have a great deal more sympathy for a nation like Canada because of that country's vastly better racial image-although a cynic might point out that it has only a marginally better performance.

In view of recent developments in the Australian Labor Party's policy on immigration it is perhaps appropriate to consider bere whether there are likely to be significant changes in the administration of Australian immigration policy towards non-Europeans within the next few years.

At the Federal Conference of the ALP in June (1971) a new clause, "the avoidance of discrimination on any grounds of race or colour of skin or nationality' was added as one of the bases of ALP immigration policy. ${ }^{74} \mathrm{~A}$ cynic could argue that this is without significance since among the other bases listed is an effective escape clause, 'the avoidance of the difficult social and economic problems which may follow from an influx of peoples having different standards of living, traditions and cultures'. When taken together with the stated views of leaders of the Party, however, the nondiscrimination clause is, in my view, important. In proposing the Clause Mr Dunstan described immigration policy as administered by the Liberal Government as 'the grossest of racial discrimination' and deplored the fact that Australia had accepted fewer Asian migrants since the War than Canada had in one year. Mr Whitlam appears to hold similar beliefs. As long ago as 1966 he is reported to have said:

If it is necessary for people to come herc to install or scrvice equipment which we cannot produce ourselves, or cannot produce promptly enough for our needs, then if they desire, they should be eligible for naturalisation after the same period of residence, wherever they come from. ${ }^{75}$

Once again a cynic could argue that this need imply no change in policy since in fact the period of residence for the naturalisation of foreigners is five years for both Europeans and non-Europeans alike. To me, however, a more reasonable interpretation is that Mr Whitlam favours in such circumstances the admission of Japanese (if they are technically the best qualified) as readily as, say, Greeks and on a permanent, not a temporary, basis. It also suggests to me that he feels that he will be able to muster sufficient support for these views in the unions. Accordingly I regard the June Con-

74 As reported in the Syditey Morning Herald, 21 June 1971.

75 Age, 19 January 1966. 
ference decision as presaging changes in our immigration procedures that would make for a better Australian image in Japan if Labor gains office. Furthermore, insofar as the non-Labor parties have, despite their Hugheses and their Pettys, traditionally tended to adopt policies on coloured immigration slightly less rigorous than those of the Labor Party, it can be argued that irrespective of who wins the next Federal elections, the policy of the Australian Government will move some distance in the direction favoured by Mr Dunstan. 


\section{END OF REPRINT}

Immigration in Australian-Japanese relations, 1871-1971 



\section{8 \\ An immigrant family ${ }^{1}$}

Jō Takasuka was born on 13 February 1865 at Matsuyama, Japan, the only son of Kahei Takasuka who had been granted samurai status for his services as a chef at the castle of the local daimyo (feudal lord). ${ }^{2}$ In 1884, when Jō was only 18 years old, Kahei transferred to him the headship of the house and the title to the family property - a not unusual procedure in the case of samurai families. ${ }^{3}$

After two years study at the Keiō Continuation School in Tokyo, Jō enrolled in the Economics Faculty of Keiō University in $1892,{ }^{4}$ but shortly afterwards went to the United States where he studied at DePauw University (Indiana) ${ }^{5}$ and Westminster College (Pennsylvania) where he graduated BA in $1896 .^{6}$

On his return to Japan, he successfully stood for election in March 1898 in the local constituency in the House of Representatives on behalf of the Rikken Seiyūkai Party. In July of the same year he married Ichi, daughter of Michimoto Maejima, a judge of the local District Court. She had received a secondary education at a famous Tokyo school for young ladies, the Watanabe Saihō Gakkō, the predecessor of today's Tokyo Kasei University. In 1900 a new electoral law greatly enlarged the franchise and changed Takasuka's seat into a much larger, single-member constituency. In these circumstances he did not contest the 1902 elections.

Accompanied by his wife and two infant children, Takasuka arrived in Melbourne on 14 March 1905 aboard the E\&A Line's Empire on a 12 months' 'Certificate of Exemption from the Dictation Test' granted for the purpose of engaging in the

\footnotetext{
Unpublished paper.

Interview with Mr Yūichi Nakasuka (the son of Jō’s cousin) at Matsuyama on 24 January 1974.

Copy of Jō's family register (koseki) provided by Matsuyama Town Hall, 24 October 1973.

Information provided by the Historical Section (Jukushi Shiryō-shitsu) of Keiō University in 1974.

Shūgiin, Gikaiseido Nanajūgonen-shi: Shügiin-giin-meikan (Tokyo: Okura-shō, 1962), p. 287.

Registrar, Westminster College, to the author, 29 October 1973.
} 
export and import trade. ${ }^{7}$ He set up in business under the name, Takasuka, Dight \& Co., Japanese Importers, at 136 Queen Street in the city and at 20 Boyd Street, Richmond. ${ }^{8}$ As a part-time activity he also taught the Japanese language at Stott \& Hoare's Business College. ${ }^{9}$

Takasuka was dilatory in applying for an extension of his 12 months' certificate of exemption. Accordingly, on 7 July 1906 he was instructed by the Commonwealth authorities to wind up his affairs and leave Australia within six months. On representations from the consul-general, however, he was granted an extension of 12 months from 1 March 1906 'on the distinct understanding that no further application is made'. ${ }^{10}$ Takasuka, however, had other plans. He had secured an interview with the Victorian premier and the minister for Crown lands and survey and had asked for the lease of an area of from 300 to 500 acres of land subject to flooding in the Mallee district. On this he proposed to experiment with rice growing. Rice culture, he told them:

is very difficult and requires special trained knowledge to be successfully done. In my native country the cultivation is in the hands of farmers who for generations have followed this culture for their living. It is a crop of extraordinary fickleness, and owing to the quantity of water used, subject to attacks of many diseases, as witness the frequent failures of the crops and ensuing famines in Japan. On the other hand rice culture affords a means of utilizing areas of marshy land not capable of cultivation for any other crops of commercial value at the present time. ${ }^{11}$

Impressed, no doubt, by the latter consideration, the minister placed the matter before the Victorian Cabinet, which on 6 July resolved to make available for this purpose an area of 300 acres on the Murray River. Accordingly, there duly appeared in the Victorian Government Gazette over the minister's signature the following advertisement:

\section{LAND AVAILABLE FOR RICE CULTURE ON THE MURRAY RIVER FRONTAGE, ABOUT FOURTEEN MILES BELOW SWAN HILL.}

Three hundred acres, in the parish of Tyntynder West, county of Tatchera, situated between the 'Cadusch' Homestead Settlement and the Murray River.

The land is subject to annual inundation. A permit to occupy the land for five years will be given the successful applicant, at an annual fee of $6 \mathrm{~d}$. per acre.

\footnotetext{
7 Al, file 25/27797, National Archives of Australia (Canberra) (hereafter 25/27797).

8 Sands \& McDougall, Melbourne Suburban and Country Directory 1906, 1907, 1908 (in 1908 the Richmond address is not listed).

9 Stott and Hoare's Business College, 21st Annual Report, 1906, p. 13.

10 Secretary, External Affairs to Consul-General, 25 July 1906, 25/27797.

11 Takasuka to Premier, 22 June 1906, Department of Crown Lands and Survey, Victoria, file 05075/204 (hereafter 05075/204).
} 
Conditions will be inserted in the permit making the cultivation of rice compulsory, and also providing for an annual expenditure of at least Ten shillings per acre during the term of five years.

If, at the end of such term, the conditions have been complied with to the satisfaction of the Minister for Lands, a perpetual lease will be granted, at an annual rent of $3 \mathrm{~d}$. per acre.

Such rent is subject to revision at the end of every period of ten years.

Applications will be received by the Secretary for Lands, Melbourne, until Friday, the 31st August, $1906 .{ }^{12}$

Takasuka lodged an application for the whole 300 acres and promptly moved with his family to the district, where they boarded with a local farmer. On 18 October he gave evidence before the local land board in support of his application. He said that he had been associated with rice cultivation nearly all his life. In Japan his father had 10,000 acres and had 'people growing rice on parts of it'. In the United States over a period of four years he had made two attempts at rice growing in Texas where he had rented 170 acres and 300 acres respectively. ${ }^{13}$ These attempts had been unsuccessful because of the low price of rice there ( $£ 10$ a ton). Thanks to a high duty, the price of rice in Australia was $£ 22$ a ton. At this price he considered the enterprise would be viable despite the expenditure that would be required to construct a levee bank five-feet high to keep out the floods. He had $£ 500$ capital and one ton of rice seed. He was trying to secure a local farmer as a partner; but, if he could not find one, he would proceed on his own (in the event, this is what he had to do). He admitted that he was not naturalised and said that this would take five years (in this respect he must have been misinformed. From the 1890s onwards the policy of Australian governments had been to make use of their executive discretion to refuse naturalisation to Asians). ${ }^{14}$

Takasuka was allotted 200 of the 300 acres. The remainder was divided equally between two Australian applicants.

On the basis of this changed set of circumstances, the consul-general prevailed on the Commonwealth immigration authorities to take a less rigid view regarding Takasuka's stay. On 3 October they informed the consul-general that, as the case was 'an isolated one, not likely to form a precedent', annual extensions of his certificate of exemption would be granted for the period of the lease. ${ }^{15}$

12 Victoria, Government Gazette, 1 August 1906, p. 3348.

13 These claims must surely have been exaggerations. The May 1898 edition of Shügiin Giin Meibo ('List of Members of the House of Representatives’) gives Jō’s annual land-tax assessment as ¥25.115. This meant an ownership of only about six acres! (I am indebted to my colleague Dr Andrew Fraser and to Dr Junji Banno of the Institute of Social Science at Tokyo University for this information.) Any real property owned by his father would have been transferred to Jo when the latter became head of the house in 1884.

14 Local Land Board, Swan Hill, Notes of Evidence, Case No. 13, 18 October 1906, 05075/204.

15 Secretary, External Affairs to Consul-General, 3 October 1906, 25/27797. 
The survey of Takasuka's allotment was completed in August the following year (1907) and his five-year permit to occupy the land commenced on 1 January 1908. Takasuka, however, did not allow such formalities to delay his experiments. His seed would deteriorate if kept. For the 1906/07 season he sowed 35 acres on land rented from SP Watson at Nyah. In this way Takasuka, with insufficient capital, embarked upon a 20-year battle against the elements in what was in those years virtually the only sustained attempt to grow rice in Victoria. ${ }^{16} \mathrm{He}$ was by disposition a theorist rather than a practical man. The story is still current in the Nyah district that on his arrival he was seen putting bait on his rabbit-traps!

The 1906 attempt was a failure. The seed was of an unsuitable variety. Furthermore, sheep got in and devoured what little of it that had come up. In 1907 he imported three other varieties from Japan and sowed 65 acres on land belonging to E O'Riley at Piangil (about 12 miles to the north-west). Because of lack of water this too was a failure. The yield was only a few bags; some of it was black, some of it was green, and it was no use for seed. ${ }^{17}$ In 1908 he brought out an 'expert' from Japan. This 'expert' (who appears to have been Takasuka's father, Kahei) brought with him 15 bags of seed of different kinds and advised him that the only way was to experiment with many varieties and to acclimatise the best. That was Takasuka's first year on his own allotment. With the aid of a contractor he began work on the levee bank and ploughed 10 acres. He was so busy with these operations, however, that he missed sowing time and no crop was planted that season. In February 1909 he tried without success through his local member of parliament to get $£ 100$ from the state government to buy bullocks for erecting the banks. ${ }^{18}$ Despite this rebuff, he continued work on banking and ploughed about 40 acres, only to have everything washed away in the big flood of that year which forced him to take refuge with his family at Nyah. ${ }^{19}$ At this stage, he sought the permission of the Commonwealth Government to bring in two Japanese with the necessary special skills as partners to remain in the Commonwealth until the expiry of his own period of admission..$^{20}$ This was refused. In 1910 he erected 1.25 miles of banking; but floods struck again and swept it away. He sowed about a quarter of an acre on the land of a neighbour, E Hungerford.

16 This account of Takasuka's rice-growing experiments is taken principally from Takasuka to Minister for Lands, 18 March 1920, 050575/204 and supplemented by the sources indicated hereunder.

17 Report of Mounted Constable CJ Levett, 18 May 1910, 25/27797. See also Takasuka to Agricultural Superintendent, 31 July 1914 in Victorian Department of Agriculture file 'Miscellaneous — Rice Culture' (hereafter 'Misc. - Rice Culture'). I am indebted to the director for kindly providing me with relevant material from this file.

18 Takasuka to Hon. John Gray, MLA, 12 February 1909, 05075/204.

19 Consul-General to Secretary, External Affairs, 20 April 1910, 25/27797.

20 Consul-General to Secretary, External Affairs, 13 November 1909, 25/27797. 
In 1911 on his own allotment he sowed 25 varieties, each in a sample plot measuring $20 \times 12$ feet. Of these, three - Kahei (named after his father), Hiderishirazu and Shinriki ${ }^{21}$ - appear to have been successfully harvested. The chief field officer of the Department of Agriculture (Temple A Smith) visited the property and reported favourably:

Mr Takasuka claims that these will yield $20 \mathrm{cwt}$. per acre of clean rice, valued at $£ 20$ per ton. The rice straw is also of value for making mats, for thatching, and the straw is also greedily eaten by stock.

The cost of growing and irrigating, including ploughing, harvesting, etc., is approximately $£ 7$ per acre.

The soil on which the rice is being grown is a strong clay loam, liable to flood for several months of the year, owing to which fact Mr Takasuka cannot grow the crop on a commercial scale at present. The rice now in the plots shows better growth than any of the other crops adjoining, such as maize.

There are approximately 500 acres of this flat suitable for rice-growing, and this land is typical of many hundreds of acres of land along the Murray of little use for other purposes. ${ }^{22}$

It was during this season that the two Australians who had been allotted land for rice-growing at the same time as Takasuka abandoned their efforts and their allotments reverted to the status of unoccupied Crown land.

It is ironical that just as there appeared some prospect of success for Takasuka's project, a threat to his tenure developed. In July 1911 Takasuka had pointed out to the Lands Department that in order to protect his allotment from flooding it was necessary to erect a bank three miles long - half of it on his allotment, half of it on Crown land. He proposed that they share expenses. ${ }^{23}$ The government was indeed contemplating extensive works of this nature in its own interests; but in these plans Takasuka's presence was a hindrance. Around his 200-acre allotment there were another 405 acres of unoccupied Crown land. By means of levee banks this could all be brought into production as a closer settlement project and the value of the land raised to at least $£ 6$ per acre. ${ }^{24}$ Although Takasuka had paid his rents, he was legally in a weak position as he had not the cash flow to enable him to effect the $£ 100$-per-annum improvements required under the conditions of his

21 In Japan, Hiderishirazu (旱不知) and Shinriki (神力) were regarded as upland (and not as wet-field) varieties. 22 Temple A Smith to Director, Department of Agriculture, 10 April 1912, 05075/204; Rept. by Mounted Constable GH Taylor, 6 May 1912, 25/27797. See also Age (Melbourne), 12 April 1912; Argus (Melbourne), 12 April 1912.

23 Takasuka to Minister, 12 July 1911, 05075/204.

24 Secretary State Rivers \& Water Supply Commission to Lands Department, 15 March and 22 June 1912, 05075/204. 
tenancy. In May 1912 he was informed that, until the government's plans for the wider reclamation project had been settled, the question of issuing the perpetual lease to him could not be considered. ${ }^{25}$

Without the protection of the levee banks Takasuka was loth to expose to risk of floods the valuable seeds that he had at last produced. In 1912 he sowed at two different places in Nyah on ground rented from W Hobson and K Mole. In 1913 on R Berry's block at Tyntynder Central he sowed a total of five acres of Kahei (now acclimatised for three years and renamed Takasuka) and Ehime (the name of his native prefecture in Japan). He harvested about 12 bags (i.e. almost one ton) to the acre. ${ }^{26}$ The five-year period of residence required under the terms of his tenancy having been completed, Takasuka moved with his family to Swan Hill in October of that year.

There were difficult problems of cultivation technique to be overcome. On 6 June 1914 he wrote to the Victorian Department of Agriculture asking for advice on how to achieve more regular ripening. In Japan the flowering stage lasted only two weeks; but at Nyah it lasted for six weeks and new ears kept shooting after the first ears had ripened. The department's reply ignored these questions. On 31 July he informed them that he was now about to experiment with the cultivation of a large area. Pointing out that his experiments to date had entailed testing 54 varieties, he appealed to them for some assistance:

During last 8 years I sacrificed much work and expenses for experimenting rice culture, so year by year I got poorer and poorer, I have not much capital for rice growing on a large scale this year, and I should be glad to get assistance from your Department.

To this letter he received a bare acknowledgment. ${ }^{27}$ Undaunted, he went ahead and that season sowed two separate plots in the Swan Hill Irrigation Area (30 acres, Original Block 24, Mrs Carroll; 20 acres, Original Block 36, J Hannon). It turned out to be a drought year and the State Rivers and Water Commission could not supply him with sufficient water. In this situation he devoted his entire ration to 10 acres on the smaller block. This strategy was successful. On these 10 acres his yield was once again 12 bags to the acre. He was able to sell the seed produced to commercial seedsmen and to the New South Wales Department of Agriculture, which sowed it at its Yanco Experimental Farm in the Murrumbidgee Irrigation Area.

25 Secretary, Lands Department to Takasuka, 22 May 1912, 05075/204.

26 According to the Victorian Journal of Agriculture (10 August 1916, p. 493), one bag of this variety unhulled weighed about 176 pounds.

27 'Misc. - Rice Culture'. 
The Great War had broken out some months previously. Takasuka donated the proceeds of the first $100 \mathrm{lbs}$ of the seed to the Lord Mayor of Melbourne's Belgian Relief Fund. This unusual gift gave rise to a paragraph in the Melbourne Age $e^{28}$ describing Takasuka's experiments. This prompted the Lands Department to instruct its local representative to report on the state of affairs on Takasuka's own allotment. That officer reported that the rice that Takasuka had produced at Swan Hill appeared suitable for the local conditions and that the yield had been very successful considering the scarcity of water that season. On the other hand, he estimated that on Takasuka's own allotment the construction of the levee bank alone would cost Takasuka $£ 700-800$. He doubted whether, even if he received a title to the land, Takasuka would be able to raise this sum together with the additional capital required for pumping equipment, channelling, fencing and ploughing. He thought that Takasuka would be much better off to remain at Swan Hill. He urged him at least to remain there growing rice until he had amassed sufficient capital to make a return to his own allotment worthwhile. Takasuka, however, was not to be dissuaded.

The officer considered the improvements effected on Takasuka's allotment 'hardly worthy of valuation': 1.125 miles of fencing in a bad state of disrepair $-£ 9$; 2.3 miles of banking much destroyed by floods $-£ 100$; the house itself $-£ 10$. The latter appears to have been a very primitive dwelling measuring only $15 \times 18$ feet, with walls made from palings and pine slabs. ${ }^{29}$

Soon after this interview, Takasuka returned to his own allotment and erected a four-roomed house measuring $32 \times 28$ feet built of Murray pine and valued at $£ 150$. He also spent another $£ 80$ on the embankments, hiring two teams of horses for this purpose. Although the sum total of his improvements still fell short of the required $£ 500$, this created a more favourable impression with the Lands Department. On 7 September 1915, its local representative reported:

I have tried to get Mr Takasuka to select a piece of ground not so costly to reclaim but he seems to be keen upon going on where he is and in view of him going to the present expenditure I think that the Department should assist him by granting a Title to the property. He says that he can manage if the title is granted to him and is in my opinion a little overconfident, however that is his own business. All I can say is that he has produced a suitable variety of rice and if the mere fact of granting him a title will enable bim to carry on his scheme successfully then the title should be granted. Mr Takasuka should receive whatever assistance can be given as he has endeavoured to make the proposition a success in spite of immense difficulties. ${ }^{30}$ [emphasis in original] 
On 5 November the perpetual lease was issued. Takasuka's troubles, however, were by no means over. The floods had again broken in before the embankment was completed. Moreover, in 1916 and 1917 the creek did not dry out in the summer as in previous years. This prevented him from continuing work on the embankment. In 1918 the creek dried and he resumed the work. In 1919 he planted rice for the first time since 1915. But he only had enough seed for five acres because, the seed being old, he had to sow at five or six times the normal density. He hoped from this to get sufficient new seed to plant a large area the following year. In this he was disappointed: with the old seed the germination was too poor and the crop failed..$^{31}$ Nor was he able to get the hoped for loan for completing the earthworks. His bank refused to lend money on the security of the perpetual lease and insisted that he get freehold. This could be done only if the Lands Department permitted Takasuka to convert his perpetual lease into a selection purchase lease. But the officials of the Lands Department had by now lost interest in Takasuka and his experiments. They wanted his land for their closer settlement scheme. In the words of the undersecretary (AA Peverill) in his advice to the minister: 'As Government works in the form of levees are contemplated which will materially enhance the value of this area and the Crown lands adjacent it is undesirable that any alienating title should be issued. ${ }^{32}$ Taking advantage of the fact that Takasuka had not planted rice every year, the department in October 1919 informed him that his request was refused on the ground that he had failed to comply with 'the cultivation condition of his perpetual lease'. ${ }^{33}$ Earlier that year they had, in reply to the annual enquiry about his activities by the Commonwealth immigration authorities, reported that Takasuka's work was not sufficiently important to justify further residence in Australia. ${ }^{34}$ In contrast to the attitude of the Victorian officials, the attitude of the Commonwealth authorities was in this case refreshingly humane. They made their own enquiries through the local police who reported favourably: 'This is a industrious, hard working respectable man. ${ }^{35}$ They appear to have been impressed by this; for they did not set in motion the machinery to deport him.

Takasuka had not been a member of parliament for nothing. He did not accept departmental decisions lying down. On 18 March 1920 he wrote to the minister for lands through his solicitor, outlining the history of his experiments since 1906. The minister referred this to the department. The local Crown lands bailiff at Swan Hill was favourable:

31 Takasuka to Secretary for Lands, 18 August 1920, 05075/204.

32 Acting Secretary to Minister, 28 May 1921, 05075/204.

33 Lands Department to Takasuka, 28 October 1919, 05075/204.

34 Director of Agriculture (Vic.) to Secretary, Home \& Territories, 11 July 1919, 25/27797.

35 Report of Mounted Constable A Llynn, 15 March 1920, 25/27797. 
I think he is a hard worker but he seems to lack method. He will never be able to grow rice or anything else on the block unless a high check levee bank is erected. If he would do that, I know of no objection to his being granted the lease as requested. ${ }^{36}$

The undersecretary, however, stood firm and on 17 May reaffirmed the previous decision, noting that 'most of the experiments have been carried out on other people's lands'. ${ }^{37}$

Next, the local member of the state parliament at Takasuka's request wrote unsuccessfully to the department asking that the matter be reconsidered. That year Takasuka sowed 70 acres of oats. The floods entered once again and he lost the lot. ${ }^{38}$

In March 1921 Takasuka wrote to the assistant minister for water supply, H Angus. Angus passed on the letter to the Lands Department, where the undersecretary once again stood firm. Angus, however, must have been impressed by Takasuka's case, for he did not let the matter end there, but in June presented Takasuka personally to the minister for lands. Takasuka on 23 June followed up the interview with a letter to the minister. This letter contains one of the most poignant sentences in Takasuka's Lands Department file:

Nearly every year I have to take all my animals out, my house getting quite surrounded by water and for two or three months during the flood I have had to row (I do so yet) over half a mile daily to let my children out and in from school. ${ }^{39}$

The minister was more sympathetic than his undersecretary and took the matter to Cabinet, which resolved to seek an opinion from the Crown solicitor 'whether in the circumstances of the case, the Minister of Lands would be violating the provisions of the Land Act ... if he allowed an application to select to proceed' ${ }^{40}$

In June Takasuka had also visited the Commonwealth immigration authorities in Melbourne and, in support of his annual application for an extension of his stay in Australia, had given them the full details of his problems with the lease. Early in July they sent one of their investigating officers to the Lands Department to find out what chances Takasuka had of converting his lease. There the investigating officer met a somewhat piqued undersecretary:

Mr Peverill stated that Takasuka was a very persistent individual and in a sense a bit of a nuisance to the Department. He made several personal applications for concessions all of which were turned down but notwithstanding the rebuffs he would go to one politician after another and enlist their sympathy and assistance

36 Report by VN Turner, 12 May 1920, 05075/204.

37 Minute by AA P[everill], 05075/204.

38 'Misc. - Rice Culture', Takasuka to Acting Collector of Customs, 12 March 1921.

39 Takasuka to Minister for Lands, 23 June 1921, 05075/204.

40 Minute by Undersecretary for Lands, 8 July 1921, 05075/204. 
with the result that they would nearly always get the question opened up again ... Mr Peverill stated that Takasuka's application was before the State Cabinet but owing to the approaching Elections nothing would be done with it for a considerable time. ${ }^{41}$

The Victorian Crown solicitor on 13 July advised that, insofar as Section 204 of the Land Act empowered the governor if he thought fit to accept the surrender of a perpetual lease and issue a selection purchase lease, the matter was one of administrative discretion and there was no legal obstacle to Takasuka's application being granted. Whether or not to grant the lease was merely a question of policy. Any failure by Takasuka to have complied with the requirement of his perpetual lease with regard to improvements did not in law disqualify him. The authorities could, however, take any such failure into consideration in exercising their discretion. ${ }^{42}$

The state elections took place on 30 August. Early in September Peverill informed the Commonwealth authorities that the matter had been decided in Takasuka's favour and that the selection purchase lease would be issued to him. ${ }^{43}$ Having received this information, the federal officials then prepared their advice for their minister regarding Takasuka's annual application for one year's further residence in Australia. On 7 October, the secretary of the federal Department of Home and Territories was advised by his chief clerk as follows:

As Takasuka is sticking to the job of proving this proposition, (all others have given it up) the Min[ister] may be prepared to extend exemption 1 year. It w[ou] ld be very hard to order him away now.

The minister, Sir George Pearce, was so disposed. Furthermore, three years later, in 1924, on departmental advice, while reserving his right to revert to the practice at any time, he ruled that Takasuka be freed from the requirement to make annual requests for an extension of his stay. ${ }^{44}$

It appears that the rice Takasuka sowed in 1921 was harvested successfully. After sowing the following year, he procured the freehold of the allotment on 4 October 1922 on payment of $£ 200 .{ }^{45}$ This crop, too, appears to have been harvested successfully. By 1927, however, his temporary good fortune had deserted him. In that year he was forced by financial need to abandon his experiments in favour of vine growing at Nyah. Then in 1934 he moved to Huntly near Bendigo where he started to grow tomatoes. Aged 69 he was now in virtual retirement and left the conduct of the business to his two sons. In 1938 the latter moved to a farm of their own at Fosterville.

41 Det. Inspr J Gleeson to Collector of Customs, 30 September 1921, 25/27797.

42 Opinion of the Crown Solicitor, 13 July 1921, 05075/204.

43 Det. Inspr J Gleeson to Collector of Customs, 30 September 1921, 25/27797.

44 Minute, 30 August 1924, 25/27797.

45 Title to Tyntynder West, Allotment 47, Vol. 4866, Fol. 973182, Victorian Titles Office. 
Late in July 1939 Takasuka embarked for Japan on the Atsuta Maru ${ }^{46}$ His father had died in 1911 leaving two dependents - Takasuka's sister and stepmother. The former had died in 1933. The latter (born in 1865 - the same year as Takasuka) died in May 1939. ${ }^{47}$ Her death was the occasion for Takasuka's return. He had to see to his possessions in Japan. He had also conceived the idea of returning to the import-export business. He would set up a company in Kobe with himself as president moving to and fro between Japan and Australia. He would make his brother-in-law vice-president to look after matters in Japan during his absences. ${ }^{48}$

On his arrival in Japan he appears to have sold up various objêts d'art in the family home at Matsuyama such as armour and screens, and invested the proceeds $(¥ 2,800)^{49}$ in Japanese war bonds. His Japanese-language new year’s greetings card distributed in January (1940), in addition to expressing his felicitations 'on the dawn of Asian advancement' and his 'thanks to our officers and men for their labours at the front' (hostilities against China had been resumed in 1937) announces that he is in business as the Australian Barter Trade \& Co.', with a room on the fourth floor of the Edo Building in Kobe where concurrently he proposes to run a correspondence school to provide instruction in an improved system of transliterating the Japanese language in the Roman alphabet. A copy of the prospectus for the correspondence school has survived. As a business proposition it sounds a good deal less practical than any of his previous ventures. For the payment of five yen, those enrolled would learn an improved system of Romanisation that 'would be comprehensible throughout the English-speaking world'. This would become the standard system of rendering Japanese overseas, instead of the conflicting methods currently in use. As a result, the Japanese language would be used more widely.

The Japanese Ministry of Education was at the time attempting to supplant the well-tried Hepburn system of Romanisation by the homegrown kunrei-sbiki system (which was incomprehensible not only to the English-speaking peoples but to the entire non-Japanese world). Under the latter system, the Emperor's younger brother, the Oxford-educated Prince Chichibu, ran the risk of being addressed by foreigners as Prince Titibu. It was widely rumoured that the mere thought of seeing the latter word towering above the wharf sheds at Southampton had been sufficient for him to decree that no ship should be named after him. If Takasuka's aim was to drive a nail into the coffin of the kunrei-shiki system, this certainly was a worthy objective. But from the little he tells us in the prospectus (and if he had there revealed too many of his secrets there would have been no need for people

46 Diary of Mrs Ichi Takasuka, entries for 11-21 July 1939, Pioneer Settlement Museum, Swan Hill. J Takasuka to Y Nakasuka, 3 July 1939 (I am grateful to Mrs T Sugai of Tokyo for making available to me this and the other family letters that follow).

47 Family register (koseki) of Jō Takasuka, Registration Section, Matsuyama Town Hall.

48 Mrs Ichi Takasuka to S Sugai, 24 February 1940.

49 At that time the exchange rate was approx. $£ \mathrm{Sgl}=17$ yen. 
to venture their five yen), it seems that what he was gunning for was not the kunrei-shiki system but the use of the macron in the Hepburn system. Whatever his beliefs on this matter, it seems fairly obvious that very few of Kobe's Japanese citizens (and it was to the Japanese that the prospectus was directed) would be willing to part with $¥ 5$ and three month’s leisure to acquire expertise in such an esoteric subject. In the event, they were not to have the chance. Throughout his life Takasuka had never had cause to visit a doctor. On the night of 15 February 1940, at his house in Matsuyama, a fatal heart attack took him in his sleep.

The inventory of Takasuka's Japanese assets compiled by his executor has survived. It shows that during his absence in Australia he had continued as owner of the family real estate, which consisted of two properties in the vicinity of Matsuyama: (i) at Suehirochō 841.5 sq. metres on which was built his own residence and eight small cabins; (ii) at Izumi-chō 224 sq. metres of agricultural land (not irrigated and not suitable for rice) and 264 sq. metres of residential land on which was built seven small cabins. The rent from the cabins on both properties and from the agricultural land amounted to $¥ 949.60$ per annum — at that time about equal to the salary of a headmaster of a primary school. Apparently he had not sold or mortgaged any of his Japanese assets to support his experiments in Australia. This is not to say, however, that the family's assets did not decline during his lifetime. When I visited Matsuyama in 1974, a local official then in his 50s who had never seen a member of the Takasuka family remembered how, when he was a boy, his mother had warned him never to go into politics or it would ruin him 'as it had the Takasukas'. This is not surprising: Takasuka had had to mount two election campaigns within five months of each other - in March and August 1898.

Like most Japanese, Takasuka left no will. Therefore under Japanese law his elder son Shō, at Fosterville, became heir to the whole of the estate. Shō promptly made over to Mario, his younger brother and partner, all rights to the portion of the property located in Izumi-chō. It was, however, many years before the estate was wound up. And then, because of Japan's rigid exchange control regulations, the proceeds could not be sent out of the country. By the time, after Shō's death, Mario in his retirement visited Japan (1975), war damage, inflation, litigation, municipal rates, etc. had reduced the value of the estate to less than the cost of his air fare.

In his years on the Murray, Takasuka developed methods of cultivation appropriate to Australian conditions. For example, instead of transplanting the seedlings by hand (as is done in Japan), he sowed the seed in its permanent position by drill, in the manner of Australian wheat farmers. With such techniques he showed that, using from two to four acre-feet of water, yields of more than one ton per acre could be obtained..$^{50}$ But it was a blind alley. Seed of the Takasuka variety supplied by him was tested for four seasons at the Yanco Experimental Farm on the Murrumbidgee

50 Age, 5 February 1924. 
Irrigation Area in New South Wales. The results were not encouraging: the 1916/17 crop was spoiled by hot winds at the time of flowering; the 1917/18 by locusts; the $1918 / 19$ by poor germination; and the $1920 / 21$ by frosts. ${ }^{51}$ The origin of today's successful rice industry in that district is the experiments conducted at Yanco in 1922/23 with three varieties from California - Caloro, Wataribune and Colusa. Successful commercial production began with each of these varieties in 1924/25 and in the years that followed Caloro gradually ousted the other two. ${ }^{52}$ Takasuka's experiments are today commemorated only by a few samples of his seeds in the Melbourne Museum and by a couple of lines in the standard English-language work on rice cultivation. ${ }^{53}$ His lasting contribution to Australia was a family that possessed to a high degree two traditional Japanese traits - industriousness and the ideal of service to the community that reared them.

At the time of his father's death in 1940, Shō Takasuka had just turned 40. He had arrived in Australia just after his fifth birthday and had not been to Japan since. Although his applications for naturalisation had been rejected (until 1956 Australian governments refused to naturalise Asians), he felt completely Australian. There were no Japanese in the district: apart from his parents and his brother and sister he had not seen a Japanese for 35 years. Although he could remember a few words of Japanese, he could not read it at all. English was the only language he knew. Life in the Mallee had provided a bare living. He had had to leave school when he was 13 and take a job on a neighbour's farm. But out of his wages he had helped to put his sister through junior high school while he learnt what he could through correspondence courses at night. But he was happy. He loved the outdoor life and its recreations. He had started senior football when he got his guernsey with the Nyah club at the age of 14 . His best win had been the Swan Hill District Singles Tennis Championship. He was also a strong swimmer. This had stood him in good stead. In 1939 on a fishing trip on the Murray River he had saved a youth, Harry Nation, from drowning. It had been a close go for both of them. At some time or other he had been made an office-bearer of just about every sports club and community activity in the district. In his early 20 s, he had been secretary and treasurer for the local branch of the temperance friendly society, the Independent Order of Rechabites. In 1934, in recognition of his fundraising activities for the Swan Hill Hospital, he had been elected a governor of that institution. ${ }^{54}$

A lot of his time had been taken up by his father's impractical ventures - rice, cotton, vines and even, at Huntly, bamboo shoots — but he and his brother, Mario, had finally been able in 1938 to start out on their own. They had rented 10 acres of irrigated land on the rich alluvial flats of the Campaspe River at Fosterville.

51 Agricultural Gazette of NSW, 3 April 1920 and 1 December 1921.

52 Rice Growing on the Murrumbidgee Irrigation Areas (Griffith: MIA Irrigation Research and Extension Committee, 1957), pp. 23, 60-61.

53 DH Grist, Rice (London: Longmans, 1965), p. 8.

54 Swan Hill District Hospital, Minutes of Committee of Management, 9 November 1934. 
They were growing tomatoes and were cropping over 1,000 cases to the acre. He was busier than ever now. The younger men were away at the war. Despite his age he had wanted to go too, but his nationality prevented it; so he had joined the Volunteer Defence Corps.

In December 1941 Japan entered the war. Shō was immediately interned at Tatura Camp pursuant to the Cabinet decision that all Japanese over the age of 16 years should be taken into custody. ${ }^{55}$ But so numerous and unconditional were the representations by his neighbours insisting on his complete loyalty that he was released within six months. The following extracts from the evidence given on his behalf before the Aliens Tribunal are typical. One local grazier described him as 'as loyal a citizen as any living in our district ... He is always on his job, and if there is anything to be done, if there is a working bee for anybody who is ill or anything like that, he is always willing to help.' Another spoke of him as 'a really good citizen': 'He will help a battler along, too. Whenever his car is going to Bendigo, he will look out for somebody to take.' It is also obvious from the evidence that Shō, like so many of the second-generation Japanese in California, was very much a practical farmer: 'He is in the first grade as a tomato grower. He understands tomato culture from the time the plants are put into the seedling beds till the tomatoes are brought to the factory.'

These feelings of respect, acceptance and goodwill appear to have extended to the whole family - to both generations. When the tribunal asked a retired selector from Nyah what reputation the Takasuka family had in the district, he replied 'Absolutely one of the best. When they left the district it was the biggest send-off held in the Nyah district. Everybody was there. ${ }^{56}$ In its careful scrutiny of aliens conducted during 1940, the Military Intelligence Section at Southern Command had come to a similar conclusion. In December 1941 it advised the minister for the army to exempt Jō's widow from the operation of the Cabinet minute. In reply, the minister (FM Forde) stated that it was beyond the power of a single minister to overrule the collective decision of his colleagues but drew attention to the fact that the minute specified no date before which implementation must be completed. ${ }^{57}$ Southern Command took the hint and never got round to interning her. She died at Goornong, Victoria, in August 1956. Her kimono and parts of her Japaneselanguage day-to-day domestic diary and recipe book for the period 1933-45 are preserved in the museum at the Pioneer Settlement, Swan Hill.

55 Cabinet Meeting, minute 1029, paragraph 5, p. 3, 9 May 1941, volume 7, A2673, National Archives of Australia.

56 Shō Noburu Takasuka - Transcript, Aliens Tribunal No. 4, 10 February 1942, MP 529/3, National Archives of Australia (Melbourne Office).

57 MP 729,65/401/147, National Archives of Australia (Melbourne office). 
On his release from internment Shō returned to his tomato growing. He served on the council of Huntly Shire from 1964 to 1970 and for one year of this period was shire president. He was also active in the affairs of the local Anglican church, where he was rector's warden and parish representative in the diocesan synod.

Shō died in retirement in Melbourne on 7 October $1972 .{ }^{58}$ His executors have placed in public custody two very fitting remembrances of his life's work. The first is his collection of some 3,000 colour slides of local flora and wildlife. These are now held by the Bendigo Field Naturalists' Club, of which he was for many years a member. The second is a 30 -minute colour-film documentary made by Hiroshima Television Broadcasting Co. when he was shire president. This received wide acclaim in Japan, winning the Japan Script Writers Guild's annual award for the best documentary film produced in Southern Honshū. A copy is preserved in the National Library of Australia and is available on loan for screening.

On 30 November 1980, on the occasion of the centenary of St George's Church, Goornong, a stained-glass window was dedicated to his memory. ${ }^{59}$ Embodied in the design are the Japanese ideographs kyōdai (brethren) and danketsu (solidarity) expressing the message of Psalm 133: 'Behold, how good and how pleasant it is for brethren to dwell together in unity.' ${ }^{60}$

Takasuka's younger son, Mario, was born in Australia in 1910. In May 1940, a few months after the outbreak of war in Europe, he volunteered for the Australian Imperial Force (AIF). His first two applications were rejected under Australian Military Regulations \& Orders No. 177, which applied the White Australian policy to the armed forces and excluded recruits who were not substantially of European origin. For his third attempt in June 1940 he went to Melbourne, where he was not known and where the recruiting officer was unfamiliar with the regulations. He had let his hair grow longer than usual to increase his height by half an inch to the five feet six inches minimum required in the AIF.

By the end of the year he was in the Middle East with 7 Battery in the 2/3 Light Anti-Aircraft Regiment. On the day of the German airborne invasion of Crete, 20 May 1941, his battery was part of the force defending the vital aerodrome at Heraklion. The gun of which he was layer brought down one German plane and scored hits on two others. They fought their gun until its ammunition was exhausted. When their position was cut off by German troops, they took to a rowing boat and pulled out to sea where five hours later they climbed aboard the British destroyer, Kingston. Before she arrived at Alexandria leaking from a near miss, they had been set afire by enemy strafing and had helped pick up survivors from the Greybound and Fiji.

58 Advertiser, 13 October 1972.

59 Bendigo Advertiser, 1 December 1980,

60 Bendigo Advertiser, 29 November 1980, contains a photograph of the window. 
The following year he received a written commendation ${ }^{61}$ from his general for his part in rescue operations after a head-on collision between a troop train and a local train at Gaza in Palestine on the night of 20/21 February 1942. Despite the danger to themselves from falling coal, he and two comrades had worked for an hour freeing the fatally injured native fireman who lay crushed under the contents of the up-ended tender.

When Japan entered the war, army headquarters made strong attempts to keep him in a rear area. These were vigorously and successfully resisted not only by Mario but also by his commanding officer who reported as follows: 'His record as a soldier both in and out of action has been exemplary and in consideration of his outstanding service on Crete I selected him for promotion as a bombadier.' The rest of the unit shared this view and when it embarked again for overseas service (this time for Oro Bay in New Guinea) Mario, now promoted to a gun sergeant, was with them.

Takasuka's daughter, Aiko, died at Swan Hill in 1970. Born in Japan in 1903, she was 19 months old when she arrived in Australia. After becoming dux of Swan Hill Higher Elementary School (1920), she joined the education department as a primary school teacher. This was possible because of Victoria's enlightened Public Service Act, which did not discriminate against aliens. ${ }^{62}$ She taught fulltime in a succession of schools in the Swan Hill district ${ }^{63}$ until 1933, when she left the service to marry a local Cornish migrant. True to the family tradition, she managed to combine a full home life with community service. She was secretary to the Methodist Ladies Guild and, while her children were at school, was an active member of the mothers' clubs and the Girl Guides Local Association. When the family grew up, she returned to teaching on a part-time basis and also conducted a regular program on the local radio station for the Swan Hill Housewives Association. It is through her four children and seven grandchildren that the Takasuka blood will continue in later generations of Australians.

DCS Sissons

Department of International Relations

Research School of Pacific Studies

Australian National University

August 1975 (revised April $1977^{64}$ and December 1980)

61 HQAIF 3763 270/1/330 reproduced in 7 Aust Lt AA Bty Routine Orders Part I, No. 62, 28 Oct 1942.

$6254 \mathrm{Vic} 1133$, Sec 109 and 110.

63 The History Section of the Victorian Education Department has kindly provided the following details of her fulltime service: Tyntynder (Junior Teacher 1921-23), Swan Hill (Junior Teacher 1923-25), Nyrraby (Temporary Head Teacher 1925-26), Meering West (Temporary Head Teacher 1926), Nyah (Assistant 1926-33). Teaching seems to be in the blood. Her eldest son is a secondary school teacher and, at the time of writing (1978), one of her granddaughters is a second-year student teacher.

64 A Japanese translation of the article revised to April 1977 was published under the title, Aru Imin no Ichizoku' in the journal Ijū Kenkyū, no. 16, March 1979, pp. 65-78. 


\section{Private diplomacy in the 1936 trade dispute with Japan}

In Australian Journal of Politics and History, Vol. 27, No. 2, pp. 143-159, 1981.

Reprinted with permission of John Wiley \& Sons, Inc.

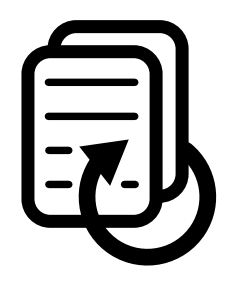





\section{Private Diplomacy in the 1936 Trade Dispute with Japan*}

D.C.S. SISSONS

\section{Introduction}

Efforts were made by Japan in 1895-96, 1915-17 and 1924-26 to induce Australia to enter into a treaty relationship as regards commerce and navigation. These ef forts were in each case firmly resisted. They were resumed in 1932, and late in 1934 the Lyons government eventually agreed to enter negotiations on this question. The Japanese were feeling the pinch of the Ottawa Agreement and, from material in the archives of their Ministry of Foreign Affairs, ${ }^{1}$ we now know that their objective in these negotiations was to reduce their trade deficit with Australia to about $¥ 50$ million. ${ }^{2}$ This would appear to be a pretty tall order. On the basis of the 1934 figures it would mean, on the assumption that imports from Australia remained unchanged, stepping up exports by a factor of $2.3 .^{3}$ An increase by a larger factor would, however, be required; for tariff concessions to Japan would have to be bought by tariff concessions to Australia, and these would increase Japan's inports from Australia. But considered alongside Japan's recent performance, in which over the period 1931-34 she had increased her exports to Australia by a factor of 3.5, a factor of 2.3 seems less than fantastic.

The Japanese presented a draft treaty, and each side tendered requests for concessions for specific items of importance to its trade. Because of the nature of Australia's exports there was not much of value that the Japanese could of fer in the way of tariff concessions. Their chief bargaining counter was their power to give or withhold assurances to continue their favourable treatment of their principal imports from Australia - wool and wheat.

Negotiations continued intermittently until, to the great surprise of the Japanese, the Australian minister in charge of the negotiations, Sir Henry Gullett, on 20 February 1936 informed the Consul-General (K. Murai) that unless imports from Japan of cotton and rayon cloth were reduced from the 1935 total of 152 million square yards to 75 million square yards the duties on these items would be raised to levels high enough to bring about such a reduction. ${ }^{3}$ In this Gullett was acting in response to strong representations by Lancashire which were supported by the

\footnotetext{
* Some reduction has been made in the length of the original article, a copy of which is available in Ms 3092 at the Australian National Library.

Except where indicated to the contrary, all references to Japanese Foreign Ministry archival material are to the file, B.2.0.0. J/B1, 'Nichi-Gó Tsūshò Jöyaku Kankei Ikken' [Tr, "Japan-Australia Commercial Treaty']. The original file appears to have been among the material destroyed by the Japanese in the interval between the Surrender and the arrival of the Occupation Force. The present file appears to have been reconstructed, from what relevant matcrial could be found scattered throughout other files. B.2.0.0. J/Bl is availabic in the Australian National Library's microfilm collection in the following reels: Vol. 1 , mfm G16i67; Vols. 2 and 3, mfm G16168; Vols. 4, 5, 6, mfm G16169; Vol. 7, mim 616170 .

Unless stated to the contrary the Japanese documents are cables from a series named 'Kaisho' [Tr. 'Negotiations'], which deall solely with the Japan-Australia tIeaty negotiations of 1934-1937. JFMA denotes Japanese Forcign Ministry Archives, FM denotes Foreign Minister. Example: 'Murai to FM 11/1 $4 / 2 / 35$ (Vol. 6)' refers to the cable, 'Kaisho'' No. 11/1 despatched by the Consul-General, Sydney (Murai) to the Foreign Minister on 4 February 1935, a copy of which is filed in B.2.0.0, 3/B1 Vol. 6 (available in reel G16\$69 in the Australian National Library's microfitn collection).
} 
British government. He hoped that as a quid pro quo the latter would continue to provide better access to the United Kingdom market for Australian primary produce (particularly meat) than the Ottawa Agreement required.

In reply, the Japanese denied that there was any need for restrictions on cottons but indicated a willingness to impose some controls on rayons that would stabilize rayon imports at about the level of the previous year.

The only response Gullett would make to this was to raise his total a fraction from 75 million square yards to 80 million.

The negotiations broke down and the Australian government on 22 May replaced the 25 per cent duty on cottons by specific duties equivalent to from 68 per cent to 85 per cent and the 40 per cent duty on rayons by specific duties equivalent to from 47 per cent to 182 per cent.

Japanese industry retaliated by completely boycotting the Australian wool sales and this boycott remained in force throughout the dispute. This retaliation became official on 25 June when the Japanese government applied an import licensing system to Australian wool, wheat and flour and imposed, in addition to the ordinary import duties, an added duty of 50 per cent ad valorem on Australian beef, butter, condensed milk, hides, beef-tallow and casein.

The Australian government, claiming that these retaliatory measures were unduly severe, on 8 July imposed a licensing system which prohibited the entry of items constituting about 40 per cent of Japan's exports to Australia.

On 20 July Gullett offered to raise the limit to 95 million square yards. ${ }^{7}$ On 2 September he offered to raise it to 100 million. Murai under instructions from his Foreign Ministry replied on 14 September that Japan was prepared to accept as the quota the level of her exports in 1935 (i.e. 152 million square yards) while reserving the right to impose quotas on her imports of Australian wool and wheat. Guliett replied the following day, informing Murai that his proposals had been placed before Cabinet, which had found them unacceptable. A further exchange of correspondence in which neither side gave any ground ended with a letter from Gullett to Murai on 1 October. To this Murai did not reply until 10 November, on which date he proposed a settlement on the basis of Australia's admitting 130 million square yards in return for Japan's admitting 400,000 bales of wool, this quota of 130 million square yards to rise at the rate of 2 million square yards for every additional 10,000 bales admitted by Japan up to a maximum of 150 million square yards per annum. ${ }^{3}$

What transpired in the interval between these two successive Japanese offers of 14 September and 10 November is the subject of this paper.

\section{The differing attitudes of Murai and the Japanese Foreign Ministry}

The policy of the Japanese Foreign Ministry was to stand firm on the figure of their 1935 exports and to leave unstated the extent to which they would undertake to import Australian wool.' Amongst the reasons underlying this was the hope that it would act as an incentive to the Australian wool industry to exert pressure on the Australian government. From the outset Murai had argued that such a strategy was mistaken. ${ }^{10}$ He considered that there was no chance of the Australians accepting the 1935 yardage. Secondly, he believed that Imperial sentiment was something widespread throughout the Australian community and feared that if Japan failed to present concrete proposals the government would use Parliament as an effective forum in which to appeal for popular support against Japanese intransigence.

On 15 September Murai reiterated his views in a long despatch in which he 
marshalled additional arguments. He pointed out that prices at the wool sales were remaining firm despite the Japanese boycott. Australians, he noted, tended to be of sanguine disposition: they were more likely to be pleased by the fact that wool prices were high than to reflect that they would be higher still if Japanese buyers returned. The Australian government would never return to the status quo ante as a basis of settlement. But even if it did, the Japanese government itself was no longer able to do so; for the Ministry of Trade and Industry's new policy for raw materials, which included expanded local production of staple fibre in order to reduce wool imports, would continue irrespective of any settlement of the present dispute. ${ }^{1}$ Although Gullett's proposals of 2 September were not acceptable, nevertheless, to the extent that they were calculated on the premise that the smaller yardage of Japanese textiles to be admitted would return approximately the same value as the previous year's, they could not be regarded as entirely unsatisfactory. Accordingly, the appropriate course was for Japan now to offer a guarantee to admit, say, 300,000 to 400,000 bales of wool annually, conditional on Gullett improving his offer of 2 September. Murai felt that, although it could be argued that such a settlement was too generous on Japan's part, it would involve sufficient loss for Australia to constitute an effective warning to other countries with a favourable trade balance with Japan not to embark on similar policies. ${ }^{2}$

This time Murai's arguments met with a more favourable response. On 16 October the Foreign Ministry informed him that although, in view of the unexpected smoothness with which the scheme to import wool from South Africa was operating, other ministries were maintaining a fairly firm attitude towards Australia, nevertheless the Foreign Ministry, in view of his despatch, was examining plans for a settlement. Hirodo, the manager of Kanematsu Ltd's Sydney branch, had cabled to his head office his opinion that if Japan undertook to admit 500,000 bales of wool annually the Australian graziers and Members of Parliament would secure a quota for Japanese textiles of 150 million square yards. Nishihara, the Australian correspondent of the Japanese daily newspaper, Hōchi Shimbun, had also cabled suggesting the possibility of a similar, though less favourable deal 500,000 bales: 120 million square yards. Murai was instructed to make informal soundings to find out more about any schemes of this kind and whether the Australian government was showing a strong interest in them. ${ }^{13}$

\section{Hirodo approaches Clunies-Ross}

Hirodo, as we have noted above, was manager of the Sydney branch of Kanematsu Ltd., the firm which handled most of Japan's wool purchases. In this capacity he and his family had resided in Australia, off and on, since 1910. From a file of personal correspondence between Dr lan Clunies-Ross and C.A.S. Hawker MHR, it appears that Hirodo's proposal of 500,000 bales of wool: 150 million square yards of textiles was the result of discussions between Hirodo and Clunies-Ross.

On 28 September Clunies-Ross wrote to Hawker, asking whether he would mind his putting before him a few suggestions made to him by 'an influential Japanese' in Sydney (identified later in the correspondence as Hirodo) 'at the end of a very adequate dinner when both his utterances and my perception may have been slightlys blurred'. " The terms for a settlement suggested were: (i) the reduction of the unfavourable trade balance to the ratio of about $1: 2.1 / 2$; (ii) the admission of 120 million yards of piece-goods at a low rate of duty in return for the admission of 350,000 bales of wool. Clunies-Ross ended his letter with the words: 'I did not know what use to make of this information but felt that you would be able to use your 
influence towards effecting acceptance of such terms if you approve of them."1s Hawker sent a reply two days later ( 30 September) and in it authorized Clunies-Ross to pass on its contents to his 'friend'. Before he posted it he read it, and CluniesRoss's letter, to Gullett. Though not unconciliatory, its response to each of Hirodo's points was negative and it attributed the present hitch in negotiations to Japan's preoccupation with more urgent matters.

Clunies-Ross wrote to Hawker on 8 October saying that he had discussed Hawker's reply with his 'friend', who had then suggested that a sliding quota (in which the admission of a larger quantity of wool would be met by the admission of a larger quantity of textiles) would be favourably received. Some such basis as the following might be acceptable: 300,000 bales/ I00 million yards $\rightarrow 400,000 / 120,000$ $\rightarrow 500,000 / 140,000$. Clunies-Ross indicated to Hawker that he personally had always favoured a settlement on such lines:

I have felt all along that such an agreement would not only adequately protect British interests assuring them of the retention of at least as great a part of the market as they now have, or even allowing considerable increase, but at the same time would ensure reasonable Japanese support for the Australian wool market.

The day after he received the Foreign Ministry's cable of 16 October instructing him to embark on informal soundings, Murai cabled his reply to Tokyo, as follows:

There are people among the local Japanese residents who consider the kind of plan that you mention a practical solution and who come to the consulate and informally make such proposals. Nevertheless it would appear that among the Australians there are none who are discussing such plans. I think it possible, however, that there are people connected with wool who have had such plans suggested to them by Japanese and who are thinking about them . . .16

This seems to be a fairly accurate appreciation of the situation. From the correspondence between Clunies-Ross and Hawker that we have quoted it appears likely that Hirodo thought up the figures, tried them on Clunies-Ross, and when he saw that the latter was favourably inclined towards them, selected out of the three pairs of figures the one with the largest yardage, added 10 million yards to it and suggested it to his head-office in Japan as a possible basis for negotiations.

Hawker replied to Clunies-Ross on 12 October. As before, his attitude to linked quotas was pretty negative; but he was not unconciliatory.

... As 1 see it, the sensible solution is for Australia to concede the highest possible quota of textiles at a reasonable tariff which is compatible with other trade etc. and let the Japanese adjust their wool purchases to their convenience... I gather from Japanese reports that our of fer has come up to 100 million yds. of textiles. I have no doubt it will be improved if the Japanese show any desire for real negotiation. . .

Clunies-Ross persisted. In reply to this letter, he wrote on 16 October:

I would be giad to know whether you consider, in the event of Japan submitting proposals for a sliding quota for wool and textiles more or less on the basis I suggested in my last letter to you, this would have any chance of acceptance by our Government . . .

\section{Murai directs Hirodo}

Up till now Hirodo may have been acting on his own initiative in his contacts with Clunies-Ross. It was, however, on 16 October that, as we have already observed, the Foreign Ministry cabled Murai instructions to make informal soundings to find out the Australian government's likely reactions to schemes linking a textiles quota to a wool quota. Thereafter we may assume that Hirodo was acting at Murai's behest. 
For on 24 October Murai cabled in reply that, believing it to be undesirable that he himself should be informally sounding out governmental attitudes behind Gullett's back, he had acquainted Hirodo with the situation; Hirodo was now working on it through Clunies-Ross, saying that he had received instructions from his head-office whom he believed to be privy to the thinking of the Japanese government on this question. 'In this cable Murai described Clunies-Ross as forthright, well disposed towards Japan and well regarded by the Australian government. ${ }^{7}$ We can add a few more brush strokes to this sketch.

\section{Dr Ian Clunies-Ross}

Dr Ian Clunies-Ross was at that time the head of the McMaster Animal Health Laboratory of the CSIR in Syoney. He was born in 1899. From his youth he appears to have been particularly interested in Asian history, culture and politics. By nature outgoing and convivial, he made many friends including a young Japanese writer, Isamatsu Kitakoji, then serving as a visiting lecturer under Professor A.L. Sadler in the Department of Oriental Studies at the University of Sydney. This led CluniesRoss in about 1925 to undertake as a hobby the study of the Japanese language and Japanese history. ${ }^{13}$ In 1927 he passed in Japanese I at the University as a part-time student. Unlike most people who studied Japanese at universities until quite recently, he seems actually to have been able to speak it.

In order to experience at first hand this country that so interested him CluniesRoss applied for and secured a visiting research fellowship at the Institute of Infectious Diseases at Tokyo University and spent nine months there in 1929-30.'9 As he was interested in such questions as security in the Pacific and Japan's trade and population problems he attended as a member of the Australian delegation the triennial Institute of Pacific Relations Conference which was held at Kyoto during his visit.

As he was much sought after as a public speaker, his views on Japan and the Pacific became well known in the years following his return to Australia. In 1933 he was called as a witness for the defence in a court case in which the proprietor of the Daily Telegraph claimed that he was being libelled by articles in Truth that alleged that the Telegraph's campaign on the subject of Australia's inadequate defences was merely a 'stunt' to increase sales. Examined by R. Windeyer K.C., Clunies-Ross was able to testify that he had come upon no evidence of hostile intent towards Australia during his stay in Japan. ${ }^{20}$

Early in 1935 Clunies-Ross wrote a paper, 'Factors Influencing the Development of Australian Trade with Japan', in a book, Australia and the Far East: Diplomatic and Trade Relations, that he edited for the Australian Institute of International Affairs. In this paper he made a careful analysis of the changes in Japan's population growth and living standards (both urban and rural) and noted a corresponding increase in the proportion of imports to local production in rural commodities of interest to Australia. He saw good prospects for increased imports of such commodities from Australia - provided Japan's exports of manufactured goods continued to expand. His conclusion was that the future prosperity of Australia will to an increasing extent be dependent on that of her great neighbour in the Far East'. ${ }^{21}$

Later in that year (1935), with the assistance of the Graziers Association of NSW, Clunies-Ross again visited Japan to conduct a quick survey of the sheep-raising industry throughout the Japanese empire. The trade dispute broke out shortly after his return to Australia. A letter that he wrote to the Department of External Affairs at that time (11 June 1936) contains a courteous offer to provide them with 
Information on 'the development of woollen substitutes in Japan and the possible replacement of wool for certain specific purposes by such substitutes'. The department's reply carefully ignored this offer. A month later (21 July) he was requested by Gullett to delete from the offtcial report on his survey, which CSIR was publishing, the sentence, "the influence of harmonious trade relations on the continued growth of Japanese demand cannot be ignored'. Clunies-Ross complied, but placed his views on record in a letter to the secretary of the CSIR (28 July):

... I would have liked to have said very much more than I did about the effect of their present policy on the future of our woollen industry, but had hoped I might be permitted this one mild reference to a policy which I consider the very essence of ineptitude. ${ }^{21}$

\section{C.A.S. Hawker, MHR}

Clunies-Ross's correspondent, Charles Hawker, who held the South Australian seat of Wakefield in the federal Parliament for the United Australia party, was one of the more distinguished characters in federal politics during this period. Born in 1894, he was at Cambridge when the Great War broke out. He enlisted immediately in the Somerset Light Infantry. As a platoon commander he lost an eye at Loos (September 1915) and was declared medically unfit for further service. On discharge from hospital he went back for a term to Cambridge but managed to secure his return to France in 1917. As a company commander at 3rd Ypres (October 1917) his spine was injured by a shell from the barrage that was supporting his attack, and he became paralysed from the waist down. He was many months in hospital. Sir Edwin McCarthy, who worked closely with him in the Department of Commerce in the early 1930 s, attributes Hawker's breadth of knowledge and his intellectual rigour in part to the diet of serious reading and deep thought that he imposed on himself during his long and painful periods in hospital. In this he sees a similarity to F.D. Roosevelt. ${ }^{23}$ In 1919 Hawker resumed his studies at Cambridge in a wheel-chair and topped the Seconds in the Historical Tripos. By the time he returned to Australia in 1920 he had taught himself to walk on two sticks. He entered Parliament in 1929 and in 1932 became Minister for Commerce, in which position he provided from Australia valuable administrative support for the Australian ministers (Bruce and Gullett) at the Ottawa conference. Within a year he resigned from the ministry. There appear to have been two reasons for this. The first was that the government had failed to reduce expenditure (particularly parliamentary salaries) to the extent of its electoral promises. The second was that his views on the tariff were closer to those of the Country party than to those of his fellow ministers, who in office were showing themselves much less enthusiastic about tariff reform than they had been in opposition. ${ }^{24}$ It was Hawker, and not a member of the Opposition, who described the tariff policy of the Lyons government as 'government by the feeble for the greedy'. ${ }^{25}$ From what I have seen of his speeches, articles ${ }^{26}$ and letters, I should say that he was one of the most capable, hard-working and well informed men in the Parliarnent. He seems to have possessed to a high degree the qualities of imagination, common-sense, forthrightness and firmness. Had he not met with an untimely death in the Kyeema air disaster in 1938, I think it likely that he would have made a very considerable contribution to Australian politics or diplomacy.

Before the emergence of the trade dispute Hawker had already made arrangements for a tour of the Far East. He left Darwin by air on 25 June, the day on which the Japanese imposed retaliatory duties and import licensing. He arrived at Kobe on 11 July and spent his nine days in Japan informing himself about the dispute by means of interviews with Japanese businessmen and of ficials and with the British Commercial Counsellor and the Australian Trade Commissioner and their staffs. ${ }^{27}$ 
He had become aware only a few days before he left Australia of the magnitude of the cuts in the imports of Japanese textiles that Gullett was demanding. In a letter to Gullett on 23 June he wrote:

The figures . . , seem to reveal that you have chosen weaker ground than I had previously understood upon which to begin a tussle even though it may have been inevitable sooner or later.

While there was still such a large alternative volume of British trade still growing (including many textile lines) it must have seemed to the Japs rather wanton on our part to have asked for a cut of over 50 per cent and approximately 40 per cent respectively in their two principal businesses.

Hawker believed, however, that the government's negotiating position must not be weakened by evidence of dissension on the Australian side. One can get some idea of the difficult position in which he found himself from the British embassy's record of his interview with its Commercial Counsellor (Sir George Sansom), on whom he called on 13 July:

Mr Hawker . . . stated that he had certain misgivings as to the present treatment of the issue between Australia and Japan. He felt that both sides had gone too far and that it was foolish in an attempt to adjust trade relations to get to a point where there was practically no trade at all. He was, he said, even inclined to doubt whether the steps taken by the Commonwealth Government to protect United Kingdom exports of textiles etc. against Japanese competition were really to the advantage of the United Kingdom . . . He himself, as a wool-grower, stood to lose by the Japanese embargo on wool, and from the strictly commercial point of view he wondered whether, on return to Australia, he ought not to work for a moderation of the Commonwealth Government's policy. But in the national interest and in the interest of Empire solidarity he was quite prepared to take the opposite line should it seem on balance desirable. ${ }^{20}$

What he saw and heard in Japan confirmed Hawker in his original belief that there must be no outward appearance of disunity on the Australian side. Writing to his colleague, Senator J. Duncan Hughes, at the end of his visit he said: 'A show down was quite inevitable sooner or later particularly as regards Australia's right to put British commercial interests ahead of any other country's. A row like the present simply could not have been avoided.' He also considered that Australia's counterretaliation was having a salutary effect on the Japanese and was causing them to be disabused of their belief that their country's position as a wool importer placed Australia at their mercy. Although Japanese exporters, wool-users and the better informed of ficials were now, according to his observations, anxious to settle, he considered it essential that Australia's counter-retaliation should continute until 'an influential section of wooden headed nationalists' actually saw Japanese ships running empty and raw materials becoming scarce. "How long the cooling off period need be is only possible to tell on the spot, but it might not need to be very long. However if not judged rightly a premature approach might easily prolong the dispute by encouraging the die-hards.'

His policy with the Japanese officials and businessmen that he met in the course of his visit was 'to give them as much of Harry [sc. GuIlett]'s point of view as I could conscientiously defend'. This was easier than he feared, because 'I met no Japanese who criticized Harry's argument as I could have done for them'."

... I explained with courtesy but with absolute conviction that it was not merely that our predominant interests were in trade with England, but that we are British and that there is not enough other trade in the worid to tempt us away from our family sentiment and duty. I assured them no settlement could be reached which failed to safeguard our own industries and our commercial relations with Great Britain. . ." 
Hawker's position is best summed up in the cable that he sent to Dalziel Kelly, president of the Australian Woolgrowers Council, from Peking on about 22 July.

... Suggest wool growers can help to expedite settlement best by refraining from public criticism or private pressure for premature Australian offer but making strong private representations that compromise on original quota figures be accepted when available.

Please inform Gullett.

To Duncan-Hughes he was a little more candid.

... whatever happens Australia must not climb down abjectly and we must not contribute to her defeat by defeatism. All the same I wotsid like to know how to shift Harry [sc. Gullett] without letting the country down. $\mathrm{He}$ is dangerous.

The following letter to Gullett, written by Hawker on 29 July during his homeward journey by sea, shows where he felt the dangers lay.

. . . Personally I was shocked when 1 read that the proposais made by Austraila, so far from leaving Japan as the dominant supplier of rayon goods as indicated in your speech to the House, asked Japan to accept a cut from $65 \mathrm{~m}$ yards to $30 \mathrm{~m}$ yards and an almost equally severe set back in cottons. I litterally (sic) can't conceive how they could possibly have accepted anything approximating such a proposal . . . However I presume you had a good deal of concession up your sleeve \& that their press disclosures, or something worse, precipitated a show down on premature grounds for our best showing. I find it hard to believe that you can have blundered as the mere published facts seem to indicate . . once the principle of sheltering our markets \& industries from irrational floods of price murdering goods is established there is a great deal to be said for keeping Japanese purchasing power as high as possible. The limit to their competition for our wool is not one of need but of ability to finance. The more we can aid their ability to finance their purchases of Australian goods, the more we can buy from Britain as well. Japan's active competition for our goods has been one of the biggest factors in enlarging our capacity to buy British imports and our own manufactured goods as well. So long as Lancashire is sheltered from further defeat (for sentimental reasons of great political force) the more we can take from Japan, the more we can spend elsewhere until Japan's appetite for our goods approaches saturation. That is nowhere near yet although our trade war has given their military a feeling of insecurity about raw materials too dependent on our supply only, the feeling should wear off.

\section{'Endeavouring by means of activity on the flank, to discover the Australian Government's real objectives'}

These are the words in which the confidential Annual Report of the Foreign Ministry's Commercial Bureau describes Murai's use of Hirodo.

As we noted on page 146, although Hirodo had begun discussions with CluniesRoss in September, it may not have been until 16 October that he came under Murai's direction in these activities. By then they had reached the stage where Hirodo had, through Clunies-Ross, asked Hawker a second time whether a sliding quota for wool and textiles would have any chance of acceptance by the Australian government.

In passing on this request, Clunies-Ross had added the additional piece of information that a close personal friend of his had two or three weeks previously been told by a minister that 'Cabinet itself doubted much of what the responsible Minister told them about the negotiations. . ."31

Before Hawker had time to reply, Clunies-Ross on 19 October sent him a telegram asking if he could see him in Canberra on the 20th or the 21 st. (Does the increase in tempo mean that Murai had now entered the operation?) Apparently the 
meeting took place, and as a result Hawker on the 21 st took Clunies-Ross to see R.G. Menzies, the Attorney-General. ${ }^{32}$ My guess is that either Menzies was the minister who had expressed his misgivings to Clunies-Ross's 'close personal friend' about Gullett's accounts of the negotiations and that, at his meeting with Hawker, Clunies-Ross had revealed this to him; or that Hawker, from his own knowledge, believed that Menzies shared his own anxieties about Gullett's diplomacy. The following extract from the diary of J.P. Moffat, the United States consul-general, indicates that Menzies did dislike this policy of Gullet's and that, at about this time, this fact was ascertainable on the Canberra grape-vine.

II \& 12 February 1937. . . Squire also picked up from Townsend, ${ }^{33}$ who was with Page and Menzies in London last year, the story of the trade diversion measures from that angle. He said that Menzies had disliked it from the beginning. . . ${ }^{34}$

Menzies was not entirely without an official locus standi regarding the dispute. He, together with Page (Commerce), Pearce (External Affairs) and Gullett, was a member of the committee of Cabinet appointed on 1 October to maintain liaison regarding the Japanese dispute with a Special Wool Advisory Committee (F. Young - President of the National Council of Wool-Selling Brokers, J.P. Abbott President of the Graziers Association of N.S.W., Dalziel Kelly - President of the Wool-Graziers Council, D.T. Boyd - President of the Federal Graziers Association). ${ }^{35}$ The members of the Advisory Committee were to hold discussions later that week with Gullett (23 October) and with Menzies (24 October). ${ }^{36}$

On 22 October, the day after his meeting with Menzies, Clunies-Ross saw Hirodo. Two days later Murai cabled the Foreign Ministry a progress report on how the operation was proceeding. Clunies-Ross must have discoursed with Hirodo in some detail about his meeting with Hawker and Menzies; for this is what Murai cabled:

Hirodo reports that Hawker is of the opinion that, once having made all this fuss, it would be absolutely impossible for the Australian Government in terms of its relations with the United Kingdom and its own prestige to accept last year's figures as the quota; on the basis of 500,000 bales of wool, Ross considers 140 million yards appropriate, Hawker - 130 million; Hawker said to Menzies that these figures should be accepted but Menzies, while disclosing a sympathetic attitude, was doubtful whether in the light of Gullett's stubbornness the Government could accept them; Menzies, however, had promised to discuss it with the Prime Minister and let them know the answer; his answer would be conveyed by Hawker to Clunies-Ross; Clunies-Ross thinks that the Australian Government will try and keep the piece-goods quota as small as possible even if this means some contraction in the quantity of wool."

On 24 October Clunies-Ross sent a telegram to Hawker saying that 'our friend' wished to know Hawker's personal opinion whether 140 million or 130 million might prove satisfactory, as he wished to submit proposals that week. On the 26th, at Melbourne, he met J.P. Abbott (president of the Graziers Association of NSW and a member of the Special Wool Advisory Committee) who had come to Melbourne to discuss with other members of the Advisory Committee their strategy for discussions with ministers in Canberra on the 27th. When Abbott told him that F. Young, another member of the Advisory Committee, was going to Canberra that night to discuss the removal of Gullett, Clunies-Ross put Abbott in the picture:

... I told him of my belief that Japan would accept $130,000,000$ yards and would take 300,000 bales in return and that I took it that you [Hawker] and Menzies would support such a settlement. I said further until such time as this offer was received and rejected that it would be far better to preserve harmonious relations with Sir Henry. ${ }^{31}$ 
In reply Abbott told Clunies-Ross that he would resign from the committee if 130 million yards $/ 500,000$ bales were offered by Japan and rejected. ${ }^{39}$

Although Clunies-Ross did not know it, Murai also was planning to bring Abbott into the negotiations. In that day's cable Murai had informed Tokyo that he had now asked Hirodo to give Abbott the same kind of briefing as that given to CluniesRoss and to request him to pursue similar informal enquiries. ${ }^{40}$ On 15 October Abbott had called on Murai and told him in strict confidence that the wool industry would give favourable consideration to Japanese wishes and would endeavour to bring about a speedy settlement, but that they could at present do nothing, insofar as the Australian government had told them that the negotiations were deadlocked because the Japanese government refused to reply to their proposals. "Hirodo's approach to Abbott, however, was to prove unavailing. On 29 October Murai had to report to Tokyo that Abbott regretted that, because he was known to be proJapanese, he was not in a position vigorously to engage in informal activities of this nature, but that if the Japanese promptly put forward a fair and proper counterproposal he would do his best to get the Australian government to make concessions. ${ }^{42}$

At Abbott's request Clunies-Ross also saw Young on the 26th and spoke to him in the same sense as to Abbott.

On 28th or 29th Hawker, after his 'enquiiies' in Canberra, and after 'casually mentioning the suggestions to Gullett', '" sent Clunies-Ross the following telegram:

140 appears impossible. Agree your anxiety about meat comparison reluctantly because otherwise difficult press for $130 .^{41} 120$ reasonably safe. Much resistance to any higher figure but my personal opinion that once gap becomes small additional five could be extracted. While present gap remains resistance is growing.

Murai passed on this information to Tokyo on 29 October. Murai added that, as regards the figure for wool, although he had received no definite report, CluniesRoss, Hawker and Abbott had indicated that they thought 500,000 bales a fair figure and he had no doubt that this had been conveyed to the government and the wool industry and that they were prepared to accept this figure. Murai considered that no further internal probing was possible and urged the Foreign Ministry to lose no time in presenting proposals. He continued that recently there had been a spate of reports from Japan that public opinion was weakening, that staple-fibre was proving unsuccessful, that Australian wool was regarded as essential and that the Japanese were prepared to accept a textile quota of 120 million yards. Such reports, he said, were causing a hardening in Australian attitudes. That this was not apparent in Hawker's negotiations was interpreted by Murai as indicating a conciliatory attitude. Murai therefore asked for instructions to negotiate on the basis of 400,000 bales for 130 million yards, increasing at the rate of 2 million yards for each additional 10,000 bales up to a maximum of 500,000 bales or 150 million yards, at the old rate of duty for cottons and at $3 \mathrm{~d}$. per yard for rayons. ${ }^{45}$ The cable authorizing him to do so was despatched on 9 November.

\section{Formal diplomacy and private diplomacy in tandem}

Apparently Hirodo continued to contact Clunies-Ross after Murai resumed formal negotiations with Gullett on 10 November.

On the 12th Clunies-Ross rang Hawker, as a result of which Hawker made 'some direct enquiries' the following day and informed Clunies-Ross that 'no hitch or deadlock has occurred but that there is a methodical series of offers and counter- 
offers which is slowly converging with the utmost good feeling . . ' Hawker advised patience. ${ }^{46}$

On the 13 th Gullett presented the Australian reply to the Japanese proposals. In this he indicated that Australia would not go beyond the figure of 110 million yards and that this was conditional on Japan's conceding more than the 'unduly low' figure of 400,000 bales. He refused to accept any sliding scale providing for additional quantities of piece-goods in return for additional quantities of wool. As regards the rates of duty, he adhered to his proposals of 2 September (1.3/4d. to $2.1 / 4 \mathrm{~d}$. per yard for cottons and $4 \mathrm{~d}$. per yard for rayons). Murai, under instructions, replied on the 18th, agreeing to abandon the concept of a sliding scale, refusing to go beyond 400,000 bales, and requiring in return a quota of 135 million yards. He gave a little ground on duties. ${ }^{4}$ According to the report cabled by Murai on the 21st at the end of the three days of formal negotiations that had ensued (19, 20 and 21 November), Gullett was considerably displeased:

. . Gullett said that it was not until we had proposed 130 million yards that he believed we were showing a conciliatory attitude (He had not regarded the escalator clause as serious). At great sacrifice he had conceded an increase of 10 million yards. Despite this we had now raised our demands to 135 million. If such was our attitude, the outlook for the talks must be bleak. He had discussed the matter with Cabinet and they had agreed with him." Possibly the Japanese Government on the basis of the observations and views of people like Abbott and Clunies-Ross thought that the Australian Government was bluffing. If so, this was a mistake. The Australian Government had increased the quota figure almost to an extreme degree and would not agree to any further increases.

But apparently alI was not gloom; for later in the cable this passage appears: 'Gullett said that if the Japanese Government, in a more conciliatory spirit, made concessions, he would give the matter further consideration; but that, while the Japanese Government adopted an attitude like the present, he could not accept any further increase in the quota.' Murai in this cable reminded the Foreign Ministry that time and the state of the wool market were against them. He suggested that they should make concessions, inform Gullett that these were their limit and undertake informal activities to cause the Australian wool industry to put pressure on the government to secure their acceptance."9

On 23rd Clunies-Ross wrote to Hawker. He had heard from Hirodo that the latest Japanese proposals were on the basis of 135 million yards which, Clunies-Ross commented, 'obviously they had no grounds for expecting would be acceptable'. At the moment Hirodo appeared to Clunies-Ross to be worrying about the rates of duty. Clunies-Ross hoped that if the Japanese were reasonable about the size of the quota the Australians would not be too hard in regard to the duties.

On 25th Clunies-Ross passed on to Hawker that Hirodo felt that in complaining that Japan was raising its prices, Gullett was quite unjustiffed. Hirodo sought to demonstrate that what Murai had proposed on 10 November was not 130 million but a figure somewhere in the range of 130-150 million. Gullett's response to this had been favourable and Murai had deduced from his behaviour that 120 million was the figure at which he was prepared to negotiate. 135 million was the mid-point between this and Murai's maximum of 150 million.

Clunies-Ross's letter continues:

. . . He tells me, and this is why I write to you particularly, that if we countered whatever proposals they make with a straight out offer of $125,000,000$ yds. this would be accepted immediately and so end the whole tedious business. I thought I should let you know this in case you could take some action to have such a proposal made. Hirodo thinks, as do I also, that such an offer is reasonable and that even if Sir Henry has a maximum of $120,000,000$ in mind it might be possible to secure the extra $5,000,000$ without much difficulty. 
Hirodo says public opinion in Japan has been prepared for acceptance of $125,000,000$ but that they will definitely stick at that even at the risk of considerable further delay. .

The gist of Hawker's reply is that things were about as bad as Hirodo described them.

... all I can comment is that the position has become more difficult here. There have been a number of bitter jibes and tirades which have sharpened tempers and hardened those inclined to boggle at concession... While acrimonious discussion continues bere the prospects of generous compromise can only be precarious. .

Murai's instructions were despatched to him by urgent cable at $4 \mathrm{p} . \mathrm{m}$. on the 25th. Ungraciously and, as 1 see it, without justification, the Foreign Ministry informed him that, in the light of his appreciations of the situation as expressed in his cables, it could not but feel surprise at Gullett's capricious rejection of their proposals outright. It instructed him to negotiate on the basis of 120-125 million yards or as close to this as possible. There would be fairly strong opposition from other ministries, but if a settlement could be secured with Gullett along these lines the Foreign Ministry would try and force it through. As the other ministries had not been consulted, Murai must give Gullett the impression that he was acting on his own initiative without instructions. ${ }^{50}$

There is no indication that Clunies-Ross and Hawker were in any way involved in the next stage of the negotiations. In conformity with his instructions that he must appear to be acting without instructions, Murai proposed that his subordinate, Nihrō, and Gullett's subordinate, A.C. Moore, should confer, confining themselves solely to the piece-goods quota and piece-goods duties, with the object of proposing a formula, without commitment to either party. On 3 December agreement was reached at $1221 / 2$ million yards. ${ }^{51}$

Thus encouraged, the negotiations returned to the question of wool. On 4 December Gullett proposed that since the quantity agreed to for piece-goods was roughly equal to the quantity imported in 1934 , the wool quota, too, should be the amount imported during that year, i.e. 514,000 bales." ${ }^{52}$ As a result Hirodo was called into action again. On the 6th Clunies-Ross was writing to Hawker:

.. Hirodo when I asked him what had happened told me that the last and final thing to
impede a settlement was that having settied the quota and the duties Gullett has insisted on
them agreeing to buy 500,000 bales. I do not know whether the latter was aware that they
had reopened negotiations on the understanding that a basis of approximately $125,000,000$
yards against 400,000 bales would be acceptabie but I feel that I have been placed in a false
position and that the Japanese have grounds for feeling aggrieved. .
. . Hirodo has now cabled proposals for disguising the acceptance of 500,000 bales
against 122 million yards, namely that for the last six months of this selling season they
should take the full 500,000 or a total of 750,000 , thus making it possible to publish in
Japan a quota over the two years of about 400,000 bales [D.C.S.S. - This was possible
because the wool year goes from July to June and Japan, because of the boycott, had
bought no wool between July and December 1936 . Thus Japan's face was saved if the
period covered by the quota of 750,000 bales was said to be the two-year period extending
from July 1936 to June 1938 ].

When he received this letter, Hawker was ill and out of Canberra. He took no action on it. The final settlement signed on 26 December was not greatly different from what Clunies-Ross in the letter quoted above described as Hirodo's proposal. The period covered by the agreement was to 30 June 1938. The wool quota was 800,000 bales, but the documents were so drawn up as to avoid any mention of when the period to which the wool quota applied commenced."s 
The correspondence between Clunies-Ross and Hawker closed on 12 January with Hawker's reply:

... I quite agree that it all appeared very unreasonable. I do not know where the final urge came from for the stipulation of high minimum purchases of wools. . .

As you may gather I pooh-pooh-ed the idea of such a point being allowed to create a deadlock. However, I can quite see how if any member of that [Sc. Special Wool Advisory] Committee took the point it would frighten our Government into standing for it. . .

I am extremely sorry if I misled you in any way and thereby caused you to mislead any of your Japanese friends. Misunderstanding is a very serious danger whenever messages go from individual to individual through a long chain. It was one of the risks that we had to face. I know if any of my colleagues had asked my advice as to whether they should fetch and carry messages in the way [you and I did] ] $^{34}$ would have advised them that it was a foolish and dangerous thing to do. Nevertheless, I think it was the right thing to take the risk and on the whole we were lucky there were no further misunderstandings.

It certainly speaks very highly indeed for the frankness and integrity of your Japanese friends.

\section{Conclusions}

I think that I shouId go along with Hawker in his overall conclusion - the Japanese, Hawker and Clunies-Ross acted properly and their joint activities contributed usefully towards the settlement. Hawker's estimate of 120 million yards (see page 152) was pretty close to the mark. His contribution would have been even more helpful in achieving a more expeditious settlement if the Foreign Ministry had acted on his and Murai's advice instead of raising its price to 135 million on 18 November.

In the case of Murai, it was his duty to find out by al! legitimate means the figure at which he should negotiate, and by all legitimate means mobilize politically powerful elements in the Australian community who might be able to give him support. Reference to the Minutes of the Cabinet Meeting held at $2 \mathrm{p} . \mathrm{m}$. on 1 October indicate how successful he was in this.

It was decided . . . that the graziers representatives should be told that the Government would not stick at 5,10 or even 15 mittion yards more on the quota from Japan.

Mention was made that imports for the three years 1933-34-35 of cotton and rayon was [sic] 76,117 and 153 million yards, making an average of 115 million. It was felt by those present that this figure should be the utmost limit to which the Government should go. ${ }^{\text {ss }}$

At this stage the most that Murai had been able to get out of Gullett had been 100 million yards. He eventually managed to get, not Cabinet's 'utmost timit' of 115 million, but $1221 / 2$ million.

As regards Hawker, it seems to me perfectly proper that a ministerialist backbencher who considered that the responsible minister was conducting negotiations unskilfully should bring this and any information that he might have about the negotiations to the attention of other ministers. It might be argued that Hawker helped Murai to discover chinks in the facade of cabinet unity and that in so doing he acted contrary to the principles that he himself had enunciated. In June when Japan retaliated Hawker stressed the importance of the appearance of unity: in October he participated in an enterprise which revealed to the Japanese that Cabinet was likely to settle for a figure lower than the figure Gullett was demanding. This argument is, I think, fairly easily disposed of. The display of national unity had served its purpose and brought Japan to the negotiating table - now was the time for substantial concessions, which Gullett was not providing. ${ }^{56}$

I have not encountered a diplomatic dispute in which an Australian or British 
government claimed to the extent that Gullett and Lyons claimed in the present case that the citizen who regards the policy of his government as mistaken has a duty to be silent until the dispute has been settled. On 17 July Lyons asked representatives of the wool industry to refrain from taking any action that could embarrass the ministry in its negotiations with Japan; ${ }^{57}$ and in Parliament on 25 November he readily admitted that he had appealed 'not only to Honourable Members but also to other citizens and representatives of any industries concerned to maintain silence on the issue so that the Government might be enabled to carry on its negotiations and bring them to a conclusion in the interests of Australia and the Empire'. ss Similarly Gullett on the same day, after a speech in which a ministerialist back-bencher, P.A.M. (later Sir Philip) McBride, had criticized his policy, interjected:

The policy of settlement is about $10 \%$ of what it was yesterday. I say that deliberately because of the efforts of our alleged friends in the House. ${ }^{\text {"9 }}$

We have seen that Gullett apparently did not object to Murai communicating with him by the route Hirodo-Clunies-Ross-Hawker (see pages 144, 151). He may have felt that this gave him additional information about Murai's objectives; and he gave away nothing in return. Had he known that some of the information from Murai had reached Menzies and the prime minister over his head, ${ }^{60}$ and that Murai in the course of these exchanges had become aware that Menzies's attitude was less rigid than his own, then he would probably have reacted strongly. When, less than three months later, Cabinet became divided over the extent to which the trade diversion policy should be pushed against Canada, he is said to have become very annoyed indeed when he found out that another minister (Thorby) had discussed the negotiations with the leader of the Canadian delegation behind his back.

Finally I should like briefly to consider whether these negotiations cast any light on the question of distinctive national diplomatic styles.

The use of unofficial channels superimposed upon the formal channels during negotiations is of course by no means unknown in international relations. A good example is the Soviets' transmission of their proposals to the United States for the solution of the Cuban missiles crisis through Fomin (the senior Soviet intelligence officer in the United States) and John Scali (an American journalist) at the same time as cables were passing between Khrushchev and Kennedy. In his treatment of this issue Roger Hilsman notes that the Soviets not infrequently use unofficial channels - particularly to try out a proposal or test a reaction in advance to avoid committing themselves prematurely. ${ }^{61}$ These certainly figure among the reasons underlying Murai's use of Hirodo.

More important, however, in the case that we are studying is the objective - to discover and mobilize opposition to Gulfett and thereby make him concede more than he wished. This I should like to follow a little further.

In 1977 Dr Michael Blaker published a very interesting paper entitled 'Probe, Push and Panic: The Japanese Tactical Style in International Negotiations'. ${ }^{22}$ In this the illustrations that he used ranged from about the time of the attempts in the $1880 \mathrm{~s}$ to revise the unequal Ansei treaties down to the negotiations with the Nixon Admin. istration in 1970 over the admission of Japanese textiles. Among the examples that Blaker gives, one of the characteristics of Japanese diplomacy that seems to emerge is a willingness to make extensive efforts to plumb the dimensions of the other side's position in advance, so that negotiations can be directed on a fairly narrow front where there are good prospects of success.

In this sense, can the probing carried out through Hirodo be described as characteristically Japanese? This can be answered only by someone with greater knowledge 
of diplomacy by non-Japanese than I have. To me, however, it does not seem much different from the probing that Longfield Lloyd was carrying out in Tokyo in the course of his duties there as Australian Trade Commissioner. The Foreign Ministry refers to these in a cable sent to Murai on 7 December at the time Gullett had disconcerted them by demanding a wool quota of 514,000 bales:

... On the question of the increase demanded in the size of the wool quota, it appears that Moore has cabled Lloyd to probe our intentions by unofficial means. He has been testing the ground among the Japan-Australia Society; but they and otter people concerned have, we are informed, firmly rejected his approaches and have consistently informed him that they are not in a position to express any opinions on the Australian-Japanese negotiations. From the fact that he is making these enquiries we infer that the Australians are somewhat ill at ease regarding our feelings in this matter. . ${ }^{\text {b3 }}$

I should, perhaps, point out that the Japan-Australia Society, though it included among its principal objectives the fostering of good will, was not so much a social group (iike our English Speaking Union or Royal Commonwealth Society) as an organization of businessmen with Australian interests. This piece of information in the Foreign Ministry's cable is useful; for there are gaps in the file of cables to and from Lloyd." Moreover Lloyd (whose previous experience was with the Security Service) where possible avoided using names - even in ciphered cables. Probably Lloyd's activities in this direction were the result of Moore's cable of 28 November which ends: 'Minister considers you should make best endeavour with eminent quarters mentioned in your cable 19 th November to use their influence to obtain Japanese Government's endorsement Nihro proposal'. From the Foreign Ministry's cable that we have quoted, it seems likely that these 'eminent quarters' included the president of the Japan-Australia Society, Baron Sakatani, who was a member of the House of Peers. Lloyd repiled on 1 December that he had done so "and was given a reaction of most encouraging nature, immediately following which the said quarters suitably urged the Foreign Office'. This is not without its humorous side. It will be remembered that Nihrō was instructed by the Foreign Ministry to secure agreement at as close as possible to $120-125$ million yards and to say that this was his private proposal and that he was acting without instructions (see page 154). Lloyd now goes to Sakatani and gets him and his fellow members of the Japan-Australia Society to urge the Foreign Ministry to support its own proposals! Next, when Gullett had included sub-quotas for different varieties of textiles in the terms of settlement, Moore cabled on 2 December: 'any help you can obtain from sectional interests with which you are in touch' would be appreciated. Then on 3 December, when Moore was holding out for 514,000 bales (the 1934 figure) and Murai was holding out for 400,000 , Moore cabled: 'Would greatly appreciate your best endeavours with the friendly sections with which you are in touch to support 1934 figure with Japanese Government'.

Admittedly, Lloyd appears to have picked up less of value from his contacts in 'eminent quarters' than did Murai from Hawker; but there is no indication that this was through lack of trying.

\section{NOTES}

1. Murai to FM $11 / 14 / 2 / 35$ (vol. 6)

2. At the then rate of approx. $¥ \mathrm{I}=\mathrm{A} 1 / \mathrm{S} / 2 \mathrm{~d}$ this would be about $\mathrm{fA} 3.64$ milion.

3. Ōkurashō, Bōeki Nempō.

4. Ibid.

5. Tsūshōkyoku Shirstumu Hökoku 1936 [Tr. 'Confidential Report of the Commercial Bureav of the Japanese Ministry of Foreign Affairs for the Year 1936'1, 718-19, Item SP341 Reel 168 in the US 
Library of Congress microfilm edition of Archives in the Japanese Minisfry of Foreign Affairs 1868-1945 (Australian National Library microfilm G5993).

6. See my 'Manchester v. Japan: The Imperial Background of the Australian Trade Diversion Dispute with Japan, 1936', Australian Outlook, vol. 30 (December 1936), 480-502.

7. Gullett to Hawker, 12 August 1936 (Australian National Library, Ms 4848, C.A.S. Hawker Papers. from which alt the communications to and from Hawker cited in this article have been taken).

8. JFMA, B.2.0.0. J/B1 (vol. 4).

9. FM to Murai 79 and $8031 / 8 / 36,858 / 9 / 36,8611 / 9 / 36$ (vol. 3).

10. Murai to FM 20S/1 15/8/36 (vol. 6), 229 and 2303 and $4 / 9 / 36$ (vol. 4).

11. Murai, under instructions, had warned Gullett of this possibility on 9 July (FM to Murai $717 / 7 / 36$ vol. 3). Later, on 7 September the Foreign Ministry had cabled to Murai that this policy had been adopted (FM to Murai $847 / 9 / 36$ vol. 3 ).

12. Murai to FM Despatch $38015 / 9 / 36$ (vol. 4).

Murai to FM $24116 / 9 / 36$ (vol. 6).

13. FM to Murai $8816 / 10 / 36$ (vol. 3).

14. Clunies-Ross to Hawker $16 / 10 / 36$.

15. Clunies-Ross to Hawker $28 / 9 / 36$.

16. Murai to FM $26817 / 10 / 36$ (vol. 6).

17. Murai to FM 272 $24 / 10 / 36$ (vol. 4).

18. Information kindly provided by Lady Clunies-Ross, to whom I am also indebted for giving me access to fanily letters written by Sir lan during his visits to Japan.

19. He kept a diary of the visit, which he hoped to publish. A few sections of the manuscript survive among his papers. They indicate that he was a perceptive and sympathetic observer with the gift of ready communication and that the Australian reading public was the loser from his inability to find a publisher.

20. Archives Authority of NSW, 6/1658 - Stenographic Record in Causes 1933, Denison v. Truth and Sportsman, 249-253.

21. 1. Clunies-Ross (ed.), Australia and the Far East: Diplomatic and Trade Relations (Sydney, 1935), $153-201$, at 185 .

The second part of his paper is a most detailed and perceptive treatment of the appropriate rote of Japanese studies in the Australian education system. Some of the reforms that he then considered urgent appear, now, forty-five years later, to be at last on the verge of implementation.

22. CSIRO Archives, File G16: 'Visit to Japan by Dr I.C. Clunies-Ross to Survey the Japanese Sheep Raising Experiment'. I am grateful to Mrs Mariory O'Dea for bringing this to nny attention and to the Secretary (Administration), CSIRO for granting me access to it.

23. Interviewed $28 / 1 / 75$.

24. The principal source of my information about Hawker is L. Needham, Charles Hawker: Soldier, Pastoralist, Statesman (Adelaide, 1969).

25. Austratia, Parliamentary Debates, vol. 138, 161-167, 10/3/33.

26. C.A.S. Hawker, 'The Japan-Australia Trade Dispute', Australia Asiatic Bulletin, April 1937. id., 'Australia's Foreign Trade Treaties', British Commonwedth Relations Conference 1938, Australian Supplementary Papers, series B, no. 3.

27. Hawker to Duncan-Hughes, $19 / 7 / 36$.

28. British Embassy, Tokyo to Foreign Secretary, Despatch No. $401 \mathrm{E}$ of $17 / 7 / 36$ - Foreign Office F4773/119/23 (Public Record Office, London).

29. Hawker to Duncan-Hughes $19 / 7 / 36$.

30. Hawker to Gullet1 20/7/36.

31. Clunies-Ross to Hawker $16 / 10 / 36$.

32. Clunies-Ross to Hawker $22 / 10 / 36$.

33. Presumably A.R. Townsend, Department of Trade and Custons who according to Commonwealth of Australia, Parliamentary Debates, vol. 151, 186 (16/9/36), accompanied Page on his overseas tour with Menzies.

34. J.P. Moffat, 'Diary' (September 1935-March 1937) (unpublished), 736. The diary is available in the Australian National Library's microfilm collection as mfm GT251.

35. Sydney Morning Heratd, 2/10/36.

36. Sydney Morning Herald, 26/10/36.

37. Murai 10 FM $27224 / 10 / 36$ (vol. 4).

38. Clunies-Ross to Hawker $26 / 10 / 36$.

39. Clunies-Ross to Hawker 29/10/36 (telegram).

40. Murai to FM $27326 / 10 / 36$ (vol. 6).

41. Murai to FM $26615 / 10 / 36$ (vol. 6).

42. Murai to FM $27929 / 10 / 36$ (vol. 6).

43. Hawker to Clunies-Ross $3 / 11 / 36$. 
44. Using the increased duties on Japanese textiles as a bargaining counter, Australia bad won a $15 \%$ inctease in her meat exports to the United Kingdom. Hawker had suggested using this to argue that a Japanese textiles quota of $15 \%$ less than the 1935 figure was appropriate, i.e. $85 \%$ of $152=129$ or, in round figures, 130 (mitlion yds.). Clunies-Ross feared that such an approach might make the textiles quota vulnerable if subsequent concessions were gained on meat (Clunies-Ross to Hawker $22 / 10 / 36)$.

45. Murai to FM $27929 / 10 / 36$ (vol. 6),

46. Hawker to Clunies-Ross $13 / 11 / 36$.

47. Texis in JFMA B.2.0.0. $\mathrm{J} / \mathrm{Bl}$ vol, 4.

48. There appears to be no reference in the Cabinet Minutes to any discussion of this subject in the interval 5-24 Novernber (Australian Archives, Canberra Office, AA1975/246).

49. Murai to FM 291 and $29221 / 11 / 36$ (vol. 6).

50. FM to Murai $9625 / 11 / 36$ (vol. 3).

51. JFMA: B.2.0.0. J/Bl vol. 4: Memorandum dated 3/12/36 initialled by $\mathrm{K}$. M[urai] and A.C. M.[oore]. The formula mentioned in this document is $102 \mathrm{l} / 2$ million yards plus unrestricted entry for bag-making calico. As the agreed estimate for the latter was 20 million yards, 1 have, as elsewhere, for simplification combined the two.

52. Tsūshōokyoku Shitsumu Hókoku 1936, 723.

53. Murai to Gullett 26/12/36. (Australian Archives A981, item Trade 68 part 2.)

54. In the first draft of the letter, in place of these words were the words ' 1 do'.

55. Australian Archives, Canberra Office, AA 1975/246.

56. There was perhaps some inconsistency when on 26 November he expressed his former attitude and exhorted other Members of Parliament to follow his example (Austratia, Parliamentary Debates, vol. 152, 2399).

57. Sydney Morning Herald, 18/7/36.

58. Australia, Parliamentary Debates, vol. 152, 2269. See also ibid., $2397(26 / 11 / 36)$.

59. Ibid,, 2330. McBride and Hawker were friends and appear to have held similar views on the trade dispute throughout (Hawker to Duncan Hughes 23/6/36). Both tad absented themselves from Party meetings, fearing that if they criticized Gullett's policy it might leak to the press and that if they were silent they would be committed to support him (Hawker to Gullett $28 / 12 / 36$ ).

60. A passage in Hawker's letter to Clunies-Ross of 3 November suggests that Menzies tried to bring Gullett into the picture immediately and had been restrained only by Clanies-Ross's insistence that his information was confidential.

61. R. Hilsman, To Move a Nation (New York, 1967), 216, 219. I am grateful to Dr C. Holbraad for bringing this to my attention.

62. R.A. Scalapino (ed.), The Foreign Policy of Modern Japan (Berkeley, 1977), 55-101.

63. FM to Murai $1007 / 12 / 36$ (vol. 3).

64. Australian Archives, A601, item $402 / 17 / 27$. 
Private diplomacy in the 1936 trade dispute with Japan 


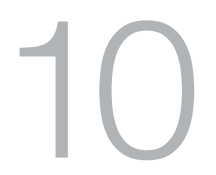

\title{
Manchester v. Japan: The imperial background of the Australian trade diversion dispute with Japan, 1936
}

\author{
In Australian Outlook, \\ Vol. 30, No. 3, pp. 480-502, 1976. \\ Taylor \& Francis Ltd, www.tandfonline.com \\ reprinted by permission of the publisher.
}

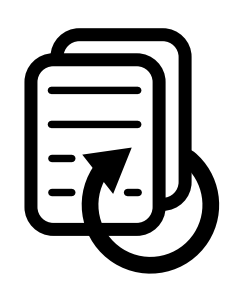




\title{
MANCHESTER v. JAPAN: THE IMPERIAL BACKGROUND OF THE AUSTRALIAN TRADE DIVERSION DISPUTE WITH JAPAN, 1936
}

\author{
D.C.S. SISSONS*
}

On arriving in Australia, the Mission was immediately impressed with the intense loyalty, not only expressed by the people they were privileged to meet, but sincerely felt everywhere. The Mission also found a strong sentiment in favour of trading with the United Kingdom rather than allowing foreign countries to obtain too large a hold of the Australian market. (Report of the Manchester Mission to Australia, 1936)

Future historians may well see the signing of the Basic Treaty of Friendship and Cooperation last June as part of a long process that began in 1894. In that yeat the Japanese Government sought, unsuccessfully, to induce the Australasian Colonies to join the Anglo-Japanese Treaty of Commerce and Navigation of that year. Strong attempts were made by Japan from 1915 to 1917 and in 1924 and 1926 to induce Australia to join the successor to that treaty, signed in 1911 .

Late in 1934, the Lyons Government eventually acceded to the Japanese request to discuss the possibility of a Treaty of Friendship, Commerce and Navigation. The Japanese presented a draft treaty and each side tendered requests for tariff reductions on specific items of importance to its trade. On the basis of these, negotiations continued intermittently until, to the great surprise of the Japanese, the Australian Minister in charge of the negotiations, Sir Henry Gullett, on 20 February 1936, informed the Consul-General (Kuramatsu Murai) that unless imports from Japan of cotton and rayon cloth were reduced substantially to levels satisfactory to the Australian Government the duties on these items would be raised to levels high enough to bring about such reductions. The Japanese denied that there was any need for restrictions on cottons but indicated a willingness to impose some controls on rayons. ${ }^{1}$ This reply was unacceptable to the Australian Government, which, on May 22nd, replaced the 25 percent ad. val.

\footnotetext{
University.

* Fellow in the Department of Intemational Relations, Australian National

1 Tsushokyoku Shitsumu Hokoku 1936 [Tr. 'Confidential Report of the Commercial Bureau of the Japanese Ministry of Foreign Affairs for the Year [936'], p. 717 .

There is a copy of this report in Item SP34I Reel 168 in the US Library of Congress microfilm edition of Archives in the Japanese Ministry of Foreign Affairs $1868-1945$ available in the Australjan National Library.
} 


\section{MANCHESTER $\vee$ JAPAN}

duty on cottons by specific duties equivalent to from 68 percent to 85 percent ad. val. and the 40 percent ad. val. duty on rayons by specific duties equivalent to from 47 percent to 182 percent ad. val. Japanese industry retaliated by completely boycotting the Australian wool sales and this boycott remained in force throughout the dispute. Japanese retaliation became official on June 25 th when the Japanese Government applied an import licensing system to Australian wool, wheat and flour and imposed, in addition to the ordinary import duties, an added duty of 50 percent ad. val. on Australian beef, butter, condensed milk, hides, beef-tallow and casein. The Australian Government, claiming that these retaliatory measures were unduly severe, on July 8 th imposed a licensing system which prohibited the entry of items constituting about 40 percent of Japan's exports to Australia. ${ }^{2}$

For many of us whose schooldays spanned the period from about 1934 down to, say, the sinking of the Bartolomeo Colleoni or the fall of Benghazi, Imperial sentiment was an ubiquitous and pleasurable influence. It was constantly with one in the class-room in such fare as the works of Henry Newbolt; it was with one outside school hours in the Cubs and Scouts and in the pages of the Boys Own Paper. And even in peace time the pageantry of Imperial sentiment often expressed itself in the symbols of Imperial defence - e.g. the presence of H.M.S. Sussex at the Centenary celebrations and Australian troops on sentry duty at Buckingham Palace during the 1937 Coronation. It was perhaps because of such early influences that, when I first came to study this dispute with Japan, I found myself with a preconception that its underlying rationale might be something like the following: Threatened by a powerful Japan alien to us in race and in values - a Japan that had only recently indicated in Manchuria its thirst for territorial aggrandisement - our only hope of survival lay in the military support of our fellow citizens in the United Kingdom. Was it brotherly, was it fair, was it reasonable to expect Britain to come to our defence if we helped to put Lancashire out of business by spurning the output of its mills in favour of the cheaper Japanese product. Before long, however, I discovered that, although arguments of this nature were occasionally put forward ${ }^{3}$ (and may have influenced some people to support Gullett's policy of 'Trade Diversion' after its announcement), the role played by defence in the formulation of that policy was almost negligible. The possible ramifications that his policy might have for Australia's defence seem to have occurred to Gullett in the uncomfortable hours of foreboding that so often follow the making of big decisions,

2 Department of Trade and Customs: $37 / 985$ 'Summary Showing the Value of Japanese Trade with Australia which is affected as a result of the Import Prohibitions...' [Australian Archives A425].

3 See for example the statement by the Austratian Association of British Manufacturers in the Argus (Melbourne), 20/3/36. 


\section{D.C.S. SISSONS}

and his feelings were that his policy would decrease rather than increase our military security. The following is the British High Commissioner's report to the Dominions' Secretary on a meeting with Gullett on April 24th, four days after Cabinet had agreed in principle to Gullett's proposals to raise the duties on foreign textiles:

Sir Henry Gullett went on to say that he was definitely apprehensive that these proposals would lead eventually to trouble between Japan and Australia, and he expounded at some length his views as to the indefensibility of Australia against Japanese attack. A couple of destroyers outside Sydney Harbour might easily cause something like an evacuation of Sydney, and no help could be expected from the rest of the Empire until a grave humiliation had been imposed on Australia.

The High Commissioner did not take these fears very seriously. His report continues:

You are aware, Sir, that Sir Henry Gullett is inclined at times to take extreme views on subjects with which, perhaps, he is not fully acquainted, and I have not gathered from such conversations as I have had from time to time with his colfeagues, that his opinion as to the imminence and probable results of warlike action by Japan are widely shared in the Cabinet. ${ }^{4}$

We now know that Japan's involvement in Manchuria had, in fact, produced feelings of relief rather than of alarm in the minds of the Lyons cabinet. Like Alfred Deakin at the outoreak of the Russo-Japanese War thirty years earlier, ${ }^{s}$ they appear to have welcomed Japan's expansion on the Asian mainland as likely to draw her energies away from the South Pacific. In the course of the goodwill mission to Australia by Katsuji Debuchi (formerly Japanese Ambassador to Washington and Permanent Under-Secretary for Foreign Affairs), two Australian Ministers, Pearce (External Affairs) and Hughes (Health), volunteered to him assurances that, so far as Australia was concerned, Japan had carte blanche in Manchuria. ${ }^{6}$

Claims that the policy weakened Australia's security, expressed in rather more sophisticated terms than were Gullett's remarks to the High Commissioner, formed part of the attack by its critics. Take, for example, Norman Cowper in the series of broadcasts over $2 \mathrm{GZ}$ during October (1936) in which he attacked the policy:

4 Great Britain, Foreign Office, F3097/119/23 [Public Record Office, London]. The author would like to acknowledge the assistance of Mrs N. M. Budd (470 Kings Road. London, S.W.10) in finding and copying all Public Record Office material used in the preparation of this paper.

5 Sydney Morning Herald, 6/1/04.

6 References to discussions with Pearce (4 September 1935) and Hughes (5 September 1935) in Dubuchi's confidential report on his mission. Japanese Ministry of Foreign Affairs file: L3.3.0.14 [Australian National Library]. 


\section{MANCHESTER v. JAPAN}

... at the very moment when it is becoming clear that the British Fleet can no longer be relied upon to defend Australia, and when Britain is preoccupied with recurring crises in Europe, at that very moment we are rushed into provocative action against Japan action which will tend to make her desperate. Is that in the interests of Australia? Or of Britain? ${ }^{\text {? }}$

The extent to which such fears were felt does not appear to have been inconsiderable. There is unconscious irony in Gullett's comment to the ministerialist M.H.R., Charles Hawker: 'The row has had two or three extraordinary good effects. It has brought defence to the fore into its proper place ...' [Emphasis added D.C.S.S. ${ }^{8}$

From the very outset of the dispute the Australian Government and its officials readily admitted that the purpose of their action against Japanese textiles was to protect the position of United Kingdom textiles in the Australian market. It was an extension of Australia's traditional trade policy, accurately described by Sir John Latham, with characteristic forthrightness, in a broadcast to the Japarese people during his goodwill mission there in 1934:

... in Australia we protect our own industries. As a part of the British Empire we then naturally and properly consider the interests of the British Empire and its various parts. We are then prepared to make trade arrangements with the countries which trade generously with ourselves. ${ }^{9}$

The action against the Japanese textiles, however, gave the British product a much higher margin of tariff protection than the 15 percent for cottons and the 17\% percent for rayons required by the Ottawa Agreement 10 - margins that had been fixed after much hard bargaining. Guliett expiained the underlying reason for this grant of additional benefits to the United Kingdom exporter to Murai on February 20 th $^{11}$ and to Parliament on May 22nd:

[The Government] has reluctantly come to the conclusion, based solely upon the necessity to grant protection to British industry,

7 This point was developed a little furthet in a pamphlet, is It Necessary?; An Examination of the Commonwealth Government's Trade Diversion Policy, (Sydney, 2\} August 1936), written by Edward Masey who later achieved fame as a member of the Australia First Movement. Ward, the Labor M.H.R, appears to have made use of Masey's pamphlet for the argtiments used in his speech in Parliament on November 26th. (Commonwealth Parliamenary Debates, Vol. i52, p.2405).

8 Letter from Gullett to Hawker $12 / 8 / 36$ (Hawker Papers -.. Australian National Library).

9 Quoted by J. A. Lyons in a nation-wide broadcast on 25/8/36. The script of Lyons' broadcast is available in Australian Archives A98 $\mathrm{I}$ Trade 58 Part 2

to 'Imperial Economic Conference, Ottawa, 1932 - Report', Commonwealth of Australia, Parliamentary Papers, 1932-34, Vol. 4, pp. 1043-50.

11 Tsushokyoku Shitsumu Hokoku 1936, p.717. 


\section{D.C.S. SISSONS}

and our complete reliance on the market of the United Kingdom for the absorption of our exportable surplus of all difficult-selling commodities. that the imports of these low-priced foreign textiles cannot continue unchecked. ${ }^{12}$

By difficult selling commodities he meant such things as meat, dairy produce and dried fruits for which there was virtually no market outside the United Kingdom and which depended for their sales in the United Kingdom on the margins of preference that they enjoyed there. ${ }^{13}$ Later in the course of the dispute Gullett elaborated on the same argument in a letter to Hawker. Drawing Hawker's attention to the fact that Australia was now importing a smaller volume of cotton fabrics from the United Kingdom than in the slump year, 1931, he wrote:

The great increase in the imports of rayons from Japan is not due to a particular demand for rayons... Where the Japanese rayons were cheaper than comparable cotton fabrics a heavy swing to the rayon material occurred...

In considering the cotton quantities, I suggest you cannot disregard the Ottowa Agreement aspect and the fact that cottons are the great item in British exports to Australia. I think you must agree that Britain was justified in expecting that her relative position as a supplier would not deteriorate under the agreement. We certainly gave Britain what we believed would be an effective preference. No doubt it would have proved so in normal circumstances. Due to factors outside Britain's control, the preference proved illusory and unreal being nullified first by the heavy depreciation in Japanese currency and then by the Japanese attack on the Australian market...

Could we logically go on pressing Britain for an expanding share of her market in meat, butter and so on by reducing her imports from Argentine and Denmark if we were not prepared even to maintain the pre-Ottawa position of her most important item? I am certain we would not have displayed the same patience in reversed positions. ${ }^{14}$

The Government's policy was in effect to sacrifice the interests of Australia's second-best customer whose annual purchases of Australia's exports amounted to $\mathrm{EA} 12 \mathrm{~m}$ for those of her best customer whose annual purchases were $1 \mathrm{~A} 54 \mathrm{~m}$, in the hope of winning additional trade with the latter.

12 Commonwealth of Australia. Parliamentary Debates (hereafter referred to as $C P D$ ), Vol. 150, p. 2215

13 For the significance of these commodities in national development see C. Hawker, M.H.R., 'Australia's Foreign Trade Treaties' [British Commonwealth Relations Conference 1938, Aust. Suppl. Papers B (3) pp.12-13].

14 Letter from Gullett to Hawker $12 / 8 / 36$ (Hawker Papers - Australian National Library). 


\section{MANCHESTER $\mathbf{v}$. JAPAN}

The British Government was careful to make it clear to all that Australia was not acting under its influence in this matter. The Dominions' Secretary (Malcoln MacDonald) explained to the House of Commons that the Australian Government had 'reached their decision without prior consultation with His Majesty's Government in the United Kingdom.' ${ }^{15}$ The Parliamentary Under-Secretary, the Marquess of Hartington, put this manifestation of Empire spirit to good effect in the Midlands constituencies. At Retford he told the local Conservatives how

Australia, of her own accord, and without solicitation, imposed almost prohibitive duties on American and Japanese goods in order to help Lancashire. It was a generous and free gift. At least $f 1,500,000$ worth of goods will be imported in the first year from Lancashire in excess of previous years. It is wonderful that a government 12,000 miles away should ask its people to undergo considerable risks and losses to help a distressed section of the Old Country. ${ }^{16}$

That Australia had acted on its own initiative was also a point made by the United Kingdom High Commission in Canberra in off-therecord conversations. On at least one occasion this was expressed in language rather less eujogistic than Lord Hartington's. The diary of J.P. Moffat, the United States Consul-General in Sydney, contains the following account of a conversation that he had with Percivale Liesching, the number-two man at the High Commission, early in November (1936).

He said that his task here was far harder than in Ottawa; that Canada, - and South Africa - knew what they wanted and had developed a national consciousness. Australia was still colonially minded, more so even than Rhodesia or Kenya; wanted to do what she thought England wanted, but illogically didn't want advice or even full information from England before she acted...

What happened last May was as follows: he and his chief knew that Australia was going to make a move restricting trade. It was only twenty-four hours or so before the new policy was tabled that they were handed a copy of the program. As a matter of fact, despite certain apparent advantages to Britain, she was not a clear gainer from the trade diversion scheme. She did profit in textiles, but he was sceptical of other gains. The whole scheme was the product of arm-chair thinking . . ${ }^{17}$

15 Great Britain, Parliamentary Debates, Commons, Vol. 315, Col. 266 $(21 / 7 / 36)$

16 Argus (Melbourne), 3/7/36. This report was later quoted in the Austratian Parliament by two ministerialist back-benchers critical of Gullett's policy - P.A.M. (later Sir Philip) McBride on 25/11/36 and Senator J. Duncan-Hughes on 2 \& 3/12/36 (CPD Vol. 152, pp.2327\& 2662).

17 Diary of J. P. Moffat (microfilm of typescript). Entry for $3 \& 4 / 11 / 36$ pp.605-06 [A ustralian National Library\}. 


\section{D.C.S. SISSONS}

Australian ministers were equally insistent that Australia had acted independently. For example. when the President of the Graziers Federal Council (D.T. Boyd) on July 8th (1936) as a member of a deputation from the wool industry protesting against the raising of the textiles duties, asked the Prime Minister whether this was done at the request of the British Government, Lyons replied, categorically, 'No'. ${ }^{18}$ R.W. Dalton, United Kingdom Senior Trade Commissioner in Australia, in a despatch to the Department of Overseas Trade dated April 2nd (1936) describes a similar denial by Gullett and the scepticism with which the Japanese received such assurances:

When I was in Canberra last week Sir Henry Gullet made a point (at a private party) of talking to me ... \{ He said $\}$ that in a "very candid" conversation which he had recently had with the Japanese Consul-General . . . Murai had said that in Japan they were convinced that United Kingdom Government influence was the origin of the actions detrimental to Japanese trade which the Australian Government proposed to take. Sir Henry Gullett said that this was not so and that any action which the Australian Government might take would be of its own volition. To this Murai retorted that as they were speaking quite "candidly" to one another he must say that he was unable to accept this view and he added that the speeches of the Manchester Mission showed clearly that the proposed action was influenced by the United Kingdom and that was consistent with other actions of the United Kingdom elsewhere in the world. ${ }^{19}$ What was the Manchester Mission and these 'other actions by the United Kingdom elsewhere in the world' to which Murai was alluding?

During his visit to the United Kingdom the previous year, (1935), the Australian Prime Minister, J.A. Lyons, visited Manchester on June 12th. The Manchester Guardian at the time reported that he devoted two hours of this visit to a private meeting with representatives of the cotton trade to hear their representations on the effect of the Australian tariff on Lancashire textile exports and on the question of Japanese competition. No further details of the meeting were pubIished. ${ }^{20}$ The Dominion Office archives, however, indicate that on that occasion the representatives of the industry urged that the Australian Government take action against Japanese textiles by means of specific duties or import restrictions and that Lyons undertook to put these suggestions fully before his colleagues when he returned to Australia. ${ }^{21}$

18 Graziers Association of N.S.W., General Council, Australian-Japanese Trade, (letterpress, 16pp., 1936), p.9.

19 Great Britain, Foreign Office, F2552/119/23 [Public Record Office, London!.

20 Manchester Guardian. 13/6/35.

21 Telegram No. 83 to U.K. Rep. in Australia, 15 August 1935. Dominions Office 9279A/21/32 [Public Record Office, London]. 


\section{MANCHESTER $\checkmark$. JAPAN}

On October 16th (1935) the Australian press carried a cable item that the Manchester Chamber of Commerce had announced that it was despatching to Australia in January a Mission consisting of two of its members, Sir Ernest Thompson and Mr H.C.M. Ellis, to promote mutual trade between the Manchester region and Australia; the Mission would be away for four or five months, during which time recommendations relating to the tariff would be considered. ${ }^{22}$

It was on January 23rd, two days before the Manchester mission boarded the Strathnaver for Australia, that the Lyons cabinet reached the fateful decision that steps should be taken as soon as practicable to reduce the import of Japanese art silk and cotton piece goods by the imposition of specific duties or other means. ${ }^{23}$ It would, however, be some months before the Government could announce this decision. There had to be adequate time for the Japanese Government to furnish counter-proposals and for these to be considered. It was also desirable that the announcement should come at the end of the Parliamentary session so that the opponents of the restrictions would be unable to use Parliament as their forum.

Dalton (the U.K. Trade Commissioner) later admitted that the idea of a Manchester Mission had originated with him and that he had proposed it at a time when he considered it inconceivable that the Australian Government would readily take restrictive measures against Japan. ${ }^{24}$ This suggests that the role that the Department of Overseas Trade had for the Mission was that it should rally interests favourable to such measures in a campaign that, it was hoped, might force the Australian Government to take action. Not only was such a campaign now unnecessary; it could also be positively hamful. It would mean that, when the Government's decision was eventually announced, it would appear to be the result of dictation by United Kingdom commercial interests. This would unnecessarily alienate such Australian nationalist sentiment as existed. In the event, this is precisely what happened. Not only Japanese writers, but Australian critics like Norman Cowper, ${ }^{25}$ Edward Masey (later of 'Australia First' fame) and D.A.S. Campbell made much of the argument that the Government had succumbed in the face of the Mission's assault. Murai, of course, knew better than this; for it was on February 20th, when the Strathnaver was still in the middle of the Indian Ocean, that Gullett had informed him of the Government's intentions. Nevertheless, it was the presence of the Mission, its statements - and perhaps something in its demeanour

\footnotetext{
22 Argus (Melbourne), 16/10/35.

23 Australian Archives: A2694.

24 In his despatch dated 2/4/36. Great Britain, Foreign Office, F2552/119/23 [Public Record Office, London].

25 N. L. Cowper, The Trade Diversion Policy (Sydney: Beacon Press, 1936).
} 


\section{D.C.S. SISSONS}

- that confirmed him in his belief that the initiative for the forthcoming tariff changes came from the United Kingdom Government. Possibly the fact that it was Thompson who was leading the Mission had something to do with this. Murai would have been well aware that Thompson had led the British Economic Mission and the Cotton SubMission that had been sent to Japan by the Department of Overseas Trade in 1930 to study the competitive power of Japanese industry ${ }^{26}$ and that, more recently, he had been one of the representatives of the textile industry in the abortive talks sponsored by the Board of Trade which preceded the imposition of import restrictions against Japanese goods throughout the Colonial Empire in May 1934.27

In the changed circumstances that now attended the arrival of the Mission, as soon as the Strathnaver berthed in Melbourne on March 2nd (1936), Thompson and Ellis were whisked off to an unpublicised meeting with several Federal ministers who, on behalf of their colleagues, informed them in confidence of the Government's intentions.

To Dalton's dismay, the hints that he and the Ministers had sought to convey to the Mission about the line that it should now take were very soon proved to have fallen on stony ground. (Daiton subsequently learned that the Mission had been despatched by its constituents with instructions to adopt a 'very firm attitude'). Before the sun had set Thompson had told an open meeting of the Melbourne Chamber of Commerce that restrictive quotas against Japanese goods were the only way to deal with the situation. This prompted a telephone call to Dalton from the High Commissioner, requesting him to convey to the Mission that under the circumstances their remarks had produced some annoyance at Canberra. The Mission, however, was undeterred. That day Thompson proceeded to tell a similar audience that he intended to ask the Prime Minister to implement the promises made during his recent visit to England [emphasis added D.C.S.S.] and that he hoped that specific duties or restrictive quotas would be imposed on 'goods produced under conditions so different from those prevailing in British countries.' The following day, at a luncheon given in his honour by Victorian Ministers at Parliament House, he reminded his audience that all parties in Australia subscribed to the principle of a White Australia because they knew that the white man's standard of living could be endangered by the introduction of coloured labour: 'I make this suggestion to you - that just as the employment of such labour here would do this, so would the importation of too great a quantity of goods manufactured by coloured labour'.

\footnotetext{
26 Department of Overseas Trade, Report of the British Economic Mission to the Far East, 1930-31 (London: H.M.S.O., 1931).

British Economic Mission to the Far East, 1930-31, Report of the Cotton Mission (London: H.M.S.O., 1931).

27 Manchester Guardian, 3/2/34, 15/3/34.
} 


\section{MANCHESTER v. JAPAN}

On March 9th the Mission moved on to Canberra. On March 13th it reached Sydney and there the worst happened. Its visit coincided with the Annual Conference of the N.S.W. Graziers' Association, whose President, J.P. Abbott, took this opportunity to remark on 'the tremendous complaint' being aired by the Mission against Japanese imports in the Australian and other traditionally British markets. Abbott argued that if Japan was unable to dispose of her products, the only alternative open to her would be a bloody war in the Pacific. Furthermore, the Mission seemed oblivious to the fact that for years it had been Japan that had sustained prices at the Australian wool sales when other nations had dropped out. Abbott continued that he had learnt that day from a very reliable source that it was the Government's intention to impose restrictions. He called on the Conference, not only as wool growers, but as patriotic Australians, to do all in their power to prevent this 'act of madness'. A motion endorsing these views was passed with very few dissentients. ${ }^{28}$

The cat was out of the bag. The issue was joined. From now on the Government would have to spend a considerable amount of its energy propitiating its rural supporters. This time it was Gullett himself who got on to the telephone to Dalton and told him to pass on to the Mission that, thanks to their statements, the Government's position was becoming so difficult that it might be impossible for it to carry out its intentions. Dalton considered this no mere threat but a reasonable statement of the position. This time Thompson showed some signs of contrition: he offered to use his influence to get the Australian Association of British Manufacturers to tone down a press statement that they were preparing in answer to the Graziers. Dalton replied that he should tell the Association that it would be 'extremely inadvisable' for them to intervene in the matter. But, as usual, affairs were beyond Dalton and Guilett's control. A statement of the British Manufacturers appeared in the press the following day.

When Dalton's report on the Mission's progress reached London a month later, all that the Dominions Office could do was to suppress a shudder and implore the Secretary of the Manchester Chamber of Commerce himself to go to Plymouth, get to the Mission before they landed or met the press, and impress upon them that "they must not be foolish'.29

You will remember that the second reason that Murai gave to Gullett for his conviction that the initiative for the restrictive measures came from the British Government was 'other actions of the United Kingdom elsewhere in the world.' Let us take a brief look at Britain's trade policy towards Japan in the preceding three years.

A rgus, 19/3/36.

29 Foreign Office, F2552 and 2982/119/23. 


\section{D.C.S. SISSONS}

In 1929 the United Kingdom was still the world's principal exporter of cotton textiles $-£ 3,670 \mathrm{~m}$. By 1933 the figure had fallen to $£ 2,030 \mathrm{~m}$ and she had yielded pride of place to Japan with $£ 2,090 \mathrm{~m}$. Over the same period of time the average unit price of Japanese cottons had fallen from $5.3 \mathrm{~d}$. to $2.6 \mathrm{~d}$. (cf. the fall in price of the British product from $6.5 \mathrm{~d}$. to $4.8 \mathrm{~d}$.). In this situation the British Govemment, on 24 April 1933, proposed discussions between the representatives of British and Japanese textile interests, with a view to bringing about a reduction of Japanese exports where they competed with the British product, in both British and foreign markets. As an indication that it possessed some bargaining power, on May 16th it gave the requisite 6 months' notice to terminate the application of the Anglo-Japanese Commercial Treaty to the West African colonies. Taks between the Japanese and British industrialists (among them Sir Ernest Thompson) eventually began in London the following February (1934) but broke down within a month when the $\mathbf{J}$ apanese refused to discuss Dominion and third country markets and insisted that any reductions must be mutual and not confined to Japanese exports. ${ }^{30}$ The President of the Board of Trade thereupon, on May 7 th, announced the imposition of restrictive quotas on cotton and rayon textiles throughout the colonial Empire. In British West Africa, where most favoured nation treatment was no longer obligatory, the quotas applied only to Japanese textiles. Elsewhere quotas based on the quantities imported during the period 1927-31 were applied to all foreign textiles equally. As a result imports into the colonial Empire from Japan fell from $238 \mathrm{~m}$ sq. yds. in 1933 to $60.4 \mathrm{~m}$ in 1935 , while those from the United Kingdom rose from $157 \mathrm{~m}$ to $258 \mathrm{~m}$. In British West Africa over the same period imports from Japan fell from $102 \mathrm{~m}$ to $7.5 \mathrm{~m}$ sq. yds. while those from the United Kingdom rose from $102 \mathrm{~m}$ to $364 \mathrm{~m}$. 31

Similar action was taken against the entry of Japan's cotton textiles into India. On 10 April 1933 the Indian Government gave the requisite 6 months' notice to terminate the Indo-Japanese Commercial Convention of 1904 and, in order to strengthen its position for the negotiation of a more favourable Agreement, on June 6th raised the tariff on foreign cottons from 50 percent to 75 percent while leaving the British Preferential rate unchanged at 25 percent.

This was but the latest of a series of tariff changes that had borne more heavily on Japanese than on United Kingdom textiles. Over the period 1928/29 to 1932/33 Japan's share of India's cotton textiles imports had risen from 18.4 percent to 43.6 percent while the United

Manchester Guardian, 3/2/34, 15/3/34.

31 S. Kawashima, Nihon Gaikō Bunsho Bessatsu: Tsūshō Jōyakū to Tsūshō Seisaku no Hensen (Tokyo: Sekai Keizai Chosakai, 1951), pp. 837-48. 


\section{MANCHESTER v. JAPAN}

Kingdom's share had fallen from 75.0 percent to 49.3 percent. ${ }^{32}$ On 28 May 1930 the Indian Government had implemented a tariff schedule which gave British goods a preferential margin of 5 percent. In the case of plain greys, where the cheapness of the Japanese product was particularly marked, a specific duty $(3.1 / 2$ annas per lb) was imposed. The Japanese Government had promptly protested that such preferential treatment violated Article 1 of the Commercial Convention, which guaranteed to Japanese goods the lowest customs duty applicable to 'similar products of any other foreign origin'. To this the British Government had replied on October 14th (1930) that the meaning of 'foreign' could include other parts of the British Empire. ${ }^{33}$ In September 1931 and April 1932 the margin of British Preference had been raised to $6.1 / 4$ percent and 25 percent. ${ }^{34}$

The Japanese spinners, who in normal years took from 50 percent to 70 percent of India's cotton crop, retaliated against the June 1933 tariff by purchasing all their requirements elsewhere. The Japanese Foreign Ministry, however, considered that boycotts were a dangerous method of diplomacy and offered to open negotiations for a new Commercial Convention. The Indian Government readily agreed. (It appears to have believed that a boycott was impossible. Its denunciation of the current Convention had, indeed, been partly aimed at increasing its sales of raw cotton to Japan: it hoped to negotiate a new Convention under which Japan would be required to purchase certain specified amounts). Negotiations opened at Simla in September (1933). ${ }^{35}$

As happened two years later in Australia, a delegation from Manchester appeared during the negotiations. This was the British Cotton Delegation, led by Sir William Clare Lees. In its representations to the Indian Government it sought acceptance of the principle that duties on United Kingdom textiles should be such as would afford United Kingdom producers full opportunity of reasonable competition with domestic producers and a margin of preference over foreign goods at least equal to that afforded to other British exports in the Ottawa Agreement. ${ }^{36}$

In the new Commercial Agreement signed at Simla in April (1934) the duty on Japanese textiles was reduced to 50 percent. (As the tariff on British goods was in June lowered to 20 percent this gave the latter a preferential margin of 30 percent). The Agreement also provided a quota for Japanese cotton textiles which was linked to the amount

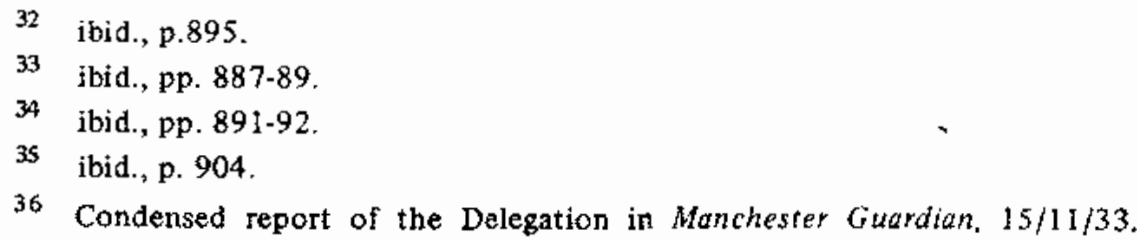




\section{D.C.S. SISSONS}

of raw cotton that Japan purchased from India. The maximum in any year would be 400 million yards and this would be conditional on Japan's purchasing $1.1 / 2$ million bales. ${ }^{37}$ This in effect froze the quantity of Japanese cotton textiles imported into India at a figure lower than the average for the years 1928-1932 (478.4m yds) and much lower than the level achieved for the year $1932(644.7 \mathrm{~m})$. ${ }^{38}$ The Agreement, moreover, divided the Japanese quotas into sub-quotas in the following proportions: plain greys 45 percent, bordered greys 13 percent. bleached (white) 8 percent, coloured 34 percent. This was of particular advantage to United Kingdom exporters; for it restricted Japan very severely in the bleached lines where she had been most rapidly overtaking the United Kingdom. In these lines Japan's proportion of India's imports had risen from 2.9 percent in 1929-30 to 29.1 percent in 1932-3, while the United Kingdom's share had declined from 92.2 percent to 69.2 percent. By confining Japan to the greys it was confining her to the field where she must increasingly give place to India's expanding local production. ${ }^{39}$

Murai would also have been aware of similar, more recent developments in Egypt. Britain was by far Egypt's best customer. In 1934, for example, 32 percent of Egypt's exports went to the United Kingdom, as against 8.8 percent to Japan. ${ }^{40}$

In April 1935 a Mission of Economic Enquiry led by Hafex Afifi Pasha (formerly Ambassador in London) was despatched to England. Their purpose, as stated in their terms of reference, was 'to enquire Greato the position of the interchange of trade between Egypt and Great Britain, to consider means conducive to the increased consumption of Egyptian products in British markets, and to receive such statements and suggestions as may be made to them with a view to simulate the demand for British goods in Egyptian markets'. 41 The British Government proposed to them that Egypt should establish quotas whereby 53 percent of her textile imports should be allotted to the United Kingdom and 19 percent to Japan. ${ }^{42}$ (In 1934 their respective shares of the market had been 19 percent and 68 percent). ${ }^{43}$ The Mission, however, on its retum recommended instead a general surtax on imports from countries with depreciated currencies, as likely to furnish

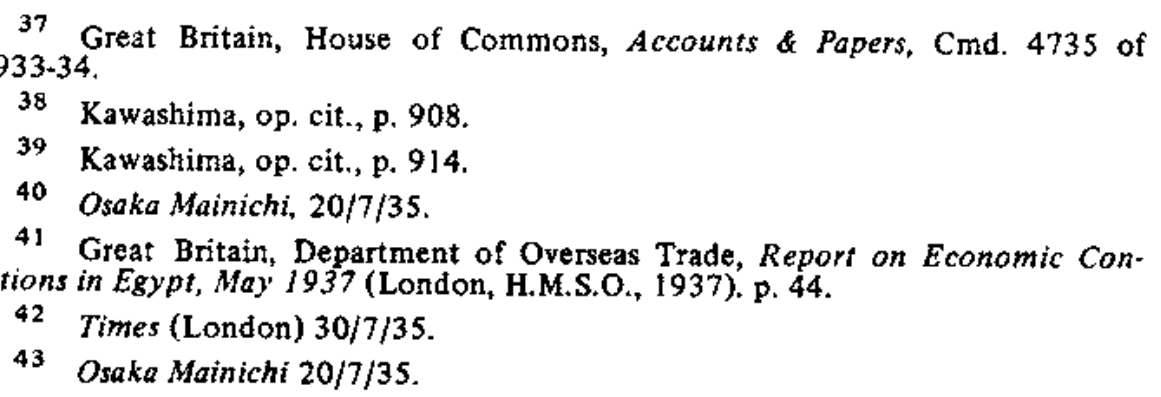




\section{MANCHESTER $v$. JAPAN}

'reasonable protection to home textiles while allowing Lancashire full scope to establish its goods more firmly in the Egyptian markets.' [emphasis added D.C.S.S.] ${ }^{4}$ The Egyptian Government accordingly, on $18 \mathrm{July} 1935$, gave the required three months' notice to terminate the Japan-Egypt Commercial Agreement and on September 19 th imposed a 40 percent surtax on Japanese goods. Japan entered into negotiations for a new Agreement, but after seven months these broke down without any results having been achieved. Egypt's imports of cotton piece goods from Japan declined from 142.1 million sq metres in 1935 to 71.3 million in 1936, while those from the United Kingdom rose from 30.3 million to 51.2 million. ${ }^{45}$

In his belief that the initiative for Gullett's action against Japanese textiles came from the United Kingdom Government, Murai's judgment does not appear to have been at fault. On 15 August 1935 a telegram was sent over the signature of the then Dominions' Secretary, J.H. Thomas, to Lyons via the High Commissioner. A copy was sent to Gullett (who was still in Europe) direct. The telegram referred to the representations made to Lyons by the textiles industry during his visit to Manchester in June and to his undertaking to put these fully before his colleagues on his return. It enclosed additional information furnished by the industry to the President of the Board of Trade on July $24 \mathrm{th}$ regarding the continued advance by Japanese cottons and rayons in the Australian market. It concluded with the following significant two paragraphs:

The Lancashire interests appreciate that the position of Japan as a market for Australian products is an important factor from your point of view. They also recognise that in these circumstances it may be difficult to restrict Japan to her relative position some years back as was done by the quotas in India and the Colonies. It is for this reason that they feel that, if the situation is not to be allowed to go from bad to worse, action should be taken as soon as possible.

Feeling is running high in Lancashire, and we hope that the Commonwealth Government will be able to give the views and proposals of the Joint Committee full consideration and that they may find it possible to take action which will safeguard Lancashire's important trade to Australia from the competition which owes its origin to a standard of living which is alien to both our own countries. ${ }^{46}$

In Australia the actual process of setting in motion the preliminary steps that would eventually result in the recommendation of restrictive measures to Cabinet must have been begun before Gullett left

Times, 30/7/35.

45 Report on Econonic Conditions in Egypt, May 1937, p. 45.

46 Great Britain, Dominions Office 9279 A/21/32. 


\section{D.C.S. SISSONS}

Europe so that specific proposals would be ready for his consideration on his return. There survives in the Australian Archives ${ }^{47}$ a detailed submission on the subject (eight pages in length, supported by another eight pages of trade statistics) completed in the Trade Agreements and Treaties Division of the Department of Trade and Customs on 27 November 1935, a few days before Gullett's arrival back in Canberra. The rise in tariffs proposed in this document to assist British textiles is significantly less than those eventually recommended to and approved by Parliament. But more important for our purposes is the fact that it begins with the words: 'In submitting representations to the Commonwealth Government on the question of Japanese competition, the United Kingdom Government pointed out ...' [emphasis added D.C.S.S.]. It also refers specifically to the information furnished by the British industry to the President of the Board of Trade on July 24th. It is therefore reasonable to suppose that this Australian submission was the result of the telegram from the Dominions' Secretary.

The telegram from Lyons to the British prime-minister (Baldwin) despatched on May 18th (1936), shortly before the new tariff measures were presented to Parliament, also gives a good indication of where the initiative came from:

... The heavy duty restrictions which we will place on imports of Japanese textiles are certain in our view to confer very substantial and increasing benefits upon Lancashire manufacturers and they are made to meet the express wishes of your Government [ emphasis added - D.C.S.S.l. It is true, of course that indirectly we look to these restrictions to confer benefits upon Australia by increasing opportunities for our exports in the United Kingdom.

The steps however lay us open to retaliation from Japan which is our second best customer for wool and indeed for all our exports and in view of this we would not have felt justified in imposing restrictions had it not been for your repeated requests [emphasis added - D.C.S.S.] and for our urgent need for a larger share in United Kingdom markets ... ${ }^{48}$

The mention in this telegram of 'repeated' requests suggests that pressure was exerted over a period and that Australia's compliance was not easily achieved. This seems to have been the case. As long before as 23 March 1933 Stanley Bruce, our Resident Minister in London, was writing to Lyons on the subject. Referring to official representations that the Manchester Chamber of Commerce proposed to make to

47 Aust. Archives (Sydney Office), ST 127 Series 2 Box 1, Trade \& Customs, B.36/274. Rev. Fr. Brian Murphy kindly brought this document to my attention. London!.

48 Great Britain, Dominions Office, 9279A/21/58 [Public Record Office, 


\section{MANCHESTER $y$. JAPAN}

the British Government about Japanese competition in Australia, he wrote:

I acquiesced in this, although I held out no hope that the Commonwealth would be in a position to amend the present duties without receiving an adequate quid pro quo from the United Kingdom. ${ }^{49}$

When on 23 January 1936 the Australian Government eventually complied, and decided in principle on restrictive measures, the British appear to have been quite taken by surprise. Dalton, in a despatch to the Department of Overseas Trade, wrote: 'We are aware ourselves that decision to act restrictively on Japanese is almost a complete volte face on the part of the Government and I do not think that anybody here could have expected such action...' He speaks of the Government being now "ready to do more than we could even have hoped for a year ago'. ${ }^{50}$

How is the Australian Government's volte face to be explained? Had it been offered (or was it about to be offered) the quid pro quo that Bruce had said would be necessary?

It was widely assumed at the time that the Australian restrictions on Japanese textiles were part of Australia's diplomatic offensive on the United Kingdom to secure a continuation of the favourable treatment for Australian meat that she had received since the Ottawa Conference in July 1932. ${ }^{51}$ This interpretation has been followed by later writers. ${ }^{52}$ Ross Duncan, for example, in his article on beef exports under imperial preference in the 1930s, notes that, atthough there is no direct evidence linking the imposition of restrictions on Japanese textiles with the meat negotiations, "the coincidence of timing is strongly suggestive'..$^{33}$

The continued growth of the Australian meat industry was regarded by the U.A.P. - Country Party cabinet as very important, both nationally and electorally. This depended very largely on the United Kingdom market and the amount of protection it received there against its better established, more efficient Argentine competitors and their more tasty product. Under Britain's trade treaty with Argentina due to expire in November 1936, Argentina had accepted some restrictions on the quantity of her meat exports to the United Kingdom, in return for certain benefits, including duty-free entry. Australia insisted that when this treaty expired Britain should impose duties and additional

49 Austrajian Archives, CP576, Personal Papers of E. Abbot, ComptrollerGeneral of Customs, Bundle 3.

so Despatch dated 2/4/36. Foreign Office, F2552/119/23.

51 e.g. Cowper, p. 6, Masey p. 16, P.A.M. MeBride M.H.R. (CPD Vol. 152 , p. 2329).

52 e.g. P. Drysdale, 'Australja's Trade with Japan before the War and the Trade Diversion Episode' (Canberra: A.N.U., Dept. of Economics, RSPacS, 20pp. mimeo, (964), p. 1 l.

53 R. Duncan, 'Imperial Preference: The Case of Australian Beef in the 1930s', Economic Record, Vol. 39 (1963), p. 165. 


\section{D.C.S. SISSONS}

quantitative restrictions on Argentine meat in the interests of Australian producers. The British Government was unwilling to do this to the extent required by the Australians, because one result would be to reduce both the purchasing power of the Argentinians to buy British exports (including textiles) and the return on the considerable amount of British capital invested in the Argentine meat industry. In 1935 Lyons and Gullett appear to have devoted a good deal of their visit to the United Kingdom to making representations to the British Government regarding the stand that they wished it to adopt in its negotiations on a new treaty with Argentina. As a result Australia had given provisional approval to a scheme for a long-term settlement of the question, which was then communicated to the Argentine Government. Discussions between the Australian and the British Governments were to be resumed when the Australian ministers, Page and Menzies, visited England in 1936. As we have already observed, it was on January 23rd that the Australian cabinet decided in principle on the restrictive measures against Japanese textiles. Discussions with the British Government on the Argentine question appear to have been resumed on the initiative of Page and Menzies in London in April (1936). They now appear to have demanded a firmer approach to Argentina than that agreed to the previous year. Then Australia had been prepared, herself, to accept a low tariff and some quantitative restrictions, provided that a considerably highet tariff and much greater cuts were imposed on Argentina. Whether they now raised their demands because they felt that their action against Japanese textiles had given them greater leverage against the United Kingdom, or whether, as they said to Malcolm MacDonald, it was because they felt that Argentina, with only seven months of treaty status left her, was in a weaker bargaining position than the previous year, ${ }^{54}$ I cannot tell. By June 8th the British Government appears to have agreed that a duty shoukd be levied on foreign meat only and, in the discussion between British and Commonwealth ministers on that day, the Australian attack was directed against the British Government's attempt to escape from the invidious position of itself being the meat in the sandwich of contention between these two exporting countries and after one year hand over the task of regulating supplies to an international producers' conference. Australia insisted that Britain must determine the allocations for a longer period. In the course of this argument Australian ministers referred to the textiles question. $\mathrm{Mr}$ Menzies enquired how the British Government would like 'an inter-

S4 Great Britain, Cabinet, Committee on Trade \& Agriculture, T.A.C. (36)3, 'Note of a discussion bet ween the Secretary of State for Dominion Affairs, Dr Earle Page and Mr Menzies on April 7th [1936].

Great Britain, Foreign Office, A4944/32/2, Note of a meeting between U.K. Ministers and Commonwealth Ministers at the Dominions Office . . 8th June, $1936 \ldots$ 


\section{MANCHESTER $v$. JAPAN}

national rayon conference to be appointed in Australia to enable Lancashire and Japan to sit down with one another and to divide up the available market between them'. Mr Bruce (now Australian High Commissioner) went further and used threats:

He wanted, it to be realised that if Argentina were allowed her own way this time under the threat of reducing her purchases of United Kingdom goods, it would be quite impossible for Australia to continue her own recent policy of giving preference to United Kingdom cotton and rayon goods etc.

On June 12th MacDonald informed Page and Menzies that Cabinet had met that morning and proposed that a duty of $3 / 4 \mathrm{~d}$. per pound be levied on foreign beef but not on Dominions beef, that the British Government should hand over the power of allocation to the international conference only after two years and that during that period imports from both Argentina and the Dominions would be confined to their present levels but that Argentina would be required to reduce her shipments of the more desired and more remunerative chilled beef in favour of frozen beef while the Dominions would be unfettered in the extent to which they could substitute chilled beef in place of frozen. ${ }^{55}$ On June 17th Lyons cabled to the British Prime Minister that these proposals were 'deeply disappointing' and 'totally unacceptable' and that the two years' standstill at current levels followed by abandonment of allocation to an international conference was a complete abandonment of the commitment undertaken by the British Government at the Ottawa Conference to give the Dominions an expanding share of meat imports into the United Kingdom. In this telegram Lyons referred to the Japanese question:

As you are aware my Government recently introduced amendments and licensing systems which are severely and provocatively restrictive upon imports from certain foreign countries. As a result of these amendments we are at the moment engaged in very difficult and delicate position with regard to Japan whose trade representatives here have entirely ceased purchasing wool flour wheat and other commodities. So far all-Australia wool growers Council has temporarily refrained from condemnation of Government and Press with some exception is supporting Government. This restraint and support however are quite conditional on expectation that we shall succeed in endeavours we are making to reach friendly arrangements with Japan. We have also had protests from Government of U.S.A. and two other foreign countries. If we could not make satisfactory meat arrangements we could not justify our recent international tariff legislation...

I am not exaggerating when I say that if your Government's proposals made to Page and Menzies were published in Australia national sentiment would be deeply slocked and whole trade diversion

Great Britain, Foreign Office, A5057/32/2. 


\section{D.C.S. SISSONS}

policy and my Government would be placed in hazardous position... ${ }^{56}$

The High Commissioner in Canberra met Lyons and Gullett the following day, as a result of which he cabled that they had expressed the view that they were likely to be defeated when Parliament met early in September unless the opposition of primary interests could be averted. He considered that, despite the 'deplorablc' way in which it was expressed, the telegram represented apprehension and disappointment that were both very strong and genuine. ${ }^{57}$

In London Bruce called on MacDonald and repeated Lyons's arguments. If hopes for an expanding market for Australian products in the United Kingdom were dashed, feeling in Australia would be such that there would be a great agitation for the defeat of the textile tariff proposals. Australian Ministers would not accept any meat agreement which did not contain an all-over cut in foreign imports and an overall expansion ir Dominion imports into the United Kingdom. ${ }^{s 8}$

The United Kingdom still had some latitude in its negotiating position with Argentina. For she had not yet proposed to Argentina the formula proposed to Page and Menzies on June 12th. She was still negotiating there on the basis of a tougher formula - a 5 per cent net reduction in foreign chifled beef (i.e. a reduction not replaceable by any increase in frozen beef), to be carried out over a two year period. ${ }^{59}$ Faced with such strong resistance by Australia to the June I2th proposals, the United Kingdom interdepartmental committee on the beef negotiations and the Doninions Secretary (MacDonald) both proposed on June 22 nd that in the negotiations with Argentina the United Kingdom should continue to demand a 5 per cent net reduction in forcign chilled beef, but over a three year instead of a two year period, and an equivalent expansion in Dominion imports. This was accepted by the Cabinet Committee on Trade and Agriculture on June 24 th. ${ }^{60}$ In defending the proposal MacDonald informed the Committee that if they adhered to the position of June 12 th the new textile duties 'stood every chance of defeat' in the Australian Parliament. ${ }^{61}$

56

57

58 Great Britain, Cabinet, Committee on Trade and Agriculture, T.A.C.(36) 24,
Memorandum by the Secretary of State for Dominion Affairs, 22 June 1936 . [Public Record Office, CAB 27/620/8642].

59 ibid., T.A.C. (36). 20, Memorandum by the Official Committee on the Beef Negotiations, 22 June 1936 [Public Record office, CAB 27/620/8642]. 60 ibid., T.A.C. (36) 6 th Mtg., Conclusions of the Sixth Meeting of the Com mittee, 24 June 1936. [Public Record Office, CAB 27/619/8642]. See also the cable from the Dominions Office to the U.K. High Commissioner Canberra, 25 June 1936 [Public Record Office, FO A5507/32/2].

$6 \mathrm{t}$ ibid., T.A.C. (36). 24 [Public Record Office, CAB 27/620/8642]. 


\section{MANCHESTER v. JAPAN}

The Australian Government was informed of its victory the following day.

It is perhaps surprising that Whiskard, MacDonald, and MacDonald's colleagues in Cabinet took at face value Lyons and Gullett's fears that the Australian Government would be defeated in the House on a combination of the meat and the Japanese trade issues. Murai in his cables and despatches to Tokyo argued that the Lyons Cabinet could not be brought down on its Japanese policy. He considered that the dissidents among the ministerialist back-benchers had the option of supporting the Government or being expelled from the Party. Since their interests and beliefs prevented their foining the Labor Party and since they lacked the numbers or the leadership to form a new party, they would toe the line. As regards the Opposition, it would be difficult for the Labor Party to launch a whole-hearted attack on the Government on this issue without appearing to abandon the policy of Protection. Nor would they choose to come to power on an issue which would require them when in office to demolish the Ottawa Agreement. As regards public opinion generally, he maintained that Australians, because life was easy for them and because of their good climate, were cheerful and care-free. They were inclined to be pleased that wool prices were high rather than indignant at the fact that they would be higher still if the Japanese boycott was ended. ${ }^{62} \mathrm{l}$ found Murai's arguments so convincing that I suspected that, in their attempts to influence the British Government, Lyons and Gullett had expressed fears which they did not believe. The Lyons Papers, however, contain a record (in indirect speech) of a three-way discussion by telephone between Lyons and Gullett (in Canberra) and Page (in Eondon) on June 24th which indicates that they were not dissembling.

Sir Henry Gullett advised Dr Page of the very critical position we are in with Japan at the moment. He mentioned that we have got an extraordinarily good press - probably the greatest press we have ever had on anything - but of course we would be entirely lost in the whole matter if we did not get restriction on foreign beef. Every Australian newspaper has rallied to the Government, and this Japanese question has submerged everything else; if we get a setback now, probably the Government would go. If we fail on this matter of beef, it will go a long way to destroy the whole Ottawa principle so far as it is popular in Australia. It will bring our whole case down ... The Prime Minister emphasised the dangers of the position if Australia did not get something worth while in the beef negotiations. If Britain lets us down in this the Government will be wrecked. ${ }^{63}$

62 Murai to Foreign Minister: Telegram Kaisho 230/1 despatched 4/9/36; Despatch 380 despatched 15/9/36 (Japanese Ministry of Foreign Affairs Archives: B.2.0.0. J/B1 Vol. 4). [Australian National Library microfilm G.16169].

63 Australian National Library, Ms 4851, Box 5, 'Trade and Customs 1932-36'. 


\section{D.C.S. SISSONS}

The difference between the forebodings of the Australian Ministers and Murat's more sanguine view of their position may be explained in part by the interval of time that separated them. Murai expressed his predictions in reports despatched on September 4th and September 15th (we do not know how he read the situation in June; for most of the reports he sent during the period January lst to August 9th have not survived). Possibly it was because the British Government adopted the more conciliatory stand on beef that in September the number of dissidents among the U.A.P. and Country Party back-benchers was so small. Another factor may have been the unexpected strength of the wool market when the Sydney wool sales opened on August 31st.

The above would appear to establish that the British Government modified its policy on the meat question in important respects as a result of threats by the Australian Government that it would otherwise adopt a more conciliatory policy towards Japan on the textile question. This was a very successful piece of bargaining; for there is evidence that there was very little sympathy for the Australian stand on the meat question among British ministers and officials. We have Dalton's views in some detail and there is no reason for thinking that they wete not widely held. Briefty, he considered that Britain's concessions on meat at Ottawa - to restrict supplies from Argentina and give Australia preferred treatment and the assurance of an expanding shate of the United Kingdom market - were great concessions made in exchange for the promise of more generous treatment for British manufacturers in the Australian market than they were given to understand would be possibie without such concessions. In return, in the Ottawa Agreement Australia undertook, besides granting certain margins of preference for British goods (Article 8), to lower protective duties by Tariff Board enquiries to levels that would afford United Kingdom producers full opportunity for reasonable competition (Articles 10 and 11). Instead the Tariff Board had, adopted criteria that made a mockery of this understanding. Dalton continued: . . Australia's interpretation of Article 10 necessarily imples that new duties, even though they may be reductions of the old, may justifiably be prohibitive either in whole or in part; that interpretation therefore denies us (and would even in more prosperous times continue to deny us) the benefits which we anticipated and for which we gave in return benefits of immediate value to Australia. ${ }^{64}$

64 Great Britain, Board of Trade 11/647 - 'Memorandum prepared by H.M.'s Senior Trade Commissioner in Australia in connection with the forthcoming visit of an Australian delegation, 14 March 1935 [Public Record Office, London].

For the Tariff Board's interpretation of Articles 10 and 11 and the controversy surrounding it see D.B. Copland and C.V. Janes, Australian Trade Policy: A Book of Documents 1932-1937 (Sydney: Angus \& Robertson, 1937), pp. 101 120 . 


\section{MANCHESTER v. JAPAN}

When Lyons's cable of June 17th reached the Foreign Office the task of writing the initial minute on it fell to J.M. Troutbeck, the senior of the First Secretaries in the American Department. ${ }^{65}$ On this occasion he wrote:

... There is a general feeling in Government circles (as was clear from the last meeting of the $T[$ rade and]. A [griculture]. C [abinct]. Committee) that it is time to call a hait to Australian pretensions. It was felt that they have got into the habit of thinking that they can browbeat the United Kingdom Government who will, when it comes to the point, always give way to them. They have behaved very badly over this question of beef exports, and placed us in a most humiliating position vis-a-vis the Argentines, whom we eventually had to beg not to exercise their admitted rights under the Roca Agreement [i.e. the existing British treaty with Argentina D.C.S.S.]. The feeling of the Committee was that it was time the Australians were told "where they get off"...

... if, after being offered further concessions, they still maintain their attitude of protest, it seems to me that the position should be explained to them in far plainer language than has been used hitherto. The language used at the T.A.C. meeting was very different from anything that has yet been used to the Australians so far as I am aware.

These views were apparently shared by the Permanent Under-Secretary himself, (Sir Robert Vansittart), for he minuted the paper 'Mr Troutbeck has written a very good minute, and I agree with his conclusions .. .66

The fact that the basic decision to impose restrictions on Japanese textiles was taken on January 23rd, several months before Page and Menzies referred to the latter in their negotiations with the British Government, suggests to me that the textite restrictions were not adopted specifically as part of the tactics in the meat negotiations. Had the latter been the case, one might have expected the Australian Government to link the two issues when it initially informed the British Government of the textile restrictions. Rather, I think the purpose of the restrictions was, as Gullett stated in his speeches, to put Australia in a better position in all its negotiations, then and thereafter, regarding the entry of all Australia's primary products into the United Kingdom. Gullett has been criticised for taking the action he did against Japan without first securing a promise of a quid-pronquo from the United Kingdom. ${ }^{67}$ In the light of what transpired, I am not sure that such criticisms are completely justified. As regards her relations

65 Subsequently Sir John Troutbeck, GBE, Head of the British Middle East Office (Cairo) (1947-50), Ambassador to Iraq (1951-54).

66 Great Britain, Foreign Office, A5185/32/2. [Public Record Office FO371/ $19755]$,

67 e.g. $C P D$, Vol. 151, p. 1003 Mr Forde (9/10/36). Masey, op. cit., p. 17. 


\section{D.C.S. SISSONS}

with Great Britain, was not what Australia did ... made a generous, unilateral gift and then, when after some time it was not reciprocated, indicated that such generosity was endangering our relations with Japan and could not continue unless requited - was not this more appropriate for fostering the harmonious nature of relations within the family (as well as giving Australia greater flexibility as to where and when to seek concessions from Britain) than a more crude deal along the lines of 'You do this and we'll do that'? At the end of June there was still enough fluidity in the negotiations between Australia and Japan for Page and Menzies' threat to the British Government to be quite credible. Whether the hoped-for gains for these Australian products in the United Kingdom market could be of such magnitude as to justify risking Japanese retaliation against Australian wool and other Australian exports together with long term Japanese ill-witl, is, of course. a different question which I shall be examining in a later paper. 


\section{END OF REPRINT}

Manchester v. Japan: The imperial background of the Australian trade diversion dispute with Japan, 1936 



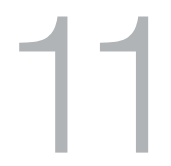

\title{
Correspondence on the trade diversion episode
}

\author{
Unpublished \\ From Papers of DCS Sissons (MS 3092) at the \\ National Library of Australia (Series 3, Box 7).
}

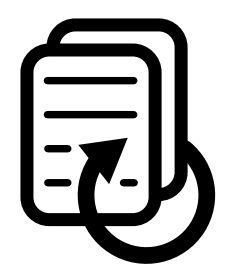





\section{Qem. ms Sirsons,}

September.

Thank you for your letter of loth

I regret that I have no personal recollection of the matters of which you write. I do not believe that I was, in any important way, concerned with such matters at the time and, if I was, it has certainly all now completely faded from my mind with the passage of so many years.

In the above circumstances, I think you would agree that there would be no useful purpose in our meeting to discuss.

I am,

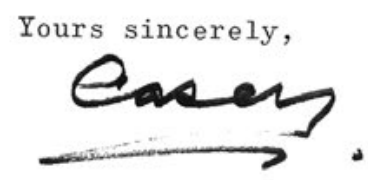

D.C.S. Sissons, Esq.,

The Research School of Pacific Studies, The Australian National University, Box 4, P.0., CANBERRA, A.C.T. 2600. 
The R.t. Hon. the Lord Casey, K.G., P.C., G.C.M.G., 314 Albert Stréet. EAST MELBOURNE, VIC. 3002 .

\section{Dear Lord Casey,}

Please excuse this letter from a stranger. I write at the suggestion of my colleague, Dr. T.B. Millar, who thought that you might be prepared to spare me a few minutes to discuss the Trade Diversion Policy of 1935-36 in connection with a History of Australian-Japanese Relations which is being written in this Department.

In the years that have elapsed since then, several writers have dealt with the subject. The position of most of them is essentially the same as that taken by Gidin at the time (Enclosure A).

The Commonwealth Archives office has, unfortunately, been able to produce very little material on the subject.

So far the most interesting source of information that has come to light is the private diary of J.P. Moffat, who was at the time the United Consul-General in Sydney. A typescript copy of this is in the Australian National Library. You may be interested in his account (dated 30 June 1936) of a discussion that he had with you on the subject in regard to its application to the United States (Enclosure B). Were you at any stage able to tell him the 'long story' to which you referred?

Presumably your balance of payments worries were with regard to imports from the United States and not those from Japan. It was hoped that imports from the United States would have been replaced by domestic manufactures thereby increasing London funds. There was, however, as I understand it, no suggestion that Japanese cotton and rayon piece-goods were to be replaced by anything but the higher priced English product.

The principal question that still remains unanswered is the extent to which the increased tariffs were imposed by Australia on Japanese piece-goods as the direct result of pressure by the British Government. Moffat had different views on this at different times. For example his diary entry for 
5. 1930 indicates that he believed the statelicht attributec: oo the Secretary of the Charuer of hanufactures that it was the fritish Trade Mission (Sir Ernest Thompson) that had persuadeu the Lyons Government to restrict both Anerican and Japunese traae. But his entry for 3 and 4 iovember 1936, in which he records the substance of an interview with Liesching of the british high Comrission, shows that he found liesching's remarks convincing.

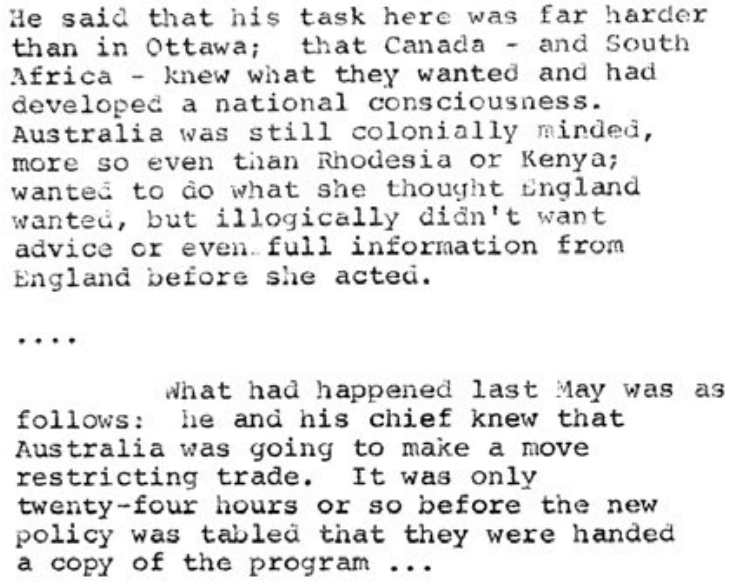

Moffat's account (27 and 28 February 1937) of a discussion with McClure Smith of the Sydney Horning Herald shows a similar attitude.

... lie said that he had been surprised how many people believed that the trade diversion policy against the United States and Japan was inspired by Whitehall, where as a matter of fact he knew that it had embarrassed the Foreign office and perhaps other sections of the Government.

I said the trouble was the British policy was not clear, that the Foreign office and the Board of Trade did not always walk hand-in-hand, that representatives of Lancashire and Yorkshire came out purporting to speak on behalf of certain governmental agencies, etc., and that the man in the street could not tell fust what British policy was. I said it was a great pity that the Foreign office did not do more to impress its views upon Australia. 
Finally there is Moffat's entry of 11 and 12 vebruary, 1937.

Squire also picked up from T'ownsenu, who was with page and Menzies in London last year, the story of the trade aiversion measures fron that angle. He said that Menzit; had disliked it from the beginning, but that Page and Murphy were so exultant that they dia not even take too much to heart a snub Girect given them by Neville Chamberlain, who said that it would not make one whit of difference in Anglo-Australion negotiations.

(D.C.S.S. underlining)

I apologise for writing to you at such length. I thought, however, that it was only proper to give you an accurate picture of the kind of things that I hoped to discuss before asking whether you were prepared to see me.

I shall be visiting Melbourne from September 28 th to October 5th; but if this were an inconvenient time for you, I could make a special visit to Melbourne later in the year.

I am very sorry indeed to trouble you with this matter.

Yours sincerely, 
SNCLOSURL: A.

\author{
Giblin on Trade Diversion, 1936
}

\begin{abstract}
Apart fron: the principles involved, the most
dangerous fecture of the new policy is the threat to wool, on which our whole economy is based. Japanese imports were already subject to very severe customs duties, and this new savage ciscrimination against Japan can be expected to stir national resentment to a frenzied dance, whenever it suits Japanese authorities to call the tune.
\end{abstract}

... [H] igh prices for wool would not be nearly so effective in encouraging suistitutes as the passionate national sentinent of a people devoted to taking any and every means to overcome their dejendence on wool. That is the prospect before us. Japan was buying wool in large and increasing quantities. She is showing ability to make textiles of wool so cheaply for export as to open up new markets for wool, which neither Great Britain nor Australia could attempt, and so more than make up any loss on account of substitutes. This promising development was nipped in the bua ... The tragic possibilities are endiess. In return, there seems a prospect that Great Britain will buy a little more inferior beef at unprofitable prices in place of the better product of Argentina.

More broadly, looking at the gloomy internal situation, one would have expected a conciliatory foreign policy for the next few years, until international relations are improved, or we have at least done something aciequate for defence. Two leading features of such a policy would be to enhance in every way our friendly relations with the Unitec States of America, and to avoid with particular care any action calculated to provoke Japan. Both these important considerations appear to have been deliberately flouted.

Quen Jupiter vult perdere, dementat prius.

[Extracts from Joseph Fisher Lecture by Professor L.F.Giblin, 25 June 1936 as reproduced in D.B.Copland and C.V. Janes, Australlan Trade Policy: A Book of Documents 1932-37 (Sydney: Angus \& Robertson 1937) pp. 301-02] 


\section{ENCLOSURE B.}

Extract from Private Diary of J.P. Moffat,

U.S. Consul-General in sydney

[30 June 1936]

Dick Casey, the Federal Treasurer, spent today in town; we lunched together and later on Lilla and I joined Mrs. Casey and himself at a small cocktail party. lie talked without reserve about the trade situation and $s$ aid that the one thing he wanted to inwress upon me was that tile reasons for action given in the fustralian note of June 6 were scrupulously exact. ... Phrased in somewhat different terms from tirose contained in the note, nis constant anxiety vas to protect the present Australian exchange rate. ...

I told him that never once had we objected to Australia or any other country restricting its imports in order to protect its financial position provided it were not done in a discriminatory manner. It was what Australia had cione and the way Australia had done it that had given such a tremendous shock to the Government and to public opinion at home. He did not deny that other ways and means might have been found to accomplisi the same result and saic: that some day in the future he would tell me a long story. That did not, however, change the absolute need to encourage local industry anci to increase purchases from Great Britain as the sole market for Australian primary products, which was susceptible to material increase. ... 


\section{The Australian National University}

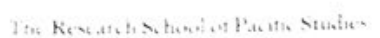

Department of Intemational Relations

reference DCSS/gbn

\author{
GP() Box 4. Canberta, AC'T 2601 \\ Telegramsa cables Natuni Canberra \\ Telex An 62 (x) \\ Telephone 062.495111 \\ 24 th October, 1984.
}

Dr. W.J. Hudson,

Editor of Historical Documents,

Department of Foreign Affairs,

PARKES, A.C.T. 2600.

Dear Bill,

Many thanks for your letter (August 23rd) and the enclosures from Casey's correspondence with Hankey.

please excuse my delay in replying. I've been somewhat disorganised by visits to the Australian Archives Sydney and Melbourne offices.

What fascinating letters they are. By the time you have finished with him there will be hardly an incident in inter-war public affairs either here or in Britain about which you don't have extensive expert and inside knowledge!

It was very good of you to pass this on to me. As you will see from the enclosed correspondence, I tried to get such information from Casey himself in 1971 - but without success. I had to let the matter drop and content myself with a rather unsatisfactory paragraph (pp. 32-33) in a work-in-progress paper, The Australian-Japanese Trade Negotiations 1935-36: The Negotiators, Their objectives and Their Administrative Environments, that I produced in 1975. As there may be one or two other points in early attempt by might, conceivably, interest you (e.g. an coordinating by Latham to give External Affairs a the liberty of enclosing a negotiations) I have taken

With thanks and best wishes,

Yours sincerely,

D.C.S. Sissons

Encl: 2 
FOREIGN AFFAIRS

23.8 .84

Sear Danid,

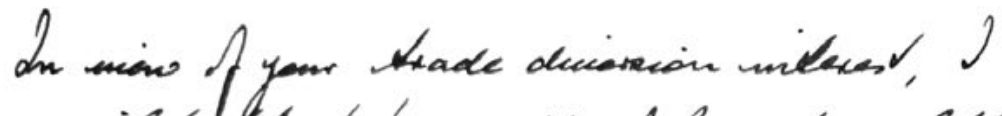

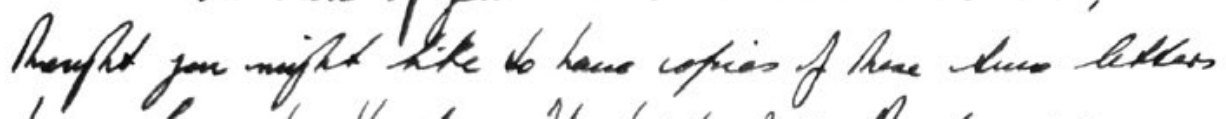

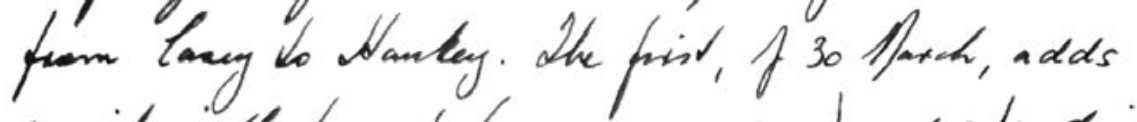

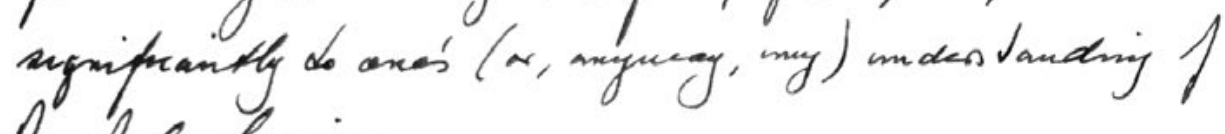
the whole huericoss.

Shese ne ferem the Nankey Pafers at Chuschill

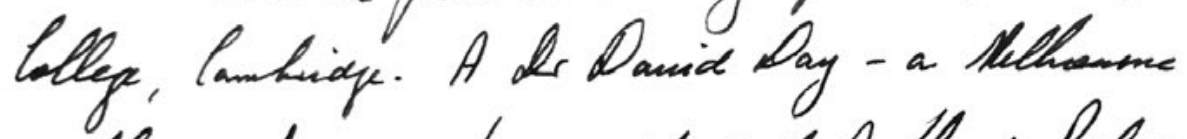

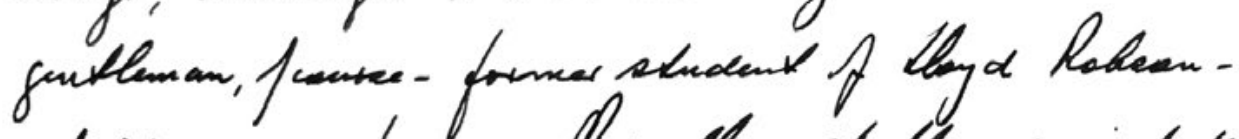
copicid a suroy for me. Masuellares celuff, and michodes

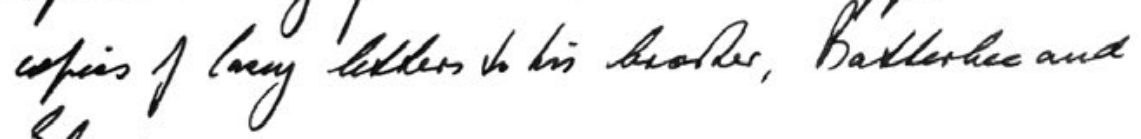
Slenayne.

byands,

Bill Andean 


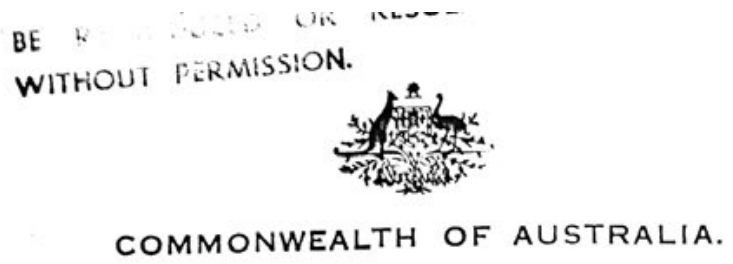

THE TREASURY.

AIR NLII.

CANBERRA, F.C.T.

30 th March, 1936.

PERSONII AND

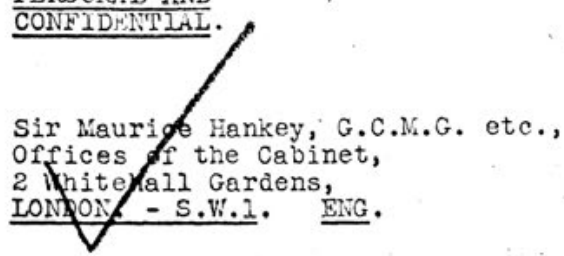

My dear Siaurice,

An event of consequence is taking place - Maie is writing to Adeline. She is making such a song-and-dance about it thet I feel in honour bound to parallel the event by at least a note to you. It will, I expect, as usual, turn out to be a recital of our own locel troubles and difficulties - and will largely ignore your infinitely greater problems. However, I will say (if I may) that you're makins an extraordinarily brave shot at a very devil of a problem in this FrancoGerman racket. I expect that it is not unhelpful to have a man like Bruce as President of the League Council at this time - but the main solution has to be hammered out by you people. I expect, by the way, that, as Great Britain is next on the list to find a President for the League, that you'll probably get Bruce to remain as President till September - as it might be embarrassing to have to emasculate Eden by making him President at a time when he is one of the principal protegonists.

One's impression of Eden, at this long rance, is that he's stacking up pretty well. From my remembrance of things, I can well realise that Vansittart's position may be one of considerablo difficulty. He used to be markedly pro-French - and may well (although this is a guess) have been one of the factors that encouraged the Hoare-Laval formula for the carving up of Abyssinia - that broucht Hoare down in flames. If one is richt in this, vansitiart must be rather diminished in stature by the incident. I can well imarine him looking over the list of Embassies and wondering which one he'li choose for himself. If and when it comes to choosing a new head of the F.O., I 
h: - a OR OR RSSOLU

vithour PERMISSION. $\quad-2-$

can't, from my knowledgo of the men, get past Lampson - althouph I p.pect Drumond and to a lesser extent Phipps are well in the running. 'don't know Clark.

However, the above is all idle speculation.

Geographically and in point of time, I'm too far away to be able to add anything of any value. However, this is'nt going to stop me commentine on the position - to the extent, at least, of sayinfs that the sooner oll the shackles are removed from Germany the better. It seems clear that, Hitler's Reich being built on national pride, he will be impossible to deal with while peace treaty blots on the German escutcheon exist. The demilitarised zone is the last of them - barring their de-colonisation, which is not so easily cured.

I imagine your main problem is to get France to cool down and accept the new Rhineland position. When everyone concerned has blown off enough steam over the unilateral repudiation of treaties, I imagine Britain will endeavour tactfully to get a new series of "Locarno" type treaties negotiated, with Germany on a completely equal basis with everyone else. The Franco-Russian treaty may unduly complicate this aim - I don't know enough about it.

$$
\dot{1} \cdot
$$

$\dot{I}$ mentioned Bruce and the possibility (or, rather, the advisability in the general interest) of his going into British politics, in my last letter to you. Since then, the press cables from Iondon have been busy with speculation on the subject. I don't know if anything is afoot; I hope so. He seems to me so obviously fitted for the job, particularly after his term as President of the League Council.

Menzies and Page are in London, I don't know if you will have seen either of them. Unless you've known Page for some time you are unlikely to be impressed, but under a rugged exterior he does possess some unusual gifts - particularly those of imagination, immense energy and drive, a good deal of resourcefulness, and complete imperturbability in awkward corners.

for your private ear:

And now for my own troubles - if I may unburden myself

I have been struggling for 8 months with the man-sized problem of our overseas balance of payments - and at long last have come to some sort of conclusion in my own mind about it all. I won't bother you with all the manifold areument (on which I have personally written many hundreds of thousands of words in Memoranda for our written many the gist of $1 \mathrm{t}$ is this -- that, in the absence of Cabinet) resumptie of our Exports with which to pay our interest and sinking of the sale debt to you, and also pay for our imports. With 
- "

-increasine prosperity, wo are tending to inport at a himher lovel ths. we can afford, at our present exchange rnte and bcaring in mint the -iirst charge on our Iondon funds - the interest and sinking furd on $1 \%$ overseas debt. We have ( to cut down our imports by some means or other. The 'MEAivis' is whet is exercising me: Neither the United Kincdom nor Australia wants us to default on our overseas interest paymonts(and of course, come what $=y$, we won't) - and neither you nor we want the exchange rate to slip. This exchanje rate business is one-way traffic. You can deprecide your currency as easily as kiss your hand, but it is almost beyonc. mortal power to appreciate it again. If your exchance rate slips, it apparently siips for good. So that we want at all costs for nearly so to save our exchange rate from slipping. And it need not slip if we are inteliigent - provided we don't experience the nasty phenomenon of a flicht of Capital. I've had two experiences (luckily both minor ones) of a panic flight in the last two years - but we've been able to stop both of them - however, it is an anxious business when it starts, as one is fightinf something which one can't see, and which is'nt influenced by logical processes of thought - mob stuff. However, to get back to my main argument: We have a
variety of more or less mechanical means open to us to diminish the flow of imports - all of them unpleasant to all concerned. The one logical argument - is that - and I find it hard to get away from, as a logical argument - is that we should encourage sufficient overseas provide the Australian community goods here that are now imported, to provide the Australian community with what it wants without the necessity to import them. Based on our present income from exports, we should aim at producing $25 \mathrm{~m}$. or $210 \mathrm{~m}$. worti of Eoods in Australis tiat are now being imported. This would bring us to sometining like batane in our overseas balance of payments and relieve us of the recurins
periods of anxiety about our exchange rate.

I don't know how much all this reads to rou ge some. I have been so steoped in it all that I may be short-circuitim to someone who is not dealing with this problem every day.

Our position is getting better all the time - in t:at we have at the moment threo big industries in course or esirbisit.t. themselves here - paper pulp, tin plate and basic heavy cicmiculs. Every year shows more and more such industries miarting here. ife have got to speed up this migration of industries - so that within a cripie of years, we can bridge tho gap between income and outso in cur crorscas balance of payments. 
*ventualities of further depreciation of the Australian pound or the isk of default - neither of which you people want - nor us either.

By the way, when I speak of encouraging the migration or industries from overseas to Australia - I mean this: that we shoula tooth-comb our list of imports (from wherever arising - but in particular those coming from other than the United Kingdom) and list those items that are now imported in sufficiont volume to warrant the establishment of factories to make thein in Australia. Having done this, we should go out after British manufacturers of those goods and discuss with them the establishment of branch Works here, with adequate tarife protection. So far as such goods have previously been imported (or largely imported) from non-British countries, their manufacture here means no loss (or no appreciable loss) of employment in U.K. - and it is this type of goods that we would naturally go after first.

Well, so much for this. I wanted to tell you what is in my mind, not that we have yet got very far with the idea - but I am going to try and have it pressed on with - and I hope you may see some results before lons. But I'd be glad if you'd be very cautious about having any knowledge of it, as it might well be misunderstood if anything premature is said.

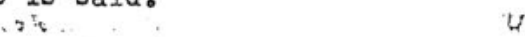

I am just reading Esher's letters and am finding them

Best of luck to you,

Yours ever -

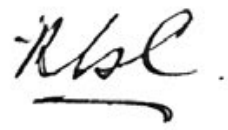


PERMISSION

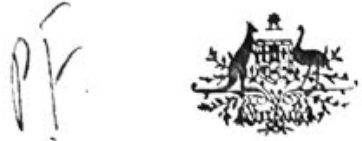

COMMONWEALTH OF AUSTRALIA.

AIR NAIL.

THE TREASURY,

CANBERRA, F.C.T

9 th June, 1936.

Personel.

Sir Maurice Fankey, G.C.B. etc.,

Orfices of the Cabinet,

2 Whitehall Garaens,

LONDON - S...1. ENG.

My dear Naurice,

My last letter to you was dated 30 th March, to which you very promptly and interestingly wrote me a handwritten letter in reply cated 20th April. In my letter I had told you something of one of my $10=$ rather 'our') major preoccupations in the shape of the high level of imports into Australia and, if continued, its effect on the balance of payments - and my own idea of the gradual and eventual solution of the problem lying in the encouragement of the migration of sufficient

industries to Australia to produce enough goods locally to take the place of, say, $25 \mathrm{~m}$. or so of imports, and so relieve the strain on our Londor. funds.

You will have recognised, I expect, in the "trade bombshell" that we have recently exploded, the result of our efforts to help the baiance of payments position. It is (on a famous precedent) divided into three parts:-

1. The imposition of severe specific duties on foreign (Japanese, in actual fact) artificial silk and cotton piecegoods. Japan has so eaten into the U.K. trade with Australia in these goods, by outrageous and continued price-cutting, that, at the present rate, within 18 months Britain wouldn't have been in the picture at ali, under the ad valorem duties that existed until recently. We had to do something to salvage some reasonable proportion of our consumption or these textiles for U.K. Even under the new duties Japan will probably still have the ma jor part of the trade - but U.K. will be able (with $7 \frac{1}{2}$. per yard against. Japan, in rayon) to regain a rair amount or her lost trade. Similarly in the case of cotton piecegoods. 


\section{-}

2. By the imposition of a license system in respect of a 11 st of named goods, we aim to deflect a couple of million pounds worth of trade from U.S.A. to U.K. Every country except U.S.A. will be given a license to export these goods to Australia. In noint of fact, the result will be that U.K. will get the vast bulk of this diversion, although some part of it will swell existing Australian manufacture, and a small proportion will go to "good customer" countrles such as France and Germany and Belgium.

3. By the alteration of duties on motor car chassis from ad valorem to a weight basis and by giving increased preference to U.K, a diversion of imports of chassis from U.S.A. and Canada to U.K. wili be brought of imports of chassis rrom U.S.A. and Canada thaiting" of imports of chassis Prom U.S.A. and Canada to the numbers imported in the 12 months just ended. We are also preparing to do everything possible to promote the manufacture of chassis in Australia, by a system of bounties per chassis (230 per chassis in the first year of their manufacture, declining annually thereafter

The things we are aiming at in all the above are two-fold:-

(i) To deflect trade from our two "bad customer" countries (i.e., countries with which we have a persistent and increasingly bad trade balance) -- U.S.A. and Canada - to the U.K., for the obvious reason that we can reasonably well count on being able to export more to U.K. in exchange for the increased imports from U.K. and

(ii) To promote and encourage industries to establish in Australia (e.g., primarily motor car chassis manufacture - but meny smalier ones as well) - and so directly reduce the volume of imports necessary to satisfy the growing purchasing power of the Australian people.

You can't make omelettes without breaking eggs - and the piercing screams You can't make are adversely affected by all the foregoing are rending the of those who arent. More subdued murmurs of assent and satisfaction come from those who have been handed a gift on a silver salver.

In another direction, but with the same general objective, we are making available 2250,000 on a $\mathcal{L}$ for $\mathcal{L}$ basis to stimulate the search for making availablralia. About 2750,000 has been spent in the past on llow oll in Australia. this activity aid as to where to look for oll and, with the best more than we did as to where to look for oli and, with in 2 or 3 years technical advice for not) as to whether there is flow 011 in we will solve the mystery (or not) as to whether there is flow oll in we wistia. 


\section{$\because \mathrm{R}: S O L D$}

ERMISSION. - $3-$

and the spending of 2250,000 on an intelligently conducted search 13, at worst, a good gamble.

There seem to be at present a number of balls in the air at the same time with which I am, in one way or another, trying to jugBle. I have a local Australian loan of $29 \mathrm{~m}$., launchod a few days ago - and Bruce has his $116 \mathrm{~m}$. conversion in London. I hope and pray that this \&l6 arm. London conversion will be all right - although the French strikes seem to have been called on just at the wrong moment by some malign influence. (Talking of courage -- Glendyne and his bold underwriters have a type and quality of courage that excites my very keen admiration).

I am also beginning to sort the cards out in preparation for the Budget - as well as to begin to get ready for a Conference with the State Governments on State and Commonwealth financial relations.

The Treasury (I suppose any Treasury) always presents innumerable problems which one would like to be able to tackle quicker than is possible. There is no lack of material to get one's teeth into. I am afraid I am a sore trial to my Treasury staff.

Yes, of course, I'd forgotten Cadogan. I can well imagine that he is the man for the F.O. Besides having definite brains, common-sense and resource, he has extreme tact and the useful adjunct that people naturally tend to like him.

Well - this is all for the moment. With all good wishes to Adeline and yourself from us both,

I am,

Yours sincerely,

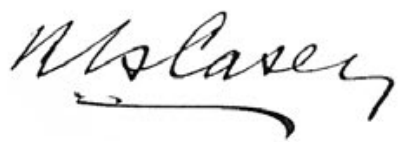


END OF REPRINT

Correspondence on the trade diversion episode 


\section{2 \\ Japan and the Australian wool industry, 1868-1936'}

\section{DCS Sissons}

\section{November 1978}

[The writer acknowledges his great debt to K Nakagawa and H Rosovsky whose 'The case of the dying kimono: the influence of changing fashions on the development of the Japanese woollen industry' (Business History Review, 1963, vol. 37, pp. 59-80) provided many of the ideas and much of the information for this paper - DCSS]

In a letter published in the Sydney Morning Herald on 6 March 1895, the New South Wales pastoralist, PN Trebeck, recalled the first attempt to develop a Japanese market for Australian wool:

In 1874 I collected all the best lots of wool, bales and cases, from our Agricultural Society's Exhibition of that year, and consigned then to Sir Harry Parkes, K.C.B., at Her B.M. Legation at Yeddo, and to his Excellency Okubo Toshimichi, Minister of the Interior Department, Yeddo. A beautiful lot of snow-white sheep and lambs' wool of Mr Kermode's was to be presented to the Mikado, and the other was for distribution among the manufacturers. In return, the Mikado sent us some good silk handkerchiefs and neckties, and also some of the cotton rugs and mats generally used in their dwellings. 
Unfortunately, nothing came of this. First, as Trebeck notes, the price of wool rose by $20-30$ per cent and the graziers lost interest. Second, and more fundamental, there were as yet no woollen manufacturers in Japan to whom it could be distributed. Things were, however, beginning to move in that direction.

When the arrival of Commodore Perry's squadron in 1853 opened Japan to Western influence, the lower classes were wearing cotton or linen kimonos and the wealthy were wearing silk. Between then and Imperial Restoration in 1868 occasioned by the overthrow of the shogunate, the only significant introduction of woollen clothing was the adoption by some of the armed services of Westernstyle uniforms. Indeed, in the years immediately preceding the restoration, the woollen material for this purpose amounted to $20-40$ per cent of Japan's total imports. The way to the adoption of Western clothing by the civil establishment was opened by the decision of the Imperial Court in 1870 to order a suit for the Emperor Meiji following the official visit of Prince Alfred, Duke of Edinburgh. ${ }^{2}$ Western uniforms were adopted by the police force and the post office in 1871, and by the embryonic railways the following year. The introduction of conscription in 1873 led to heavier imports and it was partly to conserve foreign exchange that the government decided to take the lead in establishing a pastoral and a woollen industry. To this end in 1875 it established a 7,000-acre sheep run at Shimosa astride the boundary of Chiba and Ibaragi prefectures, and in the following year sent an emissary to Germany to purchase machinery and recruit technicians for a government woollen mill, the Senjū Seiūsho, to commence production in Tokyo in $1879 .{ }^{3}$ It is in this context that early in 1878 the Home Ministry despatched to Australia a delegation led by Nagase Gikan, whose purpose was 'to make arrangements for the future regular purchase of wool at our auction sales (their government intending to manufacture the clothing of their army, police, etc.), to see the country, and to take back some sheep. ${ }^{4}$ The mission chartered two vessels and shipped 1,556 sheep from Newcastle for the Shimosa run..$^{5}$ Later in the same year, Jules Joubert, the organising secretary of the Australian exhibits at the Paris Universal Exhibition, reported that in response to an approach by the Japanese minister to France he had presented him with some of the New South Wales fleeces exhibited. Joubert justified his action with the prophetic sentence:

\footnotetext{
Osaka Yōfukushō Dōgyōkumiai, Nihon Yōfuku Enkakushi (Osaka Yōfukusho Dōgyōkumiai, 1930), p. 65.

K Itō, Nihon Yōmō Kögyōron (Tokyo: Tōyō Keizai Shimpōsha, 1957), p. $28-32$.

4 Monckton Synnot, letter dated 29 July 1878, Argus (Melbourne), 3 August 1878. See also Seiji Keizai Kenkyūjo (ed.), Nihon Yōmō Kōgyōshi (Tokyo: Seiji Keizai Kenkyūjo, 1960), p. 339.

5 The Statistical Register of N.S.W. 1878 shows the export to Japan of 1,526 sheep raised in the colony valued at 750 and 30 sheep raised outside the colony valued at 250. According to Itō (Nihon Yömō Kögyōron, 1957) they comprised merinos, southdowns, lincolns and cotswolds. According to Dalgety's Annual Wool Review (1931/32, p. 149), these sheep were principally from 'Gamboola' at Molong and 'Beltrees' at Scone.
} 
As a result of the adoption of European civilization by the people of Japan there is reason to expect that a demand for the wool of the Colony will arise, and that a commercial intercourse may be established between Sydney and Yokohama, which is destined to grow into large dimensions. ${ }^{6}$

The attempt, under government leadership, to establish a significant sheep industry proved unsuccessful and was abandoned in about $1880 .^{7}$ The government woollen mill, however, was a success. Its output expanded from 22,406 yards in 1879 to 273,754 yards in $1889 .{ }^{8}$ Initially it rolled principally on Chinese wool, but an experiment in purchasing in Australia appears to have been made very soon after it commenced operations when a small amount was bought from a Melbourne broker named Arnold (probably Geo Arnold \& Co.) through one of the foreign trading houses in Yokohama (possibly H Ahrens \& Co.). ${ }^{9}$ For the next few years, however, its Australian wool must have been purchased in London. In 1888 the deputy head of the government mill, Nozaki Teichi, visited Australia in the course of his duties and it was in this year that the export statistics of an Australian colony first record Japan as an export market for Australian wool - 196,561 pounds of scoured wool from Victoria.

Besides conserving foreign exchange by supplying local cloth for military and other uniforms, one of the purposes in establishing the government mill had been to develop the expertise and experience on the basis of which private firms could develop. From about 1886 a few small mills emerged. It was on behalf of one of these, Osaka Keito Bōseki, that in 1890 the first consignment of Australian wool (187 bales of scoured merino from James Rutherford's 'Murrumbidgerie' property near Dubbo) was bought at an Australian auction by a Japanese buyer (Kanematsu, which had just opened its Sydney office) ${ }^{10} \mathrm{We}$ are told that 'owing to the inexperience of the company, the wool proved too good and too expensive to be used profitably'. ${ }^{11}$ Indeed, Osaka Keito Bōseki failed later in that year and had to be reconstructed. ${ }^{12}$

Japan's demand for woollen clothing entailed an increased demand for Australian wool - whether Japan consumed it in the form of cloth manufactured in Europe, Australian wool purchased in London, or wool purchased in Australia. There was always some demand for Australian crossbred wool - for military uniforms, blankets and modern outer garments such as the tombi, nijümawashi, and azumakōto - cloaks developed to be worn over the traditional wide-sleeved kimono

\footnotetext{
6 P Geeves, 'Japan's first acquisition of Australian wool', Newsletter of the Royal Australian Historical Society, no. 131 (November, 1973), pp. 4-5.

7 Itō, Nihon Yōmō Kögyōron, 1957, p. 29.

8 M Kajinishi (ed.), Gendai Nihon Sangyō Hattatsushi (Tokyo: Kōjunsha, 1964), vol. 11, p. 167.

9 T Ichikawa, Nichigō Kankeishi, (Tokyo: Nichigō Kyōkai, privately printed, c 1954) p. 183.

10 Ichikawa, Nichigō Kankeishi, c. 1954, p. 183.

11 Dalgety's Annual Wool Review, 1928/29, p. 137.

12 Itō, Nihon Yōmō Kögyōron, 1957, p. 34.
} 
to protect the wearer against the weather. But one of the essential requirements of the kimono gave the Japanese from the start a bias towards merino that they had not shaken off decades after they had changed to Western dress (for example, as late as the period 1953-55, 89 per cent of Australian wool exported to Japan was merino while the average exported to other countries was only 75 per cent). Parts of the kimono touch the skin and when the Japanese began to wear woollen kimonos they required that it be soft to the skin like the silk it was replacing. ${ }^{13}$

At the outbreak of the Sino-Japanese War in 1894, the situation was roughly as follows: there was the government mill producing an unsophisticated product of reasonable quality, and about 10 firms producing the same thing - greatcoat material, flannel and blankets - to inferior standards. The war led to a great increase in production. For example, output at the government mill in 1895 was almost treble that in 1893. Over the same period, the quantity of wool exported to Japan direct from New South Wales and Victoria rose from 91,239 pounds to $1,531,776$ pounds. Uniforms (civil as well as military - in the 1880s, uniforms were prescribed for the students of government universities and colleges), however, amounted to a very small proportion of consumption. The remainder came from imports.

Much of the wool consumed in Japan at that time was in the form of delaine (mousselin de laine). ${ }^{14}$ In 1896 it accounted for 40 per cent of imported woollen fabrics. It was imported plain and dyed locally by the traditional Yüzen technique developed for dyeing silks. This light, soft and beautifully patterned material was particularly suited for women and children's wear (kimono, obi and haori). The rest of the imports were serges for men's kimono and, to a lesser but nevertheless significant extent, material for Western clothing for men. By the end of the century, in the cities, businessmen, teachers, doctors, bankers, etc. were wearing suits during business hours.

It was through the production of delaine for traditional Japanese clothing that the Japanese began to build up an efficient civil worsted industry. The demand was there and the technical processes were relatively simple. It was in 1898 that the first integrated plants for spinning and weaving delaine came into production Mosurin Bōshoku KK at Osaka (9,600 spindles; 200 looms) and Tokyo Mosurin Bōshoku KK (16 spinning frames; 660 looms and 350 hand looms). ${ }^{15}$ By 1904 more delaine was produced locally than was imported, and in the following year a small export trade commenced. ${ }^{16}$ Initially, the traditional patterns on delaine had

13 Itō, Nihon Yōmō Kögyōron, 1957, p. 96.

14 'A very light worsted cloth ... woven in plain weave from single yarns'(H Spibey (ed.) The British Wool Manual (Buxton: Columbine, 1969), p. 305). The specifications of a famous example marketed by Nihon Keori as Mosurin \#l in 1913 were: warp - merino 1/54, 62 per inch; weft — merino 1/72, 70 per inch; weight — 64 gm per yd (Nihon Keori Roküjünen-shi (Tokyo: Nihon Keori, 1957), p. 122).

15 Kajinishi, Gendai Nihon Sangyō Hattatsushi, 1964, vol. 11, p. 173.

16 Ichikawa, Nichigō Kankeishi, c. 1954, pp. 190-91. 
to be hand printed; but in about 1907, after years of experimenting, a technique was perfected whereby this could be done by machine. This brought down the price and increased the demand. It was also in the course of producing delaine that the Japanese in 1911 finally entered into the one process in the worsted industry hitherto reserved to the foreigner - wool combing. Up till that time all Japanese worsteds had been produced either from imported tops or from imported yarns. In that year Nihon Keori, with the aid of German equipment and technicians, produced the first Japanese tops and carried out every process in the transformation of raw wool into delaine. ${ }^{17}$

Despite the large increase in the production of cloth for military uniforms by both the government and private mills during the Russo-Japanese war, the increase in the output of delaine was the more significant: in the 18-year period to 1912 the former increased fivefold, the latter tenfold. ${ }^{18}$

In the 1890s, the use of imported patterned serges had become popular for men's and women's kimonos and for the long traditional skirt (bakama) adopted as the official uniform for high school girls. The local production of these serges posed greater problems than had the local production of delaine (which lent itself to large-scale production in integrated plants). Because of the small runs, the high level of quality control, and the sophisticated finishing processes required, this part of the industry was developed by small weavers (many of them in the Bisai region of Aichi prefecture) who had previously worked with cottons. Until about 1926, they relied almost entirely on imported yarn. By about 1903 they were producing serges of a quality comparable with imports. Thereafter, the local product made rapid advances in this part of the market. ${ }^{19}$ By 1913 the local annual production of these serges for traditional Japanese clothing (kijakuji) had reached 9,754,000 yards.

The local production of serges for Western clothing (yōfuku-ji) dates from the early 1920s. Demand increased after the 1923 earthquake, many of whose victims replaced their clothing with a greater proportion of Western things. In 1926 the annual value of $y \bar{o} f u k u-j i$ and cloth for uniforms (rasha) overtook that of kijakuji. Then, in the late 1920s, some women began to follow Western fashions. Symbolic of this trend was the appearance of the appappa ('a plain one-piece summer dress like a Western night-gown') on the streets of Tokyo in 1927. ${ }^{20}$ The 1930s marked the widespread adoption of Western clothing by working men and women in the cities. This was reflected in the 16-fold increase in the output of yofuku$j i$ from $3,402,000$ yards in 1924 to $53,811,000$ yards in 1934. This, however,

17 Nihon Keori Rokujünen-shi, 1957, pp. 120-21.

18 Ito, Nihon Yōmō Kögyōron, 1957, p. 40.

19 Ito Hitosuji (Tokyo: Daidō Keori, 1960), vol. 1, p. 157; H. Tamaki (ed.), Aichi-Ken Keorimono-shi (Toyohashi: Aichi Daigaku, 1957), pp. 13-16; Daidō Keori KK, Ito Hitosuji (Tokyo: Daidō Keori KK 1960), vol. 1, p. 157.

20 Nihon Keori Rokujünen-shi, 1957, pp. 236-37. 
was not yet at the expense of kijaku-ji, which reached its peak the following year. Nor had it destroyed the demand for delaine, which, though below its 1927 peak of $174,588,000$ yards, was still $134,241,000$ yards in $1935 .{ }^{21}$

This increase in Japan's production of woollen textiles was accompanied by a dramatic increase in Japan's purchases of wool in Australia - 933,836 pounds ${ }^{22}$ in $1901 ; 8,186,433$ pounds in $1911 ; 55,827,121$ pounds in $1921-22 ; 192,181,022$ pounds in 1931-32 23 (in which year Japan overtook France as Australia's secondlargest market for this commodity). This was much to Australia's advantage and there were many Australians who were glad to acknowledge this. For example, in 1936 Sir Graham Waddell, the former chairman of the Australian Woolgrowers Council, spoke of Japan as having kept the wool market together during the depression. ${ }^{24}$ The Bank of New South Wales in its monthly circular in March 1934 took a similar view and, on the basis of this and other premises, made the following observation:

In British countries, the talk often centres around the possibility of organizing the British Empire as an economic unit. Many have doubted the desirability of any such objective, and even if it were desirable, it is extremely doubtful if it were possible. The trend in Great Britain towards a diminution in imports of foodstuffs raises still further difficulties, and in the face of the rapid growth of Japanese industry, it is difficult to resist the conclusion that any survey of the rational ends of Australian trade policy in the circumstances of today must offer a more prominent place to interchange of goods with the East than it has occupied in the past. ${ }^{25}$

Surprisingly, even in the wool industry there were at that time some Australians who regarded Japan's increasing purchases of Australian wool with some anxiety. In April 1936, when the Australian Government, in an attempt to gain increased access for Australian meat in the United Kingdom market by providing greater protection to British textiles against increasing Japanese competition, was about to raise the duties on imported Japanese cotton and rayon piece goods and thereby risk provoking the Japanese to retaliate by diverting her wool purchases to other markets, WA Gibson, the general manager of Goldsbrough Mort \& Co., (one of the largest wool-broking firms) supported this policy. One of the reasons why he did so was his conviction that:

21 Itō, Nihon Yömō Kögyōron, 1957, pp. 216, 218.

22 Official Yearbook of the Commonwealth of Australia, 1901-07, p. 292.

23 Kanematsu Shōten, Gōshū (Tokyo: Kanematsu Shōten, 1943), pp. 548-56.

24 Graziers Association of NSW, Annual Conference March 1936 - Verbatim Minutes, pp. 177-80. E Masey elaborated on this in his Is it Necessary? - An Examination of the Commonwealth Government's Trade Diversion Policy (Sydney, 1936), pp. 8-9.

25 Bank of New South Wales, 'Australia and industrial development in Japan', Circular, no. 4 (March 1934), p. 9. 
if nothing is done, to the extent of their capacity the Japanese will oust other countries out of the market for woollen and other products, just as they have done in a large measure in the case of cotton ... It might take some time to adjust the conditions of the market if we compel the Japanese to refrain from buying wool from us ... but eventually the result would be that, instead of supplying Japan with our wool to enable them to oust other producers from the markets of the world, the wool would go to countries that would supply us with goods, the importation of which would not have such a disastrous effect on our local manufacturers. ${ }^{26}$

This was an old fallacy. When, in the early 1890s, Alexander Marks had tried to secure funds from the Woolgrowers' Association in Victoria to promote the establishment of a woollen industry in Japan, the response had been: 'If we gain customers in Japan we shall lose them in Europe, and so shall be no better off.' ${ }^{27}$ In the 1930s there was certainly no reason why the established European exporters in the wool textiles industry should relish competition from Japan. It is, indeed, not surprising that at the conference of the International Wool Textile Organization in Rome in June 1936 the representative of the British woollen industry drew attention to the tenfold expansion in Japan's export of woollen tissues between 1931 and 1933 and that a proposal to set up a committee to study Japanese competition was carried unanimously. ${ }^{28}$ This expansion was to continue - by a factor of 3.6 between 1933 and $1935 .^{29}$ But Britain's exports of woollen tissues also increased over this period - albeit at a more modest rate (from 25 million in 1931 to 30 million in 1935)..$^{30}$ More significant from Australia's point of view was the fact that exports constituted only a small proportion of the production of the Japanese industry (less than 9 per cent in 1935). If, in the period 1931 to 1935 , her exports had grown from $¥ 1.5$ million to $¥ 33.3$ million, her production had grown from $¥ 153.8$ million to $¥ 296.2$ million over the same period. ${ }^{31}$ As in the past, Japan's demand for Australian wool was, essentially, an addition to existing demand - brought about by an increase in the prosperity of her people and the growth of her population. It remains so to this day. For example, in 1973 Japan, though the world's largest importer of wool, occupied only sixth place as an exporter of woollen tissues. ${ }^{32}$

Almost equally far-fetched was the fear that the advantages accruing from increased purchases of Australian wool by the Japanese might be more than counterbalanced by the additional power that this might confer on them to manipulate the market.

\footnotetext{
26 General Manager to Joint Managers, Sydney, 23 April 1936 (Australian National University Archives, Goldsbrough Mort Collection, 2A/30, vol. 35, pp. 277-78).

27 'Wool trade with the East', 10 April 1908, in the possession of Winchcombe, Carson Ltd.

28 Guardian (Manchester), 21 June 1934; Argus, 22 June 1934.

29 Itō, Nihon Yōmō Kögyōron, 1957, p. 216.

30 Wool Year Book (Manchester: Textile Mercury), 1929-37.

31 Itō, Nihon Yōmō Kōgyōron, 1957,

32 Sen’i Nenkan (Tokyo: Nihon Sen'i Shimbunsha, 1975), p. 277.
} 
Gibson's successor at Goldsbrough Mort, H Le M Latrielle, appears to have thought along these lines. A few months later, when the duties had been raised and the Japanese had retaliated by boycotting the Australian wool sales, he wrote:

had matters been allowed to take their ordinary course - it might easily happen that Japan would be buying 1,000,000 bales of wool, or perhaps more, in which case her predominance in the market would have been the cause of great uneasiness - even to the most shortsighted woolgrower. ${ }^{33}$

There were, however, many in the wool industry who took a different view. Japan's eventual domination of the market was hypothetical: Yorkshire's domination was a fact. ${ }^{34}$

After the boycott of the Australian wool sales had lasted for six months, a settlement was ultimately reached on 26 December 1936 in which trade was resumed at a substantially lower level than before the dispute. A quota of 153.75 million yards was placed on the import of Japanese cotton and rayon piece-goods for the period 1 January 1937 - 30 June 1938, and Japan reduced to 800,000 bales the quantities of wool for which she would grant import permits over the same period. (In so far as Japan had purchased no Australian wool during the period June to December 1936, this was equivalent to an annual average of 400,000 bales over the two years 1936/37 and 1937/38 in comparison with Japan's purchases in Australia of 710,000 bales in 1934/35 and 785,000 bales in 1935/36.) In fact, instead of 800,000 bales, only 524,181 bales were purchased. ${ }^{35}$ This was partly the result of the Japanese economy being placed increasingly on a wartime basis after the outbreak of hostilities on China in 1937.

In the postwar period, the first bale of Australian wool arrived at Yokkaichi on the SS Eastern on 8 June 1947. Recovery was slow, but sure. In 1956/57 wool imports from Australia exceeded the prewar record. In 1959/60 Japan displaced Great Britain as Australia's premier wool market. She remains in that position today.

DCS Sissons

Department of International Relations

Research School of Pacific Studies

Australian National University

30 November 1978

33 Gen. Manager to A Allan Elder, 6 August 1936 (Goldsbrough Mort Collection 2A/30, vol. 36, p. 66).

34 The WA representatives on the Australian Wool-Growers Council were particularly insistent that Yorkshire's buying strength was such that groups of their buyers were able to bear the market by forming 'pies' in which one member bid on behalf of all. This was also known as 'lot-splitting'. See, for example, WL Sanderson to Sir Henry Gullett, 6 August 1936 (Australian National University Archives, Accession No. 256, Graziers Association of NSW Correspondence, LG 105-1936, Japan Trade Dispute, book 2).

35 Nihon Yōmō Yunyū Dōgyōkai, Nihon Yōmō Yunyū Dōgyōkai to Wagakuni Yōmō Yunyū Nanajūyonen No Ayumi (Tokyo: 1961), pp. 87-88. 


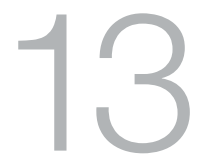

\title{
James Murdoch (1856-1921): Historian, teacher and much else besides
}

\author{
In Transactions of the Asiatic Society of Japan, \\ 4th series, Vol. 2, pp. 1-57, 1987.
}





\title{
James Murdoch (1856-1921) \\ Historian, Teacher and Much Else Besides
}

\author{
D. C. S. SIsSONS
}

Ten years ago one might have said that there was no need for an article on Murdoch-that his three-volume History of Japan and his association with William Lane's 'New Australia' commune in Paraguay were a sufficient guarantee against oblivion. But in 1977 the Japan Foundation printed a review of Japanese studies in Australia in which Murdoch received no mention. ${ }^{1}$ This, no doubt, would have afforded him some amusement. It is to Sansom that we owe the image of Murdoch's shade "happily pursuing his studies in the Elysian fields, arguing now and then in his own Doric with Rhadamanthus". ${ }^{2}$ Throughout his life he expended much ink jousting with establishments. Perhaps he remarked to Rhadamanthus how satisfying it is to the iconoclast to find that he and his works have escaped becoming authorities.

The third, posthumous, volume of Murdoch's History ${ }^{3}$ includes a 4,000-word biographical foreword (lifted without acknowledgement from the obituary columns of the Japan Chronicle ${ }^{4}$ ). Insofar as this was written by someone who was obviously acquainted with

The author is Research Fcllow in the Research School of Pacific Studies, The Australian National University, Canberra.

1 Japan Foundation Newsletter, 5:1, April 1977, p. 12. According to this review, the Department of Oriental Studies at Sydney University (to which Murdoch was appointed in 1918) was founded in 1922 by Arthur Sadler (Murdoch's successor)!

$2 \mathrm{G}$. Sansom, 'Address at the Annual Ceremony of the School of Oriental and African Studies', 1956, reproduced in Journol of Asian Studies, 24:4, 1956, p. 566.

$3 \mathrm{~J}$. Murdoch, A History of Japan: Vol HI, The Tokugawa Epoch 1652-1868, edited by J. H. Longford, London, 1926.

4 This journal (which appeared in both a daily and a weekly edition) was known until 1905 as the Kobe Choronicle. It then changed its name to the Japan Chronicle but remained under the previous editorship and ownership. Throughout this article it is referred to merely as the Chronicle. 
Murdoch and his work, ${ }^{5}$ one may ask whether, since it is readily available in any library, there is any need to go over old ground. But the following reasons alone seem sufficient to justify another biographical article: (i) the obituary contains a number of inaccuracies and sometimes in its description of Murdoch's achievements is more adulatory than informative; (ii) the author appears to lack first-hand knowledge of Murdoch's activities before his second visit to Japan (1889) and after his return to Australia (1917). These are unfortunate gaps. To the Australian historian, Murdoch's writings in the first period provide an interesting example both of the rapid and thoroughgoing acculturation of the British migrant in Australia and of radical colonial thought on such important issues of the day as republicanism, land ownership, social equality and coloured immigration. Similarly, his activities in the later period cast some light on the origins of the military intelligence community in Australia and on the emergence of distinctively Australian attitudes towards the 'Pacific Question'.

\section{Early Years}

James Murdoch, the son william Murdoch and his wife, Helen (née McDonald), was born in the parish of Fetteresso, Kincardineshire, on 27 September 1856. About his parents the parish records $s^{6}$ tell us little more than at the time of their marriage the previous year they were employed as a "farm servant" and as a domestic at 'Redcloak' (a farm which lies within the parish about a mile outside the town of Stonehaven), and that Helen died of tuberculosis when James was ten months old. But Murdoch, himself, tells us something. I have little doubt that in his short story, 'The Wooing of Webster', Murdoch, through the mouth of Francis Webster, is spcaking about his own family:

5 Japan Weekly Chronicle, 17 November 1921. As the Chronicle's obituarist wc may exclude two likely candidates, Yamagata Iso (his former student) and Miyata Mineuchi (his assistant in Sydncy). Neither was in Japan at the time of Murdoch's death. Furthermore, Miyata would not have placed Murdoch's chair in the wrong capital, Melbourne. Robert Young, the Chronicle's cditor, would himself have had sufficient knowledge of Murdoch for the task; he had published the first volume of Murdoch's History in 1903 and, in the years that followed, Murdoch had written numerous articles for him.

6 Reproduced in Sugiyama Tamaki, 'James Murcioch (II): A Bibliographical Study', Okayama Shödai Ronsō, 19:2, 1984, pp. 2-6. 
My folks had been swinkers and hedgers and hinds and drudges on the lands of a master off and on for generations. That's my father's forbears. But, notwithstanding that, we have our coat-of-arms, and can trace ourselves right away back to the day of Bannockburn, when we got them. My mother-she died when I was a brat in the cradle-was a Macdonald of Glencoe. And if we didn't have the dollars to maintain our dignity, we had pride enough any way to say nothing about it. My governor, in spite of his drudging, was the most outspoken wight in the country-side, and made Minister and Laird alike sit up and listen when he had a mind to. When the innovation in the posture of prayer came about in the kirk, ${ }^{7}$ he stood up like the valiant man he was and led a forlorn hope of one against the embattled authorities. God rest his soul-he had spunk and smeddum for a barnful.

But he had also a plentiful lack of bawbees, because he was too honest to get rich by overreaching his neighbours."

This was written some months after Murdoch had received the news of his father's death; and other parts of the same short story are, demonstrably, autobiographical.

Very little is known about Murdoch's boyhood. According to his obituary in the Aberdeen University Review, his help was required at home and it was not until he was about eleven that he started at the local school. ${ }^{9}$ Furthermore, he soon had to leave and work as a grocer's boy. ${ }^{10}$ This suggests further that Murdoch and Francis Webster may be one and the same person:

I was thirteen when I was introduced to the dignity of labour and the blessings of industry, and twelve hours a day was the tale of my toil, and fourteen on Saturdays, which was payday-it being highly proper that apprentices should be duly prepared to appreciate the holy calm of the Sabbath . . Four hungry years of this soul-eating treadmill, during which my only joy was stoten snatches of books I kept hid in holes all over the shop. . ..."1

Years later an Aberdeen book-seller remembered the boy who

7 This controversy began in the presbytery of Aberdeen. The congregation of East Church on the initiative of the incumbent, Revd J. M. Lang (1856-1858), adopted the practice of kneeling for prayer and standing for singing, until required by the Presbytery to abandon such innovations (W. T. Maxwell, $A$ History of Worship in the Chutch of Scolland, Oxford, 1955, pp. 167-68).

8 'A. M.', From Australia and Japan, London, 1892, pp. 97-98.

${ }^{9}$ Aberdeen University Review, vol. 9, p. 109.

${ }^{10}$ M. W. MacCallum, 'Professor James Murdoch', Sydney Morning Herald, 5 May 1921.

11 From Australia and Japan, p. 98. 
"would walk in the sixteen miles from Stonehaven for a new book and walk back again". 12

Murdoch was a pupil at Fetteresso parish school when, on 13 April 1875 at the age of eighteen, he gained a free place at the Grammar School, Old Aberdeen. ${ }^{13}$ Presumably he had resumed his studies at the parish school after some years at work. Perhaps, like Francis Webster, he had returned to the parish school as a hard-ridden pupil-teacher. He was at the Grammar School for six months, cramming for the Bursary examination for entrance to the University of Aberdeen. It was a small establishment-about forty boys aged from about seven to eighteen divided into two classes, studying Latin, Greek, mathematics and English, with the emphasis on the first two. Since Latin prose composition attracted one third of the marks at the Bursary examination, one hour a day, four days a week was devoted to it. ${ }^{14}$ As critics of the system pointed out, at the examination "the most accomplished linguist in Scotland might compete in vain against a Banffshire plough-boy who hardly knew his own language, and not one word of any other living language, but had acquired the knack of writing grammatical Latin prose" ${ }^{15}$ Such a régime equipped Murdoch in after years readily to master a number of written languages and to express himself powerfully, though without grace or economy, in his own.

Murdoch topped the Bursary examination. The announcement of the results in King's College quad was one of the proudest moments in his life:

That was a moment, my son! A moment worth two years, six years, ten years of an ordinary life! I have never hcard, and never shall ever hear, music like that cheer. You sec, I had just as good as breasted the tape first from fifty yards back of scratch in the quarter, and they knew it and shouted like wild things. ${ }^{16}$

12 W. L. Mackenzie, 'My Friend James Murdoch', Aberdeen University Review, vol 9, p. 228.

13 Archivist, University of Aberdeen, to author, 14 July 1982 and 6 September 1982.

14 Education Commission (Scotland), Report on the State of Education in the Burgh and Middle-Class Schools in Scotland (Great Britain, House of Commons, Papers, 1867-68, vol 29), vol 2, pp. 24-26.

${ }^{15}$ Ibid., vol. 1, pp. 115-16. For a defence of the system see $W$. D. Geddes, Classical Education in the Noth of Stotland, Edinburgh, 1869, pp. 25-33.

16 From Australia and Japan, p. 101. 


\section{University Student (1875-1880)}

The Scottish arts degree was broader than the typical degree taken by classics students in England. It embraced four elements: Latin and Greek; philosophy; mathemetics (including 'natural philosophy', that is, physics); and English. At Aberdeen there was, in addition, a compulsory science subject, natural history. ${ }^{17}$ The philosophy was taught at a relatively high standard. At the same time as they were doing very elementary Greek and mathematics, Scottish students were able to pursue arguments on such topics as Hume's theory of causality and Berkeley's theory of perception. ${ }^{18}$ The undergraduate course was of four years duration. In his first year Murdoch took Greek, Latin and English and topped the examinations in each. ${ }^{19}$ In his third year he took seventh place in logic but failed in senior mathematics and secured only a bare pass (forty-second place) in natural philosophy. As these third year results are identical with 'Webster's' we may accept the latter's explanation of them:

I just did nothing, or rather I allowed higher mathematics and physics to go to the devil, instead of wrestling with them like a man, as I ought to have done that session. I read snatches of Philosophy, and became a mild sort of Cyrenaic. And novels and romances, and ail the literary pastry, and jam, and sponge-cakes, and the rubbish generally that gives you incurable mental dyspepsia, I devoured till I was surfeited and scunnered . . . Towards examination time I did try to pull up a bit and make up the leeway, but the stuff I did was as pithless and worthless as moist muck. . Well, the smash came, and it was a smash! A miserable last prize in one class, gulfed in another, and ploughed in the third . . . The First Bursar and First Prizeman utterly ploughed. . . 20

Perhaps with Murdoch, as with 'Webster', it was the response to rejection by a woman in favour of a more affluent and socially presentable suitor. In his fourth year Murdoch achieved first class honours in classics, second class honours in mental philosophy, honourable mention (nineteenth place) in moral philosophy, and a

17 Report of Royal Commission on Scottish Universities (Great Britain, House of Commons, Papers, 1878, vol. 32), p. 24.

18 G. B. Davie, The Demotratic Intellect, Edinburgh, 1964, p. 12.

19 Murdoch's results for each year of the course are reproduccd by Sugiyama, 'James Murdoch (JI)', pp. 9-11, from Universify of Aberdecn, Faculty of Arts Students Register, vol. 1, 1860/61-1891/92.

20 From Australia and Japan, pp. 10-11. 
pass (forty-second place) in natural history and was awarded the Simpson Greek Prize, the Seafield Latin Medal and the Fullerton Travelling Scholarship ( 100 per annum for two years). ${ }^{21}$

In the obituary published in the Glasgow Bulletin we have the following picture of Murdoch as an undergraduate as seen by a contemporary:

At Aberdeen University he was regarded by seniors as well as us juniors, with admiration approaching to awe of his extraordinary cleverness. $\mathrm{He}$ was otherwise different from the common undergraduate. He had worked himself up to University level with very little tutoring or schooling, and as he was older than most of his classmates [by about three years], it is probable that he had to work for his living at the same time, though he seemed to pass through his course with financial case. Anyhow, he was not only aloof and inclin$e d$ to be dogmatic when drawn into debate but he had a curious mental twist that might have repelled worship. It did not; his queerness did not count against his scholarship and quickness of apprehension that was quite out of the common. . . True to character, he had a queer start in workaday life, and I have always wondered how he 'got on' with fellow writers in Japan and Australia, but he certainly made a fine use of his exceptional brain. . . .22

Too much should not be made of Murdoch's aloofness as an undergraduate. It does not appear to have prevented his participating in student politics. A brief item in the Aberdeen Free Press of 7 November 1878 indicates that he was one of the small group that (unsuccessfully) ran Disraeli's Home Secretary, Cross, against the young Lord Roseberry in the election for the Lord Rectorship of the University:

Mr Murdoch next ascended the platform and having somewhat ostentatiously flaunted the blue ribbon on his 'Glengarry' proceeded to assert that Imperial politics had nothing to do with university affairs-('Oh', applause and hisses). 'They did not bring forward $\mathrm{Mr}$ Cross as a conservative candidate-(groans and cheers). The arguments to the contrary were claptrap-(uproar). They brought forward $\mathrm{Mr}$ Cross because he would be able to carry the university reforms through Parliament-('Oh', and groans). At this stage a tremendous row took place at the back of the hall. ${ }^{29}$

Nor did this aloofness prevent his participating in student pranks.

21 University of Aberdecn, Calendar, 1881/1882, p. 104.

22 'A Scottish Scholar' by 'D', Bulletin 30 December 1921. "D', is presumably James Davidion, the Bulletin's assistant editor, who graduated from Aberdecn in 1881 .

23 Murdoch himself refers to this in Japan Echo, 15 Nobember 1890, p. 34. 
in later years he related how he was taken into custody by the police just as he was completing the task of collecting two dozen door-knockers and bell-pulls from the front entrances of eminent citizens. One of these belonged to Professor 'Davie'24 who, Murdoch writes, "had an unreasoning and unholy 'down' on me ever since I had the ill-advised temerity to argue matters with him when he insisted on fining me". Reluctantly compelled to return the bell-pull, Murdoch evened the score a few days later when he introduced a large and none-too-clean boar through the window of 'Davie's' drawing-room while he was entertaining 'the intellect and fashion of the University". ${ }^{25}$

Classics were taught at a considerably lower standard in the Scottish than in the English universities. Hence when Murdocb and other Scotsmen of promise wert on to Oxford they enrolled as undergraduates. Murdoch entered Worcester College in October 1879 and was awarded a Sir Thomas Cookes scholarship and Lady Holford exhibition. There is, however, no record of his taking any University examination after Responsions, which he passed in March 1880. ${ }^{26}$ He was back at Aberdeen during the $1880-1881$ session as Assistant to the professor of Greek. His duties included taking the advanced stream of the first year Greek class ${ }^{27}$ and lecturing on Sanskrit. ${ }^{28}$ A possible explanation of why Murdoch cut short his time at Oxford is his marriage. On 26 June 1880 at Lyme Regis he wed Lucy Parkes, the twenty-year-old daughter of a minister of the Independent church residing there. Possibly Murdoch felt that, with a wife to support, Oxford was a luxury that he could not afford. The Chronicle obituary states that, after Oxford, he went on to Göttingen, where he studied Sanskrit under Benfey, and to the Sorbonne. The fact that in March 1881, at a meeting of the Aberdeen Literary Society, he presented a paper on the Ramayano ${ }^{29}$ confirms that Sanskrit must have been one of his prin-

24 Presumably David Thompson, Professor of Natural Philosophy (W. K. Leask, 'The Two Davies', Interamna Borealis, Abcrdeen, 1917, pp. 122ff. I am in. debted to the Archivist, University of Aberdecn, for drawing this to my attention).

25 Boomerang, 18 May 1889 , p. 17.

26 Assistant archivist, Oxford University, to editor, Australian Dictionary of Biography, 10 October 1980.

27 Mackenzje, 'My Friend James Murdoch', pp. 229, 231.

28 In the advertisement for his History of Japan appcaring on the end-paper of his Inaugural Lecture at Sydney (Australia Must Prepare, Sydney, 1919) he is described as "sometime Assistant-Professor of Greek and Lecturer in Sanskrit in Aberdeen University".

29 This was published, after Murdoch's arrival in Austratia, in the Victorian Review 6:33, 1882, pp. 326-49. 
cipal interests in 1880. Nevertheless, his period with Benfey (and at the Sorbonne) must, of necessity, have been brief. It was also, no doubt, for family reasons that, when in November 1880 the Athenaeum advertised the headmastership of the new Grammar School at Maryborough in Queensland, with a salary of $\$ 500$ per annum and a six-roomed residence, Murdoch applied. The telegram informing him of his appointment was despatched to him on 8 March $1881 .^{30} \mathrm{~A}$ month later, on $10 \mathrm{April}$ at Lyme Regis, his first and only child, Kenneth Macdonald Murdoch, was born.

\section{Murdoch in Queensiand 1881-1888}

The Murdochs arrived in Queensland on 30 July 1881 aboard the British India vessel, Dorunda.

There are strong overtones of agnosticism and anti-clericalism in Murdoch's paper on the Ramayama. A statement in the Athenaeum advertisement that "no Clerk in Holy Orders or Public Minister of Religion" was eligible for appointment to the headmastership may have led him to hope that at Maryborough he would be among kindred spirits. If so, he was to be disappointed.

In the first week of February 1885 Murdoch on his return from an education conference in New Zealand tendered his resignation, to take effect on $30 \mathrm{~J}$ une. ${ }^{31}$ It was accepted. On 5 March, however, the trustees summarily dismissed him for resisting their authority to require members of his staff to give lessons at the Girls' Grammar School as well as at the Boys'. ${ }^{32}$ This may not have been an isolated issue. It is possible that Murdoch had already become unpopular with the trustees for other reasons. For example, one reader of the Wide Bay and Burnett News wrote to the editor that

there have been hints and inuendoes thrown out that Mr Murdoch's dismissal has nothing to do with the working of the school, in fact, is on purely domestic grounds; in other words the little demon-scandal-has crept within the Grammar School confines and has chosen another besides the head master for its victims. . . .33

${ }^{30} \mathrm{I}$ am indebted for this information to Mr J. R. L Hyne, C.M.G., of Kent Street, Maryborough, who has custody of the first outwards letter-book of the Grammar School's Board of Trustees.

31 Maryborough Chronicle, 7 February 1885.

32 Wide Bay $\&$ Burnett News, 12 March 1885 . Cuttings on this subject dated 12 and 17 March are included in file EDU/BC 251 in the Qucensland State Archives.

33 Ibid., 17 March 1885, emphasis in original. 
This suggests that Murdoch's first marriage may already have begun to disintegrate. Another letter to the editor demanded that the boys be taught "by teachers who at least respect the common religious beliefs, which are the foundation of character and fitness for our Christian way of living"' ${ }^{34}$

According to the Maryborough Chronicle, Murdoch on 6 March "took formal leave of the boys, who have good reason for viewing his departure with genuine regret, for in school, in the playground or in the social circle, Mr Murdoch has ever placed himself on the best terms with his pupils and posed before them as the scholar, the friend and the gentleman" 35

From Maryborough Murdoch went as second master to Brisbane Grammar School. His first year there must have been exhausting; for concurrently he was reading for the Bar examinations. He sat these at honours level in April 1886. There were eight two-hour papers each consisting of fifteen questions. He received 80 per cent in one paper and good marks in another five. In two papers, however, he secured only 24 per cent and 25 per cent and this reduced his overall average to 47 per cent. Consequently, he was failed. He then brought an action against the Board of Examiners in the Supreme Court, claiming that his performance had been sufficient to entitle him to admission. His counsel contended that the Board in setting questions that were too difficult to be answered in the time allotted had acted ultra vires. The judge accepted this and referred the matter back to the Board for their reconsideration, urging on them the desirability of conducting a viva voce supplementary examination. The Board, however, appealed to the full court, which rejected Murdoch's argument. It was not, however, without sympathy for him, and confirmed so much of the the original order as would enable him to go up for reexamination without paying a second fee. In his summing up, the Chief Justice pointed out that part of the trouble had been Murdoch's mistaken belief that he was obliged to answer every question and that the effort to do this had been too much for him. ${ }^{36}$

Murdoch did not persist with his intention to join the legal profession and remained at Brisbane Grammar School until the end of

34 Ibid., 12 March 1885.

35 Maryborough Chronicle, 7 March 1885.

36 Brisbane Courier, 12 June 1886 and 4 August 1886; Marybarough Chronicle, 15 June 1886 and 6 August 1886. I am indebted to Mr W. G. Rendali of Maryborough for bringing this incident to my attention. 
$1887 .{ }^{37} \mathrm{He}$ was well regarded there, the headmaster noting at the time of his departure that he had served the school most ably and faithfully. ${ }^{38}$

For about three months Murdoch worked as a journalist for Brisbane's new radical weekly magazine, The Boomerang. ${ }^{39}$ For him this was not an entirely new departure. At Maryborough he had been supplementing his headmaster's salary by freelancing for local newspapers. ${ }^{40}$

\section{'Overflowing China'}

At the end of March 1888 he set out on a visit to the Far East. This was to last a year. It seems possible that he undertook the journey in order to free himself from the frustrations (or from the recollections) of an unhappy marriage. Lucy did not accompany him and he eventually remarried in Japan in $1899 .{ }^{41}$

The following lines occur in some verse that Murdoch published in 1890:

The obied maids o' Dai Nippon are a sicht richt fair tae see,

37 S. Stephenson, Annals of the Brisbane Grammar School, Brisbane 1923, p. 15.

38 Headmaster to G. Souter, 9 June 1866 (Souter Papers, Fisher Library, University of Sydney).

39 Maryborough Chronicle, 17 November 1887.

40 In the Japan Echo, 15 November 1890, he claimed that he had "been slinging ink for some seven years off and on" in the coursc of which he had covercd most social events of importance "from a Wide Bay Blacks corroboree up to staid and solemn gubernatorial receptions and Parliamentary banquets". Indeed it seems highly likely that, at the time of his dismissal at Maryborough, the author of the articlc in the Wide Bay and Burnett News, 17 March 1885, lampooning the Board of Trustees was Murdoch himself!

41 What had become of Lucy we do not know. I am indebted to the editors of the Australian Dictionary of Biography for the information that in the State of Queensiand during the relevent period: (i) no registration of her death was madc; (ii) no letters-of-administration for her estate were issued; (iii) no decree of divorce was granted. Professor Hirakawa Sukehiro's excellent and comprehensive article on Murdoch ('Söseki no shi-Mädokku sensei', Shinchō, 78, May 1981, p. 115) draws attention to the fact that Murdoch's friend and former pupil, Yamagata, was under the impression that she committed suicide by drowning (Yamagata Isō, 'Nihon no shi-ka Mädokku', Taiyo, November 1926). This may well have been the casc. If, for example, she threw herself overboard from a steamer during the hours of darkness, then it is unlikely that the corpse would have been recovered and hence it would havc been difficult to produce sufficient evidence for the death to be registered either in Queensland (if the incident had occurred in territorial watcrs) or in London (if it had occurred while she was travelling on a British ship outside territorial waters). 
But I reck not o' their winsome wiles. A Scottish lass for me! Alas! Twas a fair that made me roam across the faem-flecked brine,

(It boots me not to make my moan, or sough or sign or pine,) But I curse the day, I e'er set e'en on her fause South Saxon face,

An' turned my back on the fouk at hame o' the kindly Scottish race. ${ }^{42}$

Murdoch introduces the same theme in his short story, 'The Wooing of Webster' (1892). In it Webster says that

a woman sent me to Australia. That was bad. And it was a woman that drove me from Australia, which was worse. Now the latter two episodes are not for publication-at least just at present, because they're other folks' secrets as wcll as mine. . . . ${ }^{43}$

Once again I suspect that this is Murdoch himself speaking. One also wonders to what extent the remarks of the hero in his short story 'Frank Morton's Finish' (1891) are autobiographical:

I'm married, but of course my wife and I never live together again. I married her because she had a hard time of it, and I thought I could make her happier, and because I thought she had real grit in her. Well, I found ott she simply looked upon a husband as a sort of machine for providing a woman with all the necessaries and luxuries of life and nothing morc. I had an idea of doing some work in my time, but she did her best to kill that. 'To make a long story short, she wanted me to became a robber and a cheat to cnable her to gratify her fancies and extravagant vanity, and I wouldn't. So we quit. . . .44

However much Murdoch prided himself on his unconventionality, ${ }^{45}$ it seems that he embarked upon matrimony with a particularly idealised conception of womanhood. His paper on the Ramayana contains the following passage:

The man that cannot appreciate what follows, is not worthy of the name-at least he deserves never to have had a mother. I question

42 'The Scot in Fxile' in A. Miall [pscud.], Don Juan's Grandson in Japan, Tokyo, 1890, p. 59.

43 From Australia and Japan, p. 96.

44 Japan Echo, 1 January 1891 , p. 20.

4.5 The Mitchell Library has a manuscript, 'Pagan and Christian', written by Murdoch in his later years under the pseudonym, 'Marius Armidis'. In the preface he addresses it to "the commor-sense, rational, unsophisticated, single and generous hearted reader, used to think his own thoughts about things in general, and more especially so, on religious, social and political questions. . ." (Mitchell Library, Sydney, A160). 
very much if anything finer can be found even in European literature....

... there stands Sitâ, with her small, lithe form of faultless outline, with long lashes, dark eyes, swelling bosom, and finely rounded arms, with a sad, sweet smile, looking up lovingly and beseechingly to her lord-doing what? Praying for the boon of being allowed the privilege of sharing the privations, the dangers, and the hardships of her husband's desert exile! It is a scene worthy of being immortalised in marble by the chisel of a Phidias. The man who reads it without being moved ought to be consigned as a mummy specimen to a fossil museum for ever!

Insofar as Lucy Murdoch was only a human being, it is possible that she was never able to measure up to such a standard.

Articles that he wrote for the Boomerang during the course of his journey indicate that Murdoch's outward route was Thursday Island, Darwin, Samarang, Batavia, Singapore, Hong Kong, Nagasaki, Yokohama. This strongly suggests that the vessel on which he travelled as far as Hong Kong was the S.S. Airlie, which left Sydney on 5 April. ${ }^{46}$

White Australia was one of the Boomerang's most persistent demands and it was at just this time that an increase in the number of the Chinese immigrants arriving in the Northern Territory had set in motion what Willard has described as the "third and last movement against Chinese immigration into the Australian Colonies'. ${ }^{47}$ It is, therefore, perhaps not surprising that Murdoch chose for the theme of his Boomerang articles, 'Overflowing China: Travelling through the Lands Invaded by the Mongol'. ${ }^{8}$. They contain many indications of Murdoch's political philosophy.

46 We know from his Boomerang articles (7 July 1888 and 1 December 1888) that Murdoch set out from Brisbane in March and that the ship's stay at Darwin was five days. The only vessel on this route in March and April to spend five days at Darwin was the Airlie. Murdoch would have joined her in Sydney, as her only Qucensland port of call was Thursday Island. The absence of Murdoch's name from the list of first and second class passengers published in The Northern Territory Times suggests that he may, as the Chronicle obituary states, have travelied steerage. Nevertheless, I feel that the Chronicle is going too far in accepting as fact the ship-board incidents related in Murdoch's novelette, Felix Holt Secundus: there is no reference to them in the Boomerang articles, although they are the kind of thing that would have appealed strongly to its readers.

${ }^{47}$ M. Willard, History of the White Autralia Polity, Melbourne, 1923, p. 69. For a more recent treatment of the anti-Chinese movement during 1888 see $\mathrm{C}$. A. Price, The Great White Walls Are Built: Restrictive Immigration to North America and Australasia 1836-1888, Canbcrra, 1974, pp. 186-98.

48 Boomerang, 12 and 19 May 1888, 9 and 30 June 1888, 7 and 14 July 1888, 4 and 11 August 1888. 
As was the case with most of the Boomerang's devotees, Murdoch's fervour for 'White Australia' was an amalgam of several elements. These come out very clearly in the articles.

There is what appears to be hostility arising out of cultural differences. Take for example his description of the lunch-time street scene in Darwin:

Put iron bars in the paneless Chinese windows, and you can fancy yourself standing before the monkey house in the Zoological Gardens at feeding time. . . ; everywhere along the sidewalks you see nothing but what looks like great white-tusked tawny apes, aquatting on their haunches on chairs and blocks of wood, eagerly and voraciously cramming the contents of dirty greasy little bowls down their throats with what seems like a filthy pair of knitting needles. They hold the dish quite close to their throats as if they were engaged in a gorging handicap. ${ }^{49}$

Similarly, he describes Chinese slecping in a tightly packed lodginghouse as "a human heap of maggots". The croupier at a gaming table is an "old pig-tailed ape". "The Chinaman", he writes, "is by nature prone to dirt and filth" 50 and "when he does go to the trouble of performing his ablutions it is no uncommon thing for him to drink the greater portion of the water he has used in the operation, having cleansed his molars and incisors with it between whiles". $51 \mathrm{He}$ is "deeply tainted with one of the gravest and most widely spread of Oriental vices. He runs riot in bribery and revels in corruption". ${ }^{52}$ Murdoch refers to the Chinese immigrants as "Chinks", "Chows", "the two-footed rabbit pest", "the saffron curse" and "the swarming yellow agony".

The second element is hostility arising out of economic competition:

Their fingers have closed on the windpipe of all the European handicrafts in the place, which lie dead and strangled . . . If any of our legislators have doubts about the effect of a Chinese industrial invasion of Australia let him come to Palmerston [Darwin] and have them set at rest once and forever. ${ }^{53}$

The third element is hostility expressed in terms of democratic aspirations:

\footnotetext{
499 June 1888

5011 June 1888 .

5130 June 1888.

524 August 1888 .

$53 \quad 12$ May 1888.
} 
Australians mean Australia to be white; that is pretty clear. We don't want to run our State on either an Indian or an old time Southern slave-state model. We want to develop into a bold, sturdy, fearless Democracy, with an intelligence widely and universally diffused. Such an ideal can only be attained by our grasping and maintaining a due idea of the dignity of toil, and cheap coloured, labour is simply fatal to the conception. ${ }^{\text {st }}$

Naturally the interrelationship between these elements among both the leaders and the led in Australian politics at the time has been a subject of interest to historians writing about the White Australia policy. Some have tried to answer the question whether one of these elements gave rise to the others. ${ }^{55}$ In Murdoch's case it looks as if the cultural hostility was brought into play by the other two elements. For in the same articles Murdoch describes with no indication of hostility or distaste the Japanese community in Darwin, although of course they were identical with the Chinese in terms of their skin colour, their use of chopsticks and their prominent teeth. The important difference was, I think, that while the Chinese outnumbered the Caucasians there were only a few dozen Japanese and that they were all engaged in a single industry, prostitution. ${ }^{56}$ Murdoch identified himself with the Caucasian artisans and labourers, whose livelihood was threatened by the Chinese; he did not identify himself with the Caucasian brothelkeepers and pimps whom, no doubt, the Japanese had put out of business. I suspect that this is not atypical and that it is often some tangible threat that sets off cultural antipathy. The patterns of one's neighbour's neckties remain merely a source of puzzlement until his cat starts eating one's goldfish. Then they become infuriating as sure proof of aesthetic (and probably moral) depravity.

While discussing Chinese exclusion in these articles, Murdoch indicates that he is a republican. Until some months after he was writing, there was room for doubt whether exclusion legislation extending to Chinese who were British subjects (for example Chinese born in Hong Kong) would receive royal assent. To Murdoch the solution was for the colonies to form a federal republic; he considered that this was likely within "a score of years or so". 3 "

Other aspects of Murdoch's radicalism emerge in the articles. He considered that Australians would be driven to nationalise

5419 May 1888.

55 For example, B. C. Mansfield, 'The Origins of "White Australia", , Australian Quatterly, 26:4, 1954, pp. 61-68.

56 Boomerang, 12 May 1888.

57 J0 June 1888 
land and that, in the process, it was possible that blood might be shed ${ }^{58} \mathrm{He}$ was opposed to aristocracy, exploitation and Empire:

Singapore may be described as a purcly Chinese town with a few aristocratic European settlers, engaged in a semi-futile attempt at blood-sucking and ostensibly 'administering' the government. Ostensibly we say advisedly, for the place is practically ruled by the yellow skins... Most Englishmen in Eastern Asia are pig-headed Conservatives and violently aggressive. They are nearly all aristocrats in feeling and sympathy or they ape aristocracy. ${ }^{59}$

\section{First Visit to Japan (1888)}

At Hong Kong Murdoch transshipped to the General Werder, ${ }^{60}$ bound for Yokohama. Insofar as Japan was to become the centre of his life, one is prompted to speculate why, on this first occasion, he went on to Japan. Perhaps a sufficient answer is that the journey to Japan was already becoming popular in Australia. For example, one of the Boomerang's leading supporters, Thomas Finney (a department-store proprietor who provided it with considerable advertising revenue), was in Japan when Murdoch landed there. Sir Thomas McIlwraith, the outgoing premier of Queensland, arrived there just as Murdoch was leaving. More to the point, Murdoch's friend ${ }^{61}$ and fellow contributor to the Boomerang, Francis Adams, had visited Japan the previous year; ${ }^{62}$ perhaps it was from him that Murdoch got the idea to include Japan in his itinerary.

Murdoch disembarked at Yokohama on 25 May. ${ }^{69} \mathrm{He}$ departed

\section{August 1888.}

5911 August 1888. Murdoch's Don Juan's Grandson in Japan, p. 80 provides similar observations on Hong Kong (and, incidentally, indicates his technical deficiencies as a versificr).

60) Boomerang, 22 December 1898.

61 Murdoch so describes him in a letter to Sir Thomas McIlwraith dated 14 April 1889 (Mcliwraith Papers, Oxiey Library, Brisbane). I am indebted to $\mathrm{Mr}$ Robert Sharman for drawing this letter to my atiention.

62. Two of the poems in Adams's Songs of the Army of the Night (Sydncy, 1888), 'To Japan' and 'Dai Butsu', are the product of this visit. For details of Adams's life and publications see Dictionary of National Biography, London, 1901, vol. 22, p. 14 and Australian Dictionary of Biography, vol. $3, \mathrm{p}, 13$.

63 The possible voyages of the General Werder were those tcrminating at Yokohama on 27 April and 25 May respectively. The passenger lists were published in the Japan Weekly Mail. There is no Murdoch on the $2 \bar{t}$ April list and there is a 'Mc. Đ. Murdoch' on the 25 May lisı (Japan Weekly Mail, 26 May 1888). 'I'he difficultics of using Japanese compositors for printing in English are notorious therefore it is likely that 'Mc. D. Murdoch' was Mr J. Murdoch. 
through the same port on 30 October ${ }^{64}$ His activities and impressions during the intervening period are the subject of ten articles in the Boomerang entitled 'Where Mcllwraith is Going: Sketches from the Land of the Japs. ${ }^{\prime 65}$

His first week in Japan was spent in the German hospital at Yokohama suffering from malaria (which he had picked up in Java). ${ }^{66}$ While recuperating in Tokyo he signed a contract to teach for ten months at an English language school that Count Okudaira had just established at Nakatsu, the castle-town of his former fief, in Kyūshū. ${ }^{67}$ Murdoch arrived in Nakatsu in the middle of June and taught at the Count's school in the mornings and at the Government's middle school in the afternoons. He remained there only six weeks. Late in July, at the start of the summer vacation, "having learned all that was to be learned about the social and domestic life of the inhabitants", he resigned ${ }^{68}$ and set out to examine the scenic attractions and historic sites of Kyūshu-mainly on foot. ${ }^{69}$ His account of the tour indicates that, despite their sharing the same 'saffron' hue and chopsticks that so offended him in the case of the Chinese, the Japanese from the outset won his admiration and affection:

A Japanese who has not been spoiled by residence in an open port is just about as pleasant and nice and jolly a fellow as you could wish

64 The passenger list for the Yokohame Martu, which departed on that date for 'Shanghai and ports', listcd a Mr Murdoch as a 'Cabin' passenger (Japan Weekly Mail, 3 November 1888).

6.5 Boomerang, 1, 15 and 22 December 1888, 5 and 12 January 1889, 2 and 9 February 1889. An additional article entiticd 'In a Japanese Gaol' appearcd on 10 May 1889.

66 Boomerang, 1 and 15 December 1888.

67 The original contract (now in the possession of Kodama Nobuyoshi of Kitakyūshū-shi) is reproduced in Sugiyama Tamaki, 'James Murdoch (I): Shashiteki kenkyü, Okayama Shödai Ronsōo, 18:33, 1983, p. 38. A copy was made in romaji, which suggests that Murdoch was already trying conclusions with the language. According to Honda Masujiro ('Prof Murdoch to gosshü no Nihon kenkyü', Eigo Seinen, 40:9, 1919, cited by Sugiyama, 'James Murdoch (l)', p. 75), Murdoch was selected for the job by Odata Tokujirō of Keiō-juku. As Keiō's Fukuzawa Yukichi himself was from Nakatsu, this seems quite likely.

68 Boomerang, 2 and 7 February 1889. According to Denki Yamada Shötarō sensei (Tokyo, 1940, cited by Sugiyama, 'James Murdoch (l)', p. 43) the school struggled on, with diminishing enrolments, under Murdoch's successor, Revd C. G. Gardner (of the SPG Mission, Tokyo) and finally closed in July 1889.

69 Boomerang, 1 and 8 December 1888; 5, 12 and 19 January 1889; 18 May 1889. 
for as a chum or a companion... In the point of pluck they are about as dare-devil a lot as are to be found in any corner of the globe whatsoever; in regard for the feelings of others they are simply unique ... The sum and substance of the whole matter is that by instinct and training the Nippon-jin is a real good radical. He is not at all self-contained or selfish in his joys and his enjoyment of life. He insists on sending his good things around. ${ }^{70}$

Although ugliness among the Chinese at Darwin aroused Murdoch's hostility and contempt, ugliness among the Japanese evokes his compassion. Take for example his description of women labourers at Shimonoseki: ". . open staring mouths that with their hideously blackened teeth and gums yawn abysmally like so many murky caverns of Erebus, are the diametrical reverse of picturesque and charming. And yet these poor creatures are polite and kindly in the extreme". "1 Part of the explanation may be that, whilc Murdoch knew the Chinese only as a stereotype, he knew the Japanese as individuals. He arrived in Japan with relatively few preconceptions and went straight to the back-blocks where, away from other Europeans, he encountered Japanese in their own environment. He knew them as the rickshaw-man, the schoolmaster, the chambermaid, the school boy-each with his own personality and hopes, and not as an undifferentiated yellow mass.

During the last weeks of his stay in Japan a fierce controversy between the Nipponjin ${ }^{72}$ and the Choya Shimbun ${ }^{73}$ regarding the former journal's allegations of inhuman exploitation and cruelty on the part of the labour contractors at the Mitsubishi colliery on Takashima (an island about fifteen kilometres from Nagasaki) provided the occasion for Murdoch to contribute some articles to the Japan Gazette (thereby beginning an association with the local English-language press that was to last for thirty years).

From the outset, the redoubtable Captain Brinkley had placed his Japan Mail squarely behind the Mitsubishi company and the contractors. ${ }^{74}$ This in itself was probably sufficient to determine the Mail's arch-rival, the Cazette, to champion the Nipponin's

70 Boomerang, 15 December 1888.

71 Boomerang, 29 December 1888

72 The Nipponjin articlcs (June and July 1888) are reproduced in Yoshino Sakuzō, Meiji Bunka Zenshü, Tokyo, 1929, vol. 21, pp. 1-30.

${ }^{73}$ A summary of the Choya Shimbun's article, appearing in the T'okyo Nichi-Nichi Shimbun on 9,12 , and 13 September 1888, is reproduced in Nakayama Yasumasa (cd.), Shimbun shissei Meiji hennenshi, Tokyo, 1935, vol. 7. pp. 136-40.

${ }^{74}$ Japan Weekly Mail, 21 July 1888, 25 August 1888. 
cause. To the Gazette the availability of the free-lance from the Boomerang must have appeared providential. Murdoch's views on capital and labour were such that he would have regarded the Nipponjin's revelations as fairly typical of what most capitalists would do if given half a chance.

Unfortunately, a complete file of the Gazette does not survive and we have therefore to make do with the quotations from Murdoch's articles that appear in the Mail. In these one can have no difficulty in recognising Murdoch at his most purple.

The Mail writes:

Going back to a period of the mine's history prior to 1881 - when it camc into the hands of its present owners-a period with which recent discussion and investigation had no manner of concern, our infuriate contemporary has worked himself into a phrensy against the "Mammon-Moloch of Plutocracy". "Takashima", he cries, "will go down to posterity as the Tartarus where some hundreds of Japanese have been immolated to satisfy the rapacity of a heartless, bloodsucking Plutocracy" as the "last stronghold of serfdom and slavery"; as a "worse than Siberian or old Spanish Main jigoku". Its story "enables one fully to realize how such a creation as Sanyarine in Zola's Germinal may come to actually exist in the fesh". It is "a lively sample of Hades upon earth". While "hecatombs of coolies are going on" "Money-Bags gently rubs his hands, sips his champagne and returns thanks to a gracious Providence". "The place is a "stifling Inferno". "Only the terrific language of Dante could do it justice. It is as foul and foetid as the last ward of Malebolge itsclf", ${ }^{75}$

The claim of the Chronicle obituarist that the reforms effected at Takashima were the results of Murdoch's "revelations" is, surely, an exaggeration. The indications are that the Nipponjin articles were published before Murdoch had so much as heard of the mine and that Murdoch's articles appeared after the Home Ministry had announced the results of its investigation and issued specific warnings to the Company.

It was during these five months in Japan that Murdoch secured the appointment of Lecturer in European History at the First

75 Japan Weekly Mail, 13 October 1888 . The Mail was vigorous in its condemnation of Murdoch's articles: "Probably in the whole hiscory of journatism there have never been published grosser or more groundless sianters than those of our crazy contemporary". The Rising Sun and Nagasaki Express took a similar view suggesting Murdoch's articles "not only prove the writer's ignorance of the subject he is writing on, but display a palpable amount of deep-rooted malice against everyone and everything connected with the Takashima colliery' (cited in Japan Weekly Mail, 18 November 1888). 
Higher School in Tokyo and decided to settle permanently in Japan. Established on the model of the German gymnasium, the Higher Schools were the link between the secondary schools and the imperial universities. Students entered them at about the age of eighteen. As the feeder to Tokyo Imperial University, First Higher School was the most distinguished school in Japan.

Under his contract, Murdoch's duties were to commence in September 1889. This left him time to return to Brisbane to wind up his affairs. He cmbarked at Yokohama on 30 October $1888 .^{76}$ With characteristic enterprise he appears to have found means to defray some of his travel costs. The Boomerang on 11 May 1889 contained an advertisement for the sale by auction of "[a] magnificent collection of Japanese Curios, Japanese Silk Goods, etc., specially selected by James Murdoch M.A. during his recent tramp of 3,000 [sic] miles through the previously unknown parts of Japan'". He had commissions from Japanese exporters to "report on the lines of Japanese produce most likely to suit Australian tastes" 77 and from the newly emerging Japanese woollen industry to examine the possibility of direct shipments of merino wool. ${ }^{78}$ Furthermore, the archives of the Japanese Ministry for Foreign Affairs indicate that he was also reporting to them on current trends in Australian politics. As regards imperial relations, he cited recent events to argue that within twenty years Australia would become an independent federal republic. On the question of White Australia he strongly advised against making indentured Japanese labour available to the sugar industry to fill the gap which the prohibition of kanakas would create: the introduction of cheap Japanese labour would be harmful to Japan's international prestige and would alienate a large element of public opinion in Australia. ${ }^{79}$

His tasks in Brisbane completed, Murdoch returned to Japan. This time he was accompanied by his son (now eight years old). They arrived at Yokohama on 19 July $1889 .{ }^{80}$

76 The passenger list of the NYK steamer Yokohama Maru departing Yokoharna for "Shanghai and ports" on 30 October includes a "Mr Mudoch" among the cabin passengers (Japan Weekly Mail, 3 November 1888).

77 Queenslander, 18 May 1889.

78 R. Wallace, The Rural Economy and Agriculture of Australia and New Zealand, London, 1891, p. 387. I am indebted to L. F. Fitzhardinge for drawing this reference to Murdoch to my attention.

79 Gaimushō, Nihon Gaikō Bunsho, vol. 22 (1889), Tokyo, 1951, pp. 550-53. Internal evidence suggests this memorandum may have been written in 1890 .

${ }^{80}$ Aboard the General Werder, from Hong Kong (Japan Weekly Mail, 27 July 1889 ). 


\section{First Higher School, Tokyo, 1889-1893}

Murdoch commenced his duties at First Higher School on 11 September. As a foreigner his salary was 200 yen per month, ${ }^{81}$ ten times that of his Japanese colleagues. ${ }^{82} \mathrm{He}$ was to continue there for four years. As at Aberdeen, he appears to have made a strong and favourable impression on those with whom he came in contact. One of his pupils, Natsume Kinnosuke, became the famous novelist Natsume Sōseki. Twenty years later he produced this vivid picture of Murdoch:

Since every word he uttered-lectures, exegesis and conversationwas in a pure Scots as yet uninfluenced by his residence in Japan, the whole class was completely bewildered. Thus we came to realise that the preordained lot of the student is to be enveloped in foy. This did not appear to worry him. He probably thought that with such a silly syllabus it didn't matter whether or not the students understood it. But because he was very outgoing and conscientious and because he combined the qualities of a thorough gentleman in the British style with a marked Bohemianism, we admired and respected him. There were never any complaints about his teaching.

We rarely saw him in a white shirt. Usually he made do with one of grey flannel. His necktie looked like a strip torn off a carryingcloth. It often came out of his waistcoat and fluttered in the breeze. It was at about that time that teachers at the Higher Schools began to wear black gowns. His was made of satin or something like it. He wore it over his flannel shirt-like a coat. Around the bottoms of the sleeves was gold braid. Originally it was either ornamental or to gather in the cuffs; but with Murdoch both these functions were completely forgotten. When he became enthusiastic about some theme that interested him, he was no longer conscious of gown or shirt or even that we were in a classroom. He would stride down from the rostrum bringing his bearded face close to us. Then, if there was a vacant desk, he would sit on it, pull out about a foot of the braid from his cuffs and strum the top of the desk with it. . . His house was like his shirt, his hat (he sometimes wore a rumpled Trilby round which

81 I am indebted to Professor Eto Shinkichi for obtaining access for me to the staff registers, Shokuin Shintaibo and Shintairoku, for the periods 1888-1891 and 1891-1904 respectively. These are held by the Administration at the Kyoyo gakubu of Tokyo University. According to the handbook (Binran) of the school for 1892 and Murdoch's letter of resignation (1893), European history is the only subject that he was teaching. But initially he may have taught English as well. Acoording to Natsume (see following footnote) he was teaching both in the period 18891890.

82 Hirakawa, Söseki no shi, p. 116. 
he had tied a weird hatband) and all his clothes. His way of life seemed simple. . . ${ }^{83}$

During his time at First Higher School Murdoch can have had little leisure. It June 1890 he published Don Juan's Grandson in Japan. Although, as is apparent from the passages quoted above this was an innocuous hotch-potch, one of the English-language dailies (probably the Mail) nevertheless described it as "so far exceeding the limits of propriety as to be to be a disgrace at once to its author and publisher". ${ }^{84}$ Murdoch's own appraisal of it seems closer to the mark:

It is 'doggerel' and in the main a very poor sample at that. Its composition consumed the not too many unoccupied moments of just seven weeks . . . The whole thing was a silly tour de force, the workmanship being essentially inartistic, slipshod, and sloppy. . . . ${ }^{85}$

In November a fortnightly magazine, the Japan Echo, appeared with Murdoch as editor. Its aim, as set forth in its prospectus, was "to give a full, fair, and impartial view of every topic of interest handled by the foreign and vernacular press. . ." ${ }^{86}$ It received a magnanimous welcome from the Mail:

. . . a decidedly pleased sensation is produced by the novelty of a fresh and by no means shallow thinker discussing Japanese subjects with straightforward vigour and without any shadow of malice. Indeed the good humour of the editor of the Echo is conspicuous. . . ${ }^{87}$

There was magnanimity on both sides: the Echo in its first issue

83 'Hakushi mondai to Mādokku sensei to yo', Sōseki zenshī, Tokyo, 1949, vol. 18, pp. 279-81. I am indebted to Dr Matsui Sakuko of Sydney University for drawing this to my attention. Murdoch seems to have continued throughout life to make a vivid and favourable impression on young people. Captain T. E. Nave, the distinguished Japanese linguist and cryptanalyst of the inter-war and World War II period writes:

I met Professor Murdoch for the first time on presenting myself for examination [in a foreign language for promotion to sub-lieutenant in 1920]. I was stunned to see a Japanese newspaper on the desk. He explained that if you recognise no characters you will lose no marks, but will gain extra marks for every one identified and given a meaning. "I want to find out how much you know; not how much you don't know". One question confirmed his approach: "Write in kano script what you do on any day". I was impressed with his practical attitude as an examiner. He gave me $90 \%$. . (Captain T. E. Nave to author 18 June 1982).

84 Japan Echo, 15 November 1890.

85 Ibid.

86 Japan Weekly Mait, 1 November 1890, p. 428

3) Ibid, 22 November 1890, p. 306. 
commended the management of the Takashima mine on the absence of a single case of cholera while an epidemic was raging in the surrounding prefecture. ${ }^{88}$

The Echo's life was short. It closed down after six issucs. Very likely, as the Mail argued from the outset, the market was too small. ${ }^{99}$ But there may have been more to it than that. Perhaps Murdoch took insufficient heed of the critic who referred to the Echo's "olla podrida of languages which in [one] number alone comprises Greek, Latin, French, Japanese, Scotch, Irish, United States and Yiddish" $\%$. Furthermore, to the Echo's predominantly north American and European readership, the constant references to Queensland and to Murdoch's past avocation there must very soon have begun to pall. In its six issues it featured no less than three short storics set in the small town of 'Thylungra' somewhere on the Queensland coast (Maryborough?) in which the "thirsty swearing sinners" despite exploitation and disapproval by "the Pharisaical money-grubbing upper ten" demonstrate the virtues of mateship, grit and good chcer. ${ }^{91}$ For although Murdoch had turned his back on Australia ("pupils all right, but 'grown-ups' too materialistic to please $\left.m c^{\prime \prime}{ }^{\prime}\right)$, the stories show that it had become a large part of him. His whole being was soaked with local associations and local imagery. This is equally apparent in his From Australia and Japan (a volume consisting of a novelette, 'Felix Holt Secundus', and six short stories), published in London in $1892 .{ }^{93}$ In these the narrator is for the most part a journalist employed by one of the Yokohama English-language dailies, whose previous job was in Australia. One indication is the similes he uscs-for example, a face " as lifeless and lustreless as a lump of

BB Japan Echo, 1 November 1890.

89 Japan Weekly Mail, 22 November 1890, p. 506.

90 Köbe Herald as quoted in Japan Echo, 1 December 1890.

91 'Fred Wilson's Fate' (15 November 1890), 'She Stuck to Him to the Last' (15 December 1890), 'Frank Morton's Finish' (1 January 1891).

92 Letter from Murdoch dated 20 September 1911 quoted in Mackenzie, 'My Friend James Murdoch', p. 232.

93 From Australia and Japan, London, 1892. During the same year the publishers also split it into three slim paper-back volumes for the one-shilling book-stall market: Felix Holl Secundus (including 'A Tosa Monogatari of Modern Times'), The Wooing of Webster (including 'Faustus Junior, Ph.D.' and 'The Bear-Hunt on Fuji-san') and $A$ Yoshiwara Episode (including 'Fred Wilson's Fate'). These are reviewed in the September 1892 number of the Review of Reviews (6:33, p. 299). The paper-backs were also pubiished overseas-all three in India, the first two in Australia. 
stale damper", a love "as dead as a ring-barked gum-tree". ${ }^{94}$ It comes through in his affection for Adam Lindsay Gordon's "The Sick Stockrider' ("I have often heard strong, bearded men chanting it with the tears running down their faces"). ${ }^{95}$ Another example is the idealiscd description of the Austalian-born that he gives in 'Felix. Holt Secundus':

Hawkston was a Queensland native, born on the slopes of the ranges just where they sweep up and spread out into the plains. It is a hotblooded, impetuous brood mostly that is reared in those quarters-a generation not over much given to unbonneting to shoddy dignities or kowtowing to the conventional lay-figures of respectability and vested interests. Every child there born of woman is brought up to ride and to shoot and to stand sauce from no-one; most of the males add to these rudiments of a liberal education the further accomplishment of hitting straight out with the left and getting in with the right when a chance offers.

In 1892, in addition to his short storics, Murdoch also wrote a novel, Ayame-san. 96

There are naturally many occasions in the stories where the narrator expresses views on political and social issues that we know from Murdoch's non-fiction writing were his own. For example, in 'Felix Holt Secundus' he applies the same epithets to the Chinese as he did in the Boomerang articles. Clergymen of the Church of England fare no better in Ayame-san than they did in 'Pagan and Christian' and in Don Juan's Grandson. Like Murdoch himself, the heroes of his stories are socialists. They quote I_assalle. But the stories tell us more about Murdoch than this. An author's imagination as expressed in his writing tells us much about the man-his ideals, his values and his dreams. There is a Walter Mitty within each of us and in the casc of an author he is there for all to see.

Murdoch's stories are all, avowedly, romances; and they were written quickly to entertain the popular market and supplement a salary. It is not surprising therefore that the characters are larger than life. The heroes are much more versatile and successful than the average person. Like those of another Scotsman classicist of humble origins, John Buchan (whose first work was commissioned by Murdoch's publisher the following year), they tend to be well

94 From Australia and Japan, pp. 109, 115 ('The Wooing of Webster').

95 Ibid., pp. 212-18 ('A Tosa Monogatari of Modern Times').

96 Ayame-san: A Japanese Romance of the 23ri Year of Metji (1890), Yokohama, 1892; London, 1893). 
endowed with past competitive achievement in a number of felds including the academic and the sporting. Hawkston in 'Felix Holt Secundus' has an unusual background for a Queensland trade union leader. $\mathrm{He}$ is an Oxford double-first who rowed for his college and only missed getting an All Souls fellowship because he invited Bradlaugh to dinner in hall. Though his job at the cattle station where he is employed is storeman, he can ride "like a Centaur or a Paladin". He is an excellent swordsman ("Now I had passed the long vac. of '83, I think it was, in Naples with San Martelli, and knew pretty well how to take care of myself when it came to sabres"). Francis Webster and Morrison (the vanished 'Australian Lassalle' whom Webster in 'A Tosa Monogatari of Modern Times' discovers turned Buddhist monk in the mountain fastnesses of Kochi prefccture) are also of this mould. Webster played intercolonial cricket and "spread-eagled seven Victorian wickets for 46". Morrison had played against the Australian eleven and had maintained his passion for Sanskrit throughout his political career.

Murdoch's heroes administer ready justice in a manner that Buchan's Richard Hannay would have recognised and approved. For example, when the corrupt, lecherous politician called to pay his suit to Ayame, Gifford, "sprang upon him and seized him by the nape of the neck as he would a cat and lifted him over the fence". Similarly, when an irate farmer threatens the social editress of the Thylungra Chronicle, Wilson "tore the whip from the bully, hurled him down the steps, and then pummelled him like an infuriated human steam-hammer". One student of this genre has made the comment that the place where rough justice is administered by chaps famous for their all-round success and sporting prowess is the prefects' room and that authors who produce heroes of this type are acting out the prefects' room ethic. ${ }^{97}$ This, however, is a good deal closer to the ethic of the Conservative MPs with whom Buchan in real life cast his lot, than to Lassalle and socialism. In one respect the code to which Murdoch's heroes adhere is closer to Sapper and Dornford Yates than to Buchan. To them forbearance and the handshake between honourable adversaries are not absolute values. Webster's advice is: "If you're hit, give the smiter room for repentance, and the biggest thrashing you can administer to help furnish the chamber." Perhaps as wageearners they are always conscious that they operate on narrow

97 R. Usbornc Clubland Herves, Loncton, 1974, pp. 4-9. 
margins. In 'A Yoshiwara Episode', it is by cheating that Whitmore wins the wagers that enable him to free the beautiful, pure, and well-born $\mathrm{O}$-haru (whom he then puts on the next boat to England to be educated "like a Newnham girl").

This leads us to the question, how did Murdoch's characters regard women? They did not place them on a pedestal. Indeed if someone from the prefects' room had heard how Gifford first encountered Ayame, he would probably have pitched him over the fence after his rival. For Gifford first espied her from the other side of the bay when, in the supposed privacy of her own back-garden, she emerged naked from the bath. He thereupon reached for his binoculars and after gazing intently through them for " a full three minutes" remarked: "What a bust! What lines, and what a poise!"

To Murdoch's characters, some women could be a pleasure to the senses, but by and large women were a bad lot. They were faithless. In the words of Fred Wilson: "There isn't a good one among the whole tribe. I'll take on hand to marry all the virtuous women in Thylungra single-handed, and yet die a bachelor." They were mercenary. When Webster was an impecunious student at Aberdeen, Marian Murray ridiculed and spurned him; when his Balliol scholarship transformed his earning potential, she welcomed him. They were cruel. When Webster suffered humiliation, Marian "tried to rub it in after the fashion of her sex". It was a woman that destroyed Lassalle and Morrison. Accordingly they were not sacrosanct. Take for example the manner of Webster's parting with Marian: "But now to me she was flesh, flesh, flesh, which God Almighty meant only to be kissed. And I had come sworn to kiss it, and then go my way. And I did". But there are exceptions; for otherwise it would not have been romances that Murdoch wrote. There is Ayame. In addition to having the best figure in Japan she came from samurai stock and takes to Homer (in Butcher and Lang's translation) "as a duckling to water". Futhermore, despite her "unalloyed sweetness and simplicity" she "talks teleology like a Hypatia". There is Lisa, the narodnik whom Hawkston meets in London - "a regular Perovskaia and Vera Sassulitch thrown into one" who, when not raising funds for the cause or shooting Tsars, sings "wonderful" Russian folk-songs. When she speaks, "a glow of spirituality lights up each one of her features, and she shines out more resplendent than a Vittoria Colonna". Unfortunately, her attempt on the Tsar's life fails-she is captured and executed. For the novelist, however, this is conve- 
nient: it leaves Hawkston free for a heroine par excellence-the young widow of an English viscount, who pursues and eventually wins him. She has "grace in each and all of her supple curves" and "the hall-mark of blood and brecding in every line of her features". She is well versed in Turgenev, Pushkin, Lermontov, Gogol and Goncharov and sings the same esoteric Russian folksongs as Lisa-in the original, to her own accompaniment. Nearer to home, she has George Eliot at her fingertips. Among such com petition it is, perhaps, not surprising that Lucy Murdoch did not stay the course.

It is not only in his heroines that Murdoch shows a high regard for "blood and breeding" and other aristocratic attributes. Hawkston owes his job in Japan to the nobility: his employer ("a thoroughly good sort") is a Japanese peer who was at Oxford with him. Here again, the parallel with Buchan is obvious. But in Buchan, traditionalist by nature and eager to become part of the existing system, a penchant towards aristocracy is not surprising. In Murdoch, who prided himself on his unconventionality and sought to replace the existing system, it suggests some internal stresses. Theoretically one could espouse socialism in order to bring a grouse-moor to every backyard and Aeschylus into every State school. (Hawkston's colleague remarks: "They read queer trash in those State schools"). There was some of this in the labour politician of Murdoch's generation who saw the government's college for cadet midshipmen as the Eton of Australia. One can see a similar attitude in one of Hawkston's exclamations:

She is a clipper though! The lines of the Venus de Milo and the head and the poise of the flashing-eyed goddess Athena. These aristocrats are really fine in their way. And why should they not be? They have had the show for generations. When $u e$ get our innings we will turn out products like her, not by the score, but by the nation.

At the same time, in Murdoch class-antagonism was strong- "Society is mainly divided into plunderers and plundered, exploiters and exploited". 98 The House of Peers was to him "the shop that misgoverns a free people by hereditary right" .99 Elsewhere he preached a strident egalitarianism and independence. It seems surprising that he did not espouse a new proletarian culture and consign aristocratic and other old world attributes into limbo, where Hawkston's colleague placed Tennyson's Clara Vere de Vere's tricks:

98 From Austratia and Japan, p. 15.

99 Hid., p. 17. 
They're all very well in a raw sodden nook-shotten England, but under the fiery sun of the plains and the ranges they simply will not do. A man there stands upon his manhood, and upon that alone, and to keep that condition of things we social democrats mean to fight as long as soul and body hang together.

These works of fiction appear by and large to have been well received by the audience to which they were addressed. ${ }^{100}$ In its review of Ayame-san, the Japan Mail spoke of "the general excellence of the book" and commended the author's "vigour of style, raciness of dialogue, happiness of simile, and marked power of portraying character". It also remarked on "an impalpable Japanese atmosphere about the story that speaks much for the writer's artistic fidelity". 101

In 1892 and 1893 Murdoch also edited for publication the autobiography and diary written in his own imperfect English by that remarkable participant in the earliest years of JapaneseAmerican relations, known to Japanese as Hamada Hikozō and to Americans as Joseph Heco. ${ }^{102}$ During these two years he also wrote the descriptive text for several small pictorial works produced by the photographer, Ogawa Kazumasa. ${ }^{103}$

So much for Murdoch's teaching and literary activities. The only other material that we have about him at this time is a letter

100 Although the Review of Reviews $(6: 33,1892$, p. 299) dismissed From Australia and Japan as "utterly hopeless from every point of view", it sold sufficiently well for Walter Scott \& Co to reissuc it in 1899 (under the title, The Wooing of Webster and Other Stories).

101 Japan Weekly Mail. 14 May 1892.

$102 \mathrm{~J}$. Heco, The Narratioe of a Japanest, cdited by J. Murdoch, 2 vois, San Francisco, 1894? In 1850 when Hcco (aged fourtcon) was travelling from Edo to Hyogo, the boat was blown out to sea. After drifting for fifty days the passengers and crew were rescued by an American vessel. In America Heco received an education and was naturalised. He returned to Japan in 1859 as interpreter at the U.S. consulate in Kanagawa, in which capacity he was aboard the U.S.S.Wyoming during its punitive bombardment of Shimonoseki. He set up his own trading house and for a time prodced a Japanese-language nowspaper, the Kaigai Shimbun. For Murdoch's alterations of Heco's MS see P. H. T. Dowding, 'Hamada Hikozo-C'I'enri I ibrary Materials', Okayama Shödai Ronsō, 18:2, 1982, pp. 219-50 and idem, " "The Narrative of a Japanese" by Joseph Heco or James Murdoch', ibid., 18:3, 1982, pp. 115-55, esp. pp. 122-49. Dowding's argument that vol. 1 was first published in 1893 (not 1892 as claimed in Manuzen Hyaktnensht) is confrmed by the review in the Japan Weekly Mail (10 Junc 1893) which states that it "has just appeared".

103 Sights and Scenes of the Tokaido, Tokyo, I892; The Hakone District, Tokyo, 1892; Scenes form the Chushingura and the Story of the Forty-Seven Roñin, Tokyo, 1892; The Nikko District, Tokyo, 1893; Scenes from Open Air Life in Japan, Yokohama, 1893. 
that he wrote to the Goverment Resident in the Northern Territory (J. Langdon Parsons) on 26 January 1892-apparently at the request of the Nippon Yũsen Kaisha (Japan Mail Steamship Co). ${ }^{104}$ This indicates an attitude to coloured immigration rather different from the one he espoused in 1889. Then he had urged the Foreign Ministry to resist any attempts to send labourers to Australia. In 1892, he drew Parsons's attention to the fact that the Japanese Government is prepared to countenance the recruitment of contract labourers-subject to certain conditions such as the provision of an adequate number of Japanese overseers, doctors and interpreters, and the requirement that the ships used be Japanese. To Parsons he pointed out that "for sugar and rice cultivation it would be impossible to find better hands than Japanese" and argued that the objections that can be levelled against the introduction of Chinese labour do not apply:

There is not the slightest danger of Japanese ever proving the menace to the colonies the Chinese have undubitably [sic] proved. The comparative insignificance of Japan's surplus population and the stay-at-home proclivities of the great bulk of the people effectually bar such prospect.

History has demonstrated that these demographic generalisations may be true-but only in the long term. Unfortunately, Murdoch failed to realise that the population base was sufficiently large and the level of economic activity sufficiently variable for there to be no guarantee against surges of emigration at particular points of time large enough to produce considerable social unrest in the recipient communities. This occurred, for example, in the United States (where the Japanese population was heavily concentrated in a few districts on the west coast) when 17,000 arrived during a single year, 1906. ${ }^{105}$ Nearer to home there was the example of Thursday Island, where in 1898 there were more Japanese than Caucasians. ${ }^{106}$

In his letter to Parsons, Murdoch calculated that the overall cost per labourer to the Australian employer would be "a trifle over 30 " per annum. In 1889 he had urged upon the Japanese Foreign Ministry that the recruiting of Japanese labour would be so prejudicial to Australian-Japanese relations that it should be

104 South Australian Archives, Government Resident, Northern Territory, In-Letters, $1374 / 4777$.

105 Strauss to Root, 21 December 1906, cited in R.A. Esthus, Theodore Roosevelt and Japan, Seattle, 1966, p. 146.

106 Report of the Government Resident, Thursdoy Islond for 1898, p. 2. 
prevented and that, if prevention was not possible, steps should at least be taken to ensure that, if Japanese labourers did go to Australia, "they should be on an equal footing with the white labourer as regards pay, hours of work, and general treatment". Then, according to his calculations, the prevailing rate for Caucasian field labourers was between $£ 39$ and $£ 52$ p.a. Now, he was offering Japanese labourers at $£ 30$ !

\section{Paraguay and London (1893-1894)}

In 1891 William Lane (a prominent member of the Queensland trade union movement and one of Murdoch's colleagues at the Boomerang) launched the New Australia Cooperative Settlement Association. ${ }^{107}$ Its object was to establish a socialist community in which land and the means of production were held in common and all worked for the common good and received an equal wage. In January 1893, 230,000 acres of land offered by the Paraguayan Government was chosen as the site for the settlement. Murdoch was one the earlier ones to answer the call. In May it was announced in the Australian press that he had become a member and would be the community's "chief educationalist". 108

Murdoch must have set out from Japan as soon as the school term ended, at the end of June, ${ }^{109}$ for he passed through London in late August. ${ }^{110}$ Form there, according to the Association's journal,

107 For the history of this venture sec G. Souter, A Peculiar People: The Australians in Paraguay, Sydney, 1968.

108 Brisbane Courier, 25 May 1893. The report in Table Tolk, 19 May 1893 that he was in Sydney awaiting embarkation with the first party of settlers would appear to be mistaken. Similarly the statement, "Why I have joined New Australia' attributed to Murdoch by G. Reeve in Windsor and Richmond Gazette, 9 April 1926 and by L. Ross, William Lane and the Australian Labour Movement, Sydney, 1937, pp. 185-86, seems to belong to someone else-the proprietor of a provincial newspaper who had bcen forty years in Australia (New Australia, 28 January 1893).

109 As Murdoch's letter of resignation at First Higher School (reproduced in Sugiyama, 'James Murdoch (I)', pp. 47-48) is dated 10 August, one must presume that he left it to be tendered at the appropriate time by someone acting on his behalf.

110 British Australian, 31 August 1893. This gives as its source the Daily Chronicle and adds that: "An account of the new Colony may be expected shortly from him". There may also be articles by Murdoch in the South American Fnglishlanguage press. There are, for example, some suggestions of his style and misogynistic cast of mind in the article by its "occasional correspondent at Asuncion" in the Review of the River Plate, 13 January 1894 (quoted in H. V. Livermore, 'New Australia', Hispanic American Historical Review, August 1950, pp. 296, 301. The article was reproduced in New Australia, 15 May 1894). 
his plan was "to go on to the United States to pick up his brother Kenneth, through to San Francisco, from San Francisco to Valparaiso, and overland across the Southern Continent to the site of the settlcment, which he expected to reach about the same time as the pioneers" "II Since this report contains one manifest errorKenneth, now aged twelve, was Murdoch's son, not his brotherwe should examine its other improbabilities carefully. It is just conceivable that Kenneth was at that time living on the east coast of the United States. The task of bringing him up may have proved too much for Murdoch. Perhaps Kenneth's mother (if still alive) or one of her family had gone to the United States. Even so, the route from Tokyo to New York does not pass through London. This itinerary makes sense only if it were necessary for Murdoch to visit both London and the Pacific coast. One possible explanation could be that Murdoch had to tidy up loose ends in the United Kingdom in connection with either his broken marriage or his father's death, and Kenneth was living not on the east coast but on the west coast of the States. The above is the principal objection to the itinerary. Travelling overland from Valparaiso to Buenos Aires, though uncomfortable-particularly when accompanied by a child-was by no means impossible at that time of the year. The gap between the Chilean and Argentinian railway systems was then only 100 miles. 112 The following year two of the settlers crossed it by mule in two days hard riding. ${ }^{113}$

The first group of settlers, 214 strong, embarked at Sydney on 16 July (1893) and reached the land allotted to them on 4 October. Almost immediately they began to fall out among themselves. On 5 December twenty-four of them wrote to the Paraguayan authorities asking for individual land grants outside the settlement. On 15 December, Lane expelied three of the community for intemperance and contumacy. In the course of the following eight days another eighty-one (31 men, 17 wives and 34 children) seceded. ${ }^{114}$ It was in this situation that Murdoch and Kenneth arrived (possibly between 15 and 23 December). To the surprise of

111 New Austrulia, 18 November 1893. According to this report, in London "he lectured, receiving prominent notices in the press". I am indebted to Gavin Souter for drawing my attention both to this item and to McLeod's account of Murdoch's arrival at New Australia.

112 F. A. Talbot, The Railway Conquest of the World, London, 1911, p. 271.

113 Souter, A Peculiar People, p. 130.

114 H. V. Livermore, 'New Australia', pp. 303-304. 
the settlers they had traversed the thirty miles from the railway on foot. 115

Unfortunately, we have becn able to discover only one account by a fellow colonist of Murdoch's brief sojourn in the settiement. It is highly partisan and was written thirty-three years after the cvent. The author, a carpenter named Allan McIcod, was one of the staunchest of the fifty-seven 'loyalists' who followed Lane to the new colony, Cosmé, when he was deposed in May. He was hostile to Murdoch for deserting the cause and its leader in their hour of need and eventually marrying a coloured woman (racial purity was one of the basic tenets of New Australia):

[Murdoch] was cornered off on nearing the village by the orators of the aggrieved party before he could reach official headquarters. Will Lane was in Asuncion on good business so it devolved on the timorous deputy to welcome our great brother, and pass him over to the genial secretary and social entertainer, John Sibbald. Murdock spent most of his time, which was limited, listening to the 'rebels'. With all his gift of tongues he was 'uncacamy' [sic] with the English language and not appearing anxious to be told things by the governing staff. He had apparently made up his mind and closed his book without taking the views of the loyalists into his calculations . . . In about a fortnight Lane rcturned from Asuncion. On being queried he allowed that he had left Murdock [sic] in his element, writing up a history of the Paraguayan war (1865-70), the archives of the country being placed at his disposition. The private conference on diverse views, by the two old friends, has not, I believe, been offered for public consumption. Lane only supplied us with the result, thus 'we agreed to differ, that's all'. ....$^{116}$

115 A. McLeod, Windsor and Richmond Gaztte, 13 May 1927. McLeod's account suggests fairly strongly that Murdoch arrived before the eighty-one moved out, that is before 22 or 23 December. Against this New Australia, no 17 (published in Sydney on 21 April 1894 after the arrival there of Iane's emissary, Whealan, who had set out from the commune on 23 December 1893) states that "James Murdoch, the Scotch professor, has not yet taken up his abode in the Settlement".

116 lbid. A community of two hundred members is, of course, too large for eveyone to know fulty the details of all that is going on and quite large enough for the gaps to be filled by a multitude of circumstantial rumours. McLeod's claim that Murdoch made his decision without hearing the loyalists' case seenns inconsistent with his statement that Murdorh proceeded to Asuncion and conferred with Lane. If Murdoch was in fact the writer of the article in the Review of the River Plate (see n. 45 above) then he was, as one might expect, quite unenamoured of some of the rebels' ringleaders. But to MCI eod and his fellows, in that highly charged atmosphere, no doubt it was a case of "he that is not with me is against me'. 
The time spent by Murdoch in New Australia varies in the different sources that are available from less than a day to a fortnight. ${ }^{117}$ By common agreement it was very short. There seems little doubt that Murdoch saw no point in becoming part of a community that was patently in the throes of disintegration. The Chronicle obituary records that in Iater years he recounted how he had witnessed "the serving out of meat to a community almost starving, with envy and jealousy so strong that the butcher weighed the meat with one hand while he kept a revolver in the other" and that he also remarked that "when the leader professed to be ordering his movements and policy by the instructions of a supernatural being, ${ }^{118}$ New Australia was no longer any place for James Murdoch". According to McLeod, Murdoch remained in South America for five or six weeks after leaving the settlement. It was presumably during that period he had the bad encounter with sunstroke which, according to the Chronicle obituary, left him permanently weakened.

After five months in London-spent principally in the Reading Room of the British Museum ${ }^{19}$-Murdoch returned to Japan

117 According to McLeod, Murdoch arrived in the morning and left at about $3.50 \mathrm{pm}$ the same day. According to the report in the Sydney Daily Telegraph (19 January 1895) of an interview with Gilbert Casey (who arrived at the settlement on about 7 March 1894 and arrived back in Australia on duty on 17 September), Murdoch remained for two days. (Cnfortunately it is not cicar whether this is what Casey said or whether it is a parenthetical interpolation by the interviewer.) According to Murdoch's fellow professor at Sydney University, Mungo MacCallum, Murdoch said that "in a fortnight" he saw that "the schemc had no bottom in it" (Sydney Morning Herald, 5 November 1921). I reject the first as unlikcly and as too precise a recollection thirty-three years after the event to be credible. According to the report of the Daily Telegraph (25 May 1894) of its intervicw with Lane's wife on her visit to Sydney, Murdoch was at New Australia long enough for the wives of some of the dissident faction to boycott Murdoch's classes as part of the protest movement against Lane's administration:

"Nothing under ordinary circumstances" Mrs Lane truly observes "would induce $\mathrm{Mr}$ Murdoch to spend his time in imparting elementary education to juveniles. His services simply could not be bought for the purpose. But here he was prepared to give the little school a start; and because there were no jams and pickles in the store the mothers refused to send their children to him"'.

118 For an example of this see Lane to Head, 15 February 1894, citcd in Souter, A Peculiar People, p. 100.

119 Murdoch to W. L. Mackenzic, 20 September 1911. White in London Murdoch also appears to have been of assistance to the settlement (from which Lane and the staunchest 'loyalists' had by then seceded) in securing the services of Alfred Rogers to act as its agent in the United Kingdom (Sydney Daily Telegraph, 19 January 1895 ). 
(where he was to remain until 1917). He had left Kenneth (not yet thirteen) behind him in South America. He was still there at the time of Murdoch's death in 1921.120

\section{Kanazawa and Tokyo (1892-1900)}

Murdoch arrived in time to take up duties in August 1894 as a lecturer in English at Fourth Higher School at Kanazawa on the Japan Sea coast.

An important source of information for the years Murdoch spent in Japan is his deshi, Yamagata Isō (1869-1959), who in Iater life became well known as a translator, as an expositor of English literature, and as an editor of local English-language newspapers and magazines. ${ }^{121}$ Yamagata was a student of Murdoch's at First Higher School and his part-time research assistant while he wrote the first volume of his History of Japan. They remained close friends throughout Murdoch's life. ${ }^{122}$

From Yamagata we learn that Murdoch's five months at the British Muscum were spent reading and translating from Latin, Spanish, French and Dutch the writings of the European religieux and traders who were in Japan during the century that preceded the expulsion decree of $1638 .{ }^{123}$ From this we may infer that when he returned to Japan it was with the intention of embarking on

120 McLeod writes:

After five or six weeks the wanderer from Japan set off on his return journey alone to acquire a Japanese wife later on. His boy, Kenneth, was left by his dad to make his own way in the world. The boy began as a stockman. When he grew up and got married he turned his hand to butchering for Hardie and

Coy, Las Palmas. At present [1927] he works for the Liebig Coy, at Santa

Helena on the Parana in charge of livestock and windmills.

Murdoch in his last will and testament (dated 20 Septembcr 1920) left the copyright of his History of Japan and $£ 500$ "to my son Kenneth Macdonald Murdoch of Santa Elcna, Entre Rios, Argentina".

121 Kawai Suimei, Nihon Kosho Tüshin, 15 May 1959, pp. 2-3; Hirakawa, Söseki no shi, pp. 119-20, 136.

122 It was an unusual friendship in that, in terms of their political philosophies, the two men were poles apart. In the Seoul Pres, Yamagata championed autocracy against democracy (see, for example, his editorial 'A World Unsafe for Democracy' reprinted in K. Kawakani (ed.), What Japan Thinks, New York, 1921 , pp. 11-20. No doubt it was partly because of his right-wing views that Yamagata was, as Murdoch tells us, "very much trusted by Count Terauchi"" (Murdoch to E. L. Piesse, 14 March 1919, Australian National Library [hercafter ANL] MS 882, f. 5/10).

123 Yamagata Isō, 'Madokku-sht no Nihon rekishi', Shomotsu Raisan, 2, 1925, p. 5. The fourteen pages devoted to 'Jesuits-Lctters from Missions' in the British Library General Catalogue of Printed Books list a number of sixteenth and seventeenth century cditions of letters from Japan. An example of where Murdoch 
scrious historical studies. In the past, school-teaching, as we have seen, had never completely absorbed his energies. Henceforth its role appears to have become, increasingly, to provide him with subsistence to enable him to write $A$ History of Japan.

Littlc is known about Murdoch's three years at Kanazawa. Since his former colleague at the First Higher School, Hanawa Torajirō (1857-1911), was Professor of English there, Sugiyama draws the reasonable inference that it was he that arranged the appointment. ${ }^{124}$

In September 1898 Murdoch returned to Tokyo to teach English and commercial history at the Higher Commercial College (today's Hitotsubashi University), ${ }^{125}$ Hanawa joined him on the staff there the following year. It was he that introduced him to Okada Takeko, whom Murdoch married on 23 November 1899.

One of the stories about Murdoch that Yamagata enjoyed telling in later years dates from this time. The Murdochs lived at Takanawa in the Shinagawa district of Tokyo. Though generous to people in need, ${ }^{126}$ Murdoch was careful with his money. (On the

made use of thesc is in A History of Japan: The Century of Foreign Intercourse, Kobe, 1903), p. 52, n. 5 , where he cites "Letter vii of Bk IV in the collections of Tursellinus". This, no doubt, is $F$. Xaverit Epistolarum libri quatuor ab $\mathrm{H}$. Tursellino. . . in Latinum conversi ex Hispano, Moguntiac, 1600. C. R. Boxer (The Christian Century in Japan 1549-1650, Berkeley, 1951, p vii) sugggests that at the British Museum Murdoch confined his research to printed books and did not use original material in the Marsden MSS housed there. It seems clear, however, from Murdoch (op. cit., p. 486, n. 19) that among the Marsden MSS he consulted at least Carvalho's 1617 Apologia. It is surprising that Murdoch dikd not take advantage of these months in Europe to consult the original confidential reports of the Jesuit missionaries that are preserved in the Ajuda ibbrary at Lisbon. Where he refers to these, it is 10 extracts quoted in L. J. Cros, Saint Francois de Xavier: Sa Vie at Ses Lettres, Toulouse, 1900, a tact which he readily acknowledges. 1 am indebted to Dr Michael Cooper for bringing this to my attention.

124 Sugiyama, 'Janes Murdoch (I)', pp. 59-61.

125 Kótó Shōgyó Gakkē lchiran as cited by Nomi Chiyako and Matsumoto Mihoko, 'J. Mädokku', Kindai Bungaku Kenkyū S'ōsho, 20, 1963, p. 89.

126 According to Yamagata, Murdoch helped him financially on a number of occasions when he was a student ("Nihon no shika Mädokku', Taiyo, November 1926, cited by Hirakawa, Soseki no shi, p. 120) and, although sparing with his tips at expensive inns, would shower largesse on poor peasants who gave him refreshments on his rambles in the country (Matsumoto Mihoko, 'Mádokkt to "Nikon rekishi" ", Gakuen, August 1941, as cited by Hirakawa, Söseki no shi, p. 164). Apparently, Murdech's frugal habits were not disturbed by his elevation to the Sydney chair. The army linguists who travelled with him to Tokyo in 1920 wcre surprised to find that when his spectacles needed replacing, he bought a pair over the counter at Woolworths (T. E. Nave to author, 18 .June 1982). In the same year, he had his will drawn up, not by a solicitor, but by a conveyancer. 
train he always travelled third class.) He was also as keen a walker as ever, and normally covered the five miles from his home to Hitotsubashi on foot. This caused the shopkeepers of Takanawa (who regarded foreigners as an extravagant breed who went everywhere by rickshaw) to refer to him as "the European pauper". When this became known to him, he bowed to local pressure. Thereafter he uscd to hire an old rickshawman on whom the task of pulling a loaded rickshaw was beginning to take its toll, but always walked beside him in front of the empty vehicle! ${ }^{127}$

In May 1900 Murdoch published an article 'Japan and Russia in the Far East' in the influential journal, North American Review. In this he discussed the accelerating rivalry between these two powers in the Korean peninsula and Japan's capacity to make war. He laid stress on the extent to which Japan's economic development was restricted by lack of capital and managerial skills and reached the conclusion that Japan had sufficient resources for a single campaign, but not for the longer war that the Russians could wage. It is a thoughtful and balanced article. ${ }^{128}$ It was, presumably, at about this time that the London Times offered Murdoch employment as its Japan correspondent. ${ }^{129}$ According to Yamagata, Murdoch declined because he wanted to concentrate on writing the History.

$$
\text { Kagoshima (1901-1917) }
$$

In 1901 the Murdochs took advantage of the opening of the Seventh Higher School at Kagoshima to move to Kyūshū. According to Hirakawa, this was because Murdoch's health was still poor and they wished to take advantage of the milder winters there. ${ }^{130}$ According to Yamagata, it was at Kagoshima that the actual

127 Matsumoto, in Hirakawa, Söseki no shi, p. 164.

128 North American Review, 70:52, 1900, pp. 609-33. If, as seems possible, Murdoch was the author of the Athenaeum's review (7 November 1903) of Brinkley's Japan and China, then he bccame more committed to this thesis. The Athenacum review (published three months before the outbreak of hostilities) argues that "in a contest with Russia, the achievement of any pcrmanent military success on the continent is an absolute impossibility to Japan".

129 Yamagata, $M \bar{a} d o k k u-s h i^{2}$, p. 5. Although Yamagata is our sole source for the Times offer, the diary of its Peking correspondent, G. E. Morrison, who discussed Japanese defence and foreign policy with him on 4 and 7 March 1900, shows that Morrison formed a favourable impression of him- "a well informed man. .. an accurate mind" (G. E. Morrison Diary, Mitchell Library, Syciney, MS 312).

130 Hirakawa, Soseki no shi, p. 127. 
writing of the History was begun. ${ }^{131}$ The first volume to appear, The Century of Foreign Intercourse, was published (by the Chronicle) in November 1903.

His employment at Seventh Higher School continued until 1908 when, he later told a Scottish friend that "the Japanese Government found it had no further need of me, and paid me off with four months' screw', ${ }^{132}$ As the personnel records of the school were destroyed in a subsequent fire, ${ }^{1.33}$ the precise circumstances of his leaving cannot be ascertained. According to one writer, it was the result of a quarrel with the principal over some quite trifling matter. ${ }^{134}$ In his remaining years in Japan he described himself as "in the condition of the proverbial church mouse" but able to cover living expenses by "scribbling for a local paper about five days every month". ${ }^{135}$ To supplement this income Murdoch took up fruit-growing. He lived about three kilometres from the school, at Yoshino on the high ground overlooking Sakurajima. ("Pure air and the scenery! As good as the Bay of Naples. ") There he planted a citron orchard. ${ }^{136}$

Although this exchange of the bustle of the classroom for the contemplative calm and austerity of the hills caused Natsume in one of his Asahi Shimbun articles to describe Murdoch as "the British hermit in Japan", 137 the Murdochs' life at Yoshino was by no means lonely. With them lived one of Takeko's younger brothers, Rokuo (1897-1967), ${ }^{138}$ Yukiteru, the son of Ozaki Yukio (the famous

131 Yamagata, Mädokku-shi', p. 5.

132 Murdoch to W. L. Mackenzie, 20 September 1911.

133 Sugiyama, 'James Murdoch (I)', p. 61.

134 Nomi and Matsumoto, 'J. Mãdokka', p. 90.

${ }^{235}$ Murdoch to W. L. Mackenzic, 5 August 1911. The local paper was the Japan Chronicle. The task of identifying these articles is difficult. The Chronicle obituary provides some clues. It indicates that two of the subjects on which Murdoch wrote for it were "incidents affecting the Dutch colony at Deshima" and the philosophy of Herbert Spencer. Harold Williams has noted a series of four articles on the former topic appearing in October and November 1908. (H. S. Williams Collection, ANL MS 6681, Box 8, file: 'Kobe Chronicle/Japan Chronicle', p. 21).

136 Murdoch to W. L. Mackenzie, 20 September 1911. The address of the property was Kagoshima-shi, Yoshino-mura, 1145. (It was there that Murdoch's widow died in 1946.) According to Sugiyama's calculations, this is today's Yoshino-cho, Iso 1143, owned by the Kawashima Gakuen (Sugiyama, 'Jannes Murdoch (I)', p. 64).

137 Asahi Shimbun, 7 March 1911, quoted in Hirakawa, Sosseki no shi, p. 132.

138 For information about Okada Rokuo, I am indebted to Kono Itsuko of Higashi Matsuyama-shi, who intcrviewed Okada's widow in 1976. 
Japanese parliamentarian) boarded with them for a year in 19081909. ${ }^{139}$ Though his health continued to be poor ("Carcass rotten and eyes permanently on strike"), Murdoch at this time described himself as "generally as cheery as the proverbial grig". ${ }^{140}$ This seems to be confirmed by Ozaki's clear and happy recollections fifty years later. The house appears to have been rather primitive (Murdoch himself described it as "a sort of stable-a clean one"). Ozaki remembercd the numerous knot-holes in the walls, through which the local children peered at them until Murdoch eventually papered over them. Like Natsume he remembered Murdoch's indifference to his physical appearance-his frayed cuffs and his patched suits. Most of all he remembered the things Murdoch enjoyed: a smoke, a glass of beer, and a walk. He remembered his great admiration for Saigō Takamori and how Murdoch would say to them: "Once Saigo walked where you are walking now." 141 He remembered his preoccupation with his History: "I'm reading fifty pages a day but I can't maintain my target of writing five a day". 142

It was while they were at Yoshino that in May 1910 the volume dealing with the earlier period, From the Origins to the Arrival of the Portuguese in 1542 was published. This time his publisher was the Asiatic Society of Japan. ${ }^{143}$

It was from Yoshino too the following year that Murdoch wrote to congratulate Natsume for declining the title, Doctor of Letters, which the Japanese Government proposed to confer on him and four other eminent scholars. He commended his former pupil for his moral backbone in deciding to remain in the company of such men as Gladstone, Carlyle and Spenser, who had declined similar honours:

139 Sugiyama, 'James Murdoch (I)', pp. 62-63.

140 Murdoch to W. L. Mackenzie, 20 September 1911.

141 Hirakawa, Soseki no shi, p. 165, based on Nomi Chiyako's notes of an intervicw with Ozaki (early 1960s?). As Hirakawa points out, Murdoch's admiration for Saigō was of long standing. Soon after his first arrival in Japan, a visit to Saigo's grave moved him to make one of few attempts at serious poetry. This is printed in Don Juan's Grandson (pp. 62-67). In one of the footnotes, Murdoch describes Saigo as "one of the finest and grandest figures that adorn the glowing pages of Japanese history".

142 Ozaki Yukiteru's contribution to Shichikso omoide-shü, Kagoshima, 1963, vol. 2, pp. 40-42, quoted in Sugiyama: 'James Murcioch (I)', p. 63.

143 Transactions of the Asiatic Society of Japan, first series, 38, (1910-12)-Report to the Annual Meeting, 1911. 
As human beings it is natural for us to strive to excel the world at large. Our distinction, however, must lie solely in our meritorious contributions to society. The ultimate right to distinction must at all times be determined by what we are and by our deeds. ${ }^{144}$

According to Yamagata, Murdoch himself at one time declined an honour from the Japanese Government. ${ }^{145}$

Apparently Murdoch's orchard was not a financial success. In April 1915 he had to return to school-teaching-at Shibushi Junior High school. His salary there-a mere 60 per cent of what he had been able to command at Kanazawa ${ }^{145}$ - was not easily won. As Shibushi is situated on the eastern side of the Ösumi Peninsula, well beyond daily commuting distance from Yoshino, his employment there must have involved him in considerable travel and separation from his home.

He was teaching at Shibushi when in August 1916 he received the offer of a university post in Australia. He accepted and on 27 February embarked for Australia on the Aki Maru.

\section{Murdoch's History of Japan}

As the manuscript for its third and final volume, The Tokugawa Epoch, 1652-1868, was completed before he left Japan, this is a suitable opportunity for us to consider his History of Japan.

Thanks to Yamagata, ${ }^{147}$ we know more about how The Century of Foreign Intercourse (published in 1903) was written than we do about the other two volumes. The sources in European languagesLatin, Spanish, Portuguese, French, Dutch and German-Murdoch translated himself. All but the first of these languages he must, at some stage of his life, have taught himself; for at Aberdeen modern languages were included in neither the school nor the university curriculum. In addition to the sources that he had copied at the British Museum, he was able to borrow rare European books from two of Britain's most distinguished orientalists, Sir Ernest Satow and B. H. Chamberlain. (To house these volumes he excavated a fire-proof study at the rear of his home.) It was not until after the completion of this volume that Murdoch

144 Murdoch's letter to Natsume as quoted by him (in Japanese translation) in Asahi Shimbun, 8/3/11.

145 Hirakawa, Sōseki no shi, p. 135 quoting Taiyo, November 1926.

146 Ibid., p. 132.

147 Yamagata Isō, 'Madokktu-shi no Nihon rekishi', Shömotsu Raisan, 2, 1925, pp. 4-8. 
was able to read Japanese. Until then, the Japanese sources were selected for him by a young history graduate from Tokyo University, Murakawa Kenko (1875-1946), ${ }^{148}$ and then translated into English by Yamagata. Yamagata has painted a vivid picture of Murdoch and himself at work:

He spent all his time on the task. Writing, or studying his sources, or deep in thought, he looked like one obsessed: his face was pale and his eyes bloodshot. I was translating the Japanese source material and he was always blaming me because this was not produced fast enough. I found this very painful. If I had been working as his employee or for wages, I should probably have resigned very early in the piece! But as I had undertaken the task in order to discharge some of the obligation towards him that I had felt from my student days, this was not possible. Feeling harassed each day, I kept translating with whatever strength I could muster. Just the material that I produced amounted to several thousand pages of handwriting.

As Yamagata was a busy journalist at the time, one can understand his feelings.

The Century of Foreign Intercourse was generally well received by Murdoch's forerunners in the Japan field. In the American Historical Review Griffis, although unhappy about its literary form, described it as "[a] great work. . . cvery page reveals his power of analysis and his acquaintance with the elements of the theme". 149 Chamberlain, although he, too, was worried by "ccrtain disorders of style", spoke highly of Murdoch's "vivid picture of the most important century of Japanese history' $1{ }^{150}$ Lafcadio Hearn greeted it with similar enthusiasm:

This important work contains much documentary material never before printed, and throws new light upon the religious history of the period. . . Perhaps the most interesting chapters are those dealing with the Machiavellian policy of Hideyoshi in his attitude to the

1 14 Murakawa's association with Murdoch appears to have been mutually advantageous. No doubt the acquaintance with original Furopean sources that enabled Murakawa to publish in 1900 Letters Written by the English Residents in Japan 1611-1623 and in 1902 an annotated edition of Hildreth's Japan as It Was and $1 s$ stemmed partly from his collaboration with Murdoch as well as from the instruction he had received from I Ludwig Riess at Tokyo Imperial University. For biographical detail see Yamanaka Kenji, "Murakawa Kenko sensei', Rekishi Kenkyū, $13: 8,1965$, pp. $75-76$.

149 Review by W. E. Grifhs in American Histarical Review, 9:4, July 1904, pp. $802-804$.

150 B. H. Chamberiain, Things Japanese, London, 1905, p. 67. 
foreign religion and its preachers; but therc are few dull pages in the book. . . Not the least merit of the work is its absolute freedom from religious bias of any sort. ${ }^{151}$

As regards this "freedom from religious bias", perhaps Geoffrey Hudson comes closer to the mark in his comments on Murdoch's History as a whole: " $\mathrm{His}$ judgments were also strongly infuenced by his intense dislike for both Buddhism and Confucianism-emotions only surpassed by his still greater dislike of Christianity." 152 On the question of the expuision of the missionaries and the proscription of Christianity Murdoch like most of his Anglo-Saxon predecessors ${ }^{153}$ (including Hearn and Chamberlain) comes down firmly on the side of Hideyoshi and the bakufu:

The Tokugawas aimed at nothing more than the justifiable deportation of foreigners whose continued presence they had reason to believe was prejudicial to the peace of Japan; and it was only when the foreigners would persist in returning to a land where they were not wanted that the Japanese Government had recourse to very regrettable, but very necessary, methods of dealing with aliens that made a merit of flouting its decrees... It is surely only the essence of common-sense and of justice to maintain that people have not only a right, but a duty, to protect themselves against unjustifiable aggression of all sorts- that of zealot alien propagandist included. ${ }^{154}$

Where the doughty free-thinker of the Maryborough class-room and author of Don Juan's Grandson differs from his fellow-writers on this issue is merely in the frequency of his asides against the persecutions conducted in the name of Christianity in Europe and the New World and by some of the Christian daimyo. ${ }^{155}$ In the English Historical Review F. V. Dickins (the translator of the Chüshingura) attacked Murdoch's approach as partisan: "The severities of the Japanese authorities are uniformly made the subject of more or less ingenious apology-the very ingenuity is a proof of their inadequacy." 156 Dickins also noted Murdoch's lack

151 L. Hearn, Japan: An Attempt at Interpreiation, London, 1904, p. 536.

152 G. F. Hudson, 'British Historical Writing on Japan', in E. G. Pulleyblank and W. G. Beasley (eds), Historians of China and Japan, London, 1961, p. 324.

153 For example, W. G. Dickson, Japan, Edinburgh, 1869, p. 158; W. E. Griffis, The Mikado's Empire, New York, 1876, chapter 25; F. Brinkley, Japar, Its History, Arts, and Literature, Boston, 1902, vol. 3, pp. 108-30.

134 The Century of Foreign Intercourse, p. 497.

155 For some of Murdoch's broadsides against Christian superstition, intolerance and persecutions, see ibid., pp. 63, 242, 378, 460-61, 495-96, 553.

156 F. V. Dickins, English Historical Review, 20, 1905, p. 569. 
of professional rigour in citing and identifying his Japanese secondary sources. (Murdoch's very haphazard documentation continued to worry reviewers of the two succeeding volumes and in 1911 caused Asakawa in his review of From the Origins to the Arrival of the Portuguese in $1542 \mathrm{~A} . \mathrm{D}$. to refer to two places where Murdoch had copied from the recent work of Japanese authors without acknowledgement. $)^{157}$

As one would expect from the creator of characters like Hawkston and Morrison, Murdoch gave full attention to the characters and particular skills of the principal actors. Whereas to Dickins the era was one of "petty civil wars, and still pettier intrigues", Murdoch, as Griffis points out, was able to show how in this period "men of real ability ruled the country" ${ }^{158}$ Griffis continues:

He holds the threads clearly in narrating the story of the three great men of Japan, and many of his pages are brilliant and fascinating. . . . In showing how Nobunaga rose and fell, and how Hideyoshi entered into his predecessor's labors, but with profounder genius, keener insight, vaster ken, and even greater energy, the author depends on no unscrutinized tradition or unchallenged legend ... Though other scholars have been fascinated by the same theme. . . there is no picture of [Hideyoshi's] personality, actions, and measures like that here presented.

The characters are certainly 'writ large'. Take for example the picture of Hideyoshi among the friars:

In mere erudition Hideyoshi was inferior to the average bucolic in the ruck of the novices in the Franciscan or in any other Order; in practical statesmanship and politics, and in all their arts and devices, Dominic or Loyola or Machiavelli would have come badly off in any encounter with him. The deluded Franciscans had to learn by dour experience that it was but ill work for pigmies to set their powers against those of a giant in the art of deception-as well as of statescraft generally. But, in common with most Caucasians, they no doubt believed, rashly enough, that great men were (and are) only to be found in Caucasian, if not Christian, lands. ${ }^{159}$

In 1903 with this volume behind him Murdoch, now almost fifty

157 K. Asakawa, American Historical Review, April 1911, pp. 630-33; anonymous reviewer of The Tokugawa Epoch (1652-1868) in Times Literary Supplement, 17 June 1926, p. 405.

159 Nation, 24 March 1904, pp. 237-38.

159 During the Century of Early Foreign Intercourse. . . , p. 286. For similar purple passages see ibid., p. 573 and vol. 1, pp. 366-72 where he accords Hideyoshi and leyasu and Yoritomo and Yoritsune their place among the great commanders. 
years of age, began to study the written language. To those who told him that he was too old for such an enterprise he would reply that Gato was eighty when he started Greek. ${ }^{160}$ According to Yamagata, Murdoch was able to read classical texts like the Kojiki and the Manyosh $\bar{u}$ within two or three years. Thereafter he appears to have made less use of Japanese assistants-he mentions none in the two volumes that followed. In his reviews of these, Asakawa Kanichi, from Yale, provides us with an expert's evaluation of Murdoch's contribution as an historian.

Writing in 1911 Asakawa noted three periods in the writing of histories of Japan by Westerners since the Meiji Restoration. The products of the first were puerile. In the second, a few Europeans acquired sufficient knowledge of the language and of Japanese culture to make an intelligent use of native assistants. In the third, "a few foreign authors seem now to have come to a point where they get firsthand glimpses of the vast literature of Japanese history and apply to it, in some measure, not scientific criticism, but what might be termed the criticism of common-sense". Asakawa found Murdoch's From the Origins to the Arrival of the Portuguese. . . by far the best product of this third period. He praised his lucidity and skilful handling of political events and drew attention to "the great abundance throughout the volume of suggestive and acute comments on subjects of importance in Japanese history". Asakawa, however, indicated that even in this third period foreign scholars, and Murdoch among them, were still inadequately acquainted with the vernacular sources and the latest work of Japanese historians. ${ }^{161}$ Murdoch's contact with contemporary Japanese historians must, indeed, have been limited: he was never to achieve an easy fluency with the spoken language; ${ }^{162}$ and at Kagoshima he was far from the centres of academic debate. This is a hard gap to cross. A generation later Asakawa must have applauded the determined efforts of a younger generation of foreign scholars like Herbert Norman to narrow it. But they, too, owed a large debt to their Murakawas.

Asakawa's review of The Tokugavea Era, 1652-1858 in 1927 was similar in its apportionment of praise and criticism. He considered it "the fullest and most competent account of the period that has appeared in any European language". He referred to Murdoch's

160 Yamagatu, 'Maddoku-shi', loc cit.

161 Asakawa, American Historical Review, loc. cit.

162 Hirakawa, Söseki no shi, p. 169. 
"penetration", his "masterly control of detail", his "skilful treatment of the political history" (whose changing scenes, Asakawa noted, were "presented in intimate terms of personal relations") and his confident, vigorous and perceptive handling of the economic aspects:

Murdoch is a splendid popularizer, not an original contributor. His strength lies in the keen historic sense which he possessed and which seems to have grown with his years. His general weakness, aside from his failure in special fields, is due to his unfamiliarity, as his bibliography proves, with most of the enormous mass of the sources of this period, Had he used more of them, some of his acute reasonings would have been revised; for, as said Fustel de Coulanges, history is not ratiocination. ${ }^{163}$

The two special fields where Asakawa found Murdoch inadequate were cultural history (to which Murdoch gave littic attention) and institutional history (where it seems to me he performed vastly better than his European predecessors but in a piecemeal fashion rather than in the systematic or scientific manner that Asakawa favoured). Among other things he criticised Murdoch for not being completely au fait with current research on the history of Japanese feudalism.

Asakawa's criticisms are just and constructive. It should, however, be noted that Japanese was his native tongue and that the feudal institutions of medieval Japan were to absorb the greater part of his academic life to the exclusion of any attempt to write a general history.

Writing in 1950 Maki Kenji (Professor of Legal History at Kyoto University) considered Murdoch in terms of his contribution to the understanding of Japanese history by Westerners. Maki accorded him high praise for his ability to transcend the cultural limitations of his predecessors and for his perceptiveness in discerning similar processes giving rise to similar phenomena in both societies. Murdoch, for example, saw feudalism developing in Japan at about the same time as it did in Europe and for similar reasons. This was no news to Japanese historians, but it was an important point that had eluded Chamberlain and Hearn. ${ }^{169}$

Murdoch, as wc have observed, was by temperament the scep-

163 K. Asakawa, American Historical Review, October 1927, pp. 139-40.

164 Maki Kenji, Kindoi ni okeru seiyojin no Nihon rekishi kan. Tokyo, 1969, pp. 148-56. I am indebted to Professor Watanabe Akio for bringing this book to my attention. 
tic-doubting externals and doubting conventional wisdom. His need to assault the complacency of his fellow Europeans led him to make some interesting comparisons. Take for exmple:

The present open-mouthed surprise of the West at the unexpected development in the North-East Pacific is mainly due to misconceptions of the import of the word civilisation. Many very worthy people seem to fancy that anything that is not strictly synonymous with European, or so-called Christian culture, cannot be regarded as civilisation. At the end of the sixteenth century. . it is abundantly clear. . that the Island Empire was fully abreast, it not positively in advance, of contemporary Europe in all the essentials of cultured and civilised life. ${ }^{165}$

In his introductory chapter to the History as a whole, he argues that the matrix that made possible the remarkable rate of sustained progress that followed the Meiji Restoration was already in place when the appearance of Commodore Perry's squadron brought the era of seciusion to a close. He considered the essential constituents of this matrix to be: (i) a large homogeneous population; (ii) an underlying social organisation that was sound and stable; (iii) a sense of honour and of conduct; (iv) a vigorously active national intellect; (v) a talent for organisation. Thus at a time when many of Murdoch's contemporaries were arguing that Japan's modernisation was no more than a flimsy veneer, he portrayed it as something which sprang from roots in her past and which would, accordingly, continue. Not surprisingly, this was an interpretation that Japanese found satisfactory. "It was through Murdoch", wrote Maki (to whom Japan's traditions and achievements meant much) "that foreigners first encountered a history of Japan that was accurate, impartial and balanced".

Murdoch's History remained the standard work for more than a generation. Eventually he yielded pride of place to Sansom (whose first volume appeared in 1958 and third volume in 1966). Undergraduates, however, continue to be referred to him-probably because of the detail with which he treats some events. ${ }^{166}$

165 From the Origins to the Arival of the Portuguese. . ., pp. 2-3. See also his comparison of administration under the Hojo with that under their European contemporaries (ibid., p. 455).

166 Murdoch's three volumes were reprinted by Kegan Paul in 1933, 1949 and 1952 and, after the lapse of the original copyright, by Frederick Ungar Ltd in 1964. 


\section{Duntroon and Sydney University ${ }^{167}$}

When Murdoch returned to Australia in 1917 it was to take up an unusual appointment-a lectureship in Japanese at the Royal Military College, Duntroon, to be held concurrently with a parttime lectureship in Japanese at Sydney University, two hundred miles away. The decision in 1916 (in the middie of the Great War, in which Australia and Japan were allies) that the Australian Army should embark on the serious study of the Japanese language provides evidence pointing to a serious apprehension on the part of the Minister for Defence (Senator George Pearce) and some of his cabinet colleagues that Japan would make war with Australia within the period subject to present defence planning. ${ }^{168}$ It appears that the initiative in establishing the lectureship came from the minister, himself, and that the details were worked out by the Chief of the General Staff, Brigader General H. J. Foster. There were four candidates for the lectureship. Two, J. H. Longford (destined some years later to be the editor of the third, posthumous volume of Murdoch's History of Japan) and J. W. Robertson-Scott (then in charge of Britain's wartime propaganda in Tokyo), were suggested by the Foreign Office; two, Murdoch and a British Army linguist, Captain A. M. Cardew, R, E., by the embassy in Tokyo. Seldom can an academic appointment have been made by a stranger process or on the basis of greater ignorance concerning the candidates. Murdoch was Foster's third choice. His first was Longford, whom the Foreign Office described as a former consular officer aged fifty-five. As he was already in receipt of a pension, it was thought that he would be available for $£ 100$ per annum less than the embassy's nominees. Longford was interviewed for the job by the Australian prime minister, W. M. Hughes, during the latter's visit to London, and made a favourable impression. When it was discovered that Longford's age was, in fact, sixty-seven, Cardew was selected. The Indian government, however, refused to release him. And so they settled upon the man whom the cable from the embassy described as "Murdoch of Kagoshima Japan with excellent knowledge of Japanese.

167 Except where otherwise indicated, the information in this section is derived from Australian Archives (hereafter AA), A3688, fles 488/R1/55 and /56.

169 See, for example, my 'Attitudes to Japan and Defence 1890-1923', unpublished University of Melbourne M.A. thesis, 1956, chapter 3. 
He is journalist about 60 who has been teacher in Japanese schools and written on Japanese history." No one involved in the selection process knew that Murdoch had teaching experience at tertiary level. They did not even know the titles of his books. They were unaware that he had ever lived in Australia-let alone that he had been an associate of such radicals as William Lane and the prime minister's foe, T. J. Ryan, the Labour premier of Queensland. ${ }^{169}$

At Duntroon it was decided that, in each annual intake, eight of those cadets who had demonstrated linguistic proficiency at the entrance examination should study Japanese as their foreign language throughout their four years at the college. Murdoch took up his duties with the first year class on 20 March 1917. During the year an additional ad hoc class was also formed from members of the college staff who were eager to learn the language. ${ }^{170} \mathrm{On}$ Mondays and Tuesdays he was to teach at the university, where he would be assisted by a native 'Reader' who would do "the bulk of the language instruction", 17 which Murdoch would "coordinate and supplement with lectures on history, economy, sociology, etc." . His teaching at the university was what a later generation would have called 'University Extension lectures'; for the bye-laws of the university precluded an arts student from enrolling for a modern language that he had not studied at matriculation. This was a provision that Murdoch supported. ${ }^{172}$ (The first matriculation examination in Japanese took place a few weeks after Murdoch's death in 1921).

169 About Longford they were equally ignorant. They were unaware that he had just retired from the chair of Japanese at King's College, London, where he had been since 1903 .

170 It was upon three members of the latter class that the teaching of Japanese at Duntroon was to devolve throughout the period 1922-1930-Professor J. F. M. Heydon (1922-1924), Captain J. R. Broadbent (1924-1926) and Captain G. H. Capes (1928-1930) (Royal Military College of Australia, Annual Reports, $1916 / 1917$ to 1930 , passim)

171 This rather disparaging attitude towards language leaching on the part of those engaged to conduct it appears to have been rather widespread. Longford, in the course of his regotiations with the Australian authorities had written:

... apart from the teaching of the elements of Japancse, which any missionary hack might accomplish, I believe I could have rendered good service, in itself worth all the money paid for it, by promoting some knowicdge of real Japan, which could only be done by a man of the world with long expert experience of his subject. . .

172 Obituary by Professor M. W. MacCallum, Sydney Morning Herald, 5 November 1921. 
The 1917/1918 long vacation Murdoch spent in Japan purchasing books for the university library and selecting two native speakers-one, the 'Reader' for the university; the other, to teach at two Sydney high schools.

The year 1918 was exacting. Besides his duties at Duntroon and at the university, he had additional work in Sydncy supervising the teaching of the language at the high schools. He was living in two places-at Sydney from Sunday to Wednesday and at Duntroon for the remainder of the week. It was the year of the 'Spanish 'flu' pandemic and he suffered two bouts within four months. This left its mark on him (he was sixty-two). In April 1919 he wrote: "I have for some time noticed odd lapses of memory on my part; and an extraordinary tendency to get headaches and to lose mental grip after a little exertion. .." ". ${ }^{73}$ The year, however, also brought recognition and advancement. In the middle of $1918 \mathrm{Mur}-$ doch received an attractive offer of employment in Japan. ${ }^{174}$ To this the university responded by proposing to the Defence Department that, if the latter would contribute the equivalent of Murdoch's Duntroon salary ( $\$ 600$ per annum.), it would appoint him Professor of Oriental Studies for a period of seven years at $£ 1,000$ per annum. and "at the same time leave his services available for doing all that the Commonwealth Government requires of him". The Defence Department made two further stipulations: (i) Murdoch was to be given "an opportunity to visit Japan annually during the long vacation and such part of the first term as may be necessary"'; (ii) his services were to be madc available to assist the governments of other states to introduce the study of the language. The appointment to the chair took effect on 1 October 1918. Under the new arrangement Murdoch's function at Duntroon was "to continue the conduct and supervision of Japanese studies". This he was to discharge by periodic visits, the actual teaching there being conducted by his brother-in law, Okada Rokuo.

\section{Murdoch and the D.M.I. ${ }^{175}$}

It seems probable that the principal purpose of the annual visits to

173 Murdoch to E. L. Piesse, 3 April 1919 (ANL MS 882, f. 5/11).

174 This, presumably, is the offer from Waseda University referred to by Nomi and Matsumoto, ('J. Mádokku', p. 91).

175 For a more detailed treatment of this topic see pp. 73-106 of my 'Anstralia's First Professor of Japanese-James Murdoch', ANL MS 3092). 
Japan was the down-to earth one of ensuring regular supervision for the succession of trainee interpreters whom, it was envisaged, the Army would be sending to Japan. There is, however, evidence that the defence authorities considered as one of their more important intelligence sources the observations and predictions regarding Japanese politics and public opinion that Murdoch would bring back.

He embarked on the first of these journeys on 27 September 1918 and arrived back in Sydney on 14 March. The result of this visit may be seen in a series of twenty-four personal letters from Murdoch to E. L. Piesse, the Director of Military Intelligence, covering the period 6 December 1918 to 26 August $1919^{176}$ - a period during which Japan's policies were frequently the subject of much anxiety (it covered Japan's Siberian expedition, the confrontation between Australia and Japan at the Paris Peace Conference, and Japan's victory over President Wilson on the Shantung question).

Piesse was an unusual person to be D.M.I. he was not a regular soldier, but a solicitor. He was one of the members of the Citizen Military Forces ('Saturday-afternoon soldiers') mobilised at the outbreak of war for full-time home service. In May 1918 he had embarked on a comprehensive examination of all papers relating to Japan in the archives of the principal federal departments. This took him four months and led him to somewhat unorthodox conclusions:

If the papers that have been shown to me represent all the knowledge the Government had, 1 should say that our policy of defence against Japan is inadequately supported by evidence. I am not concerned to say this policy was not justified, although the view I hold of Japan's foreign relations leads me to think that hitherto her eyes have not been turned to us, but merely to point out that a policy involving a vast expenditure appears to have been decided without a sufficient foundation of knowledge. . . . 177

By temperament, however, Piesse was judicious and open-minded. That a threat had not existed did not mean that one could not develop. Movements in Japanese politics and in the international relations of the Pacific region should be subjected to continuous observation and analysis. Since he regarded British Foreign Office

176 E. L. Piesse papers, ANL MS 882, ff. 5/5-5/40.

177 Unofficial letter from Piesse to Senator G. Pearce (Minister for Defence), 13 November 1918 (ANL MS 882). 
sources on such matters to be inadequate and slanted, he believed that Australia must undertake such analysis for herself. ${ }^{178}$ At the time Murdoch embarked for Japan the friction between the Japanese and the United States governments over the extent of Japan's military intervention in Siberia was causing Piesse some anxiety. He considered that it was in Australia's interest that Japanese expansion should take place on the north Asian mainland rather than in the Pacific. If the United States countered Japan's continental activities, Piesse feared that this would produce frustration and resentment throughout the entire Japanese community and provide a favourable environment for the southern school of Japancse imperialists (hitherto a small minority), who urged that Japan's true destiny lay in the south. ${ }^{179}$

Murdoch arrived in Japan on 23 October. The leters indicate that he had access to an extensive range of information and opinion. At the British embassy the Japanese Secretary (E. M. Hobart-Hampden) and Robertson-Scott were men he had known for thirty years. At the American embassy he had two-hour sessions with the ambassador, Roland Morris (who had recently returned from a month in Siberia). He was granted an interview with Shidehara, the head of the Ministry for Foreign Affairs. ${ }^{180}$ What he saw and heard inclined him to believe that the future trend of Japanese politics would be salutary. To quote from his letter of 25 January:

I've had rather a strenuous time of it in Tokyo, where I put my digestion if not my immortal soul in deadly peril. I had several spreads with my journalistic friends with whom I swapped wisdom with fairly satisfactory results. ${ }^{181}$ The collapse of Germany has at last had its effect;--German militarism is now being held up as a terrible exam-

178 Memorandum by E. L. Piesse, "The Far Fastern Question: Recent Developments and their Significance for Australia', 22 October 1918 (AA, A2219, vol. 1, item D.M.I. \$180/13).

179 Ibid.

180 Although Nomi and Matsumoto (' $J$. Mädokku', p. 86) clain that Shidehara was one of Murdoch's students at Eirst Higher School, it seems clear that he was an alumnus not of First Higher School but of Third Higher School, Kyoto (Shidehara Kijüūo, Tokyo, 1955, pp. 18-20).

181 That Murdoch used these meetings with Japanese journalists to good effect to argue Australia's case is attcsted by an editorial in Herald of Asia on 4 January which noted new and encouraging elements in Australian-Japanese relations (including the establishment of the Syciney chair) and explained the White Australia policy as necessary to foster the industrial progress of a slowly growing communisy. 
ple; and able editors are everywhere preaching to their public the advisability of turning over a new leaf. Japanese policy in China is now altering greatly for the better; and on the whole, the country has become reasonable, very reasonable. In short, things are now much more hopeful than they have been since 1914 .

It was during the last weeks of Murdoch's visit that the racial equality issue emerged. The first of a series of public demonstrations took place in Tokyo on 28 January and it was on 13 February (three days before Murdoch left Japan on his homeward journey) that the Japanese delegate at the Paris Peace Conference proposed the insertion into the Covenant of the League of Nations of the following clause:

The equality of nations being a basic principle of the League of $\mathrm{Na}$ tions, the High Contracting Powers agree to accord, as soon as possible, to all alien nationals of States members of the League, equal and just treatment in every respect, making no distinction either in law or in fact on account of their race or nationality.

This was a matter of obvious concern for Australia; for Australian immigration and industrial legislation discriminated against the Asian and other colourcd races. On 4 March Piesse sent a letter to await Murdoch on his arrival in Sydney in which he asked Murdoch to come to Melbourne and discuss this matter with him. In his reply (from Sydney on 14 March while the ship was in quarantine) Murdoch wrote:

This racial discrimination agitation extends all over Japan; \& it has been engineered by the military party. It may very well become dangerous if not met properly. I talked to the Japanese Vice-Minister for Foreign Affairs [Shidehara] about the matter, \& I had scveral din. ners with my journalistic friends where I orated on the matter. . .

P.S. I get at several Japanese papers over the racial discrimination pother; we $c d$ do quite a lot to counter the agitation and make it harmless, I think.

The discussions between Piesse and Murdoch in Melbourne extended over several days and gave rise to two memoranda from Piesse to the Chief of the General Staff on the subject. ${ }^{182}$ In them Piesse accepted Murdoch's analysis that the movement was organised by militarist and other right-wing elements who saw in it a means whereby they could: (i) divert the attention of the populace from internal social and industrial issues; (ii) counter popular sym-

182 AA, A2219, vol. 6, 'Racial Discrimination', item D.M.I. S180/26; ANL MS 882, ff. $2 / 118 \mathrm{H}$. 
pathy for the League of Nations, which, if established, would lead to disarmament and a reduction in their own power and prestige; (iii) disarm Chinese hostility, which was a barrier to Japan's continental expansion. Accordingly, Piesse argued, the appropriate policy for the English-speaking countries to adopt at Paris was to discuss sympathetically the Japanese proposal, to demonstrate that many of the restrictions imposed on Japanese overseas were economic and not racial in origin, and to show a readiness to administer any inevitable restrictions in as agreeable manner as possible. In this connection Piesse suggested that Australia give favourable consideration to long-standing Japanese proposals (repeated as recently as 1916) for a formal treaty in which Australia guaranteed to the Japanese most favoured nation treatment regarding entry, accompanied by a 'Gentlemen's Agreement' in which Japan undertook to issue passports only to merchants, tourists, students, etc. This latter suggestion sprang from Piesse's conclusion that status and not freer immigration was what the Japanese sought in the racial equality clause. A letter from Murdoch dated 24 April, no doubt, confirmed him in this conclusion. In it Murdoch drew Piesse's attention to the fact that the quest for status was the underlying theme of Kikuchi Dairoku's article on Japan in the 1910/1911 edition of the Encyclopaedia Brittanica. With the conviction of one who had lived in Japan during the prolonged negotiations that resulted in the termination of extra-territoriality, Murdoch added: "the Japanese are in real earnest over that."

The attitude of the Australian prime minister, W. M. Hughes, to the racial equality clause was very different. The Melbourne Age on 21 March had told how Hughes had sought an interview with the Paris correspondent of the New York Sun and proclaimed to the world that Australia would not agree to the inclusion of racial equality in the Covenant in any form. Piesse considered that Hughes had thereby gratuitously placed Australia in a position where she could not win. If Hughes succeeded in bringing America into line, then this might cause the Chinese and other Eastern races to regard Western domination as the fundamental issue in world politics and to accept Japanese leadership. In which case, Piesse argued, "we are in sight of the next world war". If on the other hand America, now or at some time in the future, accepted the Japanese position, then Australia would be isolated and at Japan's mercy.

The statements by Hughes that Piesse so deprecated continued at almost daily intervals. In Paris on 6 April the Japanese delegate, 
Baron Makino, approached the representative of a leading Australian newspaper and through him appealed to the Australian public. Makino's message was that the Japanese people were convinced that only Australian opposition stood in the way of their proposal and that they would hold Australia accountable if it failed. Murdoch regarded this very seriously. On 10 April he wrote to Piesse:

From what Makino is reported to have said to the Sun's representative, the fat is in the fire and things are getting even more serious than I expected them to be. Are we prepared to fight at any time within five years from now?... We can maintain the White Australia policy intact, I believe, if we go about it in the right way; and that too without any fighting and with very little unpleasantness. If we continue to play the game of the Japanese military clique, it is quite possible that there will be something a good deal worse than unpleasantness. . .

The fate of the racial equality proposal is well known. ${ }^{183}$ It was put to the vote at the final session of the Peace Conference's League of Nations Commission on 11 April. Although eleven out of a total of seventeen votes were cast in its favour, President Wilson as chairman of the meeting ruled that unanimity was necessary and that the proposal was therefore defeated.

Later in the month the manner in which the Peace Conference disposed of the Shantung question caused Murdoch and Piesse similar concern.

The Chinese government by accepting Japan's notorious 'Twenty-One Demands' in 1915 had agreed to recognise any arrangement which the Japanese and German governments might subsequently make regarding German rights in this province. Two years later Japan in a series of secret agreements had received from Great Britain, France and Russia formal assurances of their sup-

183 It is, perhaps, of interest that $T$ ojo in his evidence at the International Military Tribunal for the Far East argued that the immigration legislation in English-speaking countries (he specifically mentioned the Australian legislation of 1901) and the rejection of the racial equality provision at the Paris Peace Conference in 1919 were among the factors influencing his government to formulate its Greater East Asja Policy (IMTFE, Proceedings, 30 November 1947, pp. $36430-$ 34). Whether this was his own belief or whether it was an idea fed to him by his tcam of defending officers (Japanese and American), we cannot telt, Be this as it may, it certainly appears to havc been one of the arguments that influenced the Indian member of the 'Tribunal to cast his vote for an acquittal. (See International Mititary Tribunal for the Far East: Dissentient Judgment of Justice $R$. B. Pal, Calcutta, 1953), pp. 317-20. 
port for such claims, in return for greater Japanese assistance in the war against Germany. When at the Peace Conference Japan sought the implementation of these agreements, China (which in August 1917 had declared war on Germany) claimed that her acceptance of the twenty-one demands had been secured under duress and demanded that German rights and interests in Shantung should be ceded to her and not to Japan. President Wilson's sympathies were with the Chinese, but, lacking the support of the other allies (who were committed by their 1917 undertakings), he gave way. Accordingly, on 30 April the clauses of the peace treaty embodying the Japanese claim were accepted by the Council of Four.

It was with surprise as well as dismay that Murdoch and Piesse watched the course of the events moving towards this conclusion. They, like the rest of the world, were completely unaware of the 1917 secret agreements. On 24 April 1919, the day on which these were published in the daily press, Murdoch wrote to Piesse:

If Japan can work her own sweet will in China to the uttermost, she will deem herself strong enough to challenge America even ... We drive Japan to seek alliances; and by 1935 or so we have Germany, Russia and Japan acting together-Japan with control over the inexhaustible resources of China. With these resources at her command, she will be able to build ships as fast as America. And the next war will be a war of the air far more than last one been.

An official memorandum by Piesse dated 6 May echoes these views. ${ }^{184}$

Murdoch's letters to Piesse are also interesting in demonstrating that his attitude to race had become somewhat more liberal and sophisticated over the years. In his letters of 3 and 24 April 1919 he endorses the basic thesis expounded by Revd S. L. Gulick in his Evolution of the Japanese-Social and Psychic. ${ }^{185}$ Gulick argued that "the main differences between the great races of mankind to-day are not due to biological, but to social conditions; they are not physico-psychological differences, but only socio-psychological differences". Gulick was critical of the Western publicists who "pride themselves on their high education and liberal sentiments" but at the same time misapply scientific theories in order to justify

184 AA, A2219/5, 'China-Japan \&', item D.M.I. \$180/27.

185 Published in New York by F. H. Revell \& Co. For a brief but informative account of the life and work of this remarkable missionary, scholar and propagandist see the article by R. S. Schwantes in Dictionary of American Biography, supplement number 3, 1941-1945, New York, $\$ 973$. 
"the arrogance and domineering spirit of Western nations". ${ }^{186}$ To Murdoch, the attribution of innate qualities to particular races was "pestifirous explosive poppy-cock". It was explosive because "if we really want war, all we've got to do is to keep on harping upon our pseudo-scientific racial 'biology" ".

Much water had indeed passed under the bridge since Murdoch attempted to fan the fires of race hatred among his Boomerang readers by the use of such phrases as "white-tusked tawny apes". It is not, however, surprising that with thirty years of experience similar to Gulick's Murdoch should be driven to similar conclusions. The typical foreign resident worked, lived and relaxed among other members of the foreign community. This limited his opportunities for sustained observation of the individuals who made up the wider community beyond. It also made it likely that any observations that he did make would be of the 'they' and 'us' variety. Murdoch and Gulick, however, were atypical. By the nature of callings and circumstances they spent most of their time with individual Japanese-in Gulick's case with parishioners and native clergy, in Murdoch's case with pupils and members of his own household. Their experience being of this nature, it is not surprising that they reached the conclusion that there was as wide a diversity of talent and personality in Japan as elsewhere and that cultural patterns were not innate, but acquired.

Murdoch, as has been observed when dealing with his History of Japan, identified and laid considcrable stress on certain Japanese national characteristics such as a sense of honour, a vigorously active national intellect, and a talent for organisation. But he did not suggest that these characteristics were innate.

$$
1920-1921
$$

After "nearly three years of incessant locomotion" Murdoch was, at his own request, excused from visiting Japan in the 1919/1920 long vacation. The 1920/1921 visit was of short duration. He left Sydney on 24 September and was back early in January. After seeing that the two most promising of his army students, Captain J. R. Broadbent and Captain G. H. Capes, were properly launched on their two years stay as language students, he seems during the visit to have exercised his customary watching brief over the Japanese political scene. This time his prognosis was a little more sanguine: "Australia has nothing to be anxious about from Japan

186 Gulik, Evolution of the Japanese, p. 19. 
just now, but ten years hence it may be very different." 187 On his return he journeyed to Melbourne to convey his impressions to the minister in person. Murdoch also saw the prime minister (Hughes) at least once (and possibly twice) at about this time to discuss the renewal of the Anglo-Japanese alliance, one of the principal agenda items for the forthcoming Imperial Conference. Murdoch warned Hughes that one of the aims of the militarists was to drive a wedge between Britain and America and that the arrogant attitude of some Americans played right into their hands. He felt that there was "a good deal more than a mere off-chance of America drifting into war with Japan within the next ten years". ${ }^{18 B}$ At the Imperial Conference Hughes argued in terms of an immediate threat. Japan, he said, was spending more than half her budget on armaments. This tremendous drain on her resources could not continue for any length of time. Her ambitious projects must be realised in the near future. ${ }^{189}$

Murdoch died at Sydney on 30 October 1921 of cancer of the liver, the symptoms of which had begun to appear about five months previously. Volume iii of his History of Japan, covering the Tokugawa period (1652-1868), was still unpublished, although he had completed the manuscript in Kagoshima. Allen \& Unwin had approached him in 1914 but nothing had come of this-possibly because of the wartime paper shortage. At the time of his arrival in Australia he had been trying to arrange publication at his own expense and had organised about two hundred subscribers in Japan and the United Kingdom. ${ }^{190}$ It was not to appear until 1926 (under the Kegan Paul imprint and with the assistance of Longford as editor). We can gain an inkling of their difficulties from the description of Murdoch's writing technique given by Mungo MacCallum in Murdoch's obituary in the Sydney Morning Herald:

187 Murdoch to Secretary, Defence Department, 11 January 1921 (AA, MP431, file 871/12/105).

188 Murdoch to the Prime Minister, 3 March 1921 (ANI. W. M. Hughes Papers, MS 1538 , f. 16/2677).

189 Stenographic record of 9 th meeting (29 Junc 1921) of the Conference, p. 15 (ANL MS 1538, f. 25/440). Yamagala in suggesting in his November 1926 Taiyo article that Murdoch was the principal influence determining Hughes's policy on the alliance is, 1 feel, overstating his case. Hughes and his ministers were publicly supporting renewal of the alliance wcll before they had the benefit of Murdoch's advice (Scc for example the $A$ rgus [Melboume] 11 August 1920 and 4 September 1920).

190 Murdoch to Brigader General H. J. Foster, 15 June 1917 (AA, A3688, fle $488 / \mathrm{R} 1 / 55$ ). 
In a way the last volume [that is the projected vol. iv covering the period 1868-1912] was finished, and in a way it was never begun. This is no paradox: his method of working explains its absolute truth. He had a memory, like Macaulay's, extraordinarily retentive and ready, so that he seemed able to recall at will anything he ever knew, e.g. the number of a page in which some passage occurred, though he had not read the book for years. This gift, so useful to a historian, determined his procedure. He hunted out all the authorities, assessed them, assimilated their information, pondered it in his mind-all this without taking a single note-and when the heterogeneous material was reduced to a coherent and organic whole took his pen and gave it its fnal shape in words. A few weeks before his death he said: 'My fourth volume is now ready: I have only to write it, which will take a month or two'. Now that fourth volume, though ready, will never be read. In this as in much else his death was premature, though he lived till 65. ${ }^{191}$

The structure that Murdoch had played so large a part in building began to crumble within a few weeks of his death.

Okada left Duntroon at the end of the 1921 academic year and no successor was appointed (presumably-he was one of the early victims of the severe retrenchments in the military establishment that attended the postwar depression). Although Japanese remained in the curriculum at Duntroon until December 1938, no full-time teacher was ever again appointed and the subject never regained the prestige of the Murdoch-Okada years. Apart from Broadbent and Capes, who returned to Australia in 1922, no other Duntroon graduates were sent to Japan for further language training. Nor did the study of the language prosper among the civil community. A survey by the Directorate of Military Operations in 1935 revealed that there were then only seven people in Australia familiar with the Japanese language-Murdoch's successor at Sydney University (Professor A. L. Sadier) and six persons "able to read and write imperfectly"' 192

In short, the seed that Murdoch sowed did not yield fruit that multiplied. It is possible that, had he survived to cultivate it, the result might have been different: those who knew him seem agreed that even in his last years he was a man of great energy. ${ }^{193}$ But

191 Sydney Morning Herald, 5 November 1921.

192 AA, MP431, file 929/16/69.

193 His energy is attested by his ability to sell his ideas to the N.S.W. Department of Education and, within eighteen months of his arrival in Australia, to have native teachers installed in two metropolitan high schools (Sydney Morning Hetald, 31 October 1921). 
possibly it was stony ground in which, no matter how devoted the cultivator, the initially promising growth was bound to wither away once the sun was up. ${ }^{194}$ Unfortunately, Murdoch cannot be credited with establishing the tradition from which to-day's annual harvest of young linguists stems. His lasting achievement lies elsewhere-in producing what remained for a generation, to use Asakawa's phrase, "by far the best" history of Japan written by a foreigner.

194 The infuence of the Washington treaties should not be underestimated. On 13 April 1922 Piesse wrote to his departmental head:

The Washington Conference has now brought about a great change in our position relative to Japan. Whatever the ultimate outcome of the treaties made at the Conference, there can, I think, be no doubt that the detailed study of Japanese affairs which we contemplated in 1920 is, for the next few years at least, quite unnecessary. . .

No doubt the treaties had a similar impact on public opinion generally. 


\section{END OF REPRINT}

James Murdoch (1856-1921): Historian, teacher and much else besides 